UNIVERSIDAD DE BURGOS

DEPARTAMENTO DE DERECHO PUBLICO

DOCTORADO SOCIEDAD PLURAL Y NUEVOS RETOS DEL DERECHO

Tesis doctoral

\title{
SUBORDINACIÓN JURÍDICA Y \\ TERCERIZACIÓN LABORAL: EL PROBLEMA CONSTITUCIONAL EN BRASIL.
}

Rafael da Silva Marques

DIRECTORES

Dr. Jesús Lahera Forteza

Dra. Nuria Belloso Martín 
Subordinación jurídica y tercerización laboral: el problema constitucional en Brasil

Tesis presentada en el Programa de Doctorado del Departamento de Derecho Público en el Programa Sociedad Plural y Nuevos Retos del Derecho por Rafael da Silva Marques para la obtención del titulo de doctor.

Dirigida por los Doctores D. Jesús Lahera Forteza, Profesor Titular de Derecho del Trabajo en la Universidad Complutense de Madrid y por Dña. Nuria Belloso Martín Profesora Titular de Filosofía del Derecho en la Universidad de Burgos. 
Para Riani. Si yo he hecho esta tesis por mí, yo vivo por tí. 
Agradezco a Riani por la comprensión y la fuerza que me ha dado cuando tuve que redactar el texto de la tesis.

Agradezco a mis tutores Dr. D. Jesús Lahera Forteza y Dra. Dña. Nuria Belloso Martín que fueran más que tutores. Fueron amigos e hicieron de un deseo una realidad.

Agradezco también a la profesora Dra. Dña. Carmen Cueva Puente por las tutorías que hicimos juntos y por su inestimable colaboración en esta investigación.

Agradezco a mis padres por el ejemplo de vida y a mis hermanos por la fuerza que me dan.

No hay como no agradecer al Tribunal Regional del Trabajo de la Cuarta Región, Río Grande del Sur, por el período de beca que me ha concedido en dos oportunidades, durante diez meses.Para terminar agradezco a mis colegas funcionarios de las $29^{a}$ Sala Laboral de Porto Alegre, 4 ${ }^{\mathrm{a}}$ Sala Laboral de Gravataí, 1ํ Sala Laboral de Passo Fundo y 4ํㅗ Sala Laboral de Caxias do Sul. 
INTRODUCCIÓN

\section{Capitulo I}

\section{La Flexibilización de las normas laborales y la democracia distributiva ............................................................................. 21}

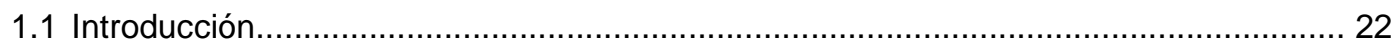

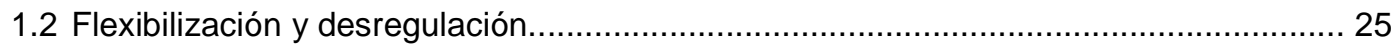

1.3 El Estado social y la paradoja de la estabilización liberal........................................ 34

1.4 La cuestión sindical y la pérdida de la conciencia de clase.................................... 52

1.5 La pérdida de la conciencia de clase........................................................ 59

1.6 La democracia distributiva-comunicativa-educativa-cultural

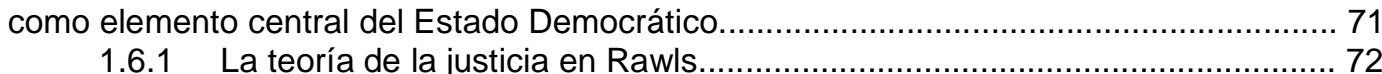

1.6.2 La democracia distributiva-comunicativa-educativa-cultural....................... 76

1.6.2.1 La cuestión del lenguaje.................................................. 87

1.6.2.2 La educación como superadora del capital

y la constitución cultural................................................................. 96

1.7 La reconquista de la conciencia de clase ........................................................... 108

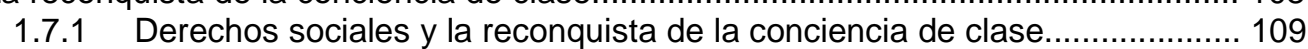

1.7.2 Conciencia de clase y estabilización de

la relación entre el capital y el trabajo....................................................... 113

1.8 La dignidad de la persona humana como criterio

interpretativo y como punto de llegada........................................................... 115

\section{Capitulo II}

\section{La tercerizacion en el orden jurídico brasileño ................ 125}

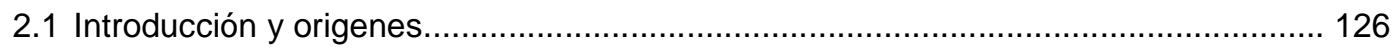

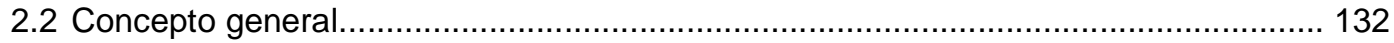

2.2.1 Concepto de tercerización utilizado en Brasil........................................... 137

2.2.2 En los países de América Latina......................................................... 143

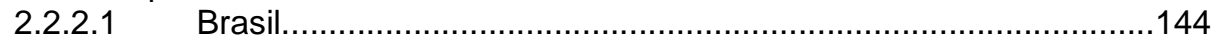

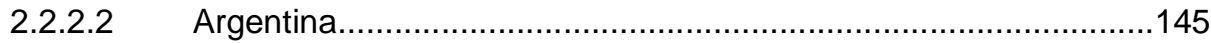

2.2.2.3 Chile ........................................................................... 150

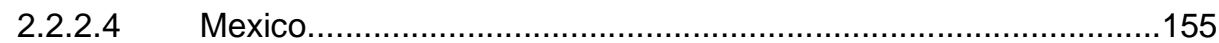

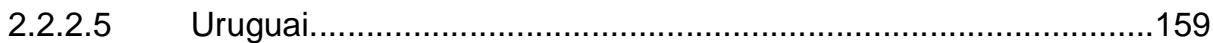

2.2.3 En la Unión Europea.........................................................................................163

2.2.3.1 En el marco de la UE.......................................................163 
2.2.3.2 Breve referencia a otros países

europeos, en especial el caso de Francia y Portugal...................................... 170

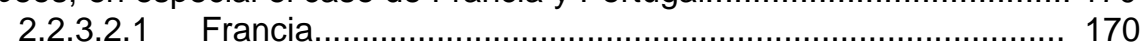

2.2.3.2.2 Portugal.................................................................... 183

2.3 Estudio detenido de la tercerización en España como

paradigma del modelo europeo.......................................................................... 190

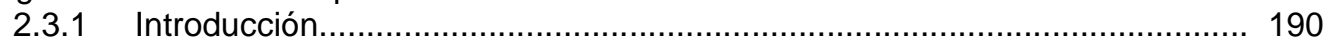

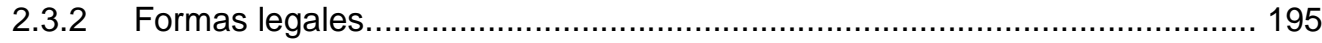

2.3.2.1 Las contratas y subcontratas.................................................... 195

2.3.2.2 La descentralización productiva en la

Administración Pública española............................................................ 205

2.3.2.3 Las Empresas de trabajo temporal

(estudio del art. 43.1 y 1 del ET y ley 14/1994, de 1 de junio -LETT-)........... 212

2.3.2.4 Las contratas y subcontratas y las

normas de seguridad social.

2.3.2.4.1 La responsabilidad de la empresa

contratante principal en materia de seguridad

social no correspondente a la propia actividad ..................................... 216

2.3.2.4.2 La responsabilidad de la empresa

contratante principal en materia de seguridad

social correspondente a la propia actividad.

2.3.3 Forma ilegal: la cesión ilegal de mano de obra

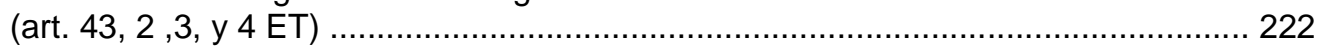

2.3.4 La prevención de los riesgos laborales en

contratas o subcontratas.

2.4 Estudio detenido de la tercerización en el

ordenamiento jurídico brasileño.

2.4.1 Concepto de la doctina brasileña y

crítica inicial a la tercerización...

2.4.2 De la responsabilización del tomador de los

servicios en el caso de tercerización.

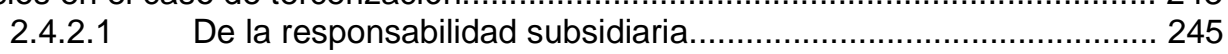

2.4.2.2 De la responsabilidad solidaria.................................................. 253

2.4.3 Ley del trabajo temporal - ley 6.019/74 (trabajo

a través de empresas de trabajo temporal)............................................................ 263

2.4.4 Forma ilegal: La cesión ilegal de mano de obra......................................... 266

2.4.5 Supuestos concretos de tercerización previstos en

el ordenamiento jurídico brasileño

2.4.5.1 Tercerización en el servicio público.................................................. 269

2.4.5.1.1 Normatividad y visión crítica........................................... 274

2.4.5.1.2 Las reclamaciones 6.970 y 8.233 y la inconstitucionalidad del artículo 71, párrafo primero, de la ley 8.666/93.....

2.4.5.1.3 De la constitucionalidad del artículo 71, párrafo primero, de la ley 8.666/93.

2.4.5.2 Régimen de concesión y permiso de la prestación

de servicios públicos.

2.4.5.3 Ley general de las telecomunicaciones...................................... 286

2.4.5.4 Servicios de seguridad, vigilancia y transporte

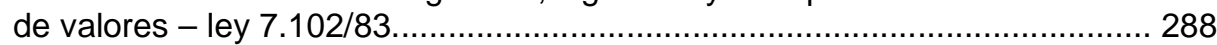

2.4.5.5 Actividades de movimiento de mercancías -

ley $12.023 / 09$.

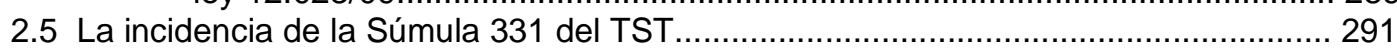

2.5.1 La dudosa legitimidad de la distinción entre actividad

medio-actividad fin.

2.5.2 El papel de la subordinación. 


\section{Capitulo III}

\section{La subordinación juridica .................................................... 297}

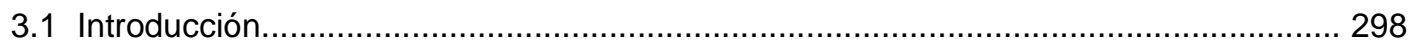

3.2 Subordinación jurídica.................................................................................... 300

3.2.1 Concepto para la doctina y de la jurisprudencia............................................ 302

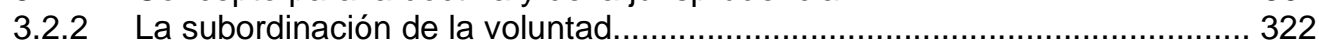

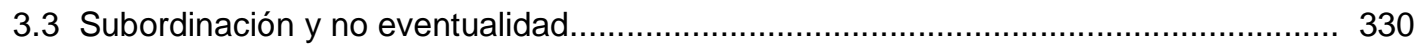

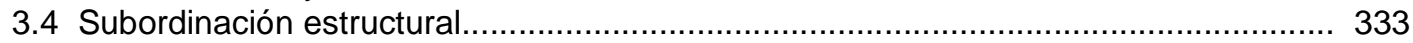

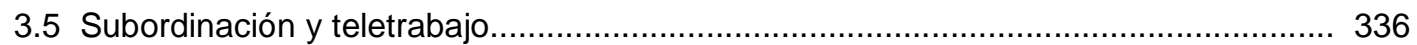

3.6 La parasubordinación italiana y el trabajador español

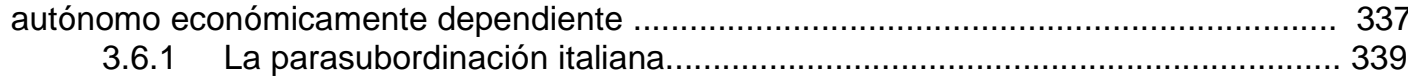

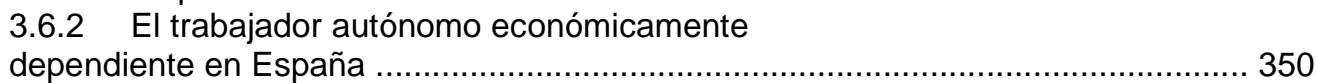

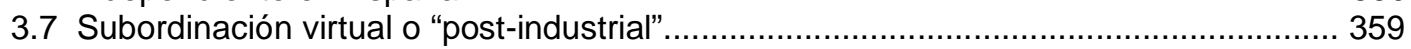

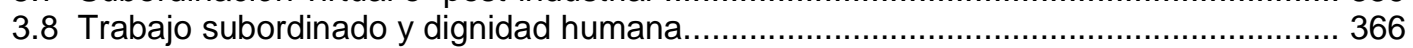

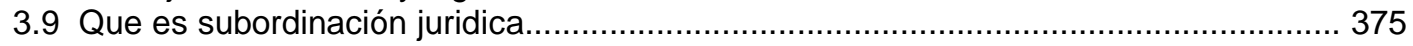

3.9.1 El concepto propuesto de subordinación jurídica......................................... 377

\section{Capitulo IV}

\section{Tercerización y Constitución............................................. 381}

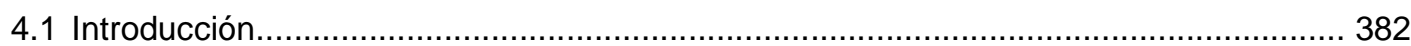

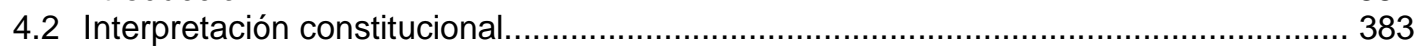

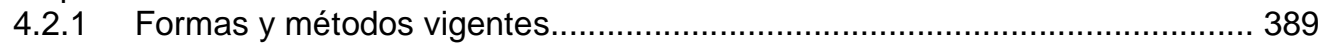

4.2.2 Alcance y límites..................................................................................... 394

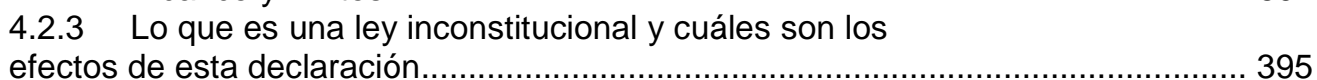

4.3 La relación de empleo como regla absoluta........................................................... 396

4.3.1 Los imperativos categóricos y los imperativos hipotéticos............................396

4.3.2 La regla del artículo $7^{\circ}$, inciso I, primera parte, de la

Constitución brasileña de 1988............................................................................. 403

4.3.2.1 Concepto de relación de empleo en la Constitución

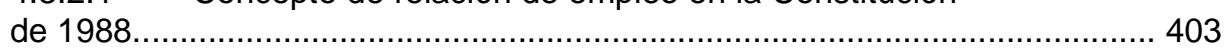

4.3.2.2 El proceso comunicativo de formación de la norma

constitucional.......................................................................................... 412

4.3.2.3 Hermenéutica, dialéctica e historia................................................ 430

4.3.3 La relación de empleo como concepto constitucional.................................. 440

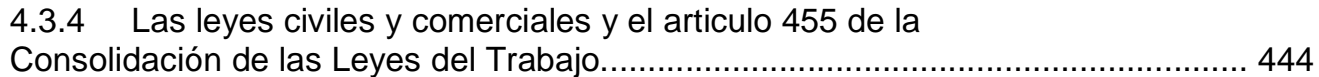

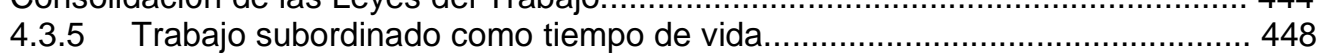

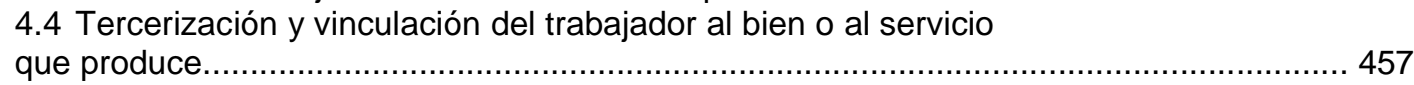

4.4.1 Porque quien produce no es dueño - cuestión de la
apropiación de la plusvalía. .................................................................................. 457

4.4.2 La alienación y los efectos de la "doble" alienación

en la perspectiva constitucional - Los límites a la alienación...................................... 462 
4.5 La ley brasileña de tercerización y la cuestión constitucional....................................... 473

4.5.1 Objetivos de la ley.......................................................................... 476

4.5.2 Beneficiados con la "legalización” de la tercerización....................................... 477

4.5.3 La cuestión sindical y la tercerización..................................................... 478

4.5.3.1 Huelga y tercerización.......................................................... 481

4.5.4 Alternativas de tutela en caso de tercerización .......................................... 482

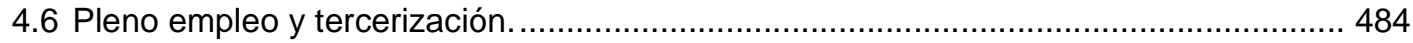

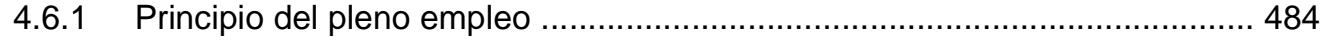

4.6.2 El trabajo como elemento de existencia humana digna................................ 486

4.7 Hipótesis de constitucionalidad de la tercerización - Posibilidad de

que sea más beneficiosa para el trabajador

CONCLUSIONES

FUENTES

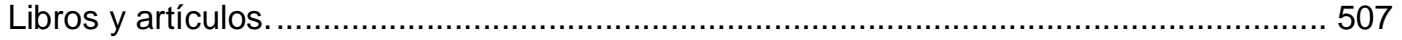

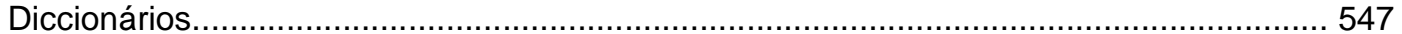

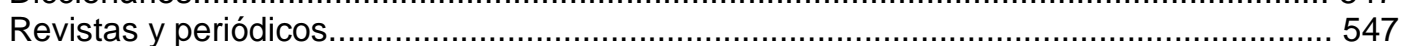

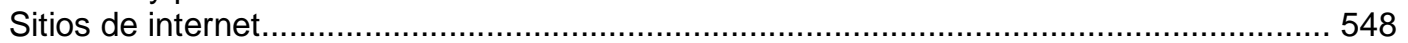




\section{INTRODUCIÓN.}

Somos conscientes, y esto lo reconocemos de antemano, que la temática que analizaremos a lo largo de nuestra investigación genera polémica no sólo en la jurisprudencia, sino también en la doctrina, que acaba, en relación a la tercerización, repitiendo, muchas veces sin mayores reflexiones o incluso sin criterio, lo que dicen los tribunales acerca de la cuestión.

Nos proponemos llevar a cabo una reinterpretación de las normas jurídicas constitucionales relacionadas con la clase trabajadora (trabajador subordinado) situándola como centro del modo de producción capitalista.

En esta investigación utilizaremos el término tercerización para referirnos a los contratos entre empresas o entre empresas y la administración pública, como pueda ser el suministro de trabajadores como tales como sucede en los casos de limpieza y seguridad. No utilizaremos el término de descentralización productiva y, por tanto, no lo abordaremos en la Tesis- ya que el tema de la descentralización productiva en Brasil es diferente de la tercerización. La descentralización productiva comprende la división, a través de terceras empresas, por parte de la producción de la empresa principal, fuera de la plantilla de ésta (una es la empresa principal y las otras empresas "sistemistas", como en el caso de las empresas que hacen el montaje de automóviles). Lo justificaremos más extensamente en el II Capítulo de la presente Tesis Doctoral. El tema de la tesis es la Sumula 331 del Tribunal Superior del Trabajo que trata del hecho de poner 
trabajadores a la disposición de tercera persona para la prestación de servicios y no para la ejecución de obras o productos acabados.

En Brasil, el movimiento y la práctica de la tercerización es constante, incluso por parte de órganos públicos. Son innumerables los casos de empresas contratadas por otras para prestar trabajo de vigilancia o limpieza en que, transcurridos pocos meses después de la contratación, los trabajadores no perciben nada, sin que haya otra alternativa que la de recurrir al poder judicial. En la mayoría de las ocasiones, ni siquiera se consigue encontrar al empleador, por lo que el tomador acaba transfiriendo el perjuicio causado al trabajador.

Por otro lado, además del problema crónico de la falta de pago o pago tardío, la tercerización trae consigo la debilitación de la clase trabajadora. Los sindicatos a los que pertenecen estos trabajadores se acaban debilitando, sin poder de negociación. Se podrá ver en la tésis que el pago a los trabajadores tercerizados es mas pequeño que aquel de los trabajadores contratados de forma directa, lo que lleva a una participacion mas débil dentro del moviminento sindical. De otro lado, el hecho del trabajador prestar trabajo fuera de la empresa contratante, disminuye el contacto con sus colegas de trabajo y, por eso, una menor participación en el movimiento del sindicato.

En la presente investigación nos proponemos profundizar en este tema. No seguiremos un esquena clásico, sino que realizaremos un análisis de la cuestión de clase, pérdida de la conciencia de clase, formas de reconquista o recuperación en parte de esta conciencia, emancipación por el trabajo subordinado, a partir de la dignidad humana, y subordinación jurídica como criterio constitucional de vinculación del trabajo por cuenta ajena directamente con el beneficiado por el servicio prestado. 
Y para que este análisis resulte coherente y racional, es preciso examinar no sólo los requisitos de la relación de empleo, sino también las consecuencias de este contrato sobre la persona del trabajador.

El trabajador que presta servicios de forma subordinada lo hace, evidentemente, dentro de la lógica capitalista. De él deriva la "plusvalía", diferencia entre el valor que reciba el prestador del trabajo y lo que el tomador gana con la venta del producto o servicio. La perspectiva bajo la que desarrollaremos nuestra investigación llevará en cuenta matizes marxistas, pero aunque habrá análisis marxista (Marx, Meszáros, Poulantzas y Althusser, entre otros), la investigación no es marxista, porque se desarolla, por evidente, dentro del modo de producción capitalista.

En nuestro trabajo de investigación intentaremos poner de manifiesto la cuestión de los efectos del capitalismo sobre las personas y sobre el trabajador y la forma en que, una vez insertado en este sistema, es recogido por la Constitución brasileña de 1988, artículo 7º, I, intentando analizar la cuestión de la subcontratación de trabajadores.

La cuestión es controvertida. Existe una doctrina y una jurisprudencia que se aproxima a lo que sostenemos en este trabajo. Creemos, sin embargo, que sólo así se puede evolucionar en el mundo de los hechos. La dialéctica, el pensar con fundamento, la divergencia, elementos todos esenciales de la democracia, cobran sentido junto a los fundamentos de esta introducción, con el fin de justificar la elección del tema y la forma de presentación del mismo.

La propia democracia es plural. Es conflicto de ideas, debiendo ganar el mejor argumento. Es poder fundamentar de forma libre y racional, sin influencias nefastas derivadas del dinero y del poder administrativo. 
Democracia implica un "nosotros" y no un "yo". Hay que desterrar las leyes que declaren y permitan haya ciudadanos de segunda clase. Mediante el constitucionalismo la realidad del "nosotros" se hace más que posible, se vuelve impositiva. ${ }^{1}$

Mi profesión de juez laboral, me ha permitido tener contacto casi a diario con la realidad a la que estamos haciendo referencia. Cada día más personas dejan de tener un contrato de empleo de forma directa y pasan a ser terceros, sin ninguna garantía social, aumentando aún más la miseria y la exclusión social en un país que, desde hace siglos, no consigue resolver la cuestión de la brutal desigualdad social y regional.

Defendemos una democracia distributiva-comunicativa-educativa-cultural. Si hay capitalismo, habrá también trabajo subordinado. Nuestra intención no es reformular el modo de producción. No sostenemos la superación del capitalismo, sino la humanización del mismo por el trabajo y en el trabajo.

Nos preocupa uno de los principales problemas en la relación entre capital y trabajo, la tercerización. Queremos buscar fórmulas para, poco a poco, erradicar la pobreza y la marginación, reduciendo las desigualdades sociales, con el fin de promover el bien de todos, conforme a lo que establece el artículo $3^{\circ}$ de la Constitución brasileña de $1988 .^{2}$ Por ello planteamos la discusión de la teoría marxista. No estamos sosteniendo la superación o el cambio del modo de producción capitalista. La teoría marxista, que quizá sea la que mejor analiza el capitalismo y sus efectos sobre la clase trabajadora, la utilizaremos para

\footnotetext{
1 DWORKIN, Ronald, "A democracia e os direitos do homem". En Democracia. Organizadores Robert Darnton y Olivier Duhamel. Tradução Clóvis Marques, Rio de Janeiro; Editora Record, 2001, pp. 160/162.

${ }^{2}$ Art. $3^{\circ}$ Constituyen objetivos fundamentales de la República Federal de Brasil:

I - construir una sociedad libre, justa y solidaria; II - garantizar el desarrollo nacional; III - erradicar la pobreza y la marginación y reducir las desigualdades sociales y regionales; IV - promover el bien de todos, sin prejuicios de origen, raza, sexo, color, edad y cualquier otras formas de discriminación.
} 
argumentar y sostener las ideas expuestas. Como hemos dicho, no es una tesis marxista. És una tesis que se utiliza de la teoria marxista solamente.

Consideramos imprescindible el recurrir a la teoría marxista, como forma y base de estudio, para el análisis y la interpretación del capitalismo actual. Una visión social, que muestre al trabajador como un agente histórico, de importancia histórica y, especialmente, que destaque el papel en la historia de este trabajador, no puede ser rechazada como no aplicable o superada. En este sentido, debemos dejar de lado los prejuicios doctrinales-filosóficos para buscar una ciencia viva.

Hay que reconocer, sin embargo, que existen otras doctrinas que permiten el análisis e interpretación del capitalismo. Ninguna, sin embargo, se centra en el trabajador y su importancia histórica ${ }^{3}$. Ninguna considera, abiertamente, al trabajador como elemento de transformación social ${ }^{4}$. Sin embargo, si lo que se propone es tratar acerca del trabajador, nada mejor que buscar el fundamento en la teoría marxista.

Uno de los objetivos de esta investigación es demostrar que la subcontratación de trabajadores no está permitida por el ordenamiento jurídico brasileño. En otros países sí hay esta posibilidad. La norma constitucional brasileña, concretamente, el artículo $7^{\circ}$, I, de la CF/88, lo impide.

Hemos dividido la Tesis Doctoral en cuatro Capítulos. En el I capítulo abordaremos la cuestión de los derechos fundamentales, de la desregulación y la flexibilidad de los derechos de los trabajadores y la paradoja del estado social de derecho como forma de mitigar los derechos y reducir el acceso de los trabajadores a los bienes y a los medios de producción.

\footnotetext{
${ }^{3}$ SELL, Carlos Eduardo, Sociologia Clássica: Durkheim, Weber [e] Marx, Itajaí; UNIVALI, $3^{\text {a }}$ ed; 2002.

${ }^{4}$ CATTANI, Antônio David, A ação coletiva dos trabalhadores, Porto Alegre; Editora SMCultura Palmarinca, 1991.
} 
Mediante estos instrumentos, el trabajador acaba perdiendo su conciencia de clase. Refleja la idea del tomador del trabajo, pensando como burgués y viviendo como obrero. $\mathrm{Y}$ sin conocer su papel real en la historia y su relevancia en la transformación de la sociedad, se convierte en una presa fácil de un mundo cada vez más flexible, impersonal y desigual.

Para la reconquista de la conciencia de clase por parte de los trabajadores, es necesaria la evolución hacia una democracia distributiva-comunicativaeducativa-cultural, que encuentra cobijo en las teorías de Offe y Haberlas -que defenderemos- y de Gomes Canotilho.

En el Il capítulo trataremos de las diversas formas de subcontratación o tercerización. Analizaremos los datos recientes sobre la tercerización, el valor de los salarios y una comparación con los trabajadores no tercerizados. Nos referimos, también, a un análisis del fenómeno en América Latina y en la UE, además de los casos permitidos por el ordenamiento jurídico brasileño, así como las recientes decisiones de los tribunales superiores con respecto al tema.

No habrá, en este punto, ninguna definición o un análisis más crítico sobre la constitucionalidad de la tercerización, que se analizará en el último capítulo. Presentaremos algunas críticas, concretamente con respecto a la subcontratación en el sector público, a partir de la decisión dictada por el Supremo Tribunal Federal en la Acción Directa de Constitucionalidad $16^{5}$.

En el III capítulo haremos una crítica a la subcontratación de una forma más contundente. Analizaremos el concepto de subordinación vigente en las legislaciones de los más diversos países occidentales, Brasil, España, Chile, Francia y Portugal, intentando dar una nueva visión a lo que efectivamente significa trabajar de forma subordinada.

\footnotetext{
${ }^{5}$ www.stf.gov.br
} 
Quien presta un servicio subordinado, puede acabar alienando su propia existencia al tomador del trabajo. Su ser en el mundo deja de ser un ser para sí mismo para ser un ser para el otro. El trabajador acaba prestando trabajo vinculado a un contrato de empleo, según el capricho de un tercero, que es quien le da las órdenes y dice lo qué hay que hacer, cómo hacerlo, con quien hacerlo. La subordinación de la voluntad no permite deseos. Compele deseos.

Igual situación encontramos en la subcontratación. Si hay sujeción de la voluntad en una relación de empleo entre empleado y empleador, con mayor razón habrá en una relación triangular, a través de un intermediario de mano de obra. En estos casos hay la doble alienación. El doble desprendimiento del ser en el mundo y la doble sujeción de los deseos, que deriva de la doble sujeción a ordenes, instruciones y intereses, a gusto de dos tomadores de trabajo.

Todos estos elementos servirán de pilares para nuestra investigación, para llegar a la conclusión de si es o no posible la subcontratación de trabajadores en Brasil.

¿Es esto posible si la norma constitucional no autoriza la doble subordinación?

Analizaremos estas cuestiones y daremos cumplida respuesta a las mismas en los capítulos III y IV.

Podremos ver que estar subordinado no es sólo estar sujeto a las órdenes. No intervienen sólo las órdenes directas. La sujeción al poder por parte de un tercero puede producirse incluso en los casos donde no hay un determinado agente superior que lo que hace expresamente. Las órdenes de producción, provenientes de un sistema informatizado que estandariza las acciones del trabajador y trata de alcanzar un fin, somete también al trabajador al poder del tomador del trabajo convirtiéndole en un empleado 
Intentaremos superar el consagrado por la jurisprudencia brasileña de que hay un vínculo de empleo cuando un determinado individuo trabaja vinculado a la actividad-fin del tomador. Incluso porque nadie sabe bien lo que es la actividad-fin. Tanto es así que el Tribunal Supremo español acabó por decidir, en los casos de subcontratación, lo que es "propia actividad"` prevista en el artículo 42 del Estatuto de los Trabajadores, dando una interpretación restrictiva.

En nuestro análisis del contexto brasileño, tomaremos dos instrumentos como claves en nuestra argumentación: la Súmula 331 del Tribunal Superior del Trabajo y el artículo 7º I, de la Constitución brasileña de 1988.

En el IV y último capítulo abordaremos la cuestión central de esta investigación: la (in)constitucionalidad o no de la subcontratación de los trabajadores en Brasil. Los límites de esta investigación no tendrán en cuenta la deslocalización de las empresas y tampoco la transferencia de parte del sector productivo a otras empresas tales como sucede en el caso de las empresas automovilísticas. El tema central concierne a los trabajadores en régimen precario, como por ejemplo vigilancia, limpieza, informática, compensación bancaria entre otros.

No vamos a detenernos en el examen de la subcontratación que mejora la situación económica y social de los trabajadores dado que ésta es expresamente permitida por la norma constitucional brasileña cuando, en el encabezamiento del artículo $7^{\circ}$, establece que son derechos de los trabajadores los destinados a la mejora de su condición social.

\footnotetext{
${ }^{6}$ SS.TS, de 29 de octubre de 1998, Ar/9049 y de 20 de julio de 2005, Ar/5595. PEDRAJAS MORENO, Abdón y SALA FRANCO, Tomás, Contratas y empresas de trabajo temporal; responsabilidades, Tirant lo Blanch, Valencia, 2006, p. 34, e ALBIOL MONTESINOS, Ignacio, ALFONSO MELLADO, Carlos, BLASCO PELLICER, Ángel y GOERLICH PESET, José Maria, Estatuto de los trabajadores: concordando con la jurisprudencia de los Tribunales Constitucional y Supremo; Tirant lo Blanch, Valencia, $2^{\mathrm{a}}$ ed., 2001, p. 381
} 
Se constata, sin embargo, que el problema de la doble alienación, en teoría, permanece, y debe analizarse dicha ventaja caso por caso por el intérprete, aunque, se reconoce, las meras diferencias salariales por sí solas no compensan la alienación de la existencia del trabajador con más de un tomador del trabajo.

También nos ocuparemos del control de constitucionalidad de las leyes. No analizaremos la cuestión de si esta forma de control perjudica o no el principio democrático de la separación de los poderes y de la soberanía del pueblo. Nuestra investigación se limitará a presentar la actuación del poder judicial como garante de la democracia a través de la interpretación constitucional vinculada a los derechos fundamentales y a la dignidad humana. ${ }^{7}$

Prestaremos especial atención a la relación de empleo como regla constitucional absoluta. A partir de la teoría kantiana, la norma del artículo 7ํㅗ I, de la Constitición brasileña de 1988 establece que se contempla como un derecho de los trabajadores además de otros, la relación de empleo. Pero ¿a qué relación de empleo se refiere? ¿Podría servir este concepto para justificar la subcontratación?

La Consolidación de las Leyes del Trabajo brasileña -CLT- no autoriza la subcontratación, salvo en los casos de contrata de obra (y no de servicios), conforme al artículo 455. Además, la regla es la contratación bilateral, directa empleador y empleado, en la forma de los artículos $3^{\circ}$ y 442 del mismo texto.

Con este trabajo de investigación, pretendemos presentar una teoría un tanto diferente de la habitualmente propugnada por la jurisprudencia y la doctrina. Son las teorías procedentes de las Universidades, Facultades y grupos de estudios aquellas que permiten el avance del conocimiento. Es lo que hace a la vida digna de ser vivida. Lo que nos motiva es intentar integrar a la mayoría de la población

\footnotetext{
${ }^{7}$ Ver BELLOSO MARTín, Nuria, "Algunos dilemas sobre la jurisdicción constitucional". En Revista do Direito no. 33, Programa de pós-graduação em direito - PPGD, Santa Cruz do Sul, Edunisc, junho/dezembro de 2010, passin.
} 
en un mismo objetivo de reconquista de conciencia de clase y su aplicación a los contratos de trabajo subordinados, estos como agentes de transformación.

En cuanto a la metodología utilizada en nuestra investigación, destacamos la hermenéutica constitucional, además del método deductivo. Aclaramos seguidamente algunos de los términos que más frecuentes utilizamos a lo largo de nuestra Tesis Doctoral.

Entendemos por súmulas las decisiones reiteradas de los tribunales pasadas, por la decisión de estos mismos tribunales, a enunciados, que, salvo las súmulas vinculantes del Supremo Tribunal Federal, no vinculan a los jueces de instancias inferiores. ${ }^{8}$

El término tercerización será usado como sinónimo de subcontratación de trabajadores para prestación de servicios. No analizaremos la cuestión, como ya hemos dicho anteriormente, de la deslocalización de las empresas o incluso la transmisión, como sucede en las empresas montadoras de vehículos, de parte de

\footnotetext{
${ }^{8}$ En el derecho brasileño, se llama "súmula" a un expediente que registra la interpretación pacífica o la mayoritaria adoptada por un Tribunal con respecto a un tema específico, con la doble finalidad de hacer pública la jurisprudencia para la sociedad, así como de promover la uniformidad entre las decisiones. Es la jurisprudencia que, cuando votada por el "Supremo Tribunal Federal" se convierte en un precedente obligatorio para que todos los demás tribunales y jueces, así como la administración pública, directa e indirecta, tendrá que seguir. En la práctica, adquiere fuerza de ley, creando un vínculo jurídico y poseyendo efectos erga omnes.

Finalmente, hay que tener presente que la citada "súmula" no vincula el Poder Legislativo, bajo pena de crear una indeseable petrificación legislativa, ni siquiera al propio STF, que puede alterar el sentido defendido en una "súmula" vinculante, mediante votación que reúna el mismo quórum necesario para su aprobación inicial ( 2 / 3 de sus miembros).

La súmula vinculante se creó el 30 de diciembre de 2004, mediante la Enmienda Constitucional no 45, que añadió el artículo 103-A de la Constitución brasileña: "El Supremo Tribunal Federal podrá, de oficio o a instancia de parte, mediante decisión de dos tercios de sus miembros, después de reiteradas decisiones sobre materia constitucional, aprobar una "súmula" que, a partir de su publicación en la prensa oficial, tendrá efecto vinculante en relación con los demás órganos del Poder judicial y con la administración pública directa e indirecta, en las esferas federal, estatal y municipal, así como proceder a su revisión o cancelación, en la forma establecida en la ley". En la actualidad una de las propuestas más importantes en el anteproyecto del nuevo Código de Proceso Civil Brasileño, que está con su aprobación en trámite, es la creación de un sistema de precedentes vinculantes para todas las instancias. En http://pt.wikipedia.org/wiki/Súmula. Acceso el 01 de mayo de 2011 a las 23:00.
} 
la producción a otras empresas, o incluso los casos de obra, en particular la construcción civil.

Tercerización, para esta Tesis Doctoral, es la contratación, por parte de una determinada empresa, de trabajadores mediante una persona interpuesta, ya sea por trabajo temporal, ya sea en los demás casos permitidos en la ley, para ejecutar un determinado servicio, en particular de vigilancia, orden y limpieza, compensación bancaria, carga y/o descarga, entre otros, formando una especie de contrato de trabajo triangular.

No descuidaremos, obviamente, los contratos de obra, especialmente porque la CLT se ocupa de los mismos cuando autoriza la subcontratación (artículo 455). Con todo, las referencias serán escuetas.

El término emancipación tendrá como base la teoría de Habermas. Para emanciparse se debe permitir que "todos", a través de la acción encaminada a la comprensión, debatan, haciendo que gane el mejor argumento. No puede haber influencias nefastas provenientes del poder económico y del poder administrativo burocrático, sino sólo la razón con el fin de obtener lo mejor para la colectividad.

Ganará el mejor argumento, aun cuando éste no sea el propio. Ello implica aceptar al otro, respetar su opinión y sus fundamentos y someterse a los consensos originados en el debate racional y democrático. Este procedimiento, ampliamente democrático, que conducirá a la verdad. La verdad, para Habermas, está vinculada a este procedimiento de interacción democrática.

Todo eso ayuda a legitimar el Estado de Derecho, esta teoría del discurso y acción comunicativa, dirigida al discurso fundamentado y libre, permitiendo que los seres humanos construyan su propia historia en conjunto con las personas que los rodean, liberando al hombre de situaciones de servidumbre y de despolitización, 
creando el llamado sujeto del conocimiento ${ }^{9}$. Eso traerá la emancipación, concepto este central en esta investigación.

Esta investigación también está impregnada de nuestra actuación como juez laboral y en la Escuela Judicial del Tribunal Regional del Trabajo de la Cuarta Región, donde hemos desarrollado varios programas de formación de jueces y magistrados, además de convenios para cursos de posgraduación con la Universidad Federal de Rio Grande do Sul, Pontificia Universidad Católica de Rio Grande do Sul.

Contribuyen también a la elaboración de esta Tesis Doctoral, el ejercicio, junto a la asociación de los jueces del trabajo de Rio Grande do Sul, (AMATRA IV), de la titularidad de las secretarías cultural y de asuntos jurídicos.

Por último, las investigaciones que hemos llevado a cabo para la elaboración de esta Tesis Doctoral se han realizado en diversos contextos. En Uruguay, en la Universidad de la República (UDELAR), en agosto de 2008; en España, en la propia Universidad de Burgos (UBU), en dos etapas, en junio/09 y en junio/10; en Brasil, en la Universidad de Santa Cruz do Sul (UNISC), desde septiembre hasta diciembre de 2009; y en Paris, Universidad Paris X, Nanterre, de 05 de enero hasta 04 de febrero de $2012^{10}$.

Abusando de la benignidad de los miembros del tribunal juzgador de esta Tesis Doctoral, les rogamos realicen una lectura sin prejuicios. Reconocemos que el tema es controvertido. Con esta investigación nos enfrentamos a la jurisprudencia brasileña ya establecida.

\footnotetext{
${ }^{9}$ GESTA LEAL, Rogério, "Habermas, Jürgen". En Dicionário de Filosofia do Direito. Vicente de Paulo Barreto (org.), Rio de Janeiro; Unisinos e Renovar, 2006, p. 404/406.

10 En relación a las notas a pie de página, dado que son mucho más numerosas las citas introducidas en portugués que en otros idiomas, por cortesía, hemos optado por traducir al español solamente las portuguesas, salvo la súmula 331 del TST. Las citas en otras lenguas y la súmula 331 , para intentar respetar la literalidad de lo expresado, las hemos transcrito en su lengua original.
} 
Capitulo I

La Flexibilización de las normas laborales y la democracia distributiva 


\subsection{Introducción.}

Lo que se pretende abordar en este apartado tiene que ver con la cuestión de la conciencia de clase, la emancipación y la democracia. Si la flexibilización y la desregulación de los derechos de los trabajadores acaba por alejarles aún más del verdadero "yo", una propuesta de democracia concreta y real intenta recuperar éstos términos.

Se sabe que así es difícil hacer, incluso porque la estructura social, el tejido social, está cada vez más contaminado por la conciencia de clase del tomador del trabajo. Este hecho, sin embargo, además de esclavizar emocionalmente al trabajador, acaba por esclavizar también al tomador del trabajo, sin que ambos sepan de eso. La diferencia es la extrema miseria que, cada día, más y más trabajadores están sometidos, recibiendo muchos de ellos menos de doscientos cincuenta dólares estadounidenses al mes, contrariando normas nacionales e internacionales ${ }^{11} 12$ en materia de trabajo.

Si la prensa y los medios de comunicación, además de los grandes conglomerados nacionales e internacionales, mantienen no sólo las clases más bajas en la total ignorancia, sino también la clase media y parte de la clase rica, cabe a aquéllos que están efectivamente comprometidos con la verdadera emancipación llamar la atención para estos hechos.

\footnotetext{
11 La creación de la Organización Internacional del Trabajo en 1919 tuvo tres objetivos principales: el humanista, en respuesta a las demandas clasistas que se afirmaban en los países donde el proceso industrial llevó a la miseria a los trabajadores; el político, para frenar el temor de que el creciente descontento de la clase obrera acabaría por causar grandes conflictos sociales, que podrían generar en revoluciones; y el económico, para equilibrar los costes de producción, evitando que unos países adoptaran, y otros no, las normas de protección al trabajo (RAUPP BOCORNY, Leonardo, A valorização do trabalho humano no Estado Democrático de Direito, Porto Alegre; Sérgio Antônio Fabris Editor, 2003, p. 59/60). En el caso de España, por ejemplo, la crisis económica de 2009/2010 trajo no sólo la reducción de los derechos sociales sino también un desempleo que puede llegar al $20 \%$ de la población económicamente activa. La situación es tan grave que hoy se discute la reducción de otros derechos sociales, por años "intocables", como el valor de los salarios.

${ }_{12}$ La OCDE informa que en 2012 el desempleo, en España, llegará hasta el 23\% de la poblacion económicamente activa y que en 2013 el indice no bajará del $22 \%$. En el segundo semestre de 2011 la tasa de paro estuvo en el $21,5 \%$ de la poblacion económicamente activa. http://www.elmundo.es/elmundo/2011/11/28/economia/1322474768.html - acceso el 08 de enero de 2012, à las 19h27min, horario de Paris.
} 
Hay, sin embargo, obstáculos. Los llamados "tanques de pensamiento", que trajeron a la superficie, al inicio de la década de los 80', el llamado neoliberalismo, generado, durante el período keynesiano, contribuyen de forma importante dentro de las universidades, los gobiernos y los medios de comunicación para que esta lógica excluyente y perversa se mantenga.

Es por eso que es necesaria una democracia distributiva-comunicativaeducativa-cultural, fruto de la acción comunicativa que debe tener como base la igualdad de condiciones, donde deberá vencer el mejor argumento ${ }^{13}$. Es a partir de esta idea inicial que se comienza a educar al pueblo y al trabajador más allá del capital para que ellos, por la educación y la cultura, retomen su conciencia de clase, dando lugar a la emancipación. ${ }^{14}$

13 Para José Bolzan la "acción comunicativa como coronación de la racionalidad comunicativa se refiere a la interacción realizada de modo intersubjetivo teniendo el lenguaje como un mecanismo coordinador. Sólo son pasibles de entendimiento dos sujetos racionales capaces de operar lingüísticamente. El concepto central de la acción comunicativa gira alrededor de la interpretación, la cual propone el entendimiento dialógico como forma de negociación en la construcción del consenso. (...). Tenemos, por tanto, que la acción comunicativa se dirige al entendimiento que, con relación a la tradición quiere la renovación del saber cultural, con relación a la acción social sirve para el establecimiento de solidaridad y, con relación a la socialización, sirve para el desarrollo de la identidad individual" (BOLZAN, José, Habermas: Razão e racionalização, ljuí; editora UNIJUI, 2005, p. 100/101).

${ }_{14}$ En el caso de Europa, en especial de España, los derechos sociales de los trabajadores están siendo reducidos. El 10 de febrero de 2012 se ha publicado el Real Decreto-Ley 3/2012 de medidas urgentes para la reforma del mercado laboral. Una de las medidas más polémicas ha sido el de la indeminzación por despido, reduciéndose al indeminzación de días por año trabajado. En realidad, no parece ser esta la solución, ya que no hay ejemplo, en occidente, de países donde se haya producido flexibilización cuya consecuencoa haya sido el avance económico. Se cuestiona si la lectura qUe habría que hacer es la del interés es facilitar los despidos y aumentar las ganancias fruto del trabajo. El objetivo, ¿es meramente económico, sin perspectiva social?. Para saber un poco más sobre esta reforma ver BAYLOS, Antonio, "Crisis y Derecho del trabajo o el Derecho del trabajo en crisis. Sobre la reforma laboral española de 2012". En Derecho laboral. Revista de doctrina, jurisprudencia e informaciones soiales, Montevideo, Uruguay, tomo LV, n. 245, eneromarzo 2012, Fundación de Cultura Universitaria, p. 37/56; CHACARTEGUI JÁVEGA, Consuelo, "La actuación de las empresas de trabajo temporal como agencias de colocación. La crisis como pretexto en el avance de la iniciaitiva privada", en Revista de derecho social, n. 57, 2012, p. 71/84; CRISTÓBAL RONCERO, Rosario, "Real Decreto-Ley 3/2012, de 10 de febrero, de medidas urgentes para la reforma del mercado laboral". En Revista española de dercho del trabajo, n. 154, Civitas, Thompson Reuters, abril-junio 2012, p. 217/219; SIERRA BENÍTEZ, Esperanza Macarena, "Comentario de las novedades del Real Decreto Ley 3/2010, de 10 de febrero, de medidas urgentes para la reforma del mercado laboral español", en Revista Justiça do Trabalho, Porto Alegre; HS Editora, no. 344, agosto de 2012, pp. 100/104. Sobre ello, aún, Miguel RodriguezPiñero y Bravo-Ferrer añade que la reforma, que empezó en 2010 y 2011 en en gobierno socialista 
Es de esta forma que los derechos de los trabajadores serán preservados. Serán considerados como verdaderos derechos fruto de conquistas y del proceso comunicativo. Es en cuanto se podrá ver la Constitución como un documento de inclusión social centrado en el trabajo humano y en la dignidad humana. Es no permitiendo que el hombre sea extremadamente explotado por el propio hombre, al poder crearse la posibilidad de doble alienación, doble transformación del humano en cosa, que se podrá alcanzar el objetivo de una sociedad libre, justa y solidaria $^{15}$.

Comenzamos el estudio por la cuestión de la flexibilización y desregulación de los derechos de los trabajadores para, seguidamente, tratar las cuestiones de clase, democracia distributiva-comunicativa-educativa-cultural, así como la importancia de las acciones comunicativas en la elaboración de la conciencia colectiva, además de la dignidad humana.

El texto es un poco polémico. Se pide que el lector se desnude de sus prejuicios y lo lea de forma integral antes de llegar a sus conclusiones.

\footnotetext{
y que fue aprofundizada por el gobierno del Partido Popular (PP), fue imposta por el Consejo de Europa para tornar más blanda la reglación del contrato de trabajo y de la negociacion colectiva. RODRIGUEZ-PIÑERO, Miguel, "La réforme espagnole de la negociation collective de 2011/2012". Dans Revue de droit comparé du travail et de la sécurité sociale, 2012/1, Bordeaux, Université Montesquieu, 2012, p. 2; GIL Y GIL, José Luis, "Espagne", Dans Revue de droit comparé du travail et de la sécurité sociale, 2012/1, Bordeaux, Université Montesquieu, 2012, p. 119/120. Aún, Eduardo Martín Puebla, añade que la nueva reforma laboral habida en España ha flexibilizado el acceso, el despido y la ejecución del contrato. Él enseña, aún, que el problema del mercado laboral español, sin embargo, no ha mejorado mismo con las medidas tomadas antes del Real Decreto $3 / 12$, por el gobierno socialista y que el paro es, hoy, aún más grande que antes, $24,44 \%$ de la poplación economicamente activa. MARTíN PUEBLA, Eduardo, "La reforme 2012 du marché du travail en Espagne: la flexibilité jusqu'au bout", dans Revue de Droit du Travail numero 7/8, juillet/août 2012, Dalloz, p. 422.

En Grecia la ley 4.046/2012 ha puesto la necesidad de reducción del sueldo minimo, a partir de 14 de febrero de 2012, en 22\%, y la ley 4.052/2012 ha alterado la ley del trabajo a través de empresas de trabajo temporal, ello para aumentar la competitividad de la economia grega. PAPADIMITRIOU, Costas, "Grèce", dans Revue de droit comparé du travail et de la sécurité sociale, 2012/1, Bordeaux, Université Montesquieu, 2012, pp. 127/128.

${ }_{15}$ Art. 3ํㅡㄴ Constituyen objetivos fundamentales de la República Federal de Brasil: I - construir una sociedad libre, justa y solidaria; (...).
} 


\subsection{Flexibilización y desregulación}

Antes de adentrarnos en el tema de la flexibilización, es preciso hacer algunas consideraciones conceptuales del término. Comenzamos, por tanto, por lo que consta en los diccionarios especializados en la materia para, después, transcribir lo que entiende la jurisprudencia ${ }^{16}$ y la doctrina ${ }^{17}$.

La flexibilización es el "conjunto de procesos y de medidas dirigidas a alterar las reglamentaciones concernientes al mercado de trabajo y a las relaciones de trabajo, tratando de hacerlas menos ordenadas y posibilitando arreglos considerados innovadores frente a una fuerte tradición de control legal de las relaciones laborales". La flexibilización se contrapone a esta tradición, que tiene como fin la protección a los trabajadores ${ }^{18}$.

Oscar Ermita Uriarte apunta que hay diferencia entre desregulación y flexibilización. La primera sería fruto de la actuación unilateral de las autoridades estatales o empleador para disminuir o eliminan derechos de los trabajadores. La denomina flexibilización unilateral. La segunda sería una especie de adaptación

16 Sobre la jurisprudencia en específico, que interesa bastante a la tercerización, Ramos Filho afirma que la precarización de los derechos de los trabajadores, aunque pueda ser de responsabilidad también del proceso legislativo, lo es, más aún, por la actuación de los jueces laborales, que, con el fin de ampliar el bienestar de los empresarios, acabó por sacrificar la clase trabajadora. (RAMOS FILHO, Wilson, "Bem-estar das empresas e mal-estar laboral: o assédio moral empresarial como modo de gestão de recurso humanos". En Cadernos da AMATRA IV. $11^{\circ}$ Caderno de estudos sobre processo e direito do trabalho, Porto Alegre; HS Editora, 2009, p. 103).

17 Sobre la influencia de los aparatos ideológicos del estado en el derecho y en la enseñanza jurídica, es interesante el pasaje de Guilherme Guimarães Feliciano. Para él "Todas estas características, sobremodo contundentes en el último cuartel del siglo XX, como también las perplejidades e incertidumbres generadas por ellas, seguramente influenciaron el Derecho y la ciencia jurídica en todas sus aspectos: en la formación del derecho (interactuando con las fuentes materiales), en la enseñanza del Derecho (dictando contenidos e ideologías para los grados curriculares) y en la aplicación e interpretación del Derecho (determinando la colonización cultural de las clases formadoras de opinión, en cuyo epicentro están juristas, operadores del Derecho y grandes usuarios del sistema judiciario)". GUIMARÃES FELICIANO, Guilherme, "Direito, Marx, Althusser, Neoliberalismo - Direito e Economia: Marx, Althusser e os Desafios da Sociedade Capitalista na Era Pós-industrial”. En Revista Síntese Trabalhista, Porto Alegre; Síntese Editora, número 180, junio/2004, p. 140.

18 HOLZMANN, Lorena e PICCININI, Valmiria, "Flexibilização". En Dicionário de trabalho e tecnologia. Organizadores Antonio David Cattani e Lorena Holzmann, Porto Alegre; Editora da UFRGS, 2006, p. 131. 
autónoma, negociada y condicionada, a cambio de determinadas exigencias o contraprestaciones. ${ }^{19}$ Ambas, sin embargo, suprimen algunos derechos de los trabajadores. ¿Qué es lo que cambia? Como podemos ver, cambia la forma, o el "cómo hacer".

Para José Martins Catharino, sirviéndose de Arturo Hoyos, la flexibilización es la posibilidad dada a la empresa para que pueda servirse de los mecanismos jurídicos que le permitan ajustar su producción, empleo y condiciones de trabajo teniendo en cuenta las oscilaciones rápidas y continuas del sistema económico, tales como la demanda efectiva, la tasa de cambio, los intereses de los bancos, la competencia internacional, además de otros factores que demandan ajuste con celeridad. $^{20}$

En un sentido amplio, la "flexibilización" es una manera de adaptación de las normas jurídicas para atender las alteraciones verificadas en la economía y en sentido estricto, es la adaptación de las normas jurídicas laborales para atender a las alteraciones en la economía, reflejadas en las relaciones entre trabajo y capital. $^{21}$

Según la visión neoliberal, la protección al trabajo será más rígida cuanto mayor sea el abanico de beneficios asegurados a los trabajadores y mayor regulación exista en cuanto a las condiciones de venta del trabajo. ${ }^{22}$

El significado de la flexibilización se pone de manifiesto si lo comparamos con la calidad existente en las relaciones laborales después de la segunda guerra mundial, especialmente donde se desarrolló el Estado de Bienestar social. El contrato de empleo en este período era a plazo indeterminado, la jornada de trabajo integral, los empleos de larga duración, entre otros. Con la flexibilización

\footnotetext{
${ }^{19}$ ERMIDA URIARTE, Oscar, A Flexibilidade, São Paulo: LTr, 2002, p. 17.

20 MARTINS CATHARINO, José, Neoliberalismo e seqüela: privatização, desregulamentação, flexibilização, terceirização, São Paulo; LTr, 1997, p. 50

${ }_{21}$ MARTINS CATHARINO, José, Neoliberalismo e seqüela (...), ibidem.

${ }^{22}$ HOLZMANN, Lorena e PICCININI, Valmiria, "Flexibilização", cit., p. 131.
} 
crece el número de trabajadores vinculados al contrato por plazo determinado, a tiempo parcial, temporales y por cuenta propia. Para aquéllos que defienden la flexibilización, estas formas contractuales eliminan los obstáculos legales a la movilidad de la fuerza de trabajo en cuanto a la forma de contratación y de despidos. $^{23}$

Con la flexibilización, el proceso de producción se modifica, adoptándose los sistemas del just-in-time y kanban. Estas modificaciones requieren un cambio en las condiciones legales que regulan las relaciones entre el capital y el trabajo, así como las condiciones de uso de la mano de obra, que expresan las condiciones macrosociales de la flexibilización. ${ }^{24}$

Ejemplo de ello es el desplazamiento de las actividades denominadas "medio" hacia fuera de la empresa. Es la llamada tercerización o subcontratación que puede producirse entre empresas o entre empresa y personas, mediante contrato. Esta práctica, sin embargo, implica diferentes grados de precarización ${ }^{25}$ de las condiciones de vida y de trabajo de buena parte de la fuerza de trabajo. ${ }^{26}$

Hay quien defiende la existencia de la flexibilización cualificada. Se emplean a individuos con un índice elevado de escolaridad, en ocupaciones altamente cualificadas, que "ofrecen perspectivas de promoción y movilidad profesional, remuneración elevada y compensaciones subjetivas en cuanto al sentido del trabajo". ${ }^{27}$

\footnotetext{
${ }^{23}$ HOLZMANN, Lorena e PICCININI, Valmiria, "Flexibilização", cit., p. 131.

24 HOLZMANN, Lorena e PICCININI, Valmiria, "Flexibilização", cit., p. 132.

25 Sobre la precarización Irene Galeazzi afirma que "la noción corriente de 'precarización del trabajo', por tanto, tiene como parámetro el régimen de trabajo asalariado y se refiere al proceso de alejamiento del patrón de calidad alcanzado con la aparición de la 'sociedad salarial (...)". GALEAZZI, Irene, "Precarização do trabalho". En: Dicionário de trabalho e tecnologia. Organizadores Antonio David Cattani e Lorena Holzmann, Porto Alegre: Editora da UFRGS, 2006, p. 203.

${ }_{26}$ HOLZMANN, Lorena e PICCININI, Valmiria, "Flexibilização", cit., p. 132.

${ }^{27}$ HOLZMANN, Lorena e PICCININI, Valmiria, "Flexibilização", cit., p. 133.
} 
No es ésta, sin embargo, la regla, dado que la flexibilización acaba por precarizar derechos sociales, tercerizar actividades en su gran mayoría que acaba afectando a trabajadores descalificados, impidiéndoles cualquier posibilidad de ahorro de dinero que no sea para subsistir meramente.

A cuesta de los derechos de los trabajadores, el Estado deja de intervenir en las relaciones de trabajo, espacio ocupado, en estos casos, por las empresas privadas, lo que acaba por fulminar años de conquistas fruto de las luchas de los trabajadores ${ }^{28}$. Estos trabajadores, además de ser mano de obra, pasan a ser piezas de maniobra en las manos de las elites (grandes empresarios, economistas y gestores privados), decidiendo no conforme a sus intereses sino de consenso con lo que quieren estas elites, sin darse cuenta de que así lo hacen. La mitigación de los derechos sociales mitiga la conciencia de sí, la conciencia de clase, el ser en el mundo. Se convierte el humano en esclavo de pocos humanos, esclavos de alma y conciencia, lo que es peor que la esclavitud del cuerpo.

A este respecto apunta Oscar Krost, acerca de la cuestión de la huelga de los trabajadores que se ha discutido mucho con respecto al tema, especialmente el de la intervención del Estado en las relaciones de trabajo, bajo el disfraz de la desregulación y la flexibilización, siempre con la intención de reducir los costes en provecho de las condiciones productivas, analizado sólo por el lado empresarial y en detrimento de las históricas conquistas de los trabajadores, "siendo, al contrario, constantemente invocado éste mismo Estado por quien tanto de él reclama cuando el interés recae sobre la adopción de medidas represivas para

\footnotetext{
${ }^{28}$ Se entiende que en América Latina el desarrollo de los derechos sociales de los trabajadores se produjo más en virtud del paternalismo estatal y copia del modelo de desarrollo de Europa más que por conquistas de estos trabajadores. Y eso se revela especialmente en países dominados por siglos de esclavismo, como es el caso de Brasil. La reducción del ser humano a mera cosa lo hace considerarse mera cosa. Él no posee, por esta razón, ninguna capacidad de reacción. Los derechos por acaso concedidos a él lo son por fuerza de presión internacional o incluso por gracia del gobernante que, la mayoría de los casos, se ve en el poder por razones de carisma o incluso de tradición (Weber).
} 
cohibir el principal medio de manifestación y del ejercicio de presión de los trabajadores, por la huelga". ${ }^{29}$

Para muchos, la flexibilización es una especie de ángel y para otros de demonio. Para los primeros es una forma de salvar el país de los males del desempleo. Para otros, es una forma de destruir todo aquello que el trabajador conquistó, privilegiando sólo el capital, haciendo que el trabajador pague la cuenta de la o de las crisis económicas. ${ }^{30}$

Cristine Berger añade que, hasta el presente momento, no hay ninguna noticia de datos económicos probadamente positivos, desde una perspectiva económica, fruto de la flexibilización ya en vigor. En el caso de Brasil, por ejemplo, la flexibilización acabó por generar el bajo e inestable crecimiento económico, con una brutal reducción del mercado de trabajo, disminución de los empleados en las grandes empresas, un aumento de la tercerización y de otras formas de precarización, complementadas por una constante presión para que se flexibilizara la remuneración y la jornada de trabajo. ${ }^{31}$

Oscar Ermita Uriarte apunta que estas demandas (flexibilizaciones) se producen por la falta de soluciones presentadas por la economía y por la imposibilidad de que la economía y la ideología liberal tengan que crear y mantener empleos, pasando la responsabilidad al derecho laboral que, como veremos más adelante, ni siquiera tiene responsabilidad en relación al aumento de los costes de producción. ${ }^{32}$

\footnotetext{
29 KROST, Oscar, "Interditos proibitórios e greve: por uma tutela da posse compatível com o exercício do direito de paralisação do trabalho". En Cadernos da AMATRA IV. $11^{\circ}$ Caderno de estudos sobre processo e direito do trabalho, Porto Alegre; HS Editora, 2009, p. 69.

${ }_{30}$ BERGER, Cristine, "A flexibilização do direito do trabalho como meio de retrocesso social". En: Revista Justiça do Trabalho, número 299, Porto Alegre: HS Editora, noviembre/2008, p. 65/66.

${ }^{31}$ BERGER, Cristine, "A flexibilização do direito do trabalho como meio de retrocesso social", cit., p. 67.

32 ERMIDA URIARTE, Oscar, A Flexibilidade, cit., p. 55.
} 
Un Ejemplo de que no es con la flexibilización o tercerización como se podrá impedir la crisis financiera de las empresas y de que el coste del trabajo no es capaz, por sí mismo, de causar la quiebra de cualquier empresa, lo encontramos en la Toyota. Esta empresa japonesa que innovó la producción con el sistema llamado "Toyotista" que, entre otras recomendaciones, justificaba la reducción del coste de la producción con la tercerización de las actividades a otras empresas, y que acumuló, en 2008, una pérdida de 1,7 mil millones de dólares americanos, con una reducción de las ventas en Estados Unidos de América del Norte del 34\% en noviembre de 2008 , impulsada por un aumento del $27 \%$ en el valor del inen japonés con relación a la moneda estadounidense. ${ }^{33}$

Flexibilizar las normas de protección al trabajo puede incluso parecer una postulación legítima de las elites y del empresariado. Eso sin embargo, no es verdad. Resulta que la reglamentación o intervención del Estado en la relación capital y trabajo se produjo con el fin de garantizar los privilegios de las elites, manteniendo el modo de producción capitalista intacto y expandiéndolo como cultura de bienestar y de igualdad, este último por el concepto de igualdad formal.

Sobre el tema Wilson Ramos Filho apunta que la intervención del Estado en el contenido mínimo de los contratos de compraventa del trabajo o de la fuerza de trabajo en los modelos capitalistas derivan de los términos de las elites empresariales y políticas de que las ideas comunistas y socialistas fuesen postas en práctica, poniendo en riesgo la continuidad del modo de producción capitalista, "concepción ésta sintetizada en la concepción según la cual el intervencionismo estatal europeo y su expresión política, la socialdemocracia, tendría 'cedidos los anillos para no ceder los dedos". ${ }^{34}$

Con la toma del poder central por los militares, ha inicio la primera grande ola flexibilizante en Brasil. La edición de la ley del Fondo de Garantía por Tiempo de

\footnotetext{
${ }^{33}$ Revista Veja. Edição 2093, ano 41, número 52, 31 de dezembro de 2008, p. 36/7.

34 RAMOS FILHO, Wilson, "Bem-estar das empresas e mal-estar laboral (...)", cit., p. 93/94.
} 
Servicio, que abarata el despido sin causa justificada, es sólo el primero paso hacia la flexibilización de las normas laborales ${ }^{35}$, proceso éste que, hasta la presente fecha, se está poniendo en marcha, según se podrá ver en el capítulo siguiente de este estudio, en cuanto a la legislación con el objeto de la legitimación de la tercerización.

Desde la perspectiva de los derechos sociales, la salida de la crisis económica actual es una mayor regulación. "La intervención es uno bien para el capitalismo, como medicina para los enfermos. El capitalismo sin intervención es un ser contradictorio, irracional y suicida, además de asesino, porque sale acabando con los países". La regulación, por lo tanto, es el camino. ${ }^{36}$

Él añade que "El Derecho del Trabajo vino como un mecanismo para equilibrar una relación socio-económica manifiestamente desigual, de ahí su carácter intervencionista. Su papel es el de asegurar que, a través de la norma jurídica, se alcancen las condiciones más favorables de inserción del trabajo y del trabajador en la sociedad económica. Fue él quien dio forma a una idea hasta entonces abstracta, la de justicia social". Más adelante Godinho Delgado pone que "El sistema económico es muy eficiente, desde el punto de vista tecnológico y de generación de riquezas, pero es cruel e ineficiente desde el punto de vista de sus propias necesidades y fuerzas, y con relación a la distribución de justicia. Prácticamente todas las lecciones del pensamiento desregulamentador han ido mal". 37

De otro lado, puede decirse, en especial en Europa y España que la flexibilidad es basicamente la capacidad del empresario de gestionar la fuerza de trabajo para hacer frente al mercado que cambia. Ella puede presentarse de dos

\footnotetext{
${ }_{36}^{35}$ RAMOS FILHO, Wilson, "Bem-estar das empresas e mal-estar laboral (...)", cit., p. 95, nota 5.

http://ext02.tst.gov.br/pls/no01/NO_NOTICIAS.Exibe_Noticia?p_cod_area_noticia=ASCS\&p_cod_n oticia=9898 - Acceso el 21 de octubre de 2009, a las $21 \mathrm{~h} 05 \mathrm{~min}$.

http://ext02.tst.gov.br/pls/no01/NO_NOTICIAS.Exibe_Noticia?p_cod_area_noticia=ASCS\&p_cod_n oticia $=9898$ - Acceso el 21 de octubre de 2008, a las 21h05min.
} 
formas: numerica o externa y funcional o interna. La primera alude la capacidad de la empresa "de realizar contrataciones y despidos, asi como para organizar su proceso productivo acudiendo a los servicios de otras empresas (empresas de trabajo temporal)". La segunda trae la capacidad empresarial de modificar las condiciones de empleo y la organización del trabajo dentro de la empresa. "Por conseguinte, esta segunda modalidad se encuentra estrechamente vinculada a los distintos elementos que definen tanto las condiciones de los trabajadores, como los poderes del empresario con vistas a su modificación". ${ }^{38}$

Es interesante decir, aún, que a partir del Consejo Europeo de Primavera de 2006 el debate en el ambito de la Unión Europea sobre la flexiseguridad, la mezcla entre la flexibilidad y la seguridad, entra en una fase máxima de aceleración. No es solamente el Libro Verde que trae informaciones sobre la flexiseguridad. En junio de 2006 la Dirección General de Empleo, Asuntos Sociales e Igualdad de Oportunidades de la Comisión constituye un grupo de espertos para revisar la noción de flexiseguridad, así como las practicas de los Estados miembros en este campo. $^{39}$

El grupo de trabajo identifica, porque la situación cambia conforme el pais, cuatro grandes itinerarios:

"Los desafíos que se presentan en cada uno de los cuatro itinerarios son: 1) reducir la segmentación del mercado de trabajo; 2) mejorar la adaptabilidad de las empresas y trabajadores, desarrollando y fortaleciendo la seguridad en los mercados transicionales;

3) reducir las diferencias apreciables entre los trabajadores en relación con las oportunidades y capacidades, y 4) mejorar las oportunidades de empleo a favor de los beneficiarios de prestaciones, regularizando el trabajo no declarado". ${ }^{40}$

\footnotetext{
38 VALDÉS DAL-RÉ, Fernendo y LAHERA FORTEZA, Jesus, "La flexiseguridad laboral en España". En Documento de trabajo 157/2010, http://www.falternativas.org/laboratorio/documentos/documentos-de-trabajo/la-flexiseguridadlaboral-en-espana, p. 16/17. - aceso el 26 de agosto de 2013, a las 18h18min.

39 VALDÉS DAL-RÉ, Fernendo y LAHERA FORTEZA, Jesus, "La flexiseguridad laboral en España", cit., p. 31.

${ }_{40}$ VALDÉS DAL-RÉ, Fernendo y LAHERA FORTEZA, Jesus, "La flexiseguridad laboral en España", cit., p. 32.
} 
En España, las tres reformas flexibilizadoras que hubo, en 1984, 1994 y en 1997 (y añado yo en 2012, con el RD 03/12), traen las tres formas de flexibilización, la externa del trabajo tempral, la interna de la negociación colectiva y la externa de los despidos (añado yo a esta ultima la reforma de 2012, RD 03/12) y hacen las relaciones laborales extraordinariamente flexibles, haciendo con que se pueda tener, en un pequeño espacio de tiempo altas cotas de empleo y de desempleo. Ello lleva a una gran inseguridad en el empleo, con la dualidad de trabajadores fixos/temporales, lo que pone el modelo español de relaciones laborales como flexible sin seguridad en el empleo, lo que debe ser considerado como unos dos retos del nuevo concepto de flexiseguridad. ${ }^{41}$

En España los punos criticos de la flexiseguridad son: la segmentación laboral, la deficiente empleabilidad, la escasa flexibilidad negociada interna, la mal resuelta conciliación laboral y familiar y la inflexibilidad insegura española. Y las tecnicas de flexieguridad son: costes empresariales y publicos; empleo temporal y desempleo, despido improcedente y desempleo, subvenciones al empleo estable, despidos por edad y proteción social, jubilaciones parciales con gasto social, suspensiones empresariales y desempleo y reducciones de jornada $y$ desempleo. $^{42}$

De aí se puede decir, como lo hacen los autores que

En definitiva, la flexiseguridad en España es paradójica, porque puede ser presentada como un mal modelo dentro de los parámetros europeos de combinación de flexibilidad y seguridad -como una inflexibilidad insegura-, pero ha utilizado de manera intensa y efectiva técnicas redistributivas de costes privados y públicos propias de la flexiseguridad laboral. El riesgo empresarial se ha socializado mediante distintas técnicas con cargo al gasto público, pero sin resultados evidentes en el mantenimiento de empleos, en la calidad de los puestos de trabajo, en transiciones rápidas en el mercado laboral y en el logro de los objetivos europeos de flexiseguridad. La socialización del riesgo ha ido dirigida esencialmente a canalizar o suavizar la destrucción de empleo, lo que, junto con una escasa negociación colectiva de los ajustes de plantilla y una pobre inversión en los servicios públicos de empleo, ha dinamitado cualquier

\footnotetext{
41 VALDÉS DAL-RÉ, Fernendo y LAHERA FORTEZA, Jesus, "La flexiseguridad laboral en España", cit., p. 35/36.

42 VALDÉS DAL-RÉ, Fernendo y LAHERA FORTEZA, Jesus, "La flexiseguridad laboral en España", cit., p. 37/44.
} 
equilibrio posible entre flexibilidad laboral y seguridad en el empleo, en un modelo, paradójicamente, con un gran gasto público en las relaciones laborales. ${ }^{43}$

Y los retos, en España son, cuanto a la flexiseguridad, la reducción de la segmentación laboral, la mejora de la intermediación laboral, la adaptación de la flexibilidad negociada en la empresa, la modernización de la negociación colectiva, la diversificación del emprelo a tiempo parcial, la aposta en la conciliación laboral y familiar, la potencialización de la formación y productividad, la inversión en protección social y el abandono de las inversiones públicas ineficientes. ${ }^{44}$

Dicho lo que es flexibilización y flexiseguridad y haciendo breves referencias a los hechos negativos y positivos, sigue el texto con la paradoja de la estabilización liberal y Estado Social.

\subsection{El Estado social y la paradoja de la estabilización liberal}

El Estado Social no es más que el avance, sin rupturas, del Estado liberal de derecho. Hay una especie de estabilización liberal con la "implementación" del Estado social, según podemos ver en el texto que sigue. Sin embargo, es interesante decir antes en que consiste y se basa el Estado Social, presentando las razones de estabilización liberal más adelante.

En la medida en que el Estado Liberal de Derecho avanza hacia la de Estado Social de Derecho, los derechos fundamentales van dinamizando su propia significación, comenzando a tratar también la acción positiva por parte de los

\footnotetext{
${ }^{43}$ VALDÉS DAL-RÉ, Fernendo y LAHERA FORTEZA, Jesus, "La flexiseguridad laboral en España", cit., p. 44/45.

${ }^{44}$ VALDÉS DAL-RÉ, Fernendo y LAHERA FORTEZA, Jesus, "La flexiseguridad laboral en España", cit., p. 47/52.
} 
poderes públicos. Y lo hace en razón del respeto a la dignidad humana y a la solidaridad. ${ }^{45}$

Y todo ello, como enseña Perez Luño, hizo que el tránsito del Estado Liberal para el Estado Social, "haya supuesto, en este plano, la extensión de la incidencia de los derechos fundamentales a todos los sectores del ordenamiento jurídico y, por tanto, también al seno de las relaciones entre particulares". 46

Como hemos visto, la teoría liberal maximiza la figura del hombre en su aspecto singular, único capaz de decidir sobre su vida, pasiones, intereses, sobre su propiedad. El proyecto jurídico que de ahí deriva tiene como centro este hombre en su aspecto individual y sólo, alienado de su medio-ambiente. Ocurre que hay una reacción a eso. Esta reacción se hace sentir a comenzar por las doctrinas socialistas y también por las crisis vividas por el modelo liberal. El privilegio a la idea de la comunidad en un sentido amplio, va a permitir, en el campo jurídico, al apoyo de la idea del derecho social. ${ }^{47}$

Es también este derecho social que, en el umbral del siglo veinte, esbozará una nueva idea de Estado, muy cerca del perfil liberal, pero que tendrá funciones positivas, dejando de lado el corte minimalista "atado a las garantías internas y externas". El Estado comienza a ser el regulador y promotor del bienestar social. Es la idea de lo que suele llamarse welfare state que se estructurará más en serio después de la segunda guerra mundial, donde el aspecto de la promoción, comenzará a integrar definitivamente la expresión jurídica y política del siglo pasado. ${ }^{48}$

45 PEREZ LUÑO, Antonio E., Los derechos fundamentales. Temas clave de la Constitución española, Madrid; Ed Tecnos, 9a ed.; p. 20/21.

46 PEREZ LUÑO, Antonio E., Los derechos fundamentales, cit., p. 23.

47 BOLZAN DE MORAIS, José Luiz, A idéia do direito social: $O$ Pluralismo Jurídico de Georges Gurvitch, Porto Alegre; Livraria do Advogado Editora, 1997, p. 32/33.

${ }^{48}$ BOLZAN DE MORAIS, José Luiz, A idéia do direito social (...), cit., p. 33. 
Como se observa, el Estado Social comienza a exigir del Estado un papel ya no negativo, sino activo, no sólo que garantiza las libertades individuales, sino que actúa en la protección de los derechos. Es un modelo de Estado garantizador, con "atribución de actuación positiva de garantía de aplicación de los intereses mayores de la comunidad". 49

No existe, como ya hemos mencionado, con el Estado Social, ninguna ruptura con el modelo clásico del Estado de Derecho, sino sólo la concesión, por parte del Estado, de prestaciones positivas para la colectividad, además de la estabilización del modelo liberal jamás roto.

Es por eso que podemos decir que el fin del Estado de Bienestar Social acabó trayendo, en materia laboral, foco de este estudio, la desregulación y la flexibilización de las leyes de protección al trabajo y al trabajador ${ }^{50}$. Esas conquistas de esta forma de Estado comienzan a ser consideradas demasiado caras no sólo para el ente estatal sino también para las empresas privadas que comenzaron a tener dificultades económicas frente a la competitividad internacional.

Es por eso que podemos decir que el fin del Estado de Bienestar Social acabó trayendo la desregulación y la flexibilización de las leyes de protección laboral y el trabajador. Las conquistas de esta forma del Estado comenzaron a ser superadas a partir de que tanto el ente estatal como las empresas privadas, empezaron a tener dificultades económicas frente a la competitividad internacional.

\footnotetext{
49 TRINDADE DE SOUZA, Rodrigo, Função social do contrato de emprego, São Paulo; LTr, 2008, p. 37.

50 El constitucionalismo social fue festejado por la Constitución mejicana de 1917 que estableció ciertas garantías para el trabajador, como límite de jornada, edad mínima para el trabajo, salario mínimo, seguridad social, entre otros, seguido por la constitución de Weimar de 1919 y por la Carta del Lavoro Italiana de 1927, que influyó en países como Brasil y España.
} 
Una de las soluciones predicadas por los nuevos liberales o neoliberales fue justamente la de la desregulación de la relación de empleo y la flexibilización de la legislación laboral. Surgieron la contratación temporal, tercerización o subcontratación, sustitución del sistema de garantía en el empleo por el sistema indemnizatorio (en el caso de Brasil la denominada estabilidad decenal del artículo 478 de la CLT por el régimen del Fondo de Garantía por Tiempo de Servicio), fortalecimiento de los acuerdos entre los sindicatos de empleados y empresa 0 entre sindicatos acerca de los preceptos legales, antes mínimos.

La estructura laboral, anteriormente centrada en derechos laborales sólidos y confortables, ahora está amenazada, corriendo el riesgo de perecer, frente a los problemas económicos.

El Estado Social o de Bienestar Social, no fue más que una forma de "estabilizar la democracia". Dominadas las masas más débiles de la sociedad, resulta también fácil proseguir con el avance acumulativo de capital en las manos de unos pocos. En efecto, con el Estado de Bienestar no había salida. O se hacía de esta forma, o se ponía en riesgo todo el modo de producción.

De una forma más bien blanda, Habermas cree que la ola de juridicización de las garantías laborales tuvo por objetivo el intento de equilibrar en términos jurídicos las disputas que se producirían en el ámbito práctico. Estas normas comienzan a mantener, a niveles aceptables, el conflicto entre las clases sociales. $^{51}$

En las palabras de Moreira el Estado social y democrático de derecho se caracteriza por la constitucionalización de las relaciones de clase. $Y$ son ejemplos de eso las garantías laborales y de la seguridad social. Eso sirve para equilibrar en términos jurídicos los conflictos y las disputas que existen en el ámbito de la

51 MOREIRA, Luiz, Fundamentação do direito em Habermas, Belo Horizonte; Mandamentos Editora, 3a ed., 2004, p. 58. 
acción, del mundo de la vida. En este caso las normas jurídicas tienen la función de mantener, a niveles razonables, el conflicto controlado entre las clases sociales. Debe el Estado social y democrático de derecho, por tanto, absorber los efectos externos de una producción que tiene como base y fundamento estructural la mano de obra asalariada, el trabajo subordinado. ${ }^{52}$

Por todo ello, el núcleo del pensamiento conservador y liberal ha permanecido. La ideología se ha difundido en las grandes escuelas del pensamiento económico, lideradas por Hayek, destacando también como miembros a Milton Friedmann. ${ }^{53}$

Estas escuelas y grupos de pensamiento se han denominado think tanks o estanques de pensamiento. En estos estanques el pensamiento liberal conservador permaneció almacenado subrayando la necesidad de la vuelta al liberalismo. No aceptaban en este grupo economistas y pensadores Keynesianos, ya que eso acabaría por contaminar las ideas promovidas y defendidas por el grupo. $^{54}$

Mantenido por donaciones de grandes empresas los thinks tanks mantienen en equipo técnico de alto nivel y producen textos y artículos, participando en debates en los medios universitarios, medios de comunicación y órganos de asesoría de partidos políticos, condicionando tanto a la opinión publica como al gobierno. $^{55}$

\footnotetext{
52 MOREIRA, Luiz, Fundamentação do direito em Habermas, ibidem.

53 BARBOSA GROS, Denise, Considerações sobre o neoliberalismo como movimento ideológico internacional. In www.fee.tche.br.

${ }^{54}$ BARBOSA GROS, Denise, Considerações sobre o neoliberalismo como movimento ideológico internacional. In www.fee.tche.br.

${ }^{55}$ BARBOSA GROS, Denise, Considerações sobre o neoliberalismo como movimento ideológico internacional. In www.fee.tche.br. En los últimos treinta años, la red de "think tanks" conservadores de Estados Unidos de América formuló críticas al "welfare state" y a las políticas sociales, contribuyendo no sólo a la victoria del conservador Ronald Reagen al final de los años setenta, sino a definir la forma de aplicación de las políticas públicas conservadoras en el área de la educación, seguridad social y derecho de las minorías étnicas. Este mismo fenómeno se produjo en Inglaterra. Los "think tanks" de la nueva derecha contribuyeron a la victoria de Thatcher y a la debilidad del estado de bienestar social. Y ello fue posible a raíz de las fuertes inversiones de
} 
A partir del capitalismo intervencionista y organizado, surge una nueva casta de profesionales, la de los administradores, que permite al modo de producción actual resistir mejor las críticas. Estos profesionales comienzan a ocupar importantes funciones en los sectores público y privado. Son estos ejecutivos quienes permitieron el reciclaje del modo de producción capitalista al final del siglo pasado. $^{56}$

En detrimento del nepotismo, tanto público como privado, a defender la administración científica y profesional, proporcionando un incremento en la productividad, fundamentada en la posibilidad de una ascensión profesional vertical fundada en el mérito y en el esfuerzo individual. Se observa que el enorme crecimiento cuantitativo en el número de facultades de administración, economía y

grandes empresas y que financiaron los think tanks, con sus estudios y publicaciones. $Y$ estos estudios fueron fundamentales para la consolidación del neoliberalismo como alternativa política y para su internacionalización en los años ochenta.

Estas ideas lanzadas por los liberales en las décadas de los treinta y de los cuarenta, permanecieron en el campo teórico hasta la década de los setenta, cuando entra en crisis el modo de producción capitalista. Según Hayek y otros economistas liberales "la crisis era consecuencia del excesivo poder del movimiento trabajador, pues las reclamaciones salariales y de costes sociales hechas por los sindicatos habrían comprometido la acumulación capitalista". Estos liberales empezaron a sugerir medidas como la llamada estabilidad monetaria, disminución de los costes en el campo social y la restauración de la tasa de desempleo, para así disminuir la capacidad de reivindicaciones por parte de los trabajadores y, finalmente, quebrantar el poder de los sindicatos.

Y es ahí cuando comienza el declive del pensamiento social. El Estado de Bienestar pasa a ser el culpable de la pérdida de la acumulación capitalista. El obrerismo es alcanzado de lleno, como al gran villano de la crisis. El Estado Social que acomodó las masas y permitió la continuidad del capitalismo, también hizo surgir las bases del neoliberalismo. Edificó y permitió la estabilización del pensamiento liberal y la permanencia o hegemonía del modo de producción sin verdadera perspectiva de cambio.

En América Latina, inspirado en Hayek, Milton Friedman y en el monetarismo de la Escuela de Chicago, el gobierno chileno del general Pinochet, aplicó la formula liberal. Consistió en la desregulación, desempleo, represión sindical, "redistribución" de la renta en beneficio de los ricos y las privatizaciones.

Barbosa Gros subraya que se puede observar que la existencia de un movimiento ideológico neoliberal a nivel internacional se debe mucho a las organizaciones ya mencionadas, especialmente al Institute Affairs de Inglaterra, por ser éste el núcleo original y el modelo de los centros de enseñanza e investigación de la teoría económica liberal, la Atlas Economomic Research Foundation de los Estados Unidos de América, por el papel que tiene en la creación y en el mantenimiento de los think tank" liberal conservador en todo el mundo, a la sociedad Mont Pelerin, por promover reuniones entre las grandes personalidades internacionales del mundo político y académico liberal, y a las numerosas fundaciones mantenidas por las grandes empresas de capital privado, que sustentan este movimiento ideológico neoliberal internacional.

56 RAMOS FILHO, Wilson, "Bem-estar das empresas e mal-estar laboral (...)", cit., 96. 
ciencia contable, especialmente a partir de la década de los noventa, es característica de este momento ideológico. ${ }^{57}$

De lo expuesto hasta aquí se puede concluir, como además ya hemos mencionado anteriormente que, en efecto, el Estado de Bienestar Social tuvo un papel importante en el mantenimiento del modo de producción capitalista y también en el "resurgimiento" de las teorías neoliberales. Nunca cesaron los debates liberales. Los think tanks son prueba de ello, de manera que sus ideas pasaron a formar parte de la realidad mundial a partir de los años ochenta, fortaleciéndose más en los años novena, frente a la ola de desregulación de la legislación laboral y sindical.

La cultura burguesa y neoliberal fue la que acabó triunfando. Es común hoy, en Brasil, que los trabajadores se auto-denominen "colaboradores" y que los vendedores se llamen "autónomos", frente a una situación flagrante de contrato de empleo en plantilla, conforme a la ley laboral. También es común que sindicatos negocien derechos elementales de los trabajadores a cambio, muchas veces, de una modificación salarial que sólo contemple las pérdidas monetarias anuales, 0 que cambien el trabajo extraordinario por la ayuda-alimentación, por ejemplo ${ }^{58}$.

La legislación de protección de los trabajadores y de los grandes grupos excluidos es gestionada, aprobada e incorporada por éstos, que pasan a tener un cierto grado de confianza en las autoridades en lo que respecta a la reproducción de sus intereses. A partir de ahí, comienzan las reducciones, o incluso supresiones y retrocesos en el campo social, apoyado muchas veces en una considerable propaganda por parte de la empresa, especialmente en lo que se refiere a los costes procedentes de la concreción de estos derechos.

\footnotetext{
57 RAMOS FILHO, Wilson, "Bem-estar das empresas e mal-estar laboral (...)", ibidem.

58 Conviene destacar que los convenios colectivos, en Brasil, contemplan la llamada ayudaalimentación o cesta básica o incluso "ticket-alimentación". Esta es la prueba de que los salarios son bajos y de que ni siquiera sirven para mantener la vida del trabajador y de su familia.
} 
Los deseos de garantía en el empleo y la protección estatal, poco a poco se han sustituido por el deseo de mayor autonomía y por la sobrevaloración del desarrollo personal, por el crecimiento institucional y la implicación laboral "proyecto a proyecto", pretendiendo implicar a los trabajadores en un proyecto empresarial que permitiría más felicidad, eso porque generaría mayor salario. ${ }^{59}$

El actual sistema capitalista busca su eficiencia a través de la flexibilización y mediante la defensa del modelo de empresas administradas por ejecutivos profesionales, impregnados por la ideología hegemónica, con el fin de satisfacer a los clientes y los accionistas. Esta satisfacción debe producirse mediante la movilización general de los trabajadores, por la motivación de sus líderes o precarización de los derechos sociales y relaciones de producción. Ante el temor por la pérdida de los puestos de trabajo se acaba enraizando la sumisión. Aquí es donde el acoso moral, por ejemplo, se convierte en una técnica de gestión y de estrategia empresarial. ${ }^{60}$

La precarización laboral, a partir de este nuevo modelo, constituye una estrategia organizacional cuyo objetivo político es aumentar la dominación, mediante dos técnicas complementarias entre sí, de patrón total y la evaluación individual de desempeño, ambas con la intención de incrementar la productividad y el beneficio. En relación a esto, Ramos Filho advierte que el sistema, además de secuestrar la subjetividad de los trabajadores, vinculando sus intereses a los de la empresa, permite la sustitución de empleados con más experiencia y con mejores salarios otros más jóvenes y recién egresados de las escuelas técnicas o universidades, que no hayan mantenido contacto con la producción, sin conocimiento general y, por lo tanto, que son más fácilmente controlables. ${ }^{61}$

\footnotetext{
${ }^{59}$ RAMOS FILHO, Wilson, "Bem-estar das empresas e mal-estar laboral (...)", ibidem.

60 Párrafo elaborado también con la contribución del texto de Ramos Filho. RAMOS FILHO, Wilson, "Bem-estar das empresas e mal-estar laboral (...)", cit., p. 99.

${ }^{61}$ RAMOS FILHO, Wilson, "Bem-estar das empresas e mal-estar laboral (...)", cit., p. 100/101.
} 
Esta nueva forma de gestión, por resultados, con producción ajustada termina produciendo una apariencia de mayor autonomía, con la consiguiente disminución de la subordinación, lo que acaba por seducir al trabajador. Este sistema, centrado en la mayor autonomía (aunque aparente) y producción, aumenta mucho el nivel de estrés dentro del ambiente de trabajo, generando el denominado acoso moral. ${ }^{62}$ Sin embargo, esto no se produce en todos los casos en que se adopte la producción ajustada. No obstante, en la mayoría de las compañías, se puede detectar este problema, especialmente en los países clasificados como periféricos.

Con todo, cuando el neoliberalismo se convierte en la ideología dominante, antes de la crisis de 2008, el proceso de legitimación del capitalismo ya ha quedado bastante modificado. Los derechos y garantías que habían sido garantizados por los pactos populistas y social-demócratas, comienzan a ser considerados como superfluos, como desechables e incluso como abusivos. Esto lleva al empresario a defender el bienestar empresarial a costa del bienestar social, bajo el argumento liberal de que lo mejor es asegurar el empleo, fortaleciendo la empresa. ${ }^{63}$

La pequeña y mediana empresa, que es la que en realidad genera puestos de trabajo, adopta el discurso liberal porque para ellos, efectivamente, hay un cierto coste económico en el trabajo. Se olvidan, sin embargo, de que a las grandes empresas les interesa el llamado coste social, ya que para éstas los salarios pagados a los trabajadores son bajos, aunque también defiendan, como política, la reducción de los costes, con el fin de acumular enormes beneficios, sin tener en cuenta la cuestión de quién es efectivamente el que emplea (pequeñas y medianas empresas).

62 RAMOS FILHO, Wilson, "Bem-estar das empresas e mal-estar laboral (...)”, cit., p. 102.
63 RAMOS FILHO, Wilson, "Bem-estar das empresas e mal-estar laboral (...)", cit., p. 103. 
De eso se concluye que con el objetivo de atraer empresas y capital internacional, los países periféricos, entre ellos Brasil, han acabado por flexibilizar las normas de protección al trabajo, con el fin de hacer frente a la globalización y a la competitividad internacional. $Y$ esto no se produce sólo en el campo legislativo. Lo peor es que la jurisprudencia laboral brasileña, entendiendo que más vale un puesto de trabajo que los derechos sociales, acaba por flexibilizar aún más las normas de protección, olvidándose de los preceptos constitucionales y legales. Buen ejemplo de ello es que el tema central de nuestra investigación es la subcontratación, sin previsión legal, fruto de la apropiación, por el derecho, de preceptos y fórmulas económicas toyotistas, que deja a un lado las normas legales, para crear una diferenciación de la actividad-medio y de la actividad-fin no prevista en la ley.

Todo ello, sin embargo, podría ser elaborado de forma más fiel si el procedimiento adoptado fuese claro y abierto a todos, a través de la discusión y prevaleciendo el mejor argumento. Según Luhmann, citado por Habermas:

"Las reglas formales de procedimiento bastan como premisas
legitimadoras de la decisión y no requieren, por su parte, ninguna
legitimación posterior, pues cumplen su función - absorber incertidumbre
- en cualquier caso. Conectan la incertidumbre, en cuanto tal decisión se
produzca, coincidiendo con la seguridad que tenga alguna decisión.
La validez abstracta y relativa en las normas, que pueden actuar sin una
justificación material, además de seguir el proceso correcto en su origen
y aplicación, sirve 'para estabilizar expectativas de comportamiento
contra decepciones y, por tanto, para garantizar estructuras"'."

Según Habermas, el capitalismo, a través de la doctrina liberal, aprovechó algunas de las ventajas del socialismo y se transformó en social-democracia ${ }^{65}$. El Estado Social, que "adquiere derecho al carácter de la mercancía 'fuerza de trabajo', nació de un intento que pretendía examinar 'hasta qué punto el sistema económico puede ser gravado' en beneficio de las necesidades sociales, con

\footnotetext{
${ }^{64}$ HABERMAS, Jürgen, A crise de legitimação no capitalismo tardio. Tradução Vamireh Chacon, Rio de Janeiro: Tempo Brasileiro, $2^{\mathrm{a}}$ ed., 2002, p. 125/6.

65 HABERMAS, Jurgen, "Sobre o significado do socialismo hoje. Revolução recuperadora e necessidade de revisão da esquerda". En Diagnóstico do tempo: seis ensaios, Rio de Janeiro; Editora Tempo Brasileiro, 2005, p. 138
} 
relación a las cuales la racionalidad de las decisiones de inversión de los empleadores es insensible". Esto no impide que, hoy, dada de la pérdida de "inocencia" por parte del Estado Social, no se le deba domesticar socialmente. ${ }^{66}$

Las sociedades modernas "satisfacen sus necesidades de control recurriendo a tres fuentes: el dinero, el poder y la solidaridad". No se puede reconocer un reformismo radical. El poder social y el poder integrador de la solidaridad deben estar en condiciones de afirmarse a través de las instituciones y las esferas públicas democráticas abiertas, contra los otros dos poderes, es decir contra el dinero y el poder administrativo. ${ }^{67}$

Como afirma Nuria Belloso "desde las posiciones ideológicas de la izquierda se ha acusado al Estado de Bienestar de ineficaz, burocrático y despilfarrador, represivo y coactivo". El Estado de Bienestar sería un instrumento para la estabilización capitalista y no una forma de transformarla. Continua afirmando que "entienden que el carácter burocrático del Estado de Bienestar genera unas formas represivas en su funcionamiento que le llevan a cumplir unas funciones de control político-ideológico que aminoran el debate político y estabilizan el sistema capitalista". ${ }^{68}$

Por otro lado, en este estudio merecen algunos comentarios la visión de la teoría neomarxista ${ }^{69}$ con respecto al Estado y, especialmente, con relación al

${ }^{66}$ HABERMAS, Jurgen, "Sobre o significado do socialismo hoje (...)", cit., p. 151.

67 HABERMAS, Jurgen, "Sobre o significado do socialismo hoje (...)", cit., p. 152.

68 BELLOSO MARTín, Nuria, "Del Estado del Bienestar a la sociedad del Bienestar: la reconstrucción filosófico-política de su legitimidad". En Para que algo cambie en la Teoría Jurídica. Nuria Belloso Martín, coordinadora, Burgos; Universidad de Burgos, Servicio de Publicaciones, 1999, p. 161.

${ }^{69}$ Para justificar mi interés por el marxismo podría remitir a un paralelismo con el interés que también sustentó por esta teoría Alasdair MacIntyre. Concretamente, su análisis se dibuja en el horizonte de las prácticas de la clase trabajadora y de la unidad de acción entre teoría y práctica. $Y$ esta unidad no es entendida por él solamente como una organización revolucionaria, sino más bien con la conciencia de los trabajadores de ser potenciales actores morales y políticos al mismo tiempo. Maclntyre siempre ha tenido un fino sentido para detectar la hipocresía y arrogancia de los que están en el poder y sus deseos de silenciar a quienes denuncian tal actitud despótica, críticos estos que son considerados inferiores por los poderosos. Maclntyre ve en el marxismo una ayuda para resolver tales problemas de elitismo. Al igual que Maclntyre apreciamos una finalidad ética y 
Estado de Bienestar. De ahí que tomemos la teoría de Ochando Claramunt, como punto de referencia. ${ }^{70}$

El clásico conflicto de distribución que está presente en la sociedad del trabajo, se estructura entre las cuestiones de fondo que interesan al capital y al trabajo, de tal modo que ambos disponían de poderes de amenaza, principalmente porque la parte perjudicada tenía la posibilidad de la huelga como instrumento para parar el proceso de producción. Actualmente esta realidad ha cambiado. En los conflictos de distribución institucionalizados de la sociedad de bienestar, una gran mayoría de trabajadores subordinados se enfrenta con una minoría de grupos marginales, heterogéneos que no disponen de un potencial de sanción correspondiente, pudiendo actuar sólo a través del voto, con el fin de preservar sus intereses. ${ }^{71}$

revolucionaria del marxismo. En su obra de 1968, Marxism and Christianity, subyace la tesis de que el marxismo hereda algunas de las funciones que tenía encomendadas el cristianismo. Aquel viene a entrar en acción al producirse una carencia profunda del sentido religioso en la sociedad moderna, junto con la necesidad imperiosa de acometer una crítica de calado que permita transformar dicha sociedad (GIMÉNEZ AMAYA, J.M., y SÁNCHEZ-MIGALLÓN, S., Diagnóstico de la Universidad en Alasdair MacIntyre. Génesis y desarrollo de un proyecto antropológico. Pamplona, Eunsa, 2011, p.33/42).

70 OCHANDO CLARAMUNT, Carlos, El Estado del bienestar. Objetivos, modelos y teorías explicativas, Barcelona: Ariel, 1999, p. 125/135.

Apunta que "El Estado, en esta concepción funcionalista, no es una institución neutral en una sociedad capitalista, sino que sirve a los intereses de la clase dominante. El Estado capitalista es visto como el reflejo de la propia lucha de clases existente en la sociedad capitalista y el Estado del bienestar como un cambio institucional correspondiente a una nueva etapa histórica del capitalismo".

La teoría marxista considera al Estado como un instrumento controlado por la clase dominante y que sirve como medio de represión de la clase trabajadora, constituyendo el Estado de Bienestar una respuesta necesaria a las contradicciones del capitalismo monopolista. Ochando Claramunt prosigue y apunta que "la supervivencia del capitalismo se produce gracias al papel que juega el Estado. El objetivo de la actuación estatal es la reproducción del capitalismo, por medio de sus funciones de acumulación y legitimación". Se observa, por tanto, que el capitalismo, para proseguir sobreviviendo necesita la acumulación de capital y la legitimidad política y social. Ambos requisitos son proporcionados por el Estado, maximizando la acumulación del capital y manteniendo la paz social.

El autor continúa apuntando que el Estado de Bienestar no tiene ningún efecto sobre la equidad, porque la participación del Estado sólo sirve para mantener y reproducir una desigualdad que es inherente a la naturaleza del sistema capitalista. Una distribución equitativa de bienes sólo sería posible, para Marx, si se produjera una reestructuración radical de las relaciones sociales de producción.

71 HABERMAS, Jurgen, "Sobre o significado do socialismo hoje (...)", cit., p. 154. 
El orden económico internacional acaba perfilando en los países subdesarrollados (periféricos en la expresión de Boaventura de Sousa Santos) la proporción de la plusvalía para el mantenimiento del orden capitalista. ${ }^{72}$

Lo que se produce, a partir de ahí, es una especie de capitalismo asistencial, que sobrevive gracias "a la creciente transferencia de los costes de las empresas al conjunto de la colectividad - es decir, a la clase trabajadora - y a través de la inversión financiera masiva en títulos públicos de crédito. Los costes empresariales, así, son "bancarizados" por el Estado y, en los más desarrollados, el imperialismo los exporta a los de capitalismo más débil". ${ }^{73}$

El capitalismo, cuando defiende la estatalización, lo hace por su propio interés, ya que no tiene nada que ver con la socialización o la colectivización, sino con el objetivo de la acumulación, que se renueva, de esta manera, gracias a las acciones del Estado. Sólo los defensores profesionales del sistema de libre iniciativa, formado por miembros de oficio humilde y mal pagados, defienden el dominio de la competición. ${ }^{74}$

En la función de la integración y modernización del sistema capitalista, el Estado puede proceder bien sea a través de la legitimación o de la represión.

\footnotetext{
72 Boaventura de Sousa Santos subraya que "el principio del mercado adquirió una fuerza sin precedentes, rebasando el ámbito económico y tratando de colonizar tanto el principio del Estado como el principio de la comunidad -un proceso llevado al extremo por el credo neoliberal-. En el plano económico, los desarrollos más dramáticos son los siguientes: el crecimiento explosivo del mercado mundial, impulsado por un nuevo agente creado a su medida - las empresas multinacionales -, permite eludir, incluso neutraliza, la capacidad de regulación nacional de la economía; los mecanismos corporativos de regulación de los conflictos entre capital y trabajo, establecidos a nivel nacional en el período anterior, se debilitan y la relación salarial se hace más precaria, asumiendo formas que, al menos en la apariencia, representan un cierto retorno al período del capitalismo liberal; la flexibilización y la automatización de los procesos productivos, combinadas con el abaratamiento de los transportes, permiten la industrialización dependiente del tercer mundo y destruyen la configuración espacial del aparato productivo en los países centrales con una caracterización errónea de las regiones, la emergencia de nuevos dinamismos locales, la ruralización de la industria, la desindustrialización, la subcontratación internacional etc." (SOUSA SANTOS, Boaventura de, Pela mão de Alice: o social e o político na pós-modernidade, São Paulo; Cortez, 9a ed., 2003, p. 87/88).

${ }^{73}$ GRAU, Eros Roberto, A Ordem Econômica na Constituição de 1988, cit., p. 22.

${ }^{74}$ GRAU, Eros Roberto, A Ordem Econômica na Constituição de 1988, cit., p. $22 / 3$.
} 
En el primer caso - legitimación - el Estado, cuando intermedia el conflicto de clases, da y garantiza el apoyo del dominio del capital. Actuando como un agente unificador de una "sociedad económicamente dividida y, además, fragmentada en grupos de intereses adversos, promueve - y el derecho positivo es el instrumento primordial de esta promoción - lo que he mencionado como la transformación de la lucha social en juego". 75

Por otro lado, la represión se vincula a una "concepción de hegemonía, de modo que ella se manifiesta en un primer momento como represión, suficiente para poner en una situación de lealtad y adhesión al capitalismo la masa cuantitativamente más significativa de la sociedad civil". ${ }^{76}$

La Constitución formal, especialmente cuando se la concibe meramente como programática, con normas que no adquieren eficacia plena hasta la actuación del legislador ordinario o por acto del Poder Ejecutivo, corrobora un instrumento retórico de dominación. De ahí que la Constitución se transforme en un mito. ${ }^{77}$

El mito es una forma específica de manifestación de lo ideológico en el plano del discurso ${ }^{78}$. La ideología, según Eros Grau, no produce significados que, por sí, tengan algún valor, sino que produce valores-verdad que se auto-referencian, valores referenciales que son o no verdaderos, conforme a sus relaciones con las pautas ideológicas que componen su instancia de enunciación, ya sea como formalidad o como contraste. El valor de lo verdadero, o de lo falso, en el ámbito ideológico, es arbitrario, formal y no ontológico.

Un ejemplo de ello lo constituye la Constitución mejicana de 1917 y la de la República de Weimar de 1919, donde las normas ligadas al trabajo y a la

\footnotetext{
75 GRAU, Eros Roberto, A Ordem Econômica na Constituição de 1988, cit., p. 23/4.

${ }^{76}$ GRAU, Eros Roberto, A Ordem Econômica na Constituição de 1988, cit., p. 24.

77 GRAU, Eros Roberto, A Ordem Econômica na Constituição de 1988, cit., p. 24.

78 GRAU, Eros Roberto, A Ordem Econômica na Constituição de 1988, cit., p. 25.
} 
prevención social no eran más que proyectos ideológicos, sin llegar a institucionalizar los derechos. En la misma línea prosperan las Cartas formales de los países capitalistas que predican el llamado Estado Social o capitalismo social, que en realidad no hacen más que garantizar la continuidad del sistema expropiatorio, ahora sí regulado y organizado, enmascarado como "social". ${ }^{79}$

En Brasil, los empresarios nacionales y extranjeros, no asumen, salvo raras excepciones, el papel de innovadores, haciéndose cargo de las responsabilidades que conllevan. Siempre fue el Estado quien promovió y apoyó el coste social y el papel de innovación en el ámbito empresarial. Para ello, basta recordar los Gobiernos de Vargas (década de los 40'), régimen militar (décadas de los 60' y 70') , además del gobierno del Presidente Juscelino Kubitschek y el papel del BNDES y otras agencias y sociedades gubernamentales, tales como la EMBRAPA. Las privatizaciones de las empresas estatales, se deberían orientar por una perspectiva social. La política del neoliberalismo implementada por el gobierno del Presidente Fernando Henrique Cardoso es incompatible con los fundamentos de la República, contenidos en los artículos $3^{0}$ y 170 de la Constitución brasileña de $1988 .^{80}$

\footnotetext{
${ }^{79}$ En el caso de Brasil, cualquier reformulación de la participación del Estado en la economía implica su desprivatización. "En cuanto a esta participación, además, cuando cuantificada en términos de PIB, no resulta más alta que la que se manifiesta, p. ej., en Japón, en los Estados Unidos, en Alemania, en Francia, en Inglaterra". En lo que se refiere a las recaudaciones de tributos éstas derivan, básicamente, de la imposición de los tributos indirectos regresivos. La carga tributaria no es relativamente tan alta, como si afirma, generalmente por ignorancia, falta de información o mala fe, pero acentuadamente regresiva. El trabajo es excesivamente más tributado que el capital. Las pequeñas y medianas empresas y la clase asalariada sufren mayor incidencia tributaria y fiscal, eso bajo un análisis de proporcionalidad y progresividad tributaria. GRAU, Eros Roberto, A ordem econômica na constituição de 1988, cit., p. 36 e AVILA FIGUEIREDO, Renata, Sociedade $X$ mercado. Uma proposta para desarmar os mercados e desenvolver o poder para a sociedade. En www.integracao.fgvsp.br/11/noticias.htm, acceso en octubre de 2005.

80 GRAU, Eros Roberto, A ordem econômica na constituição de 1988, cit., p. 36. Aquí se entiende que el anterior gobierno brasileño, presidido por Luiz Inácio "Lula" da Silva, y el actual, de Dilma Rousseff, es en parte un resultado de años de neoliberalismo de Fernando Henrique Cardoso. Poco ha cambiado en términos de políticas públicas, a excepción de la beca-familia, beca-escuela, e incluso el final de la persecución criminal al "Movimento dos Trabalhadores Rurais sem Terra".
} 
Nos lamentamos por un país con tantas desigualdades sociales. Además, el modelo económico neoliberal ${ }^{81}$ y la globalización están, cada día, recibiendo un mayor número de adeptos.

¿Quién no acepta como racional y benéfica la globalización económica? ¿Quién no entiende que el llamado "coste Brasil" es excesivo y que la carga tributaria es alta? Son éstos los factores del estancamiento de la economía. Lo peor es que estas tesis están ganando mucha fuerza, hasta el punto de poder, incluso, influir en las decisiones judiciales y en la elección de los gobernantes. Los que prometen reducir el "coste Brasil", reduciendo los derechos sociales, por ejemplo, especialmente los ligados al trabajador, tratan de ganarse a la clase empresarial, que es quien financia las campañas, así como los que predican la disminución de tributos y las exenciones fiscales, moneda corriente en la guerra fiscal entre los Estados de la Federación.

Esto, sin embargo, no es más que una manera de proteger y expandir aún más las desigualdades del modo capitalista de producción, aun cuando para eso se tenga que rechazar la aplicación de preceptos, fundamentos, principios y reglas constitucionales. Más vale garantizar que el capitalismo, una vez más, se adapte y continúe su camino sin saber a dónde, en detrimento de las personas que realmente mantienen este modo de producción.

Sin embargo, la globalización no es más que la globalización financiera, que pone más énfasis en la especulación que en la producción (industria), que, por supuesto, amenaza a la sociedad civil, en la medida en que "(i) está asociada a nuevos tipos de exclusión social, generando un subproletariado, en parte constituido por marginados en función de la raza, nacionalidad, religión u otra señal distintiva (underclass); (ii) instala una continua y creciente competición entre individuos; (iii) lleva a la destrucción del servicio público (= destrucción del espacio público y disminución de los valores del servicio transmitidos por él)". La

${ }^{81}$ No hay que confundir el modelo económico con el modo de producción. 
globalización, por lo tanto, por la competición global y la desintegración social, compromete, y mucho, la libertad. ${ }^{82}$

Resulta difícil entender cómo es posible una globalización con el uso eficiente y racional de los recursos, ya que incluso en el caso de los países emergentes, como Brasil, Argentina y México, por ejemplo, la tendencia es una retorno a los antiguos modelos que se basaban en la explotación de los recursos naturales, aunque sean economías industriales, lo que acabaría desembocando en un declive de este sector y en un alto índice de desempleo. ${ }^{83}$

Las altas tasas de desempleo, la desigualdad social, la exclusión social y la precarización del trabajo, no son exclusivos de los países periféricos y subdesarrollados. Eso ya está incluso sucediendo en Europa. La economía capitalista presenta un crecimiento desalentador y tasas de inversiones empresariales extremadamente reducidas. Lo que prospera es el mercado financiero, que se aprovecha de los efectos nefastos de la desregulación que, por la facilidad de movimentación del capital especulativo entre las diferentes plazas, mantiene altas tasas de valorización de activos y facilita las fusiones y adquisiciones de empresas en todos los sectores. ${ }^{84}$ Todo esto contrasta con los años dorados de la década de los años cuarenta, impulsada por la Segunda Guerra Mundial, cuando la economía se expandió y la producción se desarrolló a niveles similares a los del período 1920/1929, con una alta productividad, aumento de los salarios y tasas de desempleo mínimas. ${ }^{85}$

Lo que quieren los "reformistas-conservadores", expresión de Eros Roberto Grau, transformando el Estado en un gran villano, es la desregulación de los mercados internos y la eliminación de las barreras de entrada y salida de capital, "de modo que la tasa de intereses pueda expresarse sin distorsionar la oferta y la

${ }^{82}$ GRAU, Eros Roberto, A ordem econômica na constituição de 1988, cit., p. 40.

83 GRAU, Eros Roberto, $A$ ordem econômica na constituição de 1988, cit., p. 41.

${ }^{84}$ GRAU, Eros Roberto, A ordem econômica na constituição de 1988, cit., p. 41.

85 HUNT, E. K. SHERMAN, Howard J., História do pensamento econômico. Trad. Jaime Larry Banchimol, Petrópiolis; Editora Vozes, $13^{\text {a }}$ ed., 1995, p. 163/178. 
demanda de ahorro, en los espacios integrados de las finanzas mundiales"; para los mercados de bienes, "sumisión de las empresas a la competencia global, eliminándose los vestigios de proteccionismo y de cualesquiera políticas deliberadas de fomento; para los mercados de trabajo, flexibilización y remoción de las cláusulas sociales". ${ }^{86}$

Todo esto debilitó el poder de negociación de los trabajadores y cualquier posibilidad por parte de los mismos de mantener un mínimo posible de derechos que les garanticen la dignidad. También, la propaganda de la "globalización" y la "flexibilización" como tablas de salvación de la sociedad es intensa, llegando a las aulas universitarias y al Poder judicial que, cada día, acogen esta tesis. Olvidan que las tasas de crecimiento son notablemente inferiores al periodo en el que había una mayor intervención. El modo de producción capitalista fracasó considerablemente en su tarea de generar empleos y remunerar bien el trabajo, aumentando con ello las desigualdades, especialmente en los países subdesarrollados y periféricos. ${ }^{87}$

Por último, conviene recordar que hay una flagrante contradicción entre el neoliberalismo que excluye y margina y la democracia, que supone el acceso de un mayor número de personas a los bienes sociales. Es por eso que Eros Grau llega a la conclusión que el neoliberalismo no es más que un enemigo del Estado Democrático de Derecho. Y para superar esta situación se deben adoptar algunas medidas, tales como la cancelación de las deudas de los países subdesarrollados y la tasación del flujo de capital (una especie de Tasa $\operatorname{Tobin}^{88}$ ), con un

${ }^{86}$ GRAU, Eros Roberto, A ordem econômica na constituição de 1988, cit., p. 42.

87 GRAU, Eros Roberto, A ordem econômica na constituição de 1988, cit., p. 42/3, recomienda la lectura de las tasas de desempleo y el valor real de los salarios y tributos.

88 "La Tasa Tobin fue ideada por el economista James Tobin en 1972, poco después de la disolución del sistema de tipos de cambio de Bretton Woods, que se produjo en agosto de 1971. Proponía que todas las transacciones financieras fuesen tarifadas y que los Estados tuviesen garantía de la realización de políticas macroeconómicas y de estabilización por el hecho de que los mercados se veían constantemente afectados por la volatilización de los capitales. Además, el capital generado por la aplicación de la Tasa Tobin podría ser utilizado para erradicar la pobreza extrema en que muchos seres humanos viven. La aplicación de la tasa tendría importantes resultados, ya que las transacciones monetarias mueven cantidades astronómicas de capital. Inicialmente se cobraría un impuesto del $0,1 \%$ sobre los movimientos especulativos. El montante 
compromiso por parte de los gobiernos internacionales para abordar los problemas sociales con el fin de controlar, por lo menos, el modo de producción capitalista ${ }^{89}$.

De eso se puede concluir, sin pretensión de dar por cerrado el debate, que la estabilización democrática a través del Estado de Bienestar Social fue principalmente consecuencia del interés liberal y capitalista, sin que supusiera una ruptura con respecto al interés social en relación a la emancipación de las masas. Si los trabajadores, por ejemplo, tenían la conciencia de la clase a la que pertenecían y, a través de los sindicatos, sabían que tenían el poder de cambiar la sociedad, es a partir del Estado de Bienestar Social cuando pierden esta conciencia, ya que se alejan del movimiento sindical, buscando en el estado prestador aquello que los sindicatos y la lucha colectiva no les podía proporcionar en aquel momento.

Esta pérdida de la conciencia de clase y su forma de desarrollo será objeto de análisis seguidamente.

\subsection{La cuestión sindical y la pérdida de la conciencia de clase}

La desregulación y la flexibilización acabaron por afectar la cuestión sindical. Con la tercerización los sindicatos pierden su fuerza. Ya no detentan el poder de

recaudado iría a organizaciones de la sociedad civil con el objetivo de erradicar de la pobreza" (FIGUEIREDO, op. cit., p. 01. James Tobin), (5 de Marzo de 1918 - 11 de Marzo de 2002). Tobin fue un economista estadounidense, profesor en la Universidad de Yale y galardonado con el Premio de Ciencias Económicas en 1981. Tobin se dio a conocer en 1972 al haber ideado un impuesto sobre las transacciones financieras internacionales como una forma de reducir la especulación en los mercados financieros. Tobin propuso que los ingresos de estos impuestos se utilizaran para financiar las Naciones Unidas o para ayudar al desarrollo de los países del tercer mundo. Este impuesto fue conocido como la Tasa Tobin".

Francia, como otros paises de Europa, tales como Alemania e Italia, están barajando la posibilidad de adoptar algún instrumento en la línea de la Tasa Tobin. Ver http://www.lemonde.fr/electionpresidentielle-2012/article/2012/01/06/baroin-la-taxe-sur-les-transactions-financieres-verra-le-jouravant-fin-2012 1626757 1471069.html - aceso 08 de enero de 2012, à las 00h19min, horario de Paris.

89 GRAU, Eros Roberto, A ordem econômica na Constituição de 1988, cit., p. 46/8. 
reivindicación. Ejemplo público y notorio de este hecho es el de los empleados de los bancos. Esta categoría que, hasta el inicio de la década de los ochenta del siglo XX era considerada como una de las más fuertes, acabó por convertirse, con la automatización, en una categoría profesional, sin ningún poder de presión real.

La cuestión de la pérdida de la conciencia de clase está tan arraigada que hoy son pocos sindicatos que estimulan el recurso a la huelga como un medio de presión. No lo hacen por el temor a un reproche social, influidos por los medios de comunicación de masa, cuyos operadores, han dejado de saber lo que, de hecho, es clase social.

En el caso de Brasil, el huelguista es considerado como un desocupado, que no quiere trabajar e, incluso, como un desagradecido. Para muchos, el empleo concedido por el patrón es una dádiva. Se olvidan de que el desempleo es una de las formas más perversas de reducción de los costes de producción, financiada por la nueva ideología neoliberal ${ }^{90}$. El empleo ha pasado a ser un regalo. Una gracia otorgada por el capitalista al trabajador, siendo éste, además de esclavo disfrazado de trabajador libre, un eterno deudor moral de quien le proporciona trabajo.

Sobre este tema, Oscar Ermita Uriarte apunta que, en una perspectiva cultural y social, la posmodernidad exalta la cuestión del individualismo, perjudicando la solidaridad y los valores colectivos. Según el autor, se retira el apoyo cultural y el prestigio del movimiento sindical, de la negociación colectiva y de los movimientos huelguistas, así como de las instituciones y eventos colectivos y solidarios, afectando también a la legislación laboral y a la prevención que, para bien o para mal, han emanado del Estado y actúan de forma solidaria, volcadas hacia los sectores más débiles de la sociedad. ${ }^{91}$

\footnotetext{
90 GROS, Denise Barbosa. Considerações sobre o neoliberalismo como movimento ideológico internacional. En: www.fee.tche.br.

${ }^{91}$ ERMIDA URIARTE, Oscar, A Flexibilidade, cit., p. 22.
} 
De ahí se puede deducir que la cuestión de la flexibilización o desregulación está íntimamente ligada a la debilitación del movimiento sindical. Sindicatos débiles acaban por firmar acuerdos y convenios colectivos desfavorables, lo que debilita el propio movimiento sindical.

López Alonso, hace referencia a la cuestión del traslado, sistema de producción en red y subcontratación y a sus efectos sobre la cuestión sindical, estos fenómenos acaban por surtir efectos sobre el proceso de negociación colectiva tradicional. Conllevan más flexibilización, permaneciendo los empleados de las grandes empresas en mejores condiciones de trabajo y mejor protegidos por sus convenios sindicales. Cuanto más se distancian las empresas del centro productivo, menos derechos y protección tienen sus trabajadores. Estas empresas acaban prisioneras de los límites establecidos por las empresas centrales, lo que también se refleja en las condiciones de trabajo de sus empleados, especialmente en cuanto a la jornada de trabajo y al importe de los salarios. ${ }^{92}$

Serrano Piernas apunta que la cuestión de la tercerización y subcontratación acabó por debilitar el movimiento sindical y la acción colectiva de los trabajadores. Cita estas y otras causas como relevantes en relación a la cuestión del empeoramiento de la condición social de los trabajadores, por lo que se puede concluir que la racionalización del elemento flexibilizante puede ser la solución o, al menos, un elemento de mejora en las condiciones de vida del trabajador. ${ }^{93}$

Subraya que el sistema de la subcontratación no es más que una realidad atomizada integrada por pequeñas y medianas empresas con plantillas reducidas. Estas empresas, cuanto más lejos del núcleo productivo, presentan más elementos negativos. Cita como elementos de esta naturaleza el empeoramiento en las condiciones de trabajo de sus empleados, mayor tasa de contratación

\footnotetext{
${ }^{92}$ LÓPEZ ALONSO, Felipe. "Los cambios en el modelo económico y productivo y su influencia en la negociación colectiva". En Revista de Derecho Social n. 40, Albacete: Editorial Bomarzo, 2007, p. 234.

${ }^{93}$ SERRANO PERNAS, Fernando, "Acción sindical y descentralización productiva". En Revista de Derecho Social n. 40, Albacete; Editorial Bomarzo, 2007.
} 
temporal, baja cualificación de los trabajadores, escasa o nula formación en materia de salud y seguridad del trabajo, se facilita la presencia de "pistoleros" que hacen sus empresas solamente con un vehículo "una furgoneta" y un teléfono móvil y se dedican exclusivamente a intermediar la mano de obra. ${ }^{94}$

Llama la atención en relación a la cuestión de que la tercerización acabó por empeorar la situación de los trabajadores empleados de las empresas tercerizantes (prestadoras). Hay mayor riesgo de accidentes laborales, menor remuneración e implicación sindical, todo lo cual acaba dando lugar a una mayor explotación del trabajador subordinado. Por ello es importante la actuación colectiva, con el fin de preservar los derechos de los trabajadores de estas empresas. ${ }^{95}$ Serrano Piernas suma a todo esto el hecho de que la negociación sindical o colectiva debe tener como fin la inclusión en los convenios y conciertos colectivos de una mayor protección para los trabajadores de las empresas subcontratadas. Estas empresas son las más numerosas y la mayor parte de sus trabajadores son subordinados, trabajadores sometidos a las peores condiciones de trabajo y renta. $^{96}$

Finalmente, interesa saber el motivo por el cual se hace tanta "contrapropaganda" con relación al trabajo. La razón dada por los medios de comunicación y que parece ser aceptada, es que el trabajo cuesta caro. ${ }^{97}$ Sin embargo, esto no es verdad. El trabajo no supone ni el $15 \%$ ni el coste de la producción. Oscar Ermita Uriarte apunta que:

\footnotetext{
"Acontece, sin embargo, que en general, los derechos laborales o el grado de protección del trabajador afectan muy poco el coste total de la producción y, menos aún, el precio de venta de un producto. En la industria manufacturera, el coste del trabajo es ínfimo como porcentaje del coste total de producción y menor aún como porcentaje del precio de venta. Parece que, de media, en nuestros países, el coste del trabajo tendería a situarse alrededor del $10 \%$ del coste de la producción" ${ }^{98}$

${ }^{94}$ SERRANO PERNAS, Fernando, "Acción sindical y descentralización productiva", cit.

${ }^{95}$ SERRANO PERNAS, Fernando, "Acción sindical y descentralización productiva", cit., p. 222/223.

${ }^{96}$ SERRANO PERNAS, Fernando, "Acción sindical y descentralización productiva", cit., p. 227.

97 PASTORE, José, Trabalhar custa caro, São Paulo: LTr, 2007.

${ }^{98}$ ERMIDA URIARTE, Oscar, A Flexibilidade, cit., p. 56.
} 
El periodico de internet francés Le Monde publicó una noticia que dice que se el Mc Donalds doblase el sueldo de sus empleados, desde el más pequeño hasta de los patrones, el coste del Big Mac seria solamente 0,50 de euros más caro ${ }^{99}$. El estudio ha sido hecho por la Universidad del Kansas, lo que comprueba, una vez más la correcta analisis de Oscar Ermida Uriarte sobre el coste del trabajo dentro de las empresas privadas.

Por otro lado, Suárez apunta que la aceptación como dogma de que la rigidez del mercado de trabajo es la causa principal de los malos resultados de la política de empleo hizo que desde 1976, en España, se hayan implantado una serie de medidas legislativas flexibilizadoras, siempre con el propósito de fomentar el empleo. ${ }^{100}$ Estas medidas, sin embargo, no han logrado los efectos deseados. Suárez indica que los desempleados, en España, en 1975 alcanzaron la cifra de doscientos cincuenta seis mil quinientos setenta uno trabajadores, 1,91\% de la población económicamente activa del país. En el último trimestre de 1994, se llegó a tres millones, seiscientos noventa ocho mil cuatrocientos trabajadores, $23,90 \%$ de la población económicamente activa. Los datos hablan por sí mismos, y revelan que los gobiernos que han adoptado fórmulas para la solución de este problema no han tenido éxito. ${ }^{101}$

Tanto es verdad que, con el auge de la crisis económica los contratos temporales en España tuvieron una significativa disminución del 2,5\% totalizando, el 25 de abril de 2009 , el $25,41 \%$ de los contratos de trabajo. ${ }^{102}$

99 http://bigbrowser.blog.lemonde.fr/2013/07/30/laddition-combien-couterait-un-big-mac-si-mcdodoublait-ses-salaires/ - aceso el 31 de julio de 2013, a las 11h07min.

${ }_{100}$ SUÁREZ, Fernando, "Informe español", ". En Crisis del estado de bienestar y derecho social, Pamplona: ESADE - Facultad de Derecho. J.M. Bosch Editor, 1997, p. 86.

101 SUÁREZ, Fernando, "Informe español", cit., p. 86/87.

102 Vid. el reportaje del periódico El País sobre la crisis económica de finales de 2008 e inicio de 2009: "el único efecto positivo - aunque indeseado - de la destrucción de empleo es la caída de la temporalidad. La proporción de asalariados que trabajan con un contrato eventual se sitúa ahora en el 25,41\%, 2,5 puntos menos que en el trimestre anterior. Se trata de la tasa más baja desde 
Por otro lado, José Maria Zufiaur, miembro del Comité Económico y Social Europeo, apunta que la gran pérdida de empleos en España en esta última crisis tiene origen en el hecho de que haya baja productividad y, también, por causa del modelo laboral. Para Zufiaus, el modelo laboral español registra una elevada temporalidad y que, a pesar del coste, permite el despido con cierta facilidad si es comparado con los demás países europeos. En la mayoría de los países europeos el despido sin justa causa es imposible. En estos países, la rescisión del contrato debe ser autorizada por el juez, la Administración, o aceptada por los sindicatos. Considera que no debe forzarse la reforma laboral, sino que deben centrarse los esfuerzos en crear empleos de calidad, elevar la productividad a niveles que puedan fomentar la educación, la formación y la investigación. Finalmente, concluye que Alemania mitigó los efectos de la recesión en el mercado de trabajo mediante la reducción temporal de la producción y reducción de jornada de trabajo en lugar de los despidos. ${ }^{103}$

De ahí, podemos deducir los motivos por los cuales se está tratando de forma tan injusta el trabajo subordinado. Efectivamente, si este último no cuesta caro, pero hay publicidad que afirma lo contrario, será porque el problema es otro. El problema, por tanto, está en la acción colectiva de los trabajadores. Los grandes economistas, y aquí podemos incluir el nombre de aquellos mentores de los think tanks, en efecto, pretenden la desestabilización de la clase trabajadora a través de la flexibilización y el desempleo para mantener la dominación por parte de las

1989 y relega la temporalidad - hasta hace poco más de un año, el principal problema del mercado laboral español - a un segundo plano". (El País, sábado, 25 de abril de 2009, p. 25).

Hay que destacar que el $91 \%$ de los contratos de empleo, firmados en abril de 2011, fueron contratos temporales, denominados "contratos basura", (http://www.wikipedios.com/economia/unmillon-de-nuevos-contratos-basura-son-la-realidad-de-las-cifras-de-paro/ - acceso el 08 de enero de 2012, à las 19h53min, horario de Paris), lo que muestra la fragilidad de la economia capitalista y de la flexibilización, que aumenta la concentracion de renta, ya que las empresas que pueden contratar por tiempo indefinido no lo hacen para reducir costes, sin tomar en consideración la situación humana y económica del trabajador.

Hay que añadir que dos tercios de los accidentes laborares en España se producen con trabajadores temporales, lo que prueba, otra vez, la precariedad de esta forma de contratación. http://www.empleopublico.net/enews4.php?var=454 - acceso el 08 de enero de 2012, a las 19h43min, horario de París.

${ }^{103}$ El País, domingo, 26 de abril de 2009, p. 28. 
elites capitalistas. ${ }^{104}$ Separando a los trabajadores de los sindicatos y de los movimientos sociales, serán más vulnerables, y se les podrá manejar fácilmente.

En Rio Grande do Sul, Estado de la federación brasileña, hay una campaña declarada contra las "escuelas itinerantes" creadas por el movimiento de los trabajadores rurales sin tierra (MST). Hay incluso funcionarios públicos cuya misión no es sólo la de combatir esta forma de enseñanza sino la de intentar criminalizar las acciones del movimiento que no se resigna al orden jurídico excluyente, actualmente en vigor. ${ }^{105}$

Finalmente, en 2011 se comenzó a discutir la reapertura de las escuelas itinerantes en Rio Grande do Sul. El espacio de formación educativa pública de calidad, dirigida ahora a la produccion agrícola confía en que suponga un beneficio para los niños y adolescentes hijos de trabajadores sin tierra. Sin embargo, no faltan opositores a esta propuesta, con el argumento de que las escuelas

\footnotetext{
104 Sobre el coste del trabajo y la propaganda claramente tendenciosa realizada por la prensa, resulta interesante un artículo del Jornal Zero Hora, el 09 de abril de 2009, p. 26, titulado "El Gobierno desiste de reducir las cargas sociales en los salarios". En un cuadro anexo, el periodista presenta un porcentaje del $85,77 \%$ como el beneficio que obtiene el empresario sobre el valor del salario pagado. Se olvida decir, sin embargo, que de estos $85,77 \%$ al menos el $36 \%$ son fruto de contribuciones sociales que tienen como objetivo el de reducir los riesgos de accidentes laborales, así como de mantener vivo al trabajador y recuperarlo en caso de enfermedad o incluso de accidente, sin ningún coste para el patrón. Por otro lado, omite que el decimotercer salario (salario de paga extra en Brasil en la época de la navidad), sirve exclusivamente para estimular la economía, así como el aumento de 1/3 sobre el valor de las vacaciones. Los citados "beneficios" concedidos al trabajador lo son, en efecto, para preservar y recuperar al trabajador, devolviéndolo, sin coste, a la línea de producción y para estimular la economía y el mercado. Prueba de ello es el artículo publicado en el Jornal Zero Hora intitulado "MP x sem-terra - a desistência do homem que enfrentava o MST".

${ }^{105}$ Prueba de ello es el artículo publicado en el Jornal Zero Hora intitulado "MP x sem-terra - a desistência do homem que enfrentava o MST". Jornal Zero Hora, 09 de abril de 2009, p. 04/05.

El texto se refiere al cierre de las escuelas itinerantes, con la quiebra del convenio existente entre el Gobierno del Estado y el movimiento. Las escuelas tenían como propósito prestar una enseñanza un poco distinta de la habitual, teniendo en cuenta la condición social de los alumnos, hijos de trabajadores sin tierra. En efecto, la escuela intentaba mostrar a cada alumno su real papel dentro de la sociedad, lo que parece haber desagradado no solo a la prensa sino también a las elites y al gobierno, este fiel reproductor de la ideología dominante.
} 
itinerantes hacen un "lavado de cerebro" a nos niños, lo que no es verdad, porque eso podría suceder en cualquier escuela, y no solamente en las del MST. ${ }^{106}$

A la pérdida de la conciencia de clase, por tanto, se llega a través de la precarización y flexibilización de los derechos sociales. Los trabajadores, por este motivo, ya no forman parte de los sindicatos, perdiendo su capacidad de actuación colectiva. La sociedad, a través de los medios de comunicación y de la propaganda, ha acabado por repetir e introyectar en su "ADN" una especie de retroceso en materia laboral como algo saludable para todos. Es extraño que hoy el coste de una buena escuela esté al alcance de una pequeña parte de la población y que aún así, se incentive y se defienda el retroceso en el campo laboral y social. Se cree que la cuestión de clase, aquélla relacionada con el hecho de que cada uno sea consciente de su papel en el entramado del tejido social y económico, es la responsable de esta enorme disparidad económica existente entre ricos y pobres. Hay cada vez más pobres. Hay cada vez menos "clase media" y, al mismo tiempo, más desregulación y flexibilización de la legislación social.

\subsection{La pérdida de la conciencia de clase}

Para tratar adecuadamente la pérdida de la conciencia de clase conviene que nos referimos previamente a la ideología y a los aparatos ideológicos del Estado. Por consiguiente, comenzaremos por una breve introducción de lo que es ideología y su posición dentro de la estructura económica, según Marx y, después, continuaremos con algunas consideraciones sobre los aparatos ideológicos del Estado según Poulantzas y Althusser. Antes, sin embargo, nos vamos a ocupar de las clases sociales.

\footnotetext{
106 WEISSHEIMER, Marco Aurélio, As escolas itinerantes do MST, En http://rsurgente.opsblog.org/2011/05/06/as-escolas-itinerantes-do-mst/ acceso el 08 de enero de 2012, à las 20h08min, horario de París.
} 
Para la teoría marxista, las clases sociales son grupos de agentes sociales, hombres, definidos, 'principalmente', por su lugar en el 'proceso de producción', en la esfera económica, por tanto, en el conjunto de la 'división social del trabajo'. ${ }^{107}$

La ideología, para Marx, es parte, junto con el derecho y el gobierno, de la superestructura, que se basa en las fuerzas productivas y relaciones de producción (infraestructura). ${ }^{108}$

Para Poulantzas la ideología no consiste solamente en un sistema de ideas o representaciones. Es también un conjunto de prácticas materiales, extendiéndose a los hábitos, costumbres, al modo de vida de los agentes, moldeándose como una amalgama al conjunto de las prácticas sociales, políticas y económicas. "Las propias relaciones ideológicas son esenciales en la constitución de las relaciones de propiedad económica y de posesión, en la división social del trabajo en el propio seno de las relaciones de producción". El Estado, solamente con la represión, no puede reproducir la dominación a través de la fuerza o represión. Debe apelar a la cuestión ideológica que acaba por legitimar la violencia y "contribuye a organizar un 'consenso' de ciertas clases y fracciones dominadas con relación al poder político". ${ }^{109}$ La ideología no es algo neutral en la sociedad. Existe tan sólo ideología de clase. Concretamente, la ideología dominante consiste en un poder especial de la clase dominante. ${ }^{110}$

Lo que acaece es que la ideología dominante se encarna en los aparatos del Estado y que también tienen el papel de elaborar y propagar esta ideología (dominante). $\mathrm{Y}$ eso es importante en la cuestión de la división del trabajo, de las clases sociales y de la dominación de clases. Es éste el papel de ciertos aparatos

\footnotetext{
107 POULANTZAS, Nicos, "Classes sociais e luta de classes". En: Poulantzas, Organizador Paulo Silveira. Coordenador Florestan Fernandes, São Paulo, Ática, Coleção Grandes Cientistas Sociais n. 47,1984 , p. $95 / 96$.

${ }^{108}$ SELL, Carlos Eduardo, Sociologia Clássica: Durkheim, Weber [e] Marx, Itajaí; UNIVALI, $3^{\text {å ed., }}$ 2002, p. 172.

109 POULANTZAS, Nicos, "Os aparelhos ideológicos: o Estado, repressão + ideologia?" En: Poulantzas, Organizador Paulo Silveira. Coordenador Florestan Fernandes. Ed Ática, Coleção Grandes Cientistas Sociais n. 47, 1984, p. 77.

${ }^{110}$ POULANTZAS, Nicos, "Os aparelhos ideológicos (...)", cit., p. 77.
} 
que derivan de la esfera del Estado y que han sido designados como "aparatos ideológicos del Estado", tanto si forman parte de hecho del Estado, como si tienen un carácter jurídico privado. Se trata de la iglesia, la escuela, la radio y la televisión (aparato oficial de información), aparato cultural, entre otros. De ahí podemos concluir que la ideología dominante interviene en la organización de los aparatos (ejército, policía, justicia, administración) encargados especialmente del ejercicio de la violencia. ${ }^{111}$

Noam Chomsky apunta que las elites económicas, líderes políticos y gestores ideológicos no creen en la democracia. Comparten intereses ideológicos y ven el mundo de la misma manera. Para ellos, el trabajador no es más que un robot, con movimientos controlados, fruto de una industria de la propaganda especialmente relacionada con la televisión. ${ }^{112}$ Sostiene que:

\begin{abstract}
"Rápidamente las elites se dieron cuenta de que también pueden ocuparse de lo que llaman el control fuera del trabajo. De la misma manera que controlamos a la gente en el trabajo, la podemos controlar fuera del trabajo y convertirla en robot. Y para eso existe un programa de masas que intenta influir en la gente desde la infancia, para que sus únicos valores sean el consumo personal, sin que le importe otra cosa. A eso se lo conoce como la filosofía de la inutilidad y todo el valor personal está ligado a cuantos objetos inútiles uno pueda juntar y cuanto más endeudado esté uno, mejor. Hay un gran esfuerzo por lograr que la gente sea así. Y, en algún punto, es un esfuerzo exitoso". ${ }^{113}$
\end{abstract}

En la misma vertiente, Althusser apunta que la reproducción de la fuerza de trabajo (fuerzas productivas) se da a través del salario, medio material que se le entrega al trabajador por el servicio prestado al capitalista. El salario es indispensable para la reproducción material de la vida del trabajador, con alimento, vestuario, educación de los hijos, reproduciéndose como fuerza de trabajo ${ }^{114}$, como mano de obra, representando una pieza en el sistema capitalista.

\footnotetext{
111 POULANTZAS, Nicos, "Os aparelhos ideológicos (...)", cit., p. 78.

112 CHOMSKY, Noam, "Bush y los años del miedo", En Conversaciones con Jorge Halperín, Buenos Aires: Le Monde Diplomatique, 2003, p.40/41.

${ }_{113}$ CHOMSKY, Noam, "Bush y los años del miedo", cit., p.41.

${ }^{114}$ ALTHUSSER, Louis, Aparelhos Ideológicos de Estado (...), cit., p. 56.
} 
No basta, sin embargo, con asegurar la fuerza de trabajo (trabajadores) y las condiciones materiales para su reproducción. La reproducción se debe dar contando con un elemento fuera del proceso productivo, como por ejemplo, el sistema escolar capitalista. ${ }^{115}$

Althusser afirma, por otro lado, que la reproducción de la fuerza de trabajo no exige sólo la reproducción de su cualificación, sino también la de su sometimiento a las normas del orden vigente, es decir, una reproducción de la sumisión de los trabajadores a la ideología dominante "y una reproducción de la capacidad de perfecto dominio de la ideología dominante por parte de los agentes de la explotación y represión, de modo que los mismo aseguren también 'mediante la palabra' el predominio de la clase dominante". ${ }^{116}$

Conviene que ahora recordemos brevemente los conceptos de infraestructura y de superestructura. Por consiguiente, recurriremos a Marx, que divide la sociedad en niveles y presenta la infraestructura como la base económica formada por las relaciones de producción y por las fuerzas productivas; la superestructura es la que comprende dos niveles: el jurídico/político (el derecho y el Estado) y el ideológico. ${ }^{117}$

\footnotetext{
115 ALTHUSSER, Louis, Aparelhos Ideológicos de Estado (...), cit.,, p. 57/58. ¿Qué se aprende en la escuela, se pregunta Althusser? Se aprende a leer, a escribir, a contar, cultura científica y literaria, además de avanzar un poco dentro del sistema de estudio. Estas técnicas y formas de aprendizaje están relacionadas y se utilizan en los diferentes puestos de la producción (una forma de instrucción para trabajadores, otra para técnicos, una para ingenieros y una diferente para gerentes superiores, etc.). En efecto, qué se aprende es el "know-how" capitalista.

Complementando a Althusser, Chomsky apunta que las escuelas son centros de adoctrinamiento y obediencia impuestos. Lejos de favorecer el pensamiento independiente, la escuela, a lo largo de la historia, "no ha dejado de interpretar un papel institucional dentro de un sistema de control y coerción. Una vez que se te ha educado, se te ha socializado ya de una manera que respalda las estructuras de poder que, a su vez, te recompensan generosamente". Para el autor, en las escuelas hay un adoctrinamiento tendencioso y que incapacita incluso a las personas instruidas a la hora de comprender las ideas más elementales referentes a la realidad y a la verdad (CHOMSKY, Noam, La (des) educación, Barcelona: Crítica, 2007, p.23/24).

${ }_{116}$ ALTHUSSER, Louis, Aparelhos Ideológicos de Estado (...), cit., p. 58.

${ }^{117}$ ALTHUSSER, Louis, Aparelhos Ideológicos de Estado (...), cit., p. 60.
} 
Como subraya Althusser, sin las bases (infraestructura), la cumbre (superestructura) no puede sustentarse ${ }^{118}$, lo que prueba que ésta depende de aquélla, aunque sea la última quien detenta el poder sobre el Estado y la ideología, caracterizándose como la clase dominante.

Este Estado no es más que el reflejo de la clase dominante. Es un medio de represión donde la burguesía asegura su dominación frente a la clase obrera, para someterla al proceso de la extorsión de la plusvalía, al proceso de la explotación capitalista declarada. El (Estado) es un aparato represivo, represión ésta ejercida a través de sus más diversos órganos como la policía, los tribunales, los centros penitenciarios, al servicio de las elites frente al proletariado, teniendo por función la reproducción del modo capitalista de producción. ${ }^{119}$

¿Qué son, en efecto, los aparatos ideológicos del Estado y cómo actúan? Althusser apunta que fue Gramsci quien tuvo la idea de que el Estado no está formado sólo por el aparato represivo, sino también por un cierto número de instituciones existentes en la sociedad civil, tales como la iglesia, la escuela, los sindicatos, etc. Los aparatos ideológicos del Estado no se confunden con los aparatos represivos del Estado. Los aparatos represivos del Estado son el gobierno, la administración, el ejército, la policía, los tribunales, las prisiones, y funcionan a través de la violencia, al menos en situaciones-límite, ya que la represión, por ejemplo, administrativa, puede producirse sin ningún acto violento. $^{120}$

Los aparatos ideológicos del Estado son las Iglesias, las Escuelas, la familia, el Derecho, la política, los sindicatos, la cultura y otros. No significa que no haya, así como en el caso del "Derecho", algunos aparatos ideológicos que al mismo tiempo son aparatos ideológicos y aparatos restrictivos del Estado. Una distinción que no es completa, pero que sirve para la mayoría de los casos, es la de que los

\footnotetext{
${ }^{118}$ ALTHUSSER, Louis, Aparelhos Ideológicos de Estado (...), cit., p. 60.

119 ALTHUSSER, Louis, Aparelhos Ideológicos de Estado (...), cit., p. 62/63.

120 ALTHUSSER, Louis, Aparelhos Ideológicos de Estado (...), cit., p. 67/68.
} 
aparatos represivos del Estado forman parte del poder público y, por potro lado, los aparatos ideológicos del Estado del poder privado. ${ }^{121}$

Los aparatos represivos del Estado funcionan principalmente por la represión, a pesar de que pueda tener un aspecto ideológico, pero secundario (ARE). Por su parte, los aparatos ideológicos del Estado operan preferentemente y principalmente por la ideología, aunque tengan el carácter coercitivo, ya que las escuelas, iglesias, sindicatos e incluso las familias tienen sus formas de violencia como las exclusiones, incluso el castigo físico y las sanciones en general. ${ }^{122}$

La ideología utilizada por los aparatos ideológicos del Estado es la ideología de las elites dominantes. Es la ideología burguesa capitalista. Y esta ideología es difícil de combatir. Tanto es así que Lenin, cuando la Revolución toma el poder creando en Rusia la Unión de las Repúblicas Socialistas Soviéticas, intenta revolucionar el aparato ideológico de la escuela pública, para que el proletariado soviético, que se apropió del Estado, pudiera garantizar su propio futuro con la dictadura del proletariado y con el socialismo. ${ }^{123}$

¿Cómo es la reproducción de las relaciones de producción, tan esencial para mantener el orden capitalista?

Althusser sostiene que la reproducción de las relaciones de producción viene dada por la ideología en el ámbito jurídico-político, es decir, en el ámbito de la superestructura, junto con los aparatos del estado (ARE y AIE). Quien controla los aparatos represivos del Estado y los aparatos ideológicos del Estado son las elites

\footnotetext{
121 ALTHUSSER, Louis, Aparelhos Ideológicos de Estado (...), cit., p. 69.

122 ALTHUSSER, Louis, Aparelhos Ideológicos de Estado (...), cit., p. 70.

${ }^{123}$ Chomsky apunta que las escuelas fueron diseñadas para apoyar los intereses del sector dominante de la sociedad, "La gente de mayor riqueza y bienestar". Hace mucho tiempo la educación nos impone que comprendamos la necesidad de prestar respaldo a las estructuras de poder, especialmente para las grandes empresas y los hombres de negocios. Deformada, por lo tanto, con su forma de adoctrinamiento de los jóvenes la formación de éstos evitando que se enseñen doctrinas e informaciones no deseadas. ALTHUSSER, Louis, Aparelhos Ideológicos de Estado (...), cit., p. 71 y

CHOMSKY, Noam, La (des) educación, cit., p. 25.
} 
capitalistas dominantes, reproduciendo el poder represivo e ideológico existente con el fin de mantener la propiedad privada y el trabajo asalariado.

El papel de los aparatos represivos del Estado consiste, como aparato represivo, en garantizar, por la fuerza (física o no), las condiciones adecuadas para la reproducción de las relaciones de producción que nada no son más que las relaciones entre capital y trabajo, relaciones de explotación. Garantizan, además, que los aparatos ideológicos del Estado puedan ejercer sus funciones, garantía ésta ejecutada a través de la represión. ${ }^{124}$

En cuanto a los aparatos ideológicos del Estado, se debe tener en cuenta que es mediante los mismos como el modo de producción capitalista se repite e incorpora en la mente de las personas una ideología de exclusión y desigualdad. La educación impartida por los profesores, se transmite a sus alumnos y crea, para estos mismos alumnos, una especie de ética de exclusión social fundamentada en que todo está al alcance de quien efectivamente quiera trabajar.

Todos los aparatos ideológicos del Estado compiten, y por lo tanto no se excluye, por razones obvias, la escuela, con el mismo fin: reproducción del modo de producción capitalista, componiendo la superestructura ideológica que asegura esta reproducción. ${ }^{125}$

Gran parte de esta ideología se aprende fuera de la escuela. No hay ningún aparato ideológico que disponga durante tantos años, de audiencia obligatoria y, añadimos, ingenua, de cinco o seis días por semana, con una media ocho horas por día, de la totalidad de los niños de la sociedad del capital. ${ }^{126}$

Esta realidad convierte a estos niños en ciudadanos para el mercado, reproduciendo, de forma inconsciente, la lógica que les fue impuesta por los años

\footnotetext{
24 ALTHUSSER, Louis, Aparelhos Ideológicos de Estado (...), cit., p. 74.

125 ALTHUSSER, Louis, Aparelhos Ideológicos de Estado (...), cit., p. 78.

126 ALTHUSSER, Louis, Aparelhos Ideológicos de Estado (...), cit., p. 80.
} 
de enseñanza a los modelos dominantes, sin ningún tipo de oposición. Los niños son presas fáciles, manejables, y serán adultos ya manipulados, piezas de reproducción de la lógica de dominación capitalista. ${ }^{127}$

Conviene recordar que los aparatos ideológicos del Estado y el propio Estado sólo tienen sentido desde un punto de vista de la lucha de clases, como aparato de la lucha de clases, que mantiene las condiciones de explotación y de su reproducción. "No hay lucha de clases sin clases antagónicas". Los aparatos ideológicos del Estado no son la realización de la ideología en general, o incluso la realización sin conflictos de la ideología dominante. La ideología de la clase dominante no se convierte en dominante por gracia divina, o por la simple

${ }^{127}$ Chomsky, refiriéndose a los espectadores, afirma que la idea de los verdaderos agentes del sistema es, por la propaganda, forjar valores e imponer el consumismo ciego. Y este proceso comienza cuando el ser humano es niño lo que confirma lo está hasta aquí expuesto por los textos de Althusser con respecto a los aparatos ideológicos del Estado (CHOMSKY, Noam, "Bush y los años del miedo", cit., p.42).

El mismo autor, en otra obra, refiriéndose a la forma de actuar de las elites dominantes, representadas fielmente por el Estado, para controlar el "rebaño", cuelga un martillo sobre la cabeza de los ciudadanos que, una vez moviéndose, sufre el golpe fatal. En las sociedades democráticas, al contrario, no se puede mantener a las personas controladas de forma bruta, lo que hace que, para controlar a la opinión pública, se debe optar por la propaganda. En esta tarea de control de la opinión pública, la clase instruida se hace indispensable, y la escuela desempeña un papel relevante, central. (CHOMSKY, Noam, La (des) educación, cit., p. 31).

Los mecanismos que producen y reproducen la relación entre los explotadores y los explotados del orden capitalista son naturalmente "encubiertos y disimulados por una ideología de la escuela universalmente aceptada, que es una de las formas esenciales de la ideología burguesa dominante: una ideología que representa la escuela como neutra, desprovista de ideología (una vez que es laica), donde los profesores, respetuosos de la 'conciencia' y de la 'libertad' de los niños que les son confiadas por los 'padres"', que también son "libres", entendidos como propietarios de sus hijos, conducidos a la libertad, a la moralidad, a la responsabilidad adulta con su ejemplo, conocimiento, literatura y virtudes en general libertarias (CHOMSKY, Noam, La (des) educación, cit., p. 31).

"En los estados totalitarios, en cambio, controlas al 'rebaño' colgando un martillo sobre sus cabezas: al que se mueva de su lugar, le chafas la cabeza. Pero en las sociedades democráticas, no se puede confiar en la fuerza bruta para mantener la población a raya, así que, para controlar la opinión pública, hay que optar principalmente por la propaganda. En esta tarea de control de la opinión, la clase instruida resulta indispensable, y la escuela desarrolla una función crucial" (ALTHUSSER, Louis, Aparelhos Ideológicos de Estado (...), cit., p. 80).

La Escuela, substituta de la Iglesia como el aparato ideológico, junto con la familia, desempeña, por la forma como actúa, desde los primeros años de vida hasta la conclusión de la formación intelectual del ciudadano, como forma de reproducción de las relaciones de producción del modo capitalista que, constantemente amenazado por la lucha de clases, consigue, infiltrándose junto con el proletariado, garantizar su hegemonía y mantener, para las elites dominantes, las relaciones de explotación a través del trabajo asalariado y la acumulación de capital en las manos de unos pocos. 
asunción del poder por parte del Estado. Mediante el establecimiento de los aparatos ideológicos del Estado, esta ideología se convierte en dominante. ${ }^{128}$

Para la ideología de la clase dominante hay una reproducción de las relaciones de producción, manteniendo el orden capitalista (elite dominante) intacta, sin que los propios afectados (proletarios y trabajadores en general) sean conscientes de ello, puesto que "dominados" por la reproducción ideológica capitalista desde la familia, pasando por la iglesia, sindicatos, escuela y el derecho (estructura tanto ideológica como represiva).

Conviene tener presente el problema de la pérdida del poder de crítica, por el que personas y ciudadanos apenas desarrollan la función de pensar. Se limitan a recibir las informaciones que provienen de la opinión pública de forma casi acrítica, informaciones publicadas que aceptan sin contrastar ni reflexionar. Acaban siendo controlados por los que manejan los hilos del poder, los empresarios de la comunicación, cuyo único propósito es ganar dinero con el aumento de la audiencia. Los politicos acaban olvidando los principios y los

\footnotetext{
128 Tanto que Althusser afirma que "este establecimiento no se lleva a cabo por sí sólo, al contrario, es la prueba de una dura e ininterrumpida lucha de clases: en primer lugar contra las antiguas clases dominantes y sus posiciones en los antiguos y nuevos AIE, en segundo lugar, contra la clase explotada" (ALTHUSSER, Louis, Aparelhos Ideológicos de Estado (...), cit., p. 106). Es Interesante, aquí, hacer referencia a las primeras frases de la obra El Manifiesto del Partido Comunista: "Hasta nuestros días, la historia de la sociedad ha sido la historia de las luchas de clase. Hombre libre y esclavo, patricio y plebeyo, barón y siervo, maestro-artesano y aprendiz - en una palabra, opresores y oprimidos, en constante oposición - han vivido en una guerra interrumpida, ahora franca, ahora disfrazada; una guerra que siempre terminaba con una transformación revolucionaria de toda la sociedad o por la destrucción de las dos clases en lucha" (MARX, Karl e FRIEDRICH, Engels, Manifesto Comunista. Comentado por Chico Alencar, Rio de Janeiro; Garamond, 1998, p. 51).

En el mismo sentido, Lenin aduce que: "En cuanto a la época moderna, la de la victoria completa de la burguesía, de las instituciones representativas, del sufragio ampliado (jhasta universal!), de la prensa cotidiana barata, que penetra en las masas, etc., la época de las asociaciones poderosas y cada vez más vastas, la de los obreros y de los patrones, etc., mostró, aún con más evidencia (aunque a veces bajo una forma muy unilateral, "pacífica", "constitucional") que la lucha de las clases es el motor de los acontecimientos" (LÊNIN, "Karl Marx". En: As três fontes e as três partes constitutivas do marxismo, São Paulo: Global Editora, 6 Ed; 1988, p. 26).
} 
ideales para centrarse en el exclusivo propósito de llegar o de mantenerse en el poder. $^{129}$

Son ciudadanos que no pueden reaccionar en los momentos de crisis porque son incapaces de piensar, se convierten en ciudadanos que pierden, de hecho, su propia condición de ciudadanos para convertirse en siervos. ${ }^{130} \mathrm{Y}$ los siervos, que no tienen poder de reacción, no son capaces de analizar y discernir lo que sucede a su alrededor. Hoy se habla mucho en participación publica y de democracia deliberativa, pero se delibera menos que nunca. La opinión públia está controlada por grupos de empresarios que operan como socios de los partidos politicos, y el parlamento se halla sumido, desde hace décadas, en una de las más profundas crisis de su história, convertiédose en mero comparsa del poder ejecutivo. ${ }^{131}$

La lucha por la reproducción de la ideología dominante es una batalla inacabada que siempre necesita renovación, hay que queda sujeta a la lucha de clases.

Marx, en la obra La Ideología Alemana, destaca que la clase que dispone de los medios de producción material dispone, también, de los medios de producción espirituales (ideas), lo que hace que los que no disponen de los medios de producción material estén siempre sometidos a las ideas de los que poseen los medios de producción material. ${ }^{132}$

Chomsky apunta que:

"Las elites no quieren la democracia. La gente puede querer la democracia, pero los poderosos y los privilegiados no quieren la democracia. $\mathrm{Y}$ eso también incluye a algunos intelectuales. Muchos

\footnotetext{
129 SERNA BERMUDEZ, Pedro, "Politica posmoderna y crisis de la razón jurídica", En Anuario de la Facultad de Derecho de la Universidad de a Coruña, 13, Universidade de a Coruña, 2009, p. 1083.

130 SERNA BERMUDEZ, Pedro, "Politica posmoderna y crisis de la razón jurídica”, cit., p. 1085.

131 SERNA BERMUDEZ, Pedro, "Politica posmoderna y crisis de la razón jurídica”, cit., p. 1087.

132 MARX, Karl, A ideologia alemã. Tradução Frank Muller, São Paulo; Martin Claret, Coleção Obra Prima de Cada Autor, Textos Integrais, 2006, p. 78.
} 
intelectuales no quieren la democracia. Los intelectuales progresistas casi siempre se opusieron a la democracia. Y las decisiones más importantes, en todo ese período y hasta el día de hoy, las toma lo que se llama la oligarquía. Los hombres responsables son quienes deben tomar las decisiones y la población tiene que ser espectadora y no participante. La población es lo que Alexander Hamilton llamaba "la gran bestia que tiene que ser domada y controlada". No se la puede dejar fuera de control, hay que controlarla de una manera u otra. La mejor manera es teniendo un "control en el trabajo" y convirtiendo a la gente en robot, y un 'control fuera del trabajo', a través del control de las actitudes y los sentimientos". ${ }^{133}$

Es, sin duda, a través de la reproducción por los aparatos ideológicos y también represivos del Estado de la ideología dominante como los trabajadores han perdido su conciencia de clase. No sólo el obrero, sino también las personas de la clase media como los servidores públicos, los técnico-científicos e incluso los pequeños comerciantes, los trabajadores autónomos y los microempresarios, cuyos intereses son comunes, han acabado repitiendo el discurso dominante de la desregulación y la flexibilización laboral, dando mayor peso y valor a los aspectos del mercado y de la economía. ${ }^{134}$

${ }^{133}$ CHOMSKY, Noam, "Bush y los años del miedo", cit., p.45/46.

134 A este respecto, es interesante la obra de Thomas Frank, donde el autor presenta el mercado como un ente ya absorbido por la población en general, en un concepto de "mercado popular y democrático" en que cada uno, por sí mismo, puede invertir en acciones y cuidar de ellas como si fuesen suyas (FRANK, Thomas, Deus no céu e o mercado na terra, cit).

Muestra cómo la sociedad acaba deformando el mundo e incorpora el aspecto económico como algo propio, como algo que forma parte activa y detiene el control. Las personas se sienten colaboradoras de las empresas y agentes conscientes del mercado, comprando y vendiendo acciones. Lo hacen sin saber que repiten la ideología que les es impuesta por quien detenta el poder y abandonan la cuestión de clase, renunciando a un futuro mejor para sí y para sus descendentes, que serán meros repetidores del orden excluyente actualmente vigente.

Frank afirma que para preservar los beneficios de los propietarios la solución fue el populismo de mercado. La nueva empresa con aspecto verdaderamente revolucionario, comenzaría adoptando el lenguaje populista de su archienemigo, el movimiento laboral. Pero transformaría este lenguaje de forma sutil. Mientras que el movimiento laboral identificaba a los trabajadores con el pueblo, los teóricos de la administración de los años noventa buscarían (y buscaron) un nuevo pueblo, cuyas demandas legitimarían la empresa poniendo en tela de juicio el poder de los demás (FRANK, Thomas, Deus no céu e o mercado na terra, cit., p. 236).

El nuevo pueblo sería el mercado. Solamente atendiendo a las demandas del mercado, afirmaban los nuevos teóricos de la administración, una organización atendería al pueblo, convirtiéndose en una parte legítima de la vida democrática de la nación. Al hacer la integración del mercado para sus operaciones, los ejecutivos se volverían más justos, amables y capaces de escuchar. Tendrían que escuchar al mercado, cooperar con el mercado y permitir la organización de las fábricas por el mercado (FRANK, Thomas, Deus no céu e o mercado na terra, cit., p. 236).

Este mismo "mercado democrático", que trata las personas como partes de producción y como mercancía, en última instancia, descompone y cataliza el valor de las acciones de las empresas en el mercado financiero, favoreciendo a los propietarios de las acciones, a la hora de proceder al de despido de sus empleados o de sus "súbditos" o "agentes". En la parte final de este texto, subraya 
En relación a la reducción de los salarios y el empeoramiento de las condiciones de trabajo, Chomsky apunta que el sistema de jubilaciones que invierte en las acciones de una determinada empresa acaba haciendo que los beneficiarios de estos sistemas de jubilación pretenden una valorización de las acciones a cualquier precio, incluso a costa de reducir las condiciones sociales y salariales de los trabajadores de las empresas que tengan el programa de jubilación privada invertido en acciones. Esto rompe el sistema de solidaridad, o lo que Chomsky denomina "emoción humana". Exacerba el individualismo y aleja la cuestión colectiva del plan de las relaciones humanas. ${ }^{135}$

Por otro lado, no hay que olvidar también la importancia de los think tanks para la consolidación de la pérdida de la conciencia de clase por parte de los trabajadores. Todos estos elementos sumados han acabado por generar lo que hoy se puede denominar como colaborador, o trabajador domesticado y sin capacidad asociativa y reivindicativa.

No podemos negar que la teoría marxista conlleva críticas. Marx hace un análisis profundo de la sociedad y de las elites dominantes. Su teoría, sin embargo, llevada a la práctica, ha demostrado que tiene problemas y defectos. No enfrenta a la cuestión de la naturaleza humana y clasifica los derechos humanos como una forma presentada por las elites burguesas para impedir la dictadura del

Frank: "si nuestro jefe nos había empujado hacia la línea del desempleo, probablemente lo haría para aumentar el valor de sus propias acciones de la empresa". FRANK, Thomas, Deus no céu e o mercado na terra, cit., p. 128.

La democracia en el trabajo tiene por objetivo que los trabajadores hagan sugerencias con respecto a la eficiencia de las empresas, lo que lleva invariablemente a despidos y aumento de producción (FRANK, Thomas, Deus no céu e o mercado na terra, cit., p. 302).

De otro lado, Alain Touraine enseña que el individualismo extremo tiene por objetivo la perpetuación del mercado, y pone de lado el pesamiento colectivo, solamente para tener ventajas económicas, en contra el social. TOURAINE, Alain, Após a crise, Petrópolis, RJ; Editora Vozes, 2011, p. 133.

135 CHOMSKY, Noam, "Bush y los años del miedo", cit., p.43. "Si trabajo en una planta de General Motors y mi jubilación está invertida en acciones de GM, estoy obligado a trabajar más horas con un salario más bajo con menos beneficios y sin ninguna consideración de bien estar personal para aumentar mi pensión. Es la manera perfecta de lograr que la gente se convierta en su peor enemigo". 
proletariado. Desprecia, con este argumento, los años de conquistas y lucha de los trabajadores y de los pueblos, subestimando el ser humano como agente de transformación social.

En el siguiente apartado vamos a discutir qué se puede hacer para superar este problema. Proponemos una "democracia distributiva-comunicativa-educativacultural".

\subsection{La democracia distributiva-comunicativa-educativa-cultural como elemento central del Estado Democrático}

Ralws y Habermas buscan y concentran sus esfuerzos en un nuevo método de legitimación de la democracia, llegando a conclusiones análogas. "La normatividad del derecho y de la justicia sólo puede nacer de la 'autonomía' moral de los propios ciudadanos, de la cooperación y de la discusión entre ellos y condiciones de libertad y de igualdad, con el fin de 'hacer que el uso de sus derechos de comunicación sean orientado hacia el bien público'”. La autonomía moral, para ambos, deberá ser entendida como un conjunto institucionalizado de prácticas y procesos, que garanticen que son los ciudadanos los responsables por los principios y normas a las que deben someterse. ${ }^{136}$ Esta justificación pública

\footnotetext{
${ }^{136}$ AUDARD, Catherine, "O princípio de legitimidade democrática e o debate Rawls-Habermas". En Habermas: o uso público da razão. Rainer Rochlitz (coord.), Rio de Janeiro; Tempo Brasileiro, 2005, p. 82. Sobre este mismo tema conviene destacar que la idea de justicia como equidad, propia del contractualismo rawlsniano y de un consenso racional y argumentativo, propio también de la ética comunicativa habermasiana y de Apel, poseen un parentesco innegable. En los dos casos, el sentido de "justificado" que se atribuye a las normas y a los principios se entiende en términos de seguimiento de las reglas procedimentales y en los dos casos se entiende que el procedimiento incorpora en sí unas fuertes exigencias simétricas en las posiciones correlativas de los partícipes del propio procedimiento. Sin embargo, hay diferencias. Para la ética del discurso, hablar de normas y de principios como bien fundamentados remite a la idea de un consenso racional, alcanzando discursos prácticos y reales en virtud sólo de la fuerza de los argumentos. Rawls intenta articular la justicia como equidad a través de una situación hipotética de deliberación. No hay aquí ningún tipo de motivación moral, orientándose los agentes por las máximas de prudencia, todos de forma mutuamente desinteresada. Las deliberaciones, en el caso de Rawls, suceden a través de un "velo de ignorancia", filtrando todo tipo de información de carácter general, ocultando toda la información particular relativamente a los individuos involucrados. Éstos ignoran no sólo sus condiciones y particulares capacidades, además de los trazos concretos de su psicología, desconociendo sus planes de vida y las concepciones de vida buena y feliz. RODILLA, Miguel Angel, Leyendo a Rawls, Salamanca; Ediciones Universidad de Salamanca, 2006, p. 29/30.
} 
supone un elemento nuevo intersubjetivo, es decir, "la existencia de un verdadero debate público en que cada ciudadano puede presentar sus 'razones' a todos los otros, y un acceso igual de todos a los procesos de deliberación y de decisión, que acaba por desempeñar el papel de un criterio transparente de justicia”. ${ }^{137}$

De aquí cabe deducir que resulta legítima la limitación de la conducta por el derecho. El proceso de formación de este derecho debe ser fruto de la acción por deber en la línea kantiana, donde todos los miembros de la colectividad deben ser considerados como un fin en sí mismo, todos en igualdad de condiciones y con la facultad de presentar ideas en el mismo espacio físico y temporal. De ahí surge la democracia distributiva, a la que calificamos como comunicativa-educativacultural. El lenguaje emancipa. Saca a la superficie lo que generalmente se denomina Estado Democrático de Derecho. En el marco de este lenguaje, se deben originar los procesos culturales y educacionales desarrollados e inclusivos que servirán de fundamento a la democracia distributiva-comunicativa-educativacultural.

Uno de los pilares para construir la concepción de democracia que proponemos es la teoría de la justicia de Rawls. Sobre la misma vamos a limitarnos a recordar brevemente algunas de sus claves, ya que se trata de una teoría por todos conocida.

\subsubsection{La teoría de la justicia en Rawls. ${ }^{138}$}

John Rawls, concibe la justicia como un conjunto de principios que deberían regir la definición y la distribución equitativa de los derechos y deberes de los

\footnotetext{
137 AUDARD, Catherine, "O princípio de legitimidade democrática e o debate Rawls-Habermas", ibidem.

${ }_{138}$ Sobre John Rawls vid. OLIVEIRA, Nythamar, Rawls, Rio de Janeiro; Jorge Zahar Editor, 2003, SEABRA DA CRUZ JÚNIOR, Ademar, Justiça como equidade: liberais, comunitaristas e a autocrítica de Rawls, Rio de Janeiro; Editora Lumen Juris, 2004, PÉREZ BERMEJO, Juan Manuel, Contrato social y obediencia al derecho en el pensamiento de John Rawls, Granada; Editorial Colmares, 1997\# e GONZÁLEZ ALTABLE, Maria Pilar, John Rawls. Una concepción política y liberal de la justicia, Barcelos Portugal; Biblioteca Universitaria, 1993.
} 
miembros de la sociedad. El resultado de este estudio es una teoría deontológica de la justicia social, de matiz contractualista, próxima a la concepción kantiana, y válida para las sociedades democráticas. ${ }^{139}$

Los principios de la justicia deben ser escogidos en una situación determinada. Nadie debe ser favorecido o desfavorecido por la suerte natural o las circunstancias sociales debido a la elección de los principios. Los principios no se adaptan, también, a casos personales. Las concepciones particulares e individuales sobre el bien no afectarán a los principios adoptados. Se excluyen las contingencias que crean disparidades entre los hombres y que permiten que se orienten por sus prejuicios. Así se llega al velo de la ignorancia de manera natural. ${ }^{140}$

Junto al velo de la ignorancia, Rawls defiende que no debe haber alguna influencia exterior con respecto al proceso, de formulación de los principios de justicia de modo que no haya fraude, permitiendo así que todos tengan las mismas oportunidades de ganar. Reivindica la aplicación justa y correcta de las reglas que determinan la justicia de los resultados y no un criterio que venga extraño, externo y único. Esta exigencia es paralela a la formulada por Habermas de encontrar sólo "en las condiciones estructurales de la comunicación entre los ciudadanos la fuente de normatividad del derecho positivo democrático". ${ }^{141}$

Las partes, por tanto, en la posición original, son iguales, es decir, todas tienen los mismos derechos en el proceso de elección de los principios. Esto es consecuencia de la igualdad entre los seres humanos como personas éticas y que

\footnotetext{
139 RAMALHO RABENHORST, Eduardo, "Teoria da justiça”. En Dicionário de Filosofia do Direito. Vicente de Paulo Barreto (org.), Rio de Janeiro; Unisinos e Renovar, 2006, p. 804.

140 RAWLS, John. Uma teoria da justiça, Tradução Almiro Pisetta Lenita Maria Rímoli Esteves, São Paulo; Marins Fontes, $2^{\mathrm{a}}$ ed., 2002., p. 20/21

${ }^{141}$ AUDARD, Catherine, "O princípio de legitimidade democrática e o debate Rawls-Habermas", cit., p. 95.
} 
tienen un sentido de justicia. Los principios, por lo tanto, dado el velo de la ignorancia, son definidos en condiciones de igualdad, sin favoritismo. ${ }^{142}$

En el caso de que haya discrepancias de criterios y/o principios se puede modificar la evaluación de la situación inicial o revisar los juicios actuales. Esto se llama equilibrio de ponderación. Rawls no pretende que los principios de justicia propuestos sean verdades necesarias o que puedan derivar de este tipo de verdad. $^{143}$

Todo ello nos permite mostrar la relevancia de la justicia y de la posibilidad de obtener el mayor número de ventajas, alejándose de los preceptos utilitaristas.

La teoría de la justicia nos permite poner en relación la justicia, con proporcionales o iguales distribuciones no sólo de bienes, sino de educación y cultura, a través de la deliberación ${ }^{144}$, situación ésta que lo aproxima a Habermas. Ambos defienden que se debe buscar un acuerdo sobre los fundamentos de la deliberación, a través de la razón. La justicia, para ambos, tiene un carácter procedimental y aspiran a que se aplique con éxito en la sociedad. ${ }^{145}$

A partir de este concepto de justicia, transitando por los conceptos comunicativos habermasianos pretendemos configurar un concepto de democracia distributiva-comunicativa-educativa-cultural. Democracia para distribuir, de forma proporcional y justa, no sólo bienes sino principalmente la calidad de educación y cultura. Distribuir educación y cultura es distribuir

142 RAWLS, John. Uma teoria da justiça, ibidem.

143 RAWLS, John. Uma teoria da justiça, cit., p. 22/23.

144 Aquí es que se redirecciona el estudio a Habermas y la comunicación intersubjetiva que él sostiene.

${ }^{145}$ Sería interesante aquí hacer referencia al texto del que discrepa, en definitiva, Habermas de Rawls. Para el primero el proceso de formación social es comunicativo, fruto del debate, venciendo el mejor argumento. Habermas hace referencia al giro intersubjetivo, denominado lingüístico. Ya Ralws hace referencia a una posición original y con restricciones de informaciones, considerando por concepción de justicia no lo que sea resultado del debate fundamentado, sino de la conciencia privada de cada individuo, limitado por el velo de la ignorancia. Pero se puede, como se hace creer en este estudio, acercarse a los dos en una teoria de la democrácia. 
democracia, poder de elección, elementos racionales para el discurso, independencia y, especialmente, posibilidad emancipatoria concreta.

Hacemos notar que las referencias a Rawls sirven de apoyo a lo que pretendemos defender en esta investigación. No sustentamos, como hace Ralws, una teoria transcedental de la justicia, sino una teoria que parta de los modelos rawlsianos de una sociedad idealmente justa para, una vez aplicándola al mundo real, permita cambiar la realidad. ${ }^{146}$ Hay que acercar la teoria trascedental de la realidad, lo que aportará, como sostenemos aquí, una democracia más desarrollada que la que se conoce hoy. ${ }^{147}$ La propuesta es osada, pero, posible.

Sen se pregunta qué es una sociedad justa ${ }^{148}$. $Y$ busca responder a esta cuestión valiéndose de la razón ${ }^{149}$ y del transcedentalismo de Rawls.

Aunque Rawls presente la justicia como equidad, no utiliza un ejemplo concreto, sino una situación de deber-ser. Por nuestra parte, para llevar a cabo nuestro análisis, hemos adoptado las ideas de justicia, de igualdad y de desarrollo humano para colocarlas como epicentro de este estudio que tiene por norte también la emancipacion humana. Nuestro objetivo ha sido el de reflexionar, concretamente, acerca de la pérdida de la conciencia de clase y la búsqueda de la emancipacion a través del trabajo, elemento de existencia humana y no solamente de alienación ${ }^{150}$.

\footnotetext{
146 SEN, Amartya, L'idée de justice. Paul Chemla et Éloi Laurent, Paris; Flammarion, 2010, p. 31 , 44 y 142. "Le résultat, globalement, a étéle développement de théories de la justice centrées sur l'identification transcedentale des institutiones idéales" (p. 13). "Nous avons besoin d'une interprétation de la justice fondée sur les accomplissements parce que la justice ne peut rester indiferente aux vies que mènent réellement les gens" (p. 44). "Une théorie de la justice doit avoir quelque chose à dire sur les choix qui s'offrent réellement à nous, et pas seulement nous retenir dans un monde imaginaire et peu plausible d'une insurpassable splendeur" (p. 142/3).

${ }^{147}$ SEN, Amartya, L'idée de justice, cit., p. 132.

${ }_{148}^{148}$ SEN, Amartya, L'idée de justice, cit., p. 13.

149 SEN, Amartya, L'idée de justice, cit., p. 44. "Être en mesure de raisonner et de choisir est un aspect déterminant de la vie humaine".

${ }_{150}$ Vid. PÉREZ LUÑO, A.E., "El trabajo como problema filosófico: un libro del Profesor Luigi Bagolini", en La Filosofía del derecho en perspectiva histórica. Estudios conmemorativos del 65 aniversario del autor. Homenaje de la Facultad de Derecho y del Departamento de Filosofía del
} 
La cuestion de la razón no debe mantenerse alejada. La razón forma parte del ser humano y no se puede separar de la misma. Es por ello que la razón y el derecho de escojer forman parte de esta teoria, complementada por la teoria de la acción comunicativa de Habermas.

\subsubsection{La democracia distributiva-comunicativa-educativa-cultural.}

En relación a la justicia distributiva o a las ventajas distributivas, Höffe afirma que "donde existe no sólo una ventaja colectiva, sino distributiva, no se necesita otra legitimación". Las ventajas distributivas tienen en cuenta el mayor número de ventajas y beneficios para todos, superando la cuestión de la desventaja general, buscando siempre el criterio de la justicia. ${ }^{151}$

Para el autor alemán, el de los filósofos sobre las instituciones debe tener un triple objetivo:

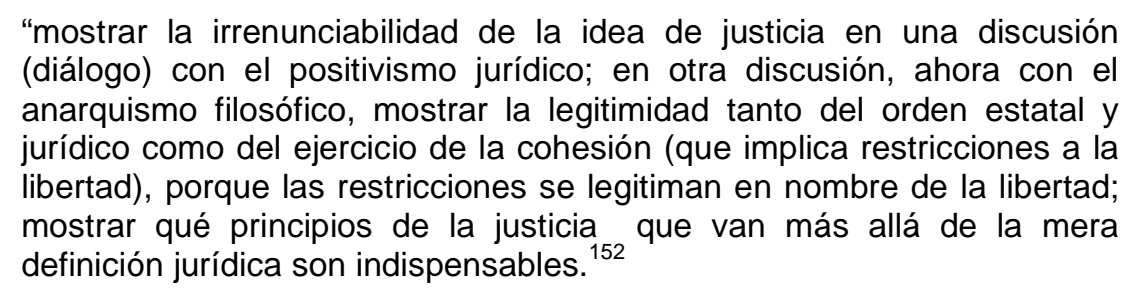

En el mismo sentido que Höffe, Teresa Vicente Giménez afirma que el mejor camino para la paz, la superación de la pobreza y de la desigualdad es el reconocimiento efectivo de los derechos sociales tanto a nivel local como

Derecho de la Universidad de Sevilla. Coordinador: R. González-Tablas Sastre. Universidad de Sevilla, Secretaria de Publicaciones, 2009, p. 577-584

151 HÖFFE, Otfried, Justiça política (...), cit., p. 60.

152 TEIXEIRA DOS ANJOS, Alberico, "Höffe, Otfried". En Dicionário de Filosofia do Direito. Vicente de Paulo Barreto (org.), Rio de Janeiro; Unisinos e Renovar, 2006, p. 440. 
internacional. Para ello es necesario ampliar el alcance de los principios de justicia $y$, en particular, de la justicia distributiva. ${ }^{153}$

La difícil situación de los trabajadores, afectados por la extrema pobreza y las perniciosas consecuencias económicas y sociales de las grandes guerras mundiales, provocó que la iglesia católica interviniera en este proceso. Mediante las encíclicas papales, desarrollaran la idea de la justicia social y distributiva. Fue el inicio de lo que más tarde se denominaría la ética social cristiana. ${ }^{154}$

Sócrates, anticipando las ideas de Aristóteles y sus lecciones de ética, sostenía que toda la existencia en la sociedad debía tener como fin el bien común. La comunidad política es la forma más adecuada para que el individuo pueda desarrollar su potencial. El bien común delineado por Sócrates era equivalente al bien de todos los ciudadanos y, por lo tanto, ocuparía un papel de preponderancia frente a los bienes individuales considerados por separados. ${ }^{155}$

Cada vez que el hombre aliena sus libertades y facultades, lo hace para obtener alguna ventaja. Se limita a su ser en el mundo para buscar la felicidad y la

\footnotetext{
153 VICENTE GIMÉNEZ, Teresa, La exigibilidad de los derechos sociales, cit., p. 108. En Brasil un ejemplo flagrante de la ausencia del concepto o de la comprensión de qué es y dónde se aplica la justicia distributiva podemos encontrarlo en las universidades públicas; a través del proceso selectivo, admiten, en la mayoría de los casos, a los alumnos de las clases ricas, excluyendo a los pobres 0 a quienes cuentas con menos recursos financieros para hacer frente a la enseñanza privada de pago.

${ }^{154}$ CASTILHO, Ricardo, Justiça social e distributiva. Desafios para concretizar direitos sociais, São Paulo; Editora Saraiva, 2009, p. 3.

${ }^{155}$ CASTILHO, Ricardo, Justiça social e distributiva (...), ibidem. "La realización de este esfuerzo histórico es necesaria para que se perciba la especie de 'relación de deber' determinada por la Justicia Social y por la Justicia Distributiva, en el orden constitucional brasileño. Con el contexto sociológico será posible analizar los sujetos de esta relación y el 'objeto' que le es típico, teniendo en cuenta el objetivo primordial de estos conceptos: la promoción de la existencia de todos, según los dictámenes de la 'dignidad de la persona humana".

Recordamos que para Aristóteles la felicidad no es más que la atribución a "'cada uno de los ciudadanos de un conjunto de bienes materiales e incorpóreos necesarios para que pudiera existir sin ningún tipo de restricción, física o moral'. El sumo Bien de la ciudad, por los tanto, sería realizado cuando todos los ciudadanos pudieran desarrollar su vida independientemente de condicionantes ajenas que pudiesen caracterizar carencias" 'CASTILHO, Ricardo, Justiça social e distributiva (...), cit., p. 13).
} 
buena vida, completa y plena. $Y$ eso no se puede hacer en una sociedad utilitarista, donde se sacrificaría a unos en beneficio de otros.

La distribución, para ser justa, deberá desarrollarse teniendo en cuenta la igualdad geométrica existente entre las personas, observando la debida proporción según la relevancia que los individuos tengan para la colectividad. Se alcanzará la justicia distributiva cuando la proporción entre los méritos de los sujetos produzcan el volumen de cosas, derechos o competencias otorgados a cada uno, a cada ciudadano. ${ }^{156}$

Con estas ideas, la doctrina social católica, mediante varias encíclicas, acaba por anticipar lo que posteriormente sería conocido como función social de la propiedad. Es inadmisible que los particulares ejerzan el dominio sobre las empresas de forma ilimitada.

Las empresas, así como las propiedades, deberían desarrollarse teniendo como modelo también la relevancia social. Junto a esto, la idea de dignidad de todas las personas conlleva la obligación jurídica y moral, para los empleadores, de que no deben servirse de sus empleados solamente como un medio para lograr el lucro. La empresa debe servir a los intereses del empleador, de los empleados y de toda la colectividad. En las encíclicas también se defiende que el importe del salario debía tener en cuenta la posibilidad de que el trabajador pudiera ahorrar, con el fin de que pudiera protegerse para el futuro. ${ }^{157}$

\footnotetext{
156 CASTILHO, Ricardo, Justiça social e distributiva (...), cit., p. 21/22.

157 CASTILHO, Ricardo, Justiça social e distributiva (...), cit., p. 44. "La realización de los derechos fundamentales de segunda generación crea las condiciones materiales necesarias para la plena realización de los derechos y prerrogativas basados en la 'libertad', ya que, sin los primeros, como recuerda José Afonso da Silva, éstos se quedan en el plan de la mera previsión normativa, sin aplicación en el campo fáctico".

CASTILHO, Ricardo, Justiça social e distributiva (...), cit., p. 48. Continúa añadiendo que "Los deberes de observancia de los derechos sociales, basados sobre la Justicia Social y la Justicia Distributiva, no pueden ser identificados como una mera consagración de sentimientos 'filantrópicos'. La realización de los derechos sociales tendría como base la necesidad humanitaria de erradicar las situaciones de pobreza extrema, creando, para los individuos, las condiciones mínimas de subsistencia. Aunque no se pueda considerar el componente de la caridad como totalmente ajeno a la idea, podemos entender que éste no es el fundamento principal de la
} 
El reconocimiento de los derechos sociales, que se produce por la influencia del Estado en la economía y en la sociedad, en última instancia, aproxima la colectividad a los patrones mínimos de existencia saludable y buena vida.

Dejando a un lado las críticas vertidas por Habermas con respecto a Hoffw, ${ }^{158}$ nuestras intención es la de extraer algunas concepciones de la filosofía del derecho con el fin de ofrecer una idea de democracia compatible con el Estado Democrático de Derecho. $Y$ es siguiendo esta lógica que el estudio continua.

Este concepto de justicia distributiva puede ser elevado a democracia. Giddens apunta que la democracia es un sistema que implica competición entre los "partidos políticos por competencias de poder. En una democracia se realizan elecciones regulares y limpias, en las que todos los miembros de la población pueden participar. Estos derechos de participación democrática son acompañados por libertades civiles - libertad de expresión y discusión, junto con la libertad de formar grupos o asociaciones políticas y afiliarse a ellos". ${ }^{159}$ Eso hace que se pueda aproximar el concepto de justicia distributiva al de felicidad, de buena y plena vida. Dar a cada uno lo que es suyo, con el mayor número de ventajas a todos es el propósito de vivir en sociedad. ${ }^{160}$

\footnotetext{
consagración de los deberes de justicia Social y Justicia Distributiva, en su actual conformación. Por el contrario, se configura una mera finalidad 'secundaria' de su proclamación".

158 Sobre la crítica de Habermas, consultar la bibliografía en nota a pié de página, especialmente la obra Direito e Democracia, así como TEIXEIRA DOS ANJOS, Alberico, "Höffe, Otfried", cit., que presenta la opinión de los dos filósofos sobre el tema de la justicia.

159 GIDDENS, Anthony, Mundo em descontrole (...), cit., p. 78.

160 Ya para Vânia Siciliano Aieta, democracia no es un modelo cerrado o hermético, sino un proceso sujeto a una continua intervención y reinvención, "permitiendo una constante búsqueda en la cual puedan ser cuestionadas, en cualquier momento, las 'formas de convivencia social"'. SICILIANO AIETA, Vânia, "Democracia". Em Dicionário de Filosofia do Direito. Vicente de Paulo Barreto (org.), Rio de Janeiro; Unisinos e Renovar, 2006, p. 192. No hay confundir el concepto ya desarrollado de democracia distributiva con lo de democracia deliberativa. Ésta consiste en el autogobierno, propio gobierno, el "self government", donde las personas se pueden autogovernar, asegurando al poder público los medios para hacerlo. SICILIANO AIETA, Vânia, "Democracia", cit., p. 195. La democracia distributiva ahora aspira a distribuir no sólo los bienes sino también la educación y la cultura con el fin de catalizar la acción comunicativa en la toma de decisiones. Partiendo de esta concepción, Giddens pretende presentar el concepto de democracia distributiva.
} 
La democracia no es una cuestión de todo o nada. En ella puede haber diferentes formas y niveles de democratización. Hoy el mundo es democrático. Estas ideas, sin embargo, fueron combatidas por las elites y por los grupos dominantes en el siglo XIX y a menudo se trataron con desprecio. Giddens argumenta que "la democracia fue el ideal inspirador de las revoluciones americana y francesa, pero por un largo período de tiempo su influencia fue limitada". Se desarrolló plenamente en occidente en el siglo XX. En los últimos años, el número de gobiernos democráticos se ha duplicado. Se ha extendido a los países del mediterráneo: España, Portugal y Grecia y se ha extendido a lo largo de América Central y del Sur, aunque aún hay numerosos gobiernos no democráticos. ${ }^{161}$

Sostenemos que la democracia, aunque efectivamente tenga algunos problemas, es el mejor sistema. Puede que no sea la más adecuada para determinadas situaciones. Sin embargo, no evita que el proceso democrático en algunos de los países de democracia más antigua esté creando la llamada desilusión democrática. Hay desilusión por parte de la población en los países de tradición democrática. ${ }^{162}$

Para Giddens lo que es necesario en los países democráticos es una profundización de la propia democracia, la "democratización de la democracia". Sin embargo, la democracia debe convertirse en transnacional. Una era de globalización requiere respuestas globales, que no se apliquen solamente a la política $^{163}$ y a la economía.

A partir de esta idea de democracia que se pretendemos establecer una relación con la justicia distributiva. Si la justicia distributiva trata de utilizar el principio de que la limitación de las libertades debe traer ventajas para todos, la democracia distributiva, fruto del poder que proviene de la propia sociedad, podría,

\footnotetext{
161 GIDDENS, Anthony, Mundo em descontrole (...), cit.,, p. 79/80.

162 GIDDENS, Anthony, Mundo em descontrole (...), cit.,, p. 81/82.

163 GIDDENS, Anthony, Mundo em descontrole (...), cit.,, p. 84.
} 
perfectamente, ser clasificada como el agente que permitiera que se alcanzara esta forma de justicia.

Pero para eso es necesaria la acción comunicativa. La acción comunicativa consiste en la acción dirigida a la comprensión, donde por los menos dos sujetos actúan de forma coordenada o incluso superan esta coordinación, mediante el diálogo, reconociendo, uno frente al otro, las pretensiones de validez de este discurso, alejándose del cálculo centrado en uno mismo, para compartir los planes de acción del otro. ${ }^{164}$

Lo que pretende Habermas, a diferencia de Rawls, es hacer de la justificación ya no un ejercicio teórico e intelectual, sino "un ejercicio efectivo de la autonomía política". Para el filósofo alemán el punto de vista moral imparcial no es el resultado de la posición original, sino fruto de un proceso de argumentación intersubjetiva, que obliga a quien participe, a extender los límites de su perspectiva de interpretación, y eso a través de la idealización. Es el debate activo y la discusión que harán comprender la Constitución como un proyecto, ejercicio efectivo, como ya se ha mencionado, de la autonomía política de los miembros de la sociedad. ${ }^{165}$

Para Habermas, la racionalidad no es "una facultad abstracta, inherente al individuo aislado, sino un procedimiento argumentativo por el cual dos o más sujetos se ponen de acuerdo sobre cuestiones relacionadas con la verdad, la justicia y la autenticidad". En el diálogo cotidiano y en el discurso las verdades antes consideradas válidas e inquebrantables se pueden cuestionar, por lo que se deben justificar de manera que todas las relaciones sociales se consideren como

\footnotetext{
164 HABERMAS, Jürgen, Teoría de La Acción Comunicativa. V. I, Racionalidad de la Acción y racionalización Social, Madrid. Taurus, 1987, passim.

165 AUDARD, Catherine, "O princípio de legitimidade democrática e o debate Rawls-Habermas", cit., p. 96
} 
el fruto de negociación en la cual se tiene como objetivo el acuerdo y se respeta el argumento del otro, venciendo quien mejor argumente ${ }^{.166}$

Como ya conocemos, en un pasaje de la Teoría de la Acción Comunicativa, Habermas clasifica las formas de acción en instrumental, estratégica y comunicativa. Es esta última la que más nos interesa. ${ }^{167}$

Habermas diferencia entre la razón comunicativa y la razón práctica. Para él, la primera no está adscrita a ningún "actor singular ni a un macrosujeto sociopolítico. Lo que hace la razón comunicativa posible es el 'médium' lingüístico, a través del cual las interacciones se interconectan y las formas de vida se estructuran. Tal racionalidad está inscrita en el telo lingüístico de la comprensión, formando un 'ensemble' de condiciones posibilitadoras y, al mismo tiempo, limitadoras". 168

Los miembros de una misma comunidad deben suponer que quien habla y quien oye deben o pueden comprender las expresiones gramaticales de modo idéntico. $^{169}$

\footnotetext{
166 FREITAG, Bárbara, A Teoria Crítica Ontem e Hoje, São Paulo; Brasiliense, 1988, p. 59/60.

167 "A una acción orientada al éxito la llamamos instrumental cuando la consideramos bajo el aspecto de observancia de reglas de acción técnicas y evaluamos el grado de eficacia de la intervención que esta acción representa en un contexto de estados y sucesos; y a una acción orientada al éxito la llamamos estratégica cuando la consideramos bajo el aspecto de observancia de reglas de la elección racional y evaluamos su grado de influencia sobre las decisiones de un oponente racional. Las acciones estratégicas pueden ir asociadas a interacciones sociales. Las acciones estratégicas representan, ellas mismas, acciones sociales. Hablo, en cambio, de acciones comunicativas cuando los planos de acción de los actores implicados no se coordinan a través de un cálculo egocéntrico de resultados, sino mediante actos de comprensión. En la acción comunicativa los participantes no se orientan primariamente al propio éxito; antes persiguen sus fines individuales bajo la condición de que sus respectivos planes de acción puedan armonizarse entre sí sobre la base de una definición compartida de la situación. De ahí que la negociación de definiciones de la situación sea un componente esencial de la tarea interpretativa que la acción comunicativa requiere" (HABERMAS, Jürgen, Teoría de La Acción Comunicativa (...), cit., p.367).

${ }_{168}$ HABERMAS, Jürgen, Direito e democracia: entre facticidade e validade, Rio de Janeiro, Editora Tempo Brasileiro, volume I, 2003, p. 20.

169 "Suponen que las mismas expresiones conservan el mismo significado en la variedad de situaciones y de los actos de habla en los cuales se emplean" (HABERMAS, Jürgen, Direito e democracia: entre facticidade e validade, cit., p. 29).
} 
Es eso que va a dar validez al derecho. La aproximación entre el hablante y el oyente, en razón de la comprensión lingüística es el camino a la comprensión comunicativa y la legislación consciente. ${ }^{170}$

Un orden jurídico no puede garantizar sólo que las personas tengan sus derechos reconocidos por todos. El reconocimiento de los derechos recíprocos de cada uno por todos los otros debe estar apoyado en las leyes legítimas que garanticen a cada uno libertades iguales, de modo que la "libertad del arbitrio de cada uno pueda mantenerse junto con la libertad de todos los participantes, por tanto, del proceso legislativo, que salen del papel de sujetos privados del derecho, asumen, eso por su condición de ciudadanos, la perspectiva de miembros de una comunidad jurídica "libremente asociada, en la cual un acuerdo sobre los principios normativos de la reglamentación de la convivencia ya está asegurado a través de la tradición o se puede conseguir a través de una comprensión según reglas normativamente reconocidas". ${ }^{171}$

Pero los participantes no deben actuar sólo orientados por el éxito particular, sino para la comprensión, lo que acabaría por legitimar el proceso legislativo, teniendo en cuenta la voluntad unida y consciente de todos los ciudadanos libres e iguales. $^{172}$

El problema que parece surgir es cuando el poder administrativo y el dinero, de forma camuflada, actúan hasta el punto de hacer creer a los participantes que son ellos quienes legislan libres y conscientemente, de forma comunicativa. Lo

\footnotetext{
170 "El concepto de 'acción comunicativa', que tiene en cuenta la comprensión lingüística como mecanismo de coordinación de la acción, hace que las suposiciones contrafactuales de los actores que guían sus acciones por pretensiones de validez adquieren relevancia inmediata para la construcción y el mantenimiento de órdenes sociales: porque éstas se mantienen en el modo de reconocimiento de las pretensiones de validez normativas. Esto significa que la tensión entre facticidad y validez, embutida en el lenguaje y en el uso del lenguaje, regresa en el modo de integración de individuos socializados - al menos de individuos socializados comunicativamente debiendo ser elaborada por los participantes. Más adelante veremos que esta tensión es estabiliza de modo peculiar en la integración social llevada a cabo a través el derecho positivo (HABERMAS, Jürgen, Direito e democracia: entre facticidade e validade, cit., p. 35).

171 HABERMAS, Jürgen, Direito e democracia: entre facticidade e validade, cit., p. 52/53.

172 HABERMAS, Jürgen, Direito e democracia: entre facticidade e validade, cit., p. 53.
} 
que se deduce del discurso de Habermas es que la acción comunicativa supera, si se realiza de forma correcta y consciente, donde, de forma libre, los agentes pueden decidir-, la actuación estratégica o incluso aquélla dominada por el dinero y por el poder administrativo. Sólo habrá derecho válido y legítimo en los casos en los que no hay interferencia de estos elementos en el proceso legislativo.

A menudo el derecho atribuye una apariencia de legitimidad al poder no legítimo. No se para a observar si las realizaciones de las interacciones jurídicas están apoyadas en el consentimiento de los ciudadanos asociados, o si resultan de la mera "autoprogramación del Estado y del poder estructural de la sociedad" ni tampoco, en el caso de que estuvieran apoyadas en este sustrato material, produce por sí, la "necesaria lealtad de las masas". ${ }^{173}$

John Sitton, partiendo de la acción comunicativa y la vida social de Habermas, afirma que para que una persona alcance sus objetivos en la vida social, debe recurrir a acciones de coordinación en sus relaciones con el otro. ${ }^{174}$

Hay dos formas de coordinar la acción dentro de la sociedad, que son: por influencia o por conocimiento. La acción coordinada por la influencia se produce cuando uno o más actores emplean, además de las razones reales, los incentivos, tales como las amenazas, el dinero, el juego de relaciones emocionales, la retórica manipuladora o algo similar. En este caso, no se escucha a la razón y las palabras se convierten en armas. Este es un tipo de acción estratégica, donde llegar al objetivo es lo más importante, siendo todo lo demás sólo un medio para la consecución de ese fin. La acción comunicativa se apoya en la acción coordinada mediante el consentimiento. Es mediante la existencia o la generación de un conocimiento común de hechos, normas o experiencias que la acción comunicativa se desarrolla. Conviene señalar que esta forma de acción es necesaria para la existencia de un lenguaje común y para el éxito de los objetivos

\footnotetext{
173 HABERMAS, Jürgen, Direito e democracia: entre facticidade e validade, cit., p. 62.
}

174 SITTON, John, Habermas y la sociedad contemporánea, cit., p. 115. 
del individuo. Lo que une a los agentes es compartir suposiciones o situaciones, formando convicciones racionales. ${ }^{175}$

En la acción comunicativa, hay un término medio que permite que se llegue a la comprensión. Por lo tanto, se puede afirmar que el conocimiento común, la comprensión común, crean convicciones comunes, sociedad común, donde todos los participantes forman parte real y concreta de toda actuación, al servicio de la estructura social y gubernamental en beneficio de todos.

La racionalidad comunicativa, por tanto, es la acción mediante la cual se llega a una comprensión y prevalece el mejor discurso, la comprensión fundamentada y se refuta la acción estratégica, amplía el rol de las posibilidades, formando un cierto tipo de lógica de desarrollo social. La racionalización cultural, fruto de la trayectoria de visiones del mundo, establece una gama de oportunidades para el proceso de aprendizaje y que pueden producirse de manera innovadora, consignando los reales problemas a los que la sociedad se debe enfrentar. Sitton apunta como ejemplo la instigación científica. ${ }^{176}$

Por lo tanto, la racionalización cultural no lleva a una racionalización más amplia de la vida social. Para que eso suceda, para que los potenciales culturales se hagan efectivos en el mundo empírico, los avances culturales deben promover la transformación de las prácticas sociales y sustituir las formas más tradicionales de hacer las cosas. ${ }^{177}$

A través de la acción comunicativa, orientada a la comprensión, se estructura la sociedad. Reconocer en el otro un ser racional de derechos y deberes y establecer con él un debate, en igualdad de condiciones sin sorpresas estratégicas, es el primer paso para la consecución de una democracia comunicativa, una democracia distributiva, con el mayor número de ventajas y

\footnotetext{
175 SITTON, John, Habermas y la sociedad contemporánea, cit., p. 115/116.

176 SITTON, John, Habermas y la sociedad contemporánea, cit., p. 123/124.

177 SITTON, John, Habermas y la sociedad contemporánea, cit., p. 126.
} 
accesos para todos, fruto de la participación fundamentada e integral de la colectividad.

La cultura, la sociedad y la persona se implican recíprocamente. El concepto jurídico del orden del derecho como una asociación de miembros del derecho, que es mantenido hasta estos días por los discursos filosóficos, es demasiado concreto para la teoría de la sociedad. En términos de la teoría de la acción comunicativa, el sistema de acción "derecho", forma parte del componente social del mundo de la vida. Como el mundo de la vida sólo y tan sólo se reproduce con la cultura y las estructuras de personalidad, por la acción comunicativa - de comprensión - las acciones jurídicas acaban siendo un medio a través del cual las instituciones del derecho deben reproducirse con las tradiciones jurídicas compartidas entre los agentes, intersubjetivamente $\mathrm{y}$, también, con las capacidades subjetivas de la interpretación de las reglas del derecho. ${ }^{178}$

Todo esto demuestra la importancia de la acción comunicativa, dirigida a la comprensión, tanto en la cuestión educacional como de validez del derecho. Y es a través de la validez del derecho como la acción comunicativa puede o debe contribuir al avance del concepto de democracia hasta el punto de llegar a una democracia que aporta el máximo beneficio y el acceso a todos. Aquí entra en juego el elemento educacional y cultural. Mediante el diálogo se puede llegar a una verdadera comprensión democrática para la construcción, a través de la acción comunicativa, de la democracia distributiva.

Para Habermas, la legitimidad del derecho está sólidamente anclada en las prácticas democráticas. "El ciudadano dispone de dos medios para verificar esta legitimidad: un medio teórico, las discusiones racionales, pero también un medio práctico: las garantías que la libertad de expresión, de comunicación, de discusión

178 HABERMAS, Jürgen, Direito e democracia: entre facticidade e validade, cit., p. 112. 
reciben del Estado". Así se puede diferenciar el principio democrático del principio moral, que concierne sólo al juicio y no a la práctica de los ciudadanos. ${ }^{179}$

Antes de continuar con nuestra investigación, conviene que realicemos algunas consideraciones sobre el discurso y el lenguaje. Además de Habermas, nos referimos a otros autores, con el fin de sentar adecuadamente la base de la cuestión de la educación, la cultura y la comunicación.

\subsubsection{La cuestión del lenguaje.}

En este apartado nos ocuparemos de la forma de llegar a la democracia distributiva-comunicativa-educativa-cultural. Mediante el lenguaje ${ }^{180}$ el hombre se comunica en el mundo y con el mundo y con él que forma la sociedad. Depende del lenguaje para mantenerse como está o para elevarse a una condición de vida mejor. A través del lenguaje se puede llegar a los estándares aceptables de la buena vida y no alienada. Por ello vamos a delinear algunas líneas sobre el lenguaje seguidamente.

En cuanto a la forma de hacer llegar la democracia distributiva-comunicativaeducativa-cultural, podemos partir de Ernildo Stein. Afirma que el hombre no es sólo un animal que tiene la razón o la palabra. Para él "la condición humana se sustenta por la posibilidad del diálogo comprensivo". La palabra acaba por

\footnotetext{
179 AUDARD, Catherine, "O princípio de legitimidade democrática e o debate Rawls-Habermas", cit., p. 97.

${ }^{180}$ " 'Un lenguaje - según Carnap - es un sistema de sonidos, o más bien, de hábitos producidos mediante los órganos correspondientes, con el propósito de servir de comunicación entre las personas, es decir, con el propósito de influir en sus actos, decisiones y pensamientos. En lugar de los sonidos lingüísticos, añade Carnap, se producen, a veces, otros movimientos tales como gestos y signos, mediante tambores, clarines, cohetes, serpentinas, etc. Así, parece convincente asignar al término lenguaje un alcance bastante amplio, para incluir en él todos estos sistemas y medios de comunicación, independientemente del material que utilizan. A su vez, el lenguaje hablado es el más importante y, a menudo, constituye la base de cualquiera otro lenguaje, en el sentido de que se aprende los otros lenguajes con el subsidio del lenguaje hablado. En efecto, tal hecho es accidental, ya que cualquiera otra clase de lenguaje se puede aprender independientemente del lenguaje hablado" (WARAT, Luis Alberto, O direito e sua linguagem, Porto Alegre; Sérgio Antônio Fabris Editor, 2a ed., 1995, p. 38).
} 
sostener al hombre. Muestra al hombre con sus múltiples modos de ser en la historia, de sobrevivir en las instituciones y a través de las instituciones. ${ }^{181}$

En el mismo sentido, Heidegger subraya que el lenguaje es la morada del ser. Así, la esencia del lenguaje sólo puede ser pensada en correspondencia con el ser. En esto consiste el vivir del hombre, del ser humano en el mundo. ${ }^{182}$ Afirma que el pensamiento trabaja en la construcción del ser. La sociedad, así, es la sociedad que piensa ${ }^{183}$. Sería la sociedad del diálogo y del lenguaje, ambas con intención democrática distributiva y comunicativa.

El lenguaje, para Habermas, representa lo que funciona como un supuesto básico para el acuerdo a través de la comprensión, sirviendo la capacidad de hablar y de comunicarse como el telón de fondo donde debe producirse el proceso del conocimiento. ${ }^{184}$

Tanto en lo que se refiere a la distinción hegeliana entre el trabajo y la alienación, en su 'traducción en términos de 'intereses del conocimiento' (ligados a las actividades instrumentales o a las actividades ejercidas a través de la comunicación), como también en la diferenciación entre tipos fundamentales de realidad", Habermas trata siempre de deducir la originalidad de la relación con el mundo, formada por el intercambio de visiones y por la coordinación de acciones, para el lenguaje. ${ }^{185}$

Mediante la teoría de la acción comunicativa Habermas defiende la resistencia, por parte del mundo de la vida, a una coalición entre el mercado y sus

\footnotetext{
181 STEIN, Ernildo, História e ideologia, Porto Alegre; Movimento, 3aㅡ ed; 1999, p. 45.

182 HEIDEGGER, Martin, Cartas sobre el humanismo. Traducción de Helena Córtes y Arturo Leyte, Madrid: Alianza Editorial, 2006, p. 43.

183 HEIDEGGER, Martin, Cartas sobre el humanismo, cit., p. 81.

184 BOLZAN, José, Habermas: razão e racionalização, cit., p. 127.

185 No se trata de "establecer una jerarquía entre el conocimiento y la moral - son diferentes aspectos o modalidades de actos de comunicación, pero sí para contestar el primado de un modo ontológico particular, que es el vínculo entre la cognición y la relación instrumental con el mundo" (ROCHLITZ, Rainer, "Razão e racionalidade em Habermas". En Habermas: o uso público da razão. Rainer Rochlitz (coord.), Rio de Janeiro; Tempo Brasileiro, 2005, p. 9).
} 
tendencias sistémicas y el "Estado", además de la práctica de la elite de separar el resto de la sociedad de los recursos vitales del conocimiento científico, del debate sobre las normas y los fines. Más adelante, Habermas añade que la economía en el modo de producción capitalista intenta inexorablemente "deshacerse de los desequilibrios que genera, desplazándolos hacia el mundo vivido de la educación, de la cultura, de la solidaridad social, únicas esferas cuyos recursos aún no se ha utilizado plenamente". ${ }^{186}$

Para Haberlas, mediante el derecho, si es fruto del poder comunicativo, se puede superar este problema. Se alcanza cuando las masas se libran del poder que les es impuesto por las elites, manteniendo la plena posesión de su soberanía política. $^{187}$

Sin embargo, el derecho a la discusión y a la comunicación no es un derecho político secundario, sino un derecho humano positivo. En este sentido se desarrolla la argumentación de Habermas sobre la soberanía popular y los derechos humanos. También es el propósito de John Ralws, de superar los límites del liberalismo clásico y llegar al liberalismo "político". ${ }^{188}$

Habermas va a defender, en la obra Derecho y Democracia, la tesis de que el derecho positivo, que tienen todos los ciudadanos que participen en procesos políticos de formación de la voluntad general, es un derecho humano, teniendo el mismo un carácter imperativo ${ }^{189}$. $Y$ es esta condición la que va a legitimar la defensa de una democracia distributiva, fruto de un proceso comunicativo, dependiente de una educación más allá del capital y otorgando relevancia al aspecto cultural. ${ }^{190}$

\footnotetext{
${ }_{186}$ ROCHLITZ, Rainer, "Razão e racionalidade em Habermas", cit., p. 19/20.

187 ROCHLITZ, Rainer, "Razão e racionalidade em Habermas", cit., p. 20/21.

188 AUDARD, Catherine, "O princípio de legitimidade democrática e o debate Rawls-Habermas", cit., p. 100.

189 AUDARD, Catherine, "O princípio de legitimidade democrática e o debate Rawls-Habermas", cit., p. 102.

${ }_{190}$ La política debe ser obra de los ciudadanos que buscan no sólo los intereses privados, sino son en conjunto una "comunidad de sujetos libres e iguales asociados bajo la égida del derecho" y que
} 
Habermas explota la naturaleza de una competencia comunicativa o pragmática universal, con el objetivo de reconstruir el sistema de reglas donde el interlocutor puede establecer situaciones de combinación en general. En pocas palabras "una teoría de la competencia comunicativa 'debe aclararnos las operaciones (Leistungen) que interlocutor y oyente realizan mediante universales pragmáticos cuando transforman oraciones en profecías". A eso Habermas lo denomina reconstrucción racional, teniendo por modelo la lingüística de Chomsky. 191

Como sabemos el filósofo alemán propone como único principio moral de la ética discursiva el principio de la universalización, según el cual "toda norma moral válida debe satisfacer la condición de que todos los afectados puedan libremente aceptar las consecuencias directas e indirectas (Folgen und Nebenfolgen) que un seguimiento universal de esta norma pueda, presumiblemente, tener para la satisfacción de los intereses de cada individuo (y preferirlas a las consecuencias de las posibles regulaciones alternativas)". 192

Este es el principio de universalidad, fruto del discurso, que conduce a la emancipación. Y es a través del lenguaje, como se aprende en la escuela, como se puede alcanzar un nivel de comprensión democrático como quiere Habermas, elevando las condiciones para vivir bien y feliz, sin el yugo de la alienación y de la cosificación. Si el capitalismo aliena y transforma todo y a todos en mercancía, mediante la ética discursiva, fruto de la acción comunicativa, se puede superar esta realidad. El principio es el de la educación superando el ámbito meramente económico, más allá del capital. Eso es lo que pretendemos demostrar en esta

establecen sus voluntades políticas a través del proceso comunicativo, en el espacio público de una sociedad civil independiente del Estado. La política no debe servir ni al mercado y ni al Estado, pero sí a sus ciudadanos en primer plan (ROCHLITZ, Rainer, "Filosofia política e sociologia em Habermas", cit., p. 163).

191 RUIZ DE AZÚA, Javier Bengoa, De Heidegger a Habermas: hermenéutica y fundamentación última en a filosofía contemporánea, Barcelona; Editorial Herder, 1992, p. 134.

${ }_{192}$ RUIZ DE AZÚA, Javier Bengoa, De Heidegger a Habermas: hermenéutica y fundamentación última en a filosofía contemporánea, cit., p. 138. 
investigación, con un enlace al tema de la subcontratación de los trabajadores, condición ésta (subcontratación) que maximiza la alienación y aleja el humano de los niveles mínimos de dignidad y felicidad.

Como base con respecto a lo dicho hasta ahora, se entiende que la acción pautada por la coordinación, de forma comunicativa, donde todos en iguales condiciones presenten argumentos, permite estabilizar la democracia. La democracia real se produce cuando todos pueden elaborar sus discursos, cuando todos emiten sus argumentos, ganando el mejor. Por esta razón, para alcanzar la democracia distributiva es necesaria la acción comunicativa. Esto, sin embargo, actualmente, depende de la educación y de la cultura, elaboradas con elementos que trascienden al capital. Eso es lo que debe hacer, también, la democracia, distribuir la cultura, la educación, la inclusión y el acceso, y no limitarse a garantizar el derecho al voto a través de representantes. Democratizar es incluir. Incluir es educar. Educar es libertar. Libertar es vivir. Las personas viven para ser felices.

Es esta forma de educación que purifica el proceso de comunicación, permitiendo la estabilización democrática. El tema de la democracia y estabilización democrática será objeto de nuestra atención a lo largo de nuestra Tesis. Por el momento, volvemos a la cuestión de la educación más allá del capital, concluyendo con la cultura como forma de emancipación, fruto de su aplicación como derecho fundamental de segunda dimensión.

Conviene destacar, como establece Michel Foucault, que el discurso no es sólo aquello que traduce las luchas o los sistemas de dominación, sino aquello por lo cual se lucha ${ }^{193}$, de manera que el discurso es el elemento de emancipación. Sin embargo, hace falta un vínculo entre el discurso racional bien fundamentado y la práctica, lo que se puede conseguir mediante la educación más alla del capital.

193 WARAT, Luis Alberto, Introdução geral ao direito II. Epistemologia jurídica da modernidade, Porto Alegre; Sérgio Antônio Fabris Editor, 1995, p. 74. 
El juridicialismo "nos hace vivir su visión del mundo (centrada en la ley) como absoluta y nos muestra algo de este universo de verdades absolutas contenidas en la ley, ocultando lo demás como condición inquebrantable del poder de la glosa. Sin secretos, ningún poder enigmático consigue afirmar su magia". Esto muestra la importancia del juridicialismo en la producción social de la subjetividad y en el establecimiento de la sociedad industrial como cultura y permite la "puesta en escena de una representación mitológica del poder, como una gestión fuera de la historia". 194

Warat llama la atención sobre el hecho de que no se puede olvidar que la cultura, la política y la economía capitalista, en la actualidad, se desarrollan en escala mundial y que su fuerza viene de este carácter transnacional, no pudiendo tolerar que los movimientos sociales permanezcan en un permanente estado de germinación. Es necesario articular la búsqueda de su institucionalización. Es decir, sin embargo, advierte el autor, no es fácil, siendo necesaria "una energía que permita institucionalizar la diferencia evitando los riesgos de la recuperación ideológica. Los movimientos sociales tienen la necesidad de penetrar en las instituciones ganando espacio sin claudicar de su espíritu marginal”. ${ }^{195}$

El lenguaje, para Warat, no sólo permite el intercambio de informaciones y conocimiento, sino también funciona como un medio de control de informaciones y conocimiento. Con esta afirmación se puede situar precisamente la corriente lingüístico-epistemológica denominada positivismo lógico 0 empirismo contemporáneo. "Un lenguaje defectuoso puede, por lo tanto, en muchas

\footnotetext{
${ }^{194}$ WARAT, Luis Alberto, Introdução geral ao direito II (...), cit., p. 78. En esta misma obra el autor apunta, en la página 84, que "la censura se instala en la institución social, provocando en los actores sociales una especie de 'ceguera histórica', es decir, surge una ceguera como fuga de una realidad que no se quiere ver, que nos hace evitar ver lo que no queremos. En este sentido podríamos decir que el juridicialismo disimula la sumisión a los juegos institucionales del poder, provocando una 'ceguera discursiva', que asegura nuestro vínculo con la institución social como garante de nuestros deseos. Una garantía establecida por el desplazamiento mítico de la función social de la ley; se queda en secreto el papel de la ley como lugar tópico de aprisionamiento del deseo y se exalta ilusoriamente su papel como ideal de paz y bienestar social".

195 WARAT, Luis Alberto, Introdução geral ao direito II (...), cit., p. 94.
} 
circunstancias, por sí mismo, nos da una imagen distorsionada de nuestras preocupaciones cognoscitivas". Así para que sea realmente un discurso realmente científico, se debe renunciar a la metafísica, analizándolo desde la perspectiva del lenguaje. $^{196}$

Hacer ciencia es "traducir en un lenguaje riguroso los datos del mundo; es elaborar un lenguaje más riguroso que el lenguaje natural", ${ }^{197}$ viendo lo que son las cosas y cómo son, sin la influencia de patrones metafísicos que puedan enturbiar la realidad e interferir en la investigación y en su objetivo final que es la verdad.

Sobre la base de los positivistas lógicos, se puede decir que se requiere mucha cautela con la cuestión lingüística, el lenguaje de las ciencias. La ciencia se hace con el lenguaje y, al mismo tiempo, es ella misma lenguaje, lo que hace que la comprensión coherente y sistémica del mundo se logre a través del lenguaje. Destacan los positivistas lógicos la importancia del lenguaje para la ciencia del derecho, ya que construye su objeto sobre datos que se expresan mediante el propio lenguaje, lo que significa que el "lenguaje de la ciencia jurídica habla sobre algo que ya es lenguaje anteriormente a esta habla". ${ }^{198}$

Otra cuestión que no debe olvidarse es la de los estereotipos. Estereotipo es "una expresión o una palabra que pretende generar adhesiones valorativas, comportamientos $u$ opiniones desde un proceso de significación, en el cual el receptor del mensaje lo aceptada de modo acrítico, basado en solidaridades significantes epidérmicas". Los estereotipos son fruto de un largo proceso de persuasión y provoca una total dependencia del término estereotipado a "una relación evocativa ideológicamente determinada", transmitiendo un mensaje de dominación y aceptación de una ideología. ${ }^{199}$

\footnotetext{
196 WARAT, Luis Alberto, O direito e sua linguagem (...), cit., p. 37.

197 WARAT, Luis Alberto, O direito e sua linguagem (...), ibidem.

198 WARAT, Luis Alberto, O direito e sua linguagem (...), cit., p. 38.

199 WARAT, Luis Alberto, O direito e sua linguagem (...), cit., p. 72.
} 
Estos discursos contienen estereotipos con un grado de persuasión elevado, en la medida en que consiguen la identificación de la conclusión con la forma estereotipada. Las falacias no formales son ejemplos, dentro de la gramática, de esta alienación. La falacia no formal concierne a los razonamientos desprovistos de rigor lógico, sin que se utilicen los criterios lógicos que conducen a una conclusión. Representan un conjunto estereotipado de "formas metodológicas que funcionan como principios de inteligibilidad de los razonamientos persuasivos". 200

Así, cuando el Tribunal Superior del Trabajo hace alusión a la tercerización, clasificándola como posible en los casos de trabajo relacionados con la actividadmedio del tomador de servicios, si no hay personalidad ni subordinación, no se sirve de los criterios lógicos para el análisis que establece el artículo $3^{\mathrm{el}}$ de la $\mathrm{CLT}^{201}$ ni tampoco del artículo 7을 encabezamiento, de la CF/88. ${ }^{202} \mathrm{El}$ primero, en ningún momento hace alguna distinción entre la actividad-medio y la actividad-fin, refiriéndose sólo al trabajo no eventual (permanente); y el segundo, como apunta que la regla es la mejora de la condición social de los trabajadores, no permitiría la subcontratación, puesto que ésta reduce la condición social de los trabajadores.

El Tribunal se sirvió de un criterio únicamente económico o de administración (actividades-medio y actividades-fin), sin analizar la base legislativa laboral y los efectos de esta situación, permitiendo la subcontratación. Hoy el término tercerización podría ser clasificado como un estereotipo, puesto que es fruto de un proceso de persuasión, que dio origen a la 'súmula' 331 del TST, aceptada acríticamente y repetida por la gran masa de los jueces, economistas y sindicalistas en Brasil.

\footnotetext{
200 WARAT, Luis Alberto, O direito e sua linguagem (...), cit., p. 73/75.

Art. $3^{\circ}$ - Se considera empleado toda persona física que presta servicios de naturaleza no eventual al empleador, sob la dependencia de este y mediante salario.

202 Art. 7은 Son derechos de los trabajadores urbanos y rurales, además de otros que tratan de mejorar su condición social: (...).
} 
Se impone superar esta lógica, bajo pena del total control de los bienes y de los elementos de la vida por parte del poder del dinero.

Los discursos relacionados con la ideología tienden a "deterritorializarse del registro simbólico, para invadir a los sujetos. Tenemos, así, el intento de generar 'cuerpos ideológicos', que actúan de forma fascista sobre sí mismos”. Por lo tanto, podemos observar que los juristas, ligados a las concepciones jurídicas, no tienen en cuenta las solidaridades semiológicas "co-productivas y extranominativas que determinan las enunciaciones jurídicas normalizadoras de los cuerpos" ${ }^{203}$. Esto hace aún más arduo pero no menos factible, el trabajo de quien se enfrente, a cara descubierta, a las concepciones y los modelos ya dados.

Se percibe así como está posicionado el discurso en la sociedad. La sociedad depende de él para existir, y simultáneamente está disfrazado de una falsa verdad, con sus dogmas que no reflejan la realidad social. Usado como forma de control y dominación, debe ser revertido, como medio de lucha, para superar el orden excluyente en las interpretaciones judiciales extremadamente dogmáticas y reaccionarias, haciendo valer el espíritu del Estado Democrático de Derecho.

Warat muestra parte del camino a seguir, así como los demás autores anteriormente citados. Es preciso, sin embargo, superar esta cuestión de extrema exclusión y alcanzar un nivel de comprensión democrático que permita la superación de esta brutal alienación del ser en el mundo. Ahora, el hombre está en el mundo para tener una buena vida y ser feliz. Si trabaja, debe hacerlo no como pieza (orden capitalista), sino como forma de realización e integración con los otros hombres y con la naturaleza.

Hechas las referencias sobre el papel y la importancia del lenguaje, es necesario ahora trabajar este lenguaje. Se busca, por eso, una educación que

${ }^{203}$ WARAT, Luis Alberto, O direito e sua linguagem (...), cit., p. 102. 
supere al capital y una constitución cultural. Para explicarlo tomaremos como referencia a István Mészáros y su obra Educación más allá del capital, además de Gomes Canotinho y otros autores que fundamentan la relación entre educación, cultura, emancipación y democracia.

\subsubsection{La educación como superadora del capital y la constitución} cultural

Conviene comenzar preguntándonos cómo llegar a este nivel de comprensión democrático que permita la construcción de una democracia distributiva y comunicativa, teniendo como base lo que hasta ahora venimos presentando ¿Cómo hacer este enlace?

En Brasil el, artículo 205 de la Constitución de 1988 preceptua una relación de crédito del ciudadano y de debito del estado cuanto a la educación. El individuo es acreedor de la educación, siendo ella, por lo tanto, un derecho de la gente y un deber del poder público. 204

La República de Platón no es sólo un tratado político, sino también de justicia y de educación. La justicia es la finalidad del Estado, dando a cada uno lo que es suyo y su lugar dentro de la sociedad, según sus méritos y aptitudes. Pero para que eso se realice, y para que el Estado funcione bien, de forma justa, es necesario formar al ciudadano con sus funciones y tareas, y aquí se incardina la educación, centrada en el desarrollo del ciudadano en cuanto a su formación. ${ }^{205}$

\footnotetext{
${ }^{204}$ GORCZEVKI, CLÓVIS e SIMÕES PIRES, Francisco Luiz da Rocha, "Direitos fundamentais, educação e cidadania: tríade inseparável". Em Direito constitucional: constitucionalismo contemporâneo, Renato dos Reis, Jorge e Gorczevski, Clóvis (org.), Porto Alegre, Norton Editor, 2005, p. 16.

${ }_{205}$ MOREIRA, Luiz, Fundamentação do direito em Habermas, Belo Horizonte; Mandamentos Editora, $3^{\text {a }}$ ed., 2004, p. 47, nota 58.
} 
Para Mészáros los procesos educacionales y sociales más exhaustivos de reproducción están vinculados. Para la transformación de la educación es necesaria la transformación del cuadro social en el cual las prácticas educacionales deben cumplir sus vitales e históricamente importantes funciones de cambio. Al no hacerlo de esta manera, lo máximo que se consigue es una corrección de algunos detalles defectuosos del orden educacional establecido, manteniéndose intactas las estructuras fundamentales de la sociedad como un todo, en conformidad con las exigencias inalterables de la lógica global de un determinado sistema de reproducción. ${ }^{206}$

Esta lógica elimina, de forma irreversible, cualquier posibilidad de legitimar un conflicto entre "las fuerzas hegemónicas fundamentales rivales", en un determinado orden social, como "alternativas viables" entre sí, ya sea en el campo de la producción material, ya sea en el ámbito cultural/educación. Sería, por lo tanto, absurdo esperar una formación ideal educacional considerando el orden social, donde hay un flagrante control por parte de la clase dominante. No es de extrañar que incluso las más bien intencionadas utopías educacionales, formuladas desde el punto de vista del capital, tuviesen que permanecer dentro de los límites del dominio del capital como modo de reproducción metabólica. Las posiciones de los utópicos eran sólo para las reformas, con el fin de poner remedio a los peores efectos del capitalismo, sin eliminar la brecha existente en el sistema en favor de la elite. ${ }^{207}$

La razón del fracaso de la reforma educacional se debe al hecho de que algunas determinaciones del capitalismo son irreformables. Efectivamente, el capital es irreformable, incluso por su propia naturaleza. Se mantienen algunos beneficios que se revierten para el propio sistema capitalista. Por eso, es

206 MÉSZÁROS, István, A educação para além do capital, Tradução de Isa Tavares, São Paulo; Boitempo, 2005, p. 25.

207 "Limitar un cambio educacional radical a los márgenes correctivos egoístas del capital significa abandonar de una sola vez, conscientemente o no, el objetivo de una transformación social cualitativa". (MÉSZÁROS, István, A educação para além do capital, cit., p. 26). 
necesario romper con la lógica del capitalismo con el fin de tener una alternativa educativa. ${ }^{208}$

Las soluciones no pueden ser sólo formales: deben ser esenciales.

La educación institucionalizada, especialmente en los últimos ciento cincuenta años, ha servido no sólo para proporcionar los conocimientos y el personal necesario para la máquina productiva en expansión del sistema capitalista, sino también para generar y transmitir un cuadro de valores que hace legítimos los intereses dominantes, como si no pudiera haber ninguna alternativa a la gestión de la sociedad, ya sea en la forma "internalizada" o a través de una dominación estructural y una subordinación jerárquica implacable e impuesta. ${ }^{209}$

Las tergiversaciones de este tipo son la regla cuando hay riesgos para el sistema. En estos casos, la historia debe ser reescrita y propagada de una forma distorsionada, no sólo en los órganos oficiales de gran escala y que divulgan la opinión política, desde los periódicos de gran difusión hasta las radios y las televisiones. Marx, en la obra El Capital, hace una caracterización devastadora de la forma de acumulación de capital como una cuestión vital de la historia del modo capitalista conocida como la acumulación primitiva u originaria del capital que es tratada por la economía política. ${ }^{210}$

La cuestión crucial, en el capitalismo, es asegurar que cada individuo adopte, como propias, las metas de reproducción objetivamente posibles en el sistema. Es una cuestión de internalización por parte de los individuos la de "legitimar la posición que les fue atribuida en la jerarquía social, junto con sus expectativas "adecuadas" y las formas de conducta "ciertas", más o menos explícitamente estipuladas en este terreno". Mientras que la internalización haga su papel de asegurar los parámetros reproductivos generales del sistema del capital, la

\footnotetext{
208 MÉSZÁROS, István, A educação para além do capital, cit., p. 26/7.

209 MÉSZÁROS, István, A educação para além do capital, cit., p. 35.

210 MÉSZÁROS, István, A educação para além do capital, cit., p. 36.
} 
brutalidad y la violencia pueden ser relegadas a un segundo plano -no abandonadas, sino relegadas a un segundo plano- puesto que son modalidades costosas de imposición de valores, como sucedió durante el desarrollo del capitalismo moderno. Sólo en tiempos de crisis agudas la brutalidad y la violencia vuelven. Basten ver el caso de Chile y Argentina en el periodo militar. ${ }^{211}$

Lo que debe quedar claro es que las instituciones formales de la educación son una parte importante en el sistema global de internalización ${ }^{212}$. Los individuos deben ser inducidos por los sistemas de educación formales a una aceptación activa o más o menos resignada de los principios reproductivos orientadores dominantes de la sociedad, adecuados a su posición en el orden social, y de acuerdo con las tareas reproductivas que se les atribuyen. Deben, por lo tanto, adoptar las perspectivas globales de la sociedad mercantilizada como incuestionables límites individuales a sus aspiraciones personales. Sólo una consciente acción colectiva sacará a los individuos de esta situación grave y paralizante. $^{213}$

No hay escapatoria, viendo esta lógica, del sistema escolar establecido sobre la base de la lógica del capital. No basta con reformarlo simplemente. Es preciso reformular todo el sistema de internalización, con todas sus dimensiones, visibles y ocultas. ${ }^{214}$

Por más severas que puedan ser muchas escuelas, y por muchos que puedan ser los daños que provoquen, aún así los jóvenes pueden buscar el alimento intelectual y artístico en otras fuentes. Sin embargo, la función que se adjudica hoy al sistema educacional formal es actuar como guardián y autoritario

\footnotetext{
211 MÉSZÁROS, István, A educação para além do capital, cit., p. 44.

212 ALTHUSSER, Louis, Aparelhos Ideológicos de Estado (...), cit.

${ }^{213}$ MÉSZÁROS, István, $A$ educação para além do capital, cit., p. 44/5.

214 Sistema de escuela completo significa que abarque a todos, ricos, pobres, mestizos. Que no sea un decir elitista, sino integral, de todos. Las escuelas deben ser esenciales y no meramente formales. "Romper con la lógica capitalista en el área de la educación equivale, por lo tanto, a sustituir las formas omnipresentes y muy arraigadas de internalización mistificadora por una alternativa concreta y completa". (V. MÉSZÁROS, István, A educação para além do capital, cit., p. 45).
} 
para inducir a un conformismo generalizado con ciertos modos de internalización, para subordinarlos a las exigencias del orden establecido. ${ }^{215}$

La tarea que hay que llevar a cabo va más allá de la negación del capitalismo. La negación directa de las diversas manifestaciones de alienación es todavía condicional a todo aquello que ella niega, y permanece, así, vulnerable en virtud de esta condición. ${ }^{216}$

El reto al que hay que enfrentarse no tiene paralelo en la historia. La reforma debe ser de todo el sistema, lo que conlleva la completa cobertura para todos, sin excepción, implicando pues a todos los individuos. El cumplimiento de esta nueva tarea histórica implica el cambio cualitativo de las condiciones objetivas de reproducción de la sociedad, en el sentido de reconquistar el control total del capital y la transformación progresiva de la conciencia en respuesta a las condiciones necesariamente cambiantes. Es por eso que, en la concepción marxista, la trascendencia de la alienación del trabajo resulta inevitable para la educación. $^{217}$

Por lo tanto, deben ponerse en primer plano la "universalización de la educación" y la "universalización del trabajo como actividad humana autorealizadora". Ninguna de las dos, sin embargo, es viable sin la otra. Así sucedió con Fidel Castro, en el tiempo de la universalización de la educación en Cuba, aduciendo que era necesario, antes, la universalización del trabajo. No puede haber ninguna solución eficaz para la auto-alienación del trabajo sin que se promueva, conscientemente, la universalización conjunta del trabajo y de la educación. ${ }^{218}$

\footnotetext{
215 MÉSZÁROS, István, A educação para além do capital, cit., p. 52/54.

216 "El concepto 'más allá del capital' es inherentemente 'concreto'. Tiene en cuenta la realización de un orden social metabólico que 'sostenga concretamente a sí mismo', sin ninguna referencia autojustificativa de los males del capitalismo" (MÉSZÁROS, István, A educação para além do capital, cit., p. 62).

217 MÉSZÁROS, István, A educação para além do capital, cit., p. 66/67.

218 MÉSZÁROS, István, A educação para além do capital, cit., p. 65.
} 
La educación "más allá del capital" se refiere a un orden social cualitativamente diferente. El defecto grave e insuperable del capitalismo es la "alienación de las mediaciones de segundo orden" que necesita imponer a todos los seres humanos, incluyendo las personificaciones del capital. El capitalismo no podría sobrevivir sin sus mediaciones de segundo orden (principalmente el Estado, la relación de cambio orientado al mercado y al trabajo, en su subordinación al capital). Esto significa que estas mediaciones de segundo orden imponen a la humanidad una "forma alienada de mediación". "La 'alternativa concreta' a esta forma de controlar la reproducción metabólica social sólo puede ser la 'automediación', en su inseparabilidad del 'autocontrol' y de la 'autorealización a través de la libertad sustantiva y de la igualdad', en un orden social reproductivo conscientemente regulado por los individuos asociados". Es también inseparable de los "valores" escogidos por los propios individuos sociales, conforme a sus reales necesidades y no impuestos de forma totalmente artificial, por los imperativos cosificados de la acumulación lucrativa del capital, como es el caso de hoy en día. Ninguno de los objetivos emancipadores es concebible sin la intervención más activa en la educación más allá del capital. ${ }^{219}$

Lo que propone Mészáros es una educación más allá del capital. El primer paso es enfrentarse de forma abierta y consciente a las formas de control ideológico capitalista. No se puede repetir el sistema excluyente de dominación burguesa dentro de las escuelas y sostener la versión del ser humano como un fin y no como un medio para llegar a la acumulación de capital.

Se puede añadir a esta "educación más allá del capital" de Mészáros lo que apunta Warat. Sostiene que la actuación de los juristas debe pasar por la universalidad, la investigación, la administración de la justicia, los programas de gobierno y la redefinición de los problemas de los derechos humanos ${ }^{220}$. Dados los límites de esta investigación, sólo haremos unas rápidas consideraciones

219 MÉSZÁROS, István, A educação para além do capital, cit., p. 72/73.
220 WARAT, Luis Alberto, Introdução geral ao direito Il (...), cit., p. 95/96. 
sobre los dos primeros, pasando, después, a la cuestión de la constitución cultural. $^{221}$

Warat subraya que la investigación debe ser revisada utilizando nuevas prácticas. $^{222}$

En esta línea, Gomes Canotilho apunta que el principio de la democracia económica y social no se limita, unilateralmente, a una simple dimensión económica. Las instituciones democráticas aseguran e incentivan el acceso a la cultura y a la educación, con igualdad de oportunidades y acceso a la educación básica universal, ${ }^{223}$ obligatoria y gratuita. ${ }^{224}$

La creación de condiciones concretas para el ejercicio del derecho a la cultura y a la educación es una condición esencial de una real libertad de

\footnotetext{
${ }^{221}$ La universalidad debe hacer que los estudiantes piensen en las funciones del juridicialismo en las sociedades industriales, mostrándoles "la teatralización del miedo que la enseñanza tradicional del derecho conlleva; tratando la permanente denuncia de las creencias del sentido común teórico del derecho ( $\mathrm{y}$ de las otras ciencias sociales) que sustentan la producción de un discurso jurídico destinado a producir simultáneamente efectos de adaptación y exclusión social". Defiende una forma de educación más allá de las amarras y los dogmas del capital. Una educación emancipadora basada en los patrones actuales de constitucionalidad, ciudadanía y buena vida. Es necesario crear un nuevo perfil de investigador que "entienda que las representaciones teóricas no pueden separarse de la práctica social cotidiana, son inseparables de las condiciones de esta práctica. Es un modelo de investigación puesto a servicio de las prácticas de autogestión y su forma de residencia institucional" Actuando de esta forma se cumpliría lo que establece el artículo 205 de la Constitución brasileña de 1988 en cuanto a la educación, que se refiere al pleno desarrollo de la persona, con consecuente preparación para la ciudadanía y para el trabajo. (WARAT, Luis Alberto, Introdução geral ao direito II (...), cit., p. 95).

${ }_{222}$ Art. 205. La educación, es un derecho universal y deber del Estado y de la familia, será promovida e incentivada con la colaboración de la sociedad, buscando el desarrollo completo de la persona, su preparación para el ejercicio de la ciudadanía y su calificación para el trabajo.

${ }_{223}$ Art. 206. La enseñanza será impartida en base a los siguientes principios: I - igualdad de condiciones para el acceso y permanencia en la escuela; (...).

"Cuando se habla de prestaciones existenciales para 'asegurar una existencia humana digna' se pretende también aludir a la inseparabilidad de la 'existencia digna' de una expresión cultural y, al mismo tiempo, a la inseparabilidad de la 'democracia cultural' de un deber de cuidado por las prestaciones culturales (Daiseinsvorsorge) materiales".

${ }_{224}$ GOMES CANOTILHO, J. J., Direito Constitucional e Teoria da Constituição, Lisboa, Almedina, $7^{\text {a }}$ ed; 2003, p. 349.
} 
formación y del desarrollo de la personalidad e instrumento indispensable para la propia emancipación (progreso social y participación democrática). ${ }^{225}$

Gorczevski y Simões Pires no olvidan que la educación es un derecho sujetivo público des individuo que puede ser ejercido por él o por un representante suyo, como una afirmación de la regla constitucional de desarollo del hombre, para que pueda ser considerado como verdadero ciudadano. ${ }^{226}$

Educar para los derechos humanos (o se puede decir para más alla del capital $^{227}$ ) es crear una cultura preventiva, fundamental para terminar con la violación de ellos. Con una educación vuelta a los derechos humanos uno puede aprender a distinguirlos y, por ello, mejor desfrutarlos. La educación para los derechos humanos lleva por cuenta actitudes basadas en la tolerancia, solidariedad y respeto. ${ }^{228}$

Sin embargo, dentro del principio de la democracia económica y social, Canotilho hace referencia al principio de la igualdad. Para él, entre este principio y el de la democracia económica y social, hay una conexión demasiado estrecha. La democracia económica y social abarca la libertad y la igualdad. Esto significa que no se puede interpretar el principio de la igualdad como un principio "estático", indiferente a la eliminación de las desigualdades y al de la democracia económica como un principio "dinámico", impositivo de una igualdad material. Esto podría significar la relativización de cualquiera de estos principios. El de la igualdad sería el sentido de la igualdad formal, ignorando la dimensión de la "dignidad social" y el

\footnotetext{
225 "Igualdad de oportunidades, participación, individualización y emancipación, son componentes del derecho a la educación y a la cultura, y dimensiones concretas implícitas en el principio de la democracia cultural" (GOMES CANOTILHO, J. J., Direito Constitucional e Teoria da Constituiçãa, ibidem).

${ }^{226}$ GORCZEVKI, Clóvis e SIMÕES PIRES, Francisco Luiz da Rocha, "Direitos fundamentais, educação e cidadania: tríade inseparável", cit., p. 21.

${ }^{227}$ Sin uma concepción tecnica rigorosa. Solamente para poner la importancia de la educación como forma de emancipación.

${ }^{228}$ GORCZEVKI, Clóvis, Direitos humanos, educação e cidadania: conhecer, educar, praticar, Santa Cruz do Sul; Eitora da Unisc, 2009, p. 221.
} 
de la democracia social sería sólo un instrumento de eliminación de reducción de las desigualdades en el mundo de los hechos. ${ }^{229}$

Educación, comunicación y emancipación son elementos centrales de la democracia y de la regular y del consiguiente reconocimiento derechos. ${ }^{230}$

El Movimiento de los Trabajadores Sin Tierra, en relación a la educación y a la cultura, en su página Web sostiene que la educación y el acceso a la cultura, al conocimiento y a la valorización de las sabidurías populares, es una condición esencial para que los brasileños se realicen como seres humanos plenos e integrales, y como seres humanos dignos. Ellos quieren, de hecho, la democratización y la popularización de la cultura dentro del país, fortaleciendo los espacios de intercambio cultural, promoviendo el acceso popular a los teatros, los cines, los conciertos, las exposiciones y las fiestas en general que celebren la vida, la lucha, la solidaridad y la diversidad del pueblo. ${ }^{231}$

En relación al hombre económico Robert Dahl explica que "el hombre se ha convertido en el hombre económico, la democracia se ha identificado con el capitalismo, la libertad con la propiedad y su uso, la igualdad con las oportunidades para obtener ganancias, y el proceso con el cambio económico y la

\footnotetext{
${ }^{229}$ GOMES CANOTILHO, J. J., Direito Constitucional e Teoria da Constituição, cit., pp. 350/351.

230 Peter Häberle, sostiene que la mera transcripción de textos jurídicos es insuficiente. La Constitución no es sólo un ordenamiento jurídico para los juristas que van a interpretar la norma constitucional, sino sirve también de hilo conductor para todo y cualquier ciudadano. La Constitución no se limita a ser un conjunto de textos jurídicos o un mero compendio de reglas normativas, sino la expresión de un cierto grado de desarrollo cultural y auto-representación de todo un pueblo por su legado cultural y fundamento de sus esperanzas y deseos (HÄBERLE, Peter, Teoría de la Constitución como ciencia de la cultura, Madrid; Ed. Tecnos 2000, p. 34).

Para Persons, el "foco de la nueva fase es la revolución educacional que sintetiza de alguna manera los temas de las revoluciones industriales y democráticas: igualdad de oportunidades e igualdad de ciudadanía". La madurez de la democracia se mide en razón del nivel de comunicación pública. La democracia sería la constitución política en la cual la sociedad obtiene la conciencia más pura de sí misma. Un pueblo es tanto más democrático cuanto mayor sea el papel atribuido a la reflexión, razonamiento y al espíritu crítico en la regulación de la cosa pública. Y menos democrático cuanto mayor sea el peso del inconsciente, de las costumbres ocultas (Apud, HABERMAS, Jürgen, Direito e democracia: entre facticidade e validade, cit., p. 106).

231 http://www.mst.org.br/taxonomy/term/329 - acceso el 23 de agosto de 2009, a las 15h49min.
} 
acumulación de capital. Esta mezquindad, en realidad, empobrece, si no envilece las ideas de ética y de democracia". ${ }^{232}$

El derecho de propiedad se concibe como derecho de dominio exclusivo sobre las cosas. Pero este derecho no debe referirse sólo a las cosas o al uso de las cosas, sino al ejercicio de poder sobre otros hombres, jerarquizándoles y sometiéndoles, "lo que permite su manipulación en contrariedad a la dignidad de la persona humana. Por estas razones el derecho a la propiedad privada no debe confundirse con el poder de control empresarial ni tampoco le debe servir de fundamento, que también se dice de la propiedad rural que exceda el ámbito de subsistencia económica del labrador y su familia”. ${ }^{233}$

No se puede perder de vista la propiedad como poder y su influencia sobre el ciudadano, lo que hace más nebulosas las condiciones de la democracia y la emancipación intelectual y cultural de las personas. La democracia depende también de la limitación al poder y, especialmente, al poder ejercido por la propiedad sobre el tejido social.

El gobierno democrático y la ciencia libre no pueden existir uno sin el otro. Bobbio no defiende la existencia del rey-filósofo, sino la necesidad de que existan personas que puedan hacer libre uso de la razón, lo que no se produce con el rey, que detenta la posesión de la fuerza y que es lo que lo corrompe. Volviendo a la democracia, es la que permite el libre desarrollo del conocimiento en la sociedad. $^{234}$

232 EHLERS DE MOURA, José Fernando, "Condições da democracia”, cit., p. 74.

EHLERS DE MOURA, José Fernando, "Condições da democracia", cit., p. 75.

234 Como apunta Stuart Mill, sin embargo, la autocracia necesita ciudadanos pasivos, la democracia depende de un número cada vez mayor de ciudadanos activos. "Personalmente, estoy convencido de la contribución decisiva que pueden dar las ciencias sociales a la formación de estos ciudadanos $\mathrm{y}$, por lo tanto, en última instancia, al buen funcionamiento del régimen democrático" (BOBBIO, Norberto, Teoria geral da política. A filosofia política e as lições dos clássicos, Rio de Janeiro; Editora Campus, 2000, p. 398/399). 
Este avance en el espacio o campo cultural, conlleva un crecimiento intelectual que se extiende a los otros sectores de las relaciones interpersonales, sociales y económicas. Un ciudadano trabajador mejor informado, consciente de sus deberes y de sus derechos tiene mejores condiciones reivindicatorias. Se posiciona mejor ante el tomador del trabajo y puede, como la participación de los demás, reivindicar mejores condiciones de trabajo y, de ahí, mayor dignidad.

Para concluir, y volviendo a los conceptos iniciales de este epígrafe, cuando se habla de justicia distributiva hay que tener en cuenta la distribución social de los bienes económicos, por estar asociado a la idea de redistribución que es básicamente económica. Aunque sea éste el principal núcleo de las concepciones de la justicia distributiva, también forman parte de ella tanto las oportunidades para la realización de las diferentes posiciones sociales, como la participación en el poder público. ${ }^{235}$

Por lo tanto, podemos concluir que distribuir justicia no es sólo distribuir bienes, sino también distribuir oportunidades de acceso, que se logran a través la educación de calidad en condiciones de igualdad para todos, y por la cultura. La llegada al poder público y la capacidad de toma de decisión se hace, también, de forma distributiva, distribución de la educación y de la cultura con la participación en el proceso democrático. Es la idea y el concepto de democracia distributiva.

Y para concretar conviene ampliar el concepto de la democracia distributiva. De ahí surge lo que se denomina democracia-distributiva-comunicativa-educativacultural, centrada en la acción comunicativa, que permite el debate en igualdad de condiciones, con el fin de lograr el máximo beneficio para todos. Por esto es necesaria la educación emancipatoria más allá del capital, con acceso ilimitado a la cultura como un derecho fundamental, por los canales no sólo estatales, sino también privados, lo que permitirá un nivel cultural superior al presente, situando al justicia, derechos. Elías Díaz e José Luis Colomer (coords.), Madrid; Alianza Editorial, 2002, p. 212. 
ciudadano en condiciones de evaluar la estructura social para el saber, de hecho (sin influencia de la ideología), lo que es bueno y ventajoso para toda la colectividad.

Es interesante, aún, traer al debate de la educación y de la democracia las contribuiciones de la Union Europea cuanto al desarrollo de una educación de qualidade, con una politica de formación profesional, como está en los articulos 126 y 127 del Tratado de la Unión. ${ }^{236}$

Y es, aún, a traves de las nuevas tecnologias que la sociedad de la información debe suplantar los tradicionales sistemas educativos para mejor desarrollar la propia sociedad, con la inclusión de los jovenes y de los ancianos, lo haciendo de forma permanente, creando nuevas oportunidades de $\operatorname{trabajo}^{237} \mathrm{y}$, añado yo, de democracia y inclusion social.

Por lo tanto, educar y dar cultura es distribuir democracia. Es facilitar el acceso a la información y catalizar los medios comunicativos de la toma de decisiones. El giro lingüístico propuesto por Habermas, centrado en la acción comunicativa, sólo tendrá sentido en una sociedad democrática y que distribuya los estándares educativos y culturales más que lo que actualmente se hace, más allá del capital, más allá de lo que hoy se propone por el poder del dinero y la burocracia.

Llegados a esta parte de la investigación, proponemos una forma un tanto diferente de democracia y de los conceptos de democracia. Lo que defendemos es una sociedad libre, justa y solidaria, con modelos desarrollados de acceso a la educación, a la información y la cultura, distribuidos de forma democrática e

${ }^{236}$ SÁNCHEZ BRAVO, Álvaro, A nova sociedade tecnológica: da inclusão ao controle social. A Europ@é exemplo?, Santa Cruz do Sul; Edunisc, 2010, p. 38/39.

${ }_{237}$ SÁNCHEZ BRAVO, Álvaro, $A$ nova sociedade tecnológica: da inclusão ao controle social. $A$ Europ@é exemplo?, cit., p. 38/40. 
imparcial, sin interferencias, como hemos mencionado, por parte del poder económico y de la burocracia.

Entendemos que resulta clara la relación de lo expuesto con el tema de la subordinación jurídica o incluso con la tercerización. El trabajador es, junto con la cuestión educativa y cultural, el agente de transformación social. Una vez consciente de los niveles de subordinación y de los efectos de esta subordinación en su vida y que efectivamente se produce cuando trabaja de forma subordinada, podrá exigir, partiendo del principio de dignidad humana, que las autoridades competentes interpreten mejor el ordenamiento jurídico.

Subordinada la voluntad del trabajador, su ser en el mundo, el agente subordinante, beneficiario de este trabajo fruto de esta subordinación, será su empleador. $Y$ el trabajador, por tener conciencia y cultura superior a la que actualmente posee, sabrá lo que se pasa con él de forma muy clara y real. Esta conciencia lo mantendrá empleado sí, pero de quien efectivamente es su empleador y no de quien, en la mayoría de las ocasiones, es empleado como él o no tiene cómo pagar sus salarios, fruto del trabajo prestado a las grandes corporaciones.

\subsection{La reconquista de la conciencia de clase}

La reconquista de la conciencia de clase comienza con una educación más allá del capital. Se relaciona con que Canotilho llama constitución cultural y acaba por fortalecer la conciencia de clase del trabajador asalariado. Por ello, conviene que recordemos brevemente la relación entre los derechos fundamentalessociales y la reconquista de la conciencia de clase para que, después, podamos analizar la cuestión de la estabilización democrática y la conciencia de clase. 


\subsubsection{Derechos sociales y la reconquista de la conciencia de clase}

La Constitución brasileña de 1988, como ya hemos apuntado en la parte introductoria de esta investigación, considera los derechos sociales como fundamentales a partir del artículo 6․ La Constitución española de 1978 no establece esta fórmula. En España, son derechos fundamentales sólo las libertades y garantías.

Pretendemos llamar la atención con respecto a la cuestión de los derechos sociales y a la reconquista de la conciencia de clase. La conciencia de clase aproxima al ciudadano al concepto de igualdad material puesto que, más que consciente de sus límites y de su posición dentro del tejido social y económico, está más bien preparado para reivindicar sus derechos y establecer sus límites y deberes.

Conviene subrayar que no hay ninguna crítica, aunque sea velada, al texto español. Nuestra investigación pretende mostrar que el avance de los derechos sociales y su calificación como fundamentales, pueden aproximarnos a una sociedad más equilibrada, justa y solidaria.

Sobre esta tema, Gomes Canotilho afirma que:

"La igualdad material postulada con el principio de la igualdad es también la igualdad real vinculada por el principio de la democracia económica y social. En esta perspectiva, el principio de la democracia económica y social no es un simple "instrumento", no tiene una función instrumental con respecto al principio de la igualdad, aunque se les pueda asociar una "función conformadora" tradicionalmente rechazada por el principio de la igualdad: garantía de igualdad de oportunidades y no sólo de una cierta desigualdad de oportunidades. Eso significa el deber de compensación positiva de la "desigualdad de oportunidades" (cfr. arts. $9 \% / d, 20 \% / 1,74 \% / 1$, etc.). El principio de la igualdad y el principio de la democracia económica y social se aglutinan recíprocamente en una "unidad" que no se puede reducir a momentos unidimensionales "estáticas" o "dinámicas" de la igualdad. En una fórmula sintética, podríamos decir que el principio de la igualdad es, simultáneamente, un principio de igualdad del Estado de derecho (rechtsstaatliche 
Chancengleichheit) y un principio de la igualdad de democracia económica y social (sozialstaatliche Chancengleichheit)". 238

En el caso portugués, la constitución elevó el trabajo, el empleo, los derechos de los trabajadores y la intervención de los trabajadores en un elemento constitutivo del propio orden constitucional global y en instrumento privilegiado de realización del principio de la democracia económica y social, conforme al artículo 2 de la Constitución portuguesa de 1976. Sería la Constitución del trabajo. ${ }^{239}$

Aproximándose un poco a esta teoría, según Habermas, la cultura oxigena los procedimientos de elaboración de las normas jurídicas. ${ }^{240}$

Los avances en el campo cultural, fruto de una reglamentación del trabajo y mantenimiento de los derechos derivados del contrato de trabajo acaban por estabilizar la relación entre empleado y empleador, cada uno consciente perfectamente de su papel en la sociedad y del momento de reivindicación y lucha. Es dialéctica y es saludable. El trabajador, sabiendo su importancia en el proceso histórico y económico, garantiza un futuro mucho mejor para las generaciones siguientes, puesto que permite que, por sí mismas, educadas de acuerdo con estos mismos conceptos, puedan buscar un avance social más igual y humano, sin necesidad de sujeciones a situaciones o a puestos de trabajo degradantes.

\footnotetext{
${ }^{238}$ GOMES CANOTILHO, J. J., Direito Constitucional e Teoria da Constituição, cit., p. 351.

239 GOMES CANOTILHO, J. J., Direito Constitucional e Teoria da Constituição, cit., p. 346/347.

240 Para Habermas "la diferenciación estructural del mundo de la vida conduce a la tendencia evolutiva siguiente: la sociedad tiende a ser constituida por ordenamientos legítimos de procedimientos formales de elaboración y de justificación de las normas; la cultura tiende a ser un estado de revisión permanente de tradiciones 'fluidas' y convertidas en 'reflexivas'. Estas tendencias evolutivas, como consecuencia del proceso de diferenciación estructural del mundo de la vida, solo pueden prosperar en la medida en la que las posiciones de afirmación o negación que sustentan la práctica comunicativa cotidiana no se fundamentan en un acuerdo normativo ulterior, sino que surgen de un proceso cooperativo de interpretación entre los autores sociales". En STEILTJES, Cláudio, Jürgen Habermas. A desconstrução de uma teoria, São Paulo; Germinal, 2001, p. 276.
} 
Este avance en el campo cultural, conlleva un añadido intelectual que se extiende hacia otros sectores de las relaciones interpersonales, sociales y económicas. Un ciudadano trabajador bien informado, consciente de sus deberes y de sus derechos tiene mejores condiciones para establecer sus reivindicaciones.

Las categorías que mejor se posicionan frente a cuestiones políticas y sociales y que acaban por organizarse mejor en los movimientos sindicales, son aquéllas en las que sus empleados o trabajadores están mejor pagados. Un ejemplo de ello son los bancarios, categoría que está en declive aunque todavía tenga una cierta influencia (no como a mediados de los setenta) junto con los movimientos políticos, sociales y sindicales; funcionarios públicos; empleados de empresas que ocupan cargos técnico-científicos (ingenieros, economistas, abogados, profesores); entre otros.

En relación a la reconquista de la conciencia de clase, conviene citar nuevamente a Poulantzas. Para el autor, resulta interesante la alianza entre los intelectuales y la clase obrera. Lo mejor sería la constitución de un bloque histórico, más sólido que la alianza, puesto que ésta mantiene intactos los deseos individuales de cada grupo, con el fin de retomar la conciencia de clase. ${ }^{241}$

A este respecto, Poulantzas apunta que el bloque histórico "obreros intelectuales" difiere de una simple alianza. Mientras que la alianza permite una autonomía particular de sus miembros, cada uno con sus intereses específicos y organizaciones propias, el bloque histórico significa la "vinculación y una soldadura orgánica" de todos los miembros con intereses idénticos. ${ }^{242}$ El retorno de la conciencia es posible. Se abre el camino a la educación, con un papel protagonista por parte de los intelectuales.

241 POULANTZAS, Nicos, "Classes sociais e luta de classes", cit., p. 113/115.

242 POULANTZAS, Nicos, "Classes sociais e luta de classes", cit., p. 115. 
No bastan buenas intenciones políticas. Hay que transformar las propias estructuras del Estado y de la sociedad. Para que eso se produzca, sin embargo, debe haber una modificación en relación a la parte que concierne a los aparatos del Estado y al personal estatal. Significa que el Estado capitalista expresa siempre sus contradicciones en relación a los aparatos ideológicos, dominados por la clase hegemónica. ${ }^{243}$

En la compleja relación entre lucha de clases y aparatos de Estado es la lucha de clases la que desempeña el papel principal. "No son las modificaciones 'institucionales' las que tienen como consecuencia los 'movimientos sociales'”. Es la lucha de clases la que determina las modificaciones en los aparatos del Estado $^{244}$. Es esencial la reconquista de la conciencia de clase. Sólo así la clase trabajadora podrá tener las condiciones de conocer su posición real dentro del tejido social y luchar por mejores condiciones laborales.

Esta es la importancia de la lucha de clases. Es el motor de la historia. Las clases pueden ser comprendidas más en el marco de una lucha de clases. La lucha de clase es un elemento histórico y dinámico. ${ }^{245}$ La delimitación de las clases sociales depende, como hemos visto, del proceso histórico.

Lo que se defiende aquí, es una concepción diversa del pensamiento dominante. En nuestra investigación, la asunción de los derechos fundamentalessociales acaba por despertar la acción colectiva de los trabajadores, esencial para su desarrollo histórico. ${ }^{246}$

243 POULANTZAS, Nicos, "Classes sociais e luta de classes", cit., p. 120/121.

${ }_{244}^{244}$ POULANTZAS, Nicos, "Classes sociais e luta de classes", cit., p. 122.

245 "La constitución y, por tanto, la definición misma de las clases, de las fracciones, de las estratos y de las categorías sólo se pueden realizar, considerando el factor dinámico de la lucha de clase; es decir, teniendo en cuenta sus eventuales consecuencias sobre la extensión, la restricción, la polarización, la reconstitución de una nueva forma de las divisiones sociales" (POULANTZAS, Nicos, ibidem).

${ }^{246}$ "El trabajo y la acción colectiva sirven como los hilos de Ariadna para llegar al entendimiento del proceso de transformación económica y social. El resultado de ese proceso impulsado por el colectivo de los trabajadores tiene un sentido positivo, es un proceso civilizatorio" (CATTANI, Antônio David, A ação coletiva dos trabalhadores, Porto Alegre; Editora SMCultura - Palmarinca, 1991, p. 15). 
El que apenas haya estudios al respecto, se debe al hecho de que exista una dominación ideológica que condiciona toda la materia. A pesar de que la acción colectiva de los trabajadores no tiene ninguna relevancia en el proceso histórico y social, no quiere decir que no sea un tema central. ${ }^{247}$

La relevancia de los trabajadores subordinados en el proceso de civilización, nos permite entender que nos encontramos frente a un concepto de libertad y de emancipación, fruto de los avances de los derechos sociales, que son fundamentales, consten o no en el texto constitucional como tales.

\subsubsection{Conciencia de clase y estabilización de la relación entre el capital y el trabajo}

Una vez cumplidas las etapas descritas anteriormente, el trabajador está más preparado para posicionarse adecuadamente en la estructura capitalista. La reconquista de la conciencia de clase posibilita que el hombre que trabaja actúe de forma democrática y comunicativa en el seno de la sociedad.

Esto permite estabilizar las relaciones del mismo con su empleador. Consciente de su importancia en la historia y su papel dentro del orden capitalista, aparecen más claras las formas de reivindicación de sus derechos así como de fijación de sus límites. El cómo deba de actuar frente al tomador de su trabajo y también con relación al gobierno, comienza a tener una apariencia más madura y seria, incluso más respetable. Ahora, el trabajador sabe quién es, qué es y su importancia. Si el trabajador comienza a reivindicar, es porque probablemente tiene un fondo de razón

247 CATTANI, Antônio David, A ação coletiva dos trabalhadores, Porto Alegre; Editora SMCultura Palmarinca, 1991, p. 15. 
De ahí que nace la estabilización de las relaciones. La estabilización de la relación entre capital y trabajo. La conciencia democrática y distributiva, fruto de la actuación comunicativa, muestra a cada uno lo que de hecho tiene y puede tener, así como hasta dónde puede seguir en la búsqueda de un permanente avance en el campo social, cultural, personal y humano.

Si hay una relación entre capital y trabajo estable, se pueden superar las crisis económicas. Se puede negociar, ya sea colectivamente, ya sea mediante normas estatales, cada uno con sus objetivos y se podrán buscar las mejores soluciones distributivas.

La relación de empleo directa, fruto del contrato de trabajo subordinado, debe ser la regla. El trabajador será consciente de ello cuando retome la conciencia de clase, fruto de la democracia distributiva-comunicativa-educativa-cultural. La reconquista de la conciencia de clase hace al trabajador más fuerte. Como consecuencia de esos colectivos, la cuestión de clase se fortalece. Es como un círculo vicioso. El trabajador retoma la conciencia de clase, comienza a exigir una contratación directa y ésta, que le da mayores logros, acaba por formar las bases para el mantenimiento de esta conciencia. Los avances en el campo social son evidentes. La democracia distributiva-comunicativa-educativa-cultural, que supone la contratación directa a través de la conciencia del trabajador, acaba generando otro elemento de fortalecimiento de la cuestión social: la necesidad del contrato de empleo directo con el tomador de los servicios, ya que así el trabajador sabrá precisamente cual es su papel en la historia y su importancia dentro del sistema capitalista.

Conviene subrayar que la contratación directa tiene mejores condiciones de emancipar intelectualmente al trabajador porque le proporciona más derechos y deberes. El trabajador subordinado, que presta trabajo con dependencia (depende de su empleador, pero éste también de él), una vez arraigada esta condición en la esencia de su ser, donde él pueda contar (por su relevante papel en el orden 
capitalista) con la actuación comunicativa y distributiva de su empleador, permite una mayor estabilización democrática, una superación de las crisis, dada la percepción de una mayor gama de derechos, consciente de que estos derechos son fruto de su posición histórica y de arduas conquistas en el sistema capitalista.

La contratación directa y sin intermediación de mano de obra debe ser la regla. No se debe permitir la subcontratación o la tercerización. Conviene subrayar que, en esta investigación, no se deja de lado en ningún momento la cuestión de que el modo de producción es el capitalista y tampoco se propone la superación de éste. Utilizamos en parte la teoría marxista ${ }^{248}$ como elemento de argumentación y fundamentación del discurso, como iremos analizando a lo largo de nuestra Tesis Doctoral.

\subsection{La dignidad de la persona humana como criterio interpretativo y como punto de llegada}

Actualmente se discute si, de hecho, la dignidad humana es un principio o una regla de derecho absoluta, que no permita reflexión o violación, bajo pena de inconstitucionalidad. Por consiguiente, analizaremos algunos argumentos jurídicos especialistas de diversos países.

Eric Hobsbawn ${ }^{249}$, subraya que "tanto la democracia (en cualquiera de sus versiones) como la dictadura, toman su raíz en la extraordinaria década que comenzó con la convocatoria de los Estados-Generales, la Toma de la Bastilla y la 'Declaración de los Derechos del Hombre y del Ciudadano', refiriéndose evidentemente, a la Revolución Francesa y a su importancia en el desarrollo del

\footnotetext{
${ }^{248}$ Ya hemos hecho referencia antes a GIMÉNEZ AMAYA, J.M., y SÁNCHEZ-MIGALLÓN, S., Diagnóstico de la Universidad en Alasdair Maclntyre. Génesis y desarrollo de un proyecto antropológico. Pamplona, Eunsa, 2011, p.33/42.

${ }^{249}$ En el capítulo "de un centenario a otro", en la obra Ecos de la Marsellesa. HOBSBAWN, Eric, Ecos da marselhesa. Dois séculos revêem a revolução francesa. Tradução Maria Célia Paoli, São Paulo; Editora Companhia das Letras, 1996.
} 
concepto de democracia así como a la triade de libertad, igualdad y fraternidad, dando inicio a lo que hoy se concibe como dignidad humana.

N. Belloso Martín apunta que la idea de la dignidad humana hace que se considere cada ser humano, cada persona humana como portador de algo intrínsecamente valioso y que le dota de una serie de características mantenidas incluso en situaciones precarias. No se puede negociar o disponer de la misma, ni por el propio sujeto, ni por el poder político. ${ }^{250}$ Subraya que Kant considera la dignidad como la calidad que no tiene precio, ya que el ser humano no es un medio, sino un fin en sí mismo. ${ }^{251}$

El artículo primero de la Declaración Universal de los Derechos Humanos establece que todos los seres nacen libres e iguales en dignidad y derechos. ${ }^{252}$ No hay persona que no posea dignidad. No se puede separar un concepto del otro. La fallida Carta de Derechos Fundamentales de la Unión Europea, en el Tratado que establece una Constitución para Europa, firmado el 29 de octubre de 2004 en Roma, Italia ${ }^{253}$, en su artículo primero, observa que "la dignidad humana es inviolable y será protegida". El Tratado de Lisboa, de 13 de diciembre de 2007, añade el artículo 10 "bis" al Tratado de la Unión Europea, aduciendo que la Unión se fundamenta en la dignidad humana, libertad, democracia, igualdad, respeto de los derechos humanos y del estado de derecho. ${ }^{254}$ Como se ve, no se puede tratar

\footnotetext{
250 BELLOSO MARTÍN, Nuria, "El principio de dignidad de la persona humana en la teoría kantiana: algunas contradicciones". En Direitos Fundamentais \& Justiça. Revista do Programa de Pós-Graduação Mestrado e Doutorado em Direito da PUCRS, Porto Alegre; HS Editora, Ano 2, número 04, julio/septiembre de 2008, p. 41.

251 BELLOSO MARTÍN, Nuria, "El principio de dignidad de la persona humana en la teoría kantiana: algunas contradicciones", cit., p. 50.

252 Artículo primero. "Todas las personas nacen libres e iguales en dignidad y derechos. Están dotadas de razón y conciencia y deben actuar en relación unas con las otras con espíritu de fraternidad" (en http://www.mi.gov.br/sedh/ct/legis intern/ddh bib inter universal.htm - acceso el 03 de septiembre de 2008, 15h53min).

${ }^{253}$ Articulo primero. "La dignidad humana es inviolable. Será respetada y protegida".

254 "Artículo 1 bis. La Unión se fundamenta en los valores de respeto de la dignidad humana, libertad, democracia, igualdad, Estado de Derecho y respeto de los derechos humanos, incluidos los derechos de las personas pertenecientes a minorías. Estos valores son comunes a los Estados miembros en una sociedad caracterizada por el pluralismo, la no discriminación, la tolerancia, la justicia, la solidaridad y la igualdad entre mujeres y hombres".
} 
de derechos sin tomar en consideración, necesariamente, la dignidad humana. Constituye el sustrato jurídico para todo el ordenamiento vigente.

Siguiendo en el ámbito de la Unión Europea, en la página web junto a la red mundial de computadoras de la institución, consta la explicación sobre el concepto de dignidad humana, fruto de la Carta de Derechos Fundamentales de la Unión Europea. $^{255}$

Lo cierto es que el sistema internacional de protección de los derechos humanos constituye el mayor de los legados de la llamada era de los derechos, que permitió y permite la internacionalización de los derechos humanos y la humanización del derecho internacional contemporáneo. ${ }^{256}$

Volviendo a la Declaración Universal de los Derechos Humanos, hito mayor del proceso de reconstrucción de los derechos humanos después del período nazista y fascista, Flávia Piovesan sostiene que esta norma introduce la concepción moderna de los derechos humanos y que se caracteriza por la universalidad e indivisibilidad. La universalidad no es más que la extensión universal de los derechos humanos, bajo la creencia de que la condición de ser humano, de persona, es el requisito único para la dignidad y titularidad de los derechos. La indivisibilidad se justifica porque la garantía de los derechos civiles y

255 TÍTULO I - DIGNIDAD. Explicación relativa al artículo 1 - Dignidad humana. La dignidad de la persona humana no sólo es en sí un derecho fundamental, sino que constituye la base misma de los derechos fundamentales. La Declaración Universal de Derechos Humanos de 1948 consagra la dignidad humana en su Preámbulo: «...Considerando que la libertad, la justicia y la paz en el mundo tienen por base el reconocimiento de la dignidad intrínseca y de los derechos iguales e inalienables de todos los miembros de la familia humana." En su sentencia del 9 de octubre de 2001, en el asunto C-377/98, Países Bajos contra Parlamento Europeo y Consejo, Rec. 2001, p. I-7079, apartados 70 a 77, el Tribunal de Justicia confirmó que el derecho fundamental a la dignidad humana forma parte del Derecho de la Unión. Se deduce de ello, en particular, que ninguno de los derechos inscritos en la presente Carta podrá utilizarse para atentar contra la dignidad de otras personas y que la dignidad de la persona humana forma parte de la esencia de los derechos inscritos en la presente Carta. Por lo tanto, no podrá atentarse contra ella, incluso en el caso de limitación de un derecho (http://eurlex.europa.eu/es/treaties/dat/32007X1214/htm/C2007303ES.01001701.htm - acceso el 16 de septiembre de 2008, a las $11 \mathrm{~h} 57 \mathrm{~min})$.

${ }^{256}$ PIOVESAN, Flávia. "Direitos humanos e o princípio da dignidade humana". En Dos princípios constitucionais. Considerações em torno das normas principiológicas da Constituição. George Salomão Leite (org.). Editora Malheiros, 2003, p. 180. 
políticos es un requisito previo para la observancia de los derechos sociales, económicos y culturales y viceversa. Cuando uno de ellos es violado, lo son también los otros. "Los derechos humanos componen, así, una unidad indivisible, interdependiente e interrelacionada, capaz de conjugar el catálogo de los derechos civiles y políticos con el catálogo de los derechos sociales, económicos y culturales". 257

La lógica de los derechos humanos es una lógica material, inspirada en el valor de la dignidad humana y en la tutela interna de los derechos fundamentales. Se apartan, por tanto, los criterios de temporalidad de la ley (ley posterior revoca la anterior cuando es incompatible) y especialidad (ley especial revoca la ley general en lo que ella tiene de especial). La lógica, en estos casos, es exclusivamente material, del derecho material. Prevalece la norma más beneficiosa, más protectora y más favorable a los derechos humanos, independiente de si es anterior o posterior, especial o general. En esta perspectiva en la que la primacía es de la persona humana, el ser comienza a ser concebido como un fin en sí mismo y nunca como medio, recordando la lección Kantiana. "Es un ser esencialmente moral, dotado de unicidad y de integridad, bajo el manto de la dignidad humana, valor fuente de la experiencia jurídica”. ${ }^{258}$

\footnotetext{
257 PIOVESAN, Flávia. "Direitos humanos e o princípio da dignidade humana". En Dos princípios constitucionais. Considerações em torno das normas principiológicas da Constituição. George Salomão Leite (org.). Editora Malheiros, 2003, p. 182/3.

En relación a la indivisibilidad e interdependencia entre los derechos humanos y, hasta fundamentales, Flávia Piovesan nos recuerda que: "Al examinar la indivisibilidad y la interdependencia de los derechos humanos, Héctor Gros Espiell: "Solo el reconocimiento integral de todos estos derechos puede asegurar la existencia real de cada uno de ellos, ya que sin el goce efectivo de los derechos económicos, sociales y culturales de los derechos civiles y políticos se reducen a meras categorías formales. Por el contrario, sin la realidad de los derechos civiles y políticos, sin la efectividad de la libertad entendida en su más amplio sentido, los derechos económicos, sociales y culturales carecen, a su vez, de un verdadero significado. Esta idea de la necesaria integridad, interdependencia e indivisibilidad con respecto al concepto y a la realidad del contenido de los derechos humanos, que de alguna manera está implícito en la Carta de las Naciones Unidas, se compila, se extiende y se sistematiza en 1948, en la Declaración Universal de los Derechos Humanos, y se reafirma definitivamente en los Pactos Universales de los Derechos Humanos, aprobados por la Asamblea-General en 1966, y en vigor desde 1976, en la Proclamación de Teherán de 1968 y en la Resolución de la Asamblea-General, aprobada el 16.12.1977, sobre los criterios y medios para mejorar el goce efectivo de los derechos y de las libertades fundamentales (Resolución 32/130)" (Ibidem, p.183).

${ }^{258}$ PIOVESAN, Flávia, "Direitos humanos e o princípio da dignidade humana", cit., p. 187/8.
} 
La Declaración Universal de los Derechos Humanos, al introducir la concepción contemporánea de derechos humanos consagra y acoge la dignidad humana como un valor para iluminar el universo de derechos. El requisito único y exclusivo para la titularidad de los derechos es la condición del ser humano. La universalidad de los tratados internacionales, aunque tengan la cara del positivismo jurídico, incorporan el valor de la dignidad humana. ${ }^{259}$

Ingo Wolfgang Sarlet expone que la dignidad humana está ligada a la condición de ser humano, inherente a cualquier persona humana. Es una cualidad intrínseca de la persona e irrenunciable, constituyendo un elemento que califica al ser humano como tal. Incluso el más cruel de los criminales detenta, como ser humano, dignidad. Lo que hace que los seres tengan dignidad es el hecho de que están dotados de razón y de conciencia. Lo que constituye un elemento común de todos los hombres y fundamenta su igualdad. ${ }^{260}$.

Para Pacheco Zerga la teología católica proporcionó la categoría fundamental de persona y su dignidad, algo unido a la libertad de forma inseparable. Es un predicado no sólo de unos pocos hombres sino de todos, del ser humano como tal, humano, es decir en razón de su humanidad y no sólo de un reconocimiento legal. $Y$ eso responde a un fundamento católico trascendente: el hombre fue creado a imagen y semejanza de Dios. Su dignidad, por tanto, tiene un valor supremo e infinito, puesto que él está destinado a tener una relación directa con Dios en el conocimiento y en el amor. ${ }^{261}$

\footnotetext{
259 "Eso porque todo el ser humano tiene una dignidad que le es inherente, siendo incondicionada, no dependiendo de ningún otro criterio, que no sea del ser humano. El valor de la dignidad humana se proyecta, así, por todo el sistema internacional de protección" (PIOVESAN, Flávia, "Direitos humanos e o princípio da dignidade humana", cit., p. 188).

260 WOLFGANG SARLET, Ingo, "Dignidade da pessoa humana. Parte II". En: Dicionário de Filosofia do Direito. Vicente de Paulo Barreto (org.), Rio de Janeiro: Unisinos e Renovar, 2006, p. 217/218.

261 PACHECO ZERGA, Luz, La dignidad humana en el derecho del trabajo, Navarra; Thompson Civitas, 2007, p. 23/4.
} 
La dignidad humana es así, según Godinho Delgado, y la Carta brasileña de 1988, el "fundamento de la vida en el país, principio jurídico inspirador y normativo, y también, el fin, el objetivo de todo el orden económico". ${ }^{262}$

La Constitución brasileña de 1988 confirió al principio de la dignidad humana la condición de fundamento, principio y objetivo, asegurándole cobertura en todo el orden jurídico y en todas las relaciones sociales. La Constitución va más allá de la visión estricta e individualista para trazar una dimensión social y comunitaria de afirmación de la dignidad humana. Hay un daño a la dignidad humana y a todo el modelo constitucional brasileño cada vez que alguien se encuentre privado de los instrumentos mínimos de afirmación social. ${ }^{263}$

La idea de dignidad no se reduce, según Godinho Delgado, a una dimensión particular, vinculada únicamente a los valores inmanentes de la personalidad y que no se proyectan en el campo social. Lo que se concibe como inherente a la dignidad de la persona humana es, junto a esta dimensión privada de valores, la afirmación social del ser humano. Por consiguiente, para que no haya un perjuicio en su dignidad, la persona debe tener una amplia posibilidad de afirmación social. 264

La dignidad de la persona humana es el centro de todo el sistema constitucional brasileño, español ${ }^{265}$ y también occidental. No se puede pensar en el Estado de Derecho y menos en el Estado Democrático de Derecho, sin tener presente, necesariamente, la dignidad humana. Cada vez que la dignidad de algún

262 GODINHO DELGADO, Maurício, "Os direitos fundamentais nas relações de trabalho". Em O MPT como promotor dos direitos fundamentais, Juliana Vignoli Cordeiro e Sebastião Cordeiro Caixeta (coord.), São Paulo; LTr, 2006, p. 182.

263 GODINHO DELGADO, Maurício, "Os direitos fundamentais nas relações de trabalho", cit., p. 182.

${ }^{264}$ GODINHO DELGADO, Maurício, "Os direitos fundamentais nas relações de trabalho", cit., p. $182 / 183$.

${ }^{265}$ Artículo 10. 1. La dignidad de la persona, los derechos inviolables que le son inherentes, el libre desarrollo de la personalidad, el respeto a la ley y a los derechos de los demás son fundamento del orden político y de la paz social. 
ciudadano se vea amenazada, habrá inconstitucionalidad. Habrá agresión a toda la colectividad y esta amenaza o hecho debe ser inmediatamente paralizado.

Como acertadamente ha sostenido Pedro Serna Bermúdez, la igualdad se funda en los derechos de contenido económico, social y cultural, y no al réves. La igualdad formal es una consecuencia directa de la noción de dignidad de la persona, mientras -añade- que la igualdad material considerada como un valor es confusa en cuanto a su alcance, habiéndosela identificado, en ocasiones, con la igualdad económica y real, lo que conlleva un reduccionismo difícil de justificar. ${ }^{266}$

La única forma de interpretar la Constitución es tener como norte la dignidad humana. Según Clève, existen dos formas de interpretar los preceptos constitucionales. La primera, indiferente e insensible a los instrumentos que transformaron el nuevo orden constitucional, que sería la dogmática de la razón del Estado. La segunda, que trata de estudiar el derecho constitucional teniendo como objetivo la dignidad humana, que se conoce como dogmática constitucional emancipatoria. ${ }^{267}$ Es a ésta segunda a la que nos adherimos. No se puede tolerar un Estado Democrático de Derecho que no respete escrupulosamente el principio de la dignidad humana, porque de lo contrario, se consagraría la utilización del ser humano como un medio, como una cosa e incluso como una mercancía.

La consideración de la dignidad humana como mega-principio reviste la democracia de unas características y condiciones particulares. La propuesta de cómo hacerlo la hemos venido exponiendo a lo largo del presente estudio. Por una educación más allá del capital, teniendo como modelo el procedimiento comunicativo habermasiano. Esto conllevará una vida buena y feliz, superando la total alienación en la que la sociedad se encuentra hoy en día, en la que está

\footnotetext{
${ }^{266}$ SERNA BERMUDEZ, Pedro, "La dignidad de la persona como principio del Derecho público". En Derechos y libertades 4, Madrid: Dykinson-Universidad Carlos III de Madrid, 1995, p. 292/293.

${ }^{267}$ CLĖVE, Clémerson Merlin, "A eficácia dos direitos fundamentais sociais". En: Revista de Direito Constitucional e Internacional. Cadernos de direito constitucional e ciência política, número 54, São Paulo: Revista dos Tribunais, Ano 14, janeiro a março de 2006, p. 28/9.
} 
inserto el hombre post-moderno. Es esta forma de actuación que colocará delante de sí al propio hombre con sus propias virtudes y debilidades. $Y$ es eso lo que permitirá al ser humano, al juzgador, al agente social al ciudadano una interpretación legislativa una mirara legislativa más allá del capital y de la cosificación del ser humano. El hombre tendrá como modelo su emancipación dando lugar a un proceso permanente, siguiendo el camino de la buena vida y de la felicidad, dentro de los límites de la constitución vigente.

Antes de terminar, y para reforzar lo que venimos sosteniendo, se debe destacar que el principio del articulo 1.1 de la Constitución Alemana de 1949 salvaguarda la existencia digna de todos, incluso de quienes estén, por ejemplo, en la cárcel. Debe garantizarse a todos los miembos de la sociedad el mínimo material de subsistencia, junto con el libre desarrollo de la personalidad, reconocido este último en el artículo 2.1 GG, "lo cual tiene como consecuencia la supresión de toda eficacia práctica independente del principio de la dignidad, al quedar este abosrbido por el principio de autodeterminación (...)". 268

La dignidad constituye un supuesto básico de las metas del Estado, en especial las que tienen relación con el Estado de derecho. La persona, en virtud de su dignidad, es el principal objetivo que debe de tener el Estado. Y la principal proyección de la dignidad en el sistema constitucional está en la garantía de los derechos fundamentales. ${ }^{269}$

De ahí se concluye que en el trabajo por cuenta ajena, el trabajador se vincula al bien que produce, sin la posibilidad de la doble alienación o doble cosificación. Los límites para la acción instrumental, dentro del ordenamiento jurídico, se encuentran establecidos en la Constitución, plasmados en la relación de empleo, norma ésta de interpretación estricta (porque permite la explotación de

${ }^{268}$ SERNA BERMUDEZ, Pedro, "La interpretación constitucional del principio de dignidad de la persona en el derecho alemán", En Interpretación constitucional, Director E. Ferrer-Mac Gregor, Mexico, Porrúa-UNAM, 2005, p. 1099 y 1101.

${ }^{269}$ SERNA BERMUDEZ, Pedro, "La interpretación constitucional del principio de dignidad (...), cit., p. 1112 . 
la "plusvalía"), de donde se concluye que no es posible la tercerización, allí donde haya la doble alienación o la doble explotación de la "plusvalía".

En las páginas que siguen, vamos a analizar de forma más técnica el tema. Confiamos en que el capítulo que ahora concluimos haya permitido asentar la base y el fundamento teórico de las ideas que pretendemos desarrollar en los siguientes capítulos. 


\section{Capitulo II}

La tercerizacion en el orden jurídico brasileño. 


\subsection{Introducción y origenes.}

La tercerización, hoy, forma parte de la realidad de prácticamente todas las empresas y condominios. Aparece tanto en el sector privado como en el público, con el fin de reducir los costes y, algunas veces, para especialización de mano de obra en determinadas tareas. Este fenómeno es tan significativo para el derecho del trabajo que llega a alcanzar la configuración de la subordinación ${ }^{270}$.

En Brasil, en 2009, había 8,2 millones de trabajadores tercerizados, 22,2\% de los trabajadores subordinados con registro formal y un $8,86 \%$ de la población económicamente activa, de 92,6 millones de personas, en un universo de 190 millones de habitantes. Brasil, es responsable de un 2,2\% de los trabajadores tercerizados del mundo. ${ }^{271}$

La media salarial de los empleados tercerizados, en 2009/2010, es de $\mathrm{R} \$ 918,00$, con un incremento de más del $3 \%$ si se compara con 2008/2009 cuando la cifra llegó a $\mathrm{R} \$ 878,00$. Para los trabajadores temporales la media salarial 2009/2010 es de $R \$ 902,00$ mientras que en 2008/2009 era de $\mathrm{R} \$ 849,00 .^{272}$

Sin embargo, si se compara con los valores medios de salarios pagados en Brasil, el trabajador tercerizado sale perdiendo. En 2006 el salario medio en el país era de $\mathrm{R} \$ 1.236,19$, más del $30 \%$ en comparación con el del trabajador subcontratado. ${ }^{273}$ Sin embargo, en septiembre de 2010 el salario medio pagado en el país fue de $R \$ 1.511,49$, casi el doble de lo pagado por las empresas tercerizantes. $^{274}$

\footnotetext{
${ }^{270}$ MONTOYA MELGAR, Alfredo, "Sobre el trabajo dependiente como categoría delimitadora del derecho del trabajo", cit., p. 59.

${ }^{271}$ Pesquisa Setorial 2009/2010 do Sindicato das Empresas de Prestação de Serviços a Terceiros, Colocação e Administração de mão-de-obra e de Trabalho Temporário no Estado de São Paulo (SINDEPRESTEM), São Paulo, SP, 2009/2010, p. 53.

272 Pesquisa Setorial 2009/2010 (...), cit., p. 33/37. El real, moneda de Brasil, vale 40\% del valor del Euro.

${ }_{273}$ http://www.trabalho.al.gov.br/noticias/salario-medio-do-brasileiro-cresceu-5-86-em-2006, acceso el 02 de diciembre de 2010, a las 10h22min.

274 Pesquisa Setorial 2009/2010 (...), cit., p. 33/37.
} 
Es interesante decir, aún, que más de treinta por ciento de los deudores de la justicia laboral del Rio Grande del Sur son empresas intermediadoras de manode-obra (de tercerización), lo que comprueba la fragilidad de los trabajadores frente a sus empleadores y tomadores de trabajo. ${ }^{275}$

La magistrada brasileña Katia Arruda enseña que la terceirizacion ha traído la precarización aún más fuerte a la relación laboral. Ello porque los paises perifericos, como Brasil, han adherido a la globalizacion, adoptando los preceptos del "Consenso de Washington", lo que hiere lo que consta en la Constitución de Brasil que mira a la dignidad humana y a los derechos de segunda dimensión. ${ }^{276}$

Se constata que en Brasil hay hoy 32.640 empresas de trabajo temporal y tercerizadas, con un crecimiento anual del $2,9 \%$ si se compara con $2008 / 2009$. Lo que llama la atención de este dato es que la población brasileña crece un 0,98\% al año, 1/3 del crecimiento del número de empresas de subcontratación. Sin embargo, éstas representan el $0,5 \%$ de las empresas privadas brasileñas que totalizan 5.277 .214 , lo que muestra la cantidad de empleo y renta que las empresas tercerizadas generan. ${ }^{277}$

En 2009, sólo en el sector de la tecnología de la información, la tercerización creció en Brasil entre un 10\% y un 12\%, debido a la devaluación del dólar frente a las monedas latinoamericanas, lo que calentó el mercado mejicano, argentino y brasileño. ${ }^{278}$

\footnotetext{
275

http://www.trt4.jus.br/portal/portal/trt4/comunicacao/noticia/info/NoticiaWindow?cod=755819\&action $=2$ - aceso el 07 de agosto de 2013, a las 12h53min.

MAGALHÃES ARRUDA, Kátia, "Las transformaciones del mundo del trabajo y sus repercusiones em el Brasil actual". En Revista General de Derecho del Trabajo y de Seguridad Social 24, 2011, passin.

${ }_{277}$ Pesquisa Setorial 2009/2010 (...), cit., p. 26/29.

278 http://cio.uol.com.br/tecnologia/2009/07/15/mercado-nacional-de-terceirizacao-deve-crescer-10-em-2009/. Acceso el 30 de noviembre de 2010, a las 19h01min.
} 
Por ejemplo, Juan José Martín Arribas afirma que las empresas Nike y Reebok no fabrican ningún zapato. Subcontratan empresas especialmente en Asia para que ejecuten esta tarea, encargándose sus empleados sólo del desarrollo del diseño y de la propaganda de sus productos. Sin embargo, un noventa por ciento del mercado de zapatos está controlado por empresas occidentales, pero un noventa y ocho por ciento de estos productos son fabricados en Asia. ${ }^{279}$

Para Pinto Martins "La tercerización es un fenómeno con mayor o menor intensidad en casi todos los países. En un mundo que tiende a especializarse en todas las áreas, la tercerización genera nuevos empleos y nuevas empresas, desverticalizándolas, para que puedan ejercer sólo la actividad en la que priman, delegando a terceros la ejecución de los servicios en los que no se han especializado". Es competencia del derecho del trabajo, por ser una rama dinámica, evaluar los avances en la estructura de las empresas y compatibilizarlos conforme a la ley vigente. ${ }^{280}$

El autor argumenta que ya había, durante la segunda guerra mundial, una noción de qué es hoy la tercerización. Eso se produjo cuando las empresas encargadas de la fabricación de armas se vieron desbordadas, delegando el trabajo a terceros, contratados para dar soporte al aumento de la producción de armas. $^{281}$

En el caso de Brasil, la noción de tercerización fue traída en la década de los 50' por las multinacionales, preocupadas sólo por la esencia de sus negocios. Ejemplo de tercerización es la industria automovilística, que pasó a delegar en otras empresas la ejecución de algunos componentes del automóvil. Otro ejemplo

\footnotetext{
${ }^{279}$ MARTíN ARRIBAS, Juan José, "Aproximación general a la figura del outsourcing en su vertiente internacional". En Autores Varios. La externalización de actividades laborales (outsourcing): una visión interdisciplinar. Abdón Pedrajas Moreno (org.). Valladolid; Lex Nova, 2002, p. 251. La doctrina española acepta la tercerización en los casos de descentralización productiva que envolven, tambien, la subcontratación de obras y mercancías, lo que, aunque haya controvercias, para este estudio, no se aplica al caso brasileño, como esta puesto en la Súmula 331, III, del TST. ${ }^{280}$ PINTO MARTINS, Sérgio, A terceirização e o direito do trabalho, São Paulo; Atlas, $9^{2}$ Ed., 2009, p. 1.

${ }_{281}$ PINTO MARTINS, Sérgio, A terceirização e o direito do trabalho, cit., p. 2.
} 
pionero con respecto a la subcontratación son las empresas de limpieza y conservación que existen aproximadamente desde 1967 en Brasil, además de los servicios de seguridad para instituciones bancarias (decretos-ley 1.212 y 1.213 , ambos de 1967). ${ }^{282}$

Pinto Martins cita otros ejemplos y analiza la historia de la tercerización no sólo en Brasil. Pasea por los Estados Unidos de América, por Francia con su ley de contrato temporal, ley 72-1, de 03 de enero de 1972. El autor, basándose en Rafael Caldera, apunta que el derecho laboral no puede ser enemigo del progreso, porque es fuente e instrumento de progreso. No puede ser enemigo de la riqueza, porque aspira a que la riqueza alcance un número cada vez mayor de personas y no puede ser hostil a los avances tecnológicos, dado que constituyen efectos del trabajo. $^{283}$

Sin embargo, no hay que olvidar que es, principalmente, con el fundamento en la reducción de los costes de producción, como los trabajadores son contratados por persona interpuesta, con el fin de prestar servicios a la empresa tomadora, sin que haya vínculo de empleo con ésta. Quien administra, da órdenes, aplica sanciones y paga los salarios es la empresa prestadora de los servicios, con la cual se forma la relación de empleo, conforme a la CLT. La tomadora, conforme a la jurisprudencia pacífica, tiene sólo una responsabilidad subsidiaria, conforme a los términos de la Súmula 331 del Tribunal Superior del Trabajo.

Esta lógica, sin embargo, reduce los derechos de los trabajadores. La vinculación sindical que por regla general se da teniendo en cuenta la actividad principal de la empresa ${ }^{284}$, se firma con la empresa prestadora, que paga salarios

\footnotetext{
282 PINTO MARTINS, Sérgio, A terceirização e o direito do trabalho, cit., p. 2.

283 PINTO MARTINS, Sérgio, A terceirização e o direito do trabalho, cit., pp. 2/5.

284 "Art. 570. Los sindicatos se constituyen, normalmente, por categorías económicas o profesionales, específicas, de acuerdo con la discriminación del marco de las actividades y profesiones a la que se refiere el art. 577 o según las subdivisiones que, a propuesta de la Comissão do Enquadramento Sindical, regulado en el art. 576, son creadas por el ministro del
} 
inferiores sin los mismos derechos colectivos y sin la fuerza reivindicativa sindical de la empresa tomadora de los servicios.

Por actividad principal se entiende aquélla que caracteriza la unidad de producto, operación u objeto final, para cuya elaboración las demás actividades converjan, en régimen de conexión funcional. Este concepto consta en el artículo 581, párrafo segundo, de la $\mathrm{CLT}^{285}$, artículo éste que Pinto Marins presenta, inicialmente, como un posible concepto de actividad-medio, refiriéndose también en el párrafo siguiente al artículo 60, párrafo primero, de la ley 9.472/97, ley de las telecomunicaciones. ${ }^{286}$

Por otra parte, entre 1985 y 2005, el número de empresas intermediarias de mano de obra, en São Paulo (Brasil) pasó de 257 a 6.300. En el mismo período el número de empleados tercerizados pasó de sesenta mil a cuatrocientos veinte mil, datos estos del Sindicato de los Empleados de las Empresas de Prestación de servicios a Terceros (Sindeepres). Eso constituye una muestra de la importancia del tema, aún más en razón de las consecuencias perjudiciales para el trabajador. ${ }^{287}$

En el caso de México, por ejemplo, así como en los demás países de capitalismo tardío como Brasil, la subcontratación comienza a ser, en razón del Tratado de Libre Comercio de América del Norte, un elemento de gran significación dentro de una política industrial activa con el fin de integrar las

\footnotetext{
Trabajo, Industria y Comercio. Párrafo único - Cuando quienes desempeñen cualquier actividad o profesión se constituyen, ya sea por el número reducido, ya sea por la misma naturaleza de estas actividades o profesiones, ya sea por las afinidades existentes entre ellas, en condiciones tales que no se puedan sindicalizar eficientemente por el criterio de especificidad de categoría, se les permite sindicalizarse por el criterio de categorías similares o relacionadas, entendiéndose como tales las que se incluyen en los límites de cada grupo que consta en el Quadro de Atividades e Profissões".

285 "Art. 581. (...). $\S 2^{\circ}$ se entiende por actividad principal la que caracteriza la unidad de producto, operación u objetivo final, para cuya obtención todas las demás actividades converjan, exclusivamente en régimen de conexión funcional".

${ }^{286}$ PINTO MARTINS, Sérgio, A terceirização e o direito do trabalho, cit., 132.

${ }^{287}$ Revista da Associação Nacional dos Magistrados da Justiça do Trabalho, ano XIX, número 56, janeiro de 2009, p. 10.
} 
pequeñas empresas en las grandes redes empresariales internacionales. Estas empresas pequeñas se vuelven más eficientes, capacitadas y competitivas. ${ }^{288}$

En este capitulo, nos ocuparemos de la cuestión de la tercerización tal y como se presenta en el ordenamiento jurídico brasileño. Tomaremos también en consideración otros países como España, Francia, Portugal, Argentina, Chile, Uruguay y Mexico, entre otros. Daremos énfasis a la súmula 331 del Tribunal Superior del Trabajo, destacando la cuestión no sólo de la responsabilidad subsidiaria sino también de la alternativa, fruto de la doctrina, de condena solidaria en caso de subcontratación. ${ }^{289}$

Otro punto importante que analizaremos es qué se entiende por "actividadmedio" y "actividad-fin" y si estos criterios, para el reconocimiento de la relación de empleo, son posibles, en el caso de la legislación brasileña vigente.

Examinaremos las formas "lícitas" o previstas en ley de subcontratación tercerización -, descentralización del servicio público (DL 200/67), ley del trabajo a traves de empresas de temporal ${ }^{290}$ (L. 6.019/74), servicios de seguridad, vigilancia y transporte de valores (L. 7.102/83), régimen de concesión y permiso de la prestación de servicios públicos (L. 8.987/95), ley de las telecomunicaciones (L. 9.472/97) y actividades de movimiento de mercancías (L. 12.023/09).

\footnotetext{
${ }^{288}$ MUNGARAY LAGARDA, Alejandro, "Subcontratación en microempresas y pequeña empresas de baja California". En Revista Frontera Norte, Tijuana, Mexico, año/vol. 16, Julio/diciembre 2004, p. 36.

${ }_{289}$ Sobre la evolución de la subcontratación o tercerización en Brasil, ver GANDRA DA SILVA MARTINS FILHO, Ives, "O fenômeno da terceirização e suas implicações jurídicas". Em Revista LTr, legislação do trabalho, São Paulo; LTr, ano 75, novembro de 2011, p. 1289.

${ }^{290}$ En Brasil, uno llama de trabajo temporal o (trabalho temporário) los contratos habidos entre los trabajadores, empresas de trabajo temporal y las empresas usuarias. En España trabajo temporal es aquel dl articulo 15.1 del Estatuto de los Trabajadores y trabajo a traves de empresas de trabajo temporal los del art. 43.1 y 1 del ET y ley 14/94, de 01 de junio -LETT.
} 


\subsection{Concepto general.}

Las relaciones triangulares de trabajo son aquellas en que aparecen en la misma relación jurídica tres partes, dos empresas y un trabajador. Conciertan la realización de trabajo, tarea o servicio, para ser ejecutado por el trabajador que queda posicionado entre ambas. ${ }^{291}$

Esta forma de contratación forma parte, actualmente, de la realidad laboral. En Chile, en 2004, el 50,5\% de las empresas privadas reconocían que ya habían utilizado el trabajo subcontratado, cifra ésta que en 1999 era del 42,9\%. En este país, e incluso en la gran mayoría de los países, más de la mitad de las empresas ya utilizó, en alguna ocasión, el trabajo tercerizado. ${ }^{292}$

Incluso formando parte de esta realidad no es fácil conceptuar la tercerización.

José Pastore, argumenta que con las innovaciones tecnológicas, que son demasiado rápidas, las empresas necesitan utilizar el trabajo de otras empresas o personas, especializadas. Comienzan a producir en red o en cadena. El autor destaca que lo interesante, en el caso de la tercerización, es la especialización. ${ }^{293}$

Pastore añade que la velocidad del cambio de las innovaciones industriales, que en la década de los 70' podría llegar a dos años, hoy en día puede durar días $y$, a veces, especialmente en el sector financiero, horas. La velocidad de este cambio implica, según el autor, no sólo nuevas formas de trabajar sino también un

\footnotetext{
${ }^{291}$ UGARTE, José Luís, "Relaciones laborales triangulares: la subcontratación y el suministro de trabajadores en la nueva ley chilena". En Revista do Tribunal Regional do Trabalho da 15ª Região, Campinas, SP; Editora da Escola Judicial da Magistratura, numero 30, jan./jun. 2007, p. 121.

PINTO MARTINS, Sérgio, $A$ terceirização e o direito do trabalho, cit., p. 12.

${ }^{292}$ UGARTE, José Luís, "Relaciones laborales triangulares: la subcontratación y el suministro de trabajadores en la nueva ley chilena", cit., p. 121.

${ }^{293}$ PASTORE, José, "Terceirização: una realidade dasamparada pela lei". Em Revista do Tribunal Superior do Trabalho, Porto Alegre; Magister Editora, ano 74, no. 4, outubro a dezembro de 2008, p. 117.
} 
cambio de actitud en el campo laboral. Este cambio, a efectos de eficiencia, lo denomina especialización, de donde deriva la tercerización. ${ }^{294}$

Para Pastore la ausencia de ley, en Brasil, que autorice y fije los límites de la tercerización, de donde se deriva la posibilidad de tercerización de la actividadfin, ignoran el papel estratégico de las colaboraciones propias del mundo moderno. Sostiene que los límites de las empresas se están volviendo cada vez más porosos. Cada vez resulta más difícil saber dónde comienza y termina una empresa. El texto de Pastore no contiene nada con respecto a la reducción o precariedad de los derechos en el sentido estricto de los trabajadores. El autor defiende la tesis de que habría mayores garantías para todos y más garantía jurídica si hubiera legislación en materia de tercerización. ${ }^{295}$

Bajo otra óptica, según Rodrigo García Carelli, con la tercerización, el trabajador pierde el único "estatus" que aún posee que es el de ser empleado. Se crea, dentro de la misma empresa, una división de trabajadores en castas, tales como la del empleado, tercerizado "celetista"296, practicante, cooperado, entre otros. $^{297}$

\footnotetext{
${ }^{294}$ PASTORE, José, "Terceirização: una realidade dasamparada pela lei", cit., pp. 117/118.

295 PASTORE, José, "Terceirização: una realidade dasamparada pela lei", cit., pp. 126/129.

296 Celetista es una definición derivada de la sigla C-L-T con la que se define las leyes del trabajo de Brasil, concretamente Consolidação das Leis de Trabalho (CLT).

297 Revista da Associação Nacional dos Magistrados da Justiça do Trabalho, cit., p. 10. "(...)una estrategia de gestión cuya difusión se ha venido dando con fuerza en los últimos 20 años en todos los sectores: industria, comercio, servicios, agricultura, tanto en el área pública como en el área privada. Se cree que esta relación de trabajo tiene consecuencias devastadoras: el encubrimiento de la relación de empleo; la reducción de los puestos de trabajo y sus repercusiones en los niveles de empleo; la reducción de la remuneración y de beneficios, estableciendo una división de trabajadores de "primera" y de "segunda categoría"; el aumento de la jornada e intensificación de la explotación del trabajo; la mayor exposición a situaciones de riesgo y, por consiguiente, el aumento de accidentes y enfermedades ocupacionales, entre otras consecuencias. 'Lamentablemente, sin embargo, estos problemas han quedado circunscritos al universo del trabajo, cuando, en efecto, afecta a toda la sociedad, ya sea por sus repercusiones socio-económicas, ya sea por afectar a la calidad de productos y servicios', observa. Cita ejemplos. 'Es común ver que los titulares de información relatan accidentes de trabajo fatales que implican a trabajadores tercerizados sin experiencia y sin entrenamiento en la extracción de petróleo, y en servicios de generación y distribución de energía', recuerda. 'Lotes de fichas son extraviados y registros de clientes transferidos indebidamente a otros sin que los bancos quieran asumir la responsabilidad, alegando que el problema se produjo con terceros'", añade.
} 
La tercerización se ha extendido a partir de esta nueva lógica derivada de la línea de producción toyotista y de la actuación de las empresas occidentales para resolver el problema del déficit económico. Ha traído con ella, también, una carga de miseria, penuria, bajos salarios y pérdida de los lazos sindicales y de clase. El sindicalista es muy débil a causa de la subcontratación, lo que disminuye el número de empleados dentro de las empresas, que son llevados a las empresas prestadoras de servicio.

Poco se dice sobre los trabajadores de las subcontratadas (uno llama en Brasil los trabajadores tercerizados), incluso porque no parece ser importante para el trabajo que desempeñan. Parece, también, que la definición no concierne a la tercerización sino especialmente a la descentralización productiva y a la inserción de una determinada o determinadas empresas, sobre todo pequeñas, dentro del mercado mundial.

Sin embargo, cuando la subcontratación es ventajosa para el trabajador, empleados especializados de alto nivel en las áreas de tecnología, información o incluso del derecho no necesitan la protección de la vinculación directa, dado que ésta implicaría una vinculación sindical y remunerativa menos favorable. Lo que se busca aquí es hacer hincapié en la subcontratación que precariza, como en los casos de vigilancia y de limpieza. ${ }^{298}$

Así, Jorge Luiz Souto Maior afirma que la tercerización es una práctica administrativa que se "instaló en el modelo productivo que convencionalmente se denomina 'toyotismo'”. El autor apunta que la expresión, en sí misma, no significa nada sino que es un modismo de una supuesta demostración de intelectualidad.

\footnotetext{
${ }^{298}$ Ver aquí las ventajas de la subcontratación. MUNGARAY LAGARDA, Alejandro, RAMíREZ ANGULO, Natanael, "Subcontratación en microempresas y pequeña empresas de baja California", cit., pp. 45 e 52.
} 
Toyotismo es el modelo adoptado por la fábrica japonesa Toyota, y un modelo de concebir la producción. ${ }^{299}$

Carelli llama la atención sobre el problema también de orden económico. Los trabajadores que eran empleados son cesantes y regresan por medio de empresas prestadoras de mano de obra y reciben mucho menos que cuando el vínculo era "directo". Eso implica una contratación de la economía, en especial del mercado interno, generando menos divisas y riquezas y mayor concentración de renta, disminuyendo el consumo y la producción, lo que puede ocasionar el cierre de empresas y desempleo. Si no se rompe este círculo vicioso, no hay economía que se sostenga. ${ }^{300}$

Con la tercerización no se hará crecer la economía. El desempleo debe ser combatido con el incentivo a la producción y al empresario nacional, con el crecimiento del poder económico del empleado, con un trabajo estable y digno. El Congreso, por tanto, debería prohibir la tercerización no solamente en la actividadfin, sino también impedir la intermediación de la mano-de-obra. ${ }^{301}$

En el caso brasileño, la forma como se resolvió esta cuestión de la tercerización, como establecen los artículos $2^{\circ}$ y $3^{\circ}$ de la CLT, fue la promulgación de una Súmula, número 331, que permitió la tercerización en actividad-medio del tomador de los servicios, siempre que no haya subordinación y gravamen. Hoy se puede terceirizar gran parte de las tareas de las empresas en Brasil, en razón de una visión equivocada del concepto de empleado y de empleador. ${ }^{302}$

\footnotetext{
299 SOUTO MAIOR, Jorge Luiz, "Terceirização na administração pública: una prática inconstitucional". En Revista Justiça do Trabalho, Porto Alegre; HS Editora, no. 273, setembro de 2009, pp. $7 / 8$.

${ }^{300}$ Revista da Associação Nacional dos Magistrados da Justiça do Trabalho, cit., p. 12.

${ }^{301}$ Revista da Associação Nacional dos Magistrados da Justiça do Trabalho, cit., p. 13.

${ }^{302}$ Firmino Alves Lima entiende que la legislación brasileña no permite y no impide la tercerización, según la Revista da Associação Nacional dos Magistrados da Justiça do Trabalho, ibidem, opinión con la que uno no puede estar de acuerdo, conforme a los artículos 2 y 3 de la CLT, y que analizaremos más extensamente en el último capítulo de esta investigación.
} 
Sobre este tema no se puede dejar de hacer referencia a la cuestión constitucional. Cuando el artículo $7^{\circ}$, encabezamiento, de la CF/88 establece que son derechos de los trabajadores los que se dirigen a la mejora de la condición social, no se puede admitir que la tercerización, en virtud de la Súmula, pueda modificar el texto de ley que no preveía esta forma de relación de trabajo. Por otra parte, la legislación que debe establecerse acerca del tema, por supuesto, afectaría el principio del no retroceso social, de la imposibilidad de la contrarevolución ${ }^{303}$, así como dispone, como ya hemos mencionado, el encabezamiento del artículo constitucional citado anteriormente, que no permite la adopción de derechos que no mejoren la situación del trabajador.

Partiendo de este razonamiento, en cuanto a la tercerización, desarrollaremos esta investigación. No se dejará de lado la cuestión de la subordinación, que está ligada indisolublemente al presente tema.

En Brasil, en el Congreso Nacional, se está debatiendo una ley que autorizaría la tercerización. Es lo que, además, defiende José Eduardo Duarte

\footnotetext{
303 "La prohibición de retroceso social nada puede hacer contra las recesiones y crisis económicas (reversibilidad fáctica). Sin embargo, el principio en examen limita la reversibilidad de los derechos adquiridos (Ej.: seguridad social, subsidio de desempleo, prestaciones de salud), violando claramente el principio de protección de la confianza y de la seguridad de los ciudadanos en el ámbito económico, social y cultural, y del núcleo esencial de la existencia mínima inherente al respeto por la dignidad de la persona humana. [...]. será inconstitucional una ley que extinga el derecho al subsidio de desempleo o pretenda alargar desproporcionadamente el tiempo de servicio necesario para la adquisición del derecho a la reforma (cfm. Ac TC 39/84 - Caso do Serviço Nacional de Saúde - e Ac 148/94, DR, I, 13/5/94 - Caso das propinas e, por último, Ac TC 509/2002, DR, I, 12/2 - Caso do rendimento mínimo garantido). La libertad de conformación del legislador en las leyes sociales nunca puede afirmarse sin reservas, dado que está siempre sujeta al principio de igualdad, principio de prohibición de discriminaciones sociales y de políticas antisociales. Las eventuales modificaciones de estas leyes deben observar los principios del Estado de derecho que vinculan a la actividad legislativa y al núcleo esencial de los derechos sociales. El principio de prohibición del retroceso social puede formularse así: el núcleo esencial de los derechos sociales ya realizado y efectuado a través de medidas legislativas ("ley de la seguridad social", "ley del subsidio de desempleo", "ley del servicio de salud") debe considerarse constitucionalmente garantizado, siendo inconstitucionales cualesquiera medidas estatales que, sin la creación de otros esquemas alternativos o compensatorios, se traducen, en la práctica, en una "anulación", "revocación" o "aniquilación" pura y simple de este núcleo esencial. [...]. La libertad de conformación del legislador e inherente auto-reversibilidad tienen como límite el núcleo esencial ya realizado, sobretodo cuando el núcleo esencial se reconduce a la garantía del mínimo de existencia inherente al respeto de la dignidad de la persona humana". (GOMES CANOTILHO, José Joaquim, Direito Constitucional e Teoria da Constituição, cit., pp. 339/340).
} 
Saad, para quien la Constitución brasileña no impide la tercerización, no pudiéndose prohibir el ejercicio de actividades lícitas inherentes a la administración de una empresa, conforme a los artículos $5^{\circ}, \mathrm{XIII}^{304}$ y 170 de la Carta constitucional. ${ }^{305}$

Sin embargo, el autor apunta que la libertad económica y la libre-iniciativa no pueden ser llevadas al extremo de degradar el trabajo humano. Por ello es necesaria y justificada la legislación, que deberá prever también una forma de protección y atención especial a los trabajadores tercerizados, especialmente por parte del Ministerio del Trabajo y Empleo, conforme establece el artículo 200 de la Consolidación de las Leyes del Trabajo -Consolidação das Leis do Trabajo-. ${ }^{306}$

Hechas las consideraciones generales, es necesario apresentar los límites del término tercerizacion en Brasil. Uno llama atención que hay controversia, más que puede ser superada por la lectura del alínea III de la Súmula 331 del TST.

\subsubsection{Concepto de tercerización utilizado en Brasil y en este estudio.}

El término tercerización será utilizado en esta tesis en sustitución del término descentralización productiva. Esto es debido a que en Brasil la palabra tercerización está demasiado difundida, existiendo diferencia entre ésta y aquélla. Tercerizar es, para la doctrina, jurisprudencia y el sentido comun brasileños, una forma de permitir que una tercera persona ejecute parte de los servicios necesarios de la empresa principal, utilisandose de sus propios empleados, dentro de la plantilla de la empresa principal. Sin embargo, descentralización productiva es dividir, a través de terceras empresas, parte de la producción de la

\footnotetext{
304 "Art. 5ำ Todos son iguales ante la ley, sin distinción de cualquier naturaleza, garantizándose a los brasileños y a los extranjeros residentes en el País la inviolabilidad del derecho a la vida, a la libertad, a la igualdad, a la seguridad y a la propiedad, en los siguientes términos siguientes: (...); XIII - es libre el ejercicio de cualquier trabajo, oficio o profesión, atendiendo las calificaciones profesionales que la ley establece; (...)".

305 DUARTE SAAD, José Eduardo, "Terceirização de serviços e a necessidade de una norma legal". Em Revista LTr, legislação do trabalho, São Paulo; LTr, ano 73, janeiro de 2009, p. 30/31.

${ }^{306}$ DUARTE SAAD, José Eduardo, "Terceirização de serviços e a necessidade de una norma legal", cit., p. 31.
} 
empresa principal, dentro o fuera de la plantilla de ésta. Lo que interesa en este estudio, por su influencia en la precariedad del trabajo, sueldos, seguridad social y riesgos de infortunios laborales, es la tercerización, lo que motiva que el tema sea tratado en esta tesis de esta forma. ${ }^{307}$

Sérgio Pinto Martins, aunque no diga de forma clara, informa que las empresas automovilistas tercerizan el montaje de coches, pero lo hacen de forma a subcontratar la actividad-fin, hecho no contestado en Brasil ${ }^{308}$. Eso permite que uno concluya por la concepcion restringida del término tercerización, ello porque la Sumula 331, III, del TST $^{309}$ dice que no se puede tercerizar actividad-fin, entendiendo posible, sin embargo, la descentralización productiva automovilistica. En principio, uno puede concluir que, para el Tribunal Superior del Trabajo, la tercerizacion es la transferencia, a tercera empresa, de parte de los servicios relacionados a la actividad-medio.

En este sentido, se puede decir, aún, que en el caso brasileño, se utilizam las expresiones tercerización material para los casos en que terceras empresas, lejos de la pantilla de la empresa cliente, ejecutan actividades especializadas con

\footnotetext{
${ }^{307}$ En este sentido HEINEN, Lenir, "Terceirização, um passo a diante...". En www.trt4.jus.br, acceso el 14 de mayo de 2012, 17h04min. El autor enseña que "Se o movimento histórico inicial de produção foi em direção à "reunião" das atividades em um mesmo espaço físico ("reunir para produzir"), o caminho histórico posterior (atual) é no sentido contrário, ou seja, o da fragmentação das atividades de produção, seja em termos de espaço físico, ou seja, em termos de sentido de empresa, sem que contudo, atualmente, graças - entre outros fatores - às redes de informática, haja, propriamente, prejuízo na homogeneidade do trabalho, sendo, desta forma, viável "produzir sem reunir", e continuando, desta forma, a ser possível, também, "unir sem reunir", diversamente do momento anterior, em que se fazia necessário "reunir para unir".

Tais situações ocorrem no âmbito da indústria automobilística, onde as marcas conhecidas são nada mais do que montadoras que se utilizam de autopeças produzidas por outras empresas e que se constituem das chamadas sistemistas.

Tanto ocorre, igualmente, na indústria eletroeletrônica, onde não há, propriamente, terceirizacão, mas sim redistribuição do trabalho, em que empresas menores e altamente especializadas produzem as peças que, montadas, dão corpo aos produtos eletroeletrônicos de marcas conceituadas que se encontram no comércio".

${ }_{308}$ PINTO MARTINS, Sérgio, A terceirização e o direito do trabalho, São Paulo; Atlas, 9ª Ed., 2009, p. 11.

309 “(...) III - Não forma vínculo de emprego com o tomador a contratação de servicos de vigilância (Lei $n^{\circ}$ 7.102, de 20.06.1983) e de conservação e limpeza, bem como a de serviços especializados ligados à atividade-meio do tomador, desde que inexistente a pessoalidade e a subordinação direta; (...)". No hay referencia a obra o produtos.
} 
personal própio, autonomia gerencial y económica ${ }^{310}$, lo que equivaldría a la descentralización productiva. El autor añade, aún, que no habra responsabilidade de la empresa-cliente en los casos de tercerización material lícita ${ }^{311}$.

Los casos, sin embargo, en que hay tercerización de mano de obra o personal, los casos tipicos de tercerización, que no son similares a la descentralización productiva como se puede ver, se puede llamar de tercerización personal. En nestas situaciones hay responsablidades por parte de las empresas clientes, porque ellas se utilizan de la mano de obra puesta por la empresa fonecedora, los casos en que no hay la idea universal de la tercerización material, que permite la adquisición de productos manufacturados en varias partes (mismo del mundo) para la formación de un produto final, sino de la subcontratación de mano de obra.

Así, como la tercerización en Brasil es la subcontratacion de servicios, como esta en el texto de la sumula 331, III, del TST, no haciendo el Tribunal cualquier referencia a obras o adquisición de parte de la producción de una empresa por la otra ${ }^{312}$ (ejemplo adquisición solamente de productos manufacturados), los límites conceptuales de esta tesis seran estos: tercerizacion como sinónimo de la subcontratacion de servicios similares a los de limpieza, vigilancia, informaticos o de logistica.

De otro lado, la parte principal de este estudio es la súmula 331 del Tribunal Superior del Trabajo que trata de la tercerización en Brasil y que preve en su texto las formas de suministro de mano-de-obra y no de descentralización productiva en sentido amplio.

\footnotetext{
${ }^{310}$ GUIMARÃES FELICIANO, Guilherme, "Terceirização e contratos de fornecimento industrial: notas sobre a responsabilidade jurídica de clientes e fornecedores". En Revista Magister de directo trabalhista e previdenciário, Porto Alegre, Magister, n. 24 maio/junho de 2008, p. 39.

311 GUIMARÁES FELICIANO, Guilherme, "Terceirização e contratos de fornecimento industrial: notas sobre a responsabilidade jurídica de clientes e fornecedores", cit., p. 40.

${ }^{312}$ En este sentido GUIMARÃES FELICIANO, Guilherme, "Terceirização e contratos de fornecimento industrial: notas sobre a responsabilidade jurídica de clientes e fornecedores", cit., p. 43.
} 
Sin embargo, el tema, incluso en Brasil, es controverso. Hay autores que dicen que la tercerizacíon no ocurre solamente de servicios, sino, también, en la produción de bienes y obras ${ }^{313}$.

Es interesante, aún, decir que en el caso de España, la doctrina y la jursprudencia $^{314}$ entienden que el término es apropiado, porque califica como ámbito de imputación de las normas laborales no solamente la empresa, sino también el centro de trabajo, complejo organizativo de medios materiales y humanos, unidad productiva, como está en el articulo 1.5 del $\mathrm{ET}^{315}$, de donde se puede concluir que tanto los casos de tercerización, como las empresas red y la descentralización productiva ${ }^{316}$ pertenecen al mismo centro de trabajo, puesto que

\footnotetext{
${ }^{313}$ MARINHO FALCÃO, Ismael, $A$ terceirização no direito do trabalho, Bauru, São Paulo, Edipro, 1996, p. 17.

314 BLAT GIMENO, Francisco, "El marco socioeconómico de la descentralización productiva". En Autores varios, Descentralización productiva y protección del trabajo en contratas. Estudios en recuerdo de Francisco Blat Gimeno, Valencia; Tirant lo Blanch, 2000, pp. 17/56; FERNANDEZ LOPEZ, Maria Fernanda, "Descentralización productiva, contratas y despido por causa organizada", En Autores varios, Descentralización productiva y protección del trabajo en contratas, Valencia; Tirant lo Blanch, 2000, p. 407/420; MARTíN VALVERDE, António, "Descentralización productiva y protección del trabajo en contratas: a proposito de la tesis doctoral de Francisco Blat Gimeno". En Autores varios Descentralización productiva y protección del trabajo en contratas, Valencia; Tirant lo Blanch, 2000, p. 57/76; MENENDEZ CALVO, Remédios, Negociación colectiva y descentralización productiva, Madrid, Consejo Económico y Social España, 2009, passin; VALDEZ DAL-RÉ, Fernando, "Descentralización productiva y desorganización del Derecho del Trabajo", En Revista Universitaria de Ciencias del Trabajo y Protección Social en Europa, Valladolid, 2002, Secretariado de Publicaciones e Intercambio Editorial de la Universidad de Valladolid, 2002, p. 49.

315 MARTÍN VALVERDE, Antonio, RODRÍGUEZ-SAÑUDO GUTIÉRREZ, Fermín y CARCíA MURCIA, Joaquin, Derecho del Trabajo, Madrid; Tecnos, 18ª Ed., 2009, p. 224/230.

${ }_{316}$ Ver el concepto de descentralización productiva en España en la indroducción del libro publicado por el X Congreso Nacional de derecho des Trabalho y Seguridad Social. En AAVV, Descentralización productiva y nuevas formas organizativas del trabajo,Zaragoza, 28 y 29 de mayo de 1999, Colección Informes y Estudios; serie Relaciones Laborales, n. 28, Madrid, 2000, p. 13.

Aún, para aclarar, la descentralización productiva en España puede ser entedida como "toda externalización hacia empresas autónomas o independientes - empresas contratistas - de actividades o funciones directa o indirectamente relacionadas con el ciclo productivo o de servicios que previamente eran desarrollados por la propia empresa - empresa principal". DEL REY GUANTER, Salvador, "A proposito de los requisitos des articulo 42.1 TRET, y en especial sobre la 'propia actividad': notas la luz de la STS 24 de noviembre de 1998", En AAVV, Descentralización productiva y nuevas formas organizativas del trabajo,Zaragoza, 28 y 29 de mayo de 1999, Colección Informes y Estudios; serie Relaciones Laborales, n. 28, Madrid, 2000, p. 331.
} 
posibilitan la explotación, por contrato, por otra empresa, diversa de aquélla que está establecida en el local ${ }^{317}$.

En cuanto a las empresas en $\operatorname{red}^{318}$, aquellas sociedades mercantiles diferenciadas, pero bajo la dirección de otra, la ley española supone que actúan de forma coordinada y obedecen una planificación comun, incluso en lo relativo a los recursos y políticas empresarales ${ }^{319}$. Sin embargo, en caso de Brasil, la realidad es diversa ya que, conforme a lo dispuesto en el articulo $2^{\circ}$, parrafo $2^{\circ}$, de la CLT, pertenecen todas al mismo grupo de empresas, no pudiendo englobarse 0 entenderse como descentralización productiva o tercerización.

Por lo tanto, el objeto de esta investigación será la subcontratación de trabajadores, llamada en Brasil de tercerización, excluyéndose del contenido de esta tesis temas como descentralización productiva ${ }^{320}$, y empresas en red, porque en estos casos, se otorga una mayor mayor protección al trabajador, a diferencia de lo que ocurre con la tercerización.

Hechas estas consideraciones, y teniendo como base sobre todo lo que establece la Súmula 331 del Tribunal Superior del Trabajo brasileño, tercerización es la contratación, por parte de una empresa privada, denominada tomadora, de servicio a ser prestado por tercera empresa, denominada prestadora, empresa ésta que contrata, dirige y paga a los empleados que ejecutarán estas tareas dentro de la empresa tomadora. No podrá haber subordinación directa de los empleados y/o representantes de la contratante, prestación personal de trabajo

\footnotetext{
${ }^{317}$ Ver en este mismo sentido, GARCIA-PERROTE ESCARTIN, Ignácio y GOÑI SEIN, José Luis, "Contratación daministrativa y aplicación de las normas laborales sobre contratas". En Autores varios, Descentralización productiva y protección del trabajo en contratas, Valencia; Tirant lo Blanch, 2000, p. 143.

${ }^{318}$ En Francia ver PESKINE, Elsa, Reseaux d'entreprise et droit du travail. Thèse Doctoral, Université Paris X, Nanterre, 2004, passin.

319 MARTín VALVERDE, Antonio, RODRíGUEZ-SAÑUDO GUTIÉRREZ, Fermín y CARCíA MURCIA, Joaquin, Derecho del Trabajo, Madrid; Tecnos, 18 Ed., 2009, p. 232.

${ }^{320}$ Para saber un poco más sobre los problemas de la descentralización productiva, por ejemplo en Francia, ver http://www.lemonde.fr/sport/article/2012/04/14/adidas-partenaire-olympique-accuse-dexploitation $16856393242 . h t m l$ - aceso el 16 abril 2012, 8h17min.
} 
directamente a la empresa tomadora y tampoco el pago de los salarios por parte de esta a aquellos.

Para mejor comprensión sigue el texto de la Súmula 331 del TST (en portugués por la originalidad):

\begin{abstract}
"SUM-331 CONTRATO DE PRESTAÇÃO DE SERVIÇOS. LEGALIDADE (nova redação do item IV e inseridos os itens $\mathrm{V}$ e $\mathrm{VI}$ à redação) - Res. 174/2011, DEJT divulgado em 27, 30 e 31.05.2011. I - A contratação de trabalhadores por empresa interposta é ilegal, formandose o vínculo diretamente com o tomador dos serviços, salvo no caso de trabalho temporário (Lei no 6.019, de 03.01.1974). II - A contratação irregular de trabalhador, mediante empresa interposta, não gera vínculo de emprego com os órgãos da Administração Pública direta, indireta ou fundacional (art. 37, II, da CF/1988). III - Não forma vínculo de emprego com o tomador a contratação de serviços de vigilância (Lei no 7.102 , de 20.06.1983) e de conservação e limpeza, bem como a de serviços especializados ligados à atividade-meio do tomador, desde que inexistente a pessoalidade e a subordinação direta. IV - O inadimplemento das obrigações trabalhistas, por parte do empregador, implica a responsabilidade subsidiária do tomador dos serviços quanto àquelas obrigações, desde que haja participado da relação processual e conste também do título executivo judicial. V - Os entes integrantes da Administração Pública direta e indireta respondem subsidiariamente, nas mesmas condições do item IV, caso evidenciada a sua conduta culposa no cumprimento das obrigações da Lei $n .-8.666$, de 21.06.1993, especialmente na fiscalização do cumprimento das obrigações contratuais e legais da prestadora de serviço como empregadora. A aludida responsabilidade não decorre de mero inadimplemento das obrigações trabalhistas assumidas pela empresa regularmente contratada. $\mathrm{VI}$ - A responsabilidade subsidiária do tomador de serviços abrange todas as verbas decorrentes da condenação referentes ao período da prestação laboral". ${ }^{321}$
\end{abstract}

En el caso brasileño, la tercerización está sólo autorizada para servicios especializados ligados a la actividad-medio del tomador, sin que haya suborinación jurídica y trabajo de forma personal entre el trabajador y el tomador de los servicios. El tomador sera responsable de forma subsidiaria por la deuda del empleador en los casos en que esté en el polo pasivo del proceso judicial y siempre que se haya terminado de cobrar la deuda del deudor principal, sin exito.

${ }^{321}$ Citación en portugués para evitar dudas cuanto al sentido. 


\subsubsection{En los países de América Latina}

La subcontratación, en América Latina, ha aumentado en diferentes sectores de la economía.

En el caso de Costa Rica, por ejemplo, en la plantación de bananas, palma africana, empresas de mantenimiento de redes eléctricas y de telecomunicaciones. En México, para la administración de personal. En Uruguay, especialmente en el sector forestal. En Argentina, para servicios de vigilancia y limpieza de establecimientos bancarios. ${ }^{322}$

En el caso de Brasil, la tercerización ha abarcado servicios de limpieza y conservación, vigilancia, actividades jurídicas y de contabilidad, informática, servicios de arquitectura e ingeniería, publicidad, alquiler y transporte. ${ }^{323}$

Especialmente en razón de las peculiaridades de cada país se hace necesario abordar la subcontratación de trabajadores en algunos países de América Latina. En este apartado habrá sólo una breve referencia a Brasil, tema central de este estudio, con algunas consideraciones más detalladas en cuanto a Argentina, Chile, México y Uruguay.

Es interesante decir, aún, que el termino tercerización, en Brasil es utilisada solamente para la subcontratación de servicios. No es lo que se pasa en los demás paises de América que serán tratados en este estudio, donde subcontratación se confunde con descentralización productiva ${ }^{324}$.

\footnotetext{
322 FACHINI FALVO, Josiane, Balanço da regulamentação da terceirização do trabalho na América Latina. En http://www.iela.ufsc.br/uploads/docs/134 texto3.josiane.pdf, p. 4. Acceso el 30 de noviembre de 2010, a las 8h51min.

${ }^{323}$ FACHINI FALVO, Josiane, Balanço da regulamentação da terceirização (...), cit., ibidem.

${ }^{324}$ Ejemplo GRISOLIA, Julio A. y AHUAD, Ernesto J., Ley de contrato de trabajo comentada, Buenos Aires; Editorial Estudio, 2ª edición, 2009., p. 66.
} 


\subsubsection{Brasil}

Los pasajes anteriores ya dan una idea de qué es la tercerización. De hecho, se rompe la estructura del contrato de empleo que, normalmente es bilateral, comenzado a ser "trilateral". No es sólo el tomador del trabajo, sino también el intermediario, que cede trabajadores a una determinada 0 determinadas actividades dentro de la empresa principal, quedándose estos trabajadores bajo sus órdenes y recibiendo el salario por cuenta de este agente subordinante.

La jurisprudencia brasileña admite la tercerización por regla general, sólo en los casos de servicios especializados ligados a la actividad-medio del tomador, siempre que no haya subordinación jurídica y trabajo prestado de forma personal para el tomador, Súmula 331, III, del TST.

La tercerización, por tanto, en el caso brasileño se caracteriza por el proceso en que el tomador de servicios contrata de forma indirecta, la fuerza de trabajo que necesita y provoca, con eso una especie de ruptura en el binomio empleado-empleador, dada la presencia del intermediario. ${ }^{325}$

Frente al avance de la tercerización no sólo en Brasil sino también en los países de América Latina, que en su mayoría regularon esta práctica, insertando límites a la subcontratación de trabajadores y responsabilidad solidaria del tomador, es interesante hacer una expresa referencia a algunos de ellos. ${ }^{326}$

\footnotetext{
${ }^{325}$ FACHINI FALVO, Josiane, Balanço da regulamentação da terceirização (...), cit., p. 2.

${ }^{326}$ Interesante, aún, echar um vistazo em um articulo que trata de los miedos y ventajes de la tercerización en Brasil. RODRIGUES PINTO, José Augusto, "Por que ter medo da tercerização brasileira". En Revista LTr, legislação do trabalho, São Paulo; LTr, ano 75, novembro de 2011, p. 1.304/1.311.
} 


\subsubsection{Argentina}

Con la excepción de Brasil, en los países de América Latina, una vez que haya subcontratación de trabajadores (tercerización), la responsabilidad del tomador será solidaria. En estos países rige el principio de la igualdad de tratamiento entre los empleados de la tomadora y de la prestadora, extendiéndose las disposiciones básicas del derecho del trabajo a toda la prestación. ${ }^{327}$

La legislación argentina es clara en cuanto a la forma de responsabilización, solidaria entre la tomadora y la prestadora en lo que se refiere a los derechos de los tercerizados, asegurando, por eso, un tratamiento similar a los trabajadores de la primera. Esta forma de responsabilización está descrita en el artículo 30 de la Ley del Contrato de Trabajo ${ }^{328}$, extendiéndose también al cumplimiento de los débitos de la seguridad social. ${ }^{329}$

Sigue el texto del articulo 30 de Ley del Contrato de Trabajo:

"Art. 30. Subcontratación y delegación. Solidaridad. Quienes cedan total o parcialmente a otros el establecimiento o explotación habilitado a su nombre, o contraten o subcontraten, cualquiera que sea el acto que le dé origen, trabajos o servicios correspondientes a la actividad normal y específica propia del establecimiento, dentro o fuera de su ámbito, deberán exigir a sus contratistas o subcontratistas el adecuado cumplimiento de las normas relativas al trabajo y los organismos de seguridad social. Los cedentes, contratistas o subcontratistas deberán exigir además a sus cesionarios o subcontratistas el número del Código Único de Identificación Laboral de cada uno de los trabajadores que presten servicios y la constancia de pago de las remuneraciones, copia firmada de los comprobantes de pago mensuales al sistema de la seguridad social, una cuenta corriente bancaria de la cual sea titular y una cobertura por riesgos del trabajo. Esta responsabilidad del principal de ejercer el control sobre el cumplimiento de las obligaciones que tienen los cesionarios o subcontratistas respecto de cada uno de los trabajadores que presten servicios, no podrá delegarse en terceros y deberá ser exhibido cada uno de los comprobantes y constancias a pedido del trabajador $\mathrm{y} / \mathrm{o}$ de la autoridad administrativa. El

${ }_{328}^{327}$ FACHINI FALVO, Josiane, Balanço da regulamentação da terceirização (...), cit., p. 07.

http://www.sistema9041.com.ar/Legislacion/Laboral/Contrato de Trabajo/Contrato de Trabajo 01 asp\#axzz1xVr4zY00 - aceso el 11 de junio de 2012, a lãs 16h03min.

${ }^{329}$ FACHINI FALVO, Josiane, Balanço da regulamentação da terceirização (...), cit., p. 17/18. 
incumplimiento de alguno de los requisitos harán responsable solidariamente al principal por las obligaciones de los cesionarios, contratistas o subcontratistas respecto del personal que ocuparen en la prestación de dichos trabajos o servicios y que hubieran surgido de la relación laboral incluyendo su extinción y de las obligaciones de la seguridad social. Las disposiciones insertas en este artículo resultan aplicables al régimen de solidaridad específico previsto en el artículo 32 de la Ley 22.250".

Lo que establece el artículo 30 de la Ley del Contrato de Trabajo con respecto a la tercerización, en Argentina, implica la actividad-fin de la empresa, conforme al pasaje donde consta "(...) trabajos o servicios correspondientes a la actividad normal y específica propia del establecimiento, dentro o fuera de su ámbito, (...)", lo que difiere el sistema argentino del brasileño, aunque aquél tenga una regulación general; lo que no se produce con este último.

Sobre eso, argumenta Sérgio Pinto Martins que la jurisprudencia argentina no es pacífica sobre el concepto de actividad-medio y actividad-fin y que es posible la tercerización incluso para actividad-fin. En estos casos, sin embargo, la condena será solidaria entre el tomador y el prestador de servicios. ${ }^{330}$

Antes, sin embargo, la jurisprudencia entendía que sólo habría responsabilidad solidaria en los casos en los que la prestadora desempeñara actividades ligadas al giro de la empresa tomadora, según define el artículo 6ํำ de la $\mathrm{LCT}^{331}$, con la cesión de parte del establecimiento; eso porque una actividad coadyuvante no tiene el poder de asignar dicha responsabilidad a la tomadora. ${ }^{332}$

La jurisprudencia argentina, sin embargo, está cambiando. Hay algunas decisiónes donde se entiende en un sentido contrario, como por ejemplo una sentencia dictada por mayoría (Fallo Rodrigues, Juan R. v. Embotelladora

\footnotetext{
${ }^{330}$ PINTO MARTINS, Sérgio, $A$ terceirização e o direito do trabalho, cit., p. 18.

${ }^{331}$ Art. $6^{\circ}-$ Establecimiento.

Se entiende por "establecimiento" la unidad técnica o de ejecución destinada al logro de los fines de la empresa, a través de una o más explotaciones.

${ }^{332}$ RESE, Cesar, "Intermediación de mano-de-obra y responsabilidad solidaria". Em Revista do Tribunal Regional do Trabalho da 15 Magistratura, numero 32, jan./jun. 2008, p. 165.
} 
Argentina S.A., del 15/4/1993), después del cambio en la composición de la Corte Suprema de Justicia de la Nación. En esta decisión los jueces entendieron que no era posible una interpretación tan restrictiva hasta el punto de dejar desamparado al trabajador subordinado por el simple hecho de no se produce cesión de una parte del establecimiento del tomador. ${ }^{333}$

Para esta Corte no es sólo la actividad principal la que determina la condena solidaria, es decir, que permitiría la subcontratación, sino las actividades accesorias y secundarias, debiendo haber una especie de unidad técnica de ejecución entre la empresa contratante y la contratista. ${ }^{334}$

Podemos concluir, incluso teniendo en cuenta una mayor amplitud a la que se refiere la norma legal argentina sobre la actividad normal y específica, que según el artículo 29 de la LCT, la subcontratación no está permitida en la actividad-medio ${ }^{335}$. En estos casos, la relación de empleo es directa con quien utilice o ha utilizado al trabajador, habiendo responsabilidad solidaria entre el prestador (contratista) y el tomador.

El empresario, para lograr su objeto, puede servirse de trabajadores propios, contratados directamente, o delegar parte de su actividad a terceros, mediante contrato. Esta delegación se justifica como una forma de especialización, complejidad y estrategia empresarial, lo que crea la figura de la empresa contratista y subcontratista, empresa que debe tener una cierta solvencia económica y disponer de medios para realizar las tareas para la que ha sido contratada. Esta forma de tercerización es lícita. De lo contrario, habrá una simple intermediación de mano de obra y un vínculo de empleo directamente con el tomador y una responsabilidad solidaria, artículo 29 de la LCT. ${ }^{336}$

\footnotetext{
${ }^{333}$ RESE, Cesar, "Intermediación de mano-de-obra y responsabilidad solidaria", cit., p. 165/166.

334 GRISOLIA, Julio A. y AHUAD, Ernesto J., Ley de contrato de trabajo comentada, cit., p. 67.

335 Actividad-medio es aquella que no tiene relación directa con la actividad principal o fin de la empresa.

${ }_{336}$ GRISOLIA, Julio Armando, Manual de derecho laboral, Buenos Aires; Abeledo Perrot, $6^{\text {a }}$ edición, 2010, p. 135.
} 
Por otra parte, conviene subrayar que, a partir de lo que establecen los artículos 5 y 14 de la Ley del Contrato de Trabajo argentina ${ }^{337}$ hay siempre una suposición de que el trabajador presta servicios de forma subordinada y dependiente, habiendo relación de empleo directa con el tomador de los servicios. De ahí podemos concluir que la subcontratación fraudulenta conlleva una vinculación directa con el tomador del trabajo, ya que habiendo trabajo dependiente, hay contrato de empleo. ${ }^{338}$

Sobre el artículo 14 de la Ley del Contrato de Trabajo, es interesante hacer un paréntesis. La redacción de esta disposición se dirige a combatir las actividades abusivas de los empleadores frente a los trabajadores, dando mayor valor a la realidad de los hechos, principio de primacía de la realidad. ${ }^{339}$ De ahí que esta disposición, junto con el artículo 5 de la LCT, son invocados rutinariamente cuando se trata de la subcontratación de trabajadores.

En Argentina se está, en este momento, discutiendo sobre los casos de intermediación de mano de obra en los que hay insolvencia y/o fraude. En estos casos, hay dos corrientes, una que entiende que la responsabilidad puede alcanzar a los socios y otra que no. En el último caso, la parte interesada debe comprobar que la empresa se constituyó sólo para incumplir la ley. Para los que entienden de forma más extensa, ampliando también la responsabilidad a los socios, teoría ésta defendida por los tribunales, cuando "no actúan como

\footnotetext{
${ }^{337}$ Art. $5^{\circ}$ - Empresa-Empresario.

A los fines de esta ley, se entiende como "empresa" la organización instrumental de medios personales, materiales e inmateriales, ordenados bajo una dirección para el logro de fines económicos o benéficos.

A los mismos fines, se llama "empresario" a quien dirige la empresa por sí, o por medio de otras personas, y con el cual se relacionan jerárquicamente los trabajadores, cualquiera que sea la participación que las leyes asignen a éstos en la gestión y dirección de la "empresa".

Art. 14. - Nulidad por fraude laboral.

Será nulo todo contrato por el cual las partes hayan procedido con simulación o engaño a la ley laboral, sea aparentando normas contractuales no laborales, interposición de personas o de cualquier otro medio. En tal caso, la relación quedará regida por esta ley.

${ }^{338}$ ARESE, Cesar, "Intermediación de mano-de-obra y responsabilidad solidaria", cit., p. 152.

${ }^{339}$ GRISOLIA, Julio Armando, Manual de derecho laboral, cit., p. 132.
} 
verdaderos hombres de negocios, con lealtad y diligencia", habrá responsabilidad. ${ }^{340}$

Es evidente que la intermediación de mano de obra genera incertidumbre sobre la estabilidad laboral y sindical. El individuo tercerizado es un trabajador precario, sujeto a la movilidad contractual y de difícil identificación para uno o un determinado grupo profesional o una cierta actividad. Es por eso que la reducción $y$, al final, la eliminación de esta forma de contratación, debe ser una de las banderas del derecho del trabajo. ${ }^{341}$

En Argentina, como en la gran mayoría de los países occidentales, hay la posibilidad de contratación de trabajadores a través de empresa de trabajo temporal, denominadas "empresa de servicios eventuales". Son ellas la excepción en el caso de intermediación de mano de obra del artículo 29 de la LCT, siendo, sin embargo, en virtud del artículo 29 bis de la LCT, responsables solidarias la empresa contratante y la contratada.

Esta forma de contratación se revela en los artículos 99 y 100 de la LCT y 77 a 80 de la Ley Nacional de la Empleo.

Para que sea válida la contratación eventual, los servicios a ser prestados en la empresa contratante deben ser extraordinarios y determinados de antemano, o exigencias extraordinarias y transitorias de la empresa, artículo 99 de la LCT, teniendo ellos los mismos derechos de los trabajadores de la empresa contratante, salvo en aquello que sea incompatible con la forma de contratación eventual, artículo 100 de la LCT. $^{342}$

\footnotetext{
340 FACHINI FALVO, Josiane, Balanço da regulamentação da terceirização (...), cit., p. 18.

${ }^{341}$ ARESE, Cesar, "Intermediación de mano de obra y responsabilidad solidaria”, cit., p. 180.

342 GRISOLIA, Julio A. y AHUAD, Ernesto J., Ley de contrato de trabajo comentada, cit., p. $145 / 148$.
} 
En el caso de que la agencia de trabajo eventual no esté habilitada para actuar como tal, se aplicarán los incisos $1^{\circ}$ y $2^{\circ}$ del artículo 29 de la LCT, siendo el trabajador considerado permanente con relación a la empresa tomadora (usuaria), y será titular de la relación de trabajo, sin perjuicio de la condena solidaria. Estas empresas de trabajo temporal deben observar los requisitos de la norma legal y estar constituidas como personas jurídicas, teniendo como único objeto la intermediación de mano de obra de trabajadores eventuales, artículo 77 de la Ley $24.013 / 91 .^{343}$

A grandes rasgos, las reglas de la subcontratación en la Argentina son las que hemos expuesto. Seguidamente nos ocuparemos de la regulación chilena.

\subsubsection{Chile}

En Chile, la ley 20.123/06 regula el trabajo en régimen de subcontratación, incluyendo el trabajo a través de empresas de trabajo temporal.

Francisco Walker Errázuriz, sobre ese derecho, cuyas directrices básicas, excepto en el caso de la responsabilización solidaria, no se modificaron mucho, sostiene que actualmente la empresa moderna debe realizar cada vez más sus actividades tanto con trabajadores propios, "suyos", como a través de terceros, es decir, servicios externos. Estos terceros, según el autor, se denominan "contratistas o subcontratistas". 344

Para el autor, en términos generales, "la Dirección del Trabajo en el caso chileno, ha definido al contratista como 'toda persona natural o jurídica que, mediante un contrato, ejecuta para un tercero dueño de una obra, empresa o faena, labores de ejecución o prestaciones de servicios mediante un precio

\footnotetext{
${ }^{343}$ GRISOLIA, Julio Armando, Manual de derecho laboral, cit., p. 134.

344 WALKER ERRÁZURIZ, Francisco, Derecho de las relaciones laborales. Un derecho vivo, Santiago; Editorial Universitária, 2003, p. 417.
} 
convenido, contratándose para ello los trabajadores". Añade que esta definición legislativa encuentra respaldo en el Diccionario de la Real Academia Española. ${ }^{345}$

Para él, estas otras empresas pueden actuar directa o indirectamente frente a la empresa principal. Actuando indirectamente, hay subcontratación, por lo cual la empresa principal se convierte en contratista. Pueden participar de este evento un gran número de empresas, aclara el autor chileno. Debe, sin embargo, existir un contrato civil entre la empresa principal y la contratista. ${ }^{346}$

Este contrato civil debe incluir en su contenido las obligaciones laborales del contratista con respecto a sus trabajadores. Debe prever la naturaleza de la obra, las tareas o los servicios que deben desempeñarse y si se adecuan al contrato, con los plazos de cumplimiento de las obligaciones concertadas y la forma y el importe del pago por la tarea o el servicio. ${ }^{347}$

La subcontratación, en Chile, se puede dar de dos formas: subcontratación de trabajadores y suministro de trabajadores por empresa de trabajo temporal.

En el primer caso, una empresa propietaria de una obra, contrata a otra empresa para prestar un determinado servicio, mediante contrato civil o comercial, para que ejecute, por su cuenta y riesgo, con sus propios empleados, un determinado trabajo o servicio, pudiendo ésta subcontratar parte o la totalidad de la obra para que cumpla lo que fue contratado. ${ }^{348}$

La contratación de trabajador por empresa de trabajo temporal se produce cuando una empresa, cuyo volumen corresponde al suministro de

\footnotetext{
${ }^{345}$ WALKER ERRÁZURIZ, Francisco, Derecho de las relaciones laborales, ibidem.

${ }^{346}$ WALKER ERRÁZURIZ, Francisco, Derecho de las relaciones laborales, cit., p. 417/418.

${ }^{347}$ WALKER ERRÁZURIZ, Francisco, Derecho de las relaciones laborales, cit., p. 418.

${ }^{348}$ UGARTE, José, Luís, "Relaciones laborales triangulares: la subcontratación y el suministro de trabajadores en la nueva ley chilena", cit., p. 122.
} 
trabajadores, empresa de trabajo temporal, pone a disposición de otra empresa, llamada usuaria, por un precio determinado, trabajadores empleados propios. ${ }^{349}$

En lo que se refiere a la subcontratación, según el artículo 183-A de la ley $20.123 / 06^{350}$, es tercera la empresa que contrata o subcontrata trabajadores bajo su responsabilidad, para ejecutar servicios en la planta de la tomadora. La descripción de tercero, como se puede ver, es amplia, lo que permite que la subcontratación se produzca prácticamente en todas las actividades. ${ }^{351}$

Hay que tener presente que el poder de mando ante los trabajadores debe estar siempre en manos de la empresa contratista y no de la principal o de la tomadora. Por consiguiente, se puede admitir sólo un "control indirecto y predominantemente técnico, por parte de la empresa principal hacia los trabajadores de los contratistas o subcontratistas, lo que significa que no puede existir jamás una supervisón directa de la empresa principal hacia los trabajadores de la contratista o subcontratista". ${ }^{352}$

Es esto lo que hace la distinción entre las contratistas reales y las aparentes, pues en este último caso se encuentran aquellos "colocadores o enganchadores" que sólo suministran personal a una empresa, sin contrato de naturaleza civil entre el suministrador y la empresa principal, no habiendo

\footnotetext{
${ }^{349}$ UGARTE, José, Luís, "Relaciones laborales triangulares: la subcontratación y el suministro de trabajadores en la nueva ley chilena" cit., p. 122.

${ }^{350}$ Art. 183-A. Es trabajo en régimen de subcontratación, aquél realizado en virtud de un contrato de trabajo por un trabajador para un empleador, denominado contratista o subcontratista, cuando éste, en razón de un acuerdo contractual, se encarga de ejecutar obras o servicios, por su cuenta y riesgo y con trabajadores bajo su dependencia, para una tercera persona natural o jurídica dueña de la obra, empresa o faena, denominada la empresa principal, en la que se desarrollan los servicios o ejecutan las obras contratadas.

Con todo, no quedarán sujetos a las normas de este párrafo las obras o los servicios que se ejecutan o prestan de manera discontinua o esporádica. Si los servicios prestados se realizan sin sujeción a los requisitos señalados en el inciso anterior o se limitan sólo a la intermediación de trabajadores a una faena, se entenderá que el empleador es el dueño de la obra, empresa o faena, sin perjuicio de las sanciones que correspondan por aplicación del artículo 478.

${ }^{351}$ FACHINI FALVO, Josiane, Balanço da regulamentação da terceirização (...), cit., p. 19.

352 WALKER ERRÁZURIZ, Francisco, Derecho de las relaciones laborales, cit., p. 418/419.
} 
subordinación entre los trabajadores colocados y la empresa "colocadora", lo que lo hacen empleados de la empresa principal, conforme a la legislación vigente. ${ }^{353}$

Para que no se caracterice una mera intermediación de mano de obra, artículo $183-A$ de la ley $20.123 / 06$, es preciso que haya un contrato entre la empresa principal y la contratista, que puede ser de cualquier naturaleza jurídica, que contendrá el objeto de la contratación, que debe convenirse con el mandatario, sin restringir el tipo de obra a realizar; y que la empresa contratista ejecute la obra o el servicio por su cuenta y riesgo, manteniendo el mando sobre sus trabajadores. No puede haber subordinación por parte de los empleados de la prestadora con respecto a los representantes de la tomadora. ${ }^{354}$

De ahí se constata que hay posibilidad de tercerización de actividad-fin, ya que la norma legal no establece límites y hace referencia explícita a la ley civil, que garantiza la libertad contractual y de empresa. Por eso está permitida la subcontratación en prácticamente todas las actividades, respetando las normas básicas de protección del trabajo y excluyendo el fraude contra los trabajadores.

El tipo de actividad que es objeto del contrato civil o comercial firmado entre las empresas, puede ser tanto lo que forma parte de las actividades esenciales de

\footnotetext{
353 "Hoy en día en Chile, como en otros países, las relaciones del trabajo son cada vez más complejas y sofisticadas. La relación directa "empleador-trabajador" tiende muchas veces a ser rebasada con la presencia de terceros intermediarios que revisten, por regla general, el carácter de contratistas y subcontratistas;

La figura jurídica del contratista presupone la existencia de una "empresa principal y una empresa contratista", las que pactan un contrato civil entre ellas donde se estimulan sus derechos y obligaciones recíprocas, debiendo establecerse las obligaciones laborales y provisionales de la empresa contratista para sus trabajadores;

De acuerdo con lo anterior es la empresa contratista la que posee el carácter de "empleador" por lo que siempre el vinculo de subordinación y dependencia se da entre el contratista y sus trabajadores, aun cuando éstas realicen sus labores para la principal;

Si el contratista no reviste el carácter de empleador de sus trabajadores, siendo un mero proveedor - colocador de personal de una empresa, la responsabilidad directa pasa a ser incuestionablemente de la empresa principal, puesto que la figura de subordinación o dependencia se establece entre el trabajador y la principal". (WALKER ERRÁZURIZ, Francisco, Derecho de las relaciones laborales, cit., p. 421).

${ }^{354}$ UGARTE, José, Luís, "Relaciones laborales triangulares: la subcontratación y el suministro de trabajadores en la nueva ley chilena", cit., p. 124.
} 
la tomadora como las que no son esenciales, no existiendo ninguna restricción ${ }^{355}$ como sucede, por ejemplo, en Brasil.

En lo que se refiere al contrato de trabajo a través de empresa de trabajo temporal, el suministro de trabajadores debe ser transitorio, y en situaciones especiales requeridos por la empresa tomadora (usuaria).

Las situaciones en las que se pueden contratar trabajadores por empresas de trabajo temporal son: a) suspensión del contrato de trabajo debido a bajas médicas, asistencia por maternidad o vacaciones; b) eventos extraordinarios, congresos, conferencias, ferias comerciales, exposiciones, entre otros; c) nuevos proyectos y específicos de la empresa usuaria como la construcción de nuevas instalaciones, ampliación de las ya existentes o expansión en el mercado; d) período de creación e inicio de actividades de nuevas empresas; e) aumentos ocasionales de trabajo, sean o no periódicos o extraordinarios de actividad de un determinado sector o establecimiento de la empresa usuaria; y f) trabajos urgentes, necesarios e improrrogables, que requieran una ejecución inmediata, tales como reparaciones en las instalaciones de la empresa usuaria. ${ }^{356}$

En cuanto a la responsabilidad, el derecho chileno reconoce la responsabilidad solidaria de la empresa tomadora por los débitos de la prestadora con sus empleados y que directamente trabajaron para ella, conforme establece el artículo $183-B$ de la ley $20.123 / 06^{357}$, lo que antes de la dicha norma legal se hacía por responsabilidad subsidiaria.

\footnotetext{
${ }^{355}$ UGARTE, José, Luís, "Relaciones laborales triangulares: la subcontratación y el suministro de trabajadores en la nueva ley chilena", cit., p. 125/126.

${ }^{356}$ UGARTE, José, Luís, "Relaciones laborales triangulares: la subcontratación y el suministro de trabajadores en la nueva ley chilena", cit., p. 133/134.

${ }^{357}$ Art. 183-B. La empresa principal será solidariamente responsable de las obligaciones laborales y previsionales de dar que afecten a los contratistas a favor de los trabajadores de éstos, incluidas las eventuales indemnizaciones legales que correspondan por término de la relación laboral. Tal responsabilidad estará limitada al tiempo o período durante el cual el o los trabajadores prestaron servicios en régimen de subcontratación para la empresa principal.

En los mismos términos, el contratista será solidariamente responsable de las obligaciones que afecten a sus subcontratistas, a favor de los trabajadores de éstos. La empresa principal responderá de iguales obligaciones que afecten a los subcontratistas, cuando no pudiere hacerse
} 
En el caso de que la empresa tomadora exija de la prestadora el cumplimiento de las obligaciones laborales y de la seguridad social, la responsabilidad, en la forma del artículo 183-D de la ley 20.123/06, será subsidiaria, en los mismos términos que prevé la ley uruguaya. Se constata que el sistema chileno es muy similar al uruguayo, impidiendo poco la tercerización, ya que permite la subcontratación en todas las actividades económicas, siempre que las empresas sean idóneas. La norma chilena, así como la de Uruguay, se preocupó de la protección a los trabajadores tercerizados, sin limitar, sin embargo, esta práctica. ${ }^{358}$

Estas mismas reglas de responsabilidad pueden aplicarse a las empresas de trabajo temporal y las empresas usuarias, reglas equivalentes a la subcontratación de trabajadores en general. ${ }^{359}$

Hecho este análisis, vamos a ocuparnos de México. Las reglas son similares a las ya descritas hasta aquí en cuanto a Argentina y Chile, con sus peculiaridades.

\subsubsection{México}

En México tanto la especialización como la división del trabajo están menos evolucionadas con respecto a las de los países altamente industrializados. Por ello, la subcontratación comienza a ser importante, posibilitando a las pequeñas

efectiva la responsabilidad a que se refiere el inciso siguiente. El trabajador, al entablar la demanda en contra de su empleador directo, podrá hacerlo en contra de todos aquellos que puedan responder de sus derechos, en conformidad a las normas de este Párrafo.

En los casos de construcción de edificaciones por un precio único prefijado, no procederán estas responsabilidades cuando quien encargue la obra sea una persona natural.

${ }^{358}$ FACHINI FALVO, Josiane, Balanço da regulamentação da terceirização (...), cit., p. 20.

${ }^{359}$ UGARTE, José, Luís, "Relaciones laborales triangulares: la subcontratación y el suministro de trabajadores en la nueva ley chilena", cit., p. 134. 
empresas el acceso al mercado mundial con mejores conocimientos técnicos y formación profesional. ${ }^{360}$

De ahí que hayamos optado por utilizar, como paradigma de la subcontratación fuera de América del Sur, a México. Este país, una de las mayores economías del continente americano, próximo a los Estados Unidos y a Canadá, presta a las empresas transnacionales de estos últimos, servicios a través de subcontratación mediante empresas pequeñas, que se sirven de trabajadores subordinados.

Tanto en México como en América Latina en general, la explotación de los trabajadores por empresas transnacionales es enorme, al punto de convertirse en un problema social casi incontrolable. Es la llamada "flexi-precariedad", que convierte la relación salarial moderna del siglo XX, con empleo estable de tiempo completo y salario razonable en empleo precario y parcial. ${ }^{361}$ En cualquier caso, lo que pretendemos en esta investigación es hacer referencia a la subcontratación en los países de América Latina, entre ellos México.

El artículo segundo de la Ley Federal del Trabajo de México ${ }^{362}$ establece que las normas laborales tienen por objeto la consecución del equilibrio y la justicia social entre empleados y empleadores. La misma norma legal define también, en su artículo $8^{\mathbf{0}^{363}}$, que trabajador es toda persona física que presta trabajo subordinado a otra persona física o jurídica ("moral”). Trabajo, según este

\footnotetext{
${ }^{360}$ MUNGARAY LAGARDA, Alejandro, RAMíREZ ANGULO, Natanael, "Subcontratación en microempresas y pequeña empresas de baja Califorina", cit., p. 36/37.

${ }^{361}$ SOTELO VALECIA, ADRIÁN, "La precarización del trabajo. ¿Premisa de la Globalización?" En Papeles de población, Toluca México; Universidad Autónoma del Estado de Mexico, numero 018, octubre a diciembre, 1998, p. 92.

${ }^{362}$ Artículo 20.- Las normas de trabajo tienden a conseguir el equilibrio y la justicia social en las relaciones entre trabajadores y patrones.

${ }^{363}$ Artículo 80.- Trabajador es la persona física que presta a otra, física o moral, un trabajo personal subordinado.

Para los efectos de esta disposición, se entiende por trabajo toda actividad humana, intelectual o material, independientemente del grado de preparación técnica requerido por cada profesión u oficio.
} 
precepto, es toda actividad humana, intelectual o material, independientemente del grado de preparación técnica requerido por cada profesión u oficio.

En el artículo 10 de la Ley Federal del Trabajo mexicana ${ }^{364}$ consta que patrón es la persona física o jurídica ("moral”) que se sirve de los servicios de uno o más trabajadores. Si el trabajador se sirve del trabajo de otros trabajadores, aún así el patrón será el mismo.

La legislación mejicana también presenta el concepto del intermediario. Conforme al artículo 12 de la Ley Federal del Trabajo ${ }^{365}$, el intermediario es la persona que contrata o interviene en la contratación de otra u otras personas para que presten servicios a un patrón (tomador).

La intermediación de mano de obra está prohibida, conduciendo a un vínculo de empleo directo con el tomador y a una responsabilidad solidaria del intermediador. También se produce un vínculo de empleo directo con la tomadora cuando la prestadora no tiene recursos y una estructura adecuada para administrar su negocio, además de la responsabilidad solidaria, teniendo los mismos derechos estos trabajadores que los de la empresa tomadora, (artículos 1315 de la Ley Federal del Trabajo). ${ }^{366}$

\footnotetext{
${ }^{364}$ Artículo 10.- Patrón es la persona física o moral que utiliza los servicios de uno o varios trabajadores. Si el trabajador, conforme a lo pactado o a la costumbre, utiliza los servicios de otros trabajadores, el patrón de aquél, lo será también de éstos.

${ }_{365}$ Artículo 12.- Intermediario es la persona que contrata o interviene en la contratación de otra u otras para que presten servicios a un patrón.

${ }^{366}$ Artículo 13.- No serán considerados intermediarios, sino patrones, las empresas establecidas que contraten trabajos para ejecutarlos con elementos propios suficientes para cumplir las obligaciones que deriven de las relaciones con sus trabajadores. En caso contrario serán solidariamente responsables con los beneficiarios directos de las obras o servicios, por las obligaciones contraídas con los trabajadores.

Artículo 15.- En las empresas que ejecuten obras o servicios en forma exclusiva o principal para otra, y que no dispongan de elementos propios suficientes de conformidad con lo dispuesto en el Artículo 13, se observarán las normas siguientes:

I. La empresa beneficiaria será solidariamente responsable de las obligaciones contraídas con los trabajadores; $y$

II. Los trabajadores empleados en la ejecución de las obras o servicios tendrán derecho a disfrutar de condiciones de trabajo proporcionadas a las que disfruten los trabajadores que ejecuten trabajos similares en la empresa beneficiaria. Para determinar la proporción, se tomarán en consideración las diferencias que existan en los salarios mínimos que rijan en el área geográfica de
} 
En el caso de la subcontratación lícita, la responsabilidad es de la prestadora, siendo debidos, sin embargo, en el caso de tercerización de actividadfin de la tomadora, los mismos salarios de los empleados de ésta, sin que la prestadora pueda, sobre el trabajo de estos empleados, recibir ningún importe, artículo 14 de la Ley Federal del Trabajo. En cuanto a la responsabilidad en caso de tercerización lícita, se cree que es solidaria, ya que el artículo 14 de la Ley Federal del Trabajo ${ }^{367}$ recoge la expresión "responsables", determinando un pago de igual salario en caso de subcontratación de una actividad-fin.

Se constata que en virtud del artículo 18, parte final, de la Ley Federal del Trabajo, la interpretación, en caso de duda, debe ser en favor del trabajador.

Como apunta Mayela Sánchez, la subcontratación se realiza en México sin ningún control por parte del poder público y contribuye a la reducción de los salarios y a la flexibilización de los derechos de los trabajadores, con el fin de beneficiar a las grandes multinacionales o a las grandes empresas nacionales que operan en el mercado internacional. ${ }^{368}$

En este mismo sentido argumenta Sérgio Novais, presidente de la Federación Internacional del Sindicato de la Química, Energía, Minería e Industrias diversas para América Latina y Caribe -ALCEN-, que la fiscalización del

aplicación en que se encuentren instaladas las empresas y las demás circunstancias que puedan influir en las condiciones de trabajo.

${ }^{367}$ Artículo 14.- Las personas que utilicen intermediarios para la contratación de trabajadores serán responsables de las obligaciones que deriven de esta Ley y de los servicios prestados.

Los trabajadores tendrán los derechos siguientes:

I. Prestarán sus servicios en las mismas condiciones de trabajo y tendrán los mismos derechos que correspondan a los trabajadores que ejecuten trabajos similares en la empresa o establecimiento; y II. Los intermediarios no podrán recibir ninguna retribución o comisión con cargo a los salarios de los trabajadores.

368 SÁNCHEZ, Mayela, Outsourcing, en auge $y$ sin control. Em http://ungenio.blogspot.com/2010/08/las-subcontratadoras-en-mexico.html. Acceso el 30 de noviembre de 2010 , a las $15 \mathrm{~h} 42 \mathrm{~min}$. 
trabajo, en cuanto a la tercerización, no actúa como debería, dejando a los sindicatos la denuncia de estafas y abusos. ${ }^{369}$

El efecto de la subcontratación en México, por tanto, es lo mismo que en los demás países no sólo de América Latina, sino también de Europa, que analizaremos más adelante.

\subsubsection{Uruguay}

En Uruguay, como en los demás paises, la tercerización es un proceso de flexibilización y precariedad de las normas de protección del trabajo, porque en algunos casos destruye los vínculos alcanzados entre empleado y empleador, colocando una tercera persona en medio de esta relación. También es una forma que obstaculiza la sindicalización ${ }^{370}$, lo que torna aún más débil la capacidad de demanda de los trabajadores.

Así como Perú, Uruguay posee tres legislaciones con respecto a la tercerización. Son la ley 18.098/07, que establece la contratación de servicios tercerizados por parte de organismos estatales; y las leyes 18.099/07 y 18.251/08, normas que establecen la protección de los procesos de descentralización empresarial. $^{371}$

Esta práctica es autorizada por la Constitución de la República uruguaya, artículo 36, que establece la libertad de empresa. Mediante la misma el empresario puede optar entre la realización directa de su actividad económica, utilizando para ello, recursos técnicos, materiales y humanos propios o recurriendo

\footnotetext{
${ }^{369} \mathrm{http}: / / \mathrm{www}$.adital.com.br/site/noticia.asp?lang=PT\&cod=40636. Acceso el 30 de noviembre de 2010 , a las $19 \mathrm{~h} 06 \mathrm{~min}$. Según consta en el texto, preguntado sobre la precarización y tercerización, Novais contestó que "la experiencia nos muestra que los órganos responsables de la fiscalización no actúan como deberían. En la práctica, quien acaba denunciando son los Sindicatos más organizados que en sus categorías incluyen trabajadores tercerizados".

370 ROSENBAUM, Jorge y CASTELLO, Alejandro, Régimen jurídico de la subcontratación e intermediación laboral, Montevideo; Fundación de Cultura Universitaria; 2007, p. 40.

${ }^{371}$ FACHINI FALVO, Josiane, Balanço da regulamentação da terceirização (...), cit., p. 14.
} 
a la contratación de una empresa externa, que se encargará de realizar los segmentos de la dicha actividad, con sus propios medios, incluso con trabajadores. $^{372}$

La autoridad pública debe exigir de la empresa contactada la documentación que acredite el pago de los salarios de los tercerizados y de los demás costes, artículo $3^{\circ}$ de la ley $18.098 / 07^{373}$, ello para evitar o buscar evitar la fraude.

En el caso de las empresas privadas, que se rigen por la ley 18.099/07, en su artículo primero se establece la responsabilidad solidaria entre la prestadora y la tomadora en cuanto a las obligaciones laborales, garantía social y accidentes de trabajo $^{374}$, lo que es diferente del caso brasileño, como dicho antes, donde la responsabilidad de la empresa usuaria (tomadora) es subsidiaria, o sea, primero se cobra la empresa principal y despues, si ella no paga, aquella.

Sin embargo, es el artículo $1^{\circ}$ de la ley 18.251/08, el que establece los límites en materia de subcontratación, impidiendo generalizar la tercerización. Con todo, la disposición de ley es tan amplia que permite la subcontratación en prácticamente todo tipo de actividad económica, de manera que, en la práctica, no impide esta forma de contratación. ${ }^{375}$

Este artículo deriva de lo que establecía la ley 10.449/43, en su artículo 3o, norma esta que fundamentó la actual redacción legal, después de debates parlamentarios con intervención, incluso, de la Universidad de La Republica -

\footnotetext{
372 ROSENBAUM, Jorge y CASTELLO, Alejandro, Régimen jurídico de la subcontratación e intermediación laboral, cit., p. 69.

${ }^{373}$ FACHINI FALVO, Josiane, Balanço da regulamentação da terceirização (...), cit., ibidem.

${ }^{374}$ FACHINI FALVO, Josiane, Balanço da regulamentação da terceirização (...), cit., p. 14/15.

${ }^{375}$ FACHINI FALVO, Josiane, Balanço da regulamentação da terceirização (...), cit., p. 15.
} 
UDELAR-. La diferencia está en la responsabilización que la ley anterior establecía como subsidiaria y que la actual configura como solidaria. ${ }^{376}$

A partir del concepto de subcontratista, de donde deriva la subcontratación o tercerización, se puede tercerizar tanto la actividad-medio como la actividadfin $^{377}$, dentro o fuera de la empresa tomadora, siempre que queden vinculadas por contrato, bajo pena de intermediación fraudulenta.

Conviene subrayar que hubo un debate en la doctrina y en la jurisprudencia uruguayas con respecto al ámbito de incidencia de la norma objeto de examen. Para algunos, la expresión "subcontratista" concernía sólo a la subcontratación equivalente a la de naturaleza civil, sin tener en cuenta que la expresión legal, de hecho, se extiende a las contratas, subcontratas y otras. ${ }^{378}$

Si la empresa tomadora exige el cumplimiento de las obligaciones laborales por parte de las tercerizadas, el artículo 6ํㅜ de la ley 18.251/08, transforma la responsabilidad solidaria del artículo 11 de la ley 18.099/07 en subsidiaria, reconociendo, las dos disposiciones, lícita la tercerización. ${ }^{379}$

\footnotetext{
376 GAUTHIER, Gustavo, "Amplificación de la responsabilidad del empresario que utiliza subcontratistas, intermediarios o suministradores de mando de obra: el caso uruguayo a partir de la sanción de la ley n. 18.099". En Revista do Tribunal Regional do Trabalho da 15a Região, Campinas, SP; Editora da Escola Judicial da Magistratura, numero 31, jul./dez. 2007, p. 183/192.

${ }^{377}$ Art. 1ํ. A los efectos de la Ley № 18.099, de 24 de enero de 2007:

A) (Subcontratista). Existe subcontratación cuando un empleador, en razón de un acuerdo contractual, se encarga de ejecutar obras o servicios, por su cuenta y riesgo y con trabajadores bajo su dependencia, para una tercera persona física o jurídica, denominada patrono o empresa principal, cuando dichas obras o servicios se encuentren integrados en la organización de éstos o cuando formen parte de la actividad normal o propia del establecimiento, principal o accesoria (mantenimiento, limpieza, seguridad o vigilancia), ya sea que se cumplan dentro o fuera del mismo. B) (Intermediario). Intermediario es el empresario que contrata o interviene en la contratación de trabajadores para que presten servicios a un tercero. No entrega directamente los servicios u obras al público, sino a otro patrono o empresario principal.

C) (Empresa suministradora de mano de obra). Agencia de empleo privada o empresa suministradora de mano de obra es la que presta servicios consistentes en emplear trabajadores con el fin de ponerlos a disposición de una tercera persona física o jurídica (empresa usuaria), que determine sus tareas y supervise su ejecución.

${ }^{378}$ GAUTHIER, Gustavo, “Amplificación de la responsabilidad del empresario (...)”, cit., p. 189.

${ }^{379}$ FACHINI FALVO, Josiane, Balanço da regulamentação da terceirização (...), cit., p. 16.
} 
La responsabilidad solidaria, se refiere a las obligaciones laborales, de seguridad social y también a las derivadas de las acciones por parte del banco de Seguros del Estado frente a las subcontratadas, llamadas "recuperos", de forma que esta institución estatal abre un proceso frente a la empresa prestadora, siendo la tomadora responsable solidaria, con el fin de que se paguen los gastos que correspondan a los asegurados, en el caso de falta de pago de seguro accidente del trabajo o incluso cuando haya negligencia o dolo. ${ }^{380}$

Esta solidaridad pasiva hace que el acreedor laboral tenga derecho de cobrar toda la deuda contra cualquiera de los deudores, empresa prestadora o usuaria. La insolvencia de una de las empresas solidarias debe ser soportada por las demás responsables, como establece el artículo 1.404, Inc. 2, del Código Civil uruguayo. $^{381}$

Hay que tener presente que para justificar la solidaridad no se requiere el fraude o el desvío de las normas laborales, o la reducción de costes asociados al trabajo, la diversificación de los riesgos o la especialización productiva. Nada de eso interesa cuando se trata de la responsabilidad del tomador de los servicios. Lo que interesa es que se encuadre en los supuestos que establece la ley, es decir, que haya subcontratación o tercerización. ${ }^{382}$

Sin embargo, el artículo $5^{\circ}$ de la ley 18.099/07, establece que la subcontratación con carácter temporal no puede pagar salarios inferiores a los trabajadores de la empresa principal, de acuerdo con el principio de "igual trabajo, igual salario". No se trata, sin embargo, de una equiparación absoluta, dado que no se contempla la tercerización sino sólo la contratación de trabajadores temporales. ${ }^{383}$

\footnotetext{
${ }^{380}$ GAUTHIER, Gustavo, "Amplificación de la responsabilidad del empresario (...), cit., 195/196.

381 ROSENBAUM, Jorge y CASTELLO, Alejandro, Régimen jurídico de la subcontratación e intermediación laboral, cit., p. 108.

${ }^{382}$ ROSENBAUM, Jorge y CASTELLO, Alejandro, Régimen jurídico de La subcontratación e intermediación laboral, cit., p. 107/108.

${ }^{383}$ FACHINI FALVO, Josiane, Balanço da regulamentação da terceirização (...), cit., p. 16/17.
} 
En general "la regulación uruguaya estimula las relaciones de trabajo triangulares, en la medida en que concibe conceptos amplios de empresas intermediarias, subcontratadas y proveedores de mano de obra, es decir, no limita las actividades económicas en que incidirá la tercerización y sólo impide la precariedad". Como contrapartida, la legislación de 2008 estimula la fiscalización por parte de los empresarios de las obligaciones laborales y de seguridad social, mediante la concesión de la responsabilidad subsidiaria. ${ }^{384}$

La norma legal uruguaya, artículo 1ํㅡ, B, de la ley 18.099/07, establece la posibilidad de subcontratación o de tercerización en el servicio público y entidades paraestatales que utilicen intermediarios, subcontratistas o proveedores de mano de obra, extendiendo la misma responsabilidad aplicable a las empresas usuarias privadas. $^{385}$

\subsubsection{En la Unión Europea}

\subsubsection{En el marco de la UE}

El Tratado de la Comunidad Europea, artículo 3.1, encarga a la Comisión Europea que asegure la existencia de condiciones necesarias para que las industrias del bloque, en su conjunto, logren un nivel de competitividad adecuado, con el fin de rivalizar con los Estados Unidos y Japón. Aquí es donde tuvo origen el artículo 157 del Tratado de la Unión Europea, donde consta una política horizontal, dinámica y compleja, con el fin de asegurar las condiciones necesarias de competitividad en las industrias de la Unión, entre ellas el outsourcing. ${ }^{386}$

\footnotetext{
${ }^{384}$ FACHINI FALVO, Josiane, Balanço da regulamentação da terceirização (...), cit., p. 17.

385 ROSENBAUM, Jorge y CASTELLO, Alejandro, Régimen jurídico de la subcontratación e intermediación laboral, cit., p. 72.

${ }^{386}$ MARTÍN ARRIBAS, Juan José, "Aproximación general a la figura (...), cit., p. 252/253.
} 
El incentivo a la subcontratación, aunque tenga una tendencia dirigida a grandes empresas, tiene como objetivo incluir dentro del mercado global las pequeñas y medias empresas (PYMES), de forma que en el contexto de uno de los Programas Plurianuales destinado a estas empresas, se trató la subcontratación de trabajadores. ${ }^{387}$

En la Unión Europea, la norma que autoriza y regula los contratos de duración determinada y los contratos de trabajo a través de empresas de trabajo temporal, es la Directiva 91/383/CEE, del Consejo, de 25 de junio de 1991. Esta norma tiene por objeto mejorar la condición de trabajo de los trabajadores europeos sujetos a contrato a tiempo determinado y contrato de trabajo a través de empresa de trabajo temporal, con el fin de tener mejores niveles de salud y garantía en el ejercicio de sus funciones.

Para la Directiva 91/383/CEE, artículo 1ํㅡ, 2, "las relaciones de trabajo temporal se configuran entre una empresa de trabajo temporal, representada por una entidad patronal, y el trabajador puesto a disposición y bajo la dirección de una empresa". Por lo cual, también en la U.E., esta forma de contratación está expresamente prevista y autorizada.

La Directiva mencionada no discute la validez o la posibilidad de esta forma de contratación. Sólo llama la atención con respecto a las cuestiones de garantía y salud, también de igualdad, entre los trabajadores con contrato con duración incierta y los contratos a término y temporales.

Las normas internas, según establece la exposición de motivos de la Directiva 91/383/CEE, deben regular la cuestión de los contratos de duración determinada y del contrato a través de empresas de trabajo temporal, llamando también la atención sobre la cuestión de la higiene, garantía en el trabajo y prevención de accidentes y enfermedades profesionales.

${ }^{387}$ MARTÍN ARRIBAS, Juan José, "Aproximación general a la figura (...), cit., p. 254. 
El 19 de Noviembre de 2008 la Unión Europea presenta una nueva Directiva, la número 2008/104/CE para regular la cuestión del trabajo a través de empresas de trabajo temporal en Europa. Esta Directiva, junto con la Directiva 91/383/CEE, pasan a regular, desde el 5 de Diciembre de 2011 (fecha en que comenzó la vigencia de la Directiva 2008/104), la situación de los trabajadores de las empresas de trabajo temporal, y no permite que haya una reducción de los derechos de los trabajadores en los países miembros. Los Estados Miembros de la Unión pueden adoptar disposiciones más favorables a los trabajadores. Esta Directiva viene para completar, en términos de seguridad, la Directiva 91/383/CEE, y para poner en práctica la igualdad de tratamiento en materia de seguridad y salud en el trabajo, pero también para facilitar la subcontratación por empresas de trabajo temporal, con mayor seguridad para las empresas usuarias. La norma es conocida como una Directiva de flexiseguridad. ${ }^{388}$

Por otra parte, la Resolución del Parlamento Europeo, de 26 de marzo de 2009, hace referencia a la responsabilidad social de las empresas de subcontratación en las cadenas de producción. ${ }^{389}$

Esta Resolución se elaboró teniendo como base lo establecido en los artículos 31, apartado 1, de la Carta de Derechos Humanos de Unión Europea, 39, 45, 50 y 137 del Tratado de la Comunidad Europea, además de varias directivas, directrices de la OCDE, OIT y otras Resoluciones que tienen en cuenta la cuestión de la globalización, empresas multinacionales, responsabilidad social, trabajo digno, derechos laborales en el siglo XXI, decisión del Tribunal de Justicia de las Comunidades Europeas, caso Wolff \& Müller (C-60/03), además de un estudio relativo a la subcontratación de trabajadores en el sector europeo de la

\footnotetext{
${ }^{388}$ LAULOM, Sylvaine, "La directive 2008/104: avancées et limites de la protection des travailleurs intérimaires". Revue de Droit du Travail, n. 5, Dalloz, mai, 2012, p. 309 et 311/314. 389 http://eur-lex.europa.eu/LexUriServ/LexUriServ.do?uri=OJ:C:2010:117E:0176:0180:ES:PDF, acceso el 08 de diciembre de 2010, a las 16h50min.
} 
construcción civil, realizado por la Fundación Europea para la Mejora de las Condiciones de Vida y de Trabajo.

Dicha Resolución, considera la subcontratación como una actividad económica y que puede tener aspectos negativos y positivos, de manera que los trabajadores podrían ser vulnerables con respecto a esta forma de contratación si se quisiera aplicar el principio básico de la igualdad de salario por el mismo trabajo y en el mismo lugar. La citada Resolución solicita que los poderes públicos se esfuercen para aumentar, entre los trabajadores, el grado de conocimiento de sus derechos tanto para los casos de contratación directa como para la subcontratación. ${ }^{390}$

Destaca también que es importante la subcontratación en la cadena productiva, pero que el desarrollo y el avance debe venir no sólo para la producción, sino también para el empleo. Reclama que en los casos en los que haya desobediencia por la empresa contratada de las normas laborales, el poder público no pueda contratar este tipo de trabajo para esta empresa. ${ }^{391}$

La Resolución acoge con satisfacción el hecho de que Austria, Bélgica, Finlandia, Francia, Alemania, Italia, Holanda y España, se hayan dado cuenta de los problemas relativos a la subcontratación, estableciendo sistemas nacionales

\footnotetext{
390 "Resolución 1. Pide a los poderes públicos y a todos los interesados que se esfuercen al máximo para aumentar, entre los trabajadores, el grado de conocimiento de sus derechos conforme a los distintos instrumentos (como la normativa laboral, los convenios colectivos, los códigos de conducta) que regulan su relación de empleo y sus condiciones laborales en las empresas para las cuales trabajan y las relaciones contractuales en las cadenas de subcontratación;(...)".http://eurlex.europa.eu/LexUriServ/LexUriServ.do?uri=OJ:C:2010:117E:0176:0180:ES:PDF.

391 "Resolución 4. Subraya la importancia de las empresas de subcontratación en las cadenas de producción que utilizan las nuevas tecnologías con miras a mejorar la calidad tanto de la producción como del empleo;

5. Pide a los poderes públicos nacionales que adopten o desarrollen normas que excluyan de la contratación pública a las empresas cuando se pruebe que han infringido la legislación laboral, los convenios colectivos 0 los códigos de conducta; (...)".http://eurlex.europa.eu/LexUriServ/LexUriServ.do?uri=OJ:C:2010:117E:0176:0180:ES:PDF
} 
de responsabilización. ${ }^{392}$ Todo ello lleva a considerar los modelos anteriormente mencionados como paradigmas para los demás países pertenecientes a la comunidad, teniendo en cuenta la cuestión central del trabajo, la dignidad humana y la responsabilidad social.

Sin embargo, en su Resolución, el Parlamento Europeo reitera su solicitud de que la Comisión establezca un instrumento jurídico que introduzca, en el ámbito de la U.E., la responsabilidad solidaria, respetando el ordenamiento interno de cada país, así como los principios de proporcionalidad y subsidiariedad. ${ }^{393}$

Solicita también que los interlocutores sociales asuman la responsabilidad en cuanto a la promoción de la subcontratación cooperativa para tareas únicas y específicas, además de la restricción a la multiplicación de la subcontratación, teniendo por norte siempre la cuestión de la responsabilidad social en los casos de subcontratación. ${ }^{394}$ La propia U.E. reconoce el problema de la multiplicación de la subcontratación y esta preocupada con ello. La preocupacion permite que uno concluya que esta forma de contratación debe ser excepcional y no la regla gerenal.

\footnotetext{
392 "Resolución 9. Acoge con satisfacción el hecho de que ocho Estados miembros (Austria, Bélgica, Finlandia, Francia, Alemania, Italia, los Países Bajos y España) hayan tenido en cuenta los problemas relacionados con las obligaciones de los subcontratistas como patronos estableciendo sistemas nacionales de responsabilidad y anima a los demás Estados miembros a examinar el establecimiento de sistemas similares; subraya, no obstante, que la aplicación de las normas en los procesos de subcontratación transfronterizos es especialmente difícil cuando los sistemas vigentes en los Estados miembros son diferentes; (...)". http://eurlex.europa.eu/LexUriServ/LexUriServ.do?uri=OJ:C:2010:117E:0176:0180:ES:PDF.

${ }_{393}$ "Resolución 13. Reitera su petición a la Comisión de que establezca un instrumento jurídico comunitario inequívoco que introduzca la responsabilidad solidaria a nivel comunitario, respetando al mismo tiempo los distintos ordenamientos jurídicos vigentes en los Estados miembros, así como los principios de subsidiariedad y proporcionalidad; (...)". http://eurlex.europa.eu/LexUriServ/LexUriServ.do?uri=OJ:C:2010:117E:0176:0180:ES:PDF.

${ }^{394}$ "Resolución 19. Pide a los interlocutores sociales que asuman el liderazgo en la promoción de la subcontratación cooperativa para tareas únicas específicas, por una parte, y en la restricción de la multiplicación de la subcontratación, por otra, y acoge favorablemente el desarrollo de acuerdos marco que definen la responsabilidad social en la cadena como un complemento de la regulación necesaria;(...)" lex.europa.eu/LexUriServ/LexUriServ.do?uri=OJ:C:2010:117E:0176:0180:ES:PDF. 
La U.E., propone, aún, que los trabajadores de las empresas subcontratadas puedan conciliar la vida familiar con el trabajo y que sean amparados por la legislación nacional de cada país, aplicándose las directivas comunitarias sobre maternidad y parentesco ${ }^{395}$, elevando a primer plano no sólo el trabajador en sí, sino también su familia y las generaciones futuras.

Finalmente, en el apartado 24 la Resolución "Subraya que la lucha contra las posibles consecuencias sociales negativas de la subcontratación puede afianzarse mediante la mejora del diálogo social reforzado entre las organizaciones patronales y los sindicatos", de donde se desprende que el Parlamento Europeo es sensible a las cuestiones relativas a la subcontratación de trabajadores.

Aún, es interesante añadir que la subcontratación o el "outsourcing", es la contratación de un provedor externo para suministrar servicios o productos dentro de la cadena de producción de una sociedad, suministradas, hasta entonces, directamente. No se puede olvidar que la tercerización, como esta dicho arriba, para los límites de esta tesis, es más restringida que el "outsourcing", porque lleva solamente por cuenta el suministro de servicios entre empresas, donde una de ellas, la empresa prestadora, pone a disposición de otra, tomadora, trabajadores para hacer determinada tarea, y no producir un determinado producto de forma descentralizada.

Volviendo al tema central deste epigrafe, es necesario decir que el Parlamento Europeo aprobó, el 15 de enero de 1999 una Resolución sobre condigos de conducta para las empresas europeas que operen en paises en

395 "Resolución 22. Propone que la posibilidad de los trabajadores de las empresas de subcontratación en las cadenas de producción de conciliar la vida familiar con el trabajo se proteja mediante disposiciones del Derecho nacional, y que se apliquen efectivamente las directivas sobre los permisos de maternidad y parental; (...)". http://eurlex.europa.eu/LexUriServ/LexUriServ.do?uri=OJ:C:2010:117E:0176:0180:ES:PDF. 
desarrollo ${ }^{396}$. Ello, se uno añade los codigos de conducta y el etiquetado social ${ }^{397}$, que deben tener por norte las normas de la OIT, pueden evitar la explotación de los trabajadores junto a los paises en desarrollo, creando una etica propia para los casos de "outsourcing" cuando las empresas de la Unión Europea de relacionan con los paises de capitalismo tardio.

La opinión de Martín Arribas reforza que la Unión Europea está preocupada por la cuestión de la subcontratación y no sólo en cuanto a las empresas, sino también con los trabajadores, que antes de ser trabajadores son seres humanos. Hay que conciliar la competitividad económica con la protección a los derechos humanos de los trabajadores subcontratados. ${ }^{398}$

No hay, como está dicho arriba, en la U.E., normativas sobre las contratas. La Unión deja al encargo de los paises miembros hacer las leyes sobre las contratas y subcontratas, pero exige el respeto al derecho laboral europeo.

Es interesante decir, aún, que el concept europeo de flexiseguridad busca la modernización del derecho laboral en el ambito de la Unión. Y se utiliza, tambien, de los preceptos del trabajo por empesas de trabajo temporal.

La Unión busca un equilibrio entre la flexibilidad y la seguridad, y pone como estratégias una economia basade en el conocimiento, competitiva y dinámica, capaz de crecer de manera soteníble, con más y mejores empleos y cohesión social. Dice, aún, que hace falta la integración del social y del económico, con la mesma relevancia para los dos en nivel europeo, reducción de

\footnotetext{
${ }^{396}$ DE VAL ARNAL, Jesús, "Subcontratación internacional: libertad de comercio y derecho del trabajo. Límites postulados por la Organización Internacional del Trabajo y la Unión Europea", En Descentralización productiva y nuevas formas organizativas del trabajo : $X$ Congreso Nacional de Derecho del Trabajo y de la Seguridad Social, Zaragoza, 28 y 29 de mayo de 1999, Zaragoza, Minist'rio del Trabajo y Asuntos Sociales, Subdireción General de Publicaciones, 2000, p. 559/560. 397 "Una etiqueta es una información que el fabricante o el distribuidor de un cierto producto facilita al consumidor. En I etiquetado social se facilita información sobre las circunstancias laborales de producción garantizando que el producto o servicio que se adquiere se ha hecho en condiciones de trabajo equitativas". DE VAL ARNAL, Jesús, "Subcontratación internacional (...)", cit., p. 560.

${ }^{398}$ MARTÍN ARRIBAS, Juan José, "Aproximación general a la figura (...), cit., p. 260/261.
} 
las desigualdades y protección de los individuos, con fomento a la solidariedad y justicia. ${ }^{399}$

Realizada esta exposición general, vamos a profundizar en la subcontratación de los trabajadores a nivel europeo. Los países que vamos a tratar son España, Francia, Italia y Portugal, el primero con mayor atención.

\subsubsection{Breve referencia a algunos países europeos, en especial el caso de Francia y Portugal.}

En este apartado haremos referencia a la tercerización en Francia y Portugal, pasando brevemente por el sistema legislativo de estos dos países, para después estudiar más a fondo la cuestión española como paradigma de subcontratación en el viejo continente.

\subsection{Francia $^{400}$}

El contrato de trabajo a través de empresas de trabajo temporal, así como el contrato a tiempo determinado, o mismo la "sous-traitance", son formas de precariedad, como otras, corrientes dentro del derecho del trabajo francés. Seguidamente nos ocuparemos del análisis de este fenómeno. ${ }^{401}$

Con respecto al caso francés, Sérgio Pinto Martins afirma que la ley francesa no prohíbe la intermediación de mano de obra, sino la explotación del trabajador ('marchandage'). Está prohibida la explotación extrema del obrero, conocida en Francia como tâche, el abaratamiento de los salarios o incluso la falta

399 VALDÉS DAL-RÉ, Fernendo y LAHERA FORTEZA, Jesus, "La flexiseguridad laboral en España", cit., 19.

400 FAVENNEC-HÉRY, Françoise et VERKINDT, Pierre-Yves, Droit du travail, Paris; Lextenso Éditions, 2011; JOUNIN, Nicolas, "L'illegalité sous-traitée? Les conséquences du reours à des employeurs intermédiaires dans ke secteur du bâtiment". En Revue Droit Social, numero 1, janvier 2007; LOKIEC, PASCAL, Droit du travail, Tomo I, Paris; PUF, 2011; PESKINE, Elsa, Reseaux d'entreprise et droit du travail. Thèse Doctoral, Université Paris X, Nanterre, 2004.

${ }^{401}$ MAZEAUD, Antonie, Droit du travail, Paris; Montchrestien, 6 ${ }^{\mathrm{a}}$ Ed; 2008, p. 362. 
de pago de éstos en virtud de la insolvencia del contratista. La legislación prohíbe la explotación y no el trabajo lícito. Acaba por imponer una responsabilidad solidaria. El autor añade que la jurisprudencia ha establecido como prohibido no el 'marchandage' sino su abuso. ${ }^{402}$

Pinto Martins concluye que la subcontratación es utilizada para la actividadfin de la tomadora de los servicios, siempre que la prestadora efectivamente mantenga el poder de mando. Hace referencia con un contrato llamado filialización donde la empresa principal se sirve de filiales fruto del desmembramiento de determinadas actividades. Son en estos casos admitidos incluso trabajadores con salarios inferiores y que generen menos costes sociales. ${ }^{403}$

Alexandre Agra Belmonte asegura que la tercerización en Francia sólo está permitida en los casos de trabajo a través de empresas de trabajo temporal, conforme establece el artículo 125-3 del Código del Trabajo francés. ${ }^{404}$ Resulta necesario, sin embargo, un examen más exhaustivo, porque Pinto Martins y Agra Belmone hacen un analysis un poco superficial del tema y que posee, varias otras especificidades y peculiaridades.

El movimiento sindical francés ve la tercerización como una más de las formas de precarizar las condiciones de trabajo. La tercerización, como se dice en Francia, es un modo de organización del trabajo que utiliza como base un diferencial económico y social entre empresas, una relación desigual entre contratantes y subcontratadas. Eso genera la precariedad de las empleos, fragmentación de las relaciones sociales como un todo y en especial a la clase proletaria. $^{405}$

\footnotetext{
${ }^{402}$ PINTO MARTINS, Sérgio, A terceirização e o direito do trabalho, cit., p. 19/20.

${ }^{403}$ PINTO MARTINS, Sérgio, A terceirização e o direito do trabalho, ibidem.

${ }^{404}$ AGRA BELMONTE, Alexandre, "Aspectos jurídicos atuais da terceirização trabalhista", cit., p. 33.

${ }^{405}$ PEREIRA MARCELINO, Paula Regina, Terceirização do trabalho no Brasil e na França, p. 09 En http://www.uel.br/grupo-pesquisa/gepal/segundosimposio/paulareginapereiramarcelino.pdf. Acceso el 03 de diciembre de 2010, a las 9h10min.
} 
En general, en Francia, los tipos de subcontratación son dos, además del contrato de trabajo de trabajo a través de empresa de trabajo temporal (intérimaire). La subcontratación es utilizada para los servicios de limpieza, restaurante, garantía, servicio, informática, llamados servicios generales, y para los servicios que compone el producto final. En este último caso, la frontera entre el trabajador empleado y el tercerizado puede ser bien tenue, ejemplo clásico de la industria de automóviles. ${ }^{406}$

Hay que tener presente que en los casos en los que hay externalización, es decir, subcontratación fuera de la empresa contratante, exterior a la planta de la contratante, el término que se usa es éste diverso de aquél. La "sous-traitance" es usada sólo para las subcontrataciones de trabajadores internamente, conforme la ley 75-1334. Eso muestra que la subcontratación, en este país europeo, terminologicamente, está diluida: "intérimaire", externalización y "sous-traitance". 407

En lo que se refiere a la legislación, la tercerización en Francia no discrepa mucho de Brasil. La diferencia más importante es que en ésta sí que existe la posibilidad de tercerizar la actividad-fin de la empresa, siempre que el poder de dirección continúe en manos de la empresa prestadora. Por lo general, en Francia la tercerización se produce en forma de contrata, donde una empresa contratada realiza parte de la producción de la otra empresa, dentro de esta. Lo que más llama la atención, sin embargo, en Francia, es que hay límites a la contratación por ejemplo a través de empresas de trabajo temporal, permitidos sólo en principio para la sustitución de enfermedad, accidente de trabajo, maternidad, formación profesional o sindical y demás licencias de género, jamás para sustituir huelguistas. No se puede, aún, subcontratar actividades que implican riesgos. ${ }^{408}$

\footnotetext{
406 PEREIRA MARCELINO, Paula Regina, Terceirização do trabalho no Brasil e na França., cit., p. 10.

${ }^{407}$ PEREIRA MARCELINO, Paula Regina, Terceirização do trabalho no Brasil e na França, ibidem.

408 PEREIRA MARCELINO, Paula Regina, Terceirização do trabalho no Brasil e na França, cit., p. 12/13.
} 
Es el Código del Trabajo francés ${ }^{409}$, el que da las directrices de la subcontratación, trabajo a través de empresas de trabajo temporal, régimen de trabajo compartido y tercerización en general.

Existe, por tanto, la posibilidad de la subcontratación de trabajadores, siempre que no haya explotación por parte del proveedor de mano de obra sobre los trabajadores. Cada vez que la intermediación de mano de obra pretenda eludir la aplicación de las normas legales de protección al trabajo o incluso normas colectivas habrá "marchandage" y, por consiguiente, nulidad. Esta prohibición se establece en el artículo L8231-1 del Código del Trabajo francés.

Cada vez que haya subcontratación de trabajadores, la empresa intermediaria, prestadora, deberá, necesariamente, con el fin de que pueda proporcionar mano de obra, poseer un fondo de comercio o fondo artesanal, bajo pena de que el tomador se haga cargo del vínculo de empleo, así como del pago de los salarios, de las vacaciones, descansos y festivos de los trabajadores, las horas extras, las cotizaciones de los alimentos y los beneficios que preceden y siguen al nacimiento de un hijo. ${ }^{410}$

En el caso de subcontratación a través de prestadores de mano de obra que detenta el fondo de comercio, si estos incumplen, será el tomador responsable de los salarios, vacaciones, descansos y festivos, cotizaciones de las

409

http://www.legifrance.gouv.fr/affichCode.do?cidTexte=LEGITEXT000006072050\&dateTexte=20101 201, acceso 08 de diciembre de 2010, a las 12h27min.

410 "Article L 8232-1. Lorsqu'un chef d'entreprise conclut un contrat pour l'exécution d'un travail ou la fourniture de services avec un entrepreneur qui recrute lui-même la main-d'oeuvre nécessaire et que celui-ci n'est pas propriétaire d'un fonds de commerce ou d'un fonds artisanal, le chef d'entreprise respecte, à l'égard des salariés de l'entrepreneur employés dans son établissement ou les dépendances de celui-ci et sous les mêmes sanctions que pour ses propres salariés, les prescriptions prévues :

$1^{\circ} \mathrm{A}$ l'article L. 1225-29, relatives aux repos obligatoires prénatal et postnatal ;

$2^{\circ}$ Aux articles L. 1225-30 à L. 1225-33, relatives aux dispositions particulières à l'allaitement ;

$3^{\circ} \mathrm{Au}$ livre ler de la troisième partie, relatives à la durée du travail, aux repos et aux congés ;

$4^{\circ}$ A la quatrième partie, relatives à la santé et à la sécurité au travail". 
prestaciones familiares, prestaciones de prevención social y accidentes del trabajo. ${ }^{411}$

En el caso de que los trabajadores subcontratados presten servicios en casa o en la sede de la empresa del prestador, en caso de falta de pago por parte de este, el tomador del trabajo será responsable de los salarios, vacaciones, descansos y festivos, cotizaciones de las prestaciones familiares y el cumplimiento de las obligaciones de la seguridad social. ${ }^{412}$

Es en este artículo L8232-3 del Codigo del Trabajo donde se establece la responsabilidad solidaria del tomador de trabajo por las partes no pagadas por el prestador, teniendo no sólo los obreros, sino el sistema de garantía social y de asignación familiar acción directamente contra el tomador, con el fin de que se pague lo que efectivamente produjo el trabajador.

Las entidades sindicales pueden actuar con el fin de proteger los derechos de los trabajadores, conforme al artículo L8233-1, lo que es una regla general, porque a ellos cabe la defensa de los derechos de los trabajadores representados y la busqueda de la mejoría de su condición social.

Finalmente, hay sanción penal en el caso de intermediación irregular de mano de obra, castigada con prisión. ${ }^{413}$

\footnotetext{
411 "Article 8232-2. En cas de défaillance de l'entreprise, à laquelle il est recouru dans les conditions prévues à l'article L. 8232-1, le chef d'entreprise encourt, nonobstant toute stipulation contraire, les responsabilités suivantes:

$1^{\circ} \mathrm{Si}$ les travaux sont exécutés ou les services fournis dans son établissement ou dans les dépendances de celui-ci, le chef d'entreprise est substitué au sous-traitant en ce qui concerne les salariés que celui-ci emploie pour le paiement des salaires et des congés payés ainsi que pour les obligations résultant de la législation sur les assurances sociales, sur les accidents du travail et les maladies professionnelles et sur les prestations familiales ; (...)".

412 "Article 8232-2. (...). $2^{\circ}$ S'il s'agit de travaux exécutés dans des établissements autres que ceux du chef d'entreprise ou de travaux exécutés par des salariés travaillant à domicile, le chef d'entreprise est substitué au sous-traitant pour le paiement des salaires et congés payés ainsi que pour le versement de la cotisation des prestations familiales et de la double cotisation des assurances sociales".

${ }_{413}$ "Article $L$ 8234-1. Le fait de commettre le délit de marchandage, défini par l'article L. 8231-1, est puni d'un emprisonnement de deux ans et d'une amende de 30000 euros.
} 
El espiritu de la ley en Francia, como en el marco de la U.E., es que no se puede utilizar al trabajador sólo como un medio. La intermediación de mano de obra con fines sólo lucrativos está prohibida, porque la norma legal de Franca prohíbe el "marchandage". No se considera intermediación de mano de obra el caso, por ejemplo, de los trabajadores de empresas de trabajo temporal, el trabajo a tiempo compartido o los contratos de "manequín". 414

Este artículo, junto con el anteriormente analizado, permite comprobar que en Francia se puede tercerizar, incluso la actividad-fin de la empresa tomadora. Lo que no se puede hacer es intermediar la mano de obra con fines lucrativos y en perjuicio de los trabajadores. La subcontratación de trabajadores por persona interpuesta es posible siempre que la prestadora tenga un fondo de comercio y esté debidamente registrada. La intermediación de mano de obra sin fines lucrativos está permitida, artículo L. 8241-2 del Código del Trabajo.

La juridiction peut prononcer, en outre, l'interdiction de sous-traiter de la main-d'oeuvre pour une durée de deux à dix ans.

Le fait de méconnaître cette interdiction, directement ou par personne interposée, est puni d'un emprisonnement de douze mois et d'une amende de 12000 euros.

La juridiction peut également ordonner, à titre de peine complémentaire, l'affichage du jugement aux frais de la personne condamnée dans les conditions prévues à l'article 131-35 du code pénal et son insertion, intégrale ou par extraits, dans les journaux qu'elle désigne.

Article L 8234-2. Les personnes morales reconnues pénalement responsables, dans les conditions prévues par l'article 121-2 du code pénal, du délit de marchandage défini à l'article L. 8231-1 encourent les peines suivantes :

$1^{\circ}$ L'amende dans les conditions prévues à l'article 131-38 du code pénal ;

$2^{\circ}$ Les peines mentionnées aux $1^{\circ}$ à $5^{\circ}, 8^{\circ}$ et $9^{\circ}$ de l'article $131-39$ du même code.

L'interdiction mentionnée au $2^{\circ}$ de l'article 131-39 porte sur l'activité dans l'exercice ou à l'occasion de l'exercice de laquelle l'infraction a été commise".

414 "Article 8241-1. Toute opération à but lucratif ayant pour objet exclusif le prêt de main-d'oeuvre est interdite.

Toutefois, ces dispositions ne s'appliquent pas aux opérations réalisées dans le cadre :

$1^{\circ}$ Des dispositions du présent code relatives au travail temporaire, au portage salarial aux entreprises de travail à temps partagé et à l'exploitation d'une agence de mannequins lorsque celleci est exercée par une personne titulaire de la licence d'agence de mannequin ;

$2^{\circ}$ Des dispositions de l'article L. 222-3 du code du sport relatives aux associations ou sociétés sportives ;

$3^{\circ}$ Des dispositions des articles L. 2135-7 et L. 2135-8 du présent code relatives à la mise à disposition des salariés auprès des organisations syndicales ou des associations d'employeurs mentionnées à l'article L. 2231-1". 
Por otra parte, existen las relaciones de trabajo temporal en empresas de trabajo temporal. Las empresas de trabajo temporal son aquéllas que ponen a disposición de otra empresa, para la ejecución de un trabajo o misión, un trabajador. Hay reservas para la aplicación en el ente público, conforme establece la norma. Hay que observar que habrá un contrato entre la empresa de trabajo temporal y la tomadora y otro entre el trabajador y la empresa de trabajo temporal. El primero deberá versar sobre la utilización y las actividades temporales que deben realizarse. ${ }^{415}$

Empresa de trabajo temporal es toda persona física o jurídica que preste trabajador a otra empresa, tomadora, mediante contrato, reclutando, mediante solicitación de esta, al asalariado y pagándole salario. ${ }^{416}$ La empleadora, por tanto, es la empresa de trabajo temporal, persona física o jurídica, siendo la empresa tomadora donde el trabajador presta de hecho el trabajo. Hay que tener presente que la primera deberá garantizar las fuentes financieras de pago de los empleados. ${ }^{417}$

Cada vez que una empresa tomadora se sirve de un trabajador fuera de su sede o establecimiento, se le aplican las reglas de la intermediación lícita de mano de obra del artículo L. 8241-2 del Código del Trabajo.

\footnotetext{
415 "Article 1251-1. Le recours au travail temporaire a pour objet la mise à disposition temporaire d'un salarié par une entreprise de travail temporaire au bénéfice d'un client utilisateur pour l'exécution d'une mission.

Chaque mission donne lieu à la conclusion :

$1^{\circ}$ D'un contrat de mise à disposition entre l'entreprise de travail temporaire et le client utilisateur, dit " entreprise utilisatrice " ;

$2^{\circ}$ D'un contrat de travail, dit " contrat de mission ", entre le salarié temporaire et son employeur, l'entreprise de travail temporaire.

Lorsque l'utilisateur est une personne morale de droit public, le présent chapitre s'applique, sous réserve des dispositions prévues à la section 6".

416 "Article 1251-2. Est un entrepreneur de travail temporaire, toute personne physique ou morale dont l'activité exclusive est de mettre à la disposition temporaire d'entreprises utilisatrices des salariés qu'en fonction d'une qualification convenue elle recrute et rémunère à cet effet".

${ }_{417}$ JAVILLIER, Jean Claude, Manuel droit du travail, Paris; Librairie Générale de Droit et de Jurisprudence, 1996, p. 208.
} 
El contrato entre las empresas, denominado contrato de mision, no puede prever, de ninguna manera, el suministro permanente de mano de obra o la ejecución de tareas ligadas a la actividad-fin de la tomadora. ${ }^{418}$

El trabajador que presta trabajo a través de empresas de trabajo temporal sólo puede ser usado para la sustitución de un empleado permanente durante la ausencia de éste, pasaje provisional de contrato a tiempo parcial, suspensión del contrato de trabajo, salida anticipada del trabajador permanente antes de la extinción de su cargo y antes de la entrada definitiva de un trabajador contratado a plazo indeterminado. También, en razón de la naturaleza de la actividad de la empresa contratante y del carácter estacional de la actividad, sustitución de un jefe de obra artesanal, industrial o comercial, profesional liberal o incluso de un socio no asalariado y de un jefe de explotación agrícola. ${ }^{419}$

\footnotetext{
418 "Article 1251-5. Le contrat de mission, quel que soit son motif, ne peut avoir ni pour objet ni pour effet de pourvoir durablement un emploi lié à l'activité normale et permanente de l'entreprise utilisatrice".

419 "Article 1251-6. Sous réserve des dispositions de l'article L. 1251-7, il ne peut être fait appel à un salarié temporaire que pour l'exécution d'une tâche précise et temporaire dénommée " mission " et seulement dans les cas suivants :

$1^{\circ}$ Remplacement d'un salarié, en cas :

a) D'absence ;

b) De passage provisoire à temps partiel, conclu par avenant à son contrat de travail ou par échange écrit entre ce salarié et son employeur ;

c) De suspension de son contrat de travail ;

d) De départ définitif précédant la suppression de son poste de travail après consultation du comité d'entreprise ou, à défaut, des délégués du personnel, s'il en existe ;

e) D'attente de l'entrée en service effective d'un salarié recruté par contrat à durée indéterminée appelé à le remplacer ;

$2^{\circ}$ Accroissement temporaire de l'activité de l'entreprise ;

$3^{\circ}$ Emplois à caractère saisonnier ou pour lesquels, dans certains secteurs définis par décret ou par voie de convention ou d'accord collectif étendu, il est d'usage constant de ne pas recourir au contrat de travail à durée indéterminée en raison de la nature de l'activité exercée et du caractère par nature temporaire de ces emplois ;

$4^{\circ}$ Remplacement d'un chef d'entreprise artisanale, industrielle ou commerciale, d'une personne exerçant une profession libérale, de son conjoint participant effectivement à l'activité de l'entreprise à titre professionnel et habituel ou d'un associé non salarié d'une société civile professionnelle, d'une société civile de moyens ou d'une société d'exercice libéral ;

$5^{\circ}$ Remplacement du chef d'une exploitation agricole ou d'une entreprise mentionnée aux $1^{\circ}$ à $4^{\circ}$ de l'article L. 722-1 du code rural et de la pêche maritime, d'un aide familial, d'un associé d'exploitation, ou de leur conjoint, mentionné à l'article L. 722-10 du même code dès lors qu'il participe effectivement à l'activité de l'exploitation agricole ou de l'entreprise".
} 
Normalmente el contrato de "misión" debe tener un plazo determinado. Hay casos, sin embargo, como el de sustitución de un trabajador en permiso, suspendido o antes de que comience un contrato a plazo indeterminado con relación a un trabajador permanente, como el trabajo por temporada y los casos de los artículos L 1251-6 del Código del Trabajo francés.

La duración del contrato de "misión" es de dieciocho meses, excepto el trabajo en el extranjero donde el contrato tendrá una duración hasta veinticuatro meses. Hay que tener presente que en los casos en que el trabajador está contratado para cubrir la vacante de un empleado contratado a plazo indeterminado o para la realización de trabajos urgentes y que necesiten realizarse por medidas de seguridad el plazo se puede reducir a nueve meses. ${ }^{420}$

El contrato de trabajo a través de empresas de trabajo temporal puede ser renovado una vez sólo, sin que exceda de los dieciocho meses, debiendo las condiciones de la renovación estar previstas en el contrato y estar disponibles para el trabajador antes de la resolución del contrato temporal. ${ }^{421}$

La empresa de trabajo temporal deberá proporcionar una garantía, con el fin de que se pague a los trabajadores, garantía social e indemnizaciones derivadas de esta forma de subcontratación, para el caso de quiebra o falta de pago -artículo 1251-49 del Código del Trabajo-.

\footnotetext{
420 "Article 1251-12. La durée totale du contrat de mission ne peut excéder dix-huit mois compte tenu, le cas échéant, du renouvellement intervenant dans les conditions prévues à l'article L. 125135.

Cette durée est réduite à neuf mois lorsque le contrat est conclu dans l'attente de l'entrée en service effective d'un salarié recruté par contrat à durée indéterminée ou lorsque son objet consiste en la réalisation de travaux urgents nécessités par des mesures de sécurité.

Elle est portée à vingt-quatre mois :

$1^{\circ}$ Lorsque la mission est exécutée à l'étranger ;

$2^{\circ}$ Lorsque le contrat est conclu dans le cas du départ définitif d'un salarié précédant la suppression de son poste de travail ;

$3^{\circ}$ Lorsque survient dans l'entreprise, qu'il s'agisse de celle de l'entrepreneur principal ou de celle d'un sous-traitant, une commande exceptionnelle à l'exportation dont l'importance nécessite la mise en oeuvre de moyens quantitativement ou qualitativement exorbitants de ceux que l'entreprise utilise ordinairement. Dans ce cas, la durée initiale du contrat ne peut être inférieure à six móis".

${ }^{421}$ JAVILLIER, Jean Claude, Manuel droit du travail, cit., p. 211.
} 
En el caso de falta de dinero, la empresa tomadora es responsable del pago de las deudas ante los trabajadores que le prestaran trabajo a través de la empresa de trabajo temporal y de la garantía social, por el período que duró el contrato. $^{422}$

La legislación francesa que envuelve las empresas de trabajo temporal, las usuarias y los trabajadores de aquellas es extremadamente extensa. No podemos analizarla por completo. Lo hasta ahora descrito son sólo líneas generales, con el fin de situar al lector con respecto al tema.

En Francia, también existe "le travail à temps partagé", o contrato de trabajo a tiempo compartido, fruto de una innovación legislativa (ley 2005-882, de 02 de agosto de 2005, artículo 22, actualmente artículo L. 1252 del Código del Trabajo), que tuvo por objeto, la protección de las pequeñas y medianas empresas que podrían, a través de una empresa de "le travail à temps partagé" contratar a un profesional para ejecutar un determinado servicio especializado, ya que no lo podían hacer en razón de su tamaño. ${ }^{423}$

Estas empresas, a través de la empresa de trabajo compartido, compartirían al trabajador que ejecutaría un determinado o determinados trabajos especializados conforme al contrato. El trabajador tendría un contrato a plazo indeterminado con la empresa de trabajo compartido, que pondría al trabajador a disposición de sus clientes. Una vez desobedecidas las reglas legales, habría ilegalidad, por préstamo de mano de obra con intención lucrativa, lo que es penalmente sancionado. ${ }^{424}$

\footnotetext{
422 "Article L 1251-52. En cas de défaillance de l'entreprise de travail temporaire et d'insuffisance de la caution, l'entreprise utilisatrice est substituée à l'entreprise de travail temporaire pour le paiement des sommes qui restent dues aux salariés temporaires et aux organismes de sécurité sociale ou aux institutions sociales dont relèvent ces salariés, pour la durée de la mission accomplie dans l'entreprise".

${ }^{423}$ MAZEAUD, Antonie, Droit du travail, cit., p. 384.

${ }^{424}$ MAZEAUD, Antonie, Droit du travail, cit., p. 384/385.
} 
Esta rápida panorámica de la regulación francesa permite observar que el trabajo adopta las formas más complejas, en la medida en que la empresa ya no está necesariamente ligada a un determinado trabajador por el vínculo laboral. Los contratos, aquí, están en la red, son polos de competitividad. ${ }^{425}$

Sin embargo, "les entreprises de travail temporaire peuvent exercer l'activité d'entreprise de travail à temps partagé" -artículo L. 1252-3 del Código del Trabajo francés- lo que permite concluir que las empresas de trabajo temporal pueden proporcionar mano de obra como empresa de trabajo temporal a un determinado o determinados tomadores, y también proporcionar trabajadores cualificados, que serán compartidos entre los varios clientes de esta misma empresa.

Para terminar, en Francia, hay la posibilidad de contratación de trabajadores a través de empresas de "sous-traitance", Ley 75-1334, del 31 diciembre 1975, relativa a la "sous-traitance", o sea, se puede contratar servicios como por ejemplo de seguridad o higienización, observadas las normas de protección al trabajo y los terminos de los articulos L8231.1 y L8241.1 del Código del Trabajo.

La sous-traitance est una forma de descentralización de las actividades secundarias de la empresa principal para concentrarse en sus actividades principales. "Un certain nombre de chaîne d'hotels ont, par exemple, dans les années 1990, externalisé les services d'entretien des chambres", lo que sirve, también a los servicios de higienización, seguridad, informatica y otros, conforme la Ley $75-1334$, artículo $1^{0426}$, sin que haya relación de empleo entre los

\footnotetext{
${ }^{425}$ MAZEAUD, Antonie, Droit du travail, cit., p. 385.

426 "Article 10 Au sens de la présente loi, la sous-traitance est l'opération par laquelle un entrepreneur confie par un sous-traité, et sous sa responsabilité, à une autre personne appelée sous-traitant l'exécution de tout ou partie de l'exécution du contrat d'entreprise ou d'une partie du marché public conclu avec le maître de l'ouvrage. Les dispositions de la présente loi sont applicables aux opérations de transport, le donneur d'ordre initial étant assimilé au maître d'ouvrage, et le cocontractant du transporteur sous-traitant qui exécute les opérations de transport étant assimilé à l'entrepreneur principal"
} 
trabajadores sous-traités, estos contratados por la empresa prestadora, y la empresa utilizadora. ${ }^{427}$

Ello quiere decir que habra un contrato de sous-traitance en los casos en que la empresa principal contrate una otra, que se llamará sous-traitant, para ejecutar una parte o mismo todo el contrato de obra cuando la ejecucion sea de la actividade secundaria de la empresa principal, para que esta se concentre en su objeto principal. Los empleados contratados son pagados por la empresa contratada ("sous-traitant") y estarán subordinados a ella. Esta forma de contratación sirve para los casos de servicios de limpieza, seguridad, informatica y otros.

El empresario principal tiene el derecho de saber quien son los empleados que le serán enviados. Los trabajadores pueden demandar directamente el empresario principal ("maître d'ouvrage") cuando el empleador no les ha paado. Mas, le maître d'ouvrage debe pagar solamente lo que esta previsto en el contrato de sous-traitance y del cual él há sido beneficiado. Y el valor de la deuda es limitado a lo que él debe al sous-traitant, en la fecha que él ha recibido el pedido de pago. ${ }^{428}$

Finalmente, en sentido gerenal, para todos los casos de tercerización en Francia, en el caso de fraude, las personas físicas y/o jurídicas pueden ser declaradas penalmente responsables por los delitos de "marchandage" y de

\footnotetext{
${ }^{427}$ LOKIEC, Pascal, Droit du travail, Paris; PUF, 2011, p. 219.

${ }^{428}$ Article 12. Le sous-traitant a une action directe contre le maître de l'ouvrage si l'entrepreneur principal ne paie pas, un mois après en avoir été mis en demeure, les sommes qui sont dues en vertu du contrat de sous-traitance ; copie de cette mise en demeure est adressée au maître de l'ouvrage.

Toute renonciation à l'action directe est réputée non écrite.

Cette action directe subsiste même si l'entrepreneur principal est en état de liquidation des biens, de règlement judiciaire ou de suspension provisoire des poursuites.

Les dispositions du deuxième alinéa de l'article 1799-1 du code civil sont applicables au soustraitant qui remplit les conditions édictées au présent article.

Article 13. L'action directe ne peut viser que le paiement correspondant aux prestations prévues par le contrat de sous-traitance et dont le maître de l'ouvrage est effectivement bénéficiaire.

Les obligations du maître de l'ouvrage sont limitées à ce qu'il doit encore à l'entrepreneur principal à la date de la réception de la copie de la mise en demeure prévue à l'article précédent.
} 
prestación ilícita de mano de obra con intención lucrativa y en perjuicio de los trabajadores. $^{429}$

Para terminar, la Corte de Casasión, por la Camera del Social, ha decidido que los trabajadores puestos à la disposición que estéen en las condiciones del articulo L. 2314-18-1 del Codigo del Trabajo ${ }^{430}$, pueden ser elegidos como miemboros de la delegación de los trabajadores de la empresa tomadora y, por falta de ley que lo impida, ser elegidos, tambien, para la delegación unica del personal, en el caso de las empresas con menos de docientos empleados y que opten por tener solamente la delegación única. No pueden, sin embargo, ser elegidos para el comité de empresa, como dice el articulo L. 2324-17-1 del Codigo del Trabajo ${ }^{431}{ }^{432}$

Hecho este breve análisis de la subcontratación de trabajadores en Francia, vamos a analizar, seguidamente, el caso italiano.

\footnotetext{
${ }^{429}$ LYON-CAEN, Gérard, PÉLISSIER, Jean et SUPIOT, Alain, Droit du travail, Paris, Dalloz, 1994, 17a Edição, p. 136.

${ }^{430}$ L. 2314-18-1. Dans les entreprises de travail temporaire, sont électeurs ou éligibles tous les salariés temporaires satisfaisant aux conditions d'ancienneté définies tant par l'article L. 2314-17 que par les autres dispositions des textes applicables et liés à l'entreprise par un contrat de mission au moment de la confection des listes.

Cessent de remplir les conditions d'électorat et d'éligibilité :

$1^{\circ}$ Les salariés ayant fait connaître à l'entrepreneur de travail temporaire qu'ils n'entendent plus bénéficier d'un nouveau contrat ;

$2^{\circ}$ Les salariés à qui l'entrepreneur de travail temporaire a notifié sa décision de ne plus faire appel à eux pour de nouveaux contrats.

${ }^{431}$ L. 2324-17-1. Pour les salariés mis à disposition qui remplissent les conditions mentionnées au $2^{\circ}$ de l'article L. 1111-2, la condition de présence dans l'entreprise utilisatrice est de douze mois continus pour y être électeur. Les salariés mis à disposition ne sont pas éligibles dans l'entreprise utilisatrice.

Les salariés mis à disposition qui remplissent les conditions mentionnées au premier alinéa choisissent s'ils exercent leur droit de vote dans l'entreprise qui les emploie ou l'entreprise utilisatrice

${ }^{432}$ BOULMIER, Daniel, "Salarié mis à disposition:élegibilité aus élections de la délégation du personel", En Droit social n. 3, mars 2013, Dalloz, 2013, p. 279/280.
} 


\subsection{Portugal}

La legislación portuguesa coloca los contratos de trabajo a través de empresas de trabajo temporal como contratos de trabajo sujetos a un régimen especial. Lo hace en razón de que ciertas formas de trabajo subordinado justifican regímenes propios y diferentes del ordinario. ${ }^{433}$

El trabajo a través de empresa de trabajo temporal, en Portugal -como también en otros países- sufre críticas en razón de la mercantilización del trabajo humano, permitiendo que empresas de intermediación de mano de obra logren ganancias por el empleo de trabajadores en una determinada (s) empresa (s). Tal vez sea por eso que la Convención 96 de la OIT llegó a prohibir esta práctica o a exigir un regulación rígida para este tipo de operación. En el mismo sentido lo hace la Directiva 91/383/CEE, del Consejo, de 25 de junio de 1991, que trata de las medidas dirigidas a promover la mejora en la garantía de los trabajadores y que tiene relación con el trabajo a término o trabajo para empresas de trabajo temporal. $^{434}$

En Portugal el trabajo a través de empresa de trabajo temporal fue, inicialmente, regulado por el D.L. 358/89, de 17 de octubre. Actualmente la norma que rige la materia es la Ley 19/2007, Ley del Trabajo Temporal (LTT) ${ }^{435}$.

Trabajo a través de empresa de trabajo temporal es aquél donde una empresa cede, a título oneroso o gratuito, por un tiempo determinado, a otra empresa la disponibilidad de la fuerza de trabajo de un cierto número de trabajadores. El personal cedido es remunerado por la cedente, pero integrado en

\footnotetext{
${ }^{433}$ MENEZES LEITÃO, Luís Manoel Teles de, Direito do trabalho, Coimbra; Almedina, 2008, p. 477.

${ }_{434}^{43}$ MENEZES LEITÃO, Luís Manoel Teles de, Direito do trabalho, cit., p. 478.

${ }^{435} \mathrm{http}: / / \mathrm{dre} . \mathrm{pt} / \mathrm{pdf} 1 \mathrm{sdip} / 2007 / 05 / 09800 / 33873397 . \mathrm{pdf}$, acceso el 08 de diciembre de 2010, a las $11 \mathrm{~h} 16 \mathrm{~min}$.
} 
el Contexto de la empresa contratante, utilizadora, regulado por la dirección y/o jefatura de esta. ${ }^{436}$

Esta forma de contratación es atípica, dado que quien paga los salarios no es el tomador del trabajo, reservándose a este último el poder de dirección pero no el poder disciplinario. ${ }^{437}$

La norma portuguesa incorpora las actividades de las empresas de trabajo temporal y las de cesión temporal de trabajadores de los artículos $322^{\circ}$ a $329^{\circ}$ del Código del Trabajo. La primera, respetando los límites y las imposiciones legales, es lícita, mientras que la segunda, en principio, es ilícita, salvo lo expresamente dispuesto por los artículos $323^{\circ}$ y 324ํ del Código del Trabajo.

Conforme establece el artículo $2^{\circ}$ de la LTT los sujetos de la relación de trabajo temporal son la empresa de trabajo temporal (ETT), es decir, una persona singular o colectiva cuya actividad consiste en la cesión temporal a usuarios, de la actividad de trabajadores admitidos y remunerados por la misma; el trabajador temporal, siendo la persona que celebra, con una empresa de trabajo temporal o un contrato de trabajo por tiempo indeterminado para cesión temporal; y el utilizador es la persona singular o colectiva que, con o sin fines lucrativos, ocupa, bajo su autoridad y dirección, trabajadores cedidos por una empresa de trabajo temporal. $^{438}$

Se constata que la empresa de trabajo temporal, como establece el artículo $3^{\circ}$ de la LTT, sólo puede ejercer sus actividades de cesión de trabajadores a una empresa utilizadora, después de la obtención de un permiso, que le será concedido después de haber cumplido los requisitos de la ley, entre los cuales se

\footnotetext{
${ }^{436}$ MONTEIRO FERNANDES, António de Lemos, Direito do trabalho, Coimbra; Almedina, 13a ed; 2006, p. 161.

${ }^{437}$ MONTEIRO FERNANDES, António de Lemos, Direito do trabalho, cit., p. 162/163.

${ }^{438}$ MENEZES LEITÃO, Luís Manoel Teles de, Direito do trabalho, ibidem.
} 
cita una caución -conforme al artículo 6ํㅜ de la LTT- y la comprobación anual del mantenimiento de los requisitos que exigía el permiso -artículo $11^{\circ}$ de la LTT-. ${ }^{439}$

Hay que subrayar que la empresa de trabajo temporal no puede exigir del trabajador que pague ningún importe para que lo inserte en el mercado de trabajo -artículo 13 o de la LTT-. 440

Sin embargo, a la empresa de trabajo temporal se le exigen algunos requisitos tales como: una autorización previa, una idoneidad profesional y financiera, prestación de caución, para que se garantice su seriedad, fiabilidad y capacidad financiera. La cesión temporal de mano de obra es un fenómeno que surge en la vida de cualquier empresa o entidad, independientemente de las garantías exigidas de la empresa de trabajo temporal. ${ }^{441}$

La relación de contrato de trabajo temporal se basa en dos actos jurídicos, un contrato de trabajo, entre la empresa de trabajo temporal y el trabajador, a la cual éste, mediante salario, se obliga a prestar trabajo directamente vinculado a una empresa utilizadora, manteniendo el vínculo de empleo con la ETT y otro de prestación de servicios, celebrado entre un utilizador (contratante) y una empresa de trabajo temporal, por el cual ésta se obliga, mediante pago, a ceder uno o más trabajadores temporales. El contrato de trabajo puede ser a plazo determinado 0 indeterminado, contrato de trabajo temporal en el primer caso y contrato de trabajo por un tiempo indeterminado para cesión temporal, conforme al artículo $2^{\circ}$ de la LTT. Hay que tener presente que el contrato de cesión, entre las empresas, siempre será a término resolutivo, determinado o indeterminado -artículos 2 ㅇ " $\mathrm{f}$ " y 13으, N. 2 de la LTT-.442

\footnotetext{
439 MENEZES LEITÃO, Luís Manoel Teles de, Direito do trabalho, cit., p. 478/479.

${ }^{440}$ MENEZES LEITÃO, Luís Manoel Teles de, Direito do trabalho, cit., p. 479.

${ }^{441}$ MONTEIRO FERNANDES, António de Lemos, Direito do trabalho, cit., p. 168.

${ }^{442}$ MENEZES LEITÃO, Luís Manoel Teles de, Direito do trabalho, ibidem.
} 
Los contratos deben ser necesariamente escritos -artículo $14^{\circ}, \mathrm{n} 1$, de la LTT-. El contrato por parte de una empresa tomadora, utilizadora, para la empresa de trabajo temporal no licenciada responsabiliza de forma solidaria a ésta y al utilizador por los créditos que deriven del contrato de trabajo, así como con respecto a los gravámenes sociales de los últimos tres años -artículo 17ำ n 1, de la LTT-. Sin embargo, aunque no haya contratación lícita, la empresa utilizadora será responsable subsidiaria de los créditos impagados por la empresa de trabajo temporal a sus empleados, así como los costes sociales -artículo 17ํㅗ. N. 2, LTT443

El régimen del contrato de utilización de trabajo -regulado en los artículos $18^{\circ}$ y siguientes, de la LTT- establece que sólo es posible esta forma de contratación en las siguientes situaciones: a) sustitución directa o indirecta de trabajador ausente o que se encuentre temporalmente impedido para prestar servicios; b) sustitución directa o indirecta del trabajador en relación al cual esté pendiente un juicio de acción de apreciación de licitud de despido; c) sustitución directa o indirecta del trabajador en situación de permiso no retribuido; d) sustitución de trabajador a tiempo completo que pase a prestar trabajo a tiempo parcial por un período determinado; e) necesidad debida a una vacante de puestos de trabajo y cuando ya surge de un proceso de reclutamiento que hay que cumplir f) actividades de temporada; g) aumento excepcional de la actividad de la empresa; h) ejecución de tarea ocasional o un servicio determinado precisamente definido y no duradero; i) necesidades intermitentes de mano de obra; j) necesidades intermitentes de trabajadores para la prestación de apoyo familiar directo, de naturaleza social, durante días o partes del día; y l) necesidad de mano de obra para la realización de proyectos con carácter temporal limitado a reestructuración, instalación de empresas o establecimientos, montajes y reparaciones industriales. ${ }^{444}$

\footnotetext{
${ }^{443}$ MENEZES LEITÃO, Luís Manoel Teles de, Direito do trabalho, cit., 480.

${ }^{444}$ MENEZES LEITÃO, Luís Manoel Teles de, Direito do trabalho, cit., 481.
} 
El contrato de utilización puede renovarse mientras se mantenga la causa que lo justifique, pero sólo hasta dos años -artículo $21^{\circ}, \mathrm{N}$. 1 , de la LTT-. Asimismo, no puede exceder de los seis y doce meses respectivamente en los casos que establece el artículo 18으. N. 1, "y" y "g", de la LTT -como establece el artículo $21^{\circ}$, N. 2, de la LTT-. Hay que tener en cuenta que en los casos en que el trabajador siga prestando servicios durante más de diez días tras el cese de la causa que dio lugar a la contratación temporal, el vínculo de empleo se forma directamente con la empresa utilizadora -artículo 23 de la LTT-. ${ }^{445}$

Las renovaciones del contrato deberán producirse dentro del plazo previsto y nunca exceder el límite legal de dos años, doce o seis meses, conforme el caso artículo $27^{\circ}$, N. 1 , de la LTT-. ${ }^{446}$

En relación a los contratos de trabajo por tiempo indeterminado para cesión temporal, en principio se admiten -artículo 30 de la LTT- pudiendo el empleado, cuando no esté en cesión temporal, prestar su actividad a la ETT -artículo 32, N. 1, LTT-. ${ }^{447}$

Durante la cesión el trabajador queda sujeto al régimen aplicado al utilizador, en lo que se refiere al modo, lugar, duración del trabajo, suspensión en la prestación de trabajo, garantía, higiene y salud en el trabajo y al acceso a los servicios sociales -artículo 35ํㅡ. N. 1, de la LTT- cabiendo al utilizador establecer las vacaciones y elaborar la hora de trabajo. El ejercicio del poder disciplinario, sin embargo, está en las manos de la empresa de trabajo temporal. ${ }^{448}$

Finalmente, el trabajador cedido tiene derecho al mismo salario que el trabajador de la empresa utilizadora, conforme a las normas colectivas que se aplicará al trabajador, salvo si, en el caso de un trabajador temporal, las normas

\footnotetext{
${ }^{445}$ MENEZES LEITÃO, Luís Manoel Teles de, Direito do trabalho, cit., 482

${ }^{446}$ MENEZES LEITÃO, Luís Manoel Teles de, Direito do trabalho, ibidem.

${ }^{447}$ MENEZES LEITÃO, Luís Manoel Teles de, Direito do trabalho, cit., 483.

${ }^{448}$ MENEZES LEITÃO, Luís Manoel Teles de, Direito do trabalho, cit., 484.
} 
colectivas de estas empresas de trabajo temporal les resulten más beneficiosas artículo $37^{\circ}$, N. 1, de la LTT- lo mismo se aplica a los trabajadores contratados por tiempo indeterminado para cesión temporal, a excepción de las vacaciones y décimo tercer salario, calculadas en base al promedio de las remuneraciones de los últimos doce meses -artículo 38으 de la LTT-. ${ }^{449}$

La cesión temporal de trabajadores está prevista en los artículo $322^{\circ}$ a $329^{\circ}$ del Código del Trabajo portugués. La cesión temporal no se confunde con el contrato de trabajo por tiempo indeterminado para cesión temporal del artículo $2 \stackrel{0}{ }$, "y", de la LTT. Aquélla es regulada por el Código del Trabajo ${ }^{450}$ y consiste "en la prestación temporal y eventual del trabajador del cuadro de personal propio de un empleador para otra entidad, a cuyo poder de dirección el trabajador queda sujeto, sin perjuicio del mantenimiento del vínculo contractual inicial” -artículo $322^{\circ}$ del CT- sin ninguna intermediación de empresa de trabajo temporal.

Según el artículo 323ำ del CT, sólo está permitida si está prevista en el convenio colectivo o en los estrictos términos del artículo $324^{\circ}$ del CT. La cesión tiene plazo máximo de un año, pudiendo ser renovada hasta el límite de cinco años, conforme a la letra "d" del artículo $324^{\circ}$ del CT.

El artículo $324^{\circ}$ del CT define un conjunto de condiciones en las que la cesión temporal puede producirse. Es un medio de aprovechamiento o rentabilidad de efectivos permanentes de la empresa cedente y que se encuentran en una situación de superávit. Es significativo, como podemos ver, tanto el artículo citado, como las posibilidades de adopción de esta forma de subcontratación, colaboración entre sociedades coligadas, 0 incluso entre empleadores independientemente de la relación entre ellos. Incluso, puede ser considerada

\footnotetext{
${ }^{449}$ MENEZES LEITÃO, Luís Manoel Teles de, Direito do trabalho, ibidem.

450 http://www.mtss.gov.pt/docs/Cod Trabalho.pdf, acceso el 08 de diciembre de 2010, a las $11 \mathrm{~h} 31 \mathrm{~min}$.
} 
como una forma de gestión de personal en las diversas modalidades de agrupaciones de empresas. ${ }^{451}$

Esta forma de subcontratación debe realizarse mediante un documento firmado por la empresa cedente, por el cesionario, identificando el trabajador cedido y las tareas a desempeñar, con un período de duración del contrato. En el mismo documento debe constar la declaración de concordancia del trabajador. Además, habiendo terminado la cesión el trabajador mantiene vínculo con la empresa cedente, sin perder los derechos adquiridos en el período de la cesión y su antigüedad -artículo 325ํำ del CT-.

Los trabajadores cedidos ocasionalmente no quedan incluidos en el efectivo personal de la empresa cesionaria para cuestiones de número de trabajadores, salvo en cuanto a temas de salud, higiene y garantía en el trabajo. La cesionaria tiene cinco días útiles para comunicar a la comisión de trabajadores la utilización de personal cedido de forma ocasional -artículo $326^{\circ}$ del CT-

Durante la ejecución del contrato de cesión temporal "el trabajador cedido queda sujeto al régimen de trabajo aplicable a la entidad cesionaria en cuanto al modo, lugar, duración de trabajo y suspensión de la prestación de trabajo, garantía, higiene y salud en el trabajo y acceso a sus servicios sociales" -artículo $327^{\circ}$, 1, del CT-. Es la cesionaria quien debe elaborar la hora de trabajo del trabajador cedido de forma temporal, así como conceder sus vacaciones siempre que el trabajador las disfrute trabajando para ésta. Finalmente, el trabajador cedido puede ser cedido ocasionalmente a más de una empresa tomadora artículo 327,4 y 6 , del CT-. ${ }^{452}$

\footnotetext{
451 MONTEIRO FERNANDES, António de Lemos, Direito do trabalho, cit., p. 168.

452 "Artículo 327 (...).

4 - La entidad cesionaria debe elaborar la hora de trabajo del trabajador cedido y marcar su período de vacaciones, siempre que éstas sean disfrutadas al servicio de aquélla.

(...).

6 - Sin perjuicio de la observancia de las condiciones de trabajo que resulten del respectivo contrato, el trabajador puede ser cedido ocasionalmente a más de una entidad".
} 
Finalmente, siendo ilícita la cesión temporal de mano de obra, o en los casos de inexistencia o irregularidad en la documentación, el trabajador cedido puede optar por formar parte del cuadro permanente de empleados de la empresa cesionaria, en régimen de contrato de trabajo sin término resolutivo. Esta opción debe ser ejercida hasta el término de la cesión, con comunicación a la cedente y a la cesionaria mediante carta registrada -artículo 329 del CT-.

Como podemos constatar el sistema de trabajo a través de empresas de trabajo temporal y/o cesión de trabajadores, en Portugal, en Francia y en otros países es similar, aunque cada país opte por situaciones especiales, adecuadas a su realidad. En el caso europeo, los miembros de la Unión Europea deben observar lo que establecen las Directrices comunes a la hora de legislar.

Una vez presentado este breve análisis de los países europeos, uno se detiene más atentamente a España.

\subsection{Estudio detenido de la tercerización en España como paradigma del modelo europeo}

\subsubsection{Introducción}

En el caso español, existe el contrato de obras y servicios, llamadas "contratas" y "subcontratas".

Las contratas similares a la tercerización de servicios brasileña son aquéllas que actúan en la actividad de vigilancia y/o limpieza. Sin embargo, las contrataciones y subcontrataciones en España van más allá de esas posibilidades, pudiendo caber tanto en la citada actividad-medio, como en la actividad-fin de la empresa tomadora ${ }^{453}$.

\footnotetext{
${ }^{453}$ Los términos contrata y subcontrata es atécnico segun José María Goerlich Peset. GOERLICH
} PESET, José María, "Determinación del supuesto: la noción de contrata y subcontrata de obras y 
Sin embargo, conviene resaltar que las "contratas" cuyos empleados reciben la protección de la norma jurídica laboral, tal como el artículo 42 del Estatuto de los Trabajadores, son las que se refieren a la propia actividad de la empresa principal, ligadas directamente al proceso productivo. Esta cuestión es de interpretación controvertida en los tribunales españoles. ${ }^{454}$

Se hace referencia a que en España, las normas de descentralización productiva (concepto este más amplio que lo de tercerización) tienen como base el artículo 38 de la Constitución española, que protege la libertad de empresa ${ }^{455}$, artículo éste sin uno similar en la ley y en la Constitución brasileña, pero que está presente, como ya hemos dicho, en Argentina. En el caso de Brasil, Freire de Alburquerque entiende que en principio, hay similitud entre los dos órdenes jurídicos, de España y de Brasil ${ }^{456}$.

En el articulo 38 de la Constitución española se puede leer:

"Artículo 38. Se reconoce la libertad de empresa en el marco de la economía de mercado. Los poderes públicos garantizan y protegen su ejercicio y la defensa de la productividad, de acuerdo con las exigencias de la economía general y, en su caso, de la planificación".

Sobre la cuestión de la libertad de empresa Sánchez Álvarez, siguiendo la decisión del TSJ de Andalucía (STSJ Andalucía 168/2003, Málaga, de 30 de enero), apunta que:

servicios". En AA.VV.: Descentralización productiva y protección del trabajo en contratas, Tirant lo Blanch, Valencia 2000, p. 80.

${ }^{454}$ Sobre la responsabilidad empresarial en el caso de la contratación por intermediario de forma lícita, ver también LLANO SÁNCHEZ, Mónica. Responsabilidad empresarial en las contratas y subcontratas, Madrid: La Ley, 1999, donde la autora realiza un profundo análisis del tema debatito.

${ }^{455}$ MOTTECY OLIVEIRA, Carmela, "O elemento subordinação na distinção entre "contratas" e cessão ilegal de mão-de-obra no direito espanhol". En Revista Justiça do Trabalho, número 285, Porto Alegre; HS Editora, setembro de 2007, p. 71/72.

${ }^{456}$ FREIRE DE ALBUQUERQUE, Bruna Maria Jacques, Subcontratación y precarización del trabajo. Un estudio comparativo de la norma laboral brasileña y española, Tese doctoral, Universidad de Salamanca, 2011, p. 414. 
"Comenzando por su fundamento, este se encuentra, desde luego, en el principio de libertad de empresa, recogido como derecho en el art. 38 de la Constitución Española. De las dos posibles acepciones de este principio - derecho a la iniciativa económica y capacidad del empresario para dirigir y organizar la empresa - nos interesa este último, que consistiría en "los poderes y facultades para la gestión de la empresa, incluidas las medidas referentes a la llamada gestión de personal que afectan al desarrollo del contrato de trabajo". A partir de ello es fácil llegar a la conclusión de que el mencionado derecho permite al empresario reorganizar total o parcialmente la actividad empresarial tantas veces como sea necesario o, incluso, aunque sólo sea conveniente u oportuno para hacer frente a las necesidades que el mercado le impone a la empresa, pues "la facultad de establecer el contrato de trabajo en orden a adecuar la prestación servicial del trabajador a la estructura organizativa y necesidades de la empresa, corresponde al empresario"', ${ }^{457}$

En este punto, se puede hacer una crítica a la libertad de empresa. La Constitución brasileña garantiza, como fundamento de la República, el valor social del trabajo, y como derecho fundamental, la función social de la propiedad. Por ello, la libertad de lucro puede ser moderada por una restricción del poder económico por parte del poder público (ver la Ley estadounidense "antitrustes", por ejemplo - The Sherman Anti-Trust Acto f 1890 (15 U.S.C.A. $§ 1$ et seq. ${ }^{458}$ ), donde la libertad de contratación se limita con principios como el de valor social del trabajo, no discriminación y función social de la propiedad privada, en el que la libertad de empresa se mezcla con el principio de la función social del contrato y de la empresa. ${ }^{459}$

Freire de Alburquerque añade, en relación a la subcontratación propiamente dicha, que hay que tener en cuenta que la libertad de empresa puede incidir en otras libertades y derechos protegidos por las leyes y por la Constitución, como se desprende del artículo 53.1 de la C.E., pudiendo aplicarse restricciones a

\footnotetext{
457 SÁNCHEZ ÁLVAREZ, Manuel María, "Nuevas formas de organización empresarial (...)”, cit., p. 123.

${ }^{458}$ http://iris.nyit.edu/ shartman/mba0101/trust.htm - aceso el 25 de abril de 2012, 19h49min.

459 FREIRE DE ALBUQUERQUE, Bruna Maria Jacques, Subcontratación y precarización del trabajo. Un estudio comparativo de la norma laboral brasileña y española, cit., p. 413.
} 
la libertad de empresa, derivadas éstas de la aplicación de la propia Constitución o de las leyes. ${ }^{460}$

Es importante decir que en España existen límites a la libertad de empresa, como la defensa de los consumidores y usuarios del artículo 51.1. CE, la utilización racional de todos los recursos naturales y la protección al medio ambiente del artículo 45.3 CE, la promoción de los poderes públicos de las diversas formas de participación en la empresa del artículo 129.2 C.E., la modernización y desarrollo de todos los sectores económicos, conforme el artículo 130.1, y la iniciativa pública en la actividad económica y la subordinación de la riqueza al interés general, del artículo 128.2 C.E. ${ }^{461}$

El ordenamiento jurídico español, sin embargo, prohíbe las "contratas" para el suministro de mano de obra. Deben tener por objetivo la obligación de hacer que derive en la prestación de una obra o servicio determinado para la empresa contratante, que "debe, también, contar con los medios propios para la ejecución de los servicios u obra contratada. También debe permanecer con el poder de dirección sobre sus empleados utilizados en la "contrata", ya que es el verdadero empleador y tiene obligaciones que cumplir con la empresa principal". ${ }^{462}$

La verdadera empleadora del trabajador en el caso de haber contractación entre empresas es la empresa contratada, a quien el prestador de trabajo ésta vinculado y de quien recibirá órdenes. La empresa contratada debe estar formal y materialmente constituida, con los medios necesarios para cumplir las obligaciones que se propone, asumidas con carácter empresarial conforme el articulo 42, 3, 4 y 5 del $\mathrm{ET}^{463}$. Entre la prestadora y la tomadora tendrá que constar

${ }^{460}$ FREIRE DE ALBUQUERQUE, Bruna Maria Jacques, Subcontratación y precarización del trabajo. Un estudio comparativo de la norma laboral brasileña y española, cit., p. 416.

${ }^{461}$ FREIRE DE ALBUQUERQUE, Bruna Maria Jacques, Subcontratación y precarización del trabajo. Un estudio comparativo de la norma laboral brasileña y española, cit., p. 422.

${ }^{462}$ MOTTECY OLIVEIRA, Carmela, "O elemento subordinação (...)", cit., p. 73/74.

${ }^{463}$ Artículo 42 Subcontratación de obras y servicios

3. Los trabajadores del contratista o subcontratista deberán ser informados por escrito por su empresario de la identidad de la empresa principal para la cual estén prestando servicios en cada 
un resultado, no pudiendo ser sólo un suministro de mano de obra, lo que generaría el fraude. ${ }^{464}$

A. Pedrajas Moreno, afirma que "resulta de radical importancia que sea la contratista (y nunca la principal), la que asuma realmente la 'dirección y ejecución' de la obra o servicio contratados. Y, además, estar 'en condiciones de demostrarlo'”. Apunta que las relaciones entre la empresa principal y la contratada deben darse siempre entre administradores 0 incluso gerentes. Nunca directamente entre empleados de la primera y trabajadores de la segunda" ${ }^{465}$, ello porque, en contra habrá fraude.

Así, en el caso español, que en este punto incluso se aproxima al brasileño, al haber una mera intermediación de mano de obra o incluso estando los trabajadores sólo formalmente vinculados a la "contrata", habrá fraude a los

momento. Dicha información deberá facilitarse antes del inicio de la respectiva prestación de servicios e incluirá el nombre o razón social del empresario principal, su domicilio social y su número de identificación fiscal. Asimismo, el contratista o subcontratista deberán informar de la identidad de la empresa principal a la Tesorería General de la Seguridad Social en los términos que reglamentariamente se determinen.

4. Sin perjuicio de la información sobre previsiones en materia de subcontratación a la que se refiere el artículo 64 de esta Ley, cuando la empresa concierte un contrato de prestación de obras o servicios con una empresa contratista o subcontratista, deberá informar a los representantes legales de sus trabajadores sobre los siguientes extremos:

a) Nombre o razón social, domicilio y número de identificación fiscal de la empresa contratista o subcontratista.

b) Objeto y duración de la contrata.

c) Lugar de ejecución de la contrata.

d) En su caso, número de trabajadores que serán ocupados por la contrata o subcontrata en el centro de trabajo de la empresa principal.

e) Medidas previstas para la coordinación de actividades desde el punto de vista de la prevención de riesgos laborales.

Cuando las empresas principal, contratista o subcontratista compartan de forma continuada un mismo centro de trabajo, la primera deberá disponer de un libro registro en el que se refleje la información anterior respecto de todas las empresas citadas. Dicho libro estará a disposición de los representantes legales de los trabajadores.

5. La empresa contratista o subcontratista deberá informar igualmente a los representantes legales de sus trabajadores, antes del inicio de la ejecución de la contrata, sobre los mismos extremos a que se refieren el apartado 3 anterior y las letras b) a e) del apartado 4.

${ }_{464}^{464}$ MOTTECY OLIVEIRA, Carmela, "O elemento subordinação (...)", cit., p. 74/75.

465 PEDRAJAS MORENO, Abdón, "La cesión ilegal de trabajadores". En Autores Varios. La externalización de actividades laborales (outsourcing): una visión interdisciplinar. Abdón Pedrajas Moreno (dir.). Valladolid: Lex Nova, 2002, p. 239/240. 
derechos de los trabajadores y vínculo de empleo para la tomadora. En España estas situaciones son llamadas "pseudocontratas". 466

Es necesario traer a la discusión la situación de la subcontratación en España, como paradigma del modelo europeo. No haremos un estudio comparado. Sin embargo, como hay cierta semejanza entre los modelos de los dos países, consideramos sumamente ilustrativo la referencia al caso español. ${ }^{467}$

\subsubsection{Formas legales}

\subsubsection{Las contratas y subcontratas}

El artículo 42 del Estatuto de los Trabajados forma parte de la "SECCIÓN II. GARANTÍAS POR EL CAMBIO DE EMPRESARIO'. En esta sección del Estatuto de los Trabajadores se trata no sólo la posibilidad de subcontratación a través de

\footnotetext{
${ }^{466}$ MOTTECY OLIVEIRA, Carmela, "O elemento subordinação (...)", cit., p. 78/79.

467 Bibliografía complementaria: AA. VV.: "Descentralización productiva y nuevas formas de organización del trabajo". X Congreso nacional de DTYSS, Ministerio de Trabajo, Madrid, 2000; AA.VV.: "Descentralización productiva y protección del trabajo en contratas", Tirant lo Blanch, Valencia 2000; ALBIOL MONTESINOS, Ignacio, ALFONSO MELLADO, Carlos, BLASCO PELLICER, Ángel y GOERLICH PESET, José Maria, Estatuto de los trabajadores: concordando con la jurisprudencia de los Tribunales Constitucional y Supremo, Valencia; Tirant lo Blanch, $2^{\mathrm{a}}$ ed., 2001; ALONSO OLEA, Manuel y CASAS BAAMONDE, Maria Emilia, Derecho del trabajo, Madrid; Thompson Civitas, 26르 ed., 2009; CONFALONIERI, Juan Angel, la organizacion de la empresa en la actualidad. su incidencia en el concepto de empleador. Documentacion Laboral 2011; GORELLI HERNÁNDEZ, Juan, La tutela de los trabajadores ante la descentralización productiva, Madrid; Grupo Difusión, 2007; FREIRE DE ALBUQUERQUE, Bruna Maria Jacques, Subcontratación y precarización del trabajo. Un estudio comparativo de la norma laboral brasileña y española, Tese doctoral, Universidad de Salamanca, 2011, no publicado; MARTíN VALVERDE, Antonio, RODRÍGUEZ-SAÑUDO GUTIÉRREZ, Fermín y GARCÍA MURCIA, Joaquín, Derecho del Trabajo, Madrid; Tecnos, 18를. Ed., 2009; THIBAULT ARANDA, Javier, "Sobre la utilización de las empresas de trabajo temporal y las "empresas de multiservicios" y CRISTÓBAL RONCERO, Rosario, "Subcontratación de obras y servicios". En Autores Varios. Contratación temporal, empresas de trabajo temporal y subcontratación en la negociación colectiva. Comisión Consultiva Nacional de Convenios Colectivos. Colección Informes y Estudios: relaciones laborales no. 94, Ministerio de Trabajo e Inmigración, 2010; MONTOYA MELGAR, Alfredo, Derecho del Trabajo, Madrid; Tecnos, 2009; PALOMEQUE LÓPEZ, Manuel Carlos, Derecho del trabajo, Madrid; Editorial Universitaria ramón Areces, 17a edidión, 2009; PEDRAJAS MORENO, Abdón y SALA FRANCO, Tomás, Contratas y empresas de trabajo temporal; responsabilidades, Valencia, Tirant lo Blanch, 2006; PÉREZ GUERRERO, Maria Luisa y RODRIGUES-PIÑERO ROYO, Miguel, "El articulo 43 del Estatuto de los Trabajadores: empresas de trabajo temporal y cesión de trabajadores", En Revista del Ministerio de Trabajo y Asuntos Sociales, n. 58, 2005..
} 
las contratas y subcontratas, sino también la imposibilidad de intermediación de mano de obra en los casos no autorizados por ley, conforme esta última parte con el artículo 43 del texto legal que estamos comentando.

En cuanto al término contrata, deriva de lo establecido en el Código Civil español, denominado arrendamiento de obra. Su característica principal es la existencia de un contrato de obra, con obligación de resultado. El término contrata, que se refleja en el artículo 42 del Estatuto de los Trabajadores, no es más que un contrato de prestación de obras o servicios entre empresas. Sin embargo, para que considere una contrata de hecho, la empresa debe disponer de una organización productiva propia e independiente, desarrollando una actividad lícita, propia y específica, asumiendo los riesgos y las responsabilidades del negocio. ${ }^{468}$

Aunque el artículo 42 del Estatuto de los Trabajadores se refiere a la subcontratación, se entiende que abarca también la contratación o las contratas, sin que exista razón alguna para que haya discriminación entre ellas. ${ }^{469}$

En lo que se refiere a la subcontrata, según apunta Martín Valverde, regula un determinado sistema de organización de la producción que se caracteriza por el encargo a otras empresas de parcelas u operaciones del propio proceso productivo. Ese proceso se aproxima mucho a la descentralización productiva, siendo un tipo de contrata por la cual, una empresa está obligada a realizar parte de una obra o de un servicio que le había confiado otra empresa. No se distingue, por tanto, de la contrata en ninguno de sus elementos esenciales. ${ }^{470}$

En el mismo sentido de Martín Valverde, Goerlich Peset apunta que las contratas y también las subcontratas, son una modalidad de contrato de ejecución

\footnotetext{
${ }^{468}$ MARTÍN VALVERDE, Antonio, "Responsabilidad empresarial en caso de subcontrata de obras y servicios", cit., pp. 231/232

${ }^{469}$ MARTÍN VALVERDE, Antonio, "Responsabilidad empresarial en caso de subcontrata de obras y servicios", cit., p. 233, especialmente nota al pie de página.

${ }^{470}$ MARTÍN VALVERDE, Antonio, "Responsabilidad empresarial en caso de subcontrata de obras y servicios", cit., p. 233/234.
} 
de obra, de arrendamiento de obra, según lo dispuesto en el artículo 1544 del Código Civil español. ${ }^{471}$

Las contratas o subcontratas pueden, por tanto, referirse a la ejecución de obras o servicios. La norma del artículo 42, del Estatuto de los Trabajadores no autoriza, sin embargo la mera intermediación de mano de obra, supuesto que acaba por encajarse en lo que establece el artículo 43, del Estatuto de los Trabajadores, que conlleva el fraude puesto que el "contratista" no es un verdadero "contratista" sino una persona interpuesta que sólo gana de lo trabajadores lo que gana el empleador real. ${ }^{472}$

Además, no existe relación y tampoco mediación entre el empresario principal y los trabajadores de la empresa contratada, puesto que esta última asume todos los encargos. Sin embargo, en el caso de las pseudocontratas o de las pseudosubcontratas, la clasificación no se produce en relación con el artículo 42 del Estatuto de los Trabajadores, sino también con relación al artículo 43 de la misma ley. La norma del artículo 42 sirve sólo para los casos de tercerización lícitos, dejando la intermediación de la mano de obra que acaba por formar parte de lo que establecido en el artículo 43 del Estatuto

El artículo 42 del Estatuto de los Trabajadores establece:

"Artículo 42. Subcontratación de obras y servicios.

1. Los empresarios que contraten o subcontraten con otros la realización de obras o servicios correspondientes a la propia actividad de aquéllos deberán comprobar que dichos contratistas estén al corriente en el pago de las cuotas de la Seguridad Social. Al efecto, recabarán por escrito, con identificación de la empresa afectada, certificación negativa por descubiertos en la Tesorería General de la Seguridad Social, que deberá librar inexcusablemente dicha certificación en el término de treinta días improrrogables $y$ en los términos que reglamentariamente se

\footnotetext{
${ }^{471}$ GOERLICH PESET, José María, "Actividades laborales externalizables: régimen jurídico". En Autores Varios, La externalización de actividades laborales (outsourcing): una visión interdisciplinar, Abdón Pedrajas Moreno (dir.). Valladolid; Lex Nova, 2002, p. 115.

${ }_{472}$ MARTÍN VALVERDE, Antonio, "Responsabilidad empresarial en caso de subcontrata de obras y servicios", cit., p. 235.
} 
establezcan. Transcurrido este plazo, quedará exonerado de responsabilidad el empresario solicitante.

2. El empresario principal, salvo el transcurso del plazo antes señalado respecto a la Seguridad Social, y durante el año siguiente a la terminación de su encargo, responderá solidariamente de las obligaciones de naturaleza salarial contraídas por los contratistas y subcontratistas con sus trabajadores y de las referidas a la Seguridad Social durante el período de vigencia de la contrata.

No habrá responsabilidad por los actos del contratista cuando la actividad contratada se refiera exclusivamente a la construcción o reparación que pueda contratar un cabeza de familia respecto de su vivienda, así como cuando el propietario de la obra o industria no contrate su realización por razón de una actividad empresarial.

$(\ldots) "$

El apartado 1 del artículo 42 del Estatuto de los Trabajadores autoriza la contratación o subcontratación de obras o servicios entre empresas. De ahí se deduce que hay suministro de trabajadores entre las empresas, donde una de ellas cede espacio a otra que, con sus trabajadores, desempeña las tareas.

Este procedimiento está autorizado por ley y reforzado por lo que dispone el artículo 38 de la Constitución española. El citado artículo establece que: "Se reconoce la libertad de empresa en el marco de la economía de mercado. Los poderes públicos garantizan y protegen su ejercicio y la defensa de la productividad, de acuerdo con las exigencias de la economía general y, en su caso, de la planificación."

Es por ello que, en España, la libertad de contratar y subcontratar servicios es posible, siendo inconstitucional prohibir las contratas y subcontratas. Lo que no se puede hacer en España es la cesión d emano de obra, aquella del articulo 43 del Estatuto de los Trabajadores, solamente siendo admitida esta forma de intermediación de mano de obra a traves de las empresas de trabajo temporal.

De los Cobos Orihuel confirma lo dicho anteriormente, de que la subcontratación no sufre limitaciones, porque se garantiza, por la ley y por la Constitución, la libertad de empresa, pudiendo las empresas definir libremente el 
objeto de su actividad empresarial y establecer con otros empresarios cuantas relaciones contractuales entiendan oportunas. ${ }^{473}$

Por eso, en el ordenamiento jurídico español es posible la contratación o subcontratación de obras o servicios entre empresas, debiendo la prestadora (contratada) proporcionar los trabajadores necesarios para la ejecución de esta tarea, resultando responsable del pago de los salarios, encargos laborales y prevención social, conforme a lo establecido en la ley.

La contratación o la subcontratación han de llevarse a cabo teniendo por objetivo la "propia actividad" del tomador, concepto éste que, aunque lo parezca, no és equivalente a lo que en Brasil se denomina la "actividad-fin"474. En el caso español, la tercerización de la propia actividad, hará de la empresa tomadora responsable de los sueldos y derechos no satisfechos por la empresa que contrata o subcontrata a sus empleados.

Pero se podría decir que la autorización a la subcontratación en la actividad-medio se produce al amparo de la libertad de empresa, siempre que no haya simple intermediación de mano de obra. En este último caso, sin embargo, la relación de empleo se producirá directamente con la empresa tomadora de los servicios, con responsabilización solidaria entre las empresas que han dado origen al fraude -artículo 43.3 del ET-.

Resulta difícil saber, sin embargo, para fines de responsabilidad, qué es y cuál es la extensión del término "propia actividad". La jurisprudencia española ha distinguido dos posibles interpretaciones para esta expresión: la que entiende que se trata de "actividad indispensable" para que la empresa principal alcance sus objetivos sociales, ampliando el alcance del término, es decir, todas las tareas,

473 LOS COBOS ORIHUEL, Fancisco Pérez, "El concepto de 'propia actividad' empresarial". En Descentralización productiva y protección del trabajo en contratas. Autores Varios, Valencia; Tirant lo Blanch, 2000, p. 161.

${ }^{474} \mathrm{La}$ actividad principal de la empresa se puede llamar actividad-fin. 
específicas o no, que la empresa necesite para desempeñar adecuadamente sus funciones; y la que entiende que se trata sólo de una "actividad inherente" a las específicas para que la empresa pueda operar, excluyendo las no nucleares y complementarias. $^{475}$

Entre estas dos posibilidades, el Tribunal Supremo se inclinó por la segunda posibilidad interpretativa, conforme a las decisiones del Tribunal Supremo, entre ellas la de 18 de enero de 1995, Ar/514, de 29 de octubre y de 24 de noviembre de 1998, Ar/9049 y de 20 de julio de 2005, Ar/5595-. 476

En cuanto a la responsabilidad de la empresa contratante, Llano Sánchez argumenta que el régimen de responsabilidad solidaria -contemplado en el artículo 42 del Estatuto de los Trabajadores- no es más que una garantía que va más allá de la acción directa que el Código Civil español reconocía a los trabajadores de la empresa contratada. Este artículo permite reducir los riesgos que esta forma de descentralización productiva crea, "sin olvidar que también pretende contribuir a la consecución de una finalidad preventiva, estimulando la necesaria prevención y diligencia de los contratantes en la búsqueda de contratistas solventes" ${ }^{477}$

Como apunta Martín Valverde:

"En estas condiciones, la responsabilidad solidaria no es sólo un recurso drástico para suscitar su diligencia en la elección y en la vigilancia de empresas auxiliares, sino que es también, y sobre todo, un criterio equitativo de asignación de costos laborales y sociales a todos los que van a participar de los frutos o resultados del trabajo". ${ }^{478}$

\footnotetext{
475 PEDRAJAS MORENO, Abdón y SALA FRANCO, Tomás, Contratas y empresas de trabajo temporal; responsabilidades, cit., p. 34.

476 PEDRAJAS MORENO, Abdón y SALA FRANCO, Tomás, Contratas y empresas de trabajo temporal; responsabilidades, ibidem, e ALBIOL MONTESINOS, Ignacio, ALFONSO MELLADO, Carlos, BLASCO PELLICER, Ángel y GOERLICH PESET, José Maria, Estatuto de los trabajadores: concordando con la jurisprudencia de los Tribunales Constitucional y Supremo, Valencia; Tirant lo Blanch, $2^{\mathrm{a}}$ ed., 2001, p. 381.

477 LLANO SÁNCHEZ, Mónica. Responsabilidad empresarial en las contratas y subcontratas, Madrid; La Ley, 1999, p. 217.

${ }^{478}$ MARTÍN VALVERDE, Antonio, "Responsabilidad empresarial en caso de subcontrata de obras y servicios", cit., p. 264.
} 
Así, permitida la subcontratación en el ordenamiento jurídico español -en los estrictos casos del artículo 42 del Estatuto de los Trabajadores, contratas y subcontratas lícitas, conforme a lo expuesto- el tomador de los servicios o empresario principal resulta responsable de forma solidaria por los salarios y las obligaciones de seguridad social no pagados por el empleador. En los casos de una mera intermediación de mano de obra (pseudocontratas o pseudosubcontratas) habrá fraude, siendo ilegal, con responsabilización solidaria por parte del tomador, conforme al artículo 43 del mismo texto.

Sin embargo, en el caso de subcontratación de actividad-medio, queda alejada la responsabilidad solidaria, por ausencia de previsión legal ${ }^{479}$, salvo en lo que se refiere a la acción por resarcimiento por parte de la seguridad social, de las partes gastadas con el trabajador en los casos de accidente de trabajo, cuando la responsabilidad de la empresa principal es subsidiaria, incluso si se trata de la actividad-medio, en razón de la negligencia de este último ${ }^{480}$.

En este mismo sentido, Juan Gorelli Hernández, que considera compatibles los artículos 42 del Estatuto de los Trabajadores y 127.1 de la LGSS, refiriéndose, este último, a los casos de subcontratación (contratas y subcontratas) de actividad diversa de la propia actividad de la tomadora, fijando la norma de seguridad a la responsabilidad subsidiaria de la empresa principal, forma de responsabilización ésta que exige que se agote el cobro del deudor principal. ${ }^{481}$

\footnotetext{
479 PEDRAJAS MORENO, Abdón y SALA FRANCO, Tomás, Contratas y empresas de trabajo temporal; responsabilidades, cit., p. 20. "Ausencia de responsabilidad del empresario principal o contratante en materia laboral. - Con carácter general, en materia laboral (respecto de todo tipo de condiciones laborales, incluidas la salariales), la empresa contratante principal de una obra o servicio que no sea de su propia actividad (sobre el concepto de 'propia actividad', ver infra Capítulo I, sección $3^{a}$, I) no tiene responsabilidad alguna respecto de los incumplimientos por las empresas contratistas y subcontratistas de sus obligaciones con sus trabajadores, a diferencia de lo que sucede - si bien limitadamente a la materia salarial -, cuando se trata de contratas o subcontratas de obras o servicios de la propia actividad de la empresa contratante principal".

${ }^{480}$ PEDRAJAS MORENO, Abdón y SALA FRANCO, Tomás, Contratas y empresas de trabajo temporal; responsabilidades, cit., p. 25, haciendo referencia a las sentencias del Tribunal Supremo, como por ejemplo la del 05 de mayo de 1999, Ar/4705.

${ }^{481}$ GORELLI HERNÁNDEZ, Juan, La tutela de los trabajadores ante la descentralización productiva, Madrid; Grupo Difusión, 2007, p. 301/304.
} 
Sólo se constata lo que dice Ramírez Martinez, para quien, aunque la ley se refiera sólo a responsabilidad de la empresa principal, en el caso de contratas y subcontratas, cuando el contrato trate de "propia actividad" de las tomadoras, esta responsabilidad debe ser trasladada también en los casos en los que no hay trabajo relacionado con la "propia actividad". Ello obedece a que una vez que estén excluidas estas actividades, el trabajador estaría más desamparado, dado que es donde se produce el mayor riesgo de insolvencia por parte del prestador. ${ }^{482}$

Sobre el concepto de "propia actividad", la jurisprudencia ha partido de la distinción doctrinal entre actividades inherentes y actividades indispensables (STS de 24 de noviembre de 1998), recogiendo así dos interpretaciones posibles: a) "propia actividad", como actividad indispensable, de suerte que integran el concepto, además de las actividades que forman parte del ciclo productivo, aquéllas necesarias para la organización del trabajo; b) "propia actividad", como la que integra únicamente el concepto de actividad inherente, de modo que solamente las tareas que forman parte del ciclo productivo de la empresa pueden ser consideradas como "propia actividad". ${ }^{483}$

Para Los Cobos Orihuel la jurisprudencia rechaza la interpretación más restrictiva indicada arriba. Es por ello que, para él, se debe considerar "propia actividad" empresarial también, aquella actividad complementaria del ciclo productivo, actividad ésta que por su conexión con el ciclo productivo es indispensable a la actividad empresarial principal, constituyendo la "propia actividad" del empresario. Por el contrario, no hacen parte del ciclo productivo del empresario las actividades ocasionales y/o esporádicas. ${ }^{484}$

\footnotetext{
482 RAMÍREZ MARTíNEZ, Juan M., "Las responsabilidades del empresario principal en las contratas y subcontratas". En La externalización de actividades laborales (outsourcing): una visión interdisciplinar, Autores Varios. Abdón Pedrajas Moreno (org.). Valladolid; Lex Nova, 2002, p. 150/151.

${ }^{483}$ LOS COBOS ORIHUEL, Fancisco Pérez, "El concepto de 'propia actividad' empresarial". En Descentralización productiva y protección del trabajo en contratas, En Autores varios, Valencia; Tirant lo Blanch, 2000, p. 164.

${ }^{484}$ LOS COBOS ORIHUEL, Fancisco Pérez, "El concepto de 'propia actividad' empresarial”, cit., pp. $165 / 169$.
} 
Sin embargo para el Tribunal Supremo, "propia actividad" es aquella que es esencial para toda la empresa principal. Es la actividad inherente, entendiendo por tal solo las tareas que correspondan al ciclo productivo de la empresa principal. Las actividades instrumentales, indispensables o no, están excluídas de este concepto, conforme la sentencia del 24 de noviembre de 1998 del TS. ${ }^{485}$

En cuanto a las partes debidas, la responsabilidad solidaria alcanzará sólo a los salarios de los trabajadores, importes pagados por el trabajo prestado, incluyéndose el salario en sentido estricto, descansos remunerados, vacaciones, horas extraordinarias, mejoras salariales fruto de convenio colectivo. Quedan excluidas, sin embargo, las indemnizaciones por gastos efectuados por el trabajador en el transcurso del contrato, indemnización por despido o mora por el atraso en el pago de salarios. ${ }^{486}$

Ramírez Martínez apunta que la responsabilidad solidaria del tomador, o empresa principal se restringe a las partes salariales en sentido estricto, no se extienden a las cuotas extra salariales, indemnizaciones por despido o fin de contrato, entre otros. La responsabilización, por tanto, además de ser de seguridad social, concierne sólo a los salarios, no pudiendo haber una interpretación ampliativa contenida en el artículo 42 del Estatuto de los Trabajadores. ${ }^{487}$

Antonio Martín Valverde apunta que el propósito del artículo 42 del Estatuto de los Trabajadores tiene como objetivo la protección de los trabajadores en cuanto a los salarios y a la prevención social. La responsabilidad solidaria del

\footnotetext{
485 DEL REY GUANTER, Salvador, "A proposito de los requisitos des articulo 42.1 TRET, y en especial sobre la 'propia actividad': notas la luz de la STS 24 de noviembre de 1998", cit., pp. 341/342.

${ }^{486}$ PEDRAJAS MORENO, Abdón y SALA FRANCO, Tomás, Contratas y empresas de trabajo temporal; responsabilidades, cit., pp. 34/36.

487 RAMÍREZ MARTíNEZ, Juan M., "Las responsabilidades del empresario principal en las contratas y subcontratas", cit., p. 161.
} 
apartado 2 del artículo 42, tiene como finalidad la garantía de los intereses de los trabajadores y de la seguridad social frente a un eventual incumplimiento. ${ }^{488}$

Martín Valverde llama la atención sobre un problema. A veces resulta muy difícil establecer la diferencia entre una contratación o subcontratación conforme al artículo 42 del Estatuto de los Trabajadores, por lo tanto lícita, de una transferencia de mano de obra ilícita.

\begin{abstract}
"La admisión legal sub condicione de la descentralización productiva contrasta, como se ha puesto de relieve en más de una ocasión, con la posición adoptada por la ley ante otras prácticas contractuales caracterizadas también por la 'exteriorización' del empleo, como la cesión de mano de obra o la actividad de las empresas de trabajo temporal. La línea divisoria entre unos y otros supuestos resulta a veces difícil de descubrir, sobre todo a causa de la tendencia de la práctica contractual a simular bajo capa de descentralización productiva 'lícita' lo que es en realidad una cesión de mano de obra o interposición en el contrato de trabajo prohibidas. Pero, sin perjuicio de estas dificultades casuísticas, las fronteras de los conceptos respectivos son, como tendremos ocasión de ver, perfectamente nítidas, pudiendo identificarse con ayuda de varios criterios, entre los que cuenta, en lugar destacado, el criterio de la existencia o no de "tráfico de mano de obra", 489
\end{abstract}

Como podemos ver, no sólo la legislación española sino también la doctrina rechaza cualquier posibilidad de tráfico de mano de obra, estando atenta a los posibles casos de fraude, lo que permite concluir que la contratación y subcontratación, contratas y subcontratas, deben utilizarse en los estrictos límites de la ley, bajo nulidad por fraude.

Lo que autoriza las contratas y subcontratas, además del artículo 42 del Estatuto de los Trabajadores, es lo que consta en el artículo 38 de la Constitución española. $^{490}$

\footnotetext{
${ }^{488}$ MARTÍN VALVERDE, Antonio, "Responsabilidad empresarial en caso de subcontrata de obras y servicios". En Revista de Derecho Privado. Comentarios a las leyes laborales. El Estatuto de los Trabajadores, Tomo VIII, artículos 39 a 44. Flexibilidad laboral, Autores Varios, Madrid; Editorial Revista de Derecho Privado, 2ª ed., 1998, p. 212.

${ }^{489}$ MARTÍN VALVERDE, Antonio, "Responsabilidad empresarial en caso de subcontrata de obras y servicios", cit., pp. 213/214.

${ }^{490}$ MARTÍN VALVERDE, Antonio, "Responsabilidad empresarial en caso de subcontrata de obras y servicios", cit., p. 214.
} 
Los contratos de aplicación del artículo 42 del Estatuto de los Trabajadores, pueden ser tanto de carácter privado como públicos. Goerlich Peset apunta que la posible aplicación de los preceptos laborales "a la contratación de carácter administrativo ha sido objeto tradicionalmente de discusión, fundamentalmente en atención a que los sujetos contemplados por ellos son empresarios, condición que no seria aplicable a las Administraciones Públicas cuando recurren a la contratación administrativa". El autor añade que la jurisprudencia del Tribunal Supremo, a partir de 1996, ha establecido que es posible esta forma de contratación por la Administración pública, quedando sujeta, en estos casos, a las normas laborales que regulan la subcontratación, y se encuadra en el concepto de contratas. $^{491}$

Antes de terminar es interesante decir que pueden darse contratas lícitas entre empresas del mismo grupo, como han indicado varias sentencias del Tribunal Supremo y de los Tribunales Superiores de Justicia (STSJ de Aragón, de 24 de Marzo de 1993, ref. 791). Si la relación es solamente de cesión de mano de obra habrá ilicitud, aunque las empresas sean verdaderas y del mismo grupo ${ }^{492}$

Sobre los contratos con el poder público hay algunas cosas más que decir.

\subsubsection{La descentralización productiva en la Administración Pública española.}

Es unánime en la doctrina y la jurisprudencia españolas que la Administración Pública puede servirse del mecanismo de la descentralización

\footnotetext{
${ }^{491}$ GOERLICH PESET, José María, “Actividades laborales externalizables: régimen jurídico”, cit., p. 120.

${ }^{492}$ RAMIREZ MARTíNEZ, Juan M. Y SALA FRANCO, Tomás, "Contratas y subcontratas de obras y servicios y cesión ilegal de trabajadores", cit., p. 118/120.
} 
productiva como modo de organizar su actividad, en cuanto actúa como empresario sobre sus trabajadores. ${ }^{493}$

A través de la descentralización productiva, la Administración persigue dejar de realizar actividades y tareas que con anterioridad venía haciendo, de modo que tales actividades se trasladan al sector privado. No excede recordar que el riesgo de los trabajadores en la Administración, en los casos de descentralización productiva, es el mismo que el de los trabajadores en las empresas privadas. ${ }^{494}$

Como decimos, esta práctica de descentralización productiva o administrativa en España se ha desarrollado en los últimos años. La descentralización es la transferencia a otra empresa de las actividades hasta entonces internamente ejecutadas por la empresa principal, o que antes hayan sido directamente gestionadas. $Y$ de la misma forma que el empresario común, la Administración Pública tiene la necesidad de flexibilizar su mano de obra, al igual que lleva a cabo ciertos cambios económicos y tecnológicos, para reducir costes, actividades éstas que no son las típicamente públicas, como pueden serlo la seguridad, limpieza, transportes y otras. ${ }^{495}$

Es con este ahorro de costes como la Administración puede organizar mejor sus actividades propias, dedicando el dinero a éstas conforme las exigencias del mercado. $^{496}$

Pero no es sólo para economizar costes por lo que se sirve de esta forma de contratación o descentralización productiva o administrativa. Se encuentra también toda la cuestión de la complejidad técnica de los servicios, como el

\footnotetext{
493 GORELLI HERNÁNDEZ, Juan, La tutela de los trabajadores ante la descentralización productiva, Madrid; Grupo Difusión, 2007, p. 125.

494 GORELLI HERNÁNDEZ, Juan, La tutela de los trabajadores ante la descentralización productiva, cit., p. 125.

495 GARCIA-PERROTE ESCARTIN, Ignácio y GOÑI SEIN, José Luis, "Contratación administrativa y aplicación de las normas laborales sobre contratas", cit., p. 134.

${ }_{496}$ GARCIA-PERROTE ESCARTIN, Ignácio y GOÑI SEIN, José Luis, "Contratación administrativa y aplicación de las normas laborales sobre contratas", cit., p. 134.
} 
mantenimiento de carreteras, aeropuertos, ferrocarriles, y otros. Se trata de actividades estructurales que se acometen por procedimiento de adjudicación de contratos públicos de obra. En este caso, la descentralización productiva es, sobre todo, un imperativo basado en la complejidad, lo que permite que se dedique a su misión de servicio público. ${ }^{497}$

$Y$ es en base al principio constitucional de la eficacia administrativa sobre el que la Administración puede y debe contratar de esta forma, principio contenido en el artículo 103.1 de la C.E ${ }^{498}$. La necesidad de sustituir las grandes redes administrativas y burocráticas exige que la Administración contrate a empresas privadas, más ágiles, y que podrán prestar un servicio de mejor calidad, y más barato, a los administrados. ${ }^{499}$

Aún así, no se puede permitir la intermediación de mano de obra, con el único propósito de abaratar costes. La Administración no puede tolerar la cesión ilícita de mano de obra o de trabajadores, prohibida en España, porque es ella quien, en primer lugar, debe preservar la licitud del acto y del contrato administrativo. ${ }^{500}$

Es a través de la contratación administrativa como se ejecuta la descentralización productiva o administrativa en el ámbito de la Administración Pública. Ahora bien, no todos los servicios públicos pueden ser externalizados. Se debe poner atención a los servicios y actividades de autoridad inherentes al poder público, conforme los artículos $156.1^{501} 502$ y 197 de la Ley 13/1995, de Contratos

\footnotetext{
${ }^{497}$ GARCIA-PERROTE ESCARTIN, Ignácio y GOÑI SEIN, José Luis, "Contratación administrativa y aplicación de las normas laborales sobre contratas", cit., p. 134.

${ }_{498}$ En Brasil este princípio, conocido como de la eficiencia administrativa, esta en el articulo 37 de la Constitución y justifica la subcontratación por parte del poder publico.

${ }^{499}$ GARCIA-PERROTE ESCARTIN, Ignácio y GOÑI SEIN, José Luis, "Contratación administrativa y aplicación de las normas laborales sobre contratas", cit., p. 135 y GORELLI HERNÁNDEZ, Juan, La tutela de los trabajadores ante la descentralización productiva, cit., p. 126.

500 GARCIA-PERROTE ESCARTIN, Ignácio y GOÑI SEIN, José Luis, "Contratación administrativa y aplicación de las normas laborales sobre contratas", cit., pp. 135/136.

${ }_{501}$ In http://noticias.juridicas.com/base datos/Derogadas/r2-113-1995.12t4.html\#a197 - aceso 09 de abril de 2012, 17h44min.
} 
de las Administraciones Públicas (LCAP), en los que los contratos deben ser cumplidos solamente de forma directa por la administración. ${ }^{503}$

En cambio, en supuestos diferentes de estos servicios o tareas de autoridades inherentes al poder público, se reconoce la libertad dispositiva de la Administración para llevar a cabo todas las formas de contratos administrativos, ${ }^{504}$ al encontrarse incluido dentro del principio constitucional de eficacia administrativa.

Así, cuando la Administración Publica se desvincula de una actividad, encargando su gestion a un tercer sujeto, se está ante un supuesto de descentralización productiva, siendo aplicable la legislación laboral, en concreto, el articulo 42 del ET, y resultando ser la Administración, a tenor de este precepto, la empresa principal, postura ésta coincidente con la doctina de Derecho laboral, como la STS de 15 de junio de 1996, Ar 1089. ${ }^{505}$

Se puede, conforme la doctrina y la jurisprudencia, transmitir a terceros la actividad, antes desarrollada por la Administración, a sujetos privados, o bien a sujetos privados expresamente creados por ésta para la actividad, tales como las entidades públicas empresariales, sociedades mercantiles de naturaleza mixta, o exclusivamente publica, por ejemplo ${ }^{506}$, como ocurre en Brasil en los casos de descentralización administrativa para las "autarquias", las "empresas públicas" y las "sociedades de economia mixta", estas dos últimas actuando como empresas

\footnotetext{
${ }^{502}$ Hoy articulo 275.1 del Real Decreto 03/2011, de 14 de noviembre, por el que se aprueba el texto refundido de la Ley de Contratos del Sector Público. In

http://www.boe.es/boe/dias/2011/11/16/pdfs/BOE-A-2011-17887.pdf - aceso el 09 de abril de 2012, 17h46min.

${ }^{503}$ GARCIA-PERROTE ESCARTIN, Ignácio y GOÑI SEIN, José Luis, "Contratación administrativa y aplicación de las normas laborales sobre contratas", cit., p. 136.

504 GARCIA-PERROTE ESCARTIN, Ignácio y GOÑI SEIN, José Luis, "Contratación administrativa y aplicación de las normas laborales sobre contratas", cit., pp. 136/137.

505 GORELLI HERNÁNDEZ, Juan, La tutela de los trabajadores ante la descentralización productiva, cit., p. 127.

506 GORELLI HERNÁNDEZ, Juan, La tutela de los trabajadores ante la descentralización productiva, cit., p. 128.
} 
privadas (cuando exploten la actividad económica), conforme articulo 173, parrafo primero, II, de la Constitución brasileña.

Los contratos administrativos susceptibles de ser descentralizados en España son el de ejecución de obras, aquéllos que el poder público deja al privado la construción, por ejemplo, de carreteras, la empresa privada se compromete al resultado y no a la ejecución de una actividad, conforme a lo dispuesto en el articulo 171 del Real Decreto 3/2011, de 14 de noviembre; el de gestion de servicios públicos, donde existe la facultad de transferir a un tercero la gestión de un servicio, atribuyéndose a una entidad de Derecho publico o privado la gestion de determinados servicios públicos, conforme a lo dispuesto en el articulo 172 del Real Decreto 3/2011, de 14 de noviembre; de concesión, típica contratación de naturaleza administrativa, donde una persona o empresario asume la gestion de un servicio por su cuenta y riesgo, como se recoge en los artículos 157.a) LCAP, y 277 a) del Real Decreto 3/2011, de 14 de noviembre; la gestion interesada, en desuso, donde la Administración colabora, con el gestor, en la prestación del servicio, participando de los resultados; el concierto, en el que la prestación del servicio se realiza por persona natural o juridica que desarrolla el servicio como suyo, haciendo la Administración contratos de servicios que ya se encuentran instalados y en funcionamiento, debiendo ser solamente utilizarlos, como los conciertos educativos, sanitarios u otros; de suministro, recogidos en los artículos 172 de la LCAP, y 173 y 290 del Real Decreto 03/2011, de 14 de noviembre, que tiene por objeto la compra, el arrendamiento o la aquisición y el arrendamiento de equipos y/o de sistemas informáticos, la fabricación de cosas conforme a criterios establecidos por la Administración, teniendo poco que ver con la contrata, y asimilándose más a la compraventa; de servicios, que tienen por objeto lo contenido en los artículos 197.3 de la LCAP, y 174 y 301 del Real Decreto 03/2011, de 14 de noviembre, y son los de caráter técnico, económico, industrial, comercial o de naturaleza análoga - siempre que no se encoentren comprendidos como contratos de consultoria y asistencia - trabajos específicos y concretos no habituales $u$ otros, complementarios al funcionamiento de la 
Administración, de mantenimiento, conservación y limpieza y reparación de bienes, equipos e instalaciones, y los programas de ordenador destinados a la administración pública; de consultoria y asistencia, recogidos en el articulo 197.2 de la LCAP, que son contratos que tratan de consultoría y asistencia, o cualesquiera otros servicios directa o indirectamente relacionados con éstos, y de caracter intelectual, como estudios, planes, informes, anteproyetos u otros; y para la realización de trabajos especificos no habituales, que son aquellos no comprendidos por las demás formas de contratación y que pueden ser atendidos por la Administración Pública a través de sus trabajadores. ${ }^{507}$

Pero la descentralización productiva puede generar perjuicio para el obrero. No obstante esto, la responsabilidad de la Administración, tal y como consta en el articulo 42 del ET, es controvertida.

En este sentido, aunque la interpretación del Tribunal Supremo sobre la responsabilidad solidaria sea extensiva, la interpretación que el mismo Tribunal da a la expresión "misma actividad" es restrictiva, tal y como se recoge en la Sentencia del Tribunal Supremo (STS), Ag 514, de 18 de enero de 1995, actividad que resulta imprescindible para la obtención del producto o resultado final. Esta interpretación permite que se entienda que la responsabilidad solidaria afecta solamente a las empresas, porque el precepto hace referencia al empresario, que busca el lucro, lo que no ocurre con la Administración. ${ }^{508}$

A pesar de lo anterior, existe la posibilidad de entender que la Administración Pública, cuando interviene a través de la gestión indirecta en actividades o servicios públicos, actúa investida de la condición de empresario del artículo 42 del ET. ${ }^{509}$

\footnotetext{
${ }^{507}$ GARCIA-PERROTE ESCARTIN, Ignácio y GOÑI SEIN, José Luis, "Contratación administrativa y aplicación de las normas laborales sobre contratas", cit., pp. 137/144.

508 GARCIA-PERROTE ESCARTIN, Ignácio y GOÑI SEIN, José Luis, "Contratación administrativa y aplicación de las normas laborales sobre contratas", cit., pp. 146/148.

509 GARCIA-PERROTE ESCARTIN, Ignácio y GOÑI SEIN, José Luis, "Contratación administrativa y aplicación de las normas laborales sobre contratas", cit., p. 50.
} 
No se puede olvidar que en los casos en que el empresario principal, añade de los Cobos Orihuel, es la Administración Publica, cuando contrata la prestación por ejemplo de un servicio con una empresa, para saber si este servicio se encaja o no en la "propia actividad" del ente administrativo, las funciones y las competencias deben tener sido atribuidas a esta por la ley o por reglamento. ${ }^{510}$

Hay autores que critican la subcontratación en la Administración Pública. Rodríguez Escanciano dice que: "el auge de la participación privada en el desarrollo de funciones administrativas pretende de forma deliberada apartarse de las reglas constrictivas de una gestión pública, ordenada por el Derecho Administrativo, con el fin de quedar sometida a la disciplina del mercado y sus leyes. Se trata de huir de las reglas de la contabilidad pública, de las del procedimiento administrativo, de las funciones, e incluso de la posibilidad de que sus actos pueden ser fiscalizados estrechamente por una jurisdicción especializada." 511 Y ello, como dice la autora, otorga la posibilidad a las empresas privadas de suministrar mano de obra a las públicas, lejos de la mirada de las reglas de Derecho Administrativo.

Para terminar, concluimos que debe de observarse cada caso concreto para determinar si la actividad que ha sido descentralizada es o no actividad de la Administración. En caso afirmativo, habrá responsabilidad solidaria del artículo 42 del ET. Caso contrario, si no se está ante la misma actividad, no habrá responsabilidad solidaria de la Administración Pública. ${ }^{512}$

\footnotetext{
${ }^{510}$ LOS COBOS ORIHUEL, Fancisco Pérez, "El concepto de 'propia actividad' empresarial”, cit., p. 168.

${ }^{511}$ RODRÍGUEZ ESCANCIANO, Susana, "La coordinación empresarial como estrategia de descentralización productiva: carencias normativas". En Revista de derecho social, numero 15, Alicante, Ediciones Bomarzo, 2001, p. 118.

${ }^{512}$ GARCIA-PERROTE ESCARTIN, Ignácio y GOÑI SEIN, José Luis, "Contratación administrativa y aplicación de las normas laborales sobre contratas", cit., p. 156.
} 
Conviene hacer algunas consideraciones sobre las empresas de trabajo temporal en España, forma de subcontratación de trabajadores prevista en la norma legal, conforme al artículo 43.1 del ET y ley 14/94, de 01 de junio.

\subsubsection{Las Empresas de trabajo temporal (estudio del art. 43.1 y 1 del ET y ley 14/1994, de 1 de junio -LETT-)}

Es empresa de trabajo temporal aquella cuya actividad consiste en poner a disposición de otra, por un tiempo determinado, trabajadores contratados y remunerados por la misma. Estas empresas dependen de la autorización del poder público y la contratación de trabajadores en estas condiciones depende de la intermediación que realicen estas empresas autorizadas, artículos $1^{\circ}$ y $2^{\circ}$ de la ley $14 / 94$.

Para Fernando Valdés Dal-Ré, las empresas de trabajo temporal, son las que ponen a disposición de otros empresarios, de manera provisional, los trabajadores contratados previamente con esta finalidad, poniendo entre paréntesis la estructura clásica del contrato de empleo. "La dualidad de partes contratantes $y$, lo que es más importante, la radical unicidad de la relación obligatoria por ellos creada desaparece y, en su lugar, surge una tríada de sujetos que se interrelacionan entre si”. Es por esto que esta forma de contratación no sólo rompe con la configuración de la relación laboral como una relación entre dos partes. Al multiplicar las relaciones jurídicas implicadas, "la forma de trabajar que la ETT instrumenta quiebra la noción misma del contrato de trabajo celebrado entre un trabajador y un empresario como fuente única de derechos y obligaciones". 513

\footnotetext{
${ }^{513}$ VALDÉS DAL-RÉ, Fernando, Homenage al profesor Fernando Valdés Dal-Ré a través de sus prólogos. 25 años de catedrático de derecho del trabajo (1977-2002), Valladolid; Editorial Lex Nova, 2002, p. 242.
} 
Quien detenta el poder de dirección es la empresa tomadora, en el caso la usuaria, conforme al artículo $6^{\circ}$ de la ley. El contrato deberá celebrarse por escrito, conforme a la regulación administrativa.

Conforme al artículo 6.2 de la ley 14/04 "Podrán celebrarse contratos de puesta a disposición entre una empresa de trabajo temporal y una empresa usuaria en los mismos supuestos y bajo las mismas condiciones y requisitos en que la empresa usuaria podría celebrar un contrato de duración determinada, conforme a lo dispuesto en el artículo 15 del Estatuto de los Trabajadores".

Este artículo debe ser leído junto con el artículo 15 del Estatuto de los Trabajadores, donde constan las posibilidades de contratación a plazo determinado.

El artículo 15 del Estatuto de los Trabajadores establece:

"Artículo 15. Duración del contrato.

1. El contrato de trabajo podrá concertarse por tiempo indefinido o por una duración determinada.

Podrán celebrarse contratos de duración determinada en los siguientes supuestos:

a) Cuando se contrate al trabajador para la realización de una obra o servicio determinados, con autonomía y sustantividad propia dentro de la actividad de la empresa y cuya ejecución, aunque limitada en el tiempo, sea en principio de duración incierta. Los convenios colectivos sectoriales estatales y de ámbito inferior, incluidos los convenios de empresa, podrán identificar aquellos trabajos o tareas con sustantividad propia dentro de la actividad normal de la empresa que puedan cubrirse con contratos de esta naturaleza.

b) Cuando las circunstancias del mercado, acumulación de tareas 0 exceso de pedidos así lo exigieran, aun tratándose de la actividad normal de la empresa. En tales casos, los contratos podrán tener una duración máxima de 6 meses, dentro de un período de 12 meses, contados a partir del momento en que se produzcan dichas causas. Por convenio colectivo de ámbito sectorial estatal o, en su defecto, por convenio colectivo sectorial de ámbito inferior, podrá modificarse la duración máxima de estos contratos y el período dentro del cual se puedan realizar en atención al carácter estacional de la actividad en que dichas circunstancias se puedan producir. En tal supuesto, el período máximo dentro del cual se podrán realizar será de 18 meses, no pudiendo superar la duración del contrato las tres cuartas partes del período de referencia establecido ni, como máximo, 12 meses.

En caso de que el contrato se hubiera concertado por una duración inferior a la máxima legal o convencionalmente establecida, podrá 
prorrogarse mediante acuerdo de las partes, por una única vez, sin que la duración total del contrato pueda exceder de dicha duración máxima. Por convenio colectivo se podrán determinar las actividades en las que puedan contratarse trabajadores eventuales, así como fijar criterios generales relativos a la adecuada relación entre el volumen de esta modalidad contractual y la plantilla total de la empresa.

c) Cuando se trate de sustituir a trabajadores con derecho a reserva del puesto de trabajo, siempre que en el contrato de trabajo se especifique el nombre del sustituido y la causa de sustitución".

Son éstos los límites para la adopción de los contratos por parte de empresas de trabajo temporal en España, es decir, observados los límites del artículo 15 del Estatuto de los Trabajadores, en los mismos límites en los que la empresa usuaria podría contratar directamente a empleados a plazo determinado.

Si después del término del contrato a plazo, el trabajador mantuviera prestando servicios dentro de la empresa usuaria, será con ésta con la que se establecerá la relación de empleo, conforme al artículo 7º , 2, de la ley.

El contrato de trabajo entre el trabajador y la empresa de trabajo temporal podrá ser por un plazo indeterminado, por escrito y conforme a las normas reglamentarias. No se podrán celebrar contratos de aprendizaje (artículo 10, 1 y 2, de la ley).

La remuneración será conforme a las normas colectivas de las empresas de trabajo temporal o, en su defecto, conforme a los criterios colectivos que implican la empresa usuaria, observando en lo que sea pertinente, lo que consta en el Estatuto de los Trabajadores, artículo 11 de la ley.

Sin embargo, la responsabilidad, en el caso de incumplimiento de los salarios y cuotas de seguridad social por parte de la empresa de trabajo temporal para sus empleados, es subsidiaria, conforme al artículo 16.3 de la LETT $^{514}$. Hay

\footnotetext{
${ }^{514}$ Artículo 16. "Obligaciones de la empresa usuaria.

1. (...). 3. La empresa usuaria responderá subsidiariamente de las obligaciones salariales y de Seguridad Social contraídas con el trabajador durante la vigencia del contrato de puesta a disposición, así como de la indemnización económica derivada de la extinción del contrato de
} 
que tener presente que incluso ante el artículo 127.2 de la LGSS estableciendo responsabilidad solidaria en materia de seguridad social, por el principio de especialidad, en los casos de trabajo temporal, se aplica la regla de la LETT. ${ }^{515}$

Se puede, sin embargo, sostener la aplicación de la responsabilidad solidaria del artículo 127.2 de la LGSS en los casos en que la empresa de trabajo temporal no tenga autorización administrativa para operar, convirtiéndose la cesión de mano de obra en ilegal. ${ }^{516}$

Finalmente, Javillier argumenta, refiriéndose al caso francés, pero que se aplica perfectamente a España (y a Brasil), que el principio, la regla, es la unicidad del empleador, firmándose un contrato entre el trabajador temporal y la empresa de trabajo temporal, puesto a disposición de la tomadora (empresa utilizadora). En el caso de incumplimiento de los requisitos y de las disposiciones legales, la empresa utilizadora se convierte en la empleadora del asalariado temporal, lo que crea un vínculo a plazo indeterminado. Esta empleadora deberá pagar todas las deudas del "empleador" inicial (ETT), salario y accesorios, indemnizaciones, vacaciones, etc., quedando subrogada en los derechos de acreedor frente a ETT equivalente a los pagos abonados al trabajador. ${ }^{517}$

Antes de terminar, es interesante llamar la atención al hecho de que, para Consuelo Chacartegui Jávega, "la reforma llevada al cabo por el RDL 3/2012 vuelve a apostar por la opción de que las empresas de trabajo temporal sean los mecanismos dinamizadores del empleo en España”. La autora llama la atención a

\footnotetext{
trabajo. Dicha responsabilidad será solidaria en el caso de que el referido contrato se haya realizado incumpliendo lo dispuesto en los artículos 6 y 8 de la presente Ley"

515 GORELLI HERNÁNDEZ, Juan, La tutela de los trabajadores ante la descentralización productiva, cit., p. 311.

516 GORELLI HERNÁNDEZ, Juan, La tutela de los trabajadores ante la descentralización productiva, cit., p. 312.

517 JAVILLIER, Jean-Claude, Manual de direito do trabalho, São Paulo; LTr, 1988, p. 69.
} 
la creación de empleos precarios de muy corta duración, lo que aumenta la desigualdad y la segmentación entre nos trabajadores. ${ }^{518}$

Una vez hecho el análisis de la descentralización productiva en España, conviene, con el fin de concluir este estudio, realizar una breve reflexión con respecto a la forma prohibida en el territorio español.

\subsubsection{Las contratas y subcontratas y las normas de seguridad social.}

\subsection{La responsabilidad de la empresa contratante principal en materia de seguridad social no correspondente a la propia actividad.}

El articulo 104, I de la LGS preceptua que es el empresario el responsable por el cumplimiento de la obligacion de pago las cotizaciones de previdencia social, las suyas y las de sus trabajadores. Asimismo aquellas personas que estan destacadas $n$ el artigo 1271 y 2 tambien son responsables.

El articulo 127, I de la LGS establece que "1. Sin perjuicio de lo dispuesto en el artículo 42 del Estatuto de los Trabajadores, para las contratas y subcontratas de obras y servicios correspondientes a la propia actividad del empresario contratante, cuando un empresario haya sido declarado responsable, en todo o en parte, del pago de una prestación, a tenor de lo previsto en el artículo anterior, si la correspondiente obra o industria estuviera contratada, el propietario de ésta responderá de las obligaciones del empresario si el mismo fuese declarado insolvente."

Como se puede ver, la responsabilidad es subsidiaria del contratante, pero solamente en los casos de insolvencia declarada del contratista o del subcontratista. Uno llama la atención al hecho de que la responsabilidad es para

\footnotetext{
${ }^{518}$ CHACARTEGUI JÁVEGA, Consuelo, "La actuación de las empresas de trabajo temporal como
} agencias de colocación. (...), cit, p. 84. 
los casos de subcontratación de la propia actividad, ello con base en los articulos 104. 1 y 127.1 de la LGSS y 14.1 del RD 1415/2004).

¿Pero, como si juega la responsabilidad en los casos en que la subcontratación no es de la propia actividad?

Para una parte de la doctrina tanto el comitente primeiro como todos los miembros de la cadena de subcontratacón responderan subsidiariamene por las cotas de seguridad social, hasta llegar al empresario principal. No hay razón para que el comitente princiapl y el último subcontratista responan sin que los intermediarios lo hagan igualmente. ${ }^{519}$

Para otra parte de la doctrina, que defende una interpretación más restrictiva, como hace la STSJ del Pais Vasco, de 21 de septiembre de 1999 (Ar/1386) el comitente inicial de la obra responde por las prestaciones de seguridad social subsidiariamente con el subcontratista empleador del trabajador accidentado, mientras que el contratista principal responde con el subcontratista no subsidiariamente sino por la via del articulo 42.2 del ET, de forma solidaria, el los casos de propia actividad. ${ }^{520}$

Para resolver esta cuestion es necesario analizar el articulo 42. 2 del ET y el articulo 127 de la LGSS. Para ello, se añada una parte de una sentencia del Tribunal Supremo, SYS Sala III, en u.d., de fecha 6 de julio de 2005, R 451/2004, que esta puesta en el libro de Pedrajas Moreno Y Sala Franco:

“(...) no puede marcarse una diferencia entre uno y otro tipo de responsabilidad por la circunstancia de que la obra o servicio subcontratado se refiera o no a la misma actividad propia del subcontratante, de forma tal que la responsabilidad solidaia del Art. 42 se limite a los supuestos en que así ocurra, mientras que la subsidiaria proclamada en los articulos 104 y 127 de la LGSS se refiera a los casos

\footnotetext{
519 PEDRAJAS MORENO, Abdón y SALA FRANCO, Tomás, Contratas y empresas de trabajo temporal; responsabilidades, cit., p. 27.

520 PEDRAJAS MORENO, Abdón y SALA FRANCO, Tomás, Contratas y empresas de trabajo temporal; responsabilidades cit., p. 27.
} 
en que no existe esa identidad de actividad ... Estimamos en consecuencia que cuando el apartado I del articulo 127 establece la responsabilidad subsidiaia por impago del obligado $<<$ sin perjuicio de lo dispuesto en el Art. 42 del ET>>, esta salvedad no tiene por objeto establecer un régimen de responsabilidad en el pago de cotizaciones 0 prestaciones de la Sguridad Social excluyente del sentado en en art. 42, sino complementario y acumulativo del mismo ... con absoluta independencia de que la responsabilidad prevista en el Art. 42 del Estatuto pudiese resultar optativamente exigible". ${ }^{521}$

La responsabilidad subsidiaria de la empresa contratante principal, la utilizadora, se refiere a las obligaciones contraídas por las empresas contratistas y subcontratistas, pero solamente durante la vigencia de la contrata, y llega a los descubiertos en las cotizaciones y a los costes de mora, aunque no alcanza a los recargos, intereses o cotas a la fecha de la reclamación al deudor subsidiario, articulo 14.2 RD 1415/2004 y STS, Sala III, de 18 de deciembre de 1991, Ar/9334, pero si "a las prestaciones de la Seguridad Social Pública de las que hubiera sido declarada responsable la empresa contratista o subcontratista por incumplimento de sus obligaciones de afiliación/alta y/o de cotización, estén o no sujetas al principio de automaticidad y esté o no obligada la Entidad Gestora al pago de la prestación (Art. 127. de la LGSS)". 522

La Ley General de Seguridad Social "no tiene una previsión expresa respecto del periodo de devengo de las prestaciones o ctizaciones del que el proprietario puede resultar responsable, lo que ha llevado mayoritariamente a entender, como se ha apuntado, que responderá respecto de las contizaciones devengadas y las prestaciones generadas por hechos causantes acontecidos durante la vigencia de la contrata". 523

Esta delimitación en el tiempo no tiene previsión en el articulo 127 de la LGSS y desde la derrogación del RD 1637/1995 por el RD 1415/2004, tampoco el

\footnotetext{
${ }^{521}$ PEDRAJAS MORENO, Abdón y SALA FRANCO, Tomás, Contratas y empresas de trabajo temporal; responsabilidades, cit., p. 28.

522 PEDRAJAS MORENO, Abdón y SALA FRANCO, Tomás, Contratas y empresas de trabajo temporal; responsabilidades, cit., p. 28.

${ }^{523}$ PEDRAJAS MORENO, Abdón y SALA FRANCO, Tomás, Contratas y empresas de trabajo temporal; responsabilidades, cit., p. 28/29.
} 
Reglamento General de Recaudación, lo que hace que el fundamento de la limitación temporal sea la del articulo 42.2 del ET. Uno llama la atención que la norma tampoco prevé el plazo de exigibilidad al proprietario o comitente de la responsabilidad subsisiaria más alla del termino de la contrata, por lo que se jusgara el plazo ordinario de prescripcion de cuatro años para los cotizantes, como esta en el articulo 21 de la LGSS y de cinco años para reconocimiento de prestaciones, articulo 43.1 de la LGSS. ${ }^{524}$

La acción de axigibilidad de responsabilidad subsidiaria nascera solamente cuando declarada la situación de insolvencia del obligado directo, por lo que, "sin perjuicio de la aplicación de los plazos anteriores a las obligaciones reclamadas, la exigibilidad contra el responsable subsidiario podrá hacerse efectiva exclusivamente durante un año después de la declaración de insolvencia, plazo que debe entenderse de prescripcion (STSJ de Castilha la Mancha, de 8 enero de 2002, Ar/90). ${ }^{525}$

El Estatuto de los Trabajadores, articulo 42.2, exime de responsabilidad en los casos de actividad contratada para la "construcción o reparación que pueda contratar un padre de familia respecto de su vivienda, concepto este más amplio que el del articulo 127.1 , parrafo $2^{\circ}$, de la LGSS. ${ }^{526}$

\subsection{La responsabilidad de la empresa contratante principal en materia de seguridad social correspondiente a la propia actividad.}

En los casos de contratas o subcontratas correspondentes a la misma actividad, la responsabilidad por obligaciones de seguridad social es solidaria. Esta responsabilidad dice respeto, aún a las obligaciones salariales y excluye lo

\footnotetext{
${ }^{524}$ PEDRAJAS MORENO, Abdón y SALA FRANCO, Tomás, Contratas y empresas de trabajo temporal; responsabilidades, cit., p. 29.

525 PEDRAJAS MORENO, Abdón y SALA FRANCO, Tomás, Contratas y empresas de trabajo temporal; responsabilidades, cit., p. 29.

526 PEDRAJAS MORENO, Abdón y SALA FRANCO, Tomás, Contratas y empresas de trabajo temporal; responsabilidades, cit., p. 29/30.
} 
restante de las obligaciones laborales por parte de los empresarios contratistas y subcontratistas. ${ }^{527}$

Sobre las obligaciones de sgeuridad social hay que entenderse los descubiertos por cotizaciones impagas, incluyendo los recargos por mora en el ingreso de las cuotas adeudadas y las prestaciones de seguridad social pública de las que hubiera sido declarado responsable el empresario contratista o subcontratista por falta de afiliación/alta y/o de cotización. Quedan, sin embargo, excluidas de la responsabilidad solidaria las mejoras voluntarias (planes de pensión), porque la ley se refiere s[olo a obligaciones "con" la seguridad social pública y no "de" la seguridad social. ${ }^{528}$

La responsabilidad se extiende solamente a las obligaciones asumidas por el contratista o subcontratista duramte el período de vigencia de la contrata o subcontrata, y no a las adquididas antes o despues de ella. Así, por ejemplo, el empresario principal no responderá por los salarios de tramitación de los despidos de los trabajadores adscritos a la contrata a la finalización de ésta (STSJ de Andalucía, de 19 de noviembre de 1997, Ar/4895). El empresario princpal solamente responderá por las prestaciones salariales y de seguridad social referentes al tiempo de duración de la contrata, como esta en la STSJ de Madrid, de 14 de enero de 1998, Ar/67). ${ }^{529}$

Las obrligaciones salariales y de seguridad social pueden ser exigidas del empresario durante la vigencia d ela contrata o subcontrata y durante el año seguiente de la finalización de contrata o subcontrata, siempre que el derecho exigido no hubiera prescrito. Pasado este plazo, se puede, pedir la responsabilización subsidiaria, ello cuanto a las obligaciones de seguridad social,

\footnotetext{
${ }^{527}$ PEDRAJAS MORENO, Abdón y SALA FRANCO, Tomás, Contratas y empresas de trabajo temporal; responsabilidades, cit., p. 39.

${ }^{528}$ PEDRAJAS MORENO, Abdón y SALA FRANCO, Tomás, Contratas y empresas de trabajo temporal; responsabilidades, cit., p. 44/45.

529 PEDRAJAS MORENO, Abdón y SALA FRANCO, Tomás, Contratas y empresas de trabajo temporal; responsabilidades, cit., p. 45/46.
} 
como esta en los articulos 104.1 y 127.1 de la LGSS, con lo límites de los plazos de prescripción. ${ }^{530}$

El articulo 42 del ET contempla, como han dicho López Gandía y Tatay Puchades, contempla una responsabilidad solidaria entre la empresa principal y las contratistas y subcontratistas cuanto a las obligaciones de seguridad social, durante la vigencia de la contrata. El problema es saber lo que es la propia actividad y lo que no es, cual es el alcance de la responsabilidad solidaria y que significa la expresión "surgidas durante la vigencia de la contrata". 531

Los autores dicen que esta responsabilidad es amplia, por lo que se puede enteder que abarca a todo tipo de obligaciones de seguridad social, porque es una respnsabilidad de caracter general, debiendo los articulos 42, 43 del ET y 16.3 del LETT ser interpretados de forma amplia, para que incluya todas las obligaciones en el ámbito del sistema de seguridad social. Quedarían excluidas solamente las multas y/o sanciones punitivas. ${ }^{532}$

Una cuestion que se debe plantear es si dentro del ámbito de las obligaciones de seguridad social entran las mejoras prestacionales. Gorelli Hernández dice que no, pues las "mejoras no forman parte de la acción protectora de la Seguridad Social, sin que se establecen a través de convenio colectivo (que no es fuente de la Seguridad Social)". El autor hace referencia al hecho de que se pueden encontrar opiniones contrarias, porque para ellos las mejoras prestacionales estan en el ámbito de protección de los articulos 42 y 43 del ET. ${ }^{533}$

\footnotetext{
530 PEDRAJAS MORENO, Abdón y SALA FRANCO, Tomás, Contratas y empresas de trabajo temporal; responsabilidades, cit., p. 47.

531 LÓPEZ GANDÍA, Juan y TATAY PCHADES, Carmen, "Contratas y subcontratas y responsabilidades de seguridad social". En Descentralización productiva y protección del trabajo en contratas. Autores varios, Valencia; Tirant lo Blanch, 2000, p 229.

532 LÓPEZ GANDÍA, Juan y TATAY PCHADES, Carmen, "Contratas y subcontratas y responsabilidades de seguridad social”, cit., p. 230 y GORELLI HERNÁNDEZ, Juan, La tutela de los trabajadores ante la descentralización productiva, cit., p. 155/156.

${ }_{533}$ GORELLI HERNÁNDEZ, Juan, La tutela de los trabajadores ante la descentralización productiva" cit., p. 157/158.
} 
Para terminar, como ha dicho Rosario Cristóbal Roncero, la norma del articulo 41.1 del ET se aplica a los casos de contrata o subcontrata de la própia actividad del empresario principal. El articulo establece garantías y cautelas destinadas a evitar que la utilización de la subcontratación de obras y servicios menoscabe los derechos de los trabajadores. ${ }^{534}$

\subsubsection{Forma ilegal: la cesión ilegal de mano de obra (art. 43, 2,3, y 4 ET)}

La cesión de trabajadores está prohibida en España, salvo en los casos de contratos firmados con empresas de trabajo temporal, en los estrictos límites de la ley.

El artículo 43 del Estatuto de los trabajadores establece que:

"Artículo 43. Cesión de trabajadores.

1. La contratación de trabajadores para cederlos temporalmente a otra empresa sólo podrá efectuarse a través de empresas de trabajo temporal debidamente autorizadas en los términos que legalmente se establezcan.

2. En todo caso, se entiende que se incurre en la cesión ilegal de trabajadores contemplada en el presente artículo cuando se produzca alguna de las siguientes circunstancias: que el objeto de los contratos de servicios entre las empresas se limite a una mera puesta a disposición de los trabajadores de la empresa cedente a la empresa cesionaria, 0 que la empresa cedente carezca de una actividad o de una organización propia y estable, o no cuente con los medios necesarios para el desarrollo de su actividad, o no ejerza las funciones inherentes a su condición de empresario.

3. Los empresarios, cedente y cesionario, que infrinjan lo señalado en los apartados anteriores responderán solidariamente de las obligaciones contraídas con los trabajadores y con la Seguridad Social, sin perjuicio de las demás responsabilidades, incluso penales, que procedan por dichos actos.

4. Los trabajadores sometidos al tráfico prohibido tendrán derecho a adquirir la condición de fijos, a su elección, en la empresa cedente o cesionaria. Los derechos y obligaciones del trabajador en la empresa cesionaria serán los que correspondan en condiciones ordinarias a un trabajador que preste servicios en el mismo o equivalente puesto de trabajo, si bien la antigüedad se computará desde el inicio de la cesión ilegal".

\footnotetext{
${ }^{534}$ CRISTOBAL RONCERO, Rosário, "Subcontratación de obras y servicios", cit., p. 244.
} 
Este artículo trata del tráfico de trabajadores y de la cesión de trabajadores. Él prohíbe todos los actos relativos a la cesión de trabajadores, es decir, al reclutamiento de trabajadores con el fin de cederlos a otro tomador de los servicios; responsabiliza de forma solidaria al cedente y al cesionario de la mano de obra, tanto en lo que concierne a las contribuciones de garantía social como en los créditos derivados de la relación de trabajo; y reconoce como empleador real al que toma los servicios de forma irregular. ${ }^{535}$

El propósito de este artículo es explicar porqué el tráfico de trabajadores no es más que una deformación en la relación de trabajo subordinado, que hace parecer empleador a quien, fácticamente no es. Eso implica la asignación de un contrato de empleo a quien no es empleador, lo que tiene consecuencias sindicales, así como en lo que se refiere a los derechos de los trabajadores y cuotas de seguridad social. Eso debilita la capacidad de defender a la clase trabajadora, lo que dificulta la construcción de órganos unitarios de representación profesional. ${ }^{536}$

En este mismo sentido afirma Goerlich Peset:

\begin{abstract}
"La cesión de trabajador prohibida implica, como es suficientemente sabido, la existencia de un pacto entre empresas en virtud del cual una de ellas pone sus trabajadores a disposición de la otra. Su único objeto es, pues, la mano de obra de los trabajadores de la empresa cedente, que pasa a ser utilizadas, en otra intermediación que la formal, por la empresa cesionaria. De ahí que la cesión aparezca como tráfico de mano de obra proscrito por el Ordenamiento laboral". ${ }^{537}$
\end{abstract}

El objetivo, por tanto, es la defensa de los trabajadores, tanto cuando se realice la contratación como en la ejecución de los servicios.

\footnotetext{
${ }^{535}$ MARTÍN VALVERDE, Antonio, "Responsabilidad empresarial en caso de subcontrata de obras y servicios", cit., p. 281.

${ }^{536}$ MARTÍN VALVERDE, Antonio, "Responsabilidad empresarial en caso de subcontrata de obras y servicios", cit., p. 283/284.

${ }^{537}$ GOERLICH PESET, José María, “Actividades laborales externalizables: régimen jurídico”, cit., p. 111.
} 
En una pseudo-contrata los trabajadores quedan sometidos a las órdenes de la organización y dirección del empresario contratante, mientras que el contratista se dedica solamente a la administración y gestión del personal, responsabilidades del pago y de Seguridad Social. Se afirma la idea de que, igualmente en el caso de que las dos empresas sean verdaderas, puede haber una cesión de mano de obra prohibida ${ }^{538}$ y ello porque se puede mantener la subordinación jurídica con la empresa principal, lo que origina una situación de ilegalidad.

Conviene, aún, abordar un poco más la cuestión de las empresas de trabajo temporal. Este tipo de intermediación de mano de obra, aparte de lo que autoriza el artículo 42 del Estatuto de los Trabajadores, se regula por el apartado 1 del artículo 43, del Estatuto de los Trabajadores.

Como argumenta Goerlich Peset, las normas laborales que regulan la descentralización no son prohibitivas y sí condicionantes. "Los condicionamientos laborales a la descentralización derivan, en ocasiones, de ciertas normas generales del Ordenamiento laboral, principalmente de las vinculadas al principio de estabilidad en el empleo (a); y, otras veces, de las que específicamente regulan la descentralización lícita (b)". ${ }^{539}$

Una vez hechas estas consideraciones, vamos a examinar el caso brasileño, tan complejo como los de los países ya analizados, teniendo en cuenta, también, la falta de regulación general, suplida por la jurisprudencia del Tribunal Superior del Trabajo.

\footnotetext{
${ }^{538}$ RAMIREZ MARTíNEZ, Juan M. Y SALA FRANCO, Tomás, "Contratas y subcontratas de obras y servicios y cesión ilegal de trabajadores". En Descentralización productiva y protección del trabajo en contratas. Autores varios, Valencia; Tirant lo Blanch, 2000, p. 110.

${ }^{539}$ GOERLICH PESET, José María, "Actividades laborales externalizables: régimen jurídico", cit., p. 111.
} 


\subsubsection{La prevención de los riesgos laborales en contratas o subcontratas}

El Real Decreto 171/2004, trae al debate el tema de los riesgos laborares en los casos de las contratas y subcontratas. El la Exposicion de Motivos hay referencia expresa a la necesidad de desarrollo regulamentario al articulo 24 de la Ley 31/1995, de 8 de noviembre, de Prevención de los Riesgos Laborales ${ }^{540} 541$. Este Real Decreto toma como base los criterios comunes y las consideraciones generales, de consenso de los agentes sociales.

El R.D. 171/2004 visa a la seguridad y la salud de los trabajadores, con el objetivo de combatir la siniestralidad laboral, con el intento de reforzar la seguridad y la salud en el ambito laboral en los casos de contrata y subcontrata, ello cuando una empresa admite la realización de obras o servicios en su centro de trabajo.

\footnotetext{
540 La Ley 31/1995, de 8 de noviembre, de Prevención de los Riesgos Laborales, tiene por base el articulo 40.2 de la Constitución española, que objetiva velar por la seguridad y higiene en el trabajo.

${ }^{541}$ Artículo 24. Coordinación de actividades empresariales.

1. Cuando en un mismo centro de trabajo desarrollen actividades trabajadores de dos o más empresas, éstas deberán cooperar en la aplicación de la normativa sobre prevención de riesgos laborales. A tal fin, establecerán los medios de coordinación que sean necesarios en cuanto a la protección y prevención de riesgos laborales y la información sobre los mismos a sus respectivos trabajadores, en los términos previstos en el apartado 1 del artículo 18 de esta Ley.

2. El empresario titular del centro de trabajo adoptará las medidas necesarias para que aquellos otros empresarios que desarrollen actividades en su centro de trabajo reciban la información y las instrucciones adecuadas, en relación con los riesgos existentes en el centro de trabajo y con las medidas de protección y prevención correspondientes, así como sobre las medidas de emergencia a aplicar, para su traslado a sus respectivos trabajadores.

3. Las empresas que contraten o subcontraten con otras la realización de obras o servicios correspondientes a la propia actividad de aquéllas y que se desarrollen en sus propios centros de trabajo deberán vigilar el cumplimiento por dichos contratistas y subcontratistas de la normativa de prevención de riesgos laborales.

4. Las obligaciones consignadas en el último párrafo del apartado 1 del artículo 41 de esta Ley serán también de aplicación, respecto de las operaciones contratadas, en los supuestos en que los trabajadores de la empresa contratista o subcontratista no presten servicios en los centros de trabajo de la empresa principal, siempre que tales trabajadores deban operar con maquinaria, equipos, productos, materias primas o útiles proporcionados por la empresa principal.

5. Los deberes de cooperación y de información e instrucción recogidos en los apartados 1 y 2 serán de aplicación respecto de los trabajadores autónomos que desarrollen actividades en dichos centros de trabajo.
} 
En el articulo 1 está presente el objeto del Real Decreto que tiene por objetivo el desarrollo del articulo 24 de la Ley 31/1995, teniendo él un caracter de normas minimas para la protección de la seguridad y salud de los trabajadores en los supuestos de coordinación de actividades empresariales.

Para los efectos del Real Decreto 171/2004, el centro de trabajo es cualquier área, edificada o no, donde los trabajadores deban permanecer o que deban acceder por razón de su trabajo. El empresario titular del centro de trabajo es la persona que tiene la capacidad de poner a disposición y gestionar el centro de trabajo. Por fin, empresario principal es aquél que contrata o subcontrata con otros empresarios la realización de obras o servicios correspondientes a la própia actividad del empresario titular del centro de trabajo, y que se desarrollan en el própio centro de trabajo de este último, conforme articulo 2 del Real Decreto $171 / 2004$.

La coordinación deberá garantizar la aplicación coherente y responsable de Is principios de la acción preventiva estabelecidos en el articulo 15 de la Ley $31 / 1995^{542}$, por las empresas que están en el centro de trabajo; la aplicación

${ }^{542}$ Artículo 15. Principios de la acción preventiva.

1. El empresario aplicará las medidas que integran el deber general de prevención previsto en el artículo anterior, con arreglo a los siguientes principios generales:

a) Evitar los riesgos.

b) Evaluar los riesgos que no se puedan evitar.

c) Combatir los riesgos en su origen.

d) Adaptar el trabajo a la persona, en particular en lo que respecta a la concepción de los puestos de trabajo, así como a la elección de los equipos y los métodos de trabajo y de producción, con miras, en particular, a atenuar el trabajo monótono y repetitivo y a reducir los efectos del mismo en la salud.

e) Tener en cuenta la evolución de la técnica.

f) Sustituir lo peligroso por lo que entrañe poco o ningún peligro.

g) Planificar la prevención, buscando un conjunto coherente que integre en ella la técnica, la organización del trabajo, las condiciones de trabajo, las relaciones sociales y la influencia de los factores ambientales en el trabajo.

h) Adoptar medidas que antepongan la protección colectiva a la individual.

i) Dar las debidas instrucciones a los trabajadores.

2. El empresario tomará en consideración las capacidades profesionales de los trabajadores en materia de seguridad y de salud en el momento de encomendarles las tareas.

3. El empresario adoptará las medidas necesarias a fin de garantizar que sólo los trabajadores que hayan recibido información suficiente y adecuada puedan acceder a las zonas de riesgo grave y específico. 
correcta de los metodos de trabajo por las empresas concurrentes en el centro de trabajo; el control de las interacciones de las diferentes actividades desarrolladas en el centro de trabajo, en especial cuando puedan generar riesgos o cuando se desarrollen en el centro de trabajo actividades incompatibles entre si; adecuación entre los riesgos existentes en el centro de trabajo que puedan afectar a los trabajadores de las empresas concurrentes y las medidas aplicadas para su prevención, articulo 3 del R.D. 171/2004.

Los representantes de los trabajadores son los delegados de prevención y que tienen derechos conforme el articulo 15 del RD. Hay, aún, los comités de seguridad y salud del articulo 16, que dice que "los comités de seguridad y salud de las empresas concurrentes o, en su defecto, los empresarios que carezcan de dichos comités y los delegados de prevención podrán acordar la realización de reuniones conjuntas $u$ otras medidas de actuación coordinada, en particular cuando, por los riesgos existentes en el centro de trabajo que incidan en la concurrencia de actividades, se considere necesaria la consulta para analizar la eficacia de los medios de coordinación establecidos por las empresas concurrentes o para proceder a su actualización".

Cuanto a la negociación colectiva, de conformidad con el articulo 2.2 de la Ley $31 / 1995^{543}$, los convencios colectivos podrán incluir disposiciones sobre las materias reguladas en este Real Decreto, en especial en aspectos tales como la

4. La efectividad de las medidas preventivas deberá prever las distracciones o imprudencias no temerarias que pudiera cometer el trabajador. Para su adopción se tendrán en cuenta los riesgos adicionales que pudieran implicar determinadas medidas preventivas, las cuales sólo podrán adoptarse cuando la magnitud de dichos riesgos sea sustancialmente inferior a la de los que se pretende controlar y no existan alternativas más seguras.

5. Podrán concertar operaciones de seguro que tengan como fin garantizar como ámbito de cobertura la previsión de riesgos derivados del trabajo, la empresa respecto de sus trabajadores, los trabajadores autónomos respecto a ellos mismos y las sociedades cooperativas respecto a sus socios cuya actividad consista en la prestación de su trabajo personal.

${ }^{543}$ Artículo 2. Objeto y carácter de la norma.

1. (...).

2. Las disposiciones de carácter laboral contenidas en esta Ley y en sus normas reglamentarias tendrán en todo caso el carácter de Derecho necesario mínimo indisponible, pudiendo ser mejoradas y desarrolladas en los convenios colectivos. 
prestación de informaciones a los trabajadores y sus representantes sobre la contratación y subcontratación de obras y servicios o la cooperación de los delegados de prevención en la aplicación y fomento de las medidas de prevención y protección laborales adoptadas o a ser adoptadas.

Como se puede ver este Real Decreto es un avanzo en materia de protección laboral en materia de contratas y subcontratas. España en este punto, presenta un reglamento muy avanzado y que tiene como objetivo la protección de la salud y seguridad del trabajador que presta trabajo de forma descentralizada. El Real Decreto 171/2004 trae para dentro de la protección juridica los trabajadores de contratas y subcontratas, como lo hace la Ley 31/1995 para los demás trabajadores.

\subsection{Estudio detenido de la tercerización en el ordenamiento jurídico brasileño.}

La ley brasileña establece, expresamente, por ley o decreto ley, que la tercerización no es de carácter general, sino que se refiere sólo a casos concretos. Hay casos, sin embargo, donde tienen un claro carácter fraudulento, en los que hay una intermediación de mano de obra en lugar de un contrato de tercerización. Son los contratos triangulares dichos lícitos, que vamos a analizar seguidamente.

Hay que tener presente que lo que vamos a abordar en este tópico se refiere a lo que establece la ley o un decreto en particular, tomando además en consideración la perspectiva del Tribunal Superior del Trabajo. No nos estamos refiriendo aquí, por tanto, a la posibilidad de tercerización, sino más bien a lo que la norma jurídica prevé expresamente.

Vamos, por lo tanto, a analizar los casos de tercerización considerados lícitos por la norma legal brasileña. La cuestión de la controversia acerca de la 
actividad-medio y la actividad-fin será tema en un tópico propio, razón por la cual no habrá consideraciones al respecto en este momento.

\subsubsection{Concepto de la doctrina brasileña y crítica inicial a la tercerización ${ }^{544}$}

Inicialmente es importante, igual que ya lo habemos hecho antes en el eprigrafe 2.1, conceptuar lo que quiere decir el término "tercerización". Según Rubens Ferreira de Castro, la tercerización es la posibilidad de contratar a un tercero para la realización de actividades que no constituyen objeto principal de la empresa tomadora de los servicios. Añade que esta contratación puede implicar solamente la prestación de servicios, como son los casos de vigilancia, limpieza o incluso servicios temporales y que la producción de bienes no es una forma de tercerización. Para él, no sera tercerización la contratacion y producción de bienes entre empresas, sino un contrato de compra-venta, donde lo que interesa es el producto acabado y no la actividad. ${ }^{545}$

El concepto es controvertido, porque hay autores que dicen que tercerizar es, tambien, descentralizar la creación de un producto, de un bien o obra ${ }^{546}$. Lo cierto es que el Tribunal Superior del Trabajo, por la Súmula 331, III, dice que

\footnotetext{
544 Bibliografia complementaria: FERREIRA PRUNES, José Luiz, Trabalho terceirizado e composição industrial, Curitiba; Juruá, $2^{\mathrm{a}}$ ed., 2009; COIMBRA SANTOS, Rodrigo, Relações terceirizadas de trabalho, Curitiba, Juruá, 2008; RIBEIRO DE CAMPOS, José, A terceirização e a responsabilidade da empresa tomadora de serviços, São Paulo; IOB-TOMPSON, 2006; PALMEIRA SOBRINHO, Zéu, Terceirização e restauração produtiva, São Paulo, LTr, 2008; GANDRA DA SILVA MARTINS FILHO, Ives, "O fenômeno da terceirização e suas implicações jurídicas". Em Revista LTr, legislação do trabalho, São Paulo; LTr, ano 75, novembro de 2011; ALVARES DA SILVA, Antônio, "Responsabilidade da administração pública nas terceirizações". Em Revista $L T r$, legislação do trabalho, São Paulo; LTr, ano 75, março de 2011; FERREIRA JORGE NETO, Francisco e QUADROS PESSOA CAVALCANTI, Jouberto de, " A terceirização na administração pública e constitucionalidade do art. 71, lei n. 8.666/93, declarada pelo STF (novembro de 2010). Em Revista LTr, legislação do trabalho, São Paulo; LTr, ano 75, março de 2011; TULIO VIANA, Márcio, NEVES DELGADO, Gabriela e SANTOS AMORIN, Helder, "Terceirização - aspectos gerais - a última decisão do STF e a súmula n. 331 do TST - novos enfoques". Em Revista LTr, legislação do trabalho, São Paulo; LTr, ano 75, março de 2011.

${ }^{545}$ FERREIRA DE CASTRO, Rubens, A terceirização no Brasil, São Paulo; Editora Malheiros, 2000, p. 86/87.

${ }^{546}$ COIMBRA SANTOS, Rodrigo, Relações terceirizadas de trabalho, cit., p. 95.
} 
tercerización es poner la mano de obra a la disposición de tercera persona, sin el carácter personal y sin subordinación.

José Alberto Couto Maciel afirma que la tercerización se define como la contratación realizada por "una empresa de servicios, de trabajo a ser prestado por una persona física (profesional autónomo), o persona jurídica, empresa especializada para realizar un determinado servicio no relacionado con las actividades-fin de la contratante, sin la existencia de los elementos que caracterizan la relación de empleo, como subordinación, de costumbre, tiempo, personal y salario". El autor llama la atención sobre el hecho de que se admite la tercerización en servicios especiales tales como de vigilancia y de limpieza y en otras relacionadas con la actividad-medio del tomador, conforme a la súmula 331 del Tribunal Superior del Trabajo, documento éste que toma el lugar de la ley acerca de la materia. ${ }^{547}$

\title{
Para Rodrigo García Schwarz,
}

\begin{abstract}
"En la cesión de mano de obra una empresa pone a disposición los trabajadores de la empresa contratante, en las dependencias de esta o en las de terceros, para que realicen servicios continuados relacionados o no con la actividad-fin de la empresa. Se trata de la expresión más común del fenómeno conocido como tercerización laboral.

El Derecho del trabajo prohíbe la contratación de trabajadores a través de una empresa interpuesta -la figura del marchandage-. La contratación de mano de obra, por tanto, cualificada en la conducta de aquél que contrata trabajadores y les pone simplemente a disposición de un empresario, de quien recibe órdenes, no es un procedimiento admitido, formándose, en el caso, un vínculo de empleo directamente con el tomador". ${ }^{548}$
\end{abstract}

El autor añade que el Tribunal Superior del Trabajo, al publicar la Súmula 331, hace una clara distinción entre actividad-medio y actividad-fin, para verificar

${ }^{547}$ COUTO MACIEL, José Alberto, "Terceirização na atividade-fim. Empresas de telecomunicações e outras concessionárias do serviço público. Novos projetos de lei e inovações de liminar concedida no STF". En Revista do Tribunal Superior do Trabalho, Porto Alegre; Magister Editora, ano 74, no. 4, outubro a diciembre de 2008, p. 137.

${ }^{548}$ GARCIA SCHWARZ, Rodrigo, Direito do trabalho, Rio de Janeiro; Elsevier, 2 $2^{\mathrm{a}}$ ed; 2009 p. 66. 
la legalidad o ilegalidad de la tercerización o de la cesión de mano de obra. Para Schwarz, "de todos modos, el factor principal es la verificación de la inexistencia de la personalidad y de la subordinación directa para el tomador en la prestación de servicios; si están presentes tales elementos, se forma el vínculo de empleo directamente con el tomador". 549

Carmen Camino argumenta que la tercerización o "terciarización" de los servicios en la empresa debe examinarse a la luz de los rasgos típicos de la relación de empleo, "no eventualidad de los servicios, subordinación jerárquica del empleado y personalidad de la prestación de la fuerza de trabajo - bajo una óptica más flexible, a fin de permitir, en determinadas circunstancias, la delegación de algunas actividades de la empresa para terceros". 550

La autora añade que la jurisprudencia del Tribunal Superior del Trabajo, desde una perspectiva más flexible, acabó por crear la posibilidad de tercerización de la actividad-medio del tomador de los servicios, siempre que el trabajo no sea prestado de forma personal y/o subordinado al tomador. Suma eso a las posibilidades de tercerización permitidas por ley y muestra que es posible esta forma de contratación en los casos de vigilancia, higiene y limpieza, en virtud del artículo 577 de la CLT ${ }^{551}$, junto con el Anexo I. ${ }^{552}$

Para Gustavo Filipe Barbosa García, la tercerización "puede ser entendida como la transferencia de ciertas actividades del tomador de servicios que serán ejercidas por empresas distintas". Lo que importa, a efectos del derecho del trabajo, es disponer de un trabajador que preste servicios al tomador, pero con

\footnotetext{
549 GARCIA SCHWARZ, Rodrigo, Direito do trabalho, cit., p. 66/67.

550 CAMINO, Carmen, Direito individual do trabalho, Porto Alegre; Síntese Editora, 4ª ed; 2004, p. 235/236.

551 "Art. 577 de la CLT - El cuadro de Actividades y Profesiones en vigor fijará el plan básico del encuadramiento sindical".

552 CAMINO, Carmen, Direito individual do trabalho, cit., p. 236/237.
} 
una relación jurídica con la empresa prestadora de servicios. La relación, en estos casos, es trilateral o triangular. ${ }^{553}$

La tercerización es cada vez más común hoy, como una manera de reducir los costes, proporcionar servicios con mayor eficiencia, productividad y competitividad, que son objetivos evidentes en tiempos de globalización. Sin embargo, hay límites a esta forma de contratación, para proteger las garantías del contrato de empleo. ${ }^{554}$

En el caso brasileño, la jurisprudencia ha entendido que es lícita la tercerización en los casos de actividad-medio del tomador de servicios, sin llegar a formar un vínculo jurídico directo con este último. Su responsabilización, en el caso de un eventual incumplimiento por parte del prestador es subsidiaria; es decir, obliga, más bien, a agotar las posibilidades de cobrar al deudor principal, al prestador (empleador) para, después de la ejecución, tomar las medidas frente a quien contrate los servicios.

En este sentido, establece la Súmula 331 del Tribunal Superior del Trabajo:

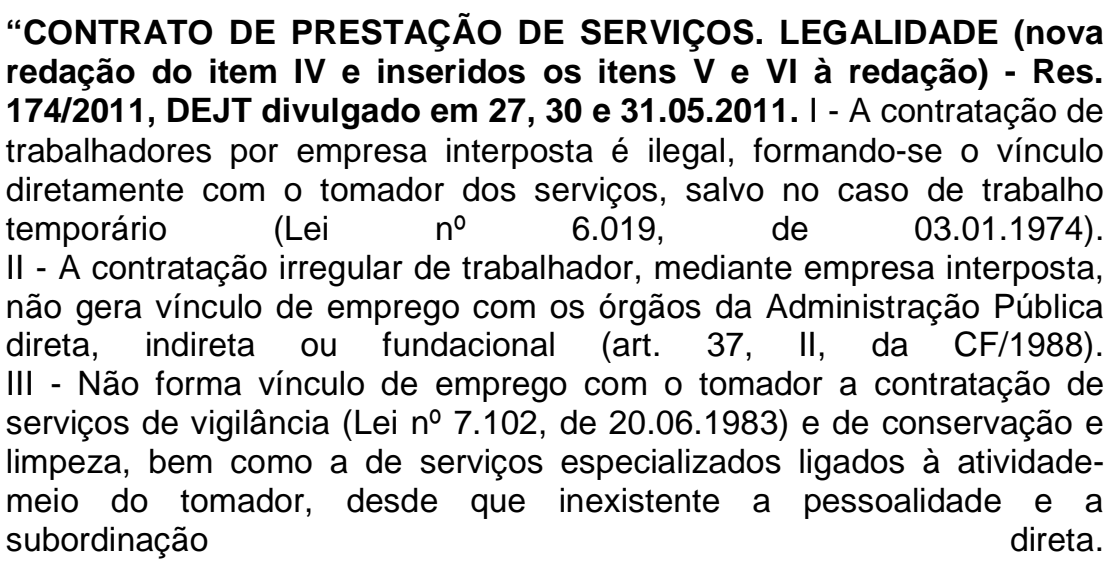

${ }^{553}$ BARBOSA GARCIA, Gustavo Filipe, "Responsabilidade da administração pública na relação de trabalho triangular". En: Revista Justiça do Trabalho, número 291, Porto Alegre: HS Editora, março de 2008, p. 7.

554 SÁNCHEZ ÁLVAREZ, Manuel María, "Nuevas formas de organización empresarial. Deslocalización, descentralización y externalización. Empresa principal, contratas y subcontratas". En Siniestralidad laboral y derecho penal, Madrid; Consejo General del Poder Judicial. Centro de Documentación General. Cuadernos de Derecho Judicial, XV - 2005, 2006, p. 109/110. 
IV - O inadimplemento das obrigações trabalhistas, por parte do empregador, implica a responsabilidade subsidiária do tomador dos serviços quanto àquelas obrigações, desde que haja participado da relação processual e conste também do título executivo judicial. V - Os entes integrantes da Administração Pública direta e indireta respondem subsidiariamente, nas mesmas condições do item IV, caso evidenciada a sua conduta culposa no cumprimento das obrigações da

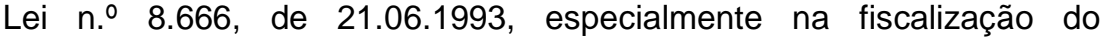
cumprimento das obrigações contratuais e legais da prestadora de serviço como empregadora. A aludida responsabilidade não decorre de mero inadimplemento das obrigações trabalhistas assumidas pela empresa regularmente contratada. VI - A responsabilidade subsidiária do tomador de serviços abrange todas as verbas decorrentes da condenação referentes ao período da prestação laboral".

Jorge Souto Maior argumenta que con el fin de conferir un patrón jurídico al fenómeno de la descentralización del trabajo, exigencia ésta según el autor de la "ola de modernidad", el Tribunal Superior del Trabajo, en 1993, publicó el Enunciado 331, "por el cual se comenzó a considerar lícita la tercerización, en la 'actividad-medio' de la empresa y atribuyendo una responsabilidad 'subsidiaria' de la empresa tomadora de los servicios". 555

Para Souto Maior este criterio adoptado por el Tribunal Superior del Trabajo no fue acertado. Justifica argumentando que para diferenciar la tercerización lícita de la ilícita, "se partió de un presupuesto impreciso, a saber, la diferencia entre actividad-fin y actividad-medio. Es muy inseguro tratar de definir lo que tiene que ser una y otra. El servicio de limpieza, por ejemplo, a menudo descrito como actividad-medio, ¿será también una actividad-medio? Y, si se trata de un hospital, el servicio de limpieza ¿puede considerarse en un segundo plano de importancia?". El autor se pregunta, pues, lo que sería una actividad-fin. Dónde comienza la actividad-medio y dónde termina la actividad-fin. Acaba por asociar la actividad-fin de la empresa al lucro que, de hecho, es su objetivo principal. ${ }^{556}$

\footnotetext{
555 SOUTO MAIOR, Jorge Luiz, Curso de direito do trabalho, cit., p. 143.

556 "Es todo muy impreciso y sirve sólo para generar dudas de las cuales se valen algunos seguimientos económicos para generar inseguridad jurídica a los trabajadores. En el fondo, la gran verdad es que el fin de las empresas es la obtención del lucro. Todo lo demás es un medio para alcanzar el mismo fin. En este sentido, todas las actividades permanentes de una empresa se interconectan de forma inseparable y poseen igual relevancia, en el contexto más amplio de la
} 
Souto Maior añade que la Súmula 331 del Tribunal Superior del Trabajo acabó por legalizar la intermediación de mano de obra, prohibida en Brasil ${ }^{557}$, conforme al antiguo enunciado 256 del Tribunal Superior del Trabajo. ${ }^{558}$ Lo que sucede es que la tercerización acabó por reducir los costes de producción a las empresas, así como hemos establecido en el capítulo anterior de esta investigación, revalorizar o supravalorar las acciones de las empresas en el mercado financiero, al coste del trabajo precario de "sus" empleados.

La edición de esta Súmula 331 del Tribunal Superior del Trabajo desvirtuó completamente la función histórica del derecho del trabajo en su objetivo de protección del trabajador. Atendió una reclamación empresarial, como se ha dicho, sin aportar ningún beneficio en términos de especialización o de producción, precarizando únicamente el trabajo. ${ }^{559}$

En la práctica judicial, añade Souto Maior, se pueden percibir perfectamente los efectos de la tercerización. Ha contribuido a dificultar, demasiado, la identificación del empleador real de aquél que busca sus derechos ante la justicia del trabajo. ${ }^{560}$ El trabajador muchas veces no sabe ni el nombre de la empresa o incluso de su "superior" jerárquico. Sabe sólo que trabajó dentro de la empresa "tal", como "tercero".

Además de todos estos problemas la tercerización acaba por alienar aún más a los trabajadores de los medios de producción. "Su integración, que antes se imaginaba por el ejercicio del trabajo, hoy es impensable. El trabajador tercerizado no se inserta en el contexto de la empresa tomadora; es siempre dejado de medio

\footnotetext{
estructura empresarial formada, para la obtención de la iniciativa". (SOUTO MAIOR, Jorge Luiz, Curso de direito do trabalho, cit., p. 143/144).

557 SOUTO MAIOR, Jorge Luiz, Curso de direito do trabalho, ibidem.

558 Enunciado 256 (cancelado). "Contrato de prestación de servicios. Legalidad. Salvo en los casos de trabajo temporal y de servicio de vigilancia, previstos en las Leyes 6.019, de 31.1.1974, y 7.102, de 20.6.1983, es ilegal la contratación de trabajadores mediante empresa intermediaria, formándose el vínculo laboral directamente con el tomador de los servicios".

559 SOUTO MAIOR, Jorge Luiz, Curso de direito do trabalho, ibidem.

560 SOUTO MAIOR, Jorge Luiz, Curso de direito do trabalho, cit., p. 145.
} 
lado, incluso para que no se diga que hubo subordinación directa entre la tomadora de los servicios y el trabajador". ${ }^{561}$

Se crean, bajo el amparo de la Súmula 331 del Tribunal Superior del Trabajo, trabajadores de segunda clase dentro de la misma empresa ${ }^{562}$. Unos tienen "mayor dignidad" que otros. Reciben protección de las comisiones internas de prevención de accidentes (CIPA's) y los otros (terceros) no. La dignidad del "empleado" parece ser mayor que la del tercero. Parece que la vida, que el "ser en el mundo" del empleado contratado en forma vale más que la del otro humano contratado por persona interpuesta.

De ahí se puede ver que no podría haber tercerización lícita. No hay como aceptar la tercerización sin que haya una reducción considerable en los derechos y dignidad del trabajador. En efecto, la norma del artículo $7^{\circ}$, encabezamiento, de la Constitución brasileña de 1988 establece que los derechos de los trabajadores deben tener por objetivo central la "mejora de la condición social de éstos". No hay mejora cuando se crean, dentro de la misma empresa, "castas" de trabajadores, trabajadores éstos que generan el lucro para la misma empresa. Hay que tener presente que el lucro es el fin de la empresa, de la iniciativa económica, sin tener en cuenta, dentro de las reglas, lo que se va a hacer para llegar a conseguirlo.

Jorge Souto Maior, que en una determinada etapa de sus investigaciones jurídicas, entendió que era posible proteger al trabajador sin negar la tercerización,

\footnotetext{
561 "Hay, sin embargo, otro efecto poco evaluado, pero intensamente perverso como es el de la irresponsabilidad concreta en cuanto a la protección del medio-ambiente de trabajo. Los trabajadores tercerizados, al no integrarse en las CIPA's y al no tener una representación sindical en el ambiente de trabajo, se someten a trabajar en las condiciones que les son presentadas, sin ninguna posibilidad de rechazo institucional. El medio-ambiente laboral, asimismo, es relegado a un segundo plano, generando un sensible aumento de las enfermedades en el trabajo". (SOUTO MAIOR, Jorge Luiz, Curso de direito do trabalho, cit., p. 146).

${ }^{562} \mathrm{Y}$ el problema puede tener sus reflejos en la salud del trabajador, por la pérdida de referencia de su lugar de trabajo. "La despersonalización del local del trabajo entraña además una pérdida de los referentes; la tendencia de abrir el espacio puede revelarse catastrófica para las relaciones de trabajo..." MIALON, Marie-France, "Nouvelles formes de gouvernance et attentes morales des salariés. L'experience française", Revista do Tribunal Regional do Trabalho da $3^{\text {a }}$ Região, Belo Horizonte, v. 50, n. 80, jul/dez, 2009, p. 177. Esta autora menciona los casos de suicidio en las empresas francesas por causa del trabajo.
} 
llegó a la conclusión de que no se puede tolerar este fenómeno. No cabe que el derecho, "se adapte a las injusticias sino que sirva de instrumento eficaz para combatir cualquier tipo de reducción de la dignidad humana (...)”. Esta conclusión tiene en cuenta los principios de protección al trabajo, además del significado literal de las leyes que inciden sobre estas hipótesis fácticas a las que se refiere la tercerización. ${ }^{563}$

No se puede alienar al trabajador, doblemente, doble alienación, del bien que produce. Si el trabajador se aliena cuando se produce la mercancía, pues es ésta la que crea vida propia, los frutos de la venta o la comercialización del producto deben quedar lo más cerca posible de él, dado que son estos valores los que van a garantizar el pago de su salario. Cuando se producen bienes a favor de terceros, quien trabaja no tiene la garantía del pago. No tiene algo concreto que permita asegurar el cumplimiento de su crédito, considerando que la energía empleada en la producción de este mismo bien no puede ser devuelta jamás.

Es importante recalcar que si el legislador hubiera querido la tercerización con carácter general, lo podría haber hecho por ley, y no lo ha hecho hasta hoy. Por eso, la interpretación 331 del TST, hiere la voluntad del legislador, que no ha creado la posibilidad de la subcontratación en sentido general en Brasil. Como ha dicho Goerlich Peset, cuando estudia las contratas y la posibilidad o no de que

\footnotetext{
563 “Ahora, la Súmula N. 331, del TST, al dar cobijo a la reivindicación de la economía, en lo que se refiere a la necesidad de la implementación de la tercerización, hizo letra muerta del art. $2^{\circ}$ de la CLT, el cual considera empleador a la "empresa" que asume los riesgos de la actividad económica. Ahora, quien se inserta en el contexto productivo de otros, con la mera prestación de servicios, ya sea personalmente, ya sea en la forma de una empresa de prestación de servicios, no asume ningún riesgo económico relativo a la producción, de ahí el porqué, según la definición legal, no puede considerarse empleador.

La vinculación de la figura del empleador al riesgo de la actividad económica tiene sentido porque es éste quien, administrando la producción, posee los bienes corpóreos e incorpóreos necesarios para la consecución de los fines empresariales. Estos bienes, a su vez, constituyen los garantes naturales del pasivo laboral que se genera". (SOUTO MAIOR, Jorge Luiz, Curso de direito do trabalho, ibidem).
} 
cualesquiera relaciones interempresariales puedan ser consideradas como contratas: "Si el legislador hubiera querido esto, lo habría dicho expresamente" 564

Tarso Gerno, sobre eso, afirma, en un estudio sobre la ley del trabajo temporal -ley 6.019, de 03 de enero de 1974 (empresa de trabajo temporal)- que esta forma de contratación transforma al empleado, doblemente, en una pieza del engranaje productivo, no pudiendo él ni siquiera escoger a quién o a qué tomador se adhiere, haciendo de manera que es doblemente explotado, "sometido a aquella tensión de intereses entre dos empresas que buscan lucro y necesitan, pues, intensificar la explotación de su fuerza de trabajo, cuya plusvalía se divide a favor de dos patrones". 565

Una tercerización, añade Souto Maior, que sea necesaria o indispensable para la realización empresarial, independientemente de que esté ligada a la actividad-medio o a la actividad-fin, no puede ser transferida a terceros, sin que se considere que aquél que se sirve del trabajador subordinado y que asume los riesgos de la actividad económica es el empleador real. ${ }^{566}$

Sin embargo, Souto Maior entiende que la tercerización podrá concretarse válidamente, sólo en el sentido de mantener una relación de empleo entre los "trabajadores y la empresa prestadora, cuando la prestación de servicios posea una actividad empresarial propia, asumiendo el riesgo económico, que es propio de la actividad empresarial, y su contratación se destine a la realización de servicios especializados, es decir, servicios que no sean indispensables 0 permanentes en el desarrollo de la actividad productiva de la empresa contratante (tomadora)", lo que configuraría una situación excepcional, siempre con duración predeterminada. ${ }^{567}$

\footnotetext{
564 GOERLICH PESET, José María, "Determinación del supuesto: la noción de contrata y subcontrata de obras y servicios", cit., p. 100.

${ }^{565}$ GENRO, Tarso Fernando, Direito individual do trabalho, cit., p. 115/116.

566 SOUTO MAIOR, Jorge Luiz, Curso de direito do trabalho, ibidem.

${ }^{567}$ SOUTO MAIOR, Jorge Luiz, Curso de direito do trabalho, ibidem.
} 
En un sentido opuesto, conviene citar la posición de Francisco Antônio de Oliveira. Para ese autor, lo que consta en el inciso I, de la Súmula 331, del TST ${ }^{568}$, tiene por objetivo desalentar la transformación del trabajador en mercancía. ${ }^{569}$

En cuanto al inciso III de la Súmula 331, Francisco Antônio de Oliveira argumenta que la redacción que se da a la misma no es la mejor ${ }^{570}$. Apunta como sugerencia la siguiente redacción: "No forma vínculo de empleo con el tomador, siempre que no exista la personalidad y la subordinación, la contratación de servicio de vigilancia (Ley 7.102, de 20.6.1983), de conservación y limpieza, así como los servicios especializados ligados a la actividad del tomador". ${ }^{571}$

El autor paulista se refiere, en base a la redacción de la Súmula 331 del TST, a que la personalidad y a la subordinación concierne al todo, y no solamente a las actividades de vigilancia, conservación y limpieza. Para él "existe la posibilidad de contratación, a través de empresa de terceros, para los servicios de vigilancia, servicios de conservación y limpieza, así como los servicios especializados, sin que el vínculo se forme con la empresa tomadora, siempre que en ésta no exista personalidad y subordinación". 572

F. A. de Oliveira subraya que con respecto a la subordinación, no son las pequeñas órdenes dirigidas al trabajador las que van a hacer de él un empleado de la tomadora. Por ejemplo, no se ajusta al concepto de subordinación una institución financiera que determina que un vigilante ejecute sus funciones, en el día tal, en el lugar tal, otro día en otro lugar, y así sucesivamente, ni que la

\footnotetext{
568 "Súmula 331 del TST I - La contratación de trabajadores por empresa intermediaria es ilegal, formándose el vínculo directamente con el tomador de los servicios, salvo en el caso de trabajo temporal (Ley no 6.019, de 03.01.1974) (...)".

${ }^{569}$ OLIVEIRA, Francisco Antônio, Comentários às súmulas do TST, São Paulo; Eitora Revista dos Tribunais, $6^{\circ}$ ed., 2005, p. 834.

570 "Súmula 331 (...) III - No forma vínculo de empleo con el tomador la contratación de servicios de vigilancia (Ley no 7.102, de 20.06.1983) y de conservación y limpieza, así como la de servicios especializados ligados a la actividad-medio del tomador, siempre que no exista la personalidad y la subordinación directa (...)".

${ }_{571}$ OLIVEIRA, Francisco Antônio, Comentários às súmulas do TST, cit., p. 835.

572 OLIVEIRA, Francisco Antônio, Comentários às súmulas do TST, cit., p. 836.
} 
limpieza deba realizarse en los horarios y conforme al movimiento de la empresa, comenzando, por ejemplo, por esta o por aquella sala. Advierte que en el caso de un desempeño deficiente, la empresa tomadora debe comunicarlo a la prestadora para que adopte las medidas oportunas. No puede haber personalidad 0 subordinación, sin que se caractericen cualquiera de estos dos elementos, como ya hemos indicado, de pequeñas intervenciones o determinaciones genéricas. ${ }^{573}$

Sin embargo, Barbosa García argumenta que las restricciones en cuanto a la subcontratación en Brasil "son impuestas para tutelar las garantías inherentes a la relación de empleo, de forma que se preserve el valor constitucional del trabajo (arts. $1^{\circ}$, inciso IV, 170, caput, de la CF/88), respetando el principio magno de la dignidad de la persona humana (arts. $1^{\circ}$, inciso III)". Hace referencia al hecho de que -conforme a la Súmula 331 del Tribunal Superior del Trabajo- se pueden tercerizar las actividades-medio de las empresas pero no las actividades ligadas al fin de la tomadora de los servicios. ${ }^{574}$

De ahí se desprende que la Súmula 331 del Tribunal Superior del Trabajo, cuando excluye si se puede terceirizar la actividad-fin, se dirige a proteger el trabajador, -posición con la que no podemos concordar-, en razón de que no hay, en la legislación brasileña, una previsión legal para la tercerización en un sentido general.

Lo que se debe tener presente, y que será objeto de estudio en este capítulo de forma específica, es que la tercerización está permitida en el caso del trabajo a través de empresas de trabajo temporal según la ley 6.019/74, servicios de vigilancia de la ley 7.102/83, administración pública conforme al decreto-ley 200/67, ley de las telecomunicaciones conforme al 9.472/97, régimen de las concesiones y permisos públicos, ley $8.987 / 95$ y ley $12.023 / 09$.

\footnotetext{
573 OLIVEIRA, Francisco Antônio, Comentários às súmulas do TST, cit., p. 836/837.

574 BARBOSA GARCIA, Gustavo Filipe, "Equiparação salarial na terceirização de serviços". En Revista Justiça do Trabalho, número 296, Porto Alegre; HS Editora, agosto de 2008, p. 61.
} 
En los casos de tercerización el objeto del acuerdo entre las empresas es la realización de un servicio. El tomador contrata la realización de algun servicio y no el trabajo de este o de aquel trabajador. Poco importa quién o cuál trabajador ejecutará las tareas, en el caso de que lo haga. Las sustituciones o faltas al trabajo son administradas por la prestadora, sin ninguna interferencia de la tomadora. Si no es así, habrá un vínculo directo entre la tomadora y el trabajador, quedando la prestadora en la condición de una mera intermediaria de mano de obra, responsable solidaria en razón del incumplimiento del artículo $9^{\circ}$ de la $\mathrm{CLT}^{575}$, responsabilidad ésta en base al artículo 942 del Código Civil brasileño. ${ }^{576}$.

En este mismo sentido argumenta Barbosa García que en la tercerización "no importa la persona que esté efectivamente prestando los servicios tercerizados, sino la actividad empresarial contratada, siendo irrelevante cualquier sustitución de trabajadores de la prestadora. La empresa tomadora, en la tercerización, contrata el servicio empresarial ofrecido, pero no la mano de obra o un determinado trabajador". En los casos en los que hay tercerización lícita "quien deba fiscalizar, controlar y organizar las actividades del empleado (del servicio tercerizado) no es el ente tomador, sino el empleador, que es la empresa prestadora. Al final, en el caso que se examina, la relación jurídica del tomador es con la citada empresa y no con los empleados de esta". ${ }^{577}$

Sin embargo, habiendo una dirección por parte del tomador, Barbosa García reconoce que puede haber habido intermediación de mano de obra, caso en que, en virtud del artículo 9ำ de la CLT, habrá incumplimiento de los preceptos

\footnotetext{
575 "Art. 9o - Serán nulos de pleno derecho los actos practicados con el objetivo de desvirtuar, impedir o falsificar la aplicación de los preceptos contenidos en la presente Consolidación".

576"Art. 942. Los bienes del responsable por la ofensa o violación del derecho de otros quedan sujetos de la reparación del daño causado; y, si la ofensa tiene más de un autor, todos responderán solidariamente para la reparación. Párrafo único. Son solidariamente responsables con los autores, los coautores y las personas designadas en el art. 932".

${ }_{577}$ BARBOSA GARCIA, Gustavo Filipe, "Equiparação salarial na terceirização de serviços", cit., p. 62.
} 
jurídico-laborales, no produciendo, frente al trabajador, ningún efecto para este contrato de prestación de servicios. ${ }^{578}$

En cuanto al poder público, cuando éste contrata servicios tercerizados, la Súmula 331, II, del Tribunal Superior del Trabajo ${ }^{579}$ establece que no habrá un vínculo de empleo entre el trabajador y la administración, incluso en los casos de contratación irregular, dada la ausencia de concurso público, exigido por el artículo 37 , inciso II y párrafo $2^{\circ}$, de la Constitución brasileña de $1988^{580}$.

Barbosa García recuerda que conforme a la orientación jurisprudencial 321 de la SBDI-I del Tribunal Superior del Trabajo ${ }^{581}$, con relación al período anterior a la Constitución federal de 1988, una vez que haya contratación ilegal de trabajadores, por persona interpuesta, hay vínculo directamente con el tomador de los servicios, incluso si se trata del poder público, ya que la Constitución brasileña

578 " $\mathrm{Si}$, con el fin de tercerizar una cierta actividad, se contratara una empresa prestadora, pero el tomador ejerciera el poder directivo ante el trabajador, éste, seguramente, en realidad, tendrá su relación jurídica de empleo con el propio tomador. Se trata de la consecuencia de la tercerización considerada ilícita.

Además, incluso la empresa que intermedió la mano de obra, también puede responder, de forma solidaria, por los créditos laborales, en base al art. 942 del Código Civil de 2002 (correspondiente al Art. 1.518 del Código Civil de 1916), c/c art. 8o, párrafo único, de la CLT, justamente por haber participado en la lesión del derecho derivado de la tercerización fraudulenta". (BARBOSA GARCIA, Gustavo Filipe, "Equiparação salarial na terceirização de serviços", cit., p. 63).

579 "Súmula 331 (...); II - La contratación irregular de un trabajador, mediante empresa intermediaria, no genera un vínculo de empleo con los órganos de la administración pública directa, indirecta o fundacional (art. 37, II, de la CF/1988)".

580“Art. 37. La administración pública directa e indirecta de cualquiera de los Poderes de la Unión, de los Estados, del Distrito Federal y de los Municipios obedecerá a los principios de legalidad, impersonalidad, moralidad, publicidad y eficiencia y, también, al siguiente: I - los cargos, empleos y funciones públicas son accesibles a los brasileños que cumplan con los requisitos establecidos en la ley, así como a los extranjeros, en la forma de la ley; II - la investidura en cargo o empleo público depende de aprobación previa mediante concurso público de pruebas o de pruebas y títulos, de acuerdo con la naturaleza y la complejidad del cargo o empleo, en la forma prevista en la ley, con excepción de los nombramientos para cargo en comisión declarado en ley de libre nombramiento y exoneración; (...); § oㅡ - La no observancia de lo dispuesto en los incisos II y III implicará la nulidad del acto y la punición de la autoridad responsable, en los términos de la ley".

581 "Súmula 331 (...); II - La contratación irregular de trabajador, mediante empresa intermediaria, no genera un vínculo de empleo con los órganos de la administración pública directa, indirecta o fundacional (art. 37, II, de la CF/1988)". 
de 1967, con redacción de la enmienda constitucional número $1 / 69^{582}$, no exigía, a los empleados públicos regidos por la CLT, la aprobación en concurso público. ${ }^{583}$.

Rodrigo Coimbra Santos, en relación al período anterior a la Constitución brasileña de 1988, hace otra consideración. A partir de la orientación jurisprudencial 321, de la Sección de Litigios Individuales 1, -Seção de Dissídios Individuais- del tribunal Superior del Trabajo, en las contrataciones por empresas interpuestas, antes del 05 de octubre de 1988, no había la posibilidad de la condena de forma subsidiaria del tomador de los servicios, debiendo existir un reconocimiento del vínculo de empleo para este último, incluso siendo un ente público, salvo para el trabajo temporal y los servicios de vigilancia. ${ }^{584}$

Hay que tener presente que la Constitución brasileña de 1988 no aportó nada nuevo que pudiera modificar la interpretación como para admitir la tercerización. Por el contrario, los derechos de los trabajadores deberían tratar de mejorar la condición social de éstos, lo que esta forma de contratación no hace.

Volviendo al presente, la responsabilidad del poder público, en los casos de tercerización lícita, será subsidiaria, conforme a la redacción del inciso IV de la Súmula 331 del Tribunal Superior del Trabajo, así como en los casos de los

\footnotetext{
582 "Art. 97. Los cargos públicos serán accesibles a todos los brasileños que cumplan los requisitos establecidos en la ley. $\S 1^{\circ}$ La primera investidura en cargo público dependerá de la aprobación previa, en concurso público de pruebas y títulos, salvo los casos indicados en la ley. (...)".

583 "Art. 37. La administración pública directa e indirecta de cualquiera de los Poderes de la Unión, de los Estados, del Distrito Federal y de los Municipios obedecerá a los principios de legalidad, impersonalidad, moralidad, publicidad y eficiencia y, también, al siguiente: I - los cargos, empleos y funciones públicas son accesibles a los brasileños que cumplan con los requisitos establecidos en la ley, así como a los extranjeros, en la forma de la ley; II - la investidura en cargo o empleo público depende de aprobación previa mediante concurso público de pruebas o de pruebas y títulos, de acuerdo con la naturaleza y la complejidad del cargo o empleo, en la forma prevista en la ley, con excepción de los nombramientos para cargo en comisión declarado en ley de libre nombramiento y exoneración; (...); § 2o - La no observancia de lo dispuesto en los incisos II e III implicará la nulidad del acto y la punición de la autoridad responsable, en los términos de la ley".

584 COIMBRA SANTOS, Rodrigo, "Repensando a responsabilidade subsidiária do tomador de serviços terceirizados nas atividades lícitas". En Revista justiça do trabalho, Porto Alegre; HS Editora, no. 288, dezembro de 2007, p. 62/63.
} 
tomadores privados ${ }^{585}$. Este tema de la responsabilidad será tratado en un apartado específico sobre la responsabilización en los casos de tercerización, tanto lícita como ilícita, porque hay decisión reciente, Acción Directa de Constitucionalidad numero 16 que altera en parte los términos da Súmula 331 del TST.

Finalmente, no hay razón para no aplicar la norma laboral que impide la transferencia del vínculo jurídico de la empresa productiva, conocida como tomadora, porque si no fuera así se negaría, en concreto, la vocación adquirida por el derecho del trabajo de extraer de sus normas y principios una respuesta humanista, con el fin de combatir toda y cualquier forma de precariedad de la condición de ser humano del trabajador dentro de la relación de empleo. ${ }^{586}$

La cuestión de la licitud y constitucionalidad de la tercerización será tratada más adelante. Por ahora lo importante es saber lo que generalmente se entiende por tercerización.

\subsubsection{De la responsabilización del tomador de los servicios en el caso de tercerización}

Como ya hemos mencionado anteriormente, la tercerización, desde el punto de vista del análisis jurídico, nace como una forma de organización empresarial. $^{587}$

La tercerización, es una especie de relación de trabajo, considerada atípica en contraste con la relación de trabajo tradicional. La tercerización y la relación de

\footnotetext{
585 "Súmula 331 del TST (...); IV - El incumplimiento de las obligaciones laborales, por parte del empleador, implica la responsabilidad subsidiaria del tomador de los servicios, con respecto a las obligaciones, incluso en cuanto a los órganos de la administración directa, de las autarquías, de las fundaciones públicas, de las empresas públicas y de las sociedades de economía mixta, siempre que hayan participado en la relación procesal y consten también del título ejecutivo judicial (Art. 71 de la Ley no 8.666, de 21.06.1993)".

${ }_{586}^{586}$ SOUTO MAIOR, Jorge Luiz, Curso de direito do trabalho, cit., p. 148.

${ }^{587}$ COIMBRA SANTOS, Rodrigo, "Repensando a responsabilidade subsidiária (...)", cit., p. 59.
} 
trabajo se han fortalecido con la nueva redacción del artículo 114 de la Constitución brasileña de 1988, modificada por la enmienda constitucional 45, del 08 de diciembre de $2004 .^{588}$

Así como se ha desarrollado el concepto de tercerización, ha acabado por desarrollarse el concepto de responsabilidad en los casos de tercerización. En el ordenamiento jurídico brasileño, no hay ningún artículo de ley que prevea, salvo en los casos de contrata y subcontrata -artículo 455 de la CLT- la responsabilidad en el caso de contratación de trabajadores ante terceros y trabajo temporal. Consciente de ello el Tribunal Superior del Trabajo ha editado, en 1993, la Súmula 331 , creando algunas reglas sobre la tercerización, incluso con respecto a la responsabilidad, que ha pasado a ser subsidiaria.

Esta situación se ha mantenido sin cambios hasta la actualidad. Se debe ejecutar y agotar la ejecución del prestador de los servicios con el fin de cobrar, después, la deuda del tomador. Éste deberá constar del título ejecutivo, porque se ha beneficiado de la prestación de los servicios ${ }^{589}$, incluso comprobando la correcta elección y fiscalización con respecto al cumplimiento de la legislación social.

La cuestión de la responsabilidad del tomador de los servicios es importante. En la actualidad, destaca el ministro del Tribunal Superior del Trabajo Vantuil Abdala, hay 9.259 procesos en el Tribunal Superior del Trabajo en los que el trabajador cobra del tomador de los servicios importes no pagados por el prestador. Y recuerda que menos de un diez por ciento de los procesos presentados en Brasil llegan al TST, lo que permite entender las dimensiones del

\footnotetext{
${ }^{588}$ COIMBRA SANTOS, Rodrigo, "Repensando a responsabilidade subsidiária (...)", ibidem.

589 En este sentido: "RESPONSABILIDADE SUBSIDIÁRIA. A CEF recebeu a força de trabalho da Reclamante, devendo responder subsidiariamente quanto às obrigações trabalhistas, nos termos do Enunciado 331, IV, do TST. Revista conhecida e provida". (Proc. no RR-274292/1996-9 - 6 Região - AC. 2 ${ }^{\text {a }}$ Turma, Rel. Min. Moacyr Roberto Tesch Auersvald. Recorrente: Maria Izabel de Lira Neto. Recorrida: Caixa Econômica Federal - CEF. TST, un., DJU 30.10.98, p. 123).
} 
problema creado por la tercerización y la importancia del tema relacionado con la responsabilidad del tomador del trabajo. ${ }^{590}$

Es interesante decir que, aunque no haya previsión en la ley para la responsabilización subsidiaria, el Tribunal Superior del Trabajo ha puesto como regla esta foma de responsabilización. Sobre ello son necesarias algunas consideraciónes en especial sobre la necesidad de superacion del entendimiento de la responsabilidad subsidiaria, por el de la solidaria.

\subsubsection{De la responsabilidad subsidiaria}

El Tribunal Superior del Trabajo, por la Súmula 331, IV, entiende que en los casos de tercerización lícita, la responsabilidad del tomador de los servicios por los débitos del prestador hacia sus empleados es subsidiaria. Pero ¿qué es la responsabilidad subsidiaria?

En el Diccionario Jurídico de la Academia Brasileña de Letras Jurídicas consta que responsabilidad subsidiaria es "la responsabilidad incidente sobre garantías que sólo son llamadas cuando es insuficiente la garantía principal. Ej.: los bienes de los socios en las sociedades de responsabilidad ilimitada, sólo perseguibles a falta de suficientes bienes sociales. CC, art. 1023". El diccionario define como subsidiario lo que es secundario, es decir lo que concede subsidio. ${ }^{591}$

Caio Mário Da Silva Pereira afirma que el beneficio de orden da derecho al garante o fiador para que exija primero la ejecución de los bienes del deudor principal en caso de deuda con el acreedor. Hace la distinción entre la solidaridad y el beneficio de orden, siendo, en este caso ambos, deudor y garante,

\footnotetext{
${ }_{590}$ Revista da Associação Nacional dos Magistrados da Justiça do Trabalho, cit., p. 13.

591 Dicionário Jurídico: Academia Brasileira de Letras Jurídicas, Rio de Janeiro; Forense Universitária, 9ae ed; 2004, p. 759/760 e 822.
} 
responsables de la cosa toda, sin posibilidad de que este último exija primero la ejecución de los bienes del deudor principal. ${ }^{592}$

Mário Julio de Almeida Costa, sostiene que la obligación será subsidiaria cuando su cumplimiento pueda exigirse sólo en el momento en que el deudor principal no cumpla o no pueda cumplir la obligación que le compete ${ }^{593}$. De ahí podemos concluir que en una prestación de servicios existe en primer lugar la necesidad de agotar primero las posibilidades de cobro del deudor principal y, en segundo lugar, si eso resultara infructuoso, exigir al tomador de los servicios el cobro por haber sido quien, efectivamente, se ha beneficiado de la prestación de trabajo.

Coimbra Santos apunta que para que haya responsabilidad subsidiaria es necesario que la tercerización sea lícita, que los derechos laborales no hayan sido pagados por el deudor principal o prestador de los servicios y que, conforme a la Súmula 331, IV, del TST, la tomadora tenga el título ejecutivo, es decir, que forme parte de la relación jurídica procesal. ${ }^{594}$

Francisco Walker Errázuriz defiende que la responsabilidad subsidiaria hace entender que siempre habrá un responsable principal, un deudor principal, en el caso chileno de la tercerización, el contratista (prestador), siendo el primero responsable por ser el empleador, y un deudor secundario, empresa principal (tomador), que se transforma en una especie de empleador indirecto y que responderá "subsidiariamente" del empleador principal. ${ }^{595}$

¿Qué justificaría la condena, en los casos de tercerización lícita, del tomador de los servicios de forma subsidiaria? ¿Cuál o cuáles doctrinas pueden

\footnotetext{
592 SILVA PEREIRA, Caio Mário da, Instituições de direito civil, Rio de Janeiro; Forense, vol. III, 1995 , p. 332.

${ }^{593}$ COIMBRA SANTOS, Rodrigo, "Repensando a responsabilidade subsidiária (...)", cit., p. 60.

${ }_{594}$ COIMBRA SANTOS, Rodrigo, "Repensando a responsabilidade subsidiária (....)", cit., p. 61/63.

${ }^{595}$ WALKER ERRÁZURIZ, Francisco, Derecho de las relaciones laborales, cit., p. 424.
} 
fundamentar la elección realizada por parte de la jurisprudencia 'sumulada' del Tribunal Superior del Trabajo?

Sobre la responsabilidad subsidiaria, las decisiones que entienden que debe haber la condena del tomador de los servicios de forma subsidiaria sostienen que o hubo mala elección o hubo mala fiscalización, las llamadas culpa "in eligendo" y culpa "in vigilando". 596

Antes de analizar lo que son específicamente cada una de estas especies de culpa, debemos conceptuar la culpa. ¿Qué es, según el ordenamiento jurídico brasileño, la culpa?

Para Aguiar Dias "culpa es la falta de diligencia en la observancia de la norma de conducta, es decir, el desprecio, por parte del agente, del esfuerzo requerido para observarla, con resultado no objetivado, pero previsible, siempre que el agente se detuviera en la consideración de las posibles consecuencias de su actitud" ${ }^{597}$ A partir de este concepto vamos a empezar a desarrollar, en esta investigación, lo que es la culpa, comenzando por la legislación brasileña.

Para la ley civil brasileña, artículo 186 del Código Civil, "aquél que, por acción u omisión voluntaria, negligencia o imprudencia, viole el derecho y cause daño a otros, aunque sea exclusivamente moral, comete un acto ilícito", de donde deriva el concepto de culpa, según ya hemos mencionado y se puede constatar, según la doctrina brasileña, observando, evidentemente, los límites que nos hemos impuesto en esta Tesis Doctoral.

Sobre este tema, Pablo Stolze Gagliano y Rodolfo Pamplona Filho sostienen que la culpa, en su sentido amplio, "deriva de la inobservancia de un

${ }^{596}$ FIGUEIRAS DE GOIS, Luiz Marcelo, "A súmula 331 do TST à luz da certidão negativa de débitos trabailhas". En Revista Justiça do Trabalho n. 331, Porto Alegre; HS Editora, julho de 2011, p. 89.

${ }^{597}$ AGUIAR DIAS, José, Da responsabilidade civil, Rio de Janeiro; Forense, $6^{\text {a }}$ ed., vol. 1, 1979, p. 136. 
deber de conducta, previamente impuesto por la ley, en atención a la paz social. Si esta violación es deliberada, el agente actuó con dolo; si es por negligencia, imprudencia o impericia, su actuación es sólo culposa, en sentido estricto". Los autores elaboran el concepto después del análisis de varios autores brasileños y extranjeros, así como lo que consta en la legislación brasileña. ${ }^{598}$

Añaden además que son elementos de la culpa la voluntariedad de la conducta del agente, es decir, la actuación del agente causador del daño debe ser voluntaria y, si ésta está dirigida a la consecución del resultado habido, habrá dolo; previsibilidad que se entiende por el hecho de que el perjuicio causado sea previsible; y violación de un deber de cuidado. Defienden que hay, por la ley brasileña, grados de culpa, grave, leve y muy leve, además de las especies de culpa, in vigilando, in eligendo, in custodiendo, in comittendo o in faciendo y in omittendo o in negligendo o in non faciendo. ${ }^{599}$

\section{Y ¿qué son culpa in eligendo y culpa in vigilando"?}

Para Pablo Stolze Gagliano y Rodolfo Pamplona Filho la culpa in vigilando es la que "deriva de la falta de vigilancia, de fiscalización, teniendo en cuenta la conducta de un tercero por quien nos responsabilizamos. Ejemplo clásico es la culpa atribuida al padre por no vigiar el hijo que causa el daño". Los autores hacen referencia a que esta especie de culpa figura en el artículo 932, I, del Código Civil brasileño ${ }^{600}$, que consagra la responsabilidad objetiva. La culpa in eligendo es la que deriva de la mala elección. "Tradicionalmente, se apunta como ejemplo la culpa atribuida al patrón por un acto dañoso del empleado o del comitente". Los autores sostienen que este ejemplo también perdió importancia en virtud del

\footnotetext{
598 STOLZE GAGLIANO, Pablo, PAMPLONA FILHO, Rodolfo, Novo curso de direito civil. Responsabilidade civil, São Paulo; Editora Saraiva, Vol. III, $7^{\text {a }}$ ed., 2009, p. 123/124.

599 STOLZE GAGLIANO, Pablo, PAMPLONA FILHO, Rodolfo, Novo curso de direito civil (...), cit., p. 126/133.

600 "Art. 932. Son también responsables por la reparación civil: I - los padres, por los hijos menores que estuvieran bajo su autoridad y en su compañía; (...)".
} 
artículo 932, III, del Código Civil brasileño ${ }^{601}$ que establece, en estos casos, la responsabilidad objetiva. ${ }^{602}$

Coimbra Santos, también según la doctrina civilista, afirma que hay culpa in eligendo en los casos en que la responsabilidad se atribuye a quien escogió mal a la persona que participó en el acto. Y la culpa in vigilando se produce cuando la responsabilidad se le "imputa al que pasó por alto la obligación de vigilar la conducta de otros". 603

$Y$ es por la culpa in eligendo e in vigilando porque la jurisprudencia se asienta con el fin de justificar la condena del tomador de los servicios, de forma subsidiaria, impagando los créditos no cumplidos por la empresa prestadora de servicios.

Coimbra Santos apunta, también, que hay culpa "in eligendo" en la tercerización teniendo en cuenta la mala elección de la prestadora de servicios, pero afirma que eso no es un fundamento incuestionable, ya que tenemos la opinión del Tribunal Superior del Trabajo en un sentido distinto. El autor hace referencia a un juicio de la Quarta Turma do Tribunal, Recurso de Revisión 102/2003-015-03-00-9 -Sala Cuarta del Tribunal de Apelación-, donde el relator niega el fundamento de la culpa in eligendo como fundamento de la responsabilidad subsidiaria de la tomadora, "sosteniendo que tal responsabilidad se produce independientemente 'de cualquier inconveniente económicofinanciero', fundamentando la responsabilidad subsidiaria del tomador de servicios exclusivamente en la culpa in vigilando". ${ }^{604}$

\footnotetext{
601 "III - el empleador o comitente, por sus empleados, funcionarios y agentes, en el desempeño del trabajo que es de su competencia, o en razón de él; (...)".

602 STOLZE GAGLIANO, Pablo, PAMPLONA FILHO, Rodolfo, Novo curso de direito civil (...), cit., p. $130 / 131$.

${ }^{603}$ COIMBRA SANTOS, Rodrigo, "Repensando a responsabilidade subsidiária (...)", cit., 65.

604 "SOCIEDADE DE ECONOMIA MISTA. INTERMEDIAÇÃO DE MÃO-DE-OBRA. RESPONSABILIDADE DA TOMADORA DOS SERVIÇOS. VERBAS PERSONALÍSSIMAS E DE CARÁCTER PUNITIVO. La responsabilidad subsidiaria de la CEMIG se materializa a raíz de la culpa in vigilando, que está asociada con el concepto de inobservancia de la obligación de la empresa tomadora de garantizar el cumplimiento de los derechos laborales debidos a los
} 
En Brasil se sigue hablando de culpa en los casos de tercerización, con el fin de responsabilizar al tomador de los servicios. En el caso francés existe la denominada, para estos casos, presunción de responsabilidad. Coimbra Santos añade que no se trata de responsabilidad objetiva y apunta que hay un equívoco, con respecto a la utilización de la culpa in eligendo e in vigilando, dado que no existe esta forma de culpa por parte del tomador, que no podría ser responsable por el hecho que hubiera cometidos otros, sin cometer acto ilícito. ${ }^{605}$

Como podemos observar, la cuestión de la culpa, con el fin de establecer la responsabilidad civil, no es suficiente. De ahí surge o se avanza para liberarse de la idea de culpa, "desplazando el fundamento de la responsabilidad hacia el riesgo, también llamada la responsabilidad objetiva". Probados el daño y el nexo causal surge el deber de reparar, no teniendo en cuenta la culpa. El responsable es quien causó el daño y por lo tanto la responsabilidad civil es objetiva, sin tener como base la culpa, sino el hecho material de la causalidad. ${ }^{606}$

De ahí surgen las teorías del riesgo-beneficio, riesgo creado, riesgo profesional, riesgo excepcional y riesgo integral. Para Coimbra Santos, en cuanto a la tercerización, sólo las dos primeras tienen importancia.

La teoría del riesgo-beneficio dice que "responsable es aquél que obtiene beneficio de la actividad dañosa, partiendo del razonamiento de que quien tiene el beneficio debe correr el riesgo". Esta teoría es ampliamente aceptada en el derecho como fundamento de la responsabilidad subsidiaria del tomador de los servicios en los casos de tercerización, ya que el trabajo prestado, aun cuando por

\footnotetext{
empleados de la empresa prestadora, independientemente de la verificación del incumplimiento de la ley en la tercerización o de la eventual no idoneidad económico-financiera. De esta forma, la condena subsidiaria del tomador de servicios abarca todas las cantidades adeudadas por el deudor principal, incluyéndose las multas, eso porque, tal como sucede con las demás cantidades, son adeudadas en razón de la culpa in vigilando, motivo por el cual no se considera la limitación de la responsabilidad. Recurso conocido y proveído". (COIMBRA SANTOS, Rodrigo, "Repensando a responsabilidade subsidiária (...)", cit., 65/66).

${ }^{605}$ COIMBRA SANTOS, Rodrigo, "Repensando a responsabilidade subsidiária (...)", cit., 66.

${ }^{606}$ COIMBRA SANTOS, Rodrigo, "Repensando a responsabilidade subsidiária (....)", cit., 67.
} 
persona interpuesta, implica un beneficio para el tomador. En este caso, "la responsabilidad del tomador tendría un carácter muy objetivo, es decir, sin importar la comprobación de la culpa". El tomador responde por los perjuicios ocasionados al trabajador por parte del prestador que no lo pagó, porque se benefició de los servicios prestados por parte del trabajador. ${ }^{607}$

La teoría del riesgo creado amplía el concepto de la teoría del riesgobeneficio, porque aumenta los costes del agente y disminuye con relación a la víctima, partiendo del presupuesto de que esta última no tiene los medios para probar que el daño producido derivó de una ventaja o de un beneficio logrado por el causador del daño, que era la dificultad impuesta por la teoría del riesgobeneficio. En este caso lo que importa es la actividad, independientemente de que el resultado sea beneficioso o no. "La idea fundamental de la teoría del riesgo creado, según Caio Mário, su mayor defensor del país, puede simplificarse: 'cada vez que una persona, por su actividad, crea un riesgo para otros, debería responder por sus consecuencias dañosas'”. 608

Esta teoría del riesgo-creado está consagrada en el párrafo único del artículo 927 del Código Civil brasileño ${ }^{609}$.

En palabras de Coimbra Santos

"Esta teoría, ahora prevista en el CC 2002, encaja perfectamente en el terreno de la responsabilidad existente en la tercerización, y siendo compatible con los principios del Derecho del Trabajo, especialmente con el principio de protección, que permite utilizar, de forma suplementaria, la norma de derecho común, teniendo en cuenta la autorización dada por el art. $8^{\circ}$ de la CLT. En este sentido, la jurisprudencia de Brasil ya ha utilizado el párrafo único del art. 927 del

\footnotetext{
${ }^{607}$ COIMBRA SANTOS, Rodrigo, "Repensando a responsabilidade subsidiária (...)", cit., 67/68.

${ }^{608}$ COIMBRA SANTOS, Rodrigo, "Repensando a responsabilidade subsidiária (....)", cit., 69.

609 "Art. 927. Aquél que, por acto ilícito (Arts. 186 y 187), cause daño a otros, queda obligado a repararlo. Párrafo único. Habrá obligación de reparar el daño, independientemente de la culpa, en los casos especificados en la ley, o cuando la actividad normalmente desarrollada por el autor del daño implique, por su naturaleza, un riesgo para los derechos de los demás".
} 
CC 2002, como fundamentación legal para la responsabilidad subsidiaria del tomador de servicios en la tercerización". ${ }^{610}$

Hay que tener presente, como advierte Coimbra Santos, que el riesgo de la actividad es del empleador, en virtud del artículo $2^{\circ}$ de la CLT, siendo esta disposición la que permitirá la adopción de la teoría del riesgo creado. ${ }^{611}$

Conviene destacar que, en el caso brasileño, se prevé para la teoría de la responsabilidad subjetiva, artículo 927, encabezamiento, del Código Civil y objetiva, conforme al párrafo único de este mismo artículo, lo que permite que se fundamente la responsabilización en el caso de tercerización en base a las dos teorías. $^{612}$

El autor concluye su artículo, argumentando que no se puede ser tan paternalista hasta el punto de prever la responsabilidad subsidiaria para el tomador de los servicios en caso de tercerización considerada lícita por el Tribunal Superior del Trabajo. Sugiere un mayor estudio sobre el tema, para que se establezcan los límites de la responsabilidad subsidiaria. ${ }^{613}$

Las impresiones de Coimbra Santos contribuyen al desarrollo de la presente investigación. Sin embargo, no podemos adherirnos a la conclusión del autor. En el caso de tercerización, como el propio autor resalta, existe una relación de trabajo. De esta relación de trabajo hay uno o dos beneficiarios. No se puede trasladar al trabajador los perjuicios de una relación laboral donde su "empleador" no ha efectuado los pagos. Quién debe hacerse cargo del débito es el que se benefició de esta prestación de trabajo, incluso porque efectuó la contratación a través de una persona interpuesta para reducir los costes de producción. No se aprovechó del trabajo y, aún así, asumió el riesgo. No hay que olvidar que hubo una mala fiscalización, con respecto a las partes no pagadas al trabajador, además de una mala elección, debiendo, el que eligió mal o sólo fiscalizó, por la

\footnotetext{
${ }^{610}$ COIMBRA SANTOS, Rodrigo, "Repensando a responsabilidade subsidiária (...)", cit., 70.

${ }^{611}$ COIMBRA SANTOS, Rodrigo, "Repensando a responsabilidade subsidiária (...)", ibidem.

${ }^{612}$ COIMBRA SANTOS, Rodrigo, "Repensando a responsabilidade subsidiária (...)", cit., 71/72.

${ }^{613}$ COIMBRA SANTOS, Rodrigo, "Repensando a responsabilidade subsidiária (....)", cit., 75.
} 
teoría de la responsabilidad civil, hacerse cargo de los costes de su elección y/o negligencia.

Después de estas consideraciones sobre la responsabilidad subsidiaria, son necesarias algunas líneas acerca de la responsabilidad solidaria. Aunque el Tribunal Superior del Trabajo no ampare la tesis de la responsabilidad solidaria en el caso de tercerización lícita, hay autores que lo hacen, según podremos constatar seguidamente.

\subsubsection{De la responsabilidad solidaria.}

La norma civil brasileña establece que hay solidaridad cuando en la misma afluyen más de un acreedor o más de un deudor, cada uno con derecho o deber para toda la deuda, artículo 264 del Código Civil brasileño ${ }^{614}$.

Sin embargo, "la solidaridad no se presume; resulta de la ley o de la voluntad de las partes", conforme al artículo 265 del Código Civil brasileño.

Para la doctrina, la solidaridad se produce cuando, con relación a un vínculo jurídico, afluyen más de un deudor o más de un acreedor, cada uno con derecho u obligación sobre toda la deuda. ${ }^{615}$

Sérigo Pinto Martins argumenta que hay solidaridad en los casos en que al existir una multiplicidad de acreedores o de deudores o de unas y otras, cada acreedor tiene derecho a toda la deuda, como si fuera un sólo acreedor o cada deudor estará obligado a todo el débito, como si él fuera el único deudor. Afirma que la solidaridad no se presume, viene de la ley o de la voluntad de las partes,

\footnotetext{
614 "Art. 264. Hay solidaridad, cuando en la misma obligación concurre más de un acreedor, o más de un deudor, cada uno con derecho, u obligado, a toda la deuda".

615 Dicionário Jurídico: Academia Brasileira de Letras Jurídicas, Rio de Janeiro; Forense Universitária, 9ae ed; 2004, p. 815.
} 
conforme al artículo 896 del Código Civil brasileño de 1916 y artículo 265 del Código civil brasileño de 2002. El autor añade que en el derecho del trabajo no hay definición que sea solidaridad, por lo tanto se aplica, en razón de la omisión, la legislación civil sobre el tema. ${ }^{616}$

Francisco Walker Errázuriz considera que la responsabilidad solidaria es un término propio del derecho civil, donde hay una obligación recíproca entre dos o más personas sobre la misma deuda. "En el caso en análisis, la responsabilidad solidaria consiste en que la empresa contratista comparta con la empresa principal el carácter de empleador, lo que trae consigo que el trabajador pueda demandar indistintamente y a su elección en caso de incumplimiento, ya sea a la empresa principal o la empresa contratista". ${ }^{617}$

Prosigue y afirma que para los profesores Francisco Tapia y Roberto Torres, teniendo en cuenta lo que establece el artículo 1.511 del Código Civil chileno, la responsabilidad solidaria existe en los casos en que estamos en presencia de un acreedor, una obligación en dinero, divisible, por tanto y en virtud de la ley, el acreedor puede cobrar toda la deuda a cualquiera de los varios deudores. $^{618}$

F. A. Motta Peixoto Giordani afirma, en lo que se refiere a la subcontratación, que la responsabilidad del tomador de los servicios debe ser solidaria. Justifica que por el artículo 265 del Código Civil brasileño debe ser entendida no sólo en un sentido estricto "ley" sino como "derecho", ordenamiento jurídico en su totalidad, lo que permite que se incluyan los principios para fines de solidaridad y no sólo las reglas. ${ }^{619}$

\footnotetext{
${ }^{616}$ PINTO MARTINS, Sérgio, A terceirização e o direito do trabalho, cit., p. 135.

617 WALKER ERRÁZURIZ, Francisco, Derecho de las relaciones laborales, cit., p. 423.

${ }^{618}$ WALKER ERRÁZURIZ, Francisco, Derecho de las relaciones laborales, ibidem.

619 PEIXOTO GIORDANI, Francisco Alberto Motta, "Intermediação de mão-de-obra - una leitura que leva à responsabilidade solidaria entre as empresas prestadora e tomadora de serviços”. En Revista LTr, legislação do trabalho, São Paulo; LTr, ano 72, julho de 2008; p. 791
} 
La responsabilidad solidaria tiene, en la propia CLT, una regla propia en los casos de subcontratación (obras). El artículo 455 de la $\mathrm{CLT}^{620}$ establece que los trabajadores de las subcontratistas pueden postular sus créditos directamente frente a la empresa contratista principal, independientemente de una acción frente al subcontratista, su empleador. Hay que tener presente que la aplicación de la analogía consta de forma explicita en el artículo 8o, encabezamiento, de la CLT ${ }^{621}$, donde se justifica la aplicación al caso concreto, mismo que de tercerizacion, en el caso de que no exista una norma legal, convenio colectivo o contractual que determine la responsabilidad en este último caso.

Conviene subrayar lo que apunta Eduardo Gabriel Saad sobre la analogía. Para él, citando a Pedro Nunes, la analogía es una operación mediante la cual "se aplica, a la especie no prevista por la ley, la norma jurídica similar". Sin embargo, afirma que hay dos formas de analogía. La analogía jurídica o analogía juris y la analogía legal o analogía legis. La primera, refuerza y sirve para resolver el caso que no está previsto en ninguna disposición legal, que fuerza al aplicador a recurrir al sistema jurídico, al espíritu del sistema jurídico, en su totalidad o a los principios jurídicos. La segunda es la que se produce cuando falta un artículo de ley para resolver un caso concreto surgido. Aquí es donde se invoca la disposición legal que regule un caso similar. ${ }^{622}$

\footnotetext{
620“Art. 455 - En los contratos de subcontrata el subcontratista responderá por las obligaciones derivadas del contrato de trabajo estipulado, cabiendo, todavía, a los empleados, el derecho de reclamación contra el contratista principal por el incumplimiento de aquellas obligaciones por parte del primero. Párrafo único - Al contratista principal queda exceptuada, en los términos de la ley civil, la acción regresiva contra el subcontratista y la retención de importes para éste debida, para la garantía de las obligaciones previstas en este artículo" (La cursiva es nuestra).

621 "Art. 80 - Las autoridades administrativas y la Justicia del Trabajo, a falta de disposiciones legales o contractuales, decidirán, conforme al caso, por la jurisprudencia, por analogía, por equidad y otros principios y normas generales de derecho, principalmente del derecho del trabajo $y$, también, de acuerdo con los usos y costumbres, el derecho comparado, pero siempre de manera que ningún interés de clase o particular prevalezca sobre el interés público".

622 SAAD, Eduardo Gabriel, DUARTE SAAD, José Eduardo e CASTELLO BRANCO, Ana Maria Saad, CLT comentada, São Paulo; LTr, $41^{\mathrm{a}}$ ed, 2008, p. 75.
} 
Otra forma de aplicar la condena solidaria utilizando la analogía se basa en el artículo 15 de la ley 6.019/74 ${ }^{623}$, ley del trabajo a través de empresas de trabajo temporal, otra forma de tercerización autorizada por ley. Para esta disposición, la empresa tomadora es responsable de los créditos de la seguridad social, remuneraciones e indemnizaciones en caso de quiebra. Este fundamento es más débil que el del párrafo anterior, porque la norma legal se refiere expresamente a quiebra. Se puede tomar en consideración, en base a los principios y la teoría del riesgo-beneficio o incluso el riesgo creado, con el fin de dar a cada uno lo que es suyo, para justificar esta posición. Sin embargo, en cuanto a la analogía, es mejor utilizar la del párrafo anterior. Queda constancia de esta posibilidad de interpretación.

La reciente ley 12.023, de 27 de agosto de 2009, -que "dispone sobre las actividades de movimiento de mercancías en general y sobre el trabajo separado", además de autorizar la participación de los trabajadores separados en toda y cualquier actividad de movimiento de mercancías, dado que usa la expresión "en general" en su artículo $1^{\circ}$, encabezamiento ${ }^{624}$, que de hecho es un retroceso social,- establece, en su artículo $8^{\circ}$, que la responsabilidad de la empresa tomadora será solidaria a la del sindicato en cuanto a la remuneración del trabajador implicado ${ }^{625}$.

Considerando lo que hasta ahora se ha dicho con respecto a la analogía, autorizada por el artículo $8^{\circ}$, encabezamiento, de la CLT, la responsabilidad del tomador de los servicios, en caso de tercerización, debe ser solidaria. Hay que

\footnotetext{
623 "Art. 16 - En el caso de quiebra de la empresa de trabajo temporal, la empresa tomadora o cliente es solidariamente responsable por el recogimiento de las contribuciones de seguridad social, en lo que se refiere al tiempo en que el trabajador estuvo bajo sus órdenes, así como en relación con el mismo período, por la remuneración e indemnización previstas en esta Ley".

624 "Art. 10 Las actividades de transporte de mercancías en general ejercidas individualmente por cada trabajador, a los fines de esta Ley, son las desarrolladas en las áreas urbanas o rurales sin vínculo laboral, mediante intermediación obligatoria del sindicato de la categoría, a través de un acuerdo o Convención Colectiva de Trabajo para la ejecución de las actividades".

625“'Art. 8ㅇ Las empresas tomadoras o usuarias del trabajo individual responden solidariamente por la efectiva remuneración del trabajo contratado y son responsables por la recogida de los encargos fiscales y sociales, así como de las contribuciones o de otros importes debidos a la Seguridad Social, en el límite del uso que hagan del trabajo individual intermediado por el sindicato".
} 
tener presente que la nueva legislación, ley 12.023/09, más moderna, refuerza la responsabilidad solidaria en los casos de intermediación de mano de obra autorizadas por la ley, lo que permite concluir que este artículo, por analogía, puede aplicarse a los demás casos de tercerización.

La crítica, sin embargo, que se podría hacer y, efectivamente, tiene bastante fundamento, es que el artículo $3^{\circ}$ de la ley 12.023/09, creó otra forma de tercerización y, aún así, en su artículo 8º, nada hace constar con respecto a la responsabilidad solidaria para esta forma de tercerización, sino sólo para los casos de trabajo separado.

Por otra parte, otra forma de justificar, de forma jurídica, la condena solidaria, es servirse del derecho comparado.

El derecho comparado, en virtud del artículo 8ํㅡ, encabezamiento, de la CLT es una forma de integración del derecho del trabajo brasileño. A falta de disposiciones legales o contractuales, el juicio deberá servirse, en el momento de una decisión, también del derecho comparado, porque, conforme al artículo 126 del Código de Proceso Civil brasileño ${ }^{626}$, de aplicación subsidiaria y conforme al artículo 769 de la $\mathrm{CLT}^{627}$, no pueden renunciar a establecer el derecho del caso concreto.

Eduardo Gabriel Saad afirma que cuando la omisión de la legislación nacional no pueda completarse a través de los procedimientos ya mencionados en el artículo $8^{\circ}$ de la CLT, se podrá recurrir al derecho comparado, es decir, a las normas legales existentes en otros países, que versen sobre la misma materia.

\footnotetext{
626 "Art. 126. El juez no está exento de sentenciar o despachar alegando laguna u vacío en la ley. En el juicio de la demanda cabe aplicar las disposiciones legales, sin tener que recurrir a la analogía, a las costumbres y a los principios generales del derecho. "

627 “Art. 769 - En los casos omisos, el derecho procesal común será fuente subsidiaria del derecho procesal del trabajo, excepto en aquello en que sea incompatible con las normas de este Título".
} 
En palabras del autor, el derecho comparado permite "captar la experiencia de otros pueblos y utilizarla en beneficio de la clase trabajadora de nuestro País". ${ }^{628}$

Y, en cuanto al derecho comparado, el artículo 42.1 del Estatuto de los trabajadores español establece que la responsabilidad del tomador de los servicios, en el caso de subcontratación, será solidaria con la del proveedor de los servicios o intermediario de mano de obra ${ }^{629}$.

La utilización de este artículo de la legislación española puede perfectamente justificarse, en el ordenamiento jurídico brasileño, según lo que dispone el artículo 8ㅜㄹ encabezamiento, de la CLT. No hay, en Brasil, regla que trate de la materia. No se puede dejar al trabajador desasistido. No hay norma que determine la responsabilidad subsidiaria para los casos de tercerización en general, lo que permite tomar en consideración, en el caso de que no se pretenda utilizar los argumentos anteriormente expuestos acerca de la analogía, las normas del derecho comparado.

Souto Maior, citando a Roberto Vieira de Almeida Rezende, subraya que para el derecho español, es lícita la contratación de trabajadores por persona interpuesta, pero existirá responsabilidad solidaria entre el prestador y el tomador en estos casos, conforme al artículo 42 del Estatuto de los Trabajadores. Al haber fraude, el empleador será considerado el tomador de los servicios, más o menos lo mismo que sucede en Brasil. ${ }^{630}$

Jorge Souto Maior, refiriéndose también al derecho comparado, afirma que la legislación Argentina establece, en los casos de tercerización, la

${ }^{628}$ SAAD, Eduardo Gabriel, DUARTE SAAD, José Eduardo e CASTELLO BRANCO, Ana Maria Saad, CLT comentada, cit., p. 76.

629 "Artículo 42. Subcontratación de obras y servicios. (...). 2. El empresario principal, salvo el transcurso del plazo antes señalado respecto a la Seguridad Social, y durante el año siguiente a la terminación de su encargo, responderá solidariamente de las obligaciones de naturaleza salarial contraídas por los contratistas y subcontratistas con sus trabajadores y de las referidas a la Seguridad Social durante el período de vigencia de la contrata".

${ }_{630}$ SOUTO MAIOR, Jorge Luiz, Curso de direito do trabalho, cit., p. 148. 
responsabilidad solidaria entre el prestador de los servicios y el tomador por los créditos del trabajador. Esta norma está establecida en el artículo 29 bis y 30 de la ley del contrato de trabajo ${ }^{631}$, de donde se puede concluir que, por los mismos motivos anteriormente mencionados, se puede utilizar esta fuente como forma de resolver la omisión en la legislación brasileña, -en virtud del artículo 8o, encabezamiento, de la CLT-.

Souto Maior llama la atención, con el fin de justificar la responsabilidad solidaria, de que los deudores solidarios lo son por toda la deuda. En el caso de la solidaridad pasiva, -siguiendo a Caio Mário Da Silva Pereira-, se admite, en la doctrina extranjera, la responsabilidad solidaria por presunción de solidaridad, con el fin de satisfacer de forma más eficiente la obligación. ${ }^{632}$

Por otra parte, añade Souto Maior, donde hay pluralidad de deudores y acreedores y donde se puede exigir la totalidad de la deuda de todos, estaremos ante una hipótesis de solidaridad, instituto éste que traduce tal situación. Según el artículo 1.491 del Código Civil brasileño ${ }^{633}$, esta norma no está expresamente prevista para su aplicación en las relaciones laborales, no se puede utilizar. ${ }^{634}$

Sobre este tema de la tercerización, Souto Mayor apunta que:

“(...) por imperativo jurídico, la responsabilidad del tomador de los servicios, si la tercerización fuese válida, sería, necesariamente, una responsabilidad solidaria, sin beneficio de orden. Solidaridad ésta que no sería presumida, sino declarada jurídicamente, según el postulado jurídico de la culpa in eligendo.

Además, incluso el elemento culpa puede ser abandonado, atrayéndose la noción de culpa objetiva derivada de la responsabilidad civil, en los términos del art. 927 del nuevo Código Civil y su párrafo único, que consideran el acto que antes era un acto meramente culposo (véase el artículo 186, del nuevo Código) como acto ilícito.

\footnotetext{
${ }^{631}$ SOUTO MAIOR, Jorge Luiz, Curso de direito do trabalho, cit., p. 150.

632 SOUTO MAIOR, Jorge Luiz, Curso de direito do trabalho, ibidem.

633 "Art. 1.491. La hipoteca legal puede ser sustituida por caución de títulos de la deuda pública federal o estatal, recibidos por el valor de su cotización mínima en el año corriente; o por otra garantía, a criterio del juez, a petición del deudor".

${ }^{634}$ SOUTO MAIOR, Jorge Luiz, Curso de direito do trabalho, cit., p. 150/151.
} 
Y, para aquéllos más reacios, que se apegan a un formalismo jurídico, extraído del tenor del art. 896, del Código Civil ${ }^{635}$, formalismo éste que en concreto no existe, conviene recordar lo dispuesto en el art. 455, de la CLT, que puede aplicarse analógicamente al presente caso". ${ }^{636}$

El autor hace referencia a otras disposiciones legales que perfectamente podrían ser usadas por analogía para responsabilizar al tomador solidariamente con el prestador de servicios. Entre estas disposiciones está el artículo 15, párrafo primero, de la ley $8.036 / 90^{637}$, que trata sobre el Fondo de Garantía por Tiempo de Servicio. $^{638}$

Las cláusulas contractuales entre las empresas, que excluyan la responsabilidad solidaria, son nulas de pleno derecho, tratándose de derecho laboral, en virtud de lo que dispone el artículo 9ำ de la CLT, pudiendo configurarse, con respecto a la adopción de esta práctica, un acto ilícito, en los términos de la actual visión social que pide la legislación civil ${ }^{639}$, implicando, en este caso, la aplicación del artículo 942, párrafo único, del Código Civil. ${ }^{640}$

\footnotetext{
${ }^{635} \mathrm{El}$ autor se refiere al antiguo Código Civil de 1916. en efecto el artículo, conforme a la norma civil actual, es el de número 265 que establece que la solidaridad no se presume, resulta de la ley o de la voluntad de las partes.

${ }^{636}$ SOUTO MAIOR, Jorge Luiz, Curso de direito do trabalho, cit., p. 151.

637 "Art. 15. Para los fines previstos en esta ley, todos los empleadores quedan obligados a depositar, hasta el día 7 (siete) de cada mes, en cuenta bancaria vinculada, el importe correspondiente al 8 (ocho) por ciento de la remuneración pagada o debida, en el mes anterior, a cada trabajador, incluidas en la remuneración las cuotas de las que tratan los arts. 457 <http://www.planalto.gov.br/ccivil_03/Decreto-Lei/Del5452.htm> y 458 de la CLT <http://www.planalto.gov.br/ccivil_03/Decreto-Lei/Del5452.htm> y la gratificación de Navidad a la que se refiere la Ley no 4.090, de 13 de julio de 1962 <http://www.planalto.gov.br/ccivil_03/Leis/L4090.htm>, con las modificaciones de la Ley no 4.749, de 12 de agosto de 1965. <http://www.planalto.gov.br/ccivil_03/Leis/L4749.htm> § $1^{\circ}$ se entiende por empleador la persona física o la persona jurídica de derecho privado o de derecho público, de la administración pública directa, indirecta o fundacional de cualquiera de los Poderes, de la Unión, de los Estados, del Distrito Federal y de los Municipios, que admiten trabajadores a su servicio, así como aquél que, regido por legislación especial, se encuentra en esta condición o figura como suministrador o tomador de mano de obra, independientemente de la responsabilidad solidaria $\mathrm{y} / \mathrm{o}$ subsidiaria a la que eventualmente está obligado. (...)".

${ }_{638}^{63}$ SOUTO MAIOR, Jorge Luiz, Curso de direito do trabalho, ibidem.

${ }^{639}$ Actualmente, en Brasil, en virtud del artículo 421 del Código Civil, el contrato deberá tener una función social. "Art. 421. La libertad de contratar será ejercida en razón y en los límites de la función social del contrato".

${ }^{640}$ SOUTO MAIOR, Jorge Luiz, Curso de direito do trabalho, cit., p. 151/152.
} 
En otras palabras, el autor añade que estas reglas son pertinentes en el fenómeno de la tercerización, porque quien contrata a otro para proporcionarle mano de obra, aun cuando lo haga dentro de un supuesto derecho, tendrá responsabilidad solidaria por los daños causados en razón del riesgo de que expone los derechos de estos trabajadores, lo que genera responsabilidad objetiva, como establece el artículo 927 del Código Civil ${ }^{641}$.

Sin embargo, Souto Maior argumenta que el ordenamiento jurídico está constituido para la satisfacción del acreedor, eso porque éste asume una obligación libremente, lo que hace legítima la acción del acreedor para que pueda ser resarcido su crédito. El autor llega a la conclusión que la solidaridad existe precisamente para aumentar las garantías para el acreedor con respecto a la obligación, lo que permite servirse, según Caio Mário Da Silva Pereira, del principio que admite la presunción de solidariedad ${ }^{642} \mathrm{y}$, se concluye, sin necesidad de ley o de contrato para que forme parte de las relaciones jurídicas contractuales.

Es una pena, advierte F. A. Motta Peixoto Giordani, que Brasil no tenga una legislación que determine la responsabilidad solidaria entre el prestador y el tomador de los servicios en los casos de tercerización. Para el autor, podría utilizarse el ejemplo de países del Mercosur como Uruguay y Argentina, donde la norma legal establece que, en los casos de descentralización productiva, la responsabilización del tomador de los servicios es solidaria con la del prestador por los débitos no pagados en relación al trabajador. ${ }^{643}$

En el mismo sentido se orienta la propuesta de la Central Única de los Trabajadores (CUT) que desde 2004 estudia el fenómeno de la tercerización de

\footnotetext{
${ }^{641}$ Art. 927. Aquél que, por acto ilícito (Arts. 186 y 187), cause daño a otros, queda obligado a repararlo. Párrafo único. Habrá obligación de reparar el daño, independientemente de la culpa, en los casos especificados en la ley, o cuando la actividad normalmente desarrollada por el autor del daño implique, por su naturaleza, un riesgo para los derechos de los demás".

${ }_{642}$ SOUTO MAIOR, Jorge Luiz, Curso de direito do trabalho, cit., p. 153/154.

${ }^{643}$ Revista da Associação Nacional dos Magistrados da Justiça do Trabalho, cit., p. 13.
} 
forma periódica. Para la institución, al crear una norma que autorice la tercerización, debe ser obligatoria la comunicación al sindicato en el caso de subcontratación, prohibición de la tercerización en la actividad-fin, con la responsabilidad solidaria de la empresa tomadora de los servicios y penalización a quien infrinja estas reglas. ${ }^{644}$

Para el sector empresarial, la legislación relativa a la tercerización deberá prever la posibilidad de subcontratación incluso la actividad-fin, pero respetando el contrato habido entre la prestadora y la tomadora. Desde la perspectiva del empresariado, representada en el Congreso Nacional por el diputado federal Sandro Mabel (PR-GO), la responsabilización deberá ser subsidiaria, sin formar un vínculo con la tomadora y/o sus socios. Debe ser posible la contratación de terceros por profesionales liberales, de donde se concluye que los contratantes podrían ser personas físicas. ${ }^{645}$

Finalmente, lo que debe quedar claro es que la responsabilidad solidaria sirve para reforzar las posibilidades de cobro por parte del trabajador de sus créditos, así como para mejorar los niveles de cumplimiento de la norma laboral. Es una especie de antídoto venido de la legislación laboral frente a la subcontratación económica, asumiendo el tomador los riesgos por su opción de subcontratar. El objetivo, al final, es la protección del trabajador, en razón de su debilidad económica y de la debilidad económica de la empresa prestadora frente a la tomadora. ${ }^{646}$

Una vez realizadas estas consideraciones acerca de la responsabilidad en el caso de la tercerización, subsidiaria, conforme a la Súmula 331 del Tribunal Superior del Trabajo, o solidaria conforme a la doctrina, vamos a ocuparnos seguidamente de la ley del trabajo temporal.

\footnotetext{
${ }^{644}$ Revista da Associação Nacional dos Magistrados da Justiça do Trabalho, cit., p. 14.

645 Revista da Associação Nacional dos Magistrados da Justiça do Trabalho, cit., p. 14/15.

646 ROSENBAUM, Jorge y CASTELLO, Alejandro, Régimen jurídico de La subcontratación e intermediación laboral, cit., p. 44/46.
} 


\subsubsection{Ley del trabajo temporal - ley 6.019/74 (trabajo a través de empresas de trabajo temporal)}

En un principio, como recuerda Pinto Martins, no hay que confundir la empresa de trabajo temporal a la que se refiere la ley 6.019/74, con las agencias de empleo de trabajadores. Esta última sólo se limita a colocar a los trabajadores en un empleo, sin remuneración alguna y sin dirigir la prestación de sus servicios. Sin embargo, es la empresa de trabajo temporal, aquella a la que se refiere la ley, la que remunera a los trabajadores y los dirige. ${ }^{647}$

Esta ley 6.019/74 se refiere a la oferta de mano de obra temporal en situaciones especiales. Establece que empresas pueden contratar, con una empresa de trabajo temporal, empleados que prestan servicios de actividad ordinaria, siempre que se justifiquen en la contratación las vacaciones y los permisos de maternidad, entre otros. Estos contratos no pueden ser superiores a tres meses, salvo autorización expresa del Ministerio del Trabajo y Empleo ${ }^{648}$. La ley tiene como objeto, conforme al preámbulo y al artículo 4ํㅜㄹ el trabajo temporal en empresas urbanas ${ }^{649}$. Estas prórrogas no están permitidas, a excepción de los casos de fuerza mayor o necesidad imperiosa de los servicios, eso porque esta disposición no consta en el artículo 10 de la ley ${ }^{650}$.

Esta forma de contratación trilateral involucra a la empresa de trabajo temporal (ETT) o la empresa tercerizante, al trabajador temporal y a la empresa

\footnotetext{
${ }^{647}$ PINTO MARTINS, Sérgio, A terceirização e o direito do trabalho, cit., p. 129.

${ }^{648}$ Pinto Martins apunta que no basta una simple comunicación por parte de las empresas sino que es preciso un acto administrativo que autorice la prórroga. Autorización y comunicación, refuerza el autor, no son sinónimos, exigiendo la norma legal la autorización. (PINTO MARTINS, Sérgio, $A$ terceirização e o direito do trabalho, cit., p. 131).

${ }^{649}$ Preámbulo: "Dispone sobre el Trabajo Temporal en las Empresas Urbanas, y en otras Providencias".

"Art. 4ํ- Se entiende como empresa de trabajo temporal la persona física o jurídica urbana, cuya actividad consiste en poner a disposición de otras empresas, temporalmente, a trabajadores, debidamente cualificados, remunerados y asistidos por la mismas".

${ }^{650}$ PINTO MARTINS, Sérgio, A terceirização e o direito do trabalho, cit., p. 132.
} 
tomadora de los servicios (ETS) o cliente. El vínculo laboral se establece entre el trabajador y la empresa de trabajo temporal, aunque él preste trabajo en la tomadora. Esta relación, según Godinho Delgado, rompe con el modelo de la Consolidación de las Leyes del Trabajo de contratación directa, y deriva del proceso "tercerizatorio" de la legislación laboral brasileña. ${ }^{651}$

El trabajo a través de empresa de trabajo temporal (o, en Brasil, trabajo temporal) es lo que establece el artículo $2^{\circ}$, de la ley 6.019/74. La disposición legal establece que el trabajo temporal es el "prestado por una persona física a una empresa, para atender a la necesidad transitoria de sustitución de su personal regular y permanente o el aumento extraordinario de servicio". Debe, por tanto, utilizarse para necesidades transitorias de sustitución de personal regular y permanente o en los casos en que haya un desorbitado aumento de servicios.

Por otra parte, la empresa de trabajo temporal es la "persona física o jurídica urbana, cuya actividad consiste en poner a disposición de otras empresas, temporalmente, los trabajadores debidamente cualificados, por ellas remunerados y asistidos", conforme al artículo $4^{\circ}$, de la ley 6.019/74.

Por lo tanto, podemos concluir que no se puede contratar a trabajadores por empresas de trabajo temporal para sustituir a empleados de una empresa prestadora de servicio para el suministro a otra empresa, en el caso de la tomadora, porque la norma legal autoriza la contratación sólo trilateral, para necesidades de sustitución de personal permanente y regular.

Alexandre Agra Belmonte, además, apunta que no se puede confundir al trabajador contratado por empresa de trabajo temporal de la ley 6.019/74 con el contrato a plazo determinado del artículo 443 de la CLT. ${ }^{652}$ En este último caso el

\footnotetext{
651 GODINHO DELGADO, Maurício, Curso de Direito do Trabalho, cit., p. 452.

652 "Art. 443 - El contrato individual de trabajo podrá ser acordado tácita o expresamente, verbalmente o por escrito y por un plazo determinado o indeterminado. $\S 1^{\circ}$ - Se considera como de plazo determinado el contrato de trabajo cuya vigencia dependa del término prefijado o de la
} 
trabajador es un empleado y trabaja sin la intermediación de una empresa de trabajo temporal, pero lo hace para la realización de servicios de naturaleza transitoria, servicio de actividades empresariales de carácter transitorio o de carácter experimental, contrato de experiencia. En el primer caso hay una intermediación de mano de obra a través de una empresa intermediaria de mano de obra, proveedor de mano de obra temporal, para suplir la ausencia de personal regular o una extraordinaria demanda de servicio del tomador final. ${ }^{653}$

Maurício Godinho Delgado acaba por definir al trabajador de empresa de trabajo temporal:

\footnotetext{
"Trabajador temporal es aquél que, jurídicamente vinculado a una empresa de trabajo temporal, de quien recibe sus correspondientes contratos, presta servicios a otra empresa, para atender a la necesidad transitoria de sustitución del personal regular y permanente 0 el incremento extraordinario de los servicios de la empresa tomadora". ${ }^{654}$
}

Como podemos observar, las posibilidades de incidencia de este contrato son restrictivas. Estas son las necesidades transitorias de sustitución del personal regular y permanente de la empresa tomadora o necesidad que resulta del incremento extraordinario de servicios por parte de la misma empresa tomadora, artículo $2^{\circ}$, de la ley 6.019/74. Estas hipótesis se refieren a la legalidad del contrato. De no ser observada, existirá un vínculo jurídico de empleo directamente entre el trabajador y el tomador de los servicios, de conformidad con el inciso I de la súmula 331 del TST. ${ }^{655}$

\footnotetext{
ejecución de servicios especificados o incluso de la realización de un cierto acontecimiento susceptible de previsión aproximada. § $2^{\circ}$ - El contrato por plazo determinado sólo será válido en el caso de que se trate: a) de servicio cuya naturaleza o transitoriedad justifique la predeterminación del plazo; b) de actividades empresariales de carácter transitorio; c) de contrato de experiencia".

${ }^{653}$ AGRA BELMONTE, Alexandre, "Aspectos jurídicos atuais da terceirização trabalhista", cit., p. 35.

${ }^{654}$ GODINHO DELGADO, Maurício, Curso de Direito do Trabalho, cit., p. 453.

${ }^{655}$ GODINHO DELGADO, Maurício, ibidem.
} 
La duración de este contrato es de tres meses y deberá formularse por escrito, artículos 10 y 11 , enunciado, de la ley $6.019 / 74^{656}$. La norma jurídica brasileña prevé, además, el pago del salario igual entre el sustituido y sustituto.

\subsubsection{Forma ilegal: La cesión ilegal de mano de obra.}

Las formas ilegales de contratación de trabajadores por persona interpuesta, en Brasil, son prácticamente las mismas que en España, Portugal, Argentina o Francia.

Cada vez que haya subordinación o trabajo prestado de forma personal por el trabajador a la empresa principal, habrá intermediación ilegal de mano de obra y una relación de empleo directa entre el trabajador y la empresa tomadora.

En los casos en que la empresa prestadora no cumpla con las disposiciones legales, constitución lícita, contrato escrito con la empresa tomadora, habrá una cesión ilegal de trabajadores y una relación laboral directa entre el trabajador y la empresa principal, con responsabilidad, por el incumplimiento de la ley, solidaria entre estas últimas, conforme al artículos $9^{\circ}$ de la CLT y 942 del Código Civil.

Es interesante, aún, traer a la discusión la opinion de los Tribunales brasileños sobre la intermediacón ilegal de mano de obra. Ellos siguen los términos de la Súmula 331 del Tribunal Superior del Trabajo, haciendo el analisis

\footnotetext{
${ }^{656}$ Art. 10 - El contrato entre la empresa de trabajo temporal y la empresa tomadora o cliente, con relación a un mismo empleado, no podrá exceder de tres meses, salvo autorización conferida por el órgano local del Ministerio del Trabajo y Seguridad Social, según instrucciones del Departamento Nacional de Mano de obra.

Art. 11 - El contrato de trabajo celebrado entre empresa de trabajo temporal y cada uno de los asalariados puestos a disposición de una empresa tomadora o cliente será, obligatoriamente, escrito y deberán constar, expresamente, los derechos conferidos a los trabajadores por esta Ley. Párrafo único. Será nula de pleno derecho cualquier cláusula de reserva, prohibiendo la contratación del trabajador por la empresa tomadora o cliente al fin del plazo en el que haya sido puesto a su disposición por la empresa de trabajo temporal.
} 
de los hechos en los casos concretos, como uno puede ver por las Sentencias que siguen.

La intermediación de mano de obra, donde la empresa tomadora recibe trabajadores que trabajan junto a su actividad fin, es ilegal en Brasil. Ella hace con que el juez deba reconocer la relación de empleo entre el trabajador y la empresa tomadora, con la condena de la empresa intermediadora de forma solidaria (Sentencia del Tribunal Regional del Trabajo de 4ª Región, Rio Grande del Sur, Brasil, proceso 0001010-19.2010.5.04.0026 RO). ${ }^{657}$

En otra decisón el mismo Tribunal (Sentencia en el proceso 019990067.2009.5.04.0662 AIRR) dice que la intermediacion de mano de obra, tercerización, de actividad fin es ilegal y impone la condena solidaria entre las empresas, prestadora y tomadora, por los creditos del trabajador perjudicado, como ésta en los artículos 265 y 927 del Código Civil de Brasil. ${ }^{658}$

És interesante decir, aúnque cuando una empresa busca suprimir sus necesidades de mano de obra para prestar trabajo cuyo objeto sea su actividad fin, habra una fraude y la intermediación de mano de obra sera ilegal. En estos casos el vinculo laboral sera entre la empresa tomadora y el trabajador, como hace refencia la Súmula 331, III, del TST, debiendo la empresa tomadora ser responsable por los pagos ordinarios de un contrato de trabajo, cómo si ella propia

657

http://gsa3.trt4.jus.br/search?q=cache: O3gBqOIPzlJ:iframe.trt4.jus.br/nj4 jurisp/jurispnovo.ExibirD ocumentoJurisprudencia\%3FpCodAndamento\%3D43182769+inmeta:DATA DOCUMENTO:201109-12..2012-09-12+\%22intermedia\%C3\%A7\%C3\%A3o+de+m\%C3\%A3o-deobra\%22++\&client=jurisp\&site=iurisp\&output=xml no $\mathrm{dtd} \&$ proxystylesheet=jurisp\&ie=UTF$\frac{8 \& \mid r=l a n g}{6}$ pt\&access $=p \& 0 e=U T F-8$ acceso el 12 de setepmbrie de 2012, a las $11 \mathrm{~h} 03 \mathrm{~min}$.

http://gsa3.trt4.jus.br/search?q=cache:mgmsJFLtd7QJ:iframe.trt4.jus.br/nj4 jurisp/jurispnovo.Exibir DocumentoJurisprudencia\%3FpCodAndamento\%3D40650049+inmeta:DATA DOCUMENTO:2011 -09-12..2012-09-12+\%22intermedia\%C3\%A7\%C3\%A30+de+m\%C3\%A3o-deobra\%22++\&client=jurisp\&site=jurisp\&output=xml no dtd\&proxystylesheet=jurisp\&ie=UTF$8 \& \mid r=l a n g$ pt\&access=p\&oe=UTF-8 - acceso el 12 de septiembre de 2012, a las $11 \mathrm{~h} 09 \mathrm{~min}$. 
hubiera hecho la contratación (Sentencia en el proceso 000092063.2010.5.04.0332 RO). ${ }^{659}$

Lo que que queda es que no importa el sitio, el pais. Si el objetivo de la empresa prestadora es solamente poner trabajadores a la disposición de la empresa tomadora, habra ilegalidad y fraude y la relación de empleo sera reconocida entre el trabajador y esta ultima. El caso de Brasil envolucra una peculiaridad. La intermediación de mano de obra, por tratarse la tercerización, en este pais, solamente de prestación de servicios, no permite que haya prestación de trabajo junto a la actividad fin de la empresa principal, caso en que habra vinculo laboral entre el trabajador y ésta.

Así, salvo en los casos en que estén bien cumplimentados los términos legales, la cesión de trabajadores será ilícita, formado un relación de empleo con el tomador del trabajo, conforme a la Súmula 331, I, del TST.

\subsubsection{Supuestos concretos de tercerización previstos en el ordenamiento jurídico brasileño.}

La ley brasileña establece, expresamente, por ley o decreto ley, la tercerización. Hay casos prácticos fuera de los patrones de la ley, sin embargo, en los que hay un claro carácter fraudulento, en los que hay una intermediación de mano de obra en lugar de un contrato de tercerización. Son los contratos triangulares definidos como lícitos, los que vamos a analizar seguidamente.

659

http://gsa3.trt4.jus.br/search?q=cache:mgZfNTobgfkJ:iframe.trt4.jus.br/nj4 jurisp/jurispnovo.ExibirD ocumentoJurisprudencia\%3FpCodAndamento\%3D42434979+inmeta:DATA DOCUMENTO:201109-12..2012-09-12+\%22intermedia\%C3\%A7\%C3\%A3o+de+m\%C3\%A3o-deobra\%22++\&client=jurisp\&site=jurisp\&output=xml no dtd\&proxystylesheet=jurisp\&ie=UTF$\underline{8 \& \mathrm{r}=\text { lang } \mathrm{pt} \& \text { access }=\mathrm{p} \& o e=U T F-8}$ - acceso el 12 de septiembre de 2012, a las $11 \mathrm{~h} 16 \mathrm{~min}$. 


\subsubsection{Tercerización en el servicio público.}

El objetivo de este apartado no es el de tratar acerca de la administración pública, sino el de analizar la cuestión de la tercerización dentro de la administración pública. Para ello examinaremos, además de las disposiciones constitucionales, legales y de decreto, la posición de la doctrina y de la jurisprudencia al respecto, sin olvidar la Súmula 331, II y V, del Tribunal Superior del Trabajo ${ }^{660}$.

Este tema es controvertido. En principio, la tercerización en la administración pública, en Brasil, se debe utilizar para la planificación, coordinación, supervisión y control y con el objetivo de impedir el crecimiento desmesurado de la máquina administrativa, recurriendo, en estos casos, a la ejecución indirecta, trasladada a la iniciativa privada mediante contrato administrativo.

Lo que autoriza la tercerización en el servicio público es el decreto-ley 200/67, artículo 10, encabezamiento, que establece que "la ejecución de las actividades de la administración pública federal deberá ser ampliamente descentralizada", además del párrafo séptimo del mismo artículo, donde consta que "para desvincularse mejor de las tareas de planificación, coordinación, supervisión y control y con el objetivo de impedir el crecimiento desmesurado de la máquina administrativa, la administración buscará desligarse de la realización material de tareas directivas, recurriendo, siempre que sea posible, a la ejecución indirecta, mediante contrato, siempre que exista, en el área, una iniciativa privada suficientemente desarrollada y capacitada para desempeñar las cargas que deban

\footnotetext{
660 II - La contratación irregular de trabajadores, mediante empresa interpuesta, no genera un vínculo de empleo con los órganos de la administración pública directa, indirecta o fundacional (art. 37, II, de la CF/1988). III - (...). IV - (...). V - Os entes integrantes da Administração Pública direta e indireta respondem subsidiariamente, nas mesmas condições do item IV, caso evidenciada a sua conduta culposa no cumprimento das obrigações da Lei n.ำ 8.666, de 21.06.1993, especialmente na fiscalização do cumprimento das obrigações contratuais e legais da prestadora de serviço como empregadora. A aludida responsabilidade não decorre de mero inadimplemento das obrigações trabalhistas assumidas pela empresa regularmente contratada."
} 
ejecutarse", ambas disposiciones reforzados por el artículo 3ํㅡㄹ párrafo único, de la ley 5.645/70, que establecía (ya que fue revocado por la ley 9.527/97) que "las actividades relacionadas con el transporte, la conservación, la custodia, las operación de ascensores, limpieza y otras similares serán, preferentemente, objeto de ejecución indirecta, mediante contrato, de acuerdo con el artículo 10, párrafo $7^{\circ}$, del decreto-ley número 200, de 25 de febrero de 1967”. ${ }^{661}$

Conviene hacer una referencia al hecho de que, incluso existiendo una disposición legal de licitaciones, artículo 71, encabezamiento, y párrafo primero de la ley $8.666 / 93^{662}$, que exonere el ente público de cualquier parcela laboral no pagada por el prestador, no debería ser aplicado por ser inconstitucional. Recentemente la Suprema Corte de Brasil decidó que el articulo 71, encabezamiento, y parrafo primero, de la ley 8.666/93 no es inconstitucional, dejando el analysis de la responsabilidad del poder publico para el caso concreto $^{663}$.

Como hemos visto, en principio, es posible la tercerización de ciertas actividades por el poder público, transferidas a la iniciativa privada mediante contrato de licitación, resultando, conforme el caso, la posibilidad de la respectiva esfera de la administración ser como responsable de forma subsidiaria por las eventuales partes no pagadas, cuando hay mala fiscalización.

El tema de la licitud de la tercerización en la administración pública, sin embargo, es controvertido. Por ello, tomaremos como referencia a la doctrina que ha analizado el tema, especialmente a Sérgio Pinto Martins y a Jorge Luiz Souto Maior.

${ }^{661}$ En www.planalto.gov.br - Acceso el 27 de abril de 2009, a las 23h58min.

662 "Art. 71. El contratado es responsable por los encargos laborales, de la seguridad social, fiscales y comerciales derivados de la ejecución del contrato. $\S 1^{\circ} \stackrel{ }{ }$ El incumplimiento del contratado, con referencia a los encargos laborales, fiscales y comerciales no transfiere a la Administración Pública la responsabilidad por su pago, ni podrá cumplir con el objeto del contrato o restringir la regularización y el uso de las obras y edificaciones, incluso ante el Registro de Inmuebles".

${ }^{663}$ Acción Directa de Constitucionalidad 16. 
En relación a la tercerización en la administración pública, Sérgio Pinto Martins afirma que esta forma de contratación, por persona interpuesta, teniendo el erario como tomador de los servicios, es lícita, de acuerdo con los preceptos legales existentes. Apunta que la tercerización en la administración podría generar la corrupción, principalmente por no exigir el concurso público. Añade que hay concurrencia pública para la contratación de los servicios. Concluye que el Estado se beneficia de esta forma de prestación de servicios, dado que destina parte de su actividad no esencial a las empresas más competentes y con un coste menor, disminuyendo el déficit estatal. ${ }^{664}$

El Estado ya terceriza la recogida de basura, el transporte público, por sistema de concesión o permiso, además de mediar el consumo de agua, gas, energía eléctrica, en la distribución de las cuentas y asistencia técnica para el consumidor en las referidas áreas. "Se verifica incluso la tercerización de la flota de vehículos de la administración pública. Se puede contratar un sistema de radiotaxi, una central para alquilar vehículos. En ciertos casos, eso ya se ha hecho, dado el costoso mantenimiento de los vehículos públicos". 665

Pinto Martins hace referencia a la legislación ya citada en esta investigación, pero añade que el artículo 18 de la ley reglamentaria 101, de 04 de mayo de $2000^{666}$, admite la tercerización en el servicio público, porque menciona que los valores de los contratos de tercerización de mano de obra, eso cuando se refieren a la sustitución de servidores y empleados públicos, se contabilizará a los

\footnotetext{
${ }^{664}$ PINTO MARTINS, Sérgio, A terceirização e o direito do trabalho, cit., p. 141.

665 PINTO MARTINS, Sérgio, A terceirização e o direito do trabalho, cit., p. 141/142.

${ }^{666}$ Art. 18. A los efectos de esta Ley reglamentaria, se entiende como gasto total con el personal: la totalidad de los gastos del ente de la Federación con los activos, los inactivos y los jubilados, relativos a los mandatos electivos, cargos, funciones o empleos, civiles, militares y de miembros de Poder, con cualesquiera especies remuneratorias, tales como vencimientos y ventajas, fijas y variables, subsidios, réditos de jubilación, reformas y pensiones, incluso adicionales, gratificaciones, horas extras y ventajas personales de cualquier naturaleza, así como encargos sociales y contribuciones recogidas por el ente a las entidades de seguridad social. $\S 1^{\circ}$ Los valores de los contratos de tercerización de mano de obra que se refieren a la sustitución de servidores y empleados públicos serán contabilizados como "Otros Gastos de Personal".
} 
efectos de los gastos, como "otros gastos de personal", lo que confirma que la ley admite la subcontratación objeto de esta investigación. ${ }^{667}$

Así, concluye Sérgio Pinto Martins, "no hay duda de que la tercerización de servicios puede ser hecha en la administración pública. Sin embargo, no se puede hacer tercerización de mano de obra en la administración pública, ya que favorece el nepotismo y los nombramientos políticos, hiriendo la exigencia del concurso público", es decir, sólo tercerización de servicios y no de mano de obra. ${ }^{668}$

Hay, sin embargo, quien entiende que no es posible la tercerización en el servicio público. Jorge Souto Maior apunta que la tercerización nada tiene que ver con las exigencias del servicio público, salvo si se entiende que el Estado debe producir riqueza a partir de la explotación del trabajo ajeno, siendo este "ajeno" los propios miembros de la sociedad que el Estado pretende organizar y proteger. Hay que tener presente, añade el autor, que el modelo toyotista, de donde surge la tercerización, es una técnica encaminada a potenciar la explotación de la mano de obra, práctica ésta que no forma parte de aquellas relativas a los deberes del Estado. ${ }^{669}$

Para Souto Maior, la eficiencia administrativa no puede ser mejorada por la reducción y el empobrecimiento de los derechos de los trabajadores. Esto es porque al hacerlo, el Estado excluye a estas personas de esta misma sociedad, colocándolas en una condición de subciudadanía. Se constata que la tercerización por sí, reduce y precariza los derechos, dado que las empresas prestadoras ofrecen servicios, por licitación y un mejor precio a costa de la reducción de las ganancias de los trabajadores, acabando, muchas veces sin poder cumplir con sus obligaciones, dejando a los trabajadores a merced de un proceso judicial en el cual el poder público se sirve de la más variada gama de recursos para evitar el

\footnotetext{
667 PINTO MARTINS, Sérgio, A terceirização e o direito do trabalho, cit., p. 143.

668 PINTO MARTINS, Sérgio, A terceirização e o direito do trabalho, ibidem.

669 SOUTO MAIOR, Jorge Luiz, "Terceirização na administração pública: una prática inconstitucional", cit., p. 14/15.
} 
pago que debe y más, que debía haber hecho de forma correcta, contratación de personal por concurso público. ${ }^{670}$

La subcontratación en el sector público también requiere examinar la cuestión de la moralidad administrativa ${ }^{671}$. Conlleva la preocupación electoral. Existe la posibilidad de contratar a personas sin licitación pública, a cambio de votos en las elecciones. Garantiza el voto a un determinado candidato con ocasión de los pleitos electorales que, evidentemente, hiere el principio de moralidad administrativa, según el artículo 37, encabezamiento, de la Constitución brasileña de $1988 .^{672}$

Souto Maior considera que la tercerización en el sector público tiene el mismo carácter que en el sector privado; una cierta represalia por parte de los empleadores frente a los trabajadores y sus postulados. Por eso acaba siendo conveniente para la administración pública terceirizar en lugar de nombrar servidores públicos, porque si alguno de ellos causa "problemas", basta una simple llamada a la empresa prestadora para que el "problema" se resuelva. "Decir que la tercerización no causa ningún daño al trabajador y sobre todo a los servidores públicos, como una clase de trabajadores, es ignorar la realidad o no querer verla, por falta de interés o de compromiso". 673

El siguiente paso es analizar el tema de la subcontratación en el sector público bajo el aspecto normativo y legal.

\footnotetext{
670 SOUTO MAIOR, Jorge Luiz, "Terceirização na administração pública: una prática inconstitucional", cit., p. 15.

${ }^{671}$ El principio de la moralidad administrativa exije que el administrador público no se olvide de la ética y de la honestidad en los casos que le son puestos. CARVALHO FILHO, José Santos, Manual de direito administrativo, Rio de Janeiro, Lumen Juris, $17^{\mathrm{a}}$ edición, 2007, p. 18.

672 SOUTO MAIOR, Jorge Luiz, "Terceirização na administração pública: una prática inconstitucional", cit., p. 18.

673 SOUTO MAIOR, Jorge Luiz, "Terceirização na administração pública: una prática inconstitucional", ibidem.
} 


\title{
2.4.5.1.1 Normatividad y visión crítica
}

El artículo 37, encabezamiento e incisos I y II, de la Constitución brasileña de 1988 trata los principios de la administración pública, cargos, empleos y funciones públicas, así como la forma de investidura en el cargo o empleo público, que depende de concurso público de pruebas o de pruebas y títulos.

El artículo 37, de la Constitución brasileña, de 1988, establece:

\begin{abstract}
"Art. 37. La administración pública directa e indirecta de cualquiera de los Poderes de la Unión, de los Estados, de Distrito Federal y de los Municipios obedecerá a los principios de legalidad, impersonalidad, moralidad, publicidad y eficiencia y, también, al siguiente: I - los cargos, empleos y funciones públicas son accesibles a los brasileños que cumplan con los requisitos establecidos en la ley, así como a los extranjeros, en la forma de la ley; II - la investidura en cargo o empleo público depende de aprobación previa en concurso público de pruebas o de pruebas y títulos, de acuerdo con la naturaleza y la complejidad del cargo o empleo, en la forma prevista en ley, exceptuados los nombramientos para cargo en comisión declarado en la ley de libre nombramiento y exoneración; (...)".
\end{abstract}

De las disposiciones anteriores podemos concluir que la ejecución de las tareas por parte del poder público deben ser precedidas de concurso público por parte de los servidores ${ }^{674}$. La contratación de trabajadores o empresas mediante licitación hiere a la disposición constitucional del concurso público conforme al artículo 37, II, de la Constitución federal de $1988 .^{675}$

Souto Maior ya rebate, de antemano, la crítica de que el inciso XXI del artículo 37 de la Constitución brasileña de $1988^{676}$ autorizaría la tercerización

\footnotetext{
${ }^{674}$ La exigencia del concurso público deriva del principio de igualdad y de moralidad administrativa. Vid. MEDAUAR, Odete, Direito administrativo moderno, São Paulo; Editora Revista dos Tribunais, $11^{\text {a }}$ Ed., 2007, p. 263.

675 SOUTO MAIOR, Jorge Luiz, "Terceirização na administração pública: una prática inconstitucional", cit., p. 19.

676 "Art. 37. I - (...); XXI - Excepto los casos especificados en la legislación, las obras, servicios, compra y alienaciones serán contratados mediante proceso de licitación pública que asegure igualdad de condiciones a todos los concurrentes, con cláusulas que establezcan obligaciones de pago, manteniendo las condiciones efectivas de la propuesta, en los términos de la ley, lo cual solamente permitirá las exigencias de calificación técnica y económica indispensables para la garantía del cumplimiento de las obligaciones".
} 
cuando establece que, por licitación, podrá contratar obras, servicios, compra y ventas. Esta disposición no puede interpretarse de forma aislada, sino en consonancia con lo que disponen los incisos I e II del mismo artículo, sin admitir contradicción entre ambos. El hecho de que el ente público pueda contratar trabajadores mediante una persona interpuesta supondría la ineficacia de los incisos mencionados, porque la elección entre abrir el concurso o contratar una empresa quedaría a la conveniencia del administrador. ${ }^{677}$

En relación al inciso XXI, del artículo 37, de la Constitución federal:

\begin{abstract}
"El inciso XXI, evidentemente, no puede tener tal significación. Tomando el art. 37 en su conjunto e incluso el contexto del inciso XXI, en que se inserta, el término 'servicios' sólo puede ser entendido como algo que se produce fuera de la dinámica permanente de la administración y que se requiera para atender una exigencia de la propia administración, como por ejemplo, la implantación de un sistema informático, o la preparación de los servidores para trabajar con un nuevo equipo. Para esos servicios, el ente público podrá contratar a una empresa especializada, valiéndose necesariamente, de un proceso de licitación". ${ }^{678}$
\end{abstract}

Sin embargo, la posición del iuslaborista paulista no es unánime. Para enriquecer el debate, se trae a la discusión pasajes sobre el tema de "servicios" tomando dos obras brasileñas de derecho administrativo.

Aloísio Zimmer Júnior, sobre el tema, afirma que entre los "servicios" están los denominados comunes, relativos a la informática, asistencia hospitalaria, actividades auxiliares como el de ascensorista, camarero, jardinero, filmación, fotografía, traducción, entre otros, de donde podemos concluir que la tercerización está permitida por parte del erario público de estas funciones. ${ }^{679}$

Odete Medauar, con respecto a los "servicios", apunta que la doctrina hace la división entre los servicios comunes, aquellos en que para su ejecución no se

\footnotetext{
677 SOUTO MAIOR, Jorge Luiz, "Terceirização na administração pública: una prática inconstitucional", cit., p. 19.

678 SOUTO MAIOR, Jorge Luiz, "Terceirização na administração pública: una prática inconstitucional", ibidem.

${ }_{679}$ ZIMMER JÚNIOR, Aloísio, Curso de direito administrativo, Porto Alegre; Editora Verbo Jurídico, 2007, p. 378.
} 
requiere ninguna habilitación específica, como por ejemplo la limpieza; los técnicoprofesionales, donde se les exige una habilitación específica, como es el caso del mantenimiento de ascensores por ejemplo; y los técnico-profesionales especializados, desempeñados por profesionales de notoria especialización ${ }^{680}$, conforme, en este último caso, al artículo 13 de la ley 8.666/93 ${ }^{681}$.

Sin embargo, al que parece, Souto Maior tiene razón, porque la forma de contratación de personal se da por concurso público de pruebas o de pruebas y títulos. Por otra parte, al haber trabajo permanente, empleador será aquella empresa o tomador beneficiado por estos servicios, lo que impediría la tercerización. Las contrataciones por licitación, por lo tanto, que podrían encuadrarse como servicios serían aquéllas que no forman parte de la dinámica del poder público, dinámica ésta que no se confunde, con la actividad-medio o la actividad-fin.

Por otra parte, el artículo 6으, de la ley 8.666/93 que define que servicio es "toda actividad destinada a obtener una determinada utilidad de interés para la Administración, tales como: demolición, arreglo, instalación, montaje, operación, conservación, reparación, adaptación, mantenimiento, transporte, arrendamiento de bienes, publicidad, seguro o trabajos técnico-profesionales". De aquí se puede derivar que no resulta posible la contratación de mano de obra por parte del poder público por persona interpuesta, ya que ninguna de las hipótesis concierne a tareas que deban realizarse de forma permanente, sino eventuales o temporales, incluso si se trata del concepto de conservación o mantenimiento, ya que todos los demás apartados elencados, conciernen a actividades no permanentes.

\footnotetext{
${ }^{680}$ MEDAUAR, Odete, Direito administrativo moderno, cit., p. 210.

681 Art. 13. Para los fines de esta Ley, se consideran servicios técnicos profesionales especializados los trabajos relativos a: I - estudios técnicos, planificaciones y proyectos básicos o ejecutivos; II - parecer, pericias y evaluaciones en general; III - asesorías o consultorías técnicas y auditorias financieras o tributarias; IV - fiscalización, supervisión o ejecución de obras o servicios; V -patrocinio 0 defensa de causas judiciales o administrativas; $\mathrm{VI}$ - entrenamiento y perfeccionamiento del personal; VII - restauración de obras de arte y bienes de valor histórico.
} 
El artículo 37, XXI, de la Constitución brasileña de 1988 y el artículo 6ํ, II, de la ley 8.666/93 no deben perder de vista el artículo 37, II, de la CF/88, lo que lleva a concluir que, para fines de trabajo permanente, sólo es posible la contratación por concurso público.

Sin embargo, si se permitiera la contratación de personal mediante licitación, afectaría a los principios de la moralidad administrativa y de la impersonalidad. Se podría crear una especie de "corral electoral" donde los alcaldes y otros administradores, a cambio de votos en elecciones, acabarían por contratar a empresas de prestación de servicios, exigiendo la admisión de éste 0 de aquel empleado, por parte de la tomadora de los servicios, vulnerando la moralidad administrativa e impersonalidad durante la contratación de personal.

Souto Maior añade que no se puede entender que al amparo de la lógica del inciso XXI, del artículo 37, de la CF/88 se podría contratar o implementar una actividad permanente de la administración. Si así fuera, ¿cuál sería el límite? se pregunta. ¿Qué hacen los jueces sino la prestación de un servicio público para el jurisdicionado? Concluye que aunque el decreto-ley 200/67, en su artículo 10, autorice la ejecución de tareas directivas, no puede hacerlo sin observar los preceptos constitucionales (concurso público), debiendo referirse a aquello que concierne a la dinámica permanente de la administración. ${ }^{682}$

Y prosigue

"Si en los 'servicios', a los que se refiere el inciso XXI pudieran incluirse
los servicios que se realizan en el ámbito de la administración con
carácter permanente, no se podría distinguir entre los diferentes
servicios que se ejecutan, de forma natural, en la dinámica de la
administración, sino partiendo del criterio no declarado de la
discriminación, retomando, además, el carácter estamental que ha
influenciado la formación de nuestra sociedad. Pero eso, como se sabe,
o razonablemente se debería saber, hiere frontalmente los principios

682 SOUTO MAIOR, Jorge Luiz, "Terceirização na administração pública: una prática inconstitucional", cit., p. 20. 
constitucionales de la no discriminación, de la isonomía, de la igualdad y de la ciudadanía". ${ }^{683}$

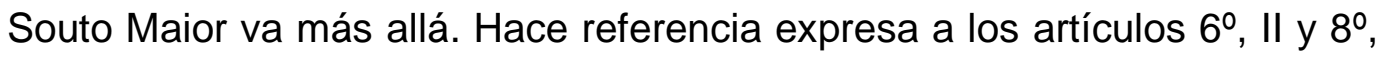
de la ley $8.666 / 93,{ }^{684}$ y argumenta que estas dos disposiciones establecen, en conjunto, que la contratación de los servicios debe producirse de forma temporal, dado que el artículo 8으, establece expresamente la posibilidad de prórroga y de plazos para la ejecución de los contratos. ${ }^{685}$

Souto Maior, en la parte final de su estudio, hace una advertencia. La defensa teórica de la posibilidad de tercerización en la administración pública ha permitido sólo la contratación de empleados de menor "status" social, con enriquecimiento de las empresas prestadoras, o mejor dicho de sus propietarios. No hay beneficio para el poder público, salvo la falsa impresión de lucro que se obtiene con la reducción del coste de la mano de obra. ${ }^{686}$

Incluso si se invoca el párrafo primero, del artículo 18, de la ley 101/00, aún así la tercerización sería inconstitucional. Este artículo no puede vulnerar lo que dispone el artículo 37, II, de la CF/88, que requiere el concurso público, y tampoco permitir que se ponga a disposición, por terceros, personal permanente en la administración.

Tanto es así que Sérgio Pinto Martins, preocupado por la cuestión del concurso público y del nepotismo, acaba creando una diferenciación entre tercerización de servicios y tercerización de mano de obra, con el fin de sostener que, en el caso de aquélla, exista una posibilidad legal para la adopción de la

\footnotetext{
683 SOUTO MAIOR, Jorge Luiz, "Terceirização na administração pública: una prática inconstitucional", ibidem.

684 "Art. $8^{\circ}$ La realización de obras y servicios debe programarse en su totalidad, siempre y cuando estén previstos sus costes y los plazos de su ejecución".

685 SOUTO MAIOR, Jorge Luiz, "Terceirização na administração pública: una prática inconstitucional", cit., p. 22.

686 SOUTO MAIOR, Jorge Luiz, "Terceirização na administração pública: una prática inconstitucional", cit., 24.
} 
subcontratación por parte del erario público, lo que no sucede en este último caso. $^{687}$

Pinto Martins peca en hacer esta distinción, dado que la tercerización de servicios no es más que el suministro de mano de obra permanente para la administración, como por ejemplo, personal de vigilancia y limpieza, entre otros. Sólo se destaca que las contrataciones para prestación de determinadas tareas como mantenimiento de edificios, informática, cursos de perfeccionamiento, no permanentes, son posibles, conforme ya hemos mencionado anteriormente, siendo ellas las reales actividades denominadas como servicios.

Incluso si los tribunales consideran posible la subcontratación con el servicio público, esta práctica debe ser erradicada a poco a poco. Y es competencia de los sindicatos y de los juristas exigir que el Estado se abstenga de efectuar contratación a través de un intermediario, respetando los preceptos básicos de la Constitución federal y los derechos del ciudadano trabajador. La defensa de los derechos fundamentales corresponde a cada uno de los miembros de la sociedad y, sobre todo, a aquellos que son capaces de medir los daños causados por su incumplimiento. La tercerización excluye, hace precario y transforma al otro en cosa. El Estado no puede tolerar esta práctica ni en el sector privado ni tampoco internamente.

\subsection{Las reclamaciones ${ }^{688} 6.970$ y 8.233 y la inconstitucionalidad del artículo 71, párrafo primero, de la ley $8.666 / 93$}

En un reciente proceso de reclamación ante el Supremo Tribunal Federal, se debatió la cuestión de la inconstitucionalidad del inciso IV de la Súmula 331 del

\footnotetext{
${ }^{687}$ PINTO MARTINS, Sérgio, A terceirização e o direito do trabalho, cit., p. 143.

688 La reclamación está recogida en el artículo 102, I, I, de la Constitución brasileña de 1988. Esta disposición (Art. 102) establece que "es de competencia del Tribunal Supremo Federal, la salvaguardia de la Constitución, cabiéndole: I - procesar y juzgar, originalmente: (...); I) la reclamación para la preservación de su competencia y garantía de la autoridad de sus decisiones; (...)".
} 
TST. El tema de la reclamación fue la infracción, por parte de este inciso de la Súmula 331 del TST, de la cláusula de reserva de plenario prevista del artículo 97 de la Constitución brasileña de 1988. Seguidamente analizaremos esta decisión.

El artículo 97 de la Constitución brasileña de 1988 establece que "Solamente por el voto de la mayoría absoluta de sus miembros o de los miembros del respectivo órgano especial podrán los tribunales declarar la inconstitucionalidad de la ley o el acto normativo del Poder Público", es decir, siempre que un tribunal, ya sea regional, de estado o incluso superior declare inconstitucional una ley o un acto normativo del poder público, deberá hacerlo por voto de la mayoría absoluta de sus miembros. A este procedimiento se denomina "reserva de plenario".

Sobre este tema, el Supremo Tribunal Federal, publicó la Súmula vinculante número 10. Esta Súmula establece que "viola la cláusula de reserva de plenario (cf, artículo 97) la decisión del órgano fraccionario del tribunal que, aunque no declare expresamente la inconstitucionalidad de la ley o el acto normativo del poder público, aleja su incidencia, en todo o en parte".

Fue precisamente en función de lo que establece esta Súmula vinculante, número 10, por lo que el Ministro del Supremo Tribunal Federal Ricardo Lewandowski, en la reclamación 6.970, concedió una medida cautelar, suspendiendo la decisión del Tribunal Superior del Trabajo que condenó al poder público a pagar, de forma subsidiaria, una cuota laboral al empleado en el caso de tercerización, en virtud de la inconstitucionalidad del artículo 71, párrafo primero, de la ley 8.666/93, inconstitucionalidad ésta que establece incluso el inciso IV de la Súmula 331 del TST ${ }^{689}$, y que tiene por fundamento el artículo 37, párrafo sexto, de la Constitución brasileña de 1988.

${ }^{689}$ Establecía em la época, hoy apartado V de la Súmula 331 del TST. 
Sin embargo, con respecto a la apreciación del mérito, el Ministro reconsideró su decisión, juzgando improcedente la reclamación, porque la edición del inciso IV, de la Súmula 331, del TST, fue debatida y decidida por el voto de la mayoría de los ministros de este tribunal.

Sin embargo, en una decisión más reciente, el Ministro Maurco Aurelio Melo, del Tribunal Supremo Federal, en una decisión monocrática, lo valoró de forma contraria al Ministro Lewandowski y juzgó procedente la reclamación para dispensar el poder público del pago de las partes laborales fruto de la condena subsidiaria, por violar, el apartado IV de la Súmula 331 del TST, la cláusula de reserva de plenario, conforme a la Súmula vinculante 10, del STF. ${ }^{690}$

Esta materia es aún controvertida. En una reciente decisión, el Tribunal Supremo Federal, Acción Directa de Constitucionalidad número 16, entendió que el párrafo primero de la ley 8.666/93 es constitucional y que no infringe el artículo 37 , párrafo sexto, de la CF/88.

Esta cuestión será objeto de un análisis más profundo en el apartado siguiente.

\subsection{De la constitucionalidad del artículo 71, párrafo primero, de la ley $8.666 / 93$}

El artículo 71, párrafo primero, de la ley $8.666 / 93^{691}$ establece que el poder público no es responsable, en los casos de no pago por parte de la empresa prestadora de servicios, por las deudas laborales, fiscales y comerciales.

\footnotetext{
${ }^{690} \mathrm{Rcl}$ 8233. Relator Ministro Marco Aurélio Melo, el 27 de abril de 2010.

691 Art. 71. El contratado es responsable por los encargos laborales, de la seguridad social, fiscales y comerciales derivados de la ejecución del contrato. $\S 1^{\circ}$ - El incumplimiento del contratado, con referencia a los encargos laborales, fiscales y comerciales no transfiere a la Administración Pública la responsabilidad por su pago, ni podrá cumplir con el objeto del contrato o restringir la regularización y el uso de las obras y edificaciones, incluso ante el Registro de Inmuebles.
} 
Esta norma de la ley 8.555/93 estaba, según el inciso IV de la Súmula 331 del TST (redacción antigua), siendo declarada inconstitucional por violar de forma expresa el artículo 37, párrafo sexto, de la Constitución brasileña de 1988.

Con la procedencia de la Acción Directa de Constitucionalidad número 16, los ministros del Supremo Tribunal Federal acabaron por entender que el artículo 71, párrafo primero, de la ley 8.666/93, es constitucional, "revocando" los términos del inciso IV, de la Súmula 331 del TST.

Sin embargo, en la decisión nada consta con respecto a la total irresponsabilidad del poder público en los casos de no pago por parte de la prestadora junto a sus empleados. Será competencia del poder público comprobar la buena fiscalización, con el fin de verse apartado del deber de pagar, conforme articulos de la Ley 8.666/93.

El Ministro Aires Brito argumenta que no se puede dejar de responsabilizar al poder público en los casos de subcontratación de trabajadores, porque la tercerización, aunque no tenga previsión constitucional, artículo 37 e incisos, de la $\mathrm{CF} / 88$, está ampliamente difundida. Lo que no se puede, adelanta el Ministro Peluso, es dejar de condenar al poder público cuando los hechos comprueben el incumplimiento. ${ }^{692}$

Es competencia, ahora, del Tribunal Superior del Trabajo y de la justicia del trabajo como un todo, investigar en cuanto a la culpa del poder público con el fin de condenarlo de forma subsidiaria. La condena no podrá ser simplemente según lo que establece el artículo 37, párrafo sexto, de la CF/88, con responsabilización objetiva, sino que deberá haber comprobada culpa por parte de la administración. ${ }^{693}$

\footnotetext{
692 http://www.stf.jus.br/portal/cms/verNoticiaDetalhe.asp?idConteudo=166785, acceso el 27 de diciembre de 2010 , a las $12 \mathrm{~h} 47 \mathrm{~min}$.

${ }_{693}$ http://www.stf.jus.br/portal/cms/verNoticiaDetalhe.asp?idConteudo=166785, acceso el 27 de diciembre de 2010 , a las $12 \mathrm{~h} 51 \mathrm{~min}$.
} 
Cabe a la administración la fiscalización de los contratos de licitación, entre ellos los de tercerización. Así lo establece el artículo 58, III, de la ley 8.666/93 ${ }^{694}$. Si no se actúa de forma precavida, no se podrá considerar aplicable la regla del artículo 71, párrafo primero, de la ley 8.666/93, porque la norma legal debe interpretarse en su conjunto, de forma que haya un sentido legislativo lógico.

Este artículo 58, III, de la ley 8666/93, se complementa con los artículos 66 y $67^{695}$ de la misma norma legal, que obliga al fiel cumplimiento de los términos acordados y a la fiscalización por parte de la administración a través de un representante o apoderado, debiendo, conforme al artículo $76^{696}$, rechazar la obra que no esté ejecutando en los términos exactos de lo que se acordó.

Según la decisión del STF, ADC 16, y las disposiciones legales antes citadas, se puede entender que no está excluida la responsabilidad del poder público en el caso de falta de pago de las empresas contratadas (tercerizadas). La administración pública deberá comprobar la correcta fiscalización en cuanto al cumplimiento de los derechos laborales, bajo pena de verse obligada a pagar, en el caso de incumplimiento por parte de la empresa prestadora, los débitos laborales de esta.

\footnotetext{
${ }^{694}$ Art. 58. El régimen jurídico de los contratos administrativos instituido por esta Ley confiere a la Administración, con relación a ellos, la prerrogativa de: (...); III - fiscalizarles la ejecución; (...).

${ }_{695}$ Art. 66. El contrato deberá ser ejecutado fielmente por las partes, de acuerdo con las cláusulas convenidas y las normas de esta Ley, respondiendo cada una por las consecuencias de su incumplimiento total o parcial.

Art. 67. La ejecución del contrato deberá ser acompañada y fiscalizada por un representante de la Administración especialmente designado, permitiendo la contratación de terceros para asistirlo y facilitarle informaciones pertinentes a esa atribución.

$\S$ 1을 El representante de la Administración anotará en un registro propio todos los sucesos relacionados con la ejecución del contrato, determinando lo que sea necesario para la regularización de las faltas o los defectos observados.

$\S 2^{\circ} \quad$ Las decisiones y medidas que excedan la competencia del representante deberán ser solicitadas a sus superiores en un tiempo hábil para la adopción de las medidas convenientes.

${ }^{696}$ Art. 76. La Administración rechazará, totalmente o en parte, la obra, el servicio o el suministro ejecutado en desacuerdo con el contrato.
} 


\subsubsection{Régimen de concesión y permiso de la prestación de servicios públicos}

El régimen de concesión y permiso de servicios públicos posee su propia forma de tercerización. Preceptua el artículo 25, párrafo primero, de la ley $8.987 / 95^{697}$ que "la concesionaria podrá contratar con terceros el desarrollo de actividades inherentes, accesorias o complementarias al servicio concedido, así como la implementación de proyectos asociados".

El artículo mencionado prevé la tercerización de las actividades inherentes del tomador de los servicios, empresa concesionaria y/o permisionaria de obra pública, que podria dar a tercera empresa la ejecución de parte de la obra concedida o permitida. De ahí se podría interpretar que el ordenamiento jurídico brasileño prevé la posibilidad de la tercerización de actividad-fin.

Es decir, sin embargo, contradice los términos de la Súmula 331 del TST ${ }^{698}$. Se constata que el hecho de que una ley vaya en contra de una Súmula del Tribunal Superior del Trabajo, por evidente, no la (ley) hace ilegal. La ley se aplicará independientemente de la Súmula, sirviéndose de ésta para los casos no amparados por la jurisprudencia reiterada del Tribunal Superior del Trabajo.

\footnotetext{
${ }^{697}$ Art. 25, párrafo primero. La concesionaria podrá contratar con terceros el desarrollo de las actividades inherentes, accesorias o complementarias para el servicio concedido, así como la implementación de proyectos asociados.

698 "Súmula № 331 del TST - Contrato de prestación de servicios. Legalidad - Inciso IV modificado por la Res. 96/2000, DJ 18.09.2000 I - La contratación de trabajadores por empresa interpuesta es ilegal, formándose el vínculo directamente con el tomador de los servicios, salvo en el caso de trabajo temporal (Ley oㅜ 6.019, de 03.01.1974). II - La contratación irregular de trabajador, mediante empresa interpuesta, no genera vínculo de empleo con los órganos de la administración pública directa, indirecta o fundacional (Art. 37, II, de la CF/1988). III - No forma vínculo de empleo con el tomador la contratación de servicios de vigilancia (Ley no 7.102 , de 20.06.1983) y de conservación y limpieza, así como la de servicios especializados ligados a la actividad-medio del tomador, siempre que no exista la personalidad y la subordinación directa. IV - El incumplimiento de las obligaciones laborales, por parte del empleador, implica la responsabilidad subsidiaria del tomador de los servicios, con respecto a las obligaciones, incluso en cuanto a los órganos de la administración directa, de las autarquías, de las fundaciones públicas, de las empresas públicas y de las sociedades de economía mixta, siempre que hayan participado en la relación procesal y consten también del título ejecutivo judicial (Art. 71 de la Ley no 8.666, de 21.06.1993)".
} 
En cualquier caso, esta forma de tercerización depende del contrato entre el prestador del servicio y la concesionaria del servicio público. Una vez que los trabajadores de la prestadora estén sujetos a las órdenes de la tomadora, en cualquier forma de tercerización, incluso la presente, se entenderá que hay vínculo de empleo con ésta, conforme se puede constatar por lo que preceptua el articulo $3^{\circ}$ de la CLT, que da al trabajador subordinado la condición de empleado de aquel que le subordina.

De otro lado, sobre este tema de la tercerización aquí debatido, Godinho Delgado, como Ministro del Tribunal Superior del Trabajo, al tratar de un caso en que la empresa solicitó la aplicación del artículo 25 de la ley 8.987/95, decidió que la actividad inherente no es lo mismo que la actividad-fin, porque afectaría a los principios clásicos que tutelan el derecho del trabajo, que tienen por objeto la protección del empleado. El Ministro pone de manifiesto el hecho de que la Súmula 331 del Tribunal Superior del Trabajo prevea los casos de tercerización lícita, sin poder aplicar el citado artículo de ley porque colisiona con la ya citada Súmula. Ésta, como deriva de la decisión de Godinho Delgado, incorpora los principios de protección y tutela del trabajo. ${ }^{699}$

El tema es controvertido. Tanto es así que en otra decisión, conforme al apartado siguiente, el Tribunal Superior del Trabajo decidió que las empresas de telecomunicaciones pueden tercerizar una actividad-fin, argumentando que la actividad-fin es sinónimo de actividad inherente. La redacción del artículo 94, II, de la ley 9.472/97 es muy similar a la del artículo 25, de la ley 8.987/95.

Dejamos constancia de la existencia de una forma más de tercerización lícita, prevista en la legislación brasileña.

699 PROCESO № TST-RR-207/2006-005-15-00.8 - Relator Ministro Mauricio Godinho Delgado Sala Sexta del Tribunal Superior del Trabajo, 10 de junio de 2009. 


\subsubsection{Ley general de las telecomunicaciones}

Al igual que en el apartado anterior, el artículo 94, II, de la ley 9.472/97 que trata de las telecomunicaciones, establece que las empresas concesionarias de telecomunicaciones podrán "contratar con terceros el desarrollo de actividades inherentes, accesorias o complementarias al servicio, así como la implementación de proyectos asociados".

El artículo mencionado prevé la tercerización de las actividades inherentes al tomador de los servicios, por lo que se podría considerar lícita la tercerización de actividad-fin de este tomador. Los argumentos tratados anteriormente, que conciernen al artículo $3^{\circ}$ de la CLT, y 7ํㅜ I, de la Constitución federal de 1988 y que, en el primer caso, no se prevé la diferencia entre la actividad-medio y la actividad-fin, considerando empleados a los trabajadores que presten trabajo de forma permanente a la empresa y, en el segundo, que exige alteraciones legislativas que se dirigen a la mejora de la condición social de los trabajadores, acaban por frustrar la posibilidad de subcontratación, según los términos del artículo 94, II, de la ley 9.472/97.

Sobre esta cuestión, el Tribunal Superior del Trabajo, en el proceso 46612002-921-21-00-4, debate si efectivamente la tercerización prevista por la ley que ahora estamos analizando, pueda alcanzar no sólo la actividad-medio del tomador, sino también la actividad-fin. Sin embargo, el Ministro Lélio Bentes Corrêa advierte del peligro de tercerizar toda la estructura de la empresa, lo que no está permitido por la jurisprudencia del TST. ${ }^{700}$

Es interesante añadir que José Alberto Couto Maciel sostiene la posibilidad de tercerización en la actividad-fin de las empresas de telecomunicaciones, así como en los casos de las empresas que actúan en el régimen de concesión y

700

http://ext02.tst.gov.br/pls/no01/no noticias. Exibe Noticia?p cod area noticia=ASCS\&p cod notici $\underline{a=9006}$ - acceso el 09 de marzo de 2009, 14h. 
permiso, en este caso la ley 8.987/95, que deriva de lo que establece el artículo 175, de la Constitución brasileña de $1988^{701}$. Ello establece que estas empresas, por prestar servicios públicos, "de relevancia y garantía nacional, tienen que ejercer tales servicios de forma que atiendan satisfactoriamente a todo el país, ya sea a través de red, o mediante satélites, o conforme a los sistemas de mayor rapidez y economía ahora actualizados, que sólo puede ser hecho mediante la tercerización de las propias actividades inherentes, esenciales o complementarios, incluso las adicionales". ${ }^{702}$

No se puede olvidar que según la jurisprudencia del Tribunal Superior del Trabajo, siempre que no haya una subordinación jurídica entre el trabajador y la empresa tomadora, el vínculo se producirá entre el empleado y la empresa prestadora, quedando la contratante como responsable subsidiaria en razón de la tercerización. Si hubier la subordinación a la empresa de telecomunicaciones, sera ésta y no la prestadora la empleadora, con responsabilidad solidaria de ellas, por el fraude a los derechos sociales, articulo 9ำ de la CLT.

En cuanto á la responsabilidad subsidiaria, ella se aplicaría en virtud del inciso IV, de la Súmula 331 del Tribunal Superior del Trabajo ${ }^{703}$, aplicable también a las concesionarias de servicio público, conforme a la ley $8.987 / 95$, por los mismos fundamentos.

Ahora, en el final de 2011, el mismo Tribunal Superior del Trabajo decidió que no se puede tercerizar la actividad fin, incluso en las empresas de telefonia. $E$ Tribunal dice que no se puede entender que el articulo 94 de la ley 9.472/97 autoriza la tercerizacion de actividad-fin. Ello porque se debe hacer una

\footnotetext{
701 "Art. 175. Corresponde al Estado, conforme a lo dispuesto por la ley, ya sea directamente o por concesión o permiso, siempre a través de licitación, la prestación de los servicios públicos".

702 COUTO MACIEL, José Alberto, "Terceirização na atividade-fim. Empresas de telecomunicações (...), cit., p. 145.

703 "Súmula № 331 del TST - (...) IV - IV - O inadimplemento das obrigações trabalhistas, por parte do empregador, implica a responsabilidade subsidiária do tomador dos serviços quanto àquelas obrigações, desde que haja participado da relação processual e conste também do título executivo judicial".
} 
interpretacion de todo el sistema jurídico que es protector del trabajador, aplicando los preceptos de la Súmula 331 del TST. ${ }^{704}$

\title{
2.4.5.4 Servicios de seguridad, vigilancia y transporte de valores - ley
} $7.102 / 83$

Otra forma de tercerización es la de los servicios de seguridad, vigilancia y transporte de valores, conforme al artículo 10, párrafo segundo, de la ley 7.102/83 que contempla otras formas de tercerización previstas en el ordenamiento jurídico brasileño.

Dispone el citado artículo y párrafo:

\begin{abstract}
"Art. 10. Son considerados como seguridad privada las actividades referentes a las prestación de servicios con la finalidad de: I - proceder a la vigilancia patrimonial de las instituciones financieras y de otros establecimientos, públicos o privados, así como la seguridad de las personas físicas; II - realizar el transporte de valores o garantizar el transporte de cualquier otro tipo de carga. (...) $\S 20$ Las empresas especializadas en prestación de servicios de seguridad, vigilancia y transporte de valores, constituidas bajo la forma de empresas privadas, además de las hipótesis previstas en los incisos del caput de este artículo, podrán prestarse al ejercicio de las actividades de seguridad privada para personas; para establecimientos comerciales, industriales, de prestación de servicios y residencias; para entidades sin fines de lucro; y órganos y empresas públicas".
\end{abstract}

Se trata de la posibilidad de contratación, por instituciones financieras, establecimientos públicos o privados, así como por personas físicas, de servicios de seguridad, vigilancia y transporte de valores a través de empresas especializadas.

Son empresas especializadas de seguridad privada las que están destinadas a la vigilancia patrimonial de las instituciones mencionadas y/o que

${ }^{704}$ http://www.tst.jus.br/noticias/-/asset publisher/89Dk/content/quarta-turma-mantem-condenacaoa-brasil-telecom-por-terceirizacaoilicita? redirect=http\%3A\%2F\%2Fwww.tst.jus.br\%2Fnoticias\%3Fp p id\%3D101 INSTANCE 89Dk \%26p p lifecycle\%3D0\%26p p state\%3Dnormal\%26p p mode\%3Dview\%26p p col id\%3Dcolu mn-3\%26p p col pos\%3D1\%26p p col count\%3D3 - aceso 15 de dezembro de 2011, a las 16h31min. 
realizan transporte de valores para estas mismas empresas, tal como se contempla en los incisos I y II del artículo 10, de la ley 7.102/83.

Esta forma de tercerización lícita aparece en la Sección III de la Súmula 331 del $\mathrm{TST}^{705}$, servicios de vigilancia y seguridad, y excluye el vínculo laboral para el tomador de los servicios, aunque resulte éste, sin embargo, responsable de forma subsidiaria.

Sólo ponemos de manifiesto que en el transcurso de esta investigación constan varias críticas a la presente forma de contratación a través de terceros, poniendo en tela de juicio su constitucionalidad y legalidad, según los artículos 7ํㅡ, encabezamiento e inciso I, de la Constitución brasileña de 1988, y 3o de la Consolidación de las Leyes del Trabajo.

\subsubsection{Actividades de movimiento de mercancías - ley 12.023/09}

La ley 12.023 de 27 de agosto de 2009 creó otra forma de tercerización en las actividades de movimiento de mercancías. El preámbulo de la ley, así como el artículo $2^{\circ}$, demuestran, respectivamente, el alcance de la norma y lo que entiende por actividad de movimiento de mercancías. ${ }^{706}$

El artículo $3^{\circ}$ de la ley 12.023/09 establece que "Las actividades de que trata esta Ley serán ejercidas por trabajadores con vínculo o relación laboral o en

\footnotetext{
705 "Súmula 331. (...); III - No forma vínculo de empleo con el tomador la contratación de servicios de vigilancia (Ley no 7.102, de 20.06.1983) y de conservación y limpieza, así como la de servicios especializados ligados a la actividad-medio del tomador, siempre que no exista la personalidad y la subordinación directa; (...)".

${ }_{706}$ Preámbulo: "Dispone sobre las actividades del transporte de mercancías en general y en el trabajo individual".

"Art. 20 - Son actividades de transporte de mercancías en general: I - carga y descarga de mercancía de granel y ensacados, costura, pesaje, embalaje, enlonamiento, ensacado, transporte, colocación, acomodación, recuperación, reparación de carga, muestreo, almacenamiento, eliminación, clasificación, apilamiento, transporte con carretillas elevadoras, paletización, huevas y vagón, carga y descarga en los mercados libres y suministro de madera en las calderas y secadoras; II - operaciones de carga y descarga; III - limpieza previa y limpieza en los lugares necesaria para la viabilidad de las operaciones o para su continuidad".
} 
régimen de trabajo separado en las empresas tomadoras del servicio". Esta disposición de ley, cuando autoriza la utilización de trabajadores con vínculo de empleo en actividad de movimiento de mercancías, acaba por legitimar, por norma legal, otra forma de tercerización, dado que no sería coherente que la primera parte del citado artículo de ley se refiriese al propio tomador como empleador porque, conforme al artículo $2^{\circ}$ de la CLT, puede, independientemente de la ley 12.023/09, reconocer la relación de empleo directa.

Por ello, la legislación objeto de examen creó otra forma de tercerización. Cuando se ocupa de "trabajadores con vínculo de empleo" se está refiriendo a las empresas prestadoras de servicio, que contratan empleados en su nombre, como empleados suyos, para proporcionar a terceros, tomadores, una prestación de servicio de logistica.

Hay que tener presente que esta disposición, por ser una norma legal reciente, carece de mayores comentarios y análisis jurisprudenciales y doctrinales. Esta es otra forma de contratación de trabajadores por intermediación de mano de obra, conocida como tercerización. En esta investigación no se abordaran los casos del trabajador "avulso" ni las cooperativas de trabajo, que pueden (y deben) analizarse aparte dada su relevancia.

Queda destacada, tambien, esta nueva forma de intermediación de mano de obra o subcontratación considerada lícita por la ley brasileña, respetando, sin embargo, los límites, prestada en las actividades de movimiento de mercancías. 


\subsection{La incidencia de la Súmula 331 del TST}

\subsubsection{La dudosa legitimidad de la distinción entre actividad medio- actividad fin}

La discusión entre actividad-medio y actividad-fin es controvertida. No se puede definir bien lo que efectivamente sea actividad-medio, aunque se pueda tener una vaga idea, teniendo en cuenta el producto o el servicio puesto por la empresa en el comercio o incluso a sus proveedores. ${ }^{707}$

Gustavo Filipe Barbosa García considera la actividad-medio como "aquélla de mero soporte, que no integra el núcleo, es decir, la esencia de las actividades empresariales del tomador". La actividad-fin es la que compone el núcleo o la esencia de las actividades empresariales del tomador. ${ }^{708}$

Para Pinto Martins, la actividad-fin "es la que concierne a los objetivos de la empresa, incluyendo la producción de bienes o servicios, la comercialización, etc. Es la actividad central de la empresa, directa, de su objeto social". Para el derecho comercial la actividad-fin concierne a lo que consta como objeto del contrato social de la empresa, es decir, la actividad principal de ésta. ${ }^{709}$

Si se puede creer que los conceptos de actividad-fin de Brasil y propia actividad utilizado en España son similares, uno debe decir que ells no se confunden. Están muy cerca, pero no son la misa cosa. La "propia actividad", és la actividad indispensable, de suerte que integran el concepto, además de las actividades que forman parte del ciclo productivo, aquéllas necesarias para la organización del trabajo. La actividad-fin, por el concepto de la doctrina y

\footnotetext{
707 Aqui, ver FERREIRA PRUNES, José, Trabalho terceirizado e composição industrial, cit., p. $41 / 50$.

708 BARBOSA GARCIA, Gustavo Filipe, "Equiparação salarial na terceirização de serviços". En: Revista Justiça do Trabalho, número 296, Porto Alegre, HS Editora, agosto de 2008, p. 61/62.

${ }^{709}$ PINTO MARTINS, Sérgio, A terceirização e o direito do trabalho, cit., 132.
} 
jurisprudencia de Brasil és solamente la actividad principal de la empresa, como esta escrito en su contrato social ${ }^{710}$.

La actividad-medio sería aquélla desempeñada por la empresa que no concierne a sus fines principales. Es la actividad no esencial, secundaria, que no es su objeto central. Clasifica la actividad-medio como de apoyo a la principal y cita como ejemplo la limpieza y la vigilancia, entre otras. Sería la actividad secundaria de la empresa, es decir la que no forma parte de su actividad normal. Al tratarse de una actividad-fin, conforme a la Súmula 331, III, del Tribunal Superior del Trabajo, advierte, no será posible la tercerización. ${ }^{711}$

Para José Alberto Couto Maciel la actividad-medio es toda aquella no esencial para la empresa, es decir, aquélla que tiene como objetivo dar soporte a las actividades principales, conforme a su contrato social y objetivos sociales, siendo la actividad-fin aquella descrita en la cláusula-objeto del contrato social de la empresa. ${ }^{712}$

Lo que llama a atención, sin embargo, como se ha mencionado en el primer párrafo de este apartado, es como se podría definir bien lo que es la actividadmedio y la actividad-fin. Ejemplo clásico es el de las instituciones financieras. Viven de los valores aplicados y movidos por una enorme gama de clientes no solamente personas jurídicas sino también físicas. ¿Cómo se puede aceptar que el servicio de vigilancia y seguridad de un banco es secundario? Si lo fuese, podría ser dejado de lado. Aún así, ¿la empresa operaría? Pero ¿qué banco va a operar sin seguridad y vigilancia? ${ }^{713}$

\footnotetext{
710 Uno hace referencia que este concepto restritivo és contestado por parte minoritaria de la doctrina y de la jurisprudencia, en especial la docrtina de la subordinación objetiva que está referida en el capitulo seguiente de este estudio.

${ }_{711}$ PINTO MARTINS, Sérgio, A terceirização e o direito do trabalho, cit., 133/134.

712 COUTO MACIEL, José Alberto, "Terceirização na atividade-fim. Empresas de telecomunicações (...), cit., p. 137.

${ }_{3}$ Ejemplo utilizado para entender la dificultad de definir la actividad-medio y la actividad-fin. Es notorio que los bancos, a los efectos de tercerización de actividades de vigilancia y seguridad tienen su propio criterio jurídico.
} 
Por otra parte, ¿cómo se puede justificar que los servicios de limpieza de una empresa que suministra alimentos a terceras empresas sea una actividadmedio? ¿Qué tipo de sociedad suministrará alimentación sin las mínimas condiciones de higiene? ¿Qué clientes suscribirían un contrato, con el fin de alimentar a sus empleados, en estas circunstancias?

¡No hay respuesta a estas cuestiones!

Tanto es así que José Alberto Couto Maciel apunta que una vez observadas con mayor detalle las actividades de las empresas, no podemos ver la diferencia entre la actividad-medio y la actividad-fin, dado que todo lo que está siendo ejecutado deriva de una necesidad empresarial. Utiliza el ejemplo de la seguridad en las instituciones financieras, limpieza y conservación para las empresas en general, así como todas las actividades que mejor se califiquen como complementarios y no como medio. ${ }^{714}$

Para Süssekind, la "tercerización es la contratación de empresas especializadas en seguimientos de producción no correspondientes al objeto final de la contratante o para la ejecución de actividad-medio no fundamentales para el funcionamiento de la empresa". Para la jurisprudencia es posible la tercerización de servicios de restauración o de preparación de alimentos, de seguridad, conservación y limpieza, conservación y asistencia de máquinas, ascensores y otros equipos, asistencia médica, contable o jurídica, transporte y selección de personal. $^{715}$

Una vez aclarado lo que es actividad-fin y actividad-medio, será posible, a partir de la jurisprudencia del Tribunal Superior del Trabajo, Súmula 331, III, la tercerización de las actividades de conservación y limpieza, vigilancia, así como

\footnotetext{
${ }^{714}$ COUTO MACIEL, José Alberto, "Terceirização na atividade-fim. Empresas de telecomunicações (...), cit., p. 138.

${ }_{715}$ SÜSSEKIND, Arnaldo, Curso de direito do trabalho, cit., p.204.
} 
aquéllas ligadas a la actividad-medio del tomador, ya que no existe la personalidad y la subordinación juridica con respecto a la prestación de los servicios ${ }^{716}$.

La jurisprudencia relativa a la Súmula 331 del TST, si se terceriza la actividad-fin del tomador, o incluso si existe tercerización de la actividad-medio, en este último caso si se mantiene la personalidad y/o la subordinación jurídica con respecto al tomador de los servicios, declara que la tercerizacion es prohibida ${ }^{717}$. En este caso, el vínculo se declarará de forma directa para este último, conforme al inciso I, de la súmula 331, del TST. Además, en casos de fraude a la ley, conforme al artículo 9º de la CLT, y 942, enunciado y párrafo único, del Código Civil brasileño ${ }^{718}$, será la empresa prestadora de los servicios responsables de forma solidaria.

\subsubsection{El papel de la subordinación}

Conforme a lo podremos ver seguidamente en el próximo apartado, lo que nos ayuda a definir los límites de la subcontratación es el concepto de subordinación. Este estudio tiene como objetivo modificar un poco la visión proveniente de la doctrina brasileña, haciendo referencia no sólo a la doctrina de

\footnotetext{
716 “Súmula № 331 del TST - (...) III - No forma vínculo de empleo con el tomador la contratación de servicios de vigilancia (Ley no 7.102, de 20.06.1983) y de conservación y limpieza, así como la de servicios especializados ligados a la actividad-medio del tomador, siempre que no exista la personalidad jurídica y la subordinación directa".

717 EMENTA TERCEIRIZAÇÃO DA ATIVIDADE-FIM. ILICITUDE. VÍNCULO DE EMPREGO DIRETO COM A TOMADORA DE SERVIÇOS. Excetuados os casos de pactuação temporária de trabalho (Lei no 6.019/74), a terceirização das atividades nucleares e essenciais (atividades-fim) da empresa é ilícita e enseja o reconhecimento do vínculo empregatício diretamente com tomador dos serviços. Inteligência da Súmula no 331 do TST. http://gsa3.trt4.jus.br/search?q=cache:paD5DLb EnUJ:iframe.trt4.jus.br/nj4 jurisp/jurispnovo.Exibir DocumentoJurisprudencia\%3FpCodAndamento\%3D45678020+inmeta:DATA DOCUMENTO:2012 -07-06..2013-07-06+\%22terceiriza\%C3\%A7\%C3\%A30\%22+atividadefim++\&client=jurisp\&site=jurisp\&output=xml no dtd\&proxystylesheet=jurisp\&ie=UTF$8 \& \mid r=l a n g ~ p t \& a c c e s s=p \& o e=U T F-8$ - aceso el 06 de julio de 2013, à las 23h31min .

718 "Artículo 9‥ Serán nulos de pleno derecho los actos practicados con el objetivo de desvirtuar, impedir o falsificar la aplicación de los preceptos contenidos en la presente Consolidação".

"Artículo 942. Los bienes del responsable por la ofensa o violación del derecho de otros quedan sujetos a la reparación del daño causado; y, si la ofensa tiene más de un autor, todos responderán solidariamente por la reparación. Párrafo único. Son solidariamente responsables con los autores los coautores y las personas designadas en el artículo 932".
} 
Brasil, sino también de España, Francia, Portugal, Chile, Argentina, Uruguay y Mexico.

\subsection{Consideraciones finales}

En este capítulo hemos destacado la importancia del tema de la tercerización, su forma de tratamiento no sólo en Brasil, sino también en América Latina y en Europa.

Los temas relativos a los trabajadores implican a la mayor parte de la población de un país. La cuestión de la tercerización adquiere especial relieve dado el mundo cada día más flexible, líquido y sin fronteras en el que vivimos.

Temas que implican servicios especializados o muy específicos, prestados por empresas de alta competencia y singularidad, donde sus empleados o trabajadores tienen mayores protecciones sociales o incluso económicas que los empleados de la tomadora no han sido objeto de atención en este estudio.

Aquellos están protegidos en razón de la peculiaridad de sus instrumentos contractuales, lo que no sucede, por ejemplo, con el personal de la vigilancia, limpieza y portería de determinadas empresas.

La tercerización, hoy en día, es uno de los elementos centrales del derecho del trabajo. Es competencia del jurista, por esta razón, tratar este tema con la mayor seriedad posible, bajo la óptica de los derechos fundamentales, dignidad humana, valor social del trabajo y de la libre-iniciativa. No se puede perder de vista la cuestión del estado democrático de derecho y de la esencialidad del trabajo en el modo de producción capitalista y globalizado. 
Capítulo III

3 La subordinación jurídica 


\subsection{Introducción}

En este capítulo pretendemos exponer las opiniones que se han surgido con relación a la subordinación jurídica y someterlas a análisis. Las analizaremos tomando como referente las opiniones vertidas por la doctrina vigente y mayoritaria pero sometiéndolas a críticas. Para ello, utilizaremos la literatura que trata sobre el tema en varios países, para, al final, esbozar algunas conclusiones.

Nuestro estudio tiene inicio con el concepto de subordinación jurídica, vinculada comúnmente al poder de mando del empleador sobre el prestador de servicios, que coloca su energía - único bien que realmente posee -, a disposición y bajo las órdenes de su patrón. El análisis de este apartado va más allá de esta conceptuación simplista.

Sin embargo, en el marco de la subordinación jurídica conviene detenerse en el estudio de la subordinación de la voluntad. Destacamos la relevancia del elemento "voluntad" para el derecho contractual y sus consecuencias dentro del contrato de empleo. Cada vez que el trabajador presta servicios de forma subordinada, en realidad, deja su voluntad de lado para repetir la voluntad de su empleador. Esta situación será analizada, así como las consecuencias que conllevan el ajuste de empleo.

En lo que se refiere a la relación de la subordinación con la no eventualidad, tema esencial en el derecho laboral brasileño, lo trataremos en un apartado específico, al igual que en el caso de la subordinación estructural. De hecho, el trabajador subordinado, sujeto a las órdenes de toda la producción, subordina su voluntad a la producción, siendo, por tanto, el que da las órdenes o determina, de la forma que sea, la ejecución de la producción, con el fin de llegar a un fin $^{719}$, su empleador.

\footnotetext{
${ }^{719}$ Ejecución de órdenes por parte del patrón para que se llegue a un fin y para que se alcance el objetivo que se propone la empresa no tiene ninguna relación con el concepto creado por la jurisprudencia brasileña, "súmula" 331 del TST de "actividad-medio y/o actividad fin" del tomador del trabajo. La ejecución de la producción, para que la empresa alcance su fin social puede ser
} 
La centralidad del trabajo ante la economía actual se deja de lado para favorecer al mercado. Quien genera la mercancía, vendiendo el único bien que posee, su fuerza de trabajo, queda relegado a un mero papel cuando, de hecho, se enfrenta a una situación, muchas veces análoga a una esclavitud inconsciente, que deriva de la subordinación de su voluntad al tomador de los servicios y de la alienación, pérdida de contacto con las técnicas de producción y con el bien producido, lo que acaba haciéndolo rehén del propio sistema. ${ }^{720}$

También nos ocuparemos de la subordinación virtual o "post-industrial". A pesar de que se produzcan avances en la tecnología y que causen inestabilidad en el sistema capitalista, siempre existirá quien preste trabajo subordinado. $Y$ existirá como elemento central en el sistema capitalista, dado que la mercancía, en el capitalismo, jamás dejará de existir. Sin mercancía no hay mercado. Sin mercado no hay capitalismo.

Junto con la subordinación jurídica, nos ocuparemos también del trabajo subordinado y de la dignidad humana.

El tema que vamos a examinar aquí no está exento de críticas que, por otra parte, son necesarias. Lo que se pretende es provocar la discusión, sacar a la superficie la cuestión de la centralidad del trabajo subordinado en el modo de producción capitalista, así como el concepto real del trabajador subordinado, aún

realizada por cualquier trabajador, siempre que este trabajo sea permanente y cuente con él el tomador del trabajo.

720 Sobre esta cuestión ver lo que apunta Chomsky, en una entrevista al periódico español "El País": preguntado si "¿Cree que la crisis económica podría provocar una crisis de valores que lleve a un cambio en la forma de organizarnos social y políticamente? R. Ya está ocurriendo, creo que está bajo la superficie, y la mayoría de la gente la está empezando a sentir de forma instintiva. En la literatura popular del siglo XIX, uno de los temas principales es que quien trabaja el molino debería poseerlo. Hay muchos escritos de la revolución industrial de campesinos que dicen: 'El sistema industrial nos ha quitado nuestra cultura, nuestra individualidad, nos ha convertido en herramientas en manos de otros'. Esas cosas las escribió gente que jamás había oído hablar del anarquismo o del marxismo, pero lo pensaba de forma instintiva. Esta crisis vuelve a impulsar esas ideas". Entrevista de Noam Chomsky a Barbara Celis el 02 de marzo de 2009.

http://www.elpais.com/articulo/cultura/soy/Don/Quijote/molinos/viento/reales/elpepicul/20090302elp epicul_1/Tes - (acceso el 25 de agosto de 2009, a las 14h26min). 
más en esta sociedad globalizada y líquida, que no se apega a nada que no tenga que ver con la acumulación de riqueza.

Comenzamos, a partir de ahora, con la subordinación jurídica propiamente dicha, concepto esencial para la comprensión de lo que es la tercerización y cuál o cuáles son sus límites, si es que efectivamente existen, frente al presente orden constitucional brasileño.

\subsection{Subordinación jurídica.}

Hay varios conceptos de subordinación. La subordinación jurídica es sólo una de las especies del género "subordinación". Teniendo por norte esta premisa, conceptuar este instituto es esencial para comprender el trabajo en el modo de producción capitalista. Tal vez lo ideal sería que no hubiese situaciones de subordinación entre personas ${ }^{721}$ y que todos vivieran en una sociedad libre de la sujeción de uno o unos sobre los demás, pero la cosa no se pasa así.

Alain Supiot, afirma con respecto al tema de la subordinación que es ella una característica de todos los países europeos para identificar el trabajo asalariado. "La difficulté partout recontrée a consisté à enfermer cette idée de dépendance dans une définition suffisamment précise". El autor francés hace hincapié que se ha debatido mucho al respecto, con dos teorías predominantes en Francia: la que defendía que empleado es aquella persona que presta servicio a terceros y de este trabajo obtiene su sustento (dependencia económica). Es lo que defendía Paul Cuche. Sin embargo, no es este el criterio que define quién es efectivamente empleado, aunque se haya discutido mucho a nivel europeo. ${ }^{722}$

Por miedo a la imprecisión, se prefirió un criterio jurídico, es decir, el de la subordinación del trabajador a las órdenes del patrón. "En France, c'est la

\footnotetext{
721 RODRIGUES GOMES, Fábio, O direito fundamental ao trabalho. Perspectivas histórica, filosófica e dogmático-analítica, Rio de Janeiro; Editora Lumen Juris, 2008, p. 56. El autor, citando a Agnes Heller argumenta que "Al bien de la verdad, el citado reconocimiento de todas las necesidades se coloca en un marco contrafáctico, es decir, como un valor concebido junto con la idea de abolir todas las relaciones sociales basadas en la subordinación y en la jerarquía".

722 SUPIOT, Alain, Critique du droit du travail, Paris; Quadrige Puf, 2e. ed, 2007, p. 112.
} 
jurisprudence que a taché en ce sens, et le contrat de travail s'y trouve généralement défini comme la 'convention par lequelle une persone s'engage à mettre son activité à la disposition d'une autres, sous la subordination de lequelle elle place, moyennant une remunération". La sumisión del trabajador al empleador, continúa el autor, es lo que constituye, de hecho, la característica esencial del contrato de trabajo. ${ }^{723}$

Esta solución fue acogida también a nivel europeo, cuando se definieron quiénes eran los trabajadores beneficiados por la libre circulación, según establece el artículo 48 del Tratado de Roma. Para el Tribunal de Justicia de la Comunidad Europea la característica central de la relación de trabajo es la circunstancia de alguien "'accomplit, pendant un certain temps, en faveur d'une autre et sous la direction de celle-ci, des prestations en contrepartie desquelles elles touche une rémunération". Para evitar problemas, debe considerarse que el contrato de empleo se caracteriza por la ejecución de una prestación a cargo de un beneficiario, dirigido por este beneficiario y bajo condición onerosa para aquél que recibe la prestación del trabajo. ${ }^{724}$

El criterio, por tanto, tanto en el plano interno francés como a nivel europeo, para la caracterización del contrato de empleo y para el de las otras formas de trabajo onerosas, es el poder de dirección del trabajo ajeno. ${ }^{725}$

Como podemos observar, no es fácil caracterizar la relación de empleo. Lo que queda, sin embargo, es el hecho de que, una vez prestado el trabajo bajo las órdenes de otros, habrá un contrato de empleo. Sin embargo, la conceptualización de la subordinación jurídica no es tan simple. Son necesarias, aún, otras consideraciones.

\footnotetext{
723 "La caractérisation du contrat de travail n'est pas à rechercer alors dans la couple 'profit/dépendance économique', mais dans la couple 'autorité/subordination'. A la perspective fonctionelle et inductive d'ajustement de la notion de contrat de travail aux besoins de protection est préférée une perspective formelle et déductive, qui fait dériver la qualification do contrat du constat de sumission d'une partie aux ordres de l'autre". SUPIOT, Alain, Critique du droit du travail, cit., 113.

${ }_{724}^{724}$ SUPIOT, Alain, Critique du droit du travail, cit., p. 113/114.

${ }^{725}$ SUPIOT, Alain, Critique du droit du travail, cit., p. 114.
} 
Marcelo Pedrazzoli, subraya que no es verdad que el trabajo a tiempo indeterminado y continuado esté disminuyendo, dando espacio a relaciones que escapan de la lógica de la subordinación. Entiende que ésta es una realidad de los países desarrollados, y que pone en jaque el actual concepto de subordinación. El autor defiende la superación de las antiguas ideologías y que la clásica expresión de igualar los desiguales ha creado varias distorsiones. ${ }^{726}$

Comenzamos, a partir de esta breve exposición, a conceptualizar la subordinación jurídica, sin perder de vista la cuestión de la importancia del trabajo subordinado y su naturaleza de elemento de existencia humana.

\subsubsection{Concepto para la doctina y de la jurisprudencia}

El capitalismo, desde la Revolución Industrial, opera de forma perversa frente al trabajo, para sacarle lo más relevante que tenga: el carácter de elemento de la existencia humana. Lo que pretende el modo de producción actual ya no es la docilidad de los agentes responsables por la transformación social (trabajadores), a favor de una lógica que no abarca a todos y que suprime la parte del trabajo como vida y existencia, relacionándola con la cosificación y el aspecto meramente económico.

El capitalista se sirve de la actividad del trabajador. Lo coloca como un fermento vivo sobre los elementos muertos que van a formar la mercancía. De ahí surge lo que se suele llamar "plusvalía". Todo el excedente de la producción industrial es fruto del trabajo subordinado. Este "fermento" agregado a la materia prima crea valor. De ahí surge la mercancía que comienza a tener un valor de cambio. La diferencia entre el coste de la materia prima y del trabajo (adición del fermento), acaba individualmente en las manos del empleador. ${ }^{727}$

\footnotetext{
726 PEDRAZZOLI, Marcelo, "Trabajo subordinado y nuevas formas de empleo en Italia (1)". En Relaciones Laborales, Editorial La Ley, Tomo I, 1989, p. 203.

727 GUERRERO, Diego, Un resumen completo del Capital de Marx, Madrid; Maia Ediciones, 2008, p. $78 / 81$.
} 
El trabajador, con ello, deja de tener el control de su vida. Pierde el comando de su alma. Se aleja de parte de su ser en el mundo y, aún, quien se apropia de él lo convence de que, efectivamente, la lógica capitalista es la correcta, ya que el trabajador tiene tan sólo, además de su trabajo, la vocación al trabajo.

A diferencia de lo que defiende Tomás Moro en su obra Utopía, donde los utopianos, hombres y mujeres, deben ocuparse de la agricultura y tener un oficio, dejando a un lado el lucro, la codicia o el comercio, y guiándose por las necesidades de existencia y mantenimiento de la colectividad, donde la jornada no sería superior a seis horas, con horas destinadas al ocio y a la recreación, que daría al trabajo un carácter de elemento de existencia humana ${ }^{728}$, el trabajo subordinado aproxima al prestador de trabajo a la condición de cosa, a mera pieza de producción.

Por ello, es necesario un estudio profundo con respecto al tema de la subordinación jurídica y de la tercerización de servicios, dado que, hoy en día, la sociedad brasileña camina hacia una menor protección de los trabajadores, especialmente servicios tercerizados.

Además, esto ya forma parte de la lógica capitalista, según cabe deducir de Thomas Frank, donde pone de manifiesto la importancia que las grandes empresas privadas dan a los despidos sin motivo que se producen en masa, como forma de valorización de las acciones de estas mismas empresas en el mercado internacional.

Frank, en este sentido, afirma que "si nuestro jefe nos empuja en la línea del desempleo, probablemente lo hace para aumentar el valor de sus propias

\footnotetext{
${ }^{728}$ MORUS, Thomas, A utopia, São Paulo; Atena Editora, $5^{\text {a }}$ Ed, 1959, p. 87/93. Destacamos el siguiente pasaje de la Utopía de Moro, donde el fin de las instituciones sociales "en la Utopía es proveer antee todo a las necesidades del consumo público e individual; y dejar a cada una el mayor tiempo posible para liberarse de la servidumbre del cuerpo, cultivar libremente el espíritu, desarrollando sus facultades intelectuales por el estudio de las ciencias y de las letras. Es en este desarrollo completo donde ellos ponen la verdadera felicidad".
} 
acciones de la empresa". ${ }^{729}$ Este hecho, en sí mismo, se convierte en un elemento esencial del tema.

Paulo Emílio Ribeiro de Villena, también se ha ocupado de la subordinación. Sostiene que subordinación es un concepto dinámico, así como lo son los conceptos jurídicos, puesto que no quieren perder el contacto con la realidad social que pretenden resolver. La subordinación debe ser considera con otra forma conceptual diversa a la de la década de los cuarenta o los cincuenta; es decir, como el desarrollo de la actividad industrial y de las prácticas empresariales, que servirá de modelo y formará el concepto del trabajador subordinado. ${ }^{730}$

Sin embargo, para Manuel Alonso García, citado por Ribeiro de Vilhena, existe, en el derecho del trabajo, una pirámide invertida y en su nivel superior, está todo el derecho laboral y su cúspide está en la base. En su opinión, las raíces del derecho del trabajo están en la subordinación, que es lo que "transformó" la contratación de los servicios en el contrato de empleo. ${ }^{731}$

Es necesario ampliar el concepto del trabajo subordinado ${ }^{732}$. No sólo debe estar vinculado a la actividad-fin de la empresa sino incluso al estado de sujeción a las órdenes, como vamos a presentar en este estudio.

Debemos partir de un nuevo marco de argumentación y hermenéutica jurídica, analizando las normas, poniendo de manifiesto los intereses y valores presentes en las mismas, sin dejar de lado la cuestión de la democracia contenida en estas mismas normas y que consta en las constituciones occidentales modernas,

\footnotetext{
${ }^{729}$ FRANK, Thomas, Deus no céu e o mercado na terra, cit., p. 128.

730 RIBEIRO DE VILHENA, Paulo Emílio, Relação de emprego: estrutura legal e supostos, São Paulo: Saraiva, 1975, p. 219.

${ }^{731}$ RIBEIRO DE VILHENA, Paulo Emílio, Relação de emprego (...), cit., p. 220.

732 VASCONCELOS PORTO, Lorena, "A relação de emprego e a subordinação - a matriz clássica e as tendências expansionistas", en Revista LTr. Legislação do trabalho. São Paulo: LTr, Ano 72, no. 7 , julho de 2008 , p. 826 .
} 
añadiendo nuevos valores culturales y éticos en la interpretación, construyendo instrumentos de "defensa de la libertad de la clase de los trabajadores". ${ }^{733}$

Subordinación, según el Diccionario Jurídico de la Academia Brasileña de Letras Jurídicas, deriva del latín, subordinatio, y es el "estado de dependencia de una persona a otra, por motivos de sujeción a las reglas de derecho o como consecuencia de una obligación asumida. Cognato: 'subordinado' (adj. Y s.m.) que o quién está subordinado o sujeto". ${ }^{734}$

En la línea doctrinal de lo que venimos apuntando, Eneida Melo Correa de Araújo afirma que la subordinación jurídica es el dato de mayor importancia para la caracterización de la relación de empleo. Revelada mediante un estado de dependencia en la que se coloca el empleado, no somete a la obediencia de las órdenes del tomador del trabajo. De hecho, "muestra un estado de sujeción típico de aquél que trabaja desprovisto de autonomía e independencia en la ejecución de las tareas, imponiendo la observancia al poder directivo específico del empresario". 735

El tomador del trabajo, deberá definir los servicios que se deben de realizar, la jornada, los intervalos y las vacaciones, las reglas para el progreso en la carrera, el lugar donde las tareas serán desempeñadas. Trabajar de forma subordinada no es más, para Eneida Melo Correa de Araújo, que un deber de hacer, obligando al trabajador a prestar el trabajo. ${ }^{736}$

Subraya que el estado de sujeción no es absoluto, sino en la medida de la ejecución del contrato y conforme a las normas contractuales, colectivas y legales. El trabajador no está con toda su existencia vinculada al tomador del trabajo. Sus planes psíquicos, físicos y morales, no están comprometidos en una relación de

\footnotetext{
${ }^{733}$ MELHADO, Reginaldo, Poder e sujeição: os fundamentos da relação de poder entre capital e trabalho e o conceito de subordinação, São Paulo; LTr, 2003, p. 74.

${ }_{734}$ OTHON SIDOU, J. M., Dicionário Jurídico: Academia Brasileira de Letras Jurídicas, Rio de Janeiro: Forense Universitária, 9ª ed., 2004, p. 821.

${ }^{735}$ CORREIA DE ARAÚJO, Eneida Melo, As relações de trabalho. Uma perspectiva democrática, São Paulo; LTr, 2003, p. 56.

${ }^{736}$ CORREIA DE ARAÚJO, Eneida Melo, As relações de trabalho (...), cit., p. 56/57.
} 
empleo. "La personalidad del hombre es un dato intocable, aspecto que resguarda su condición humana y su dignidad". 737

En el Diccionario de la Lengua Española de la Real Academia Española, subordinación es "sujeción a la orden, mando o dominio de alguien". La palabra subordinado, significa estar bajo las órdenes de otra persona. ${ }^{738}$

La gramática presenta la subordinación como un tipo de unión dependiente entre proposiciones. "Las proposiciones que se subordinan tienen una relación de dependencia, siendo una la principal (no lleva nexo) y la otra la subordinada (va introducida por un nexo), que es la que depende de la principal". ${ }^{739}$

Para la legislación brasileña el concepto de subordinación jurídica se encuentra descrito en el artículo $3^{\circ}$ de la Consolidação das Leis do Trabalho que define lo que es empleado. El citado artículo establece que "se considera empleado toda persona física que presta servicios de naturaleza no eventual al empleador, bajo la dependencia de éste y mediante salario. Párrafo único - No habrá distinciones relativas a la especie de empleo y a la condición del trabajador, ni entre el trabajo intelectual, técnico y manual”.

La norma, cuando utiliza "dependencia", lo hace refiriéndose a la subordinación jurídica. En el caso brasileño se puede afirmar una cierta equivalencia entre "dependencia" y "subordinación", por lo que consta en la letra "h" del artículo 482 de la Consolidação das Leis do Trabalho ${ }^{740}$.

Tal disposición determina que uno de los motivos para la rescisión del contrato de empleo por justa causa (despido procedente), por parte del empleador es la "insubordinación", de donde se puede concluir que es deber del trabajador

\footnotetext{
${ }^{737}$ CORREIA DE ARAÚJO, Eneida Melo, As relações de trabalho (...), cit., p. 57.

738 "Diccionario de la Lengua Española de la Real Academia Española". Tomo II, Madrid: Editorial Espasa Calpe, 22a ed., 2001, p. 2100.

739 ABRIL-MARTÍN, Paula Arenas, Gramática de la lengua española, Madrid: Edmart Libros. Colección Manuales de la lengua española, 2006, p. 227.

${ }^{740}$ Artículo 482. Constituyen justa causa para la rescisión del contrato de trabajo por el empleador. $(\ldots)$; h) acto de indisciplina o de insubordinación. (La negrita es nuestra).
} 
mantenerse subordinado al patrón y a las normas estructurales de la empresa. Para una correcta comprensión del artículo $3^{0}$ de la CLT, por tanto, resulta necesaria la lectura también del artículo 482, "h", del mismo texto, de donde se puede concluir que se trata de la expresión "dependencia", del artículo 3o, referente a la subordinación jurídica.

En España, se hace referencia expresa a la subordinación en el artículo primero del "Estatuto de los Trabajadores", cuando la norma se refiere a los trabajadores que presten trabajo“[...] dentro del ámbito de organización y dirección de otra persona [...]". La norma española dice que: "Ámbito de aplicación. 1. La presente Ley será de aplicación a los trabajadores que voluntariamente presten sus servicios retribuidos por cuenta ajena y dentro del ámbito de organización y dirección de otra persona, física o jurídica, denominada empleador o empresario".

Miguel Rodriguez-Piñero añade que la cuestión del trabajo por cuenta ajena, "ajenidad" no es un concepto nuevo. No es más progresivo que el de la dependencia, sino un concepto que antes formó parte de la legislación española y que la práctica demostró que no servía, sustituyéndolo por el de la dependencia. $^{741}$

Se constata que el autor critica el criterio presentado por Alonso Olea del que será empleado quien presta servicio para otros, en los casos en que este último se quede con el producto del trabajo. Considera insuficiente este criterio de trabajo por cuenta ajena, dado que es evidente que el empleado jamás será el dueño de los frutos producidos, no siendo éste el único criterio identificable para el reconocimiento de la relación de empleo. ${ }^{742}$

El autor hace las mismas críticas al criterio que incluye los riesgos en la producción como uno de los elementos que caracterizarían el contrato de empleo,

${ }^{741}$ RODRÍGUEZ PIÑERO, Miguel, "La dependencia y la extensión del ámbito del derecho del trabajo", Revista de Política Social, 1966, oㅜ 71, p. 149.

${ }_{742}$ RODRíGUEZ PIÑERO, Miguel, "La dependencia y la extensión del ámbito del derecho del trabajo", cit., p. 150/151. 
porque en el momento en que, en virtud del contrato, el trabajador recibe comisiones, por ejemplo, acaba también por hacerse cargo de los riesgos del negocio. $^{743}$

Para Rodriguez-Piñero, lo que va a caracterizar el contrato de empleo es el hecho de que el trabajador preste servicios bajo las órdenes de otros. Trabajar de forma dependiente, subordinada, obedeciendo las órdenes y las directrices provenientes del dueño del negocio, pudiendo este último disponer del trabajo prestado según le convenga. Debe él, respetar los límites legales y contractuales, exteriorizando, por consiguiente, un poder sobre la persona del trabajador, en los límites del contrato. Este autor también hace referencia a que si bien este criterio es mucho más preciso, no impide que existan zonas grises, lo que plantea dudas sobre la naturaleza de la relación habida. ${ }^{744}$

Sin embargo, este concepto no es definitivo. No basta el trabajo bajo órdenes. Aunque no existan órdenes directas, puede haber relación de empleo. Una vez que el prestador de trabajo presta su objeto insertado en el ámbito organizativo de otros, habrá un vínculo jurídico de empleo. ${ }^{745}$

El autor no excluye el criterio de la dependencia. Lo convierte en más elástico, adaptándolo a las crecientes exigencias sociales de protección del trabajo y del trabajador ${ }^{746}$. Lo adapta a la realidad actual del capitalismo, centrando al trabajador dentro del sistema económico presente como pieza fundamental y que debe ser protegida.

\footnotetext{
${ }^{743}$ RODRÍGUEZ-PIÑERO, Miguel, "La dependencia y la extensión del ámbito del derecho del trabajo", cit., p. 157.

744 RODRÍGUEZ-PIÑERO, Miguel, "La dependencia y la extensión del ámbito del derecho del trabajo", cit., pp. 159/161.

${ }^{745}$ MONTOYA MELGAR, Alfredo, "Sobre el trabajo dependiente como categoría delimitadora del derecho del trabajo". En AA.VV. , Trabajo subordinado y trabajo autónomo en la delimitación de las fronteras del Derecho del Trabajo. Estudios en homenaje al prof. José Cabrera Bazán, Madrid; Tecnos, 1999, p. 62.

${ }^{746}$ MONTOYA MELGAR, Alfredo, "Sobre el trabajo dependiente como categoría delimitadora del derecho del trabajo", cit., p. 62.
} 
Por lo tanto, la inserción del trabajador a la actividad del empleador sería el elemento que caracterizaria la relación de empleo. En el caso brasileño, se haría una interpretación más elástica del concepto de la no-eventualidad. Quien presta trabajo, a otros, de forma permanente y con previsibilidad, sometiéndose a las "órdenes estructurales" por ejemplo, sería el empleado.

En el caso de España, aunque no se contemple, en el artículo 1.1 del Estatuto de los Trabajadores, la no eventualidad y/o continuidad como requisito de la relación de empleo, no podemos ignorarlo por completo.

Basándonos en la jurisprudencia (TS 06 de junio de 1990, TS de 08 de octubre de 1992 y TS de 05 de noviembre de 1993) la continuidad sería un fuerte indicio de la relación de empleo. En el mundo fáctico, sería algo que debe analizarse y facilitaría la visualización de la realidad contractual de una determinada persona. $^{747}$

De todos modos, conviene señalar que la norma legal española no hace referencia a la no eventualidad o continuidad como requisito de la relación de empleo. Esta referencia es jurisprudencial, aplicable al caso concreto, con el fin de facilitar el análisis de situación fáctica vigente a un determinado profesional del derecho.

Lo cierto es que, a pesar de que no se hace referencia en la norma española al tema, cuando la misma analiza la cuestión del trabajador, no vincula la existencia o no de relación de empleo o incluso el elemento de la continuidad a la diferenciación "actividad-medio" y "actividad-fin". $Y$ no lo hace porque es prácticamente imposible saber bien lo que es la actividad medio y lo que es la actividad fin. La cuestión de la continuidad es más perceptible, como lo es saber si el trabajador está prestando trabajo dentro del ciclo productivo del empresario,

\footnotetext{
747 MARTíN VALVERDE, Antonio, RODRÍGUEZ-SAÑUdO GUTIÉRREZ, Fermín y GARCíA MURCIA, Joaquín, Derecho del Trabajo, Madrid; Tecnos, 18ª Ed., 2009, p. 178.
} 
dentro de su estructura organizativa (TS 10 de enero de 1968, TS 27 de mayo de 1992) ${ }^{748}$.

Hay que tener presente que no hay una diferenciación en la doctrina, entre la "actividad-medio" y la "actividad-fin", como quiere hacer creer la jurisprudencia brasileña, Súmula 331 del TST, con el fin de permitir la tercerización, para la estabilización de las relaciones económicas, sin tener en cuenta la cuestion social. $^{749}$

Para Manuel Alonso Olea y Maria Emilia Casas Baamonde la subordinación está relacionada con la dependencia, puesto que es el empleador quien da las órdenes al empleado en el ambiente y sobre cuestiones de trabajo. Estas órdenes se refieren al lugar, al tiempo y al modo de producción, conforme a sus criterios y a su empresa. ${ }^{750}$

Los riesgos serán los del tomador del trabajo. Pero los frutos de este trabajo prestado por otros también. $Y$ eso podrá producirse incluso con altos empleados, trabajadores manuales, intelectuales, dentro o fuera de la empresa, siempre que se esté bajo la organización y dirección de una determinada persona, artículo 1.1 del Estatuto de los Trabajadores Español. ${ }^{751}$

\footnotetext{
748 MARTín VALVERDE, Antonio, RODRíGUEZ-SAÑUdO GUTIÉRREZ, Fermín y GARcía MURCIA, Joaquín, Derecho del Trabajo, cit, p. 178.

${ }^{749}$ Se cree que la jurisprudencia brasileña solicitó prestados los conceptos de administración y economía, la actividad principal y la secundaria, para hacer una definición no autorizada por la ley. Tanto es así que la norma legal española, que no posee como requisito de la relación de empleo la "no eventualidad", no adopta este criterio. Se cree que los juristas, tomados por la ceguera colectiva y bajo el falso argumento de autoridad del Tribunal Superior del Trabajo repitió, sin reflexionar, esta jurisprudencia flagrantemente contraria a la norma legal. En este sentido: "EMENTA: VÍNCULO DE EMPLEO. La prueba de los autos revela la presencia de los requisitos necesarios para la configuración de la relación de empleo, previstos en el artículo $3^{\circ}$ de la CLT, sobretodo teniendo en cuenta que el trabajo del reclamante atendía la necesidades permanentes de la empresa, caracterizándose, así, la no eventualidad y la inserción objetiva en la finalidad de la iniciativa económica".

(Acórdão do processo 0078600-40.2008.5.04.0221 (RO) - Redator: IONE SALIN GONÇALVES Participam: ANDRÉ REVERBEL FERNANDES, ANA LUIZA HEINECK KRUSE - Data: 23/06/2010).

${ }^{750}$ ALONSO OLEA, Manuel e CASAS BAAMONDE, Maria Emilia, Derecho del trabajo, Navarra: Thompson Civitas, 24를 ed., 2006, p. 59.

${ }^{751}$ MARTíN VALVERDE, Antonio, RODRÍGUEZ-SAÑUDO GUTIÉRREZ, Fermín y CARCíA MURCIA, Joaquin, Derecho del Trabajo, cit., p. 176/178.
} 
Lo que va a caracterizar la existencia o no de la relación de empleo es, además de la subordinación/dependencia, la inserción del prestador de trabajo en la organización productiva ajena, como ya decidió el Tribunal Supremo (STS de 2 de julio de 1996, STS de 31 de marzo de 1997) ${ }^{752}$ de donde deriva, en consecuencia, la subordinación.

La doctrina que justifica la existencia de relación de empleo teniendo como base la inserción del trabajador en la actividad de la empresa tiene como objeto la mejora de la condición social del trabajador y de aumentar el abanico de los trabajadores protegidos por el sistema social laboral. En el caso de Brasil se puede utilizar el articulo $7^{\circ}$, encabezamiento, de la Constitución como regla de interpretación más benefica al trabajador, para impedir una interpretación más restrita de la subordinación y del concepto de empleado ${ }^{753}$.

En Francia se dice que conviene también subrayar que la dirección y el control del trabajo por parte de una persona con relación a la otra es un factor decisivo. Para se saber se hay subordinación, la jurisprudencia considera como empleado asalariado ("salarié") aquél que trabaja bajo la dirección técnica de un propietario. El albañil que ejecuta su trabajo en beneficio de un propietario que lo instruye, el encargado que recibe las órdenes e instrucciones imperativas sobre la venta de un determinado producto, sin espacio para ninguna iniciativa propia, son ejemplos. Cita también al agente inmobiliario que recibe, además de las instrucciones, encargo por parte del tomador de los servicios. ${ }^{754}$

\footnotetext{
752 MONTOYA MELGAR, Alfredo, "Sobre el trabajo dependiente como categoría delimitadora del derecho del trabajo", p. 67.

${ }^{753}$ Maria Vitória Queija Alvar enseña que el principio de no retroceso social que esta en el articulo $7^{\circ}$, encabezamiento, de la CF/88 es una regra que sirve para los poderes legislativo, ejecutivo y judicial, en este caso, se añade, como forma de interpretación. QUEIJA ALVAR, Maria Vitória, Os direitos fundamentais dos trabalhadores e o princípio do não-retrocesso social no Brasil, http://www.ambito-

juridico.com.br/site/?n link=revista artigos leitura\&artigo id=9212\&revista caderno=25 - aceso 20 de agosto de 2012, a las 15h27min.

754 CAMERLYNCK, G. H., Traité de droit du travail. Contrat de travail, Paris: Librairie Dalloz, 1968, p. 66/68. "(...) l'artiste de variété soumis aux directives, à la surveillance et aux règles de discipline en vigueur dans l'etablissement; I'artiste qui, tout en demeurant libre d'expression de son talent et de as personnalité, et seul maître de son interprétation à l'instant ou 'dans un élan de création
} 
Según Camerlynck, basándose en la jurisprudencia francesa, se puede concluir que el concepto de subordinación jurídica tiene en cuenta no sólo el hecho de que el trabajador está sujeto a las órdenes del tomador del trabajo, sino también porque presta trabajo en interés de este. Será, por tanto, empleado ("salarié") el trabajador que preste servicios bajo las órdenes de otros o, añadimos, que preste trabajo teniendo como base los intereses de este tercero, dejando los suyos en un segundo plano.

Por otra parte, no serán empleados aquellos trabajadores que no estén sujetos a la orden y a la dirección de un tercero. El artesano, por ejemplo, que presta su trabajo sin que sobre él y su obra exista un control directo; los artistas que producen sus propias obras sin el control de un tercero y sin que este tercero sea directamente beneficiado, con total libertad de tiempo de la ejecución de sus tareas. O incluso el médico que fija las horas de visitas conforme a sus intereses, aun cuando preste trabajo a una determinada empresa. ${ }^{755}$

Lo que interesa es que el prestador de trabajo tenga total libertad de acción, según el autor francés, actuando primero por su interés. De otro modo, la conclusión que se puede obtener es que será empleado quien preste servicios bajo las órdenes y/o el interés de un tercero, formando con él un "contrat de travail'.

La subordinación jurídica, para el derecho francés, es el "concetto centrale nel diritto del lavoro". Es también una "costruzione giuridica continuamente in formazione". Aún, para el mismo autor, la tendencia general de la jurisprudencia es la de no excluir de la aplicación del derecho del trabajo los contratos típicamente subordinados, aun cuando formalmente sean contratos denominados

artistique il donne à l'execution de l'oeuvre son caractère original', demeure néanmoins subordonné ao contrôle et aux directives du fabricant de disques qui impose une discipline, des méthodes et des moyens d'exécution du travail pour assurer les qualités techniques et musicales de l'enregistrement; le réalisateur d'un film engagé par le producteur, tenu vis-à-vis de ce dernier par un lien de subordination, malgré une certaine liberté au point de vue artistique; le médecin soumis à une discipline imposée et tenu de respecter certaines instructions dans le cadre d'un service organisé; l'expert comptable recevant des instructions et de véritables ordres par notes de service".

${ }^{755}$ CAMERLYNCK, G. H., Traité de droit du travail, cit., p. 67. 
como autónomos. Sostiene que la ampliación del concepto de subordinación, permite el "salario" de diversos trabajadores antes apartados de los derechos sociales laborales. ${ }^{756}$

Hay que tener presente, asimismo, que Antoine Mazeaud afirma que, en Francia, a diferencia de Italia donde existe el concepto de trabajo "parasubordinado" y en, Alemania, donde se pueden encontrar los "casiempleados", la tendencia es considerar a estos trabajadores como empleados subordinados, denominados "salariés". 757

Mazeaud no conceptualiza de manera diferente la subordinación. Se refiere al hecho de que alguien presta trabajo bajo la autoridad y órdenes de otros, teniendo éste el poder de controlar la prestación de servicios, aplicando sanciones en el caso de faltas cometidas por sus subordinados. "Le lien de subordination résulte de la soumission au pouvoir réglementaire, disciplinaire et de direction, dans l'accomplissement d'un travail pour compte d'autrui". ${ }^{758}$

Conviene destacar que del concepto de Mazeaud se puede percibir que el trabajo es prestado tan sólo en el interés del tomador. Eso puede parecer evidente, incluso porque, en el caso de Brasil, la Consolidación de las Leyes del Trabajo, en su artículo 2, establece que los riesgos de la actividad corren por cuenta del empleador. No es, sin embargo, tan evidente si se tiene como base la cuestión de la tercerización, donde el trabajo es prestado también en el interés del tomador, pero a través de una persona interpuesta. La cuestión del interés en la prestación del trabajo es sutil, y merece atención.

\footnotetext{
${ }^{756}$ SUPIOT, Alain, Il futuro del lavoro, cit., pp. 25 y $27 / 28$.

${ }^{757}$ MAZEAUD, Antonie, Droit du travail, Paris; Montchrestien, $6^{a}$ Ed; 2008, p. 310/311. "(...)En somme, entre le travail réellement Independent et le travail salarié, il existe de multiples points de rencontre et une 'zone grise' que l'on désigne parfois sous le terme de 'contrat de travail Independent'. Certains pays proches tentent de trouver un statut ao profit des parasubordonnés (Italie) ou quasi-salariés (Allemagne)... En France, la tendence historique a été d'assimiler certaines catégories professionnelles dépendentes à des travailleurs, ou du moins de leur appliquer le régime".

${ }^{758}$ MAZEAUD, Antonie, Droit du travail, cit., p. 311/312.
} 
El autor francés concluye este pasaje de su obra argumentando que independientemente del nombre dado al cargo, habiendo trabajo prestado de forma subordinada habrá, necesariamente, contrato de empleo, puesto que lo que interesa es "un lien de subordination". ${ }^{759}$

Con Supiot, la noción de subordinación o su contrario, la noción de dirección, designa una relación de jerarquía entre el empleador y el trabajador. Éste debe obedecer a las órdenes del primero. La idea de jerarquía, subraya el autor, no puede confundirse con una idea de desigualdad. Ésta apunta una manera de hacer una comparación objetiva entre las situaciones de hecho independientes una de la otra, mientras que la jerarquía designa un vínculo de derecho. "C'est dire que l'inegalité qui résulte de ce lien a une signification particulière: il s'agit d'une 'relation', e non pas seulement d'une 'situation' inégalitaire; et il s'agit d’une inégalité instituée par le droit, et non pas d'une situation de fait ignorée ou combattue par lui". ${ }^{760}$

Con la autorización del derecho, el vínculo de subordinación vincula, de forma jerárquica, a empleado y empleador según un principio jurídico de desigualdad, de manera que el derecho público se preocupa del derecho del trabajo, si bien no deje de ser el contrato de derecho privado, sin perder de vista que el trabajador se subordina por voluntad propia. ${ }^{761}$

El autor francés llama la atención sobre el hecho de que el contrato de empleo, donde el trabajador está bajo las órdenes de otros, no se caracteriza propiamente por lesionar el principio de igualdad. Sin embargo, hace referencia expresa al hecho de que esta desigualdad existe, autorizada por el derecho, lo que acaba derivando en que quede bajo el amparo del derecho público.

Según Supiot, en la relación de empleo hay una relación de poder del empleador sobre el empleado, que tiene el deber de obedecer, ya que el

\footnotetext{
759 MAZEAUD, Antonie, Droit du travail, cit., p. 312.

${ }^{760}$ SUPIOT, Alain, Critique du droit du travail, cit., p. 115.

${ }^{761}$ SUPIOT, Alain, Critique du droit du travail, cit., p. 109/110.
} 
empleado queda vinculado por un contrato. Lo hace (vinculación) con libertad, pero en el momento en el que está vinculado, debe, en los límites establecidos en el contrato, someterse a la acción de poder de quien le emplea, con el fin de ejecutar el contrato de empleo. ${ }^{762}$

Supiot no habla expresamente de la "ejecución de la producción". Del pasaje del jurista francés, sin embargo, se puede derivar que la sujeción a las órdenes hace que el trabajador quede sujeto a la ejecución de la producción, o al contexto de la empresa. No concierne a la actividad-medio o fin, sino a todo aquello que lleva el tomador de los servicios para alcanzar su objeto, ya sea la prestación de un servicio, ya sea la elaboración de un producto.

En el derecho alemán, una parte de la doctrina propone la ampliación del concepto de subordinación para detener la fuga del derecho del trabajo. Según sus palabras "è in Germania che questo dibattito sembra oggi più sviluppato. Una parte della dottrina propone di allargare la nozione di subordinazione per arrestare la fuga dal diritto del lavoro". 763

Para los alemanes, el contrato de trabajo viene deducido de lo que establece el párrafo 611 del BGB, llamado código civil alemán, en lo que se refiere a la locación de servicios. Llama la atención el hecho de que el BGB es de enero de 1900, sin previsión explicita en cuanto al contrato de empleo. Mediante la jurisprudencia, hoy en día, se tienen los límites y requisitos del contrato de empleo. Sin embargo, es a partir de la ley de la negociación colectiva de 9 de abril de 1949 cuando se elimina el principio de que las cláusulas contractuales más benéficiosas prevalecen sobre las cláusulas normativas. ${ }^{764}$

En Alemania la importancia de la jurisprudencia laboral es evidente. Eso no quiere decir que no haya problemas. Por ejemplo, aunque el poder judicial dé

\footnotetext{
${ }^{762}$ SUPIOT, Alain, Critique du droit du travail, cit., p. 109/110.

${ }^{763}$ SUPIOT, Alain, Il futuro del lavoro, cit., p. 25 y 30.

764 ZACHERT, Ulrich, Lecciones de derecho del trabajo alemán. Traducción del italiano por Fernando Martínez Rodriguez y Natividad Mendoza Navas, Madrid; Ministerio del Trabajo y Asuntos Sociales de España, 1998, p. 25.
} 
respuestas más rápidas a la flexibilización de conceptos y situaciones fácticas habidas dentro de la sociedad, hay un claro problema de legitimación. La función de legislar no es del Poder judicial sino del legislativo. ${ }^{765}$

Hay casos, como por ejemplo el de un gerente autónomo de la red de alimentación Mc Donalds, que trabaja de forma subordinada, como empleado, aunque documentalmente constase como trabajador autónomo. ${ }^{766}$

Esta ampliación en la interpretación de quién se considera como empleado, por tanto, se aproxima a la doctrina moderna, según hemos visto anteriormente. No muda mucho con respecto a los parametros europeos la cuestión de la subordinación. Hay pequeñas distinciones, generalmente relacionadas a los casos concretos llevados al poder judicial, que sirven precisamente para justificar la mayor amplitud del concepto de subordinación jurídica y su extensión.

En Portugal, el artículo 10 de la Ley del Contrato de Trabajo, Ley 99/2003, establece que se caracteriza por contrato de trabajo la sujeción de una persona a las órdenes y dirección de la otra, o mejor, a la autoridad de la otra, que es quien le remunera.

António Monteiro Fernandes, autor portugués, afirma que la subordinación jurídica es una relación de "dependencia necesaria de la conducta personal del trabajador en la ejecución del contrato pese a las órdenes, reglas u orientaciones dictadas por el empleador, dentro de los límites del mismo contrato y de las normas que lo rigen". En una nota a pie de página, haciendo referencia a la doctrina alemana, apunta que el elemento personal de la subordinación está relacionado con una "dependencia personal", aunque estos mismos alemanes no hagan una distinción segura entre el trabajo autónomo y el subordinado. ${ }^{767}$

\footnotetext{
765 ZACHERT, Ulrich, Lecciones de derecho del trabajo alemán, cit., p. 26.

766 ZACHERT, Ulrich, Lecciones de derecho del trabajo alemán, cit., p. 27.

${ }^{767}$ MONTEIRO FERNANDES, António de Lemos, Direito do trabalho, Coimbra: Almedina, 13 ed., 2006, p. 136.
} 
Para este autor, la subordinación puede que no se manifieste en determinados casos, no dejando, sin embargo, que haya efectivamente un trabajo subordinado. A menudo, la relación fáctica aparenta una cierta autonomía, aunque exista una verdadera subordinación jurídica. Cuanto más se avanza en la sofisticación y diferenciación de las calificaciones profesionales, menor es la apariencia de la subordinación. El autor hace referencia a una decisión judicial de 1943, cuando los magistrados sostienen que existe una subordinación jurídica del empleado con el empleador, cuando éste tiene derecho de dar órdenes, dirigir o supervisar los servicios prestados, no exigiendo, sin embargo, que lo hagan de forma permanente. ${ }^{768}$

Incluso sin la dependencia económica o técnica, puede haber subordinación. Un médico, ejemplo utilizado por Monteiro Fernandes, que trabaja como contratado por parte de un hospital, como trabajador empleado, puede, por tener también una consultoría privada, no depender económicamente de su empleador. ${ }^{769}$ Del mismo modo, los grandes ingenieros. Éstos, en muchos casos, técnicamente no son dependientes de sus empleadores, aunque haya, sin lugar a dudas, una subordinación jurídica.

La subordinación jurídica, por tanto, no es lo mismo que la dependencia técnica o económica. La subordinación jurídica da lugar a que el trabajador actúe en el seno de una organización productiva ajena - medios de producción de propiedad de los demás - dirigida a la obtención de sus fines en provecho ajeno, quedando sometido a las reglas que expresan el poder empresarial, derivado de su posición en las relaciones de producción. ${ }^{770}$

Por tanto, aunque se utilice el concepto de no eventualidad contemplado por la legislación laboral brasileña, no se puede entender que no haya relación de empleo entre empresa y trabajador que preste trabajo vinculado a la actividadmedio. Al haber trabajo permanente, dependiente, será este trabajo,

\footnotetext{
${ }^{768}$ MONTEIRO FERNANDES, António de Lemos, Direito do trabalho, cit., p. 137.

769 MONTEIRO FERNANDES, António de Lemos, Direito do trabalho, cit., p. 138/139.

770 MONTEIRO FERNANDES, António de Lemos, Direito do trabalho, cit., p. 139.
} 
necesariamente, no eventual, derivando de ahí la subordinación jurídica. Este mismo trabajador estará integrado en la empresa capitalista que de él depende para la ejecución de sus actividades. Para una persona que presta servicios en el cuadro permanente de la empresa, sin que haya trabajo autónomo (riesgo de la actividad por el trabajador) o como socio, habrá relación de empleo.

Volviendo a la doctrina brasileña, ella viene ampliando el concepto de subordinación. Es algo dinámico, dado que no pierde el contacto con la realidad. El concepto de subordinación debe extraerse objetivamente y así ser fijado. ${ }^{771}$

En este sentido, la subordinación se rige por la inserción estructural del trabajador en la dinámica del tomador de los servicios. Es estructural la subordinación que se manifiesta por la inclusión del prestador de trabajo en la dinámica del tomador de los servicios, independientemente del hecho de que reciba o no las órdenes directas, siempre que esté estructuralmente vinculada al tomador de los servicios. ${ }^{772}$

Souto Mayor afirma que la no-eventualidad, ligada a la subordinación no requiere la prestación de servicios diarios. La continuidad se refiere a algo habitual, "algo que se repite en el tiempo y que genera la previsión de la conducta". Será empleado, por tanto, quien preste servicios, incluso una vez por semana, pero en un día determinado, recibiendo, además de las órdenes, el pago del salario. ${ }^{773}$

La subordinación no consiste sólo en recibir órdenes de otros. No se restringe ni siquiera al hecho de que el trabajador preste trabajo ligado a la actividad-fin de la empresa, de donde deriva la subordinación. El concepto es más amplio.

\footnotetext{
771 SOUTO MAIOR, Jorge Luiz, Curso de direito do trabalho: a relação de emprego, Volume II, São Paulo, LTr, 2008, p. 51/52.

${ }_{772}$ SOUTO MAIOR, Jorge Luiz Souto, Curso de direito do trabalho (...), cit., p. 52.

${ }^{773}$ SOUTO MAIOR, Jorge Luiz Souto, Curso de direito do trabalho (...), cit., p. 53/54.
} 
Hay que tener presente que en el contrato de trabajo, el objeto de la prestación es la actividad que ejercerá el trabajador, la tarea que será realizada y que integrará la estrutura productiva del tomador del trabajo. Toda la tarea que compone la dinámica de la empresa, ya sea realizada por un director, por un operador de máquina o por un encargado, formará parte de la dinámica general de la empresa, en su proceso productivo o de suministro de bienes y servicios. ${ }^{774}$

Lo que se debe suprimir del concepto "anterior" es que la subordinación no es necesariamente técnica. La actividad técnica de los trabajadores debería formar parte de la rotación de la empresa, de la estructura de la empresa para que alcance sus fines. La actividad del prestador se convierte en actividad de la empresa, para que ésta pueda lograr los resultados deseados. Lo que anhela el agente subordinante no es el hombre trabajador, sino el trabajo prestado por este hombre, la energía que deriva del mismo, modificando la naturaleza, es decir, produciendo. Es la actividad del trabajador la que se integra en la empresa y no la persona del trabajador. ${ }^{775}$

Ribeiro de Vilhena defiende que la "sustancia de la relación de trabajo, como el objetivo al que se dirige el empleador, es la 'actividad', y ésta debe ser personal". Lo que vincula al empleado con el empleador es la actividad del prestador de trabajo y que acaba por caracterizar la relación de empleo. Solamente la actividad autorizará la intervención del tomador del trabajo, así como la ejecución de determinadas tareas. Es la subordinación, por tanto, la participación integrativa de la actividad del trabajador en la actividad del tomador del trabajo. ${ }^{776}$

Sin embargo, la subordinación no es un elemento de la relación de empleo, sino un resultado de la relación social que encuentra su singularidad en el contrato de empleo. Como apunta Oscar Correas, la subordinación es consecuencia de la relación de empleo y no causa o sustancia. El empleado vende su fuerza de

\footnotetext{
${ }^{774}$ RIBEIRO DE VILHENA, Paulo Emílio, Relação de emprego (...), cit., p. 227.

775 RIBEIRO DE VILHENA, Paulo Emílio, Relação de emprego (...), cit.,p. 228/229.

776 RIBEIRO DE VILHENA, Paulo Emílio, Relação de emprego (...), cit.,p. 230/232.
} 
trabajo al capitalista como mercancía, a través de un contrato típico de compra y venta, de la misma forma que se vende cualquier otra cosa, con la peculiaridad de que no se separe de la mercancía que vende. El empleado permanece en un estado de sometimiento, puesto que no puede separarse de la mercancía vendida en el momento en que el tomador del trabajo hace uso de esta mercancía. Es necesario que siga los consejos (órdenes) de quien compra la mercancía. "Eso es subordinación: una consecuencia del acto de compra y venta de la fuerza de trabajo". 777

En parámetros europeos, además de lo que ya hemos dicho, la norma legal define, para cada uno de los países, lo que es una relación de empleo y cuales son los límites para el trabajo subordinado. Apunta referencias instrumentales a la noción de trabajador, dejando el concepto del trabajador asalariado para el derecho interno de cada estado miembro. Consta, sin embargo, que la norma comunitaria, en varias ocasiones menciona al "trabajador por cuenta ajena" pero, para que tenga sentido la expresión, remite al interprete al derecho interno, por ejemplo la Directiva $91 / 533^{778}$, de 14 de octubre, artículo 1 , sobre la formación relativa al contrato de trabajo y Directiva 2002/14, de 11 de marzo, artículo $2^{779}$ sobre derechos de información y consulta. ${ }^{780}$

El Tribunal de Justicia de la Unión Europea ha decidido que la norma nacional no puede, nunca, utilizarse para alejar la aplicación de las normas comunitarias, ni para actuar contra los objetivos del derecho del trabajo (TJCE, el 23 de marzo de 1982, caso Levin). ${ }^{781}$

\footnotetext{
${ }_{777}$ MELHADO, Reginaldo, Poder e sujeição (...), cit., p. 90/1.

778 Artículo 1‥ Ámbito de aplicación 1. La presente directiva se aplica a cualquiera trabajador asalariado que tenga un contrato o una relación de trabajo definido en la legislación en vigor en un Estado-miembro y/o sujeto a la legislación en vigor en un Estado-miembro.

${ }^{779}$ Artículo 20 . Definiciones. Para efectos de esta directiva, se entiende por: (...); d) "Trabajador", cualquiera que, en el respectivo Estado-Miembro, esté protegido como trabajador por la legislación laboral nacional y de acuerdo con las prácticas nacionales; (...).

${ }_{780}$ MARTíN VALVERDE, Antonio, RODRÍGUEZ-SAÑUDO GUTIÉRREZ, Fermín y CARCíA MURCIA, Joaquin, Derecho del Trabajo, cit., p. 179/180.

${ }_{781}$ MARTÍN VALVERDE, Antonio, RODRÍGUEZ-SAÑUDO GUTIÉRREZ, Fermín y CARCíA MURCIA, Joaquin, Derecho del Trabajo, cit., p. 179/180.
} 
Un empleado subordinado será, por tanto, aquél trabajador obligado por un contrato a prestar servicios por cuenta ajena, de forma continua y con previsibilidad de conducta, independientemente del número de días de trabajo prestado, siempre que a este trabajador se le quite la "plusvalía". El hecho de trabajar ligado a la actividad-medio o actividad-fin del tomador del trabajo, no influye en cuanto a la subordinación. Se presume, cuando se constata que a aquél trabajador se le quita la "plusvalía"782, después del trabajo prestado de forma previsible $^{783}$, continua y permanente ${ }^{784}$, de donde depende el tomador de los servicios, aun que sea de forma indirecta, la consecución de sus fines y objetivos. Este concepto, queda lejos de los contratos de naturaleza civil típicos, elaborados y ejecutados de forma lícita, comprometiéndose el prestador con el resultado y no con el trabajo.

Este concepto supera parcialmente al de una parte de la doctrina brasileña a la que ya hemos hecho referencia, que apunta que es trabajador subordinado, además de la persona que recibe órdenes directas del tomador, aquél que presta trabajo ligado a la actividad-fin de la empresa. También es relevante la cuestión de la subordinación estructural, que defiende que será empleado subordinado el trabajador ligado a la dinámica del tomador de trabajo, independientemente de recibir o no órdenes de su tomador.

En el estudio de la subordinación jurídica no podemos dejar de hacer referencia a la subordinación de la voluntad. Cada vez que el trabajador presta servicios a un empleador, presta a éste, por el período de la jornada de trabajo, su

\footnotetext{
${ }^{782}$ MARTINS CATHARINO, José, Compêndio de direito do trabalho, cit., p. 205. El autor confirma en parte la tesis indicada en el párrafo anterior cuando afirma que "en el régimen capitalista, el dominio de los medios de producción explica la posición subordinante del empleador (...)".

${ }^{783}$ RIBEIRO DE VILHENA, Paulo Emílio, Relação de emprego (...), cit., p. 187. El autor hace referencia expresa a las expectativas con el elemento que hace que el trabajo sea permanente y necesario en la empresa, independientemente del tiempo de duración de la prestación de servicios. ${ }^{784}$ GODINHO DELGADO, Maurício, Curso de Direito do Trabalho, São Paulo: LTr, $6^{\circ}$ ed., 2007, p. 297. El autor plantea, como se afirma en el texto, que "(...) si la prestación es discontinua, pero permanente, ya no es posible la eventualidad", caracterizándose, por tanto, la no-eventualidad de dónde se presume la subordinación y la relación de empleo.
} 
voluntad y sus deseos. Deja de lado lo que es para sí, para obedecer lo que es para el otro. Pasa a ser un poco el otro, dejando el yo en un segundo plano. ${ }^{785}$

\subsubsection{La subordinación de la voluntad}

Inicialmente, antes de entrar en el tema de este apartado, conviene realizar algunas consideraciones acerca de la voluntad. Es elemento central de los contratos, para que el acto tenga un valor jurídico, debe manifestarse sin ningún vicio.

Puesto que la voluntad es fruto de la psique, no pudiendo ser conocida o comprobada objetivamente debe, para darse a conocerse socialmente, proyectarse externamente. $Y$ esto se hace de varias maneras. El modo principal es a través del lenguaje, con la escritura o la pronunciación de palabras. También hay casos de señales o signos, como el guiño, el apretón de manos, que en algunos lugares puede significar un "sí". Independientemente de la forma dada, lo que importa es el hecho de la aceptación de la comunicación. ${ }^{786}$

Hay, sin embargo, también casos de manifestación tácita de la voluntad, como por ejemplo servicios de "self service", transporte de autobús, entre otros. La aceptación, en este caso, resulta de la forma operativa de la actitud del sujeto que emite su voluntad. No hay que confundirla con el silencio. El silencio no es una manifestación de voluntad. No hay que confundir la falta de palabra con el silencio. "Un comportamiento de este tipo, silencioso, pero con el fin de manifestar de forma inequívoca, en el marco de las circunstancias existentes, la voluntad de concluir el contrato, se dice 'comportamiento concluyente'". 787

\footnotetext{
${ }^{785}$ Hay que observar que el dejar de ser "yo" defendido en este párrafo no tiene nada que ver con la intersubjetividad, concepto moderno de inclusión del otro, pero sí con el pasar a ser "el otro", también de carácter individual. Además: el empleado deja de ser "yo", él mismo y sus deseos. Deja de ser su pasado, su presente y su futuro. Deja de ser para los suyos, en una relación intersubjetiva, para ser "el otro" el agente subordinante. Esta lógica debe permanecer siempre a la vista de quien se ocupa del derecho del trabajo, en especial el concepto de subordinación.

${ }^{786}$ ROPPO, Enzo, O contrato. Tradução de Ana Coimbra e M. Januário C. Gomes, Coimbra; Almedina, 1988, p. 93.

${ }^{787}$ ROPPO, Enzo, O contrato, cit., p. 94.
} 
Sin embargo, en la evolución de la teoría de los contratos, el papel e importancia de la voluntad se reduce. En una sociedad de masa, donde la implementación de los negocios jurídicos debe ser rápida, es importante la seguridad. Hay, eso sí, modos de revocar un contrato o incluso los llamados vicios de voluntad, dada esta masificación del contrato. ${ }^{788}$

Lo que se quiere destacar en los párrafos anteriores, sin embargo es, aunque se sepa que el contrato de empleo es un acuerdo que depende de la voluntad de las partes, la voluntad a la que se refiere el subtítulo anterior concierne no a la voluntad contractual sino al estar en el mundo, que el trabajador no puede decidir la forma de ejecución del contrato y las realización de las tareas, dependiendo por tanto de las órdenes del tomador de los servicios.

Lo que caracteriza un contrato de empleo es la subordinación o la dicha dependencia. El trabajador está sujeto a las órdenes del empleador, a la voluntad de este que le contrató, poder éste que tiene mucho que ver con la cuestión económica y de mercado, ligada a la propiedad privada y a la libertad de empresa. $^{789}$

El trabajador no es más que un instrumento pasivo, en el sentido de que presta su capacidad física e intelectual, y por qué no decirlo, su voluntad, en el sentido que es el otro quien le dirige. Estos poderes del empleador, acaban por insertarse en el contrato de empleo ${ }^{790}$, que acaba por subordinar la voluntad del trabajador durante la ejecución del contrato de empleo.

Supiot, refiriéndose al contrato de empleo, afirma que la autonomía de la voluntad es el fundamento y la justificación de la fuerza obligatoria del contrato. El individuo se vincula a quien le contrató. El principio de la igualdad excluye que la

\footnotetext{
${ }_{788}$ ROPPO, Enzo, O contrato, cit., p. 297/298.

789 RODRIGUEZ-PIÑERO, Miguel, "Contrato de trabajo y autonomía Del trabajador". En AA.VV. , Trabajo subordinado y trabajo autónomo en la delimitación de las fronteras del Derecho del Trabajo. Estudios en homenaje al prof. José Cabrera Bazán, Madrid; Tecnos, 1999, pp. 21/22.

${ }^{790}$ RODRIGUEZ-PIÑERO, Miguel, "Contrato de trabajo y autonomía Del trabajador", cit., pp. 24/25 (nota $\mathrm{Y}$ texto).
} 
voluntad de una de las partes pueda ser impuesta sobre la otra, sin que haya un acuerdo contractual. ${ }^{791}$

Las críticas al argumento de que el contrato de empleo era igual entre empleado y empleador surge con Marx y se desarrolla más precisamente al final del siglo XIX con Tissier. Para este último, el contrato de empleo es una necesidad para el trabajador y es, frente al tomador del trabajo, la parte económicamente débil. El trabajador puede escoger sólo al empleador al que va a subordinarse, dependiendo él de la situación del mercado. Tiene, volviendo a Marx, sólo una cosa que puede vender en el mercado, que es su fuerza de trabajo. ${ }^{792}$

El análisis de la relación de trabajo fue la punta de lanza, en las palabras de Supiot, de la crítica a la cuestión de la autonomía de la voluntad y que después se extiende a las demás ramas del derecho. La mayor parte de los civilistas hoy reconoce que el efecto imperativo del contrato "découle nécessairement d'une règle extèrieure à la volonté - 'Pacta sunt servanda' -, règle dont le legislateur garantit le respect dans la mesure où elle permet de sanctionner des opérations économiquement et socialement utiles". De hecho, esta distancia tomada de la ideología individualista y voluntarista de la autonomía de la voluntad permitió incorporar a los contratos, los llamados contratos de adhesión que, al igual que el contrato de empleo, están marcados por la desigualdad entre las partes y la falta de negociación previa. ${ }^{793}$

El contrato de trabajo deriva de un acuerdo de voluntad y que genera obligaciones recíprocas. Es consensual, sinalagmático y de ejecución sucesiva. En general, es un contrato de adhesión. En estos casos (contratos de adhesión), el derecho civil tiende a proteger, según el autor, la integridad de consentimiento de la parte más débil, además de los vicios del consentimiento, por la instauración

\footnotetext{
${ }^{791}$ SUPIOT, Alain, Critique du droit du travail, cit., p. 116.

792 SUPIOT, Alain, Critique du droit du travail, cit., p. 117.

793 SUPIOT, Alain, Critique du droit du travail, cit., pp. 117/118.
} 
de un cierto formalismo. Y, así mismo, el contrato de empleo de duración indeterminada y a tiempo total no es un contrato formal. ${ }^{794}$

Lo que actualmente permanece de la autonomía de la voluntad es el libre consentimiento en obligarse. La desigualdad entre las partes en un contrato de empleo no tiene la naturaleza de hacer este contrato inválido. No invalida, igualmente, un sistema jurídico que, a la vista de otros y cuya coherencia dependa sólo de la igualdad formal o "de derecho", dependa de un acuerdo de voluntades. Supiot llama la atención de que, hasta cierto punto, una teoría jurídica puede "ignorer les situations sociales ou économiques que semblent démentir ses construtions, car ces dernières ne relèvent pas de l'économie ou de la sociologie, mais du Droit, ce est-à-dire d'un ordre idéal, où les fictions sont monnaie courante et nécessaire". 795

El derecho francés presenta, según Supiot, dos corolarios principales que tratan de materia contractual: primero, la libertad contractual lo que significa que los contratantes fijen los parámetros del pacto de forma libre. Eso no quiere decir que el contrato debe ir necesariamente precedido de negociación de las cláusulas, sino que el objeto del deber respectivo debe ser determinado o determinable. Si la determinación del objeto queda por cuenta exclusivamente de una de las partes el contrato no es válido. En lo que se refiere a la forma, la libertad contractual hace que no solamente se libere la expresión de la voluntad del vínculo de formas preestablecidas, sino que también implica que el respeto de un supuesto formalismo pueda exigir un consensualismo extremo. ${ }^{796}$

Como segundo corolario del derecho contractual francés, se establece el principio de la fuerza obligatoria de los contratos. Es decir, que lo que está convenido por las partes tiene fuerza de ley entre ellas y sólo puede ser revocado por un consentimiento mutuo o cuando la ley lo autorice. El principio de la fuerza

\footnotetext{
${ }^{794}$ MAZEAUD, Antonie, Droit du travail, cit., pp. 3114/315.

${ }^{795}$ SUPIOT, Alain, Critique du droit du travail, cit., p. 118.

796 SUPIOT, Alain, Critique du droit du travail, cit., pp. 118/119.
} 
obligatoria de los contratos implica la inmutabilidad de las cláusulas contractuales, las cuales no pueden ser revocadas salvo de común acuerdo. ${ }^{797}$

Hasta aquí hemos hecho referencia a la fuerza obligatoria de los contratos, que no muda en los casos de Francia, España, Brasil, Italia o Portugal. Seguidamente nos ocuparemos de la cuestión de la subordinación de la voluntad.

La fuerza obligatoria de una relación de jerarquía como la de subordinación ¿se puede estructurar sobre la autonomía de la voluntad? se pregunta Alain Supiot. A diferencia de la relación de subordinación del servidor público con el poder público, la relación entre el empleado y el empleador es entre iguales. Esta relación surge de la autonomía de la voluntad, pero no concierne a los principios de la autonomía de la voluntad. ${ }^{798}$

Orlando Gomes y Elson Gottschalk alegan, refiriéndose al mejicano Mário de la Cueva, que "el modo en que se constituye la relación de empleo en la gran industria, que no tiene la forma de un acto formal de adhesión, ha llevado a algunos autores a ver en el contrato de trabajo una realidad 'sui generis', según la cual sus efectos no nacerían de un puro y simple acuerdo, sino del hecho material de que el empleado comience a trabajar". ${ }^{799}$

Esta referencia al principio de la primacía de la realidad ${ }^{800}$ demuestra que la cuestión del consenso y de la voluntad, al tratarse del contrato de empleo, discrepa o puede discrepar con respecto a lo que normalmente sucede en el derecho civil, como destaca Supiot.

\footnotetext{
${ }^{797}$ SUPIOT, Alain, Critique du droit du travail, cit., p. 119.

${ }^{798}$ SUPIOT, Alain, Critique du droit du travail, cit., p. 119/120.

799 GOMES, Orlando, GOTTSCHALK, Elson, Curso de direito do trabalho, Rio de Janeiro, Forense, $13^{\mathrm{a}}$ Ed., 1994, p. 122.

${ }^{800}$ Para saber lo que es efectivamente el principio de la primacía de la realidad se recomienda la lectura de ROSSAL DE ARAÚJO, Francisco, A boa-fé no contrato de emprego, São Paulo, LTr, 1996, p. 90. El autor subraya que "(...) el contrato de empleo es un contrato simplemente consensual, pudiendo realizarse expresa (oralmente o por escrito) o tácitamente, es decir, no depende, salvo excepciones previstas en ley, de formas especiales para que se considere válido y apto para producir efectos".
} 
Al tratarse de derecho del trabajo, aunque el contrato sea nulo, surte efectos, porque en el mundo de los hechos, el trabajo fue prestado. No es más que la primacía de la realidad fáctica si se compara con el formalismo natural de los contratos. $Y$ eso sucede porque el trabajo prestado no puede ser devuelto al trabajador y porque no se puede admitir el enriquecimiento sin causa del tomador del trabajo, ya que el trabajo fue prestado. Los contratos nulos surten efectos, debiendo la nulidad ser declarada sólo con efecto ex nunc. ${ }^{801}$

Volviendo a Supiot, el vínculo de subordinación es incompatible con una predeterminación precisa de las obligaciones del trabajador. El derecho de dirección por parte del empleador -recuerda Supiot siguiendo a Durand- permite que se sirva de la fuerza de trabajo del asalariado de acuerdo con los intereses de la empresa. El contrato de empleo se limita a poner al trabajador a disposición del empleador, teniendo este último un deber de difícil determinación. En los demás contratos hay predeterminación de las obligaciones de los contratantes, que falta al tratarse de contrato de empleo. ${ }^{802}$

En ese caso no habría vínculo de subordinación sino trabajo autónomo. El objeto de la vinculación del trabajador es el de prescindir de su autonomía de voluntad y de someterla a la autonomía de la otra parte, lo que implica una amplia indeterminación de obligaciones y que pesarán sobre él durante el contrato. ${ }^{803}$

Supiot sostiene que esto hace del contrato de empleo un contrato especial. El trabajador somete su voluntad a la voluntad de quien le contrata. E, incluso en este caso, habrá contrato, pero un contrato especial (de empleo). El hecho de que

801 TOLOMEI TEIXEIRA, Marcelo, "Os efeitos do contrato de trabalho nulo". Em Revista jurídica da Amatra $17^{a}$ Região, Vitória, ES; Ano 5, no. 09, volume V, 2008, p. 87.

802 SUPIOT, Alain, Critique du droit du travail, cit., p. 120."' (...) Dans le contrat de travail, l'employeur acquiert un droit de direction continue sur l'activité du salarié pendant le cours du contrat'. L'idée de mise à disposition par laquelle se trouve ainsi caracterisé le contrat du travail a connu depuis une fortune singulière, avec la diversification juridique du pôle patronal dans les relations de travail nationales et internationales. Si le salairié se met à disposition d'un employeur, ou si cet employeur peut ensuite le mettre à disposition d'un autre, c'est parce que son engagement ne porte pas sur une ou plusieurs prestations convenues à l'avance. Si l'ensemble des tâches que le salarié doit accomplir se trouvaient précisément définies 'ab initio' par le contrat, il ne resterait aucune place pour I 'exercice du pouvoir de direction de l'employeur".

${ }^{803}$ SUPIOT, Alain, Critique du droit du travail, ibidem. 
subordine su voluntad a la del empleador, permite que éste le dé órdenes, órdenes estas dependientes del contrato, pero aún así indeterminadas.

La subordinación es, por tanto, un fenómeno jurídico derivado del contrato de empleo, donde se observa un conjunto de prerrogativas o derechos a disposición del empleador para la buena gestión de la empresa. No es más que el poder de mando, como afirma Amauri Cesar Alves. ${ }^{804}$

De aquí se deduce que el contrato de empleo es un acuerdo de sujeción. El trabajador subordina su ser en el mundo a la voluntad de terceros. Hay que tener presente que el período de jornada de trabajo es tiempo de vida ${ }^{805}$ y como tal deben ser considerado. Los argumentos de Supiot sólo ratifican lo que ya venimos apuntando y que iremos destacando a lo largo de nuestra investigación: que el contrato de empleo aliena al trabajador de una manera tal que cualquier forma que agrave o que aumente esta alienación sin la debida autorización legislativa, acaba por impedir que la misma sea válida.

El poder patronal es más amplio cuanto mayor sea la indeterminación de las obligaciones del empleado. Al tratarse de un contrato de empleo las reglas de alteración del pacto conciernen sólo a aquellas no esenciales. Derivan del poder que tiene el empleador en su empresa, "le pouvoir de direction", no pudiendo, sin embargo, afectar a lo esencial. ${ }^{806}$

En el contrato civil la voluntad se compromete y, en el contrato de empleo, la voluntad se somete. "L'engagement manifieste la liberté, La soumission la nie". Esta contradicción existente entre la autonomía de la voluntad y la subordinación de la voluntad acaba por desembocar en que el empleado mantiene una relación con el empleador tanto como sujeto cuanto como objeto del contrato. Por tanto, no se puede considerar que quedan intactos, al tratarse de derecho del trabajo, los

\footnotetext{
${ }^{804}$ ALVES, Amauri Cesar, Novo contrato de emprego (...), cit., p. 77.

${ }^{805}$ Sobre la cuestión del trabajo, concretamente, de la jornada de trabajo como tiempo de vida, se recomienda la lectura de SOUTO SEVERO, Valdete, Crise de paradigma no Direito do Trabalho moderno: a jornada, Porto Alegre; Sérgio Antônio Fabris Ed., 2009, p. 68/74.

${ }^{806}$ SUPIOT, Alain, Critique du droit du travail, cit., p. 121.
} 
principios jurídicos que se ocupan de la autonomía de la voluntad. Están desfigurados por el vínculo de subordinación y por la alteración de la calidad de sujeto de derecho que conlleva la misma. ${ }^{807}$

Estas soluciones híbridas surgen en razón de la tensión entre la autonomía de la voluntad y la subordinación que forman parte del contrato de empleo. El derecho del trabajo tuvo y tiene como razón de ser el hacer resurgir al trabajador como sujeto de derechos dentro de la empresa, es decir, civilizar el poder de dirección del patrón. El derecho legaliza pero limita el poder de acción del patrón dentro de la empresa con relación a sus empleados. ${ }^{808}$

Hay que tener presente que la subordinación limita la voluntad del trabajador a terceros. Limita, sin embargo, -ya que la subordinación esté ligada al derecho del trabajo,- al empresario en las limitaciones previstas en la norma laboral. El poder directivo está restringido a lo que consta en la norma laboral, creando un límite negativo para el empresario en función de la dependencia con la que expone al trabajador. ${ }^{809}$

Podemos concluir que el derecho del trabajo efectivamente crea una situación de ciudadanía para el trabajador en el momento en que autoriza al empleador a actuar dando órdenes al trabajador. Eso deriva de que la autorización o legalización del poder de mando hay la limitación de este poder, debiendo el mismo observar los estrictos límites de la norma jurídica vigente.

Trabajar en un estado de sujeción no es más que someter su propia voluntad a la voluntad de terceros, ya que se deben respetar los límites del derecho vigente. De hecho, el empleador también presta su objeto (como

\footnotetext{
${ }^{807}$ SUPIOT, Alain, Critique du droit du travail, cit., p. 123/124. "L'objet de l'obligation, qui forme la matière de l'engagement, étant l' obéissance aux ordres, y prend les contours imprécis de la qualification professionnelle et du poste de travail. La force obligatoire do contrat s'estompe au profit de l'employeur, le droit du salairé au respect de ses clauses dégénérant en devoir d'accepter les modifications secondaires que l'employeur entend y apporter. L'exigence d'un consentement fictif, voire au formalisme comme source d'obligations".

${ }^{808}$ SUPIOT, Alain, Critique du droit du travail, cit., p. 124.

${ }^{809}$ RODRIGUEZ-PIÑERO, Miguel, "Contrato de trabajo y autonomía Del trabajador", cit., p. 28.
} 
empresario) en un estado de sujeción, pero a la norma jurídica y a los límites del contrato de empleo y durante su ejecución plena. Dejar la voluntad al arbitrio de otros, cuando está autorizado por ley, permite concluir que esta autorización debe ser observada estrictamente, sin ningún tipo de ampliación o complemento, a pesar del "acuerdo" entre las partes. Los límites del contrato son también los límites del derecho vigente. La limitación del poder de actuar, de la voluntad del tomador de los servicios, se encuentra en la norma y en los términos del contrato.

Hechas estas consideraciones sobre la subordinación de la voluntad, donde el trabajador en la ejecución del contrato deja de actuar, por voluntad propia para ejecutar deseos ajenos ${ }^{810}$, pasamos a las cuestiones importantes relacionadas con la subordinación y a la no eventualidad (continuidad), eso porque, además de que

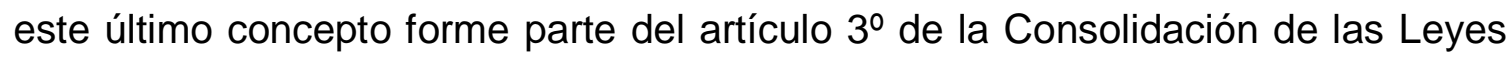
del Trabajo cuando define al empleado, está íntimamente vinculado a la cuestión de la subordinación. Quien trabaje de forma no eventual, necesariamente trabaja de forma subordinada, conforme a lo que se podrá constatar después de la lectura del apartado siguiente.

Sólo es preciso hacer constar que el derecho laboral español no consagra, de esta forma, la no eventualidad. se sirve de ella como forma, en el caso concreto, de resolver las cuestiones planteadas a los interpretes jurídicos, pudiendo ser un indicio de la relación de empleo prestado de forma continúa ${ }^{811}$.

\subsection{Subordinación y no eventualidad}

Este apartado concierne a la relación entre la subordinación y la no eventualidad, elementos caracterizadores de la relación de empleo en el derecho brasileño, conforme establece el artículo $3^{\circ}$ de la Consolidación de las Leyes del

\footnotetext{
${ }^{810}$ En este sentido ver MONERÉO PEREZ, José Luis, "La critica de los elementos de reducción normativa del concepto de trabajo en la doctrina socialista del derecho: significación técnica de la dependencia y ajenidad". En AA.VV. , Trabajo subordinado y trabajo autónomo en la delimitación de las fronteras del Derecho del Trabajo. Estudios en homenaje al prof. José Cabrera Bazán, Madrid; Tecnos, 1999, p. 221.

811 MARTÍN VALVERDE, Antonio, RODRÍGUEZ-SAÑUDO GUTIÉRREZ, Fermín y GARCíA MURCIA, Joaquin, Derecho del Trabajo, cit., p. 178.
} 
Trabajo $^{812}$. Se constata que, en España, o incluso en otros países europeos, no hay la exigencia de la no eventualidad, incluso porque, se cree, por ser también, la subordinación jurídica, derivada de un trabajo permanente y dependiente.

Una vez comprobada la no-eventualidad, se presume, de forma absoluta, la subordinación, la sujeción a las órdenes. Esta relación jurídica podrá, según el artículo $3^{\circ}$ de la CLT, protegerse por la legislación laboral brasileña.

Lo que se pretende, por tanto, es establecer la relación entre los dos institutos de la no-eventualidad y de la subordinación, con el fin de no confundirlos.

Posible es lo que resulta meramente ocasional, esporádico. Para que se caracterice la relación de empleo, el trabajo debe ser habitual. Debe haber, por tanto, un propósito de permanencia incluso cuando se ejecutan los servicios, aunque esta idea no sea absoluta, y se produzca durante un breve período de tiempo. El trabajo ocasional no genera el vínculo de empleo. Pero el permanente sí. $^{813}$

La eventualidad, para el derecho laboral, no corresponde a la intermitencia de la prestación del trabajo. En el caso de que el trabajo sea discontinuo, pero permanente, habrá un vínculo de empleo, por tratarse de trabajo no-eventual. Trabajo eventual es aquél "intrínsecamente transitorio". 814

Para una parte de la doctrina, la no-eventualidad está relacionada con la actividad de los prestadores de trabajo, ligada al fin de la empresa. Para éstos, eventual sería el trabajo realizado en tareas no-ligadas con el fin pretendido por la empresa. El problema es saber lo que es actividad-medio y lo que es actividad-fin en la esfera empresarial. Toda la actividad desempeñada por la empresa es fin,

\footnotetext{
${ }^{812}$ Art. $3^{\circ}$ - se considera empleado toda persona física que preste servicios de naturaleza no eventual al empleador, bajo la dependencia de éste y mediante salario.

${ }^{813}$ GARCIA SCHWARZ, Rodrigo, Direito do trabalho, Rio de Janeiro: Elsevier, $2^{\mathrm{a}}$ ed., 2009, pp. 26/27.

${ }^{814}$ GARCIA SCHWARZ, Rodrigo, Direito do trabalho, cit., p. 27.
} 
puesto que deriva de ella el riesgo del negocio, como establece el artículo $2^{\circ}$, de la CLT. $^{815}$

En España el artículo 42 del Estatuto de los Trabajadores establece que es posible la tercerización, siendo solidaria la responsabilidad para los casos de tercerización de la "propia actividad" de la empresa tomadora. Aunque en España uno hay controversia cuanto al alcance de la expresión legal "misma actividad". 816

La norma jurídica española, en comparación con la jurisprudencia brasileña citada anteriormente, Súmula 331 del TST, sólo demuestra que es demasiado difícil definir la actividad-medio y la actividad-fin. El concepto de la noeventualidad, por tanto, previsto en la ley brasileña, no es más que un servicio permanente, no necesariamente continuo, sino que depende la empresa para la ejecución de sus tareas.

Rodrigo Garcia Schuwarz apunta que:

\begin{abstract}
"La idea de la no-eventualidad está relacionada con el propósito de permanencia en la ejecución de los servicios, aunque esa idea de permanencia no sea absoluta, fijándose durante un breve período determinado, sólo cuando es eventual el trabajo ocasional, o esporádico. El objeto del Derecho del Trabajo es la situación fáctico-jurídica continua que corresponde a una actividad prestada por cuenta ajena y de forma subordinada. Se exige, así, el elemento de la no-eventualidad más en cuanto al vínculo que en relación a las prestaciones". ${ }^{817}$
\end{abstract}

Por tanto, puede entenderse el trabajo no-eventual el que se preste de forma permanente, ligado a la actividad de la empresa, independientemente de que haya o no continuidad. De ahí se deduce la subordinación jurídica, elemento principal para la fijación de la relación laboral, siendo necesariamente el empleado quien

\footnotetext{
${ }^{815}$ GARCIA SCHWARZ, Rodrigo. Direito do trabalho, cit., p. 27.

${ }^{816}$ Para mejor comprender el problema em España el lector poede ver lo que hemos dicho en el epigrafe 2.3 o en PEDRAJAS MORENO, Abdón y SALA FRANCO, Tomás, Contratas y empresas de trabajo temporal; responsabilidades, cit., p. 34.

817 GARCIA SCHWARZ, Rodrigo, Direito do trabalho, cit., p. 28.
} 
debe prestar trabajo a otros de forma permanente, integrándose en el proceso productivo del tomador del trabajo.

Carmen Camino confirma la tesis expresada en el párrafo anterior en cuanto al hecho de que la no-eventualidad derive de la subordinación. La "noeventualidad y la subordinación se entrelazan". Y, además, "es perfectamente posible asociar el estado subordinado del empleado a la no-eventualidad de los servicios prestados por el mismo, porque la regla es que estos dos atributos van siempre juntos". La subordinación es, por tanto, la consecuencia natural de la noeventualidad de los servicios prestados por el empleado, ${ }^{818}$ porque la sujeción pura simplemente a las órdenes queda superada por la ejecución de la producción o por la prestación de trabajo dentro de la estructura empresarial.

Nos ocuparemos, aún, de la subordinación estructural, otro instituto relevante para poder comprender qué es la subordinación jurídica y que es estar subordinado a un empleador.

Hay que tener presente que la subordinación estructural concierne al hecho de que el trabajador esté expuesto a la estructura de la empresa, recibiendo "órdenes" de la producción y ejecutándolas en beneficio del conjunto.

\subsection{Subordinación estructural}

Como hemos visto anteriormente, para una parte de la doctrina, la subordinación no se refiere sólo al hecho de que el trabajador reciba o no órdenes del empleador. También se trata de que será subordinado el trabajador que presta servicios, ligado a la actividad-fin de la empresa.

Maurício Godinho Delgado afirma que la subordinación se presenta de forma estructural, es decir, cuando el trabajador presta trabajo dentro de la dinámica de la empresa, independientemente de que reciba o no órdenes directas

${ }^{818}$ CAMINO, Carmen, Direito individual do trabalho, Porto Alegre: Síntese Editora, $4^{\text {a }}$ ed., 2004, p. 189. 
o indirectas. Las "órdenes" son dadas por la producción, por la estructura de la empresa a quien se subordina el trabajador.

Godinho Delgado considera la subordinación como un elemento esencial en la formación de la relación de trabajo. Es el principal elemento que diferencia el trabajo autónomo del vínculo de empleo. ${ }^{819}$

La subordinación se percibe bajo una óptica objetiva y no subjetiva. Actúa sobre el modo de prestación del trabajo y no sobre la persona que trabaja. Bajo la óptica subjetiva jamás se captaría un trabajo subordinado prestado por empleados de alto nivel. El trabajador recibe la dirección del tomador de los servicios, así como de la prestación de trabajo, dando relieve, por tanto, al objetivo de la subordinación. $^{820}$

Sobre la subordinación estructural, también llamada integrativa o reticular, resulta interesante la sentencia del Tribunal Regional do Trabalho da Terceira Região, Minas Gerais. En la sentencia, el relator apunta que ya no hay necesidad de órdenes directas por parte del tomador de los servicios. Basta que ordene la producción, por lo que puede concluirse que el trabajador se subordina a la estructura productiva del tomador, independientemente de la actividad desempeñada. ${ }^{821}$

Lo que debe quedar claro es la adaptación del concepto de subordinación, intentando no perder su base, para adaptar mejor este tipo jurídico-legal a las características actuales del mercado de trabajo, lo que "atenúa el enfoque sobre el mando empresarial directo, haciendo hincapié, como punto de énfasis, en la inclusión estructural del trabajador en la dinámica del tomador de sus servicios" ${ }^{822}$

\footnotetext{
${ }^{819}$ GODINHO DELGADO, Maurício, Curso de Direito do Trabalho, cit., p. 302.

820 GODINHO DELGADO, Maurício, Curso de Direito do Trabalho, cit., p. 303.

${ }^{821}$ Proceso: 01251-2007-110-03-00-5 RO - Fecha de Publicación: 11/04/2008 - Órgão Julgador: Primeira Turma - Juiz Relator: Juiz Convocado Jose Eduardo de RC Junior. En: www.trt3.jus.br acceso el 20 de junio de 2008, a las 12h32min.

822 GODINHO DELGADO, Mauricio, "Direitos fundamentais na relação de trabalho", cit., p. 667.
} 
Estructural, por tanto, es la subordinación que se manifiesta "por la inserción del trabajador en la 'dinámica' del tomador de sus servicios, independientemente de recibir (o no) sus órdenes directas, "pero acogiendo, estructuralmente, su dinámica de organización y funcionamiento'”. ${ }^{823}$

Conviene hacer referencia a Engels, citado por Reginaldo Melhado. Para el filósofo, compañero intelectual de Marx, no se puede concebir la organización empresarial sin la autoridad, de donde deriva la subordinación. Las actividades en una gran industria deben ser coordinadas y unas se subordinan a otras. Unos ponen las máquinas en movimiento, algunos hacen cálculos, otros se dedican a la planificación, sin olvidarnos de los encargados de la logística y del mantenimiento y de la limpieza. Si todas estas personas no se someten a una cierta subordinación, habrá un caos absoluto. ${ }^{824}$

De ahí se deduce, también, la existencia de la subordinación entre las actividades de la empresa, que genera, por supuesto, una subordinación estructural del prestador de los servicios a la rotación empresarial, puesto que las actividades son realizadas por estos trabajadores, que dependen, de su patrón, para la ejecución de las tareas de forma ordenada y para que puedan realizar las propias.

El trabajador que presta trabajo, incluso sin que reciba órdenes directas, se vincula a la dinámica del tomador de los servicios, y lo hace de forma subordinada, siendo, por tanto, un empleado. Este trabajador "acoge" la dinámica funcional y estructural de la empresa, pasando a formar parte de su "contexto total". El tomador coge parte del lucro del empleado. Compra este trabajo por un precio más bien bajo con respecto a lo que vende ("plusvalía"), puesto que este prestador

\footnotetext{
${ }^{823}$ GODINHO DELGADO, Mauricio, "La idea de subordinación estructural supera las dificultades de encuadramiento de situaciones fácticas que el concepto clásico de subordinación ha demostrado, dificultades que se exacerbaron con relación, especialmente, al fenómeno contemporáneo de la tercerización laboral. En esta medida, permite no sólo ampliar el campo de incidencia del Derecho del Trabajo, sino también conferir una respuesta normativa eficaz a algunos de sus más recientes instrumentos desestabilizadores - en especial, la tercerización"

${ }^{824}$ MELHADO, Reginaldo, Poder e sujeição (...), cit., p. 13/14.
} 
no es más que una parte de la estructura formada por el tomador y que se proyecta, mediante un contrato civil, a sus clientes.

\subsection{Subordinación y teletrabajo.}

En el año de 2011 el Congreso Nacional de Brasil aprobó una ley, $12.551^{825}$, que alteró el articulo 6 de la CLT, y que, ahora, considera el trabajo hecho por el trabajador en su casa o a distancia (el teletrabajo) como relación de empleo, si estuvieren presentes los requisitos del contracto de trabajo, o sea, la subordinanción (dependencia), la no-eventualidad, la onerosidad y el trabajo en carater personal (articulo 3 de la CLT).

La ley apunta, aún, que los medios de informatica y telematicos de control o supervisión, se equiparan, para los fines de la subordinación juridica, a los medos directos de control y supervisión del trabajo.

Ello quiere decir que el teletrabajador, en Brasil, recibe la misma protección laboral que el trabajador que presta su trabajo dentro de la empresa, sob los ojos del empleador. Equipara los medios telematicos y informaticos al control que existe en el contracto de empleo, siendo trabajador subordinado aquél que, mismo lejos de la empresa, exerce su mister en provecho del tomador del trabajo.

Es interesante este articulo 6 de la CLT. Él trae para dentro del derecho laboral los conceptos de subordinanción objetiva, execución, por el empleado, del objeto de la empresa, no sendo más necesarias las ordenes directas. Estas son, y siempe serán importantes y haran parte del derecho laboral. Resulta que, la duda

\footnotetext{
${ }^{825}$ Art. $6^{\circ}$ Não se distingue entre 0 trabalho realizado no estabelecimento do empregador, 0 executado no domicílio do empregado e o realizado a distância, desde que estejam caracterizados os pressupostos da relação de emprego. Parágrafo único. Os meios telemáticos e informatizados de comando, controle e supervisão se equiparam, para fins de subordinação jurídica, aos meios pessoais e diretos de comando, controle e supervisão do trabalho alheio.
} 
que habia en Brasil cuanto a los conceptos de subordinación objetiva, ahora no existen más.

La subordinación, en el caso del teletrabajo, es estructural, objetiva. Es solamente necesario que el empleado ejecute la produción, a través de los medios de informatica y telematicos dados por el empleador o que le traigan provecho para que se tenga la subordinación jurídica. Es necesario clarear, aún, que hay forma de subordinación subjetiva, mismo en los casos de teletrabajo, como por ejemplo las ordenes dadas por correo eletrónico, teléfono, pager o mismo por el sistema integrado de internte o intranet.

La condición de trabajador subordinado no cambia en los casos de trabajo à distancia. Solamente o que no se repete es el hecho del trabajador estar prestando su trabajo sob los ojos del empleador, de forma directa. El control por el empleador se hara de forma telemática y informatica, incluso las horas de labor y procuctividad (en especial esta).

Se puede decir, así, que el teletrabajo, en el caso de Brasil, aproximó el derecho laboral brasileño del concepto de subordinanción objetiva, sin dejar al lado la subordinación subjetiva.

\subsection{La parasubordinación italiana y el trabajador español autónomo económicamente dependiente.}

Las alteraciones en el mundo del trabajo, derivadas de la globalización económica y de las innovaciones en el campo tecnológico, han acabado por sacar a la luz la reestructuración productiva, permitiendo que aumentaran considerablemente los trabajadores autónomos.

Mazeaud argumenta que el derecho del trabajo no tiene ninguna vocación para aplicarse a los trabajadores independientes. Algunos de los trabajadores independientes viven en un estado de dependencia económica y que una parte de los asalariados no tiene porqué envidiar esta situación. Concluye que la condición 
de los asalariados puede aplicarse a estos trabajadores cuando haya subordinación. ${ }^{826}$

Para Maurício Godinho Delgado el trabajador autónomo es el que presta servicios sin subordinación al tomador, siendo el concepto de "autónomo", en materia laboral, antitético al de "subordinado". Aunque haya personalidad podrá no haber subordinación, caracterizándose el contrato como de trabajo autónomo, como sucede por ejemplo con médicos y abogados, entre otros. ${ }^{827}$

El trabajador autónomo es el que rige su propia prestación de trabajo, límites, hora, precio, clientes, obligándose no por el trabajo en sí, sino por una obra o cosa. Se aleja de esta relación la subordinación que, una vez que exista, hace del contrato un acuerdo laboral. ${ }^{828}$

Martín Valverde, Rodríguez-Sañudo y García Murcia añaden que, para fines de estadística, el trabajo autónomo es sinónimo de trabajo por cuenta propia, significado éste que también se encuentra en el artículo 10.1, "c" de la Ley General de la Seguridad Social española (LGSS). Lo contrario del trabajo autónomo es el contrato de trabajo subordinado, por cuenta ajena y jurídicamente dependiente. $^{829}$

Por estas razones conviene someter a discusión, aun de forma breve, la parasubordinación y el trabajo autónomo económicamente dependiente, institutos

${ }^{826}$ MAZEAUD, Antoine, Droit du travail, cit., p. 13/14.

827 GODINHO DELGADO, Maurício, Curso de direito do trabalho, cit., p. 334/336.

828 "EMENTA: Recurso de la reclamación. Representación comercial. Es tenue la diferencia entre trabajo autónomo y subordinado. El trabajador autónomo es independiente en el ajuste y en la ejecución y se caracteriza cuando hay toda libertad de acción, es decir, cuando el trabajador actúa como patrón de sí mismo, con poderes jurídicos de organización propia, a través de los cuales desarrolla el empuje de su libre iniciativa. La permanencia de los servicios para la misma empresa puede transformar el contrato de autónomo en contrato de empleo, dado que puede generar la desaparición de la autonomía, creando, en su sustitución, la subordinación jurídica. Recurso del reclamante. Diferencias salariales. Las modificaciones contractuales no han supuesto perjuicios financieros al reclamante". Acuerdo del proceso 00886-2008-561-04-00-6 (RO) - Redator: FRANCISCO ROSSAL DE ARAÚJO. Participan: MARIA HELENA MALLMANN, RICARDO CARVALHO FRAGA. Fecha: 22/07/2009 - Origen: Tribunal del Trabajo de Carazinho.

${ }^{829}$ MARTÍN VALVERDE, Antonio, RODRÍGUEZ-SAÑUDO GUTIÉRREZ, Fermín y CARCÍA MURCIA, Joaquin, Derecho del Trabajo, cit., p. 48. 
existentes en Italia y en España respectivamente y que permite comprender adecuadamente el concepto y los límites de la subordinación jurídica.

\title{
3.6.1 La parasubordinación italiana
}

La parasubordinación tiene origen, como concepto, en Italia, en 1973, ley 533. La protección, fruto del derecho del trabajo, debía de dirigirse a todos los que la necesitaban, teniendo o no contrato de empleo. La norma legal italiana, por tanto, con la parasubordinación, se dirige a proteger el prestador de trabajo, aun cuando no esté subordinado de forma directa ${ }^{830}$.

Sobre ello, aún, es necesarido decir que la parasubordinación se aplica a la relación de agencia y de representación comecial y a todas otras relaciones de colaboración que lleven por cuenta una prestación continua y coordenada, habida de forma personal por el trabajador, aunque no sea este subordinado". ${ }^{831}$

El artículo 409 del Código de Proceso Civil italiano establece:

\begin{abstract}
"Art. 409. (Controversie individuali di lavoro)
Si osservano le disposizioni del presente capo nelle controversie relative a: 1) rapporti di lavoro subordinato privato, anche se non inerenti all'esercizio di un'impresa; 2 ) rapporti di mezzadria, di colonia parziaria, di compartecipazione agraria, di affitto a coltivatore diretto, nonche' rapporti derivanti da altri contratti agrari, salva la competenza delle sezioni specializzate agrarie; 3 ) rapporti di agenzia, di rappresentanza commerciale ed altri rapporti di collaborazione che si concretino in una prestazione di opera continuativa e coordinata, prevalentemente personale, anche se non a carattere subordinato; 4) rapporti di lavoro dei dipendenti di enti pubblici che svolgono esclusivamente 0 prevalentemente attività economica; 5) rapporti di lavori dei dipendenti di enti pubblici ed altri rapporti di lavoro pubblico, sempreché non siano devoluti dalla legge ad altro giudice" (La negrita es nuestra).
\end{abstract}

Son tres los requisitos de la parasubordinación, una vez analizado lo que establece el artículo 409 del Código de Proceso Civil italiano: la continuidad, la coordinación y el trabajo personal. Hay que tener presente que no se considera la

\footnotetext{
${ }^{830}$ ALVES, Amauri Cesar, Novo contrato de emprego: parassubordinação trabalhista, São Paulo; LTr, 2004, pp. 85/88.

${ }^{831}$ http://www.studiocataldi.it/argomenti.asp?opt=dettaglio\&codice=9 - acceso el 12 de septiembre de 2012, a lãs $13 \mathrm{~h} 12 \mathrm{~min}$.
} 
subordinación, teniendo, sin embargo, el trabajador mayor protección que en los casos de contrato de trabajo autónomo. ${ }^{832}$

En los casos de parasubordinación no habra, de niguna forma, los elementos de la subordinancion juridica. Debera el trabajador, que prestar trabajo continuo, tener autonomia de administracion de su trabajo ${ }^{833}$. Él, sin embargo, dependera economicamente, con casi todo su gano del tomador del trabajo. Es por eso que la ley italiana ha crado el instituto de la parasubordinación, para proteger a estos trabjadores.

La parasubordinación se inserta entre la subordinación clásica y la autonomía y acaba configurándose como una nueva especie dentro del derecho del trabajo. Alves apunta, sin embargo, que en un primer momento, algunos autores italianos sugirieron que la parasubordinación llevó a los contratantes más débiles en una relación de trabajo a un nivel de garantías procesales mínimas. En su opinión no es así, siendo efectivamente una nueva especie dentro del derecho del trabajo, conforme hemos indicado anteriormente. ${ }^{834}$

En este sentido Adalberto Perulli dice que los trabajadores parasubordinados, como los trabajadores subordinados son dependientes económicos de los tomadores del trabajo. Pelo están entre los traabjadores

${ }^{832}$ Guide per esami e pubblici concorsi. Elementi di diritto del lavoror e legislacione sociale, Napoli; Edizioni Giurdiche Simone, 1998, p. 17. "Con il termini <parasubirdinazione> si indicano tutti quei raporti di lavoro non subordinato che però si avvicinano e si assimilano a quelo subordinato in ordine alla prezenza di un 'lavoro' o di una 'collaborazione continuativa e personale all'attività altrui ed appaiono pertanto meritevoli di tutela maggiori, o aggiuntiva, rispeto a quella stabilita per $\mathrm{i}$ lavoratori autonomi. (...). Dall'esame di esso si facilmente i tre 'requisiti' della parasubordinazione: 1. La 'continuità della prestazione laborativa riferita non tanto ad una attività duratura quanto alla reiterazione di prestazioni integranti diverse <opere>; 2. La coordinazione representata dal 'collegamento funzionale' della prestazione laborativa con l'attività esercitata dal suo destinatario; 3. il carattere <prevalentemente personale > della prestazione nel senso che il prestatore d'opera può a sua volta giovarsi di collaboratori ma in misura da non pregiudicare la prevalenza della sua prestazione".

${ }_{833}$ http://www.appuntigiurisprudenza.it/appunti-di-diritto-del-lavoro/parasubordinazione-e-lavoro-aprogetto.html acceso el 12 de septiembre de 2012 a las $13 \mathrm{~h} 18 \mathrm{~min}$.

${ }^{834}$ ALVES, Amauri Cesar, Novo contrato de emprego (...), cit., p. 88. 
subordrinados y los trabajadores autónomos, lo que considera una sinta intermediaria. $^{835}$

Lo que interesa es que "son características de la parasubordinación, por tanto, la continuidad, la coordinación, la personalidad e, incluso, sin formulación legal clara en este sentido, la debilidad contractual del trabajador con relación a su contratante". ${ }^{836}$

La parasubordnacion, en Italia, tiene unas caracteristicas, como se puede ver:

"La parasubordinazione trova il suo fondamento normativo nell'art. 409 del c.p.c. che, seppure indirettamente, ne individua i profili caratterizzanti:

- collaborazione, intesa come lo "svolgimento di ogni attività finalizzata al raggiungimento di scopi determinati da altri" (Cass. 21/02/98, sent. n. 1897), che si differenzia dal vincolo della subordinazione proprio del rapporto parasubordinato;

coordinamento nella realizzazione dell'opera con il datore di lavoro il quale può, all'uopo, fornire delle indicazioni nei limiti dell'autonomia professionale del collaboratore; nonché forme di coordinamento funzionale con la struttura organizzativa, ma è escluso l'inserimento strutturale del lavoratore nell'organizzazione gerarchica dell'impresa;

continuità della prestazione che non deve essere occasionale ma deve durare nel tempo, con un impegno costante da parte del collaboratore;

personalità della prestazione, che deve essere realizzata attraverso l'apporto lavorativo proprio del collaboratore, il quale, nell'espletamento della stessa, può utilizzare altri mezzi o essere coadiuvato da altri soggetti, fermo restando la preminenza della sua partecipazione" (negritas em el original). ${ }^{837}$

Lo que caracerizara el trabajo parasubordinado (collaboratore coordinato e continuativo, el co.co.co,) y que debe ser puesto en destaque es el hecho de que el trabajador sea el responsable, y no el patrón, por la ejecución de las tareas. E trabajo, aún, debe ser continuado, preferencialmente de forma personal (diverso,

\footnotetext{
${ }^{835}$ PERULLI, Adalberto, Levori atipici e parasubordinazione tra diritto europeo e situazione italiana. En Rivista Giuridica del Lavoro e della Previdenza Sociale. Roma, Ediesse, anni LVII, n. 4., p. $731 / 752$.

${ }^{836}$ ALVES, Amauri Cesar, Novo contrato de emprego (...), cit., p. 88.

${ }^{837}$ http://www.contrattoprogetto.info/il-lavoro-parasubordinato - acceso el 12 de septiembre de 2012, a lãs 13h24min.
} 
por lo tanto del trabajo subordinado). Son estos los requisitos del articulo 409, n. 3, del CPC italiano. ${ }^{838}$

Aún, añade, para completar, el brasileño Alves que, para ellos, "debe haber, para la caracterización del trabajo parasubordinado, además de los elementos que aporta el N. 3 del art. 409 del CPC, la inferioridad contractual del trabajador, dado que es éste la parte económicamente más débil en la contratación de trabajo, estando, por lo general, en condición de sujeción económica ante su contratante". 839

Sin embargo, Murilo Carvalho Sampaio de Oliveira, en un artículo publicado en la red mundial de computadoras, dice que:

"La idea de la parasubordinación implica que no se aplica el criterio de
aplicación del Derecho del Trabajo, dado que los procesos de
externalización de la organización de la producción tienden a constituir una
periferia de trabajadores (considerados jurídicamente) como autónomos,
aunque englobados y vinculados, en cuanto al resultado y otras
obligaciones, a la iniciativa empresarial.
La(s) topologías intermediaria(s) entre las relaciones de autonomía y
subordinación fueron articuladas por la doctrina italiana bajo el nombre de
parasubordinación o relaciones de coordinación (Silva a, 2004, p. 104). El
sufijo 'para' significa más allá, es decir, sería más allá de la subordinación.
Se trata de una nueva fattispecie que, por sus peculiaridades, atrae un
desarrollo propio y auténtico".

Dice que la superioridad en la prestación personal no se identifica con trabajo en carácter personal del contrato de empleo, pudiendo servirse de terceros. El autor afirma que

"El carácter de la superioridad de la prestación personal es bien
diferenciado de la naturaleza personalísima del contrato de empleo. Se
habla de superioridad, puesto que los colaboradores pueden incluso
utilizar el trabajo de las demás personas - terceros -, siempre que se
observe y asegure que su prestación final, resultado de su trabajo y de
terceros, sea demarcada por su calidad personal. Es decir, las
principales actividades han de ser desarrolladas personalmente por el

${ }^{838}$ DEL PUNTA, Riccardo, Diritto del lavoro, Milano, Giuffrè Editore, Terza edizione, 2010, p. 328.

${ }^{839}$ ALVES, Amauri Cesar, Novo contrato de emprego (...), cit., p. 91.

${ }^{840}$ En SAMPAIO OLIVEIRA, Murilo Carvalho, Direito do trabalho e tecnologia: o teletrabalho e a parassubordinação, p. 13. http://www.facs.br/revistajuridica/edicao_julho2007/convidados/con1.doc - (acesso 20 de julho de 2009, 15h11min). 
trabajador parasubordinado, a pesar de la posibilidad de la colaboración de terceros en las actividades accesorias.

No obstante la posibilidad de la ayuda de terceros - implicando solamente la superioridad de la personalidad -, el trabajo para considerarse como parasubordinado necesita un vínculo funcional como la actividad productiva del tomador de los servicios". ${ }^{841}$

Sampaio Oliveira destaca que el prestador de trabajo debe tener autonomía o alguna autonomía, sin que puede existir una situación de jerarquía entre el prestador y el tomador del trabajo. En sus palabras "el vínculo funcional es la medida de la relación de coordinación o colaboración. En éste no hay situación de jerarquía clara y manifiesta entre el colaborador y el tomador. Compete al colaborador prestar sus servicios con alguna autonomía (...)". 842

Del Punta llama la atención y pone en cursiva en su libro que el trabajador no puede estar subordinado al tomador del trabajo, aúnque el trabajo deba ser coordinado por él própio, como consta en el contrato de colaboración y continuado, aqui, añade el autor, como en el contrato de empleo. ${ }^{843}$

El autor sua a ello, aún, que "come pure è stato rilevato, è il dato del 'coordinamiento' che marca la pur labile liena distintiva fra un'integrazione organizzativa 'debole', come quella che si riscontra nella collaborazione in discorso, e un 'integrazione 'forte', come quella della subordinazione" ${ }^{844}$, lo que hace la diferencia entre la parasubordinación y la subordinación juridica que caracterza, esta última, la relación de empleo.

La continuidad del articulo 409 del CPC italiano es por el tiempo de la obra, el tiempo necesario para la ejecución de la obra. La continuidad no es sinónimo de estabilidad. La obra poede ser continuada, aunque no sea estable. La estabilidad implica la repetición periódica de la prestación del colaborador no solamente de

\footnotetext{
${ }^{841}$ SAMPAIO OLIVEIRA, Murilo Carvalho, Direito do trabalho e tecnologia (...), cit., p. 14. 842 SAMPAIO OLIVEIRA, Murilo Carvalho, Direito do trabalho e tecnologia (...), cit., p. 14.

843 DEL PUNTA, Riccardo, Diritto del lavoro, cit., p. 328.

844 DEL PUNTA, Riccardo, Diritto del lavoro, cit., p. 328.
} 
hecho, mas por causa de una obligación contratual precedente (Cass. 7799/1998, MGC, 1998, 1678). ${ }^{845}$

De otro modo, la forma de la continuidad pode ser reconocida cuando, en relación con la naturaleza de la obra prestada, haya la interrupción de la ejecución de la prestación, o cuando esta ultima no es exclusiva, lo que hace irrelevante que el colaborador haga una otra actividad junto a un sujeto diverso del conmitente (Cass. 7785/1997). ${ }^{846}$

La parasubordinación, aún, hace previsión de del coordinamiento, que es diferente de la subordinanción juridica. El trabajador coordinado presta su actividad en vista de la realización de un programa definido por consenso. El conmitente puede solamente concorrer para determinar la modalidad de ejecución de la prestación predeterminada, coordinandola conforme las exigencias económico-productivas. ${ }^{847}$

Aún, la prestación debe ser, preferencialmente en carater personal, prestada por el própio trabajador. Puede el prestador de trabajo utilizarse, pero de forma secundaria, de otros trabajadores. ${ }^{848}$

Están escluydas de la parasubordinación las relaciones donde el prestador de trabajo se haga representar por una empresa. Los autores hacen referencia a una decisión de la Corte de Cassción. "Sono esclusi dall'area della parasubordinazione quei rapporti in cui l'attività di collaborazione rientra nell'esecizio di un'impresa. Quando il collaboratore si avvale di una propria organizzazione imprenditoriale, infatti, viene meno il carattere prevalentemente personale della prestazione (Cass 7257/1996, MGI., 1997, 155)". ${ }^{849}$

\footnotetext{
845 Amoroso, G, DI CERBO, V e MARESCA, A., Diritto del lavoro. La Costituzione, II Códice civile e Le leggi speciali, Milano, Giuffrè Editore, volume I, terza edizione, 2009, p. 1613.

${ }^{846}$ AMOROSO, G, DI CERBO, V e MARESCA, A., Diritto del lavoro, cit., p. 1613.

847 AMOROSO, G, DI CERBO, V e MARESCA, A., Diritto del lavoro, cit., pp. 1613/1614.

${ }^{848}$ AMOROSO, G, DI CERBO, V e MARESCA, A., Diritto del lavoro, cit., p. 1614.

${ }^{849}$ AMOROSO, G, DI CERBO, V e MARESCA, A., Diritto del lavoro, cit., p. 1615.
} 
Lorena Vasconcelos Porto, siguiendo el derecho italiano y la doctrina mayoritaria, sostiene que

\begin{abstract}
"cualquier prestación laboral puede encuadrarse en el tipo de la parasubordinación, siempre que estén presentes sus presupuestos o requisitos: la coordinación, la continuidad y la prevalente personalidad. EI requisito de la superioridad (y no exclusividad) de la actividad personal es compatible con la utilización de los medios técnicos y de colaboradores, siempre que la prestación del interesado sea decisiva y no se limite a la mera organización de bienes, instrumentos y del trabajo ajeno. Se observa que la atenuación del requisito de la personalidad ya había sido prevista por el legislador italiano en el propio seno de la relación de empleo, en lo que se refiere al trabajador en domicilio, que no deja de ser empleado por el hecho de contar con la colaboración accesoria de miembros de su familia (art. $1^{\circ}$ de la Ley N. 877/1973)". ${ }^{850}$
\end{abstract}

En una transposición para el derecho brasileño, Alves afirma que la parasubordinación sería una especie de género de la relación de empleo. Y no sería la típica relación de empleo por la falta de la subordinación clásica, donde el trabajador actúa con personalidad, de forma no eventual y en beneficio exclusivo del tomador del trabajo que es quien coordina la prestación laboral, siendo el prestador de trabajo la parte más débil de la relación. La parasubordinación, estaría, por tanto, entre la autonomía y la subordinación denominada clásica. ${ }^{851}$

Antes de terminar, conviene hacer referencia a la distinción entre el teletrabajo y la parasubordinación.

Reginaldo Melhado afirma que el teletrabajo es el "ejecutado en el ámbito doméstico o durante los viajes profesionales, paralelamente al trabajo realizado en la empresa". En estos casos, refuerza el autor, las actividades aún están

850 En VASCONCELOS PORTO, Lorena, Parassubordinação: aparência $x$ essência, p. 02. http://www.ambito-juridico.com.br/pdfsGerados/artigos/5767.pdf - (acceso el 20 de julio de 2009, a las $15 \mathrm{~h} 34 \mathrm{~min})$.

851 "Una especie del género de relación de trabajo - no es la relación de empleo por faltar el elemento fáctico-jurídico de la subordinación (clásica) - en que el trabajador contratado desarrolla su labor con personalidad, de forma no eventual, en beneficio y en el interés de un contratante que coordina la prestación laborativa, siendo aquél la parte hiposuficiente de la relación laboral mantenida. La parasubordinaciíon se encuentra, entonces, entre la autonomía y la subordinación clásica (ALVES, Amauri Cesar, Novo contrato de emprego (...), ibídem). 
centradas en la empresa y el trabajador también las realiza a distancia, desde su residencia o desde un hotel, con el fin de complementar su actividad. ${ }^{852}$

Cinara L. Rosenfield y Daniela A. de Alves argumentan que el teletrabajo es sinónimo de trabajo a distancia, realizado a través de tecnologías de información y comunicación (TICs), con el fin de obtener resultados en un lugar diverso de aquel ocupado por quien ejecute la tarea. "Teletrabajadores son personas que trabajan de forma computadorizada, distanciadas del negocio de su empleador o de la persona que las contrata, y que transmiten los resultados de su actividad mediante un vínculo de telecomunicación". Las autoras recuerdan que muchos términos se utilizan como sinónimo de teletrabajo, tales como trabajo remoto, trabajo en red, telecommuting y algunas formas de trabajo a domicilio. ${ }^{853}$

Las autoras apuntan, más adelante, las categorías de teletrabajo, así como las ventajas y las críticas. Argumentan, finalmente, que el teletrabajo no puede conceptuarse simplemente como trabajo a distancia, sino como un "elemento de los cambios organizacionales estratégicos que apuntan a nuevas formas de trabajo flexible sostenidas por TICs. La flexibilidad puede ser indicada por varios elementos: tiempo, lugar, contrato, subordinación, organización funcional”. Para ellas, hay una relación próxima entre la aparición del teletrabajo y la flexibilidad presentada como una exigencia para que se garantice la competitividad entre las empresas. ${ }^{854}$

La parasubordinación, apunta Melhado, se refiere a situaciones que están entre el trabajo subordinado y el trabajo autónomo, la mayoría de las veces relacionadas con trabajadores de cualificación elevada, con gran poder contractual, al punto de dar a la prestación de trabajo algunas de las características propias del labor autónomo. "Parasubordinado sería asimismo

\footnotetext{
852 MELHADO, Reginaldo, Metamorfoses do capital e do trabalho: relações de poder, reforma do judiciário e competência da justiça laboral , São Paulo, LTr, 2006, p. 103.

${ }^{853}$ ROSENFIELD, Cinara L., ALVES, Daniela A. de, "Teletrabalho". En Dicionário de trabalho e tecnologia, Organizadores Antonio David Cattani e Lorena Holzmann, Porto Alegre; Editora da UFRGS, 2006, p. 304/305.

${ }^{854}$ ROSENFIELD, Cinara L., ALVES, Daniela A. de, "Teletrabalho", cit., p. 306.
} 
aquel trabajador vinculado a la empresa por una relación contractual en cuya esencia no se encuentra la sujeción típica del empleado convencional”. ${ }^{855}$

Aunque sea respetable y técnicamente bien desarrollado el concepto de parasubordinación propuesto por la doctrina citada, sin embargo, para el caso brsileño, no lo podemos compartir. La subordinación se presume de forma absoluta ya que hay prestación de servicio por cuenta ajena y permanente, derivando de esta permanencia o incluso de la continuidad, la previsión de conducta. La parasubordinación, una vez adoptada, acabará por caracterizar los contratos de empleo como "contratos de trabajo", sin que se pueda reconocer el vínculo de empleo.

Tanto es así que Piergiovanni Alleva argumenta que la separación legislativa producida en Italia, entre trabajo subordinado y parasubordinado, ha representado el principal instrumento de precariedad y de incumplimiento de las tutelas legales en perjuicio del trabajador. Considera que ello obedece a que el criterio de la "heterodirección" determina que el trabajador es subordinado y sometido a reglas necesarias, vinculantes y "capilares", sobre la forma de ejercer su objeto, además de los controles continuos. Es la figura del trabajador al que no se le paga para pensar, sino para repetir lo que incluso podría ser actual y legítimo al tratarse de la segunda industrialización pero que hoy es totalmente obsoleto. ${ }^{856}$

Más adelante, el autor afirma que

\begin{abstract}
"Una empresa moderna, destinada a competir en una economía de servicios, tiene, a diferencia, características y necesidades opuestas: horizontalización de las relaciones, capacidad de cada sujeto de efectuar las mejores elecciones operativas, actualización cultural y técnica continua, orientación constante de los objetivos. Sucede, entonces, de forma paradójica, que si realmente fuese necesario ser fiel al criterio en cuestión, la mayor parte de los trabajadores que son contratados como subordinados deberían ser cualificados como autónomos. Por consiguiente, el empleador tiene una amplia posibilidad de 'etiquetar' la
\end{abstract}

\footnotetext{
855 MELHADO, Reginaldo, Metamorfoses do capital e do trabalho, cit., p. 109.

856 ALLEVA, Piergiovanni, "O rubicão do trabalho subordinado". Em Revista LTr, legislação do trabalho, São Paulo; LTr, ano 73, fevereiro de 2009, p. 182.
} 
relación de trabajo de una forma o de otra como mejor considere" (cursiva en el original). ${ }^{8}$

El autor italiano concluye que "es necesario librarse de la idea de que, para substraerse a la heterodirección en sentido fuerte, se debe obligatoriamente pasar a otro tipo de contrato de empleo". Es esencial entender que la heterodirección o la auto-organización en la prestación del trabajo pueden ser tan sólo dos "modalidades directivas de un único contrato de trabajo subordinado". Un tipo único de contrato de empleo que tenga como base la dependencia socioeconómica, implicaría tanto los actuales trabajadores subordinados como a los parasubordinados. ${ }^{858}$

A eso se añade que se debe analizar en interés de quién, efectivamente, presta el trabajador los servicios. Quién se apropia del valor producido por él. Hay que investigar, igualmente, si hay necesidad, permanencia y previsibilidad en la prestación del trabajo.

Conviene subrayar, que aunque exista la utilización de terceros, lo que puede producirse es un contrato de equipo y no un trabajo autónomo ${ }^{859}$. O el trabajo es por obra, deber de resultado, autónomo, o habrá un vínculo de empleo siendo siempre éste como regla.

\footnotetext{
${ }^{857}$ ALLEVA, Piergiovanni, "O rubicão do trabalho subordinado", cit., p. 182/183.

${ }^{858}$ ALLEVA, Piergiovanni, "O rubicão do trabalho subordinado", cit., p. 184.

859 La doctrina brasileña define como contrato de equipo aquél en que el tomador de trabajo contrata a determinados trabajadores para la ejecución de una tarea, negociando el precio y las condiciones de ejecución del trabajo con un líder, que representa a los demás. Este líder, al igual que otros trabajadores no dejan de ser empleados del tomador. La diferencia es que la negociación no se da de "uno a uno". Este contrato sería aquél firmado con "un grupo de empleados, que se reunen espontáneamente para realizar un servicio común afín, de manera que el trabajo sólo es efectivo a través de los esfuerzos de todos los miembros del equipo. De hecho, se caracteriza por 'un conjunto de contratos individuales', según sostiene Délio Maranhão. Este tipo de contrato está formado por contratos individuales de trabajo autónomos e independientes, cada uno registrado en la CTPS de cada miembro, dado que el grupo no tiene personalidad". (BOMFIM CASSAR, Vólia, Direito do trabalho, Niterói; Impetus, $4^{a}$ Edição, 2010, p. 519).
} 
Para terminar en 2003 el legislador italiano, para reducir la utilisación del trabajo parasubordinado, creo el contrato de proyeto, conforme el decreto legislativo 276/03, articulos $61^{860}$ hasta 69 .

Esta forma de contrato ha sido creada para combatir la utilisación de los falsos contratos de trabajo independentes, prevendo, ahora, que las relaciones de colaboración coordenadas de caracter continu, Codigo de Proceso Civil, articulo 409, 3., seriam transformados em um ou vários contratos de proyeto a plazo determinado, conforme articulo 62 del Decreto Legislativo 276/03 ${ }^{861}$. Las

$\overline{860}$ TIPOLOGIE CONTRATTUALI A PROGETTO E OCCASIONALI

Capo I

Lavoro a progetto e lavoro occasionale

Articolo 61.

Definizione e campo di applicazione

1. Ferma restando la disciplina per gli agenti e i rappresentanti di commercio, i rapporti di collaborazione coordinata e continuativa, prevalentemente personale e senza vincolo di subordinazione, di cui all'articolo 409, n. 3, del codice di procedura civile devono essere riconducibili a uno o piu' progetti specifici o programmi di lavoro o fasi di esso determinati dal committente e gestiti autonomamente dal collaboratore in funzione del risultato, nel rispetto del coordinamento con la organizzazione del committente e indipendentemente dal tempo impiegato per l'esecuzione della attivita' lavorativa.

2. Dalla disposizione di cui al comma 1 sono escluse le prestazioni occasionali, intendendosi per tali i rapporti di durata complessiva non superiore a trenta giorni nel corso dell'anno solare con lo stesso committente, salvo che il compenso complessivamente percepito nel medesimo anno solare sia superiore a 5 mila euro, nel qual caso trovano applicazione le disposizioni contenute nel presente capo.

3. Sono escluse dal campo di applicazione del presente capo le professioni intellettuali per l'esercizio delle quali e' necessaria l'iscrizione in appositi albi professionali, esistenti alla data di entrata in vigore del presente decreto legislativo, nonche' i rapporti e le attivita' di collaborazione coordinata e continuativa comunque rese e utilizzate a fini istituzionali in favore delle associazioni e societa' sportive dilettantistiche affiliate alle federazioni sportive nazionali, alle discipline sportive associate e agli enti di promozione sportiva riconosciute dal C.O.N.I., come individuate e disciplinate dall'articolo 90 della legge 27 dicembre 2002, n. 289. Sono altresi' esclusi dal campo di applicazione del presente capo i componenti degli organi di amministrazione e controllo delle societa' e i partecipanti a collegi e commissioni, nonche' coloro che percepiscono la pensione di vecchiaia.

4. Le disposizioni contenute nel presente capo non pregiudicano l'applicazione di clausole di contratto individuale o di accordo collettivo piu' favorevoli per il collaboratore a progetto.

${ }^{861}$ Articolo 62.

Forma

1. Il contratto di lavoro a progetto e' stipulato in forma scritta e deve contenere, ai fini della prova, i seguenti elementi:

a) indicazione della durata, determinata o determinabile, della prestazione di lavoro;

b) indicazione del progetto o programma di lavoro, o fasi di esso, individuata nel suo contenuto

caratterizzante, che viene dedotto in contratto;

c) il corrispettivo e i criteri per la sua determinazione, nonche' i tempi e le modalita' di pagamento e la disciplina dei rimborsi spese;

d) le forme di coordinamento del lavoratore a progetto al committente sulla esecuzione, anche 
sanciones en los casos de no respeto a la ley son duras, transformando los contratos en contratos de duración indeterminada, articulo 69 del Decreto ${ }^{862}{ }^{863}$

\subsubsection{Trabajador autónomo económicamente dependiente en España.}

Fue la ley 20/2007, de 11 de junio que creo el Estatuto del Trabajador Economicamente Dependiente en España. Es una nueva forma de trabajo que es diferente del clasico trabajador autónomo. El trabajo es autónomo, por cuenta ajena, mas la dependencia económica no es la dependencia de organización ${ }^{864}$.

Rosa María Morato García, enseña que la ley del Estatuto del Trabajador Autónomo 20/2007, de 11 de junio, há incorporado en el orden juridico español el llamado trabajador parasubordinado, categoria jurídica novedosa en España, aunque sea conocida en Europa. El objetivo es, como esta en la Exposición de Motivos, efectuar una orden sistemática e integrada de la actividad profesional de los trabajadores autónomos en el Reino de España. ${ }^{865}$

temporale, della prestazione lavorativa, che in ogni caso non possono essere tali da pregiudicarne l'autonomia nella esecuzione dell'obbligazione lavorativa;

e) le eventuali misure per la tutela della salute e sicurezza del collaboratore a progetto, fermo restando quanto disposto dall'articolo 66 , comma 4.

862 Articolo

Divieto di rapporti di collaborazione coordinata e continuativa atipici e conversione del contratto

1. I rapporti di collaborazione coordinata e continuativa instaurati senza l'individuazione di uno specifico progetto, programma di lavoro o fase di esso ai sensi dell'articolo 61 , comma 1, sono considerati rapporti di lavoro subordinato a tempo indeterminato sin dalla data di costituzione del rapporto.

2. Qualora venga accertato dal giudice che il rapporto instaurato ai sensi dell'articolo 61 sia venuto a configurare un rapporto di lavoro subordinato, esso si trasforma in un rapporto di lavoro subordinato corrispondente alla tipologia negoziale di fatto realizzatasi tra le parti. 3. Ai fini del giudizio di cui al comma 2, il controllo giudiziale e' limitato esclusivamente, in conformita' ai principi generali dell'ordinamento, all'accertamento della esistenza del progetto, programma di lavoro o fase di esso e non puo' essere esteso fino al punto di sindacare nel merito valutazioni e scelte tecniche, organizzative o produttive che spettano al committente.

${ }^{863}$ MARTELLONI, Federico, "Brève histoire italienne d'um droit du travail 'em mode mineur". Em Revue de Droit du Travail, mensuel 4, Dalloz, avril 2013, p. 289.

864 FERNANDEZ ORRICO, Javier, "La contradictória figura del trabajdor económicamente dependiente", En Revista de la Facultad de Ciencias Juridicas y Sociales de Elche, Volumen I, numero 3, enero de 2008, pp. 231/232.

${ }^{865}$ MORATO GARCIA, Rosa María, "El reconocimiento legal de la figura del trabajador autónomo económicamente dependiente en España". En Revista Complejus, vol. 1, numero 1., jan/jun. 2010, p. 49. 
Sin embargo, antes de hablar de los trabajadores autónomos economicamente dependientes, es necesario decir lo que son los trabajadores autónomos. Los trabajadores autónomos son aquellos pequeños o medianos empresarios con independencia de la forma jurídica que utilizan (empresa individual, sociedad unipersonal), o de la actividad a que se dedican (artesanos, comerciantes, técnicos especializados, productores, prestadores de servicio en general), o mismo de la estructura que comenza a adquirir su empresa en razón de su propio desarollo (autónomos que contratan empleados o que se asocian entre si como cooperativas o trabajo asociado). ${ }^{866}$

Ahora bien. La forma de trabajo autónomo y económicamente dependiente se encuentra en una zona gris, entre el trabajo subordinado como vínculo de empleo, y el autónomo sin vínculo de empleo. Aunque sean autónomos estos trabajadores ellos dependen de un sólo cliente o empresario que es quien toma sus servicios. "Y esta dependencia económica, ocasiona una situación de vulnerabilidad contractual, posibilitando la imposición de condiciones de trabajo que no conducen a la concepción de trabajo decente". ${ }^{867}$

Fernandez Orrico dice que puede el trabajador autónomo, o mejor el falso autónomo puede, con esta ley, hallar una forma legal de regular su situación, hasta entonces ilegal. Uno no puede olvidarse que el trabajador economicamente dependiente trabaja por cuenta ajena, y esta es una forma de ahorrarse las cotizaciones sociales para las empresas para que trabajan, y que les exijen como condición para el trabajo que se den de alta en el Regimen Especial de la Seguridad Social de Trabajadores por Cuenta Propia o Autónomos (RETA). ${ }^{868}$

Lo que queda es que esta forma de trabajo, en España, es una realidad. Los trabajdores tienen autonomia laboral, pero prestan trabajo por cuenta ajena,

\footnotetext{
${ }^{866}$ MERCADER UGUINA, J. y DE LA PUEBLA PINILLA, A., "Comentario a la Ley 20/2007, de 11 de julio, del Estatuto del Trabajo Autónomo". Relaciones Laborales, vol. II, 2007, p. 1131

867 ALTEF BARROS, Veronica, "Trabalho autônomo economicamente dependente". En Revista justiça do trabalho, Porto Alegre; HS Editora, no 305, 2009, p. 43.

${ }_{868}$ FERNANDEZ ORRICO, Fco. Javier, "La contradictória figura del trabajdor economicamente dependiente", cit., p. 232.
} 
con dependencia económica de una sola fuente praticamente, lo que hay querido regular la LETA. El autor añade que el legislador fue cuidadoso al crar esta figura, para hacer bien la diferencia entre el trabajador por cuenta propia y el trabajador por cuenta ajena, aquél de la LETA. ${ }^{869}$

La relevancia, para Altef Barros, de este tema es tal que ha acabado siendo debatido también en el parlamento europeo, creando una comisión con el fin de realizar un estudio profundo sobre el mismo, incluso con debates públicos y discusiones. Adalberto Perulli ha dividido el estudio en tres capítulos. El primer capítulo examina las distinciones entre el trabajo subordinado y el trabajo autónomo, en función de las definiciones ya existentes en los estados miembros de la Unión Europea. Se han estudiado los falsos trabajadores autónomos, así como las situaciones en las que no se sabe definir si el trabajador es o no subordinado. En un segundo capítulo se describe el trabajo económicamente dependiente, presentándose tres características, con el objetivo de identificar un subgrupo en la categoría del trabajo autónomo. Finalmente, un tercer capítulo analiza los problemas y perspectivas futuras del trabajo económicamente dependiente. ${ }^{870}$

Las conclusiones han tenido en cuenta que no es fácil encontrar una solución unívoca para este problema de los trabajadores económicamente dependientes, pero que si eso se deja a merced del mercado puede producirse el llamado dumping social. Las conclusiones sugieren la intervención legislativa comunitaria, con medidas flexibles de carácter programático, pero que posibiliten que los estados-miembros las adopten conforme las peculiaridades internas, además de una serie de características como el contrato escrito, objeto del contrato bien determinado, características de la prestación laboral, reglas de pago, remuneración, sanciones en caso de retrasos, permiso maternidad,

\footnotetext{
${ }^{869}$ FERNANDEZ ORRICO, Fco. Javier, "La contradictória figura del trabajdor economicamente dependiente", cit., p. 232.

${ }^{870}$ ALTEF BARROS, Veronica, "Trabalho autônomo economicamente dependente", cit., pp. 46/47.
} 
enfermedades, accidentes, o cualquier otra suspensión posible (previsible), así como rescisión, preaviso y formación profesional, entre otros. ${ }^{871}$

Como recuerda la autora, en Italia se creó la figura del trabajador parasubordinado, que posee algunas semejanzas con el trabajo subordinado, pero que no se confunde con él. Esta situación existe además del tradicional trabajo autónomo. Es una modalidad peculiar de organización de la prestación de servicios, apunta, haciendo referencia a Otávio Silva. ${ }^{872}$

Una de las novedades, se subraya, también porque España es el primer país de la Unión Europea que crea esta regulación cuanto a la figura del trabajador autónomo económicamente dependiente. En este caso hay una regulación propia para esta situación, incluso con la extensión de los derechos específicos de los trabajadores por cuenta ajena, ya que este trabajador desarrolla su objeto con una fuerte dependencia económica del cliente o empresario tomador de los servicios por él prestados. ${ }^{873}$

Conforme al artículo 11 de la Ley española 20/07, el trabajador autónomo económicamente dependiente es quien realiza sus actividades de forma personal, habitual, directa y predominantemente para otra persona, física o jurídica, que se denomina cliente, de la cual depende económicamente al menos el $75 \%$ de sus rendimientos. ${ }^{874}$

\footnotetext{
${ }^{871}$ ALTEF BARROS, Veronica, "Trabalho autônomo economicamente dependente", cit., p. 47.

${ }^{872}$ ALTEF BARROS, Veronica, "Trabalho autônomo economicamente dependente", cit., p. 47.

${ }^{873}$ ALTEF BARROS, Veronica, "Trabalho autônomo economicamente dependente", cit., p. 49.

${ }^{874}$ Sigue el artículo con el fin de facilitar la comprensión del tema: "CAPITULO III

Régimen profesional del trabajador autónomo económicamente dependiente Artículo 11. Concepto y ámbito subjetivo.

1. Los trabajadores autónomos económicamente dependientes a los que se refiere el artículo 1.2.d) de la presente Ley son aquéllos que realizan una actividad económica o profesional a título lucrativo y de forma habitual, personal, directa y predominante para una persona física o jurídica, denominada cliente, del que dependen económicamente por percibir de él, al menos, el 75 por ciento de sus ingresos por rendimientos de trabajo y de actividades económicas o profesionales.

2. Para el desempeño de la actividad económica o profesional como trabajador autónomo económicamente dependiente, éste deberá reunir simultáneamente las siguientes condiciones:
} 
Veronica Altef Barros afirma que el elemento "básico de distinción entre el trabajo autónomo y el autónomo dependiente está en la dependencia económica. Sin embargo, con el fin de evitar dificultades en la identificación de la segunda, la ley española trae de forma más específica, cuales las condiciones que deben reunirse", conforme al artículo 11.2. ${ }^{875}$

Fernandez Orrico entiende que los 75 por ciento llevan por cuenta todos los ingresos del trabajador, la soma de todas sus fuentes de trabajo, y no solamente de una fuente. El autor enseña que el texto de la ley del articulo 11 no es claro y es por ello que él recomienda sea concretado por decreto. ${ }^{876}$

Para Alvarez Rodriguez deben haber, de forma conjunta, la ausencia de subordinación, dependencia económica y trabajo personal. Como requisitos formales el autor añade que son necesarios el reconocimiento en el texto del contrato la condición de ser el trabajador un trabajador economicamente dependiente (TRADE) y la inscripción registral del articulo 12.1 de la ley 20/2007 y 6 del RD 197/2007..$^{877}$

a) No tener a su cargo trabajadores por cuenta ajena ni contratar o subcontratar parte o toda la actividad con terceros, tanto respecto de la actividad contratada con el cliente del que depende económicamente como de las actividades que pudiera contratar con otros clientes.

b) No ejecutar su actividad de manera indiferenciada con los trabajadores que presten servicios bajo cualquier modalidad de contratación laboral por cuenta del cliente.

c) Disponer de infraestructura productiva y material propios, necesarios para el ejercicio de la actividad e independientes de los de su cliente, cuando en dicha actividad sean relevantes económicamente.

d) Desarrollar su actividad con criterios organizativos propios, sin perjuicio de las indicaciones técnicas que pudiese recibir de su cliente.

e) Percibir una contraprestación económica en función del resultado de su actividad, de acuerdo con lo pactado con el cliente y asumiendo riesgo y ventura de aquélla.

3. Los titulares de establecimientos o locales comerciales e industriales y de oficinas y despachos abiertos al público y los profesionales que ejerzan su profesión conjuntamente con otros en régimen societario o bajo cualquier otra forma jurídica admitida en derecho no tendrán en ningún caso la consideración de trabajadores autónomos económicamente dependientes".

${ }^{875}$ ALTEF BARROS, Veronica, "Trabalho autônomo economicamente dependente", cit., p. 49/50.

${ }^{876}$ FERNANDEZ ORRICO, FCo. Javier, "La contradictória figura del trabajdor economicamente dependiente", cit., p. 234.

877 ALVAREZ RODRIGUES, José Luiz, El trabajador economicamente dependiente, En http://www.madrid.ccoo.es/comunes/recursos/14/doc34441 EL TRABAJADOR ECONOMICAME NTE DEPENDIENTE.pdf, p. 2, acceso el 19 de septembrie de 2012, a las 22h57min. 
Una sentencia del Tribunal Supremo entendio que el contrato escrito no es un requisito esencial para la caracterización del TRADE. Para los Magistrados el "trabajador autónomo económicamente dependiente: Contrato escrito. No es un requisito constitutivo, sino meramente declarativo. La ausencia de contrato escrito no determina la inexistencia de TRADE, y por tanto, tampoco determina la incompetencia del orden social (STS, sala 4, de 12 de junio de 2012)". ${ }^{878}$

En otra sentencia el Tribunal Supremo ha decidio que los propositos de la ley son de dar al conocimiento de las partes dos terminos del contrato y la situación de dependencia económica. El hecho de no haber, expresamente esto en las clausulas del contrato no lo hace ilegal o invalido. ${ }^{879}$

En lo que se refiere a los derechos de estos trabajadores, la norma legal española estableció que las condiciones de trabajo, descanso semanal, festivos y

878 http://portaljuridico.lexnova.es/jurisprudencia/JURIDICO/138920/sentencia-ts-sala-4-de-12-dejunio-de-2012-trabajador-autonomo-economicamente-dependiente-cont - acceso el 19 de septiembre de 2012, a las 23h18min.

879 "Establece el artículo 12.2 LETA, que "el trabajador autónomo deberá hacer constar expresamente en el contrato su condición de dependiente económicamente respecto del cliente que le contrate, así como las variaciones que se produjeran al respecto". Esta ya no es una exigencia formal, sino que se relaciona con el necesario conocimiento por el empresario de uno de los presupuestos del contrato: la situación de dependencia económica. Esa situación normalmente sólo será conocida por el trabajador autónomo,

pues es él quien tiene la información sobre los clientes para los que presta servicios y sobre los ingresos que percibe de ellos. Por el contrario, sin el conocimiento de ese dato el cliente que concierta un contrato puede estar asumiendo un contrato de trabajo autónomo dependiente cuando en realidad su intención es la de establecer un contrato civil o mercantil de régimen común con un trabajador autónomo ordinario. Por ello, la comunicación de la situación de dependencia es un requisito para la existencia del consentimiento sobre el vínculo contractual que se establece. Hay en este sentido una confusión en la sentencia de contraste cuando señala que el régimen legal previsto para los trabajadores autónomos dependientes carecería de virtualidad, si quedara a voluntad de las partes su aplicación. No es así. La aplicación del régimen legal es, desde luego, obligatoria cuando se dan las condiciones necesarias para ello. Pero la suscripción del contrato no lo es. El trabajador autónomo y su cliente tienen que conocer la naturaleza del contrato que suscriben y el cliente tiene que saber que está contratando un servicio que se presta en una situación de dependencia económica. De ahí que el trabajador tenga la obligación de informar de esta circunstancia o la carga de probar, en su caso, que el cliente la conocía al contratar. Si conociendo esta circunstancia se contrata, el régimen legal será aplicable, aunque trate de excluirse por las partes o a través de las cláusulas del acuerdo pactado. La ley lo que pretende es garantizar el conocimiento del cliente sobre las condiciones en las que contrata. (STS de 24 de noviembre de 2011). En http://recull.creinsa.com/archivo/245 TSupremo1007.pdf - acceso el 19 de septiembre de 2012, a las 23h28min. 
jornada máxima de trabajo, serán definidos en un acuerdo escrito o un acuerdo profesional. $^{880}$

En relación al trabajador económicamente dependiente, entendemos que conviene destacar la exposición de motivos de la ley en debate, apartado III. ${ }^{881}$

La norma legal española, artículo 11 de la ley 20/2007, de 11 de julio, creó una diferenciación entre dependencia (subordinación) jurídica y dependencia económica. La doctrina española argumenta que hasta la promulgación de esta ley no había diferenciación entre dependencia y dependencia económica siendo ambas sinónimos. ${ }^{882}$

La subordinación o la dependencia jurídica está ligada al modo de ejecución del contrato de trabajo con consentimiento a las órdenes de otra persona que no es el trabajador o criterios de organización en cuanto a la ejecución de tareas. La dependencia económica está ligada al hecho de que la fuente predominante de los ingresos económicos del trabajador proviene de un sólo "cliente", "cliente" éste de quien el trabajador pasa a depender

${ }^{880}$ ALTEF BARROS, Veronica, "Trabalho autônomo economicamente dependente", cit., p. 50.

${ }^{881}$ En esta parte el texto se sostiene que "El Capítulo III reconoce y regula la figura del trabajador autónomo económicamente dependiente. Su regulación obedece a la necesidad de dar cobertura legal a una realidad social: la existencia de un colectivo de trabajadores autónomos que, no obstante su autonomía funcional, desarrollan su actividad con una fuerte y casi exclusiva dependencia económica del empresario o cliente que los contrata. La Ley contempla el supuesto en que este empresario es su principal cliente y de él proviene, al menos, el 75 por ciento de los ingresos del trabajador. Según los datos suministrados por el Instituto Nacional de Estadística, en el año 2004, ascienden a 285.600 los empresarios sin asalariados que trabajan para una única empresa o cliente. La cifra es importante, pero lo significativo es que este colectivo se ha incrementado en un 33 por ciento desde el año 2001.

A la vista de la realidad anteriormente descrita, la introducción de la figura del trabajador autónomo económicamente dependiente ha planteado la necesidad de prevenir la posible utilización indebida de dicha figura, dado que nos movemos en una frontera no siempre precisa entre la figura del autónomo clásico, el autónomo económicamente dependiente y el trabajador por cuenta ajena. La intención del legislador es eliminar esas zonas fronterizas grises entre las tres categorías. De ahí que el artículo 11, al definir el trabajador autónomo económicamente dependiente sea muy restrictivo, delimitando conforme a criterios objetivos los supuestos en que la actividad se ejecuta fuera del ámbito de organización y dirección del cliente que contrata al autónomo".

${ }^{882}$ MARTíN VALVERDE, Antonio, RODRÍGUEZ-SANUUDO GUTIÉRREZ, Fermín y GARCíA MURCIA, Joaquin, Derecho del Trabajo, cit., p. 50. 
económicamente entre el 75 por ciento y el 100 por ciento de sus rendimientos e ingresos fruto del trabajo (artículo 11.1 de la ley 20/07). ${ }^{883}$

La ley, de hecho, crea un trabajador autónomo pero económicamente dependiente de un cliente, en un régimen profesional intermedio entre el trabajo autónomo y el trabajo subordinado. Esta situación resuelve las cuestiones controvertidas, entre el trabajo autónomo y el subordinado, prefiriendo el legislador este sistema sin relación de empleo. ${ }^{884}$

Fernandez Orrico hace parecer que hay, y creo yo que haya mismo, diferencia entre el trabajador economicamente dependiente y el trabajador subordinado del articulo 1.1 del Estatuto de los Trabajadores. Si, mismo habiendo un contrato conforme la LETA, el trabajador trabajar de forma subordinada sera él empleado y no aquél de la ley $20 / 2007 .^{885}$

$\mathrm{Si}$, por ejemplo, no hay autonomia organizativa, clientes própios, maquinas propias, herramientas y materiales propios, sino que se encuentran dentro de la estrutura del cliente o, peor, utiliza el trabajador los intrumentos de la empresa cliente, este trabajador sera un falso autónomo ${ }^{886}$, y uno añade, un empreado subordinado.

Es lo que dicen Martin Valverde, Rodrigues-Sañudo y Garcia Murcia.

Para ellos la ejecución de las tareas, por parte de los trabajadores autónomos y económicamente dependientes, debe ser llevadas a cabo de forma separada de los empleados de la empresa-cliente, disponiendo el trabajador de toda la infraestructura productiva y de los materiales necesarios para su actividad, con criterios de organización propios, recibiendo del cliente el pago conforme el

\footnotetext{
883 MARTíN VALVERDE, Antonio, RODRÍGUEZ-SAÑUDO GUTIÉRREZ, Fermín y GARCíA MURCIA, Joaquin, Derecho del Trabajo, ibidem.

${ }^{884}$ MARTíN VALVERDE, Antonio, RODRíGUEZ-SAÑUDO GUTIÉRREZ, Fermín y GARCía MURCIA, Joaquin, Derecho del Trabajo, cit, p. 50/51.

${ }^{885}$ FERNANDEZ ORRICO, Fco. Javier, "La contradictória figura del trabajdor economicamente dependiente", cit., p. 235.

${ }^{886}$ FERNANDEZ ORRICO, Fco. Javier, "La contradictória figura del trabajdor economicamente dependiente", cit., p. 235.
} 
resultado que se produce, sin que se establezcan en lugares abiertos al público, ${ }^{887} \mathrm{y}$, se añade, que detenten un capital de giro de inversión en el negocio.

Ello nos permite tener una idea de los objetivos de la norma. Lo que sucede es que estos trabajadores no son más que empleados con vínculo de empleo, subordinados. La necesidad de legislación, por lo que parece en este caso, sirve sólo para alejarlos del concepto de empleado asalariado.

Al igual que sucede en Italia con los trabajadores parasubordinados, la norma viene a representar un deseo del empresariado, más preocupado por los costes de producción que por la cuestión social y por el trabajo decente. Y eso acaba produciéndose incluso si hay una previsión de protección de los trabajadores autónomos económicamente dependientes. Quedan sujetos a la empresa en razón de la producción, previsibilidad en la prestación del trabajo y dependencia mutua. Ejecutan las órdenes dado que prestan trabajo en beneficio del tomador del trabajo, ejecutando la producción, siendo parte esencial de su "marco general", trabajo sin el cual no existiría la tomadora de trabajo.

Tanto es así que Martín Valverde, Rodríguez-Sañudo Gutiérrez y García Murcia alegan que gran parte de estos trabajadores autónomos y económicamente dependientes son antiguos trabajadores subordinados, asalariados, que prestan su trabajo con autonomía funcional, pero que mantienen una vinculación personal estable con la actividad productiva del cliente. ${ }^{888}$

Es eso lo que hace que, muy probablemente, sean todos ellos empleados subordinados, con un vínculo de empleo, "protegidos" por una ley excluyente y discriminatoria que crea una legión de personas desamparadas y vulnerables, susceptibles de prestar todo tipo de trabajo a un precio muy pequeño.

La incidencia de esta ley, en España, ha sido minima.

\footnotetext{
887 MARTíN VALVERDE, Antonio, RODRíGUEZ-SAÑUDO GUTIÉRREZ, Fermín y GARCíA MURCIA, Joaquin, Derecho del Trabajo, cit., p. 213.

${ }_{888}$ MARTíN VALVERDE, Antonio, RODRÍGUEZ-SAÑUDO GUTIÉRREZ, Fermín y GARCíA MURCIA, Joaquin, Derecho del Trabajo, cit., p. 50/51.
} 


\subsection{Subordinación virtual o "post-industrial”}

El trabajo hoy en día no solamente está en las fábricas. Es mucho más nebuloso actualmente saber lo que es trabajo y lo que es ocio, donde está el tiempo de trabajo y el tiempo libre. ${ }^{889}$ La pequeña oficina del trabajador, en su hogar, ya no es sólo su oficina de lecturas y consulta en internet, sino también parte de la empresa, donde ejerce su actividad en beneficio de su empleador.

Como apunta Melhado, la alienación de la fuerza de trabajo, con el avance tecnológico, acaba experimentando una nueva fase. El trabajador ya no permanece prestando su objeto sólo dentro de la empresa. Lo hace desde casa, desde el hotel o desde dónde esté. El trabajador comienza a estar permanentemente conectado con el tomador de los servicios, que controla el tiempo de ejecución de las tareas e, incluso, envía datos con las órdenes y los períodos de trabajo. ${ }^{890}$

El avance en el campo tecnológico, que aleja al trabajador de la sede de la empresa, puede dar la imagen de que el trabajo subordinado tiene sus días contados. Al no estar el empleado dentro de la empresa, no está sujeto al poder jerárquico del empleador o a sus órdenes directas, que lo hará no un empleado, sino un trabajador sin vínculo de empleo. Fija, incluso, el final del trabajo subordinado.

Esto, sin embargo, no se sostiene. Como ya hemos apuntado anteriormente, dentro del concepto de subordinación no se encuentra, como un requisito, la cuestión de la sujeción a las órdenes directas. Ni tampoco la exposición al poder jerárquico del tomador de los servicios. De hecho, y eso será mejor tratado en la última parte de este capítulo, ya que se presta mano de obra en beneficio de la empresa, desempeñando las actividades relativas a su proceso productivo, habrá relación de empleo porque de este trabajador se obtiene la "plusvalía".

\footnotetext{
${ }^{889}$ MELHADO, Reginaldo, Metamorfoses do capital e do trabalho, cit., p. 103.

890 MELHADO, Reginaldo, Metamorfoses do capital e do trabalho, cit., p. 104.
} 
No son las órdenes directas las que determinan la relación de empleo, sino las actividades desempeñadas por el trabajador, de las cuales depende el tomador de los servicios para alcanzar su objetivo contractual o legal. Hay que subrayar el hecho de que aquí no estamos tratando de la actividad-fin y la actividad-medio. Como ya hemos apuntado, no hay legislación que, en Brasil, autorice esta distinción. Una vez que el tomador del trabajo depende de los servicios que se deben prestar y cuente con ellos para la ejecución de su objetivo, este tomador de trabajo deberá reconocer en la persona que le presta servicios la condición de empleado.

Por otra parte, al tratarse de trabajadores ligados a la investigación tecnológica y bajo el argumento de que el conocimiento de estos empleados será transferido a una máquina, que reproduce el trabajo, acaba por mitigar la cuestión de la alienación que, con todo, no puede estar exenta de criticas.

Sin embargo, el mantenimiento de la relación de empleo, incluso después la aparición y la implantación, por parte del tomador de trabajo, de las nuevas tecnologías, es evidente porque el trabajador no detenta los medios de producción. Posee sólo parte del conocimiento técnico vendido al mercado, lo que hace evidente el hecho de que esté subordinado al tomador del trabajo, ya que ejecuta parte de la producción. ${ }^{891}$

Por otra parte, la mitigación de la alienación en función de la repetición, por la máquina, del trabajo una vez producido, no se diferencia en nada con respecto a la cuestión actual de la alienación. Es evidente que habrá alienación. El hecho de que el trabajo sea intelectual o manual no se diferencia en nada, porque en el mundo de los hechos, habrá apropiación de la "plusvalía". El tomador ganará aún más sobre este trabajo que sobre aquél manufacturado.

Melhado hace una referencia interesante. Sostiene que el capital es un elemento catalizador de una pluralidad de técnicos y es capaz de fusionar la

${ }^{891}$ MELHADO, Reginaldo, Metamorfoses do capital e do trabalho, cit., p. 112/113. 
diversidad. El capital no depende del científico. Es éste al que depende del capital, dado que el capital reúne una variedad de investigaciones y trabajos singulares que sólo tienen sentido si se ven como un todo, en relación con otros trabajos. ${ }^{892}$

El mismo autor añade que el desplazamiento del poder del capital al trabajo requeriría una profunda reformulación en la naturaleza de la relación jurídica de intercambio en el que se sustenta el orden capitalista. Para ello, la capacidad de trabajo debería dejar de ser alienada como mercancía, subvirtiéndose la lógica capitalista. Y eso, por supuesto, no sucede porque la lógica de la globalización y mundialización es esencialmente capitalista. ${ }^{893}$

Michael Hardt y Antônio Negri, argumentan que la evolución de los paradigmas económicos a partir de la edad Media se presenta de la siguiente forma: el primero, en el cual la agricultura y las actividades extractivas dominaban el área económica; el segundo, en que la industria y la fabricación de los bienes duraderos fue predominante; y un tercero en que los servicios de intercambio de informaciones y la informatización representan el centro de la producción económica. El autor, haciendo referencia a Gorz, apunta que si el capitalismo moderno se ha centrado en el capital fijo y material, la era post-industrial ha valorado el capital denominado inmaterial en que los patrones clásicos de medida no pueden aplicarse. ${ }^{894}$

Sin embargo, Merçon, así como Melhado, hace una crítica a la cuestión del trabajo inmaterial. Para él, aunque el trabajo inmaterial sea efectivamente una tendencia en la sociedad post-industrial, no es una amenaza a la lógica capitalista,

\footnotetext{
${ }^{892}$ MELHADO, Reginaldo, Metamorfoses do capital e do trabalho, cit., p. 114. "La modernización tecnológica también es importante para hacer una tarea compleja que requiere grandes inversiones y conocimiento interdisciplinario. La empresa de la era tecnológica es un centro de convergencia de técnicas múltiples e interdependientes en cuyo contexto el trabajo no es más que un valor fungible. El capital es el elemento catalizador de una pluralidad de técnicos y figuras como un demiurgo capaz de fusionar la diversidad. No depende del científico, del especialista, pero estos dependen de él. El trabajo singular sólo se realiza y tiene sentido en el proceso de interacción con otros trabajos individuales singulares".

${ }_{893}^{89}$ MELHADO, Reginaldo, Metamorfoses do capital e do trabalho, ibidem.

${ }^{894}$ AMARANTE MERÇON, Paulo Gustavo de, "Além dos portões da fábrica - O direito do trabalho em reconstrução", cit, p. 55.
} 
en la medida en que éste trabajo inmaterial puede ser apropiado por el capital. Para él "además, analizándose la economía desde una perspectiva global, la explotación del trabajo menos cualificado -aunque desplazada a los países periféricos- sigue siendo un elemento indispensable para el proceso de producción post-industrial". ${ }^{895}$

Merçon argumenta, con respecto a la cuestión del valor de uso y valor de cambio en la sociedad post-industrial, que

\begin{abstract}
"Si en los primordios del capitalismo industrial el valor de cambio de una mercancía equivalía, por regla, a la cantidad de trabajo social necesario para producirla, en la post-gran industria el precio del producto se refleja en una complejidad de fuerzas productivas heterogéneas y nomensurables - además de la propia curva de la demanda y oferta.

Tomemos un ejemplo. La cantidad de trabajo necesaria para la fabricación de la Coca Cola es la misma del refresco de una marca desconocida. El producto de la Coca Cola, sin embargo, además de vender más, posee un mayor valor de cambio, que se explica por su mayor calidad - resultante del conocimiento tecno-científico desarrollado y patentado por la empresa - y por el valor comercial de la marca, fruto de un largo e intenso trabajo de marketing.

Es interesante constatar que, a diferencia del capital fijo material (instalaciones, maquinaria, herramientas), el capital inmaterial puede valorar el producto sin ser consumido en su propio valor de uso. Pero el proceso de producción capitalista nunca prescindirá de la interacción entre el trabajo vivo y el trabajo muerto (almacenado en el capital material o inmaterial de la empresa). El ejemplo del refresco demuestra bien eso: sin el trabajo de producción industrial, e incluso sin la renovación del trabajo inmaterial de la publicidad, la marca Coca Cola se traduciría en un capital inmaterial estéril.

Lo que se concluye es que, incluso la post-gran industria, el trabajo vivo representa el elemento indispensable para la producción capitalista. Sólo ya se hace inviable medir el valor-trabajo agregado al precio del producto de la misma forma que no se puede cuantificar la influencia de las demás fuerzas productivas (conocimiento tecno-científico almacenado por la empresa, valor de la marca, etc.) en la definición de aquel precio por el mercado" ${ }^{896}$ (la cursiva es del texto original).
\end{abstract}

Ricardo Antunes apunta que hoy el concepto de clase trabajadora comprende la totalidad de asalariados que vive de la venta de su trabajo y que no detenta los medios de producción, no pudiendo vivir de otra forma que no sea de la venta de su trabajo. Estos trabajadores son los que producen la "plusvalía" y

\footnotetext{
${ }^{895}$ AMARANTE MERÇON, Paulo Gustavo de, "Além dos portões da fábrica - O direito do trabalho em reconstrução", cit, p. 58.

${ }^{896}$ AMARANTE MERÇON, Paulo Gustavo de, "Além dos portões da fábrica - O direito do trabalho em reconstrução", cit, p. 60/61.
} 
participan del proceso de valorización del capital, a través de la interacción del trabajo vivo con el muerto, entre trabajo humano y maquinaria científicatecnológica. Éste es el polo central de la clase trabajadora moderna. ${ }^{897}$

Para Antunes, como el capital no puede eliminar el trabajo vivo del proceso de formación de mercancías, ya sean éstas materiales o inmateriales, debe, además de "incrementar sin límites el trabajo muerto incorporado en la maquinaria tecno-científica, aumentar la productividad del trabajo de modo que se intensifiquen las formas de extracción del trabajo excedente, en tiempos cada vez más cortos". La clase trabajadora, por tanto, abarca no sólo a los implicados en el proceso manual directo, sino también a la totalidad del trabajo social, del trabajo colectivo y de quien vende su fuerza de trabajo como mercancía a cambio de salario. ${ }^{898}$

Como trabajo productivo se entiende el material y el inmaterial, la clase trabajadora incluye la totalidad del trabajo colectivo y social, el núcleo central de los trabajadores productivos. Pero no es sólo esto. De la clase trabajadora también forman parte los trabajadores denominados "improductivos". Son éstos los que ejecutan los trabajos relacionados con los servicios, ya sean públicos, ya sean privados o incluso para uso del propio capital, no constituyendo, por eso, un elemento directo en el proceso de valorización del capital y de creación de la "plusvalía". ${ }^{899}$

A la clase trabajadora, por tanto, se deben incorporar no sólo los trabajadores productivos, sino también los asalariados, abarcando también a los

\footnotetext{
${ }^{897}$ ANTUNES, Ricardo, "A nova morfologia do trabalho e do desenho multifacetado das ações coletivas". Em Além da fábrica: trabalhadores, sindicatos e a nova questão social, São Paulo; Boitempo Editorial, 2003, p. 214/215. "Los productos, las mercancías (heterogénea) que se han diseminado (casi en partes iguales) por los mercados mundiales nacen en su proceso productivo, de la interacción (en última instancia ineliminable) entre el trabajo vivo y el trabajo muerto, aunque, a lo largo de de los años 80' y principios de la década de los 90' ha sido (casi) unísona la equívoca y eurocéntrica tesis del final del trabajo y de la consiguiente pérdida de relevancia e incluso de la validez de la teoría del valor (Habermas, 1975 y 1992).

${ }^{898}$ ANTUNES, Ricardo, "A nova morfologia do trabalho e do desenho multifacetado das ações coletivas", cit., p. 216.

${ }^{899}$ ANTUNES, Ricardo, "A nova morfologia do trabalho e do desenho multifacetado das ações coletivas", cit., p. 217.
} 
trabajadores no directamente productivos. El concepto, por tanto, de clase trabajadora debe pasar no sólo por los trabajadores que producen de forma directa las mercancías, sino por aquéllos que viven de su trabajo y no detentan los medios de producción. Quien venda, por tanto, su fuerza de trabajo a cambio de un salario, sin tomar posesión de los bienes y de los medios de producción, será un empleado. ${ }^{900}$

Antes de terminar este apartado, conviene hacer algunas referencias al economista Joseph Schumpeter. Fue él quien primero hizo referencia con respecto a los efectos de las innovaciones en el modo de producción capitalista. Para este autor, el desarrollo capitalista es un proceso de cambio cuyo motor son las innovaciones. Estas innovaciones son resultado de las iniciativas de los agentes económicos, incluyendo tanto a los individuos como a las empresas. ${ }^{901}$

La innovación acaba por derivar en "un proceso de destrucción de las estructuras económicas existentes y de creación de nuevas estructuras. El desarrollo capitalista es marcado, así, por rupturas, desequilibrios y discontinuidades. La innovación es, por tanto, la causa última de la inestabilidad en las economías capitalistas". Para Schumpeter, los ciclos económicos "son el reflejo inevitable de las tensiones provocadas por el proceso de desorganización/reorganización de las estructuras, inducido por las innovaciones. En otras palabras, en las economías capitalistas el desarrollo está irremediablemente asociado a la inestabilidad y asume una forma cíclica". Laplane termina argumentando que Schumpeter, en una obra publicada en 1942, refleja un tono pesimista sobre el futuro del sistema capitalista, "contraponiendo el dinamismo del 'sistema' económico a los problemas del 'orden social”. ${ }^{902}$

En palabras del propio Schumpeter, la forma en cómo acontecen los cambios, permite establecer una regla general de que se producen siempre a

\footnotetext{
900 ANTUNES, Ricardo, "A nova morfologia do trabalho e do desenho multifacetado das ações coletivas", ibidem.

901 LAPLANE, Mariano, "Inovações e dinâmica capitalista". Em Autores vários, Os clássicos da economia, Ricardo Carneiro (org.), v. 2, item "Adam Smith", São Paulo; Editora Ática, 2003, p. 60.

902 LAPLANE, Mariano, "Inovações e dinâmica capitalista", cit., p. 60/61.
} 
través de nuevas combinaciones de factores de producción existentes, "incorporados en nuevas fábricas y, típicamente, nuevas formas o producción de nuevas mercancías, o empleo de nuevos métodos, aún no experimentados, o produciendo para un nuevo mercado, o comprando medios de producción en un nuevo mercado". Lo que se llama, aun cuando de forma no científica, progreso económico es la asignación de recursos productivos en uso incluso hasta la fecha no experimentados en la práctica, y en su retirada "de aquéllos para quiénes sirvieron hasta ahora. Eso es lo que llamamos innovación". 903

Las referencias a Schumpeter sirven para mostrar que el sistema capitalista está en constante cambio. Las innovaciones fruto de la tecnología acaban por convertir el sistema en inestable, pero forman parte del capitalismo. El jurista, cuando analiza la cuestión del trabajo y de la tecnología, debe tener presente esta cuestión, con el fin de que pueda realizar el análisis más apropiado del sistema jurídico capitalista.

Por lo tanto, podemos decir que, -independientemente de dónde trabaje el empleado o incluso cuál o cuáles sean sus funciones o proyectos desempeñados en beneficio del tomador de los servicios, por regla general,- él será siempre el empleado. Prestará trabajo destinado a la elaboración de una determinada tarea o proyecto que forma parte de un todo, perteneciente al tomador de este trabajo y

\footnotetext{
${ }^{903}$ SCHUMPETER, Joseph Alois, "A instabilidade do capitalismo". Em Autores vários, Os clássicos da economia, Ricardo Carneiro (org.), v. 2, item "Adam Smith", São Paulo; Editora Ática, 2003, p. 80/82. "La innovación, a menos que no consista en producir e imponer al público una nueva mercancía, significa producir por unidad a un costo más bajo, poniendo fin a la antigua 'curva de oferta' e iniciando una nueva. Poco importa que esto se produzca por el uso o no de un nuevo invento, porque, en primer lugar, nunca hubo un momento en que el stock del conocimiento científico haya producido todo en términos de perfeccionamiento industrial y, en segundo lugar, no es el conocimiento lo que importa, sino sí el éxito de la tarea sui generis de poner en práctica un método no experimentado -puede no existir, y por lo general no hay ciencia nueva involucrada, e incluso si no hay ninguna diferencia para la naturaleza del proceso.

(...). La innovación con éxito es, como se ha dicho anteriormente, un tarea sui generis. No se trata de una acción del intelecto, sino de voluntad. Es un caso especial del fenómeno social del liderazgo. Su dificultad radica en las resistencias y en las incertidumbres peculiares al hecho de que se pueda realizar lo que nunca se hizo, y que sólo es accesible y atractivo para un individuo diferente y raro. Si bien las diferencias en la aptitud para el trabajo rutinario de la administración "estática" tienen éxitos diferentes haciendo lo que todos hacen, las diferencias en esta aptitud específica tiene como resultado el hecho de que sólo algunos son capaces de hacer esta cosa específica. Superar estas dificultades inherentes al cambio de práctica es la función característica del empresario".
} 
será pagado mediante salario (venta de su trabajo). El tomador contará con el trabajo que debe prestar, siendo también empleado aquél que obtendría estos pequeños servicios o proyectos que nada son o significan si no se destinan a esto.

Poco importa el nombre que se de a eso. En el mundo fáctico habrá una relación de empleo entre el tomador de este servicio y aquéllos que le presten servicios, porque este trabajo será realizado de forma alienada, obteniendo de este trabajador la "plusvalía", con el fin de negociar el producto del trabajo, cualquiera que sea, en el mercado.

En el apartado siguiente no ocuparemos de un tema importante. La cuestión de la democracia y de la dignidad humana que tienen relación con el trabajo subordinado. No hay trabajo digno cuando no se observan los patrones establecidos en la norma legal, incluso cuando este trabajo es fruto de la alienación. No hay democracia sin dignidad. No hay dignidad sin democracia, según podemos observar a partir de ahora.

\subsection{Trabajo subordinado y dignidad humana.}

Como ya hemos subrayado anteriormente, el trabajo, en el modo de producción capitalista, se convierte en el epicentro de la organización social, política y económica. Teniendo el trabajo como centro de la vida de la mayoría de las personas y de las familias ${ }^{904}$, se va creando una estructura para la sociedad y un pensamiento que favorece un mundo un poco más democrático.

El trabajo se convierte así en el vehículo de una mayor afirmación económica y social de la inmensa mayoría de las personas dentro de la lógica capitalista y una de las mayores afirmaciones de la democracia. La democracia se va ampliando incluso a quienes no poseen riqueza, conquista derivada

${ }^{904}$ En LEAL AMADO, João, Tratamento mais favorável e art. $4^{\circ}, n$. 1, do Código do Trabalho português: o fim de um princípio? En www.anamatra.org.br s sección "artículos", (consulta el 02 de enero de 2007, a las 14h43min). El autor comienza su texto dedicándolo a la mayoría de la población portuguesa, formada por trabajadores subordinados. 
principalmente de la Revolución Francesa con el Estado de Derecho. El trabajo se eleva al garante de este mínimo de democracia y la valoración del trabajo humano se convierte en uno de los pilares de la estructura social del Estado basada en la democracia. $^{905}$

En relación al trabajo regulado y subordinado, Godinho Delgado establece que:

"El empleo, regulado y protegido por normas jurídicas, se presenta, de
ese modo, como el principal vehículo de integración del trabajador en el
ámbito socioeconómico capitalista, para proporcionar un nivel de
afirmación individual, familiar, social, económica e incluso ética. Es
evidente que no se trata de un único vehículo de afirmación económico-
social de la persona física prestadora de servicios, ya que, como se ha
visto, el trabajo autónomo especializado y valorado también tiene este
carácter. Pero, sin duda, es el principal y más completo vehículo de
afirmación socio-económica de la gran mayoría de las personas
humanas en la desigualdad de la sociedad capitalista".

La estabilización democrática se logra a través de la valorización del trabajo. No hay democracia sin trabajo regulado y remunerado de forma adecuada y satisfactoria. La emancipación, los conceptos básicos del Estado Democrático de Derecho que van más allá del Estado meramente prestador, necesita de personas bien remuneradas y con cierto tiempo libre. La conciencia de clase, como ya hemos dicho en el apartado 1.4.2.2, depende, también, del factor trabajo. No hay capitalismo sin trabajo subordinado. No es democrático un país que admite la desigualdad social brutal. Y el trabajo permite la superación de este problema.

Los inconvenientes surgen a partir de una matriz teórica de la deconstrucción de la primacía del trabajo como centro democrático del modo de producción capitalista. El trabajador, por bien remunerado que esté, no pertenece a la clase del tomador del trabajo. Siempre existirá la apropiación de la "plusvalía". Siempre pertenecerá a la clase diferente de su patrón y siempre tendrá menos

\footnotetext{
905 GODINHO DELGADO, Maurício, Capitalismo, trabalho e emprego: entre o paradigma da destruição e os caminhos da reconstrução, São Paulo: LTr, 2006, p. 29.

${ }_{906}$ GODINHO DELGADO, Maurício, Capitalismo, trabalho e emprego (...), cit., p. 30.
} 
condiciones económicas que él. Por ello, se busca la destrucción del principio de que el trabajo subordinado es el núcleo y el motor del modo de producción capitalista.

No sólo los medios de comunicación, sino los juristas y economistas defienden, además de la reducción del Estado (algo que actualmente es muy discutible, con respecto a la crisis económica), la desregulación y la flexibilización de las normas de protección y tutela del trabajo. En Brasil, por ejemplo, desde la década de los años sesenta se ha verificado un retroceso en materia laboral, que culminó con la adopción del sistema de "banco de horas" ${ }^{907}$ y del contrato a plazo determinado, ambos por la ley 9.601/98.

Además, ya en el siglo XXI, todavía bajo el gobierno de Fernando Enrique Cardoso, se celebró un debate acerca de la derogación del artículo 618 de la Consolidação das Leis do Trabalho ${ }^{908}$ para hacer cumplir el acuerdo entre sindicatos en lugar de legislar. Esta norma perversa y ampliamente flexibilizadora fue rechazada por el Congreso Nacional brasileño, pero sigue viva en la memoria de los sindicatos y de los iuslaboristas brasileños.

Lo que debe estar presente es que la dignidad humana, la dignidad del trabajador, del ser humano que trabaja, como principio central de la Constitución Federal, es uno de los pilares de la democracia. No hay ningún país que tenga un desarrollo económico y social razonable en el sentido de que no protege a los

\footnotetext{
907 Sistema de compensación de las horas trabajadas, además de lo legalmente permitido en un día en el período de hasta un año, sin la contraprestación del añadido legal del 50\% o normativo, éste siempre mayor

${ }_{908}$ Art. 618. Las empresas e instituciones que no estén incluidas en el encuadramiento sindical al que se refiere el artículo 577, de esta Consolidação, podrán celebrar Acuerdos Colectivos de Trabajo con los Sindicatos representativos de los respectivos trabajadores, en los términos de este Título. (Actual redacción).

Art. 618. En ausencia de convención o acuerdo colectivos, firmados por manifestación expresa de la voluntad de las partes y observadas las demás disposiciones del título VI de la Consolidação, la ley regulará las condiciones de trabajo. Párrafo primero. La convención o acuerdo colectivo, respetados los derechos laborales previstos en la Constitución Federal, no puede resultar contraria a la ley complementar, las Leyes N. 6.321, de 14 de abril de 1976, y N. 7.418, de 16 de diciembre de 1985; la legislación tributaria, la seguridad social y la relativa al Fondo de Garantía por Tiempo de Servicio - FGTS, así como las normas de seguridad y salud del trabajo. (Propuesta de redacción).
} 
trabajadores. La estabilización de un país democrático pasa por la acomodación en favor del trabajador en las relaciones de producción. Debe darse al trabajador, también, como norma de dignidad humana y democracia, la oportunidad de entender y comprender el mundo que lo rodea y optar, incluso, por algo mucho mejor.

Hay estudios que demuestran que con el aumento del desempleo, y ahí se suma la precariedad del trabajo, aumentan también los índices de violencia urbana. La falta de perspectiva y el aumento desenfrenado de la "exigencia de consumo", hace que las personas, empleadas o dignamente empleadas, que no cometerían ciertos delitos, acaben en el mundo del crimen. ${ }^{909}$

Esta desconexión del trabajo con el mundo democrático acaba por generar estas distorsiones. Permite que los individuos emigren, cada vez más, hacia otros lugares. Pierden su dignidad, sus condiciones de agentes sociales. No tienen esperanza de emancipación de desarrollo adecuado, y acaban por cometer los delitos más diversos, comprometiendo el orden democrático y social.

Y eso sucede por la pérdida o desconexión entre la dignidad del trabajador, dignidad humana y derechos fundamentales, y el mundo de la vida, existencia humana.

\footnotetext{
${ }^{909}$ Destacamos una parte de un texto de la Revista brasileña Época, de 04 de abril de 2004 y que aborda el tema: "Violência Urbana - Pesquisa liga desemprego a aumento de crimes".

(...). La imagen cada vez más común de colas de desempleados provoca un escalofrío en la espina de los brasileños, que ven peligrar ocho años de cosecha en relación a las cartillas de trabajo. El efecto más aterrorizante de la crisis, sin embargo, solo ha sido contabilizado ahora. Una investigación inédita realizada por la Secretaría de Seguridad Pública del Estado de São Paulo ha observado lo que la población brasileña temía más: el estancamiento económico ya ha tenido impacto directo sobre el aumento de la criminalidad. El estudio fue hecho en el municipio de São Paulo, analizando los 33 tipos de intervención policial más frecuentes. Una buena parte de ellas acompaña casi mes a mes la variación en las tasas de desempleo y las caídas en el padrón de renta del brasileño. De 2001 a 2003, la ganancia media de los paulistas cayó el 18,8\% y la oferta de trabajo el $22 \%$, así como en las calles hurtos y robos a transeúntes aumentaron casi en la misma proporción, el $23 \%$. 'Al cruzar datos socioeconómicos y criminales ha sido posible probar que la extrema necesidad puede ser un incentivo al crimen', apunta el profesor Leandro Piquet Carnero, de la Facultad de Ciencias Políticas de la Universidad de São Paulo (Usp), uno de los cinco investigadores responsables del estudio(...)".En: http./mww.viaseg.com.br/noticia/2255violencia_urbana_pesquisa_liga_desemprego_a_aumento_de_crimes.html - (Acceso el 20 de febrero de 2009, $11 \mathrm{~h} 16 \mathrm{~min})$.
} 
Hay que tener presente que los derechos fundamentales son la concreción del principio de la dignidad humana. Dan el equilibrio a las fuerzas que actúan dentro de un determinado Estado, teniendo al Estado Democrático de Derecho como un medio para que se proteja, de hecho, la dignidad del ser humano. ${ }^{910}$

Jorge Miranda destaca la dignidad humana como regla-principio reconocida en un gran número de países. Citamos algunos de ellos. Irlanda (preámbulo), República Federal de Alemania (artículo $1^{\circ}$ ), India (preámbulo), Venezuela (preámbulo), Grecia (artículo $2^{\circ}$ ), España (artículo 10‥1), China (artículo 38), Brasil (artículo 1ำ, III), de Hungría, después de 1989 (artículo 54), Namibia (artículo $8^{\circ}$ y en el preámbulo), Colombia (artículo 1ำ), Bulgaria (preámbulo), Rumania (artículo $1^{\circ}$ ), Cabo Verde (artículo $1^{\circ}$ ), Lituania (artículo 21), Perú (artículo $1^{\circ}$ ), Rusia (artículo 21), África del Sur (artículo 1ำ 10 39), Polonia (artículo 30). ${ }^{911}$ Ello pone de manifiesto la importancia de este concepto para el derecho moderno y para la estructuración del Estado Democrático de Derecho.

Haciendo referencia a un país africano de lengua portuguesa, la Ley Constitucional de la República de Angola de 1992, artículo 2º , establece que "la República de Angola es un Estado Democrático de Derecho que tiene como fundamentos la unidad nacional, la dignidad de la persona humana, la libertad de expresión y de organización política y el respeto y la garantía de los derechos y libertades fundamentales del hombre, ya sea como individuo, ya sea como miembro de grupos sociales organizados" ${ }^{912}$

Jorge Miranda apunta que no es lo mismo hablar de derechos del hombre y derechos humanos, no es exactamente igual la dignidad de la persona humana y la dignidad humana. La primera expresión concierne al hombre concreto e individual y la segunda a la humanidad, como calidad común a todos los hombres

910 RODRIGUES GOMES, Fábio, O direito fundamental ao trabalho. Perspectivas histórica, filosófica e dogmático-analítica, cit., p. 48/49.

${ }_{911}$ MIRANDA, Jorge, Escritos vários sobre direitos fundamentais, São João do Estoril, Princípia Editora, 2006, p. 469.

${ }_{912}$ ALBUQUERQUE MOURÃO, Fernando Augusto, COSTA PORTO, Walter e MANTOVANINI, Thelmer Mário, As constituições dos países de língua portuguesa comentadas, Brasília; Senado Federal, Conselho Editorial, 2007, p. 51. 
o como conjunto que les incluye y va más allá. Cuando la sociedad portuguesa declara que se basa en la "dignidad de la persona humana", la Constitución repudia y aleja cualquier tipo de "interpretación transpersonal o simplemente autoritaria que pudiera permitir el sacrificio de los derechos o incluso de la personalidad individual en nombre de supuestos intereses colectivos. Sin embargo, en el art. $26^{\circ}$ se habla tanto de 'dignidad personal' (N. 3) como de 'dignidad humana'". 913

En cuanto al análisis de en qué consista la dignidad humana o de la persona humana (este texto no hace ninguna distinción), hay que decir, en primer lugar, que el ser humano tiene un valor en sí mismo, superior al Estado y a cualquier colectividad en que se integra. La persona humana es un ser situado, concreto, que desarrolla su personalidad dentro de la sociedad y en la interacción con sus similares. ${ }^{914}$

De ahí podemos concluir que aunque el trabajador preste servicio de forma subordinada no afecta a su dignidad hasta el punto de reducirlo a una cosa o a un objeto, el hecho de que preste trabajo en un estado de sujeción a terceros debe interpretarse de forma restrictiva. Si el trabajador presta servicios y lo hace bajo las órdenes de otros, subordinando su propia voluntad a terceros, este estado de sujeción debe obedecer a los estrictos límites de la ley. La ley brasileña no permite la contratación ante terceros. La Consolidación de las Leyes del Trabajo no tiene esta previsión. En este texto legal la contratación es directa. No hay permiso para la contratación por persona interpuesta. La contratación, por tanto, por persona interpuesta fuera de los parámetros legales, acaba por convertir al trabajador en la condición de una cosa, "doblemente" subordinado. Está sujeto a las órdenes del prestador de trabajo de forma inmediata y de forma mediata a las órdenes del tomador, que dirige la producción.

\footnotetext{
${ }_{913}$ MIRANDA, Jorge, Escritos vários sobre direitos fundamentais, cit., p. 473.

914 RODRIGUES GOMES, Fábio, O direito fundamental ao trabalho. Perspectivas histórica, filosófica e dogmático-analítica, cit., p 49/50.
} 
Por lo tanto, si no se observan los estrictos límites de la norma legal, la subcontratación de trabajador, excepto en los casos previstos por la ley, hiere a la dignidad del prestador de trabajo, convirtiéndole en la condición de un objeto en el mercado de trabajo. Quedará expuesto a la gran miseria y explotación de la "plusvalía", hasta el punto de perder su dignidad.

Hay que tener presente que no se puede ceder o "flexibilizar" la interpretación de la norma legal e incluso de los hechos cuando se trata de la dignidad humana. Un mínimo de deslizamiento afectará a la dignidad de toda la colectividad, poniendo en riesgo toda la estructura de protección del Estado. Cuando se trata de la dignidad humana no se puede tolerar ninguna mitigación, aunque no sea ella, evidentemente, absoluta, según sostiene Alexy, cuando el derecho que se debe preservar se superpone a aquél que está siendo mitigado ${ }^{915}$.

Al tratarse de subcontratación o tercerización, no se puede dar mayor valor o peso a la cuestión económica en detrimento del trabajo humano, especialmente

\footnotetext{
${ }^{915}$ ALEXY, Robert, Teoria dos direitos fundamentais. Tradução Virgílio Afonso da Silva, São Paulo; Malheiros, 2008, p. 111. Conviene destacar el siguiente pasaje: "En los casos en que la norma de la dignidad humana es relevante, su naturaleza de regla puede percibirse mediante la constatación de que no se cuestiona si ella prevalece sobre otras normas, sino tan sólo si ella fue violada, o no. Sin embargo, en relación a la apertura de la norma de la dignidad humana, hay un amplio margen de apreciación en la respuesta a esta cuestión. Son clarificadoras son las consideraciones del Tribunal Constitucional Federal en la decisión sobre las escuchas telefónicas: 'en lo que concierne al principio de la inviolabilidad de la dignidad humana, dispuesto en el artículo $1^{\circ}$ de la Constitución alemana (...), todo depende de la definición de las circunstancias en las cuales la dignidad humana puede considerarse como violada. Con seguridad no hay respuesta general, debiéndose siempre tener en cuenta el caso concreto'. Con la fórmula del 'trato degradante', utilizado en esta decisión, el tribunal crea a sí un amplio margen de apreciación para esa definición en los casos concretos. Y para esta definición existe la posibilidad de recurrir al sopesamiento. La utilización de esta posibilidad por parte del tribunal puede ser verificada en manifestaciones como aquella según la cual la dignidad humana no es violada 'si la exclusión de la protección judicial no está motivada por una falta de consideración o por una depreciación de la persona humana, sino por una necesidad de mantener en secreto las medidas que sirvan para la protección del orden democrático y para la propia existencia del Estado'. Eso puede ser comprendido de forma tal que, cuando el mantenimiento del secreto es necesario y otras condiciones son satisfechas - como el control jurídico a través de de órganos de representación popular y sus órganos auxiliares -, entonces, el principio de la protección del Estado tiene precedencia en relación al principio de la dignidad humana, en lo que concierne a la exclusión de la protección judicial en caso de escucha Telefónica. La contraposición entre las razones y contra-razones es perceptible desde la constatación de que, en el caso de que las condiciones mencionadas desaparezcan, la medida a ser juzgada permanecería la misma, pero no estaría ya permitida. El principio de la dignidad humana prevalecería, entonces, sobre el principio de la protección del Estado. Eso puede ser generalizado: si en el nivel de los principios la dignidad tiene precedencia, entonces fue violada a nivel de las reglas".
} 
cuando se trata de trabajo subordinado. La estructura capitalista depende del trabajo subordinado. Es el eje de todo el sistema del capital, por la que podemos concluir que el primado de la dignidad humana está estrechamente vinculado al trabajo subordinado hasta el punto de no permitir una "doble" alienación.

Para Pérez Luño, el fantasma del Leviatán económico surge, debido a que la dominación sin límites del mundo natural y humano por las leyes económicas, produce la alienación humana y conduce, sin lugar a dudas, a un desastre planetario sin precedentes. ${ }^{916}$

Aliarse con lo que está dicho en este apartado y con lo que consta en los dos últimos párrafos, las normas y los hechos que puedan dar lugar sólo a los aspectos económicos, acaban permitiendo la total alienación del hombre, lo que conducirá, sin sombra de duda, a una tragedia humana sin precedentes.

Hay que tener presente que bajo el telón de

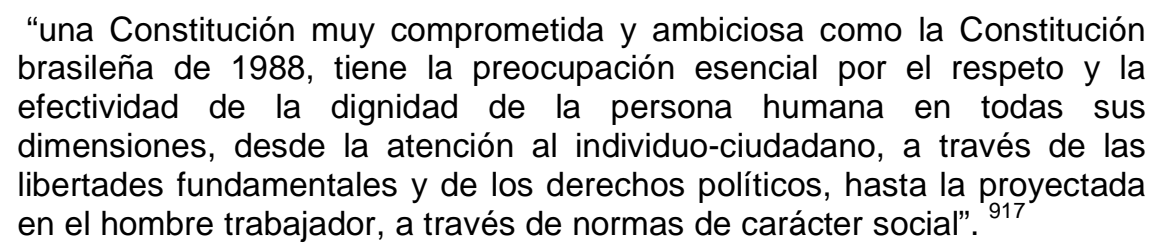

Ver en el otro a sí mismo es difícil. Aún más cuando quien mira ya tiene "reconocida" la dignidad de existir. Lo que éste debe tener presente es que si un miembro de la sociedad a la que pertenece vive en condiciones considerablemente inferiores, toda la sociedad vive en condiciones considerablemente inferiores, debiendo poner en tela de juicio el primado de la dignidad humana de toda la colectividad.

\footnotetext{
916 "La consagración constitucional del valor de la calidad de vida supone, al mismo tiempo, una definida opción en favor de un modelo cualitativo de progreso integral de la sociedad, y el expreso rechazo de un mero desarrollismo cuantitativo, a tenor de la lógica del 'Leviatán económico'; es decir, de la dominación ciega del mundo natural y humano por el imperio de leyes económicas, que producen la alienación de las personas y conducen a un desastre planetario sin precedentes". PEREZ LUÑO, Antonio E, Los derechos fundamentales, Temas clave de la Constitución española, Madrid; Ed Tecnos, 9aㅡ. ed., 2007, p. 197.

917 RODRIGUES GOMES, Fábio, O direito fundamental ao trabalho. Perspectivas histórica, filosófica e dogmático-analítica, cit., p. 341.
} 
Por ello, la preservación de la dignidad del trabajador, no permitiendo que sirva doblemente del objeto, alienación de la alienación, "doble" subordinación, se debe tomar con rigor y sin concesiones. El universo de las concesiones y de las negociaciones por parte de la clase trabajadora e incluso cuando se trata del poder legislativo, está reconocido en la Constitución federal. Lo que no encaja en estas reglas de excepción, no puede ser realizado. El primado del trabajo como elemento central del capitalismo, y la situación de simple y no doble sujeción, deben guiar al intérprete y al legislador, en función de la regla-principio de la dignidad humana, sin perjuicio de otros criterios de inconstitucionalidad.

Preservar la regla/principio de la dignidad de la persona humana como cultura, que, por sí misma, forme parte del ser en el mundo y sea reconocida por cada uno y todos los ciudadanos pertenecientes a la comunidad internacional debe ser el objetivo de los juristas, filósofos y estudiosos. Y eso se hace a todos los niveles, procesos (sentencias), escuelas, universidades y también en la relación con el ser humano concreto.

Según Alain Supiot, la práctica del derecho es un arte y no una ciencia. Las leyes de la que debe ocuparse el jurista no son las leyes científicas, sino las que buscan la verdad. El jurista del trabajo "ne doit pas se fermer à ce que par exemple I'histoire, la sociologie ou l'economie ont à dire sur le travail, et sur la manière dont elles fondent des pratiques de gestions des 'ressources humaines'”. Debe dudar y no dejarse llevar por el dogmatismo y por las normas dominantes. Eso contribuye a la eliminación del totalitarismo constante del conocimiento especializado. $^{918}$

No dejarse convencer con facilidad. Contestar, fundamentar, estudiar. Buscar siempre la verdad y no las "verdades" confeccionadas o las falsas verdades repetidas por la ausencia de duda, de negación, de dialéctica. El jurista debe ocuparse de eso. El jurista del trabajo no puede dejarse dominar por criterios meramente económicos. El trabajo es un elemento de la existencia humana y no

${ }^{918}$ SUPIOT, Alain, Critique du droit du travail, cit., pp. 262/265. 
un concepto económico. No se desprecia, por supuesto, el concepto de trabajo para la economía ${ }^{919}$, pero ésta no es un fin en sí misma hasta el punto de abarcar incluso la cuestión del trabajo humano en el mundo. ${ }^{920}$

\subsection{Que es, para esta tesis, la subordinación juridica.}

Conviene realizar algunas consideraciones para, después, analizar el concepto de subordinación jurídica.

Antes, conviene hacer alusión a quién forma y a quién no forma parte de la clase trabajadora y de la importancia de la reconquista de la conciencia por parte de los empleados de alto nivel. Eso permitirá delimitar adecuadamente el tema, con el fin de clarificar quién trabaja de forma subordinada y quiénes son los reales tomadores de este trabajo.

Según Ricardo Antunes están fuera del concepto de clase trabajadora y, se añade, de empleado, los gestores del capital que son la parte "constitutiva (objetiva y subjetivamente) de las clases padronas, ejerciendo un papel central en el control, en el mando, en la jerarquía y en la gestión del proceso de valorización y reproducción del capital". Son ellos las personificaciones asumidas por el capital. Los que viven de intereses y acumulaciones también están excluidos de la clase trabajadora. ${ }^{921}$

Sin embargo, los pequeños empresarios, tanto urbanos como rurales, que sean propietarios de los bienes y de los medios de producción, están excluidos de la noción ampliada de clase trabajadora, porque no venden su trabajo directamente a cambio de salario, aunque puedan ser aliados de la clase

\footnotetext{
919 SILVA MARQUES, Rafael da, "Trabalho para além do meramente econômico". Em Revista do Tribunal Regional do Trabalho da Quarta Região, Porto Alegre, HS Editora, número 34, 2006, p. 60.

${ }^{920}$ Sobre la discusión fin del trabajo y centralidad del trabajo se recomienda la lectura DE TONI, Mírian, "Fim do trabalho versus centralidade do trabalho". En Dicionário de trabalho e tecnologia, Organizadores Antonio David Cattani e Lorena Holzmann, Porto Alegre; Editora da UFRGS, 2006, p. $127 / 130$.

921 ANTUNES, Ricardo, "A nova morfologia do trabalho e do desenho multifacetado das ações coletivas", cit., p. 218.
} 
trabajadora. Por tanto, entender a la clase trabajadora de modo más amplio, "implica entender este conjunto de seres sociales que viven de la venta de su fuerza de trabajo, que son asalariados y están desprovistos de medios de producción". 922

Estos dos primeros párrafos son esenciales para comprender el concepto de subordinación jurídica que proponemos en esta tesis. Son esenciales también las consideraciones de todos los textos que, aunque amplios, pueden fundamentar lo que se pretende defender en esta investigación.

Teniendo el lector la noción de qué es la clase trabajadora en esta sociedad post-industrial, se puede comprender quiénes son los empleados sujetos a la legislación social y, especialmente, quien, según el derecho vigente, son sus empleadores.

Hay que tener presente, como advierte Antunes, que aquellos segmentos más cualificados e intelectualizados, "que se desarrollaron junto con el avance tecnológico, por el papel central que ejercen en el proceso de creación de valores de cambio, están dotados, al menos 'objetivamente', de una mayor potencialidad y fuerza en sus acciones". Pero, continúa Antunes, "paradójicamente, estos sectores más cualificados son objeto directo de un intenso proceso de manipulación e implicación en el espacio del trabajo productivo". 923

También éstos, aunque a menudo ni siquiera lo sepan o reconozcan, forman parte de la clase trabajadora. Les falta una conciencia emancipadora, que les permita ver quienes son realmente y su importancia dentro de la estructura capitalista no como una herramienta o masa de maniobra del capital, sino como agentes bien informados y dispuestos, para beneficio de la clase a la que pertenecen, trabajar por un mundo más justo.

\footnotetext{
922 ANTUNES, Ricardo, "A nova morfologia do trabalho e do desenho multifacetado das ações coletivas", ibidem.

${ }_{923}$ ANTUNES, Ricardo, "A nova morfologia do trabalho e do desenho multifacetado das ações coletivas", cit., p. 120.
} 


\subsubsection{El concepto propuesto de subordinación jurídica.}

A partir de esta introducción comenzamos a conceptualizar la subordinación jurídica. La tarea no es fácil, incluso porque lo que se pretende con esta investigación es aportar algo más, además de lo que consta normalmente en la doctrina y en la jurisprudencia.

Se reconocen como válidos los conceptos ya realizados $\mathrm{y}$, como hemos dicho en la introducción, sirven como base para otros conceptos, más modernos y fruto de investigación científica. Por ello, pretendemos, a partir de ahora, aportar nuestro puno de vista sobre lo qué es y en qué consiste la subordinación jurídica en el modo de producción capitalista, teniendo en cuenta la inserción del trabajador dentro de este sistema no como un complemento, sino como el elemento central, del cual depende el sistema económico, incluso el "postindustrial" o el virtual.

Basándonos en lo dicho anteriormente, es posible conceptuar la subordinación jurídica, concretamente para el derecho vigente brasileño, como el estado de sujeción del trabajador, obligado a prestar servicios por cuenta ajena, de forma permanente y con previsibilidad de conducta, independientemente del número de días de trabajo prestado o a ser prestado, siempre que de este trabajador se obtenga la "plusvalía", siempre que haya venta del trabajo a un tomador de los servicios, estando el prestador de trabajo ejecutando no sólo órdenes, sino la producción, dentro del contexto empresarial.

El hecho de que trabaje vinculado a la "actividad-medio" o a la "actividadfin" del tomador de los servicios no tiene relevancia, porque esta diferenciación no consta en la norma del artículo $3^{0}$ de la $\mathrm{CLT}^{924}$.

\footnotetext{
${ }^{924}$ Art. $3^{\circ}$ - Se considera empleado a toda persona física que presta servicios de naturaleza noeventual al empleador, bajo la dependencia de este y mediante salario.
} 
Existirá, por tanto, trabajo subordinado siempre que el trabajador someta su voluntad a la voluntad de otros, es decir, cuando preste trabajo en beneficio y conforme a los deseos de otra persona. No son necesarias órdenes directas (sino sólo "órdenes" de la producción), bastando que el trabajo sea ejecutado de forma permanente y con previsibilidad de conducta (ésta por parte del tomador del trabajo, que cuenta con el trabajo que se debe prestar) en cuanto a la ejecución del objeto de la empresa, trabajo éste prestado con la explotación de la "plusvalía" y de donde deriva la relación de empleo.

De este concepto se separan los casos de contratación autónoma en los estrictos límites de la ley, cuando el trabajador se compromete con el resultado y no con el trabajo, siempre que posea los medios para administrar su negocio y el capital de giro para su inversión.

Los terminos de la subordinación que son, aquí, planteados, superan parcialmente, como ya se ha dicho, lo que expone la doctrina brasileña y que relaciona la subordinación con el concepto de la no eventualidad (trabajo vinculado a la actividad-fin de la empresa ${ }^{925}$ ). Hay que tener presente que no existe norma que autorice esta interpretación. Al parecer, según podemos ver en la parte que trata del toyotismo, este concepto es fruto de patrones económicos de orientación de producción, que no tienen un carácter jurídico y, por tanto, no se sostienen.

Conceptuada la subordinación, después de un razonamiento necesario, pasamos al estudio de la constitucionalidad de la tercerización, especialmente fruto de la Súmula 331 del Tribunal Superior del Trabajo, tema central de esta investigación e íntimamente vinculado a la subordinación. Hay que tener presente que la doctrina y la jurisprudencia brasileñas diferencian entre "actividad-medio" y "actividad-fin", diferenciación ésta directamente relacionada con el concepto de subordinación.

${ }^{925}$ Concepto creado por la súmula 331 del TST. 
Se constata, como ya hemos destacado en la introducción, que lo que pretendemos es realizar un análisis independiente y científico sobre la subordinación jurídica y la tercerización, además de establecer los límites constitucionales para la subcontratación.

Esto quiere decir investigar si la Constitución permite la alteración, a través de patrones económicos, del concepto de subordinación jurídica y si acoge, como constitucional, la tercerización de los servicios, teniendo como base lo que establecen los artículos $3^{\circ}$ de la Consolidación de las Leyes del Trabajo y 7ํㅜ, encabezamiento, de la Constitución brasileña de 1988 . $^{926}$

Pasamos, por tanto, al tema de la constitucionalidad (o no) de la tercerización. En este próximo capítulo examinaremos más detalladamente la Súmula 331 del Tribunal Superior del Trabajo y su proyección en la estructura jurídica brasileña. En el presente apartado sólo hemos realizado alguna referencia al respecto, que no permite sacar conclusiones definitivas sobre el tema.

${ }^{926}$ Art. 3ํ - Se considera empleado toda persona física que presta servicios de naturaleza no eventual al empleador, bajo la dependencia de éste y mediante salario..

Art. $7^{0}$ Son derechos de los trabajadores urbanos y rurales, además de otros destinados a la mejora de su condición social: (...). 
Capítulo IV

4. Tercerización y Constitución. 


\subsection{Introducción}

La tercerización, como veremos más adelante, es un fenómeno que forma parte de la actual realidad económica, laboral y social.

No cabe imaginar la estructura laboral, no sólo la brasileña sino tampoco la capitalista en general, sin el fenómeno de la tercerización. Bajo la óptica constitucional brasileña, ¿es posible tercerizar? ¿Podría el Tribunal Superior del Trabajo formular la "súmula" $331^{927}$, que amplía el concepto de tercerización? El proceso democrático brasileño ¿ha autorizado la doble alienación? ¿La doble explotación del hombre por el hombre?

En este capítulo vamos a examinar estas cuestiones junto con otras. ¿Hay garantías para el trabajador que produce un determinado bien o servicio de que será pagado si trabaja para un tomador y un prestador? ¿Quién se queda con el bien? ¿A quién se dirige el beneficio del bien elaborado o del servicio prestado? Cuestiones como éstas son las que entendemos que deben analizarse cuando se trate de la tercerización.

\footnotetext{
${ }_{927}$ Para facilital al lector la lectura de este trabjo, repetimos aqui los terminos de la Súmula 331 del TST. CONTRATO DE PRESTAÇÃO DE SERVIÇOS. LEGALIDADE (nova redação do item IV e inseridos os itens V e VI à redação) - Res. 174/2011, DEJT divulgado em 27, 30 e 31.05.2011. I - A contratação de trabalhadores por empresa interposta é ilegal, formando-se o vínculo diretamente com o tomador dos serviços, salvo no caso de trabalho temporário (Lei oํ 6.019, de 03.01.1974). II - A contratação irregular de trabalhador, mediante empresa interposta, não gera vínculo de emprego com os órgãos da Administração Pública direta, indireta ou fundacional (art. 37, II, da CF/1988). III - Não forma vínculo de emprego com o tomador a contratação de serviços de vigilância (Lei $n^{\circ}$ 7.102, de 20.06.1983) e de conservação e limpeza, bem como a de serviços especializados ligados à atividade-meio do tomador, desde que inexistente a pessoalidade e a subordinação direta. IV - O inadimplemento das obrigações trabalhistas, por parte do empregador, implica a responsabilidade subsidiária do tomador dos serviços quanto àquelas obrigações, desde que haja participado da relação processual e conste também do título executivo judicial. V - Os entes integrantes da Administração Pública direta e indireta respondem subsidiariamente, nas mesmas condições do item IV, caso evidenciada a sua conduta culposa no cumprimento das obrigações da Lei n.o 8.666, de 21.06.1993, especialmente na fiscalização do cumprimento das obrigações contratuais e legais da prestadora de serviço como empregadora. A aludida responsabilidade não decorre de mero inadimplemento das obrigações trabalhistas assumidas pela empresa regularmente contratada. VI - A responsabilidade subsidiária do tomador de serviços abrange todas as verbas decorrentes da condenação referentes ao período da prestação laboral.
} 
Para ello vamos abordar las cuestiones constitucionales de interpretación, relación de empleo como regla constitucional indisonible y absoluta, trabajo como tiempo de vida y trabajo subordinado como tiempo de vida para terceros, pleno empleo y tercerización, así como la nueva ley de tercerización que tramita en el Congreso Nacional brasileño y que encuentra una fuerte resistencia por parte del empresariado.

Comenzamos con unas breves consideraciones sobre la interpretación constitucional.

\subsection{Interpretación constitucional.}

Una ley ordinaria no puede ser contraria a la Constitución de un país. Los juristas, así como los legisladores, están directamente vinculados a la Constitución, como fundamento de validez de las demás normas e interpretaciones de todo el derecho de un determinado lugar en un determinado tiempo.

Negar eso equivaldría afirmar que el mandatario es superior al mandante, que el empleado es más que el patrón, que los representantes del pueblo son más importantes que el propio pueblo. ${ }^{928}$

Por eso existen instrumentos para proteger la Constitución. El principio de la primacía de la Constitución constituye una nueva etapa en la evolución del Estado de Derecho en el cual "la legitimidad constitucional integra la legitimidad administrativa y jurisdiccional". En este sentido también se han creado tribunales, en muchos países europeos, destinados a la protección de la Constitución,

${ }_{928}$ GONZÁLEZ-TREVIJANO SÁNCHEZ, Pedro José, El tribunal constitucional, Navarra; Editorial Aranzadi, 2000, p. 23. 
instituciones éstas que detentan mayor poder cuanto mayor sea el grado de violación de los derechos. ${ }^{929}$

El punto de partida de la jurisdicción constitucional radica en considerar la Constitución como una norma jurídica, norma ésta de jerarquía superior a las demás, siendo, por eso, un parámetro de control de las demás normas. Este doble carácter de la Constitución, de norma y de norma superior, proviene del constitucionalismo estadounidense, a quien se debe, también, la creación de la jurisdicción constitucional, reelaborada años más tarde por Hans Kelsen. ${ }^{930}$

En Estados Unidos, cualquier juez puede controlar la constitucionalidad de las leyes. Esta decisión tiene efecto sólo entre las partes. Sin embargo, mediante la teoría del stare decisis se puede dar un efecto general a las decisiones, si lo hace la Corte Suprema, con efecto vinculante a las demás instancias judiciales. Esta declaración es de nulidad de la ley, de imposibilidad de aplicación de la misma, con efecto retroactivo. ${ }^{931}$

De hecho, fue a través del modelo estadounidense, especialmente el caso paradigmático “Marbury contra Madison", en 1803, cuando los tribunales constitucionales comenzaron a declarar, en su totalidad o en parte, la inconstitucionalidad de las leyes. Por consiguiente, fue en Estados Unidos donde nació el sistema constitucional de control de las leyes por parte del poder judicial, debiendo la Constitución prevalecer sobre las demás leyes promulgadas por el poder legislativo, existiendo un tribunal capaz de decidir sobre la validez o no de las leyes del parlamento. ${ }^{932}$

\footnotetext{
${ }_{929}$ GAMBINO, Silvio, "La jurisdicción constitucional de las leyes. La experiencia italiana desde la óptica comparada". En AA.VV., La aplicación jurisdiccional de la constitución, Geraldo Ruiz-Rico Ruiz (dir.). Valencia; Tirant to Blanch Alternativa, 1997, p. 263/264.

${ }^{930}$ LOZANO MIRALLES, Jorge y SACCOMANNO, Albino, El tribunal constitucional. Composición y principios jurídico-organizativos (el aspecto funcional), Valencia; Tirant lo Blanch, 2000, p. 23/24.

${ }_{931}$ LOZANO MIRALLES, Jorge y SACCOMANNO, Albino, El tribunal constitucional (...), cit., p. $24 / 25$.

${ }_{932}$ GALLEGO-DÍAZ, Soledad, "Marbury contra Madison". En El País, Columna, Opinión, domingo, 04 de julio de 2010, p. 19. En El País, Columna de Opinión, domingo, 04 de julio de 2010, p. 19. En este artículo el autor analiza la reciente decisión del Tribunal Constitucional español sobre el
} 
El modelo propuesto por Kelsen, denominado control concentrado de constitucionalidad -a diferencia del estadounidense, conocido como difuso-, concentra la declaración de inconstitucionalidad en un sólo órgano y no en todos los tribunales. Para Kelsen, el Tribunal Constitucional no debe formar parte del Poder judicial ${ }^{933}$, debe limitarse a examinar la compatibilidad de las normas abstractas, la constitucional y la impugnada, eliminado la que no sea compatible con la Constitución. La declaración de ilegitimidad de la norma es de nulidad, con efectos ex nunc, estableciéndose, también, las acciones de constitucionalidad cuyos efectos son erga omnes y se reconoce la legitimidad de determinados actores políticos para proponer este tipo de acción. ${ }^{934}$

Para Kelsen, el Tribunal Constitucional desempeña sólo una actividad general y abstracta similar a la parlamentaria. Deberá expulsar del orden jurídico las normas que se opongan a la Constitución, que lo definirá como legislador negativo. ${ }^{935}$

estatuto de autonomía de Cataluña, comparando la decisión, en cuanto a la constitucionalidad, con la decisión-marco de control de constitucionalidad, dictadas por la Corte Suprema de los EE.UU. denominada "Marbury v. Madison". Se recomienda la lectura atenta de la decisión del Tribunal Constitucional español que trata del estatuto de autonomía de Cataluña.

${ }_{933}$ En Brasil, el Supremo Tribunal Federal, a quien compete el control concentrado de constitucionalidad de las leyes, forma parte del Poder judicial como órgano máximo, juzgando las acciones directas de constitucionalidad, las acciones directas de inconstitucionalidad y los recursos extraordinarios que implican la materia constitucional, en este último caso como "instancia final de jurisdicción".

${ }_{934}$ LOZANO MIRALLES, Jorge y SACCOMANNO, Albino, El tribunal constitucional (...), cit., p. 25. "La aparición definitiva del control judicial de las leyes no se va a producir hasta el año 1803, con ocasión de la sentencia del juez Marshal en el caso "Marbury versus Madison". Evidentemente no es una resolución que nace de la nada, sino que recoge el bagaje doctrinal de predecesores tan sobresalientes como, por ejemplo, James Otis en 1761, en contra de las medidas fiscales de Gran Bretaña, Patrick Henry en 1763, y Sharp en 1774, que rechazaba las leyes del parlamento británico frente a órdenes restrictivas de los derechos reconocidos en la "Carta Magna"; y de manera más moderna, de la "Judiciary Act" de 1789, que habilitaba a los órganos judiciales para supervisar las leyes dictadas por el Parlamento. La sentencia anulaba por primera vez una ley federal y abría el control de la legislación por el Tribunal Supremo. En ella se defiende la cláusula de supremacía, al hilo de lo preceptuado en el reproducido artículo VI de la Constitución de 1787" (GONZÁLEZTREVIJANO SÁNCHEZ, Pedro José, El tribunal constitucional, cit., p. 23).

935 GONZÁLEZ-TREVIJANO SÁNCHEZ, Pedro José, El tribunal constitucional, cit., p. 31. 
Como ya sabemos, Kelsen construyó su doctrina partiendo de la idea de jerarquía, como una pirámide normativa, presidida por la Constitución. Esta jerarquía comienza con la norma de menor posición jerárquica, hasta llegar a la Constitución, fundamento de validez de las demás -apoyándose en la norma hipotética fundamental-. Así pues, la coherencia y el buen funcionamiento del orden jurídico impone garantías de respeto al texto constitucional, lo que es el requisito inamovible para asegurar el ejercicio regular de las funciones estatales que incluyen, definitivamente, los actos jurídicos de creación del derecho o de su aplicación.

Los dos modelos sirven de base para determinar los distintos sistemas de jurisdicción constitucional. En el caso de Brasil, por ejemplo, se utiliza un modelo mixto, que implica no sólo el modelo concentrado sino también el difuso. Cualquier juez puede, así, declarar la inconstitucionalidad de una ley, con efecto sólo entre las partes. Los tribunales deberán observar la cláusula de reserva de plenario, con votación por parte del órgano colegiado, acerca de la inconstitucionalidad de una determinada ley, conforme a la "súmula" vinculante número 10 del Tribunal Supremo Federal. ${ }^{936}$

Esta forma de proceder, por control difuso y concentrado de constitucionalidad, que en Brasil se lleva a cabo mediante acción individual en el primer caso y a instancia del Tribunal Supremo Federal en el segundo, no es una afronta al poder legislativo, sino una forma de hacer valer la jerarquía de las normas jurídicas, dando mayor peso e importancia a las constitucionales como fundamento de validez y de democracia, apoyo del Estado Democrático de Derecho.

\footnotetext{
${ }^{936}$ Súmula vinculante número 10 del STF. "Viola la cláusula de reserva de plenario (CF, artículo 97) la decisión del órgano fraccional de tribunal que, aunque no declare expresamente la inconstitucionalidad de ley o el acto normativo del poder público, aleja su incidencia, en todo o en parte".
} 
La adopción del sistema mixto o incluso el concentrado o el difuso depende de las necesidades de cada país, que debe tener en cuenta la forma de procesar el control de constitucionalidad, sea previo o posterior, con efectos para todos o sólo entre partes, o para ambos casos. ${ }^{937}$

Lozano Miralles y Saccomanno hacen referencia a otro criterio, basado en el grado de amplitud de las competencias atribuidas a los órganos decisorios, o a la amplitud atribuida a estos órganos de la justicia constitucional, distinguiendo entre órganos de escasa competencia y órganos de amplia competencia. Y eso se justifica según ellos puesto que no hay órgano, actualmente, cuya competencia sea sólo tratar acerca del control de constitucionalidad de las leyes, teniendo todos ellos alguna competencia adicional. Así, cuando se trata de las competencias de los tribunales constitucionales, cabe hacer únicamente referencia a la competencia destinada al control de constitucionalidad de las leyes ${ }^{938}$, sino también al "contencioso constitucional" que tiene como modelo preservar la supremacía y la eficacia de la Constitución ${ }^{939}$.

Esto no significa que al realizar el control de constitucionalidad de las leyes, se esté limitando el principio democrático o la soberanía popular. Lo que se hace, en estos casos, es dejar de lado el principio absolutista de la omnipotencia de la mayoría política. La ley no puede considerarse como la expresión homogénea de la voluntad de la mayoría o del interés popular, ya que, cada vez más, está sujeta, en el período de su formación, a la protección de los intereses sectoriales. La alternativa, por tanto, es la de los tribunales constitucionales, como interpretación

937 LOZANO MIRALLES, Jorge e SACCOMANNO, Albino, El tribunal constitucional (...), cit., p. $26 / 27$.

${ }_{938}$ Véase el caso brasileño en que la competencia del Supremo Tribunal Federal no es sólo la del control de constitucionalidad de las leyes, sino también otras, conforme al artículo 102 de la Constitución brasileña de 1988. En el encabezamiento del artículo 102 consta la competencia del Supremo Tribunal Federal de la Constitución.

${ }_{939}^{\circ}$ LOZANO MIRALLES, Jorge e SACCOMANNO, Albino, El tribunal constitucional (...), cit., p. 27. 
de las normas y valores constitucionales, lo que consolida el ordenamiento jurídico y lo modela de acuerdo a la Constitución. ${ }^{940}$

La justicia constitucional tiene en cuenta el principio de legalidad, es decir, que todos los actos de las autoridades deben encontrar su fundamento en una norma legal anterior, que no pueden contradecirse. Así, "la justicia constitucional establece el alcance de este principio a la misma actividad legislativa, así como a amplios sectores del área estrictamente política, de las relaciones entre los máximos órganos del Estado, convirtiendo en judicial, a través de la competencia para juzgar los conflictos de las atribuciones entre los poderes del Estado, la división del supremo poder del Estado entre una pluralidad de órganos", recíprocamente equiparados e independientes, que puede consistir en una garantía democrática. $^{941}$

La justicia constitucional, además, con respecto a los derechos humanos fundamentales, tiene una función procedimental de garantía contra los abusos por parte del poder legislativo, frenando el absolutismo de los gobernantes. ${ }^{942}$

Son los sistemas de jurisdicción constitucional vigentes los que en un Estado Democrático de Derecho contribuyen a la tarea de regular la pluralidad de los intereses constitucionalmente tutelados, lo que desemboca, actualmente, en una concepción de la Constitución como una especie de acuerdo o pacto, que tiene en cuenta determinados valores, principios y reglas fundamentales. ${ }^{943}$

El juez, por tanto, en el momento de decidir teniendo en cuenta la interpretación conforme a la Constitución no sólo debe tener presente una simple valoración de consonancia entre una norma constitucional y una disposición de

\footnotetext{
940 ALFLEN, Kelly Susane, "Os valores como fundamento da Constituição e a justiça constitucional material". En Revista Bonijuris, Ano XXII, número 558, maio/10, Curitiba; Instituto de Pesquisas Bonijuris, 2010, p. 20.

${ }_{941}$ ALFLEN, Kelly Susane, "Os valores como fundamento da Constituição (...)", cit,, ibidem.

942 ALFLEN, Kelly Susane, "Os valores como fundamento da Constituição (...)", cit,, p. 20/21.

${ }^{943}$ ALFLEN, Kelly Susane, "Os valores como fundamento da Constituição (....)", cit,, p. 21.
} 
ley, sino que debe realizar una ponderación entre las diversas disposiciones constitucionales que contienen una carga de valores sociales y económicos, o incluso, entre valores individuales de la persona y los derechos colectivos. Esta gama de valores y principios producen una especie de unidad jurídico-política y social. $^{944}$

El juez trabaja con valores y principios constitucionales, de forma que la interpretación constitucional tenga como fundamento estos mismos valores y principios, fruto del proceso comunicativo, completados por la teoría de la argumentación jurídica, y considerando la norma constitucional como un "precompromiso" entre la colectividad. ${ }^{945}$

Es este contenido material de principios, valores y derecho que hace de la interpretación constitucional que proviene de los jueces un elemento indispensable que no hay que considerar como una forma de intromisión en la esfera legislativa, sino una forma de "rematerialización" de los derechos fundamentales y valores fundamentales de la República. ${ }^{946}$

\subsubsection{Formas y métodos vigentes.}

El control de constitucionalidad de las leyes puede producirse, según su naturaleza, mediante un control externo o formal, es decir, cumpliendo con los procedimientos contenidos en la Constitución a la hora de elaborar una ley, o un control interno o material, cuando la ley resulta contraria al contenido constante de la Carta fundamental. ${ }^{947}$

\footnotetext{
${ }^{944}$ ALFLEN, Kelly Susane, "Os valores como fundamento da Constituição (...)", cit,, ibidem.

${ }^{945}$ BELLOSO MARTíN, Nuria, "Algunos dilemas sobre la jurisdicción constitucional". En Revista do Direito no. 33, Programa de pós-graduação em direito - PPGD, Santa Cruz do Sul, Edunisc, junho/dezembro de 2010.

${ }_{946}$ Vid. BELLOSO MARTíN, Nuria, "Algunos dilemas sobre la jurisdicción constitucional", cit., donde la autora cita a PRIETO SANCHIS, Luis, Justicia constitucional y derechos fundamentales, Madrid; Trotta, 2003, p. 139.

${ }_{947}$ DE ESTEBAN, Jorge y GONZÁLEZ-TREVIJANO, Pedro José, Curso de derecho constitucional español III, cit., p. 143/144.
} 
La doctrina francesa hace la misma división. Considera que la incompetencia, los vicios de procedimiento, la violación del bloque de constitucionalidad propiamente dicha y el desvío de poder, son los cuatro casos que posibilitan el control de constitucionalidad de las leyes, siendo los dos primeros agrupados por la idea de control de constitucionalidad "externo" y los dos últimos por la idea de control de constitucionalidad "interno". ${ }^{948}$

El sistema de control de constitucionalidad brasileño es mixto ${ }^{949}$ y abarca no sólo el control que lleva a cabo el poder judicial sino también el control político a través de las comisiones existentes en el Congreso Nacional y por el Presidente de la República, mediante el derecho de veto.

Una vez promulgada la ley, el poder judicial puede ejercer el control de constitucionalidad represivo que se puede ejercitar a través de la acción directa de inconstitucionalidad (artículo 103, I, de la CF/88 y ley 9.868/99), la acción directa de inconstitucionalidad por omisión (artículo 103, párrafo segundo, de la CF/88 y ley 9.868/99) y mediante la acción de incumplimiento de precepto fundamental (artículo 103, párrafo primero, de la CF88 y ley 9.882/99) observada la legitimidad para proponer la acción exigida en la Constitución también el control difuso, instado por cualquier ciudadano, que se aplicará en un caso concreto, propuesto inicialmente en juicio de primer grado. ${ }^{950}$

\footnotetext{
${ }^{948}$ ROUSSEAU, Dominique, Droit du contentieux constituitionnel, Paris; Editions Montchrestein, $4^{\text {a }}$ Ed., 1995, p. 120.

${ }_{949}$ En el sistema mixto se combina la jurisdicción constitucional concentrada y la difusa, porque quien está legitimado para decir si una norma es o no inconstitucional, además de los tribunales y jueces ordinarios, es el Tribunal Constitucional. En el caso español, esta determinación se establece en el artículo 163 de la Constitución española, en la llamada "cuestión de inconstitucionalidad" (DE ESTEBAN, Jorge y GONZÁLEZ-TREVIJANO, Pedro José, Curso de derecho constitucional español III, cit., p. 147).

${ }_{950}$ Art. 103. Podrá proponer la acción directa de inconstitucionalidad y la acción declarativa de constitucionalidad: I - el Presidente de la República; II - la Mesa del Senado Federal; III - la Mesa de la Cámara de los Diputados; IV - la Mesa de Asamblea Legislativa o de la Cámara Legislativa del Distrito Federal; V - el Gobernador de Estado o del Distrito Federal; VI - el Procurador general de la República; VII - el Consejo Federal del Colegio de Abogados de Brasil; VIII - el partido político con representación en el Congreso Nacional; IX - la confederación sindical o la entidad de clase de ámbito nacional. $\S 1^{\circ}$ - El Procurador general de la República deberá ser previamente escuchado en las acciones de inconstitucionalidad y en todos los procesos de competencia del Supremo Tribunal Federal. $\S 2^{\circ}$ Declarada la inconstitucionalidad por omisión para hacer efectiva la
} 
Por lo tanto, como destaca José Luiz Quadros de Magalhães, el control será político en los casos en los que sea ejercido por el ejecutivo o legislativo o directamente en el parlamento, poderes éstos eminentemente políticos y no por el poder judicial, que tiene una función técnica. En los casos en los que el Tribunal Constitucional no integra el poder judicial, con criterios de elección política, el control también será político. ${ }^{951}$

Siendo éstas las formas y los métodos de control de constitucionalidad existentes en Brasil, hay que decir que en otros países, incluso por la peculiaridad de cada nación y forma de organización del derecho y de la Constitución, existen, aunque no se diferencien mucho, algunas otras peculiaridades. Un ejemplo es el hecho de que el Tribunal Supremo Federal brasileño, forma parte del poder judicial, lo que no sucede en España, donde el Tribunal Constitucional no forma parte del poder judicial.

En cuanto a los efectos, la decisión emitida en sede de control abstracto de constitucionalidad posee eficacia erga omnes, beneficia o incluso perjudica terceros, y un efecto vinculante con relación a los demás órganos integrantes del Poder judicial y de la Administración Pública directa e indirecta, salvo, tan sólo, el

norma constitucional, el Poder competente podrá adoptar las medidas necesarias y, al tratarse de un órgano administrativo, dispondrá de treinta días para hacerlo. $\S 3$ - Cuando el Supremo Tribunal Federal examina la inconstitucionalidad, en teoría, de una norma legal o un acto normativo, citará, previamente, al Abogado del Estado de la Unión, que defenderá el acto o el texto impugnado.

${ }^{951}$ En este sentido: "el control será político cuando sea ejercido por un órgano que pertenece al poder ejecutivo o legislativo o ejercido directamente por el parlamento (auto-control como en Holanda, en Luxemburgo y en Finlandia), poderes que ejercen funciones predominantemente políticas y no por el poder judicial, que ejerce una función predominantemente técnica. El control será político también cuando es ejercido por Tribunal Constitucional (o Tribunal, o Consejo) que no forman parte del poder judicial y tengan una composición predominantemente determinada por criterios de elección política" (QUADROS DE MAGALHAES, José Luiz, "O controle de constitucionalidade e a reforma do poder judiciário: a necessidade de um novo supremo tribunal federal"). En http://www.uj.com.br/publicacoes/doutrinas/default.asp?action=doutrina\&coddou=3565 acceso el 15 de julio de 2010, a las 16 h51min. 
Plenario en el STF y el Poder Legislativo (en el ejercicio de la Función Legislativa). ${ }^{952}$

Y este efecto vinculante deriva de la teoría de la trascendencia de los motivos determinantes de la decisión, es decir, no sólo el mandato emanado de la decisión, sino también sus razones determinantes, que se proyectan a los casos similares, conforme establece el art. 102 , I, I, de la CF/88. ${ }^{953}$

Este modelo, similar al concebido por Kelsen, no es realizado por jueces ordinarios, sino por un órgano destinado para tal función y que tiene la obligación de supervisar y hacer valer la Constitución. Es aquí donde se presenta la denominada acción directa de inconstitucionalidad. ${ }^{954}$

En este sentido De Esteban y González-Trevijano sostienen que mediante el sistema de jurisdicción concentrada, la constitucionalidad de una ley no surge a través del litigio entre las partes, sino a través de la acción directa ante el Tribunal Constitucional. La decisión tiene efecto contra todos y no sólo entre las partes, dejando a la norma que forme parte del orden jurídico de un determinado país o lugar. ${ }^{955}$

En los casos en los que la decisión se presenta mediante un control concentrado, por lo general, ostenta eficacia inter partes, limitándose a las partes que figuran en el proceso. Sin embargo la materia puede ser apreciada por el Tribunal Supremo Federal, mediante Recurso Extraordinario, art. 102, III, b, de la

\footnotetext{
${ }^{952}$ http://www.lfg.com.br/artigos/Blog/Abstrativizacao do Controle Concreto de Constitucionalidade.pdf acceso el 15 de junio de 2010, a las 17h14min.

${ }^{953} \mathrm{http}: / / \mathrm{www}$. lfg.com.br/artigos/Blog/Abstrativizacao do Controle Concreto de Constitucionalidade.pdf acceso el 15 de junio de 2010, a las 17h14min.

${ }^{954}$ GONZÁLEZ-TREVIJANO SÁNCHEZ, Pedro José, El tribunal constitucional, cit., p. 34/35.

955 DE ESTEBAN, Jorge y GONZÁLEZ-TREVIJANO, Pedro José, Curso de derecho constitucional español III, cit., p. 148. "En el sistema de jurisdicción concentrada, la constitucionalidad de una ley no surge, como en el caso anterior, con ocasión de un litigio, sino que la misma se somete al control de constitucionalidad, por la vía de acción ante un Tribunal Constitucional ad hoc. En este caso, la sentencia que declara la inconstitucionalidad de una norma tiene efectos erga omnes, y no solo limitados a las partes de un litigio, por lo que su cancelación es definitiva y deja de formar parte del ordenamiento jurídico".
} 
CF/88. En estos casos, se pueden ampliar los efectos de la decisión, con el fin de atribuirle eficacia erga omnes, mediante el procedimiento del art. 52, X, de la $\mathrm{CF} / 88^{956}$, por la actuación política y discrecional del Senado Federal. ${ }^{957}$

Este modelo toma su raíz en el sistema norteamericano y no designa ningún órgano especial para controlar la constitucionalidad de las leyes, de manera que la pueden desarrollar todos los jueces. El peligro de las decisiones contradictorias se mitiga en razón del principio del stare decisis, que impone a los jueces que sigan el criterio de las anteriores decisiones, especialmente la de los tribunales superiores. $^{958}$

Lo que se puede decir, aún, es que en este sistema de control difuso, el juez sólo dice que la ley no se aplica a un determinado caso concreto. Sin embargo, por el principio del stare decisis, queda preservada la seguridad jurídica, debiendo los demás miembros del poder judicial adoptar las decisiones de las tribunales superiores que tienen efecto vinculante. ${ }^{959}$

Cabe también destacar que el sistema difuso no realiza un juicio directo de las leyes inconstitucionales, sino sólo en un caso concreto que se plantea al juez, lo que disminuye en gran medida las declaraciones de inconstitucionalidad. Los efectos de estas decisiones son sólo entre las partes ${ }^{960}$. Sin embargo, como hemos visto, en función del sistema de cada país, puede ampliar sus efectos, después de una decisión de un determinado tribunal, en la mayoría de los casos el Tribunal Constitucional, produciendo efectos erga omnes para la decisión tomada.

\footnotetext{
${ }^{956}$ Art. 52. Compete privativamente al Senado Federal: (...); X - suspender la ejecución, en todo o en parte, de la ley declarada inconstitucional por decisión definitiva del Supremo Tribunal Federal; $(\ldots 5)$.

57 http://www.lfg.com.br/artigos/Blog/Abstrativizacao do Controle Concreto de Constitucionalidade.pdf acceso el 15 de junio de 2010, a las 17h14min.

${ }_{958}$ GONZÁLEZ-TREVIJANO SÁNCHEZ, Pedro José, El tribunal constitucional, cit., p. 34.

959 DE ESTEBAN, Jorge y GONZÁLEZ-TREVIJANO, Curso de derecho constitucional español III, cit., p. 148.

${ }^{960}$ GONZÁLEZ-TREVIJANO SÁNCHEZ, Pedro José, El tribunal constitucional, cit., p. 34.
} 
Por último, las decisiones sobre el control de constitucionalidad pueden declarar una ley nula, por tanto con efectos retroactivos, lo que podría o puede causar muchos problemas, o anular, con efectos ex nunc, siendo válidos, hasta la declaración de nulidad, todos los actos adoptados en función de esta norma. ${ }^{961}$

\subsubsection{Alcance y límites}

El alcance de las decisiones sobre el control de constitucionalidad varía, según el tipo de acción, ya sea directa o incidental.

En el caso de la acción directa de inconstitucionalidad, hay un efecto vinculante y alcanza a todos, erga omnes. En el caso del control incidental, el alcance se limita sólo a las partes del proceso, salvo en los casos en que, con el fin de atribuirle una eficacia erga omnes, mediante el procedimiento del art. 52, X, de la CF/88, eso por la actuación política y discrecional del Senado Federal, el Tribunal Supremo Federal remite la decisión a las cámaras del Congreso Nacional para que sea suspendida, en todo o en parte, la ejecución de la ley declarada inconstitucional por el STF.

Una de las salidas, de modo que el Tribunal Supremo Federal no quede "dependiendo" del Senado Federal mientras se declara la inconstitucionalidad de control incidental, es la edición de una "súmula" vinculante. Lo cierto es que fácticamente las decisiones del STF, incluso en el caso de un control difuso, están teniendo además de un efecto vinculante, una eficacia contra todos. ${ }^{962}$

\footnotetext{
${ }^{961}$ DE ESTEBAN, Jorge y GONZÁLEZ-TREVIJANO, Curso de derecho constitucional español III, cit., p. 148/149.

${ }_{962}$ Antes de la promulgación de la "súmula" vinculante 24, del Supremo Tribunal Federal, que establece que "Es ilícita la prisión civil del depositario infiel, cualquiera que sea la modalidad del deposito", a partir de decisiones reiteradas de la Corte Suprema brasileña, las sentencias de los demás tribunales ya decidían, a partir del STF en relación al control difuso de constitucionalidad, que no es posible detener al depositario infiel.
} 


\subsubsection{Lo que es una ley inconstitucional y cuáles son los efectos de esta declaración}

Una norma o una ley inconstitucional puede ser clasificada como una "no ley". Cuando contraría una disposición constitucional, bien sea en su vertiente formal, bien sea sobre la material, esta ley pierde su fundamento de validez y deja de ser una disposición legal que vincula al ciudadano.

Como ya hemos visto, la declaración de inconstitucionalidad en Brasil, puede producirse de forma directa, con efecto frente a todos, o de forma incidental, en los casos en que la vinculación para todos debe ser dada, mediante iniciativa del Tribunal Supremo Federal, por parte del Senado de la República.

Una ley inconstitucional no vincula a los ciudadanos. E incluso hay casos de normas inconstitucionales, que contrarían las disposiciones constitucionales, pero que aún no han sido declaradas de esta manera.

Sobre esta temática versa nuestra investigación. Pero iremos más allá. Sostenemos la "inconstitucionalidad" de la "súmula" de jurisprudencia del tribunal superior y, concretamente, del Tribunal Superior del Trabajo. Conviene destacar que por la reivindicación número 8.233, el Ministro Marco Aurélio Melo, de forma indirecta y como principio, declaró "inconstitucional" el apartado IV de la "súmula" 331 del TST $^{963}$.

Por otro lado, lo que pretendemos en esta investigación es mostrar cómo se debe interpretar lo que establece el artículo $7^{\circ}$, I, primera parte, de la CF/88, a partir del ordenamiento jurídico vigente, de los conceptos y de las normas existentes y válidas que, claramente, vinculan al legislador ordinario.

${ }^{963} \mathrm{Rcl}$ 8233. Relator el Ministro Marco Aurélio Melo, el 27 de abril de 2010. 


\subsection{La relación de empleo como regla absoluta}

Desde el inicio hemos intentado hacer referencia a cuestiones tales como la conciencia de clase, flexibilización y desregulación de las normas laborales, así como las teorías sobre el trabajo y el trabajador dentro del modo de producción capitalista.

Estas teorías son una lectura esencial para la correcta comprensión de lo que presentamos a continuación. No se puede imaginar el mundo capitalista sin trabajador subordinado. Partiendo de esta lógica pretendemos abordar el tema de la relación de empleo como regla absoluta, a partir de la Constitución brasileña de 1988, apoyándonos en su artículo 7ํㅜ , I.

Por eso, recomendamos al lector que tenga presente los capítulos anteriores, ya que así podrá entender mejor lo que intentamos sostener en esta investigación.

\subsubsection{Los imperativos categóricos y los imperativos hipotéticos}

El lenguaje jurídico corriente distingue entre el derecho objetivo y el subjetivo. El derecho objetivo es el orden jurídico, el conjunto jurídico de las normas o reglas jurídicas imperativas. El derecho subjetivo es el poder o la legitimación conferida por el derecho. El derecho subjetivo es más que una mera autorización. En realidad, es una esfera de poder dentro de la cual, en cierta medida, se protegen sus propios intereses. Por tanto, el derecho subjetivo es un poder otorgado al individuo por el orden jurídico, un medio para la satisfacción de los intereses humanos. La regla jurídica que asigna la propiedad no se limita a los demás para establecer una prohibición de perturbar esta propiedad. Antes establece el dominio sobre la cosa, en el sentido de que el propietario puede exigir que no perturben esta propiedad. ${ }^{964}$

${ }^{964}$ ENGISCH, Karl, Introdução ao pensamento jurídico. Tradução J. Baptista Machado, Lisboa; Editora Fundação Caloustre Gulbenkian, $9^{\mathrm{a}}$ Edição, 2004, p. 41/43. 
Siempre que hay derechos subjetivos, cuando son otorgados, es mediante la creación de imperativos. Lo que el derecho realiza lo hace a través de mandatos. No dispone de un "saco lleno de derechos subjetivos en el cual pueda meter la mano para esparcirlos entre el pueblo". ${ }^{965}$ La valoración es importante para la regla jurídica, pero sólo hace genuina la regla jurídica si tiene un imperativo. "Con simple normas de valoración el derecho no podría ejercer el dominio que le compete sobre la vida de los hombres en comunidad. Solo en la medida en que sus normas de valoración adquieren la fuerza de manifestaciones de voluntad y, por tanto, de órdenes y mandatos, se transforman en normas jurídicas". 966

Aceptando la tesis de que las normas jurídicas son, en su contenido esencial, imperativos, en el espíritu de aquéllos que conocen el mundo conceptual de la filosofía kantiana, se plantean los interrogantes de: ¿qué son estos imperativos hipotéticos o categóricos? ¿A qué especie pertenecen los imperativos jurídicos a la luz de la terminología kantiana?

Los imperativos pueden ser hipotéticos o categóricos. Los primeros se ocupan de la necesidad práctica de una posible conducta como medio para la consecución de un objetivo. El imperativo categórico es aquél que presenta a través de una conducta como objetivamente necesaria por sí misma, sin referencia con ningún otro fin. ${ }^{967}$ El Imperativo categórico establece el fin que yo debo proponer en cada caso, incondicional y sin referencia a otro fin. La proposición no debes matar es un imperativo categórico. Del mismo modo así lo es la ley penal, siendo un imperativo categórico el hecho de que el delincuente sufra la pena. ${ }^{968}$

\footnotetext{
965 ENGISCH, Karl, Introdução ao pensamento jurídico, cit., p. 45.

966 Continua el autor y afirma que los imperativos hipotéticos "(...) son sólo buenos consejos del tenor siguiente: si quieres alcanzar éste o aquel fin, tienes que recurrir a éste o a aquél medio". Ellos no son más que indicaciones técnicas en las cuales se implica hipotéticamente un determinado fin. Es el hecho de saber lo que tienes que hacer para lograr un fin determinado (ENGISCH, Karl, Introdução ao pensamento jurídico, cit., p. 48).

${ }_{967}$ ENGISCH, Karl, Introdução ao pensamento jurídico, cit., p. 48/9

968 ENGISCH, Karl, Introdução ao pensamento jurídico, cit., p. 49.
} 
Según Kant, los imperativos hipotéticos forman parte de la acción con cierto interés. El agente actúa siempre pensando en algo que le pueda favorecer. El imperativo categórico, o moral, concierne a la actuación sin interés, sin ningún influencia sobre la voluntad, sin administrar intereses ajenos y con autoridad imperativa como una legislación suprema. ${ }^{969}$

Es la ley fundamental de la razón práctica pura. Actuar de forma que la máxima de la voluntad pueda valer siempre como principio de una legislación universal, de un proceder de todos. Es esta ley moral, por tanto, un imperativo, imperativo categórico, fuerte, impositivo. ${ }^{970}$

Por lo tanto, se puede concluir que la regla constitucional brasileña del artículo $7^{\circ}, 1^{971}$, que apunta que son derechos de los trabajadores, además de otros que tratan de mejorar su condición social, la relación de empleo, también es un imperativo categórico, ya que esta norma debe hacerse presente en cada caso concreto, de forma incondicional y absoluta, sin hacer referencia a ninguna otra finalidad. Cabe destacar que este artículo de la Constitución brasileña de 1988 no se interesa de que se pueda alcanzar otro fin. Ella misma es un fin en sí misma. Es imperativa y coloca como parámetro dentro del orden capitalista la relación de empleo subordinada independientemente de las consecuencias que esto pueda, empíricamente, originar.

Sin embargo, hay que añadir que el propio derecho fija los fines y requiere su realización de una manera tan incondicional, de un modo exactamente tan categórico como la moral. Sin embargo, el derecho no deja al deudor la elección

\footnotetext{
969 Para él "fomentar la felicidad ajena no como si yo tuviera ningún interés por su existencia (por inclinación inmediata, o, indirectamente, por cualquier satisfacción obtenida por la razón), pero sólo porque la máxima que excluya esta felicidad no puede estar incluida en un sólo y mismo querer universal' (KANT, Imanuel, Fundamentação da metafísica dos costumes, cit., p. 71/72).

970 KANT, Imanuel, Crítica da razão prática, São Paulo, SP. Editora Martin Claret, Coleção Obra Prima de Cada Autor - Textos Integrais, 2006, p. 40/42.

${ }^{971}$ Art. $7^{\circ}$ Son derechos de los trabajadores urbanos y rurales, además de otros destinados a la mejoría de su condición social: I - relación laboral protegida contra el despido arbitrario o sin justa causa, en lo términos de una ley reglamentaria, que establecerá el pago por despido, entre otros derechos; (...).
} 
de no pagar la deuda y sufrir las consecuencias o al agente criminal la elección de cometer el delito y sufrir las consecuencias. La regla, en este caso, también es un imperativo categórico. ${ }^{972}$

Es un mandato incondicional. Y esto puede aplicarse para cualquier tipo de acto ilícito o punible. ${ }^{973}$ Es también un precepto categórico el que ordena el cumplimiento de las obligaciones del derecho privado asumidas a través de las declaraciones de voluntad, especialmente a través de las conclusiones de tratados. Una vez vinculados, por tanto, por contrato, se requiere categóricamente el cumplimiento de las obligaciones asumidas.

Este imperativo categórico, determinado por el poder constituyente originario en el caso de Brasil, no implica reglas de excepción. Se impone de forma incondicionada y perentoria, sin tener en cuenta las consecuencias. No se presenta como una norma, un imperativo-medio, sino como un imperativo fuerte, categórico, un fin en sí mismo. Es decir, además, se confirma con la lectura del encabezamiento del artículo $7^{0}$ de la Constitución brasileña de 1988, que establece que son derechos de los trabajadores los que tratan de mejorar su condición social, sin excepción. ${ }^{974}$

El imperativo categórico, por lo tanto, de diferencia del imperativo hipotético, es un principio objetivo que ordena una acción incondicionalmente, porque es, en

\footnotetext{
${ }^{972}$ Como consecuencia de esta concepción, es decir de la interpretación y aplicación de los imperativos jurídicos, debemos entender (comprender) éstos como medios para alcanzar los fines que el Derecho considera buenos. Inversamente, cuando nos enfrentamos a los imperativos hipotéticos, somos libres para decidir a favor o contra el fin" (ENGISCH, Karl, Introdução ao pensamento jurídico, cit., p. 52/53).

973 "Vale con relación a tales actos el mandato estricto de su omisión, tanto por parte del Derecho como, por lo que resta, en gran medida, también por parte de la moral. Y no son menos categóricos los deberes proporcionados a la comunidad jurídica y ciertas contribuciones positivas, por ejemplo: pagar impuestos, soportar expropiaciones, etc." (ENGISCH, Karl, Introdução ao pensamento jurídico, ibidem).

${ }^{974}$ Se subraya que la norma constitucional establece SON y que no serían o que podrían ser. Es categórica, final, intransigente, fuerte.
} 
sí, buena, sin relación a los fines, debiendo ser practicada por cualquier ser racional, necesariamente querido por todo ser racional. ${ }^{975}$

El imperativo categórico no deriva de la experiencia, sino de la razón. La experiencia muestra como son las cosas y no como deberían ser. El imperativo categórico no es un imperativo empírico, sino una proposición práctica a priori. Ordena incondicionalmente porque expresa una universalidad absoluta, independientemente de todo el contenido, de todos los motivos, fines particulares, personales, sociales, culturales, considerados como valores. ${ }^{976}$

Hay tres formulas para expresar el imperativo categórico Kantiano, esto desde la formula general: "Obra sólo según una máxima tal, que puedas querer al mismo tiempo que se torne en ley universal": a) la fórmula de equiparación de la máxima a la universalidad de la ley de la naturaleza: "Obra sólo según una máxima tal, que puedas querer al mismo tiempo que se torne en ley universal de la naturaleza'"; b) la de la humanidad o de la consideración de la persona como un fin en sí misma: "obra de tal modo que uses la humanidad, tanto en tu persona como en la persona de cualquier otro, siempre y al mismo tiempo, como fin y nunca como medio simplemente"; y c) la de la autonomía o de la libertad positiva del reino de los fines. Obra de forma que "tu voluntad, a través de sus máximas, se pueda considerar al mismo tiempo como legisladora universal". La intención de Kant es la vida en comunidad, la vida política y en sociedad. ${ }^{977}$

Cabe destacar que la relación de empleo como regla universal, como imperativo categórico, más que posible, jes necesaria!

La Constitución debe ser leída, entendida en su conjunto. Si en todas las relaciones de trabajo donde la ejecución del trabajo es permanente, y donde hay

\footnotetext{
975 SALGADO, Joaquim Carlos, A idéia da justiça em Kant: seu fundamento na liberdade e na igualdade, belo Horizonte: Editora UFMG, 2a edição, 1995, p. 208.

976 SALGADO, Joaquim Carlos, A idéia da justiça em Kant, cit., p. 212/212.

977 SALGADO, Joaquim Carlos, A idéia da justiça em Kant, cit., p. 217/218.
} 
subordinación, le reconoce la relación de empleo, habrá viabilidad económica y social del sistema. Esto porque es objetivo fundamental de la República Federativa de Brasil la erradicación de la pobreza y de la marginación y la reducción de las desigualdades sociales y regionales. ${ }^{978}$ Con la contratación a través de un tercero no se reduce la desigualdad. Por el contrario: concentra la renta en manos de uno pocos. Más bien, como una regla obligatoria, como un imperativo categórico, acaba por hacer inviable el sistema.

Si en todas las relaciones en las que hay trabajo permanente, es decir, en aquellas en que la ejecución esté relacionada con la "actividad-medio" se permite la intermediación de mano de obra, el sistema tiende a ser inviable, ya sea económicamente, a causa de la concentración de la renta y la disminución del poder adquisitivo, ya sea jurídicamente por el incumplimiento del objetivo fundamental de la reducción de las desigualdades sociales y regionales.

Conviene destacar que actualmente Brasil tiene programas y políticas públicas dedicadas a complementar la renta de las personas de las clases menos favorecidas. Los criterios implican valores que se computan por persona, donde una familia que tenga, por ejemplo, uno sólo de sus miembros como receptor del salario pagado por la prestadora de los servicios, acaba por tener derecho a la prestación del gobierno ${ }^{979}$.

\footnotetext{
978 "Art. 30. Constituyen objetivos fundamentales de la República Federativa de Brasil: (...); III erradicar la pobreza y la marginación y reducir las desigualdades sociales y regionales; (...)".

979 "La Bolsa Familia es un programa de transferencia directa de ingresos con condiciones, que beneficia a las familias en situación de pobreza y de extrema pobreza. El Programa integra el Hambre Cero <http://www.mds.gov.br/resolveuid/8dff5a41bdfdc4f463bc036b50f1d879> que tiene como objetivo asegurar el derecho humano a una alimentación adecuada, promoviendo la seguridad alimentaria y nutricional y contribuyendo a la conquista de la ciudadanía por parte de la población más vulnerable al hambre.

La Bolsa Familia atiende a más de 12 millones de familias en todo el territorio nacional. Dependiendo de la renta familiar por persona (limitada a $R \$ 140$ ), del número y de la edad de los hijos, el importe recibido por la familia puede variar entre $R \$ 22$ a $R \$ 200$. Varios estudios apuntan la contribución del Programa a la reducción de las desigualdades sociales y de la pobreza.

El Programa posee tres ejes principales: transferencia de ingresos, condiciones y programas complementarios. La transferencia de renta promueve el alivio inmediato de la pobreza. Las condicionalidades refuerzan el acceso a derechos sociales básicos en las áreas de educación, salud y asistencia social. Los programas complementarios tienen por objetivo el desarrollo de las
} 
El imperativo categórico, por tanto, que deriva de todos los imperativos del deber, es una proposición práctica sintética a priori, diferenciado del imperativo hipotético que considera también los medios para lograr ciertos fines. ${ }^{980}$

Si, utilizando la razón, todos actuaran con el fin de hacer de su proposición una regla universal, esta proposición práctica a priori, daría lugar al reconocimiento de la relación de trabajo directa, sin intermediarios, para las relaciones de trabajo ejecutado de forma permanente, como quiere el artículo $3^{\circ}$ de la Consolidación de las Leyes del Trabajo. Esta es la forma más acertada, la que debe llevarse cabo, sin un objetivo final deseado, sino sólo mediante la acción de la imperativa moral: hacer lo cierto, sin experiencia práctica y sin intermediación del mundo económico.

El imperativo categórico se basa en el obrar por deber, sin relación con un fin. Obrar porque en la aplicación práctica este razonamiento es el correcto, es la regla universal de conducta y de convivencia entre todos.

Por lo tanto, si la relación de empleo es el imperativo categórico entre el tomador de los servicios y el prestador del trabajo, es necesario analizar en que términos se lleva esto a cabo. Si se permite o no la subcontratación. Sin embargo, hay que tener en cuenta que, a partir de los parámetros expuestos, es difícil sostener, dentro del orden jurídico brasileño, la doble alienación del trabajador, que será un tema de un análisis todavía más profundo.

Conviene subrayar que el papel de la filosofía y, concretamente, de la filosofía del derecho, es de destruir las falsas identidades, de desmoralizar y

familias, de modo que los beneficiarios puedan superar la situación de vulnerabilidad". (En <http://www.mds.gov.br/bolsafamilia> - acceso el 10 de agosto de 2010, a las 21h54min).

980 PASCAL, Georges, Compreender Kant. Introdução e tradução Raimundo Vier, Petrópolis, RJ; Editora Vozes, 2005, p. 128/129 
despolitizar los comportamientos ideológicos, en la medida en que se crispan y dogmatiza. Este papel de la filosofía se llama proceso de concienciación. ${ }^{981}$

\subsubsection{La regla del artículo $7^{\circ}$, inciso I, primera parte, de la Constitución} brasileña de 1988.

\subsubsection{Concepto de relación de empleo en la Constitución de 1988.}

El artículo 7º, I, de la Constitución brasileña de 1988 establece que "son derechos de los trabajadores urbanos y rurales, además de otros que tratan de mejorar su condición social: I - relación de empleo (...)". Hay un gran debate en Brasil sobre la aplicación de la segunda parte del 7º, I, de la Constitución (garantía contra el despido arbitrario o sin justa causa ${ }^{982}$. Sin embargo, no se ha llevado a cabo un análisis real del contenido de la primera parte del dicho inciso del artículo

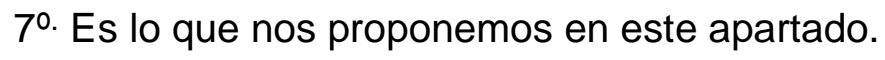

Si son derechos de los trabajadores urbanos y rurales la relación de empleo, norma constitucional necesaria ${ }^{983}$, no se puede aceptar que haya trabajo por cuenta ajena a través de intermediación de mano de obra, conocida como tercerización.

${ }^{981}$ STEIN, Ernildo, História e ideologia, cit., p. 12.

${ }^{982}$ Art. $7^{\circ}(\ldots)$ : I - relación de empleo protegido en contra del despido arbitrario o sin justa causa, en lo términos de la ley reglamentaria, que establecerá el pago por despido, entre otros derechos;

${ }_{983}$ 'Las normas se clasifican también en 'imperativas' y 'dispositivas', que se llaman asimismo, respectivamente 'de Derecho necesario' y 'voluntario', y la diferencia entre unas y otras consiste en que las normas de Derecho necesario no se pueden eliminar o sustituir por la voluntad del sujeto, y las de Derecho voluntario si. En otras palabras: no toda norma obliga de igual modo. Unas imperan determinada conducta activa o pasiva (mandatos o prohibiciones) sin dejar lugar a la autorregulación del sujeto y se llaman imperativas, de 'ius cogens' o Derecho necesario, como las que el Cc. señalan plazos de caducidad o prohíben el contrato sucesorio; mientas otras rigen a falta de esa autorregulación y se llaman de Derecho dispositivo o voluntario, porque pueden ser sustituidas o eliminadas por el arbitrio individual (...)". (LACRUZ BARDEJO, José Luis, SANCHO REBULLIDA, Francisco de Asís, LUNA SERRANO, Agustín, DELGADO ECHEVERRÍA, Jesus, RIVERO HERNÁNDEZ, Francisco y RAMS ALBESA, Joaquín, Elementos de derecho civil I. Parte general, Madrid; Dykinson, 2002, p. 112/113). 
La norma constitucional debe interpretarse siempre teniendo como base el Estado Democrático de Derecho ${ }^{984}$, el principio de la dignidad humana y los derechos fundamentales. Como hemos dicho antes, según Clemerson Clève, existen dos formas de interpretar los preceptos constitucionales. La primera, indiferente y no sensible a los instrumentos que vinieron a transformar el nuevo orden constitucional y que se denomina "dogmática de la razón del Estado". La segunda, que trata de estudiar el derecho constitucional teniendo como modelo la dignidad humana es conocida como "dogmática constitucional emancipadora". ${ }^{985}$

Si la norma constitucional garantiza la relación de empleo y lo hace en razón de la existencia de la libre iniciativa, artículo $1^{\circ}$, IV, de la Constitución ${ }^{986}$, y la coloca como derecho de los trabajadores, sólo se pueden crear nuevos derechos destinados a la "mejoría de la condición social de éstos". De ahí que no podamos aceptar que exista una relación de trabajo por cuenta ajena que no sea de forma directa para aquél que toma los servicios, con aquel dueño del producto creado por el trabajo prestado.

Esto se produce porque el espacio que la ley permite que una persona se sirva de otra como medio es la relación de empleo ${ }^{987}$. Este concepto debe interpretarse de forma restrictiva. No puede aceptarse que una norma que autorice la acumulación de la plusvalía en manos de uno o algunos, sea de aplicación

\footnotetext{
984 "El Estado Democrático de Derecho tiene un contenido transformador de la realidad, no se limita, como el Estado Social de Derecho, a una adaptación mejorada de las condiciones sociales de existencia. Así, su contenido va más allá del aspecto material de consecución de una vida digna para el hombre y actúa simbólicamente como promotor de la participación pública cuando lo democrático califica el Estado, que irradia los valores de la democracia sobre todos sus elementos constitutivos $y$, por lo tanto, también sobre el orden jurídico. Además, la idea de democracia contiene e implica, necesariamente, la cuestión de la solución del problema de las condiciones materiales de existencia" (STRECK, Lênio Luiz e BOLZAN DE MORAIS, José Luis, "Ciência política e teoria geral do estado", 2004, p. 93).

${ }_{885}$ CLĖVE, Clémerson Merlin, "A eficácia dos direitos fundamentais sociais", cit., p. 28/9.

${ }^{986}$ Art. 1ํ La República Federativa de Brasil, formada por la unión indisoluble de los Estados y Municipios y de Distrito Federal, se constituye en un Estado Democrático de Derecho y tiene como fundamentos: (...); IV - los valores sociales del trabajo y de la libre iniciativa; (...).

${ }_{987}$ Este espacio deriva del proceso democrático de formación de la norma, es fruto de la acción comunicativa habermasiana.
} 
amplia y sin restricciones, en detrimento de los que sufren la explotación y que aún así generan esta riqueza.

Existe la autorización para la acción estratégica ${ }^{988}$, pero regulada por la norma constitucional, que se estructura sobre el Estado Democrático de Derecho, derechos fundamentales y dignidad humana.

Sin embargo, los seres racionales no pueden ser utilizados sólo como un medio para que otros lleguen a los fines que se proponen. Habermas sostiene que la acción comunicativa es la regla, ya que hace posible que el otro sea un fin en sí mismo y no sólo un medio ${ }^{989}$.

Trabajando el ser humano de forma alienada, alienando su propia existencia a su empleador, la alienación consentida por la Constitución, no debe llevarnos a pensar que la interpretación del artículo $7^{\circ}$, I, primera parte, de la Constitución brasileña de 1988, no permita una interpretación a favor del alienado.

Más aún cuando la norma establece que son derechos de los trabajadores, además de los establecidos en el artículo $7^{\circ}$ de la Carta, otros destinados a la mejoría de su condición social. Sin embargo, el trabajo tercerizado no genera una mejoría en la condición social de los trabajadores. ¿Cómo aceptar, sobre la base del ordenamiento jurídico brasileño, la contratación a través de un intermediario? Esta forma de contratación ¿mejora la condición social de quién? ¿De los trabajadores o sólo de los tomadores?

Por otro lado, conviene señalar que la Constitución brasileña no establece una excepción a la relación de empleo como regla en el caso de trabajo por

\footnotetext{
${ }^{988}$ Acción que pretende la utilización del otro como un medio con el fin de asegurar que quien actúa alcance sus fines.

${ }_{989}^{9}$ La acción comunicativa es, para Habermas, la acción dirigida a la comprensión, donde al menos dos sujetos actúan de una forma coordinada o incluso superan la coordinación, a través del dialogo, reconociendo, uno en frente al otro, las pretensiones de validez del discurso, alejándose del calculo centrado en sí, para dividir los planes con los otros. (Cf. HABERMAS, Jürgen, Teoría de La Acción Comunicativa, cit.).
} 
cuenta ajena. No autoriza, por lo tanto, la tercerización a partir de la Consolidación de las Leyes del Trabajo, norma sustantiva laboral, de las que toma la Constitución prestados los conceptos de empleado y empleador, conforme a los artículos $2^{\circ}$ y $3^{\circ}$ de este texto laboral. ${ }^{990}$ A excepción del artículo 455 de la CLT ${ }^{991}$, contrata y subcontrata, que autoriza expresamente la subcontratación, pero en la fase procesal de embargo y en situación más beneficiosa.

Cualquier cambio en la interpretación, o incluso cualquier legislación posterior que permita la subcontratación, estará contaminada de inconstitucionalidad, puesto que va a cambiar el concepto constitucional sin la debida legitimación democrática.

En este sentido, debe entenderse el voto del ministro del Tribunal Supremo Federal de Brasil, en un proceso donde se discutió el concepto de facturación, -el recurso extraordinario 346.084-6, Paraná-.

En la Constitución federal no consta el sentido ni el alcance de un determinado término, como es el caso concreto de "facturación"992, como tampoco el de "tributo", "propiedad", "familia", “libertad", "vida", "crimen", "ciudadano", "sufragio", de manera que en el texto constitucional no podemos encontrar una predefinición o conceptualización formal de los términos citados, pero no se puede cerrar el texto e impedir que se adapte a la evolución histórica de los conceptos ${ }^{993}$.

Art. $2^{\circ}$ - Se considera empleador la empresa, individual o colectiva que, asumiendo los riesgos de la actividad económica, admite, asalaria y dirige la prestación de servicios.

Art. $3^{\circ}-$ Se considera empleado toda persona física que presta servicios de cualquier naturaleza al empleador, bajo dependencia de éste y mediante salario.

991 Art. 455 - En los contratos de subcontrata responderá el subcontratista por las obligaciones derivadas del contrato de trabajo estipulado, cabiendo, sin embargo, a los empleados, el derecho de reclamación contra el contratista principal por el incumplimiento de aquellas obligaciones por parte del primero. Párrafo único - Al contratista principal se le dispensa, en los términos de la ley civil, de la acción regresiva contra el subcontratista y la retención del valor a éste debido, como garantía de las obligaciones previstas en este artículo.

${ }_{992} \mathrm{Em}$ el hipotético, objeto de este estudio "relación de empleo".

${ }^{993}$ www.stf.gov.br 
Sin embargo, una vez que el texto constitucional hace referencia a un concepto de derecho fundamental, expresamente protegido por la cláusula de irretroactividad como es el caso de la expresión "relación de empleo", la apertura no puede llegar al punto de desconfigurar el concepto inicialmente adoptado por la Constitución.

Las palabras, tanto en el lenguaje natural como en la técnica, de las que se sirve el derecho positivo para la construcción de las normas, son potencialmente vagas, manteniendo un campo de referencia no definido. Hay, sin embargo, un límite a la resistencia, un concepto semántico mínimo que se reconoce en cada vocablo, más allá del cual no está, según Humberto Eco, "autorizado a decir que el mensaje puede significar cualquier cosa. Puede significar muchas cosas, pero hay sentidos que sería un despropósito que se sugiriera". 994

Cabe destacar que en la mayoría de los casos los términos se toman con un significado domestico corriente, adecuado al área temática en la que se inscriben, ya sea en el área jurídica, ya sea en el ámbito de las demás ciencias, como la economía (intereses), la biología (vida), o incluso los idiomas extranjeros como el inglés (software), sin la necesidad de un proceso autónomo de esclarecimiento. ${ }^{995}$

Si el legislador, con el fin de cumplir con las estrategias normativas, trata de añadir a algún viejo término un nuevo significado, diferente del habitual, debe hacerlo explicito mediante la construcción formal de su concepto jurídiconormativo, "sin perjuicio de establecer, en una determinada provincia jurídica, un concepto diferente con respecto a otra, lo que se puede verse bien en el art. 327 del Código Penal ${ }^{996}$, que define 'funcionario público' a los efectos penales, y en el

\footnotetext{
994 www.stf.gov.br

${ }^{995}$ www.stf.gov.br

996 Art. 327 - Se considera el funcionario público, a los efectos penales, a quien, aunque de forma temporal o sin remuneración, desempeñe un cargo, un empleo u otra función pública.

$\S 1^{\circ}$ - Se equipara al funcionario público a quien desempeñe un cargo, un empleo o una función en una entidad paraestatal, y a quien trabaja para una empresa prestadora de servicio contratado o convenida para la ejecución de la actividad típica de la Administración Pública.
} 
art. $2^{\circ}$ de la Ley de Improbidad Administrativa (Ley N. 8.429/92) ) $^{997}$ que atribuye, para sus fines, un concepto similar a la expresión 'agente público'”. 998

Por lo tanto, en el testo constitucional, ya que no hay un concepto jurídico expresado, el intérprete debe ayudarse, con el fin de hacer la reconstrucción semántica, de los instrumentos normativos disponibles en el propio sistema de derecho positivo, o en los diferentes cuerpos de lenguaje. ${ }^{999}$

El ministro del Tribunal Supremo Federal brasileño, Cesar Peluso, fundamentando su voto, subraya que el hecho del artículo 195, párrafo cuarto, de la Constitución brasileña de $1988^{1000}$, da competencia suplementaria a la Unión para instituir contribuciones sociales no específicas, que dependan de "otras fuentes destinadas al mantenimiento o expansión de la seguridad". La prueba está en que, al hacer referencia a la "facturación", además de la "nomina y el beneficio", intentó utilizar la palabra en un sentido predeterminado. De otro modo, la previsión

\footnotetext{
§ 20 - La pena se incrementará en un tercio cuando los autores de los delitos previstos en este Capítulo son titulares de cargos en comisión o de función de dirección o asesoramiento de órgano de la administración directa, sociedad de capital mixto, empresa pública o fundación instituida por el poder público.

${ }_{997}$ Art. $2^{\circ}$ se considera agente público, a los efectos de esta ley, cualquier persona que desempeñe, aunque de forma temporal o sin remuneración, por elección, nombramiento, designación, contratación o cualquier otra forma de investidura o vínculo, mandato, cargo, empleo o función en las entidades mencionadas en el artículo anterior.

${ }_{998}$ www.stf.gov.br

999 “(...) Cuando no exista el concepto jurídico expresado, el intérprete ha de ayudarse, para la reconstrucción semántica, de los instrumentos disponibles en el propio sistema del derecho positivo, o en los diferentes cuerpos del lenguaje. 6. Como ya se ha expuesto, en la Constitución Federal no hay prescripción del significado del término facturación. Si se excusó la Constitución de definirlo, el intérprete debe verificar, primero, si en el propio ordenamiento había entonces algún valor semántico al que pudiera afiliarse el uso constitucional del vocablo, sin aclaración de un sentido particular, ni la necesidad de una futura regulación por ley inferior. Si hubiera un correspondiente semántico en el orden jurídico, la presunción es de que se refiere al mismo el uso constitucional. Cuando una misma palabra, usada por la Constitución sin definición expresa ni contextual, guarde dos o más sentidos, uno de los cuales ya está incorporado en el ordenamiento jurídico, será éste, no otro, su contenido semántico, porque sería razonable suponer que el texto normativo esté aludiendo a un objeto extrajurídico. (...)". (www.stf.gov.br).

1000 Art. 195. La seguridad social será financiada por toda la sociedad, de forma directa e indirecta, en los términos de la ley, mediante recursos provenientes de los presupuestos de la Unión, de los Estados, del Distrito Federal y de los Municipios, y de las correspondientes cotizaciones sociales: (...).§ $4^{\circ}$ - La ley podrá instituir otras fuentes destinadas a garantizar el mantenimiento o la expansión de la seguridad social, conforme a lo dispuesto en el art. 154.
} 
de aquella competencia residual perdería todo el sentido, al admitir que fuesen vagos e imprecisos los conceptos de facturación, de nómina y de beneficio ${ }^{1001}$.

Lo mismo podría decirse acerca del concepto de "relación de empleo". No puede ser tan vago e impreciso de manera que permita más de una interpretación, con respecto a lo que quería decir el legislador acerca de la "relación de empleo". La base fue la legislación ordinaria en vigor en el momento, artículo $3^{0^{1002}}$ y $442^{1003}$ de la Consolidación de las Leyes del Trabajo. De otro modo, un trabajador representante comercial podría considerarse empleado, esto porque presta servicios a terceros o un obrero podría no ser empleado, porque pago también por terceros (ciertas formas de incentivo a la producción). ${ }^{1004}$

Peluso hace referencia, sin embargo, a la decisión del ministro Luiz Galloti en el recurso extraordinario 71.758-GRÃ-BRETANHA, RTJv. 66, P. 165, donde consta que es cierto que se puede interpretar la ley con el fin de evitar la inconstitucionalidad. Pero interpretar interpretando y no cambiar su texto, y mucho menos creando un nuevo impuesto que la ley no ha creado. "Si la ley pudiese llamar compra lo que no es compra, importación lo que no es importación, exportación lo que no es exportación, renta lo que no es renta, se derrumbaría todo el sistema fiscal constitucionales consagrados en la Constitución”. ${ }^{1005}$

\footnotetext{
1001 www.stf.gov.br

1002 Art. $3^{\circ}$ - Se considera empleado toda persona física que presta servicios de cualquier naturaleza al empleador, bajo la dependencia de éste y mediante salario.

${ }^{1003}$ Art. 442 - Contrato individual de trabajo es el acuerdo tácito o expresado, correspondiente a la relación de empleo.

${ }^{1004} \mathrm{Sin}$ embargo, el ministro Peluso apunta que en la larga discusión sobre la noción constitucional del concepto de "facturación", se reconocen y se deciden expresamente "dos cuestiones irrefutables: a) el sentido normativo de la expresión 'ingresos brutos de la venta de mercancía y de la prestación de servicios' que corresponde al concepto constitucional de 'facturación'; b) a partir de una denotación más amplia y extensa propia del género, el significado de la locución legal 'ingresos brutos' rebasa los límites semánticos de este mismo concepto", haciendo referencia explicita al pasaje de Humberto Ávila. (BERGMANN AVILA, Humberto, "COFINS E PIS: inconstitucionalidade da modificação da base de cálculo e violação ao princípio da igualdade". En: Repertório IOB de Jurisprudência, $2^{a}$. Segunda quinzena de julio de 1999, n. 14/99, cuaderno 1, p. 438).

1005 www.stf.gov.br
} 
Y de ahí resulta, ya sobre la base de la decisión del ministro Marco Aurélio Mello, también mencionado por Peluso, que la flexibilidad de los conceptos, el cambio de sentido, de acuerdo con los intereses en juego, conllevan la inseguridad, incompatible con los objetivos de la Constitución, que es un cuerpo político, pero lo es en relación a los parámetros que contempla y éstos no resultan inmunes al sentido real de los vocablos, especialmente los de contornos jurídicos. "Por lo tanto, no se puede poner en un plan secundario conceptos consagrados, buscandose homenajear, sin límites técnicos, el sentido político de las normas constitucionales". (La cursiva es nuestra). ${ }^{1006}$

El desastre, ya mencionado, se ha producido con respecto al sistema laboral. Todo el sistema laboral, cambiando el concepto de "relación de empleo", que permite la subcontratación donde la ley no autoriza, ha acabado por generar un nivel de marginación y desvinculación sindical que ha puesto y sigue poniendo toda la competencia reivindicativa de la clase trabajadora en riesgo, exponiéndola a la miseria material e intelectual, acabando con el equilibrio en la relación capital/trabajo.

No se puede dejar de hacer referencia al voto-divergencia del ministro Eros Roberto Grau, en el recurso extraordinario 346.084-6, Paraná. Diferencia de las distintas funciones del lenguaje en los conceptos jurídicos meramente formales, anclados en el terreno formal y su estudio permite el desarrollo de una casi topología, indicativa de una serie de posiciones lógicas, sin tener una realidad histórica. Son ejemplos: derecho, carga, y etc. Ya las regulae juris son expresiones que resumen el contenido de un conjunto de normas jurídicas, sin significado propio. Es el caso del concepto de propiedad, que sólo asume un cierto significado, en la medida en que se tiene en baja consideración la función que cumple dentro del derecho, de condensar toda la disciplina normativa relativa al modo de adquisición de poderes, facultades y deberes sobre un bien. La utilidad

${ }^{1006}$ www.stf.gov.br 
de este concepto está en la enorme cantidad de tiempo que su uso permite a quien pretenda exponer el contenido del subsistema aplicable a la propiedad. ${ }^{1007}$

La tercera función del lenguaje, llamada conceptos jurídico tipológicos, "son expresiones de la historia e indican los ideales de los individuos y grupos, pueblos y países; se ligan a los esquemas y a la elaboración de carácter, así como a la preocupaciones y a los hábitos económicos y a la creencias religiosas; a la historia del Estado y a la estructura económica; a las orientaciones filosóficas y a las concepciones del mundo". Estos conceptos se refieren a hechos típicos de la realidad, tales como la buena fe, la cosa, el bien, la causa, el dolo, el error. Estos conceptos, también llamados indeterminados, en realidad, no son conceptos, sino nociones de conceptos. ${ }^{1008}$

Para Grau, la facturación es una de estas nociones de concepto. Los conceptos son atemporales y ahistóricos y los conceptos tipológicos tienen características históricas y temporales. No habría, por tanto, la incorporación de la noción de facturación que existía entonces. Considera que lo que sucedió fue la incorporación de una de las nociones que en la época se tenía. La Constitución también podría haber definido la facturación. Al no hacerlo, prevaleció, relata el ministro, una de las posibles comprensiones que es la facturación, ingresos de la venta de mercancía y de la prestación de servicios. ${ }^{1009}$

La norma constitucional, para Grau, es creada por quien la interpreta y aplica. Las palabras escritas en los textos normativos no dicen nada y comienzan a significar algo cuando se hace su interpretación. Van a decir algo cuando el intérprete dice lo que ellas dicen. ${ }^{1010}$

\footnotetext{
1007 www.stf.gov.br

1008 wWW.stf.gov.br

1009 wwW.stf.gov.br

1010 www.stf.gov.br
} 
Si bien se puede entender que el concepto de "relación de empleo" es un concepto jurídico tipológico, vinculado a la historia y a los ideales de los individuos involucradas y que, de hecho, no se trata de un concepto y sí de una noción de concepto, adaptada de acuerdo a la realidad presente, no se puede aceptar la interpretación que transforma la "relación de empleo" en una relación de empleo directa y mediante la intermediación.

Cuando se trata de las relaciones de empleo, del derecho fundamental del trabajador, artículo 7º, I, de la Constitución brasileña de 1988, el concepto jurídico que debe utilizarse es el de la CLT, y no se puede, aunque se trate de una noción de concepto, aplicarlo o interpretarlo con el fin de que se permita una reducción significativa en las condiciones sociales de los trabajadores.

Esto se produce por expresa prohibición del artículo $7^{\circ}$ de la Constitución brasileña de 1988, que establece que "son derechos de los trabajadores, además de otros destinados a la mejoría de su condición social”, consagrando el principio de la no regresión social, de la imposibilidad de la contrarrevolución, de forma expresa. Cabe destacar que la manera de proteger la colectividad se manifiesta en las alteraciones legislativas en materia de contribuciones sociales, como la discutida en el recurso extraordinario 346.084-6, Paraná, que es la limitación nonagesimal. ${ }^{1011}$

\subsubsection{El proceso comunicativo de formación de la norma constitucional}

Por otro lado, se presume que el proceso de formación de la norma constitucional es comunicativo ${ }^{1012}$, donde impera la acción comunicativa. Los

\footnotetext{
1011 Normas legales que establecen las cotizaciones sociales sólo entran en vigor noventa días después de su publicación.

1012 Se supone que es comunicativo porque es fruto del argumento fundamentado, ganando el mejor, sin que los agentes se hayan visto obligados a manifestarse o a no elegir libremente. Aquí la influencia del poder económico y administrativo está fuera, no ejerciendo ninguna presión sobre la formación de la norma constitucional.
} 
argumentos, esgrimidos por los constituyentes sin ningún vicio, dieron lugar a arduos debates durante dos años, prevaleciendo el texto actualmente vigente, fruto de este caldo argumentativo, que dio origen, por el mejor argumento, a la Constitución.

Dentro de este proceso comunicativo se establece el artículo $7^{\circ}$, I, de la Constitución brasileña de 1988. Y es en este artículo donde además de garantizar tan sólo la mejoría de la condición social de los trabajadores, se garantiza también como regla la relación de empleo. Si el proceso comunicativo de formación de la Constitución garantiza o deja un espacio a la acción estratégica, esta forma de acción, que no es compatible con el Estado Democrático de Derecho, salvo en el proceso de formación constitucional, está autorizada por el mismo y se puede utilizar.

Pero ¿cómo se puede hacer? ¿La regla es la acción comunicativa fruto de la razón comunicativa?

Inicialmente se debe tener en cuenta en qué consiste el Estado Democrático de Derecho. Ya hemos mencionado en este texto que esta forma del Estado supera el Estado Liberal y el Estado Social creando un concepto o impulsando al el ser humano a la emancipación ${ }^{1013}$. También se supera el trascendentalismo kantiano con el fin de tener un procedimiento que lleve a la comprensión, con el mayor número de ventajas para todos.

La interpretación de las disposiciones legales que autorizan la acción estratégica $^{1014}$ debe ser restrictiva. En el caso del trabajo subordinado, la norma del artículo $7^{\circ}$, I, de la Constitución brasileña de 1988, fruto del proceso

\footnotetext{
${ }^{1013}$ En este texto no se defiende la emancipación según la concepción marxista de superación del modo de producción capitalista, sino que se dirige a traer una mayor dignidad y felicidad a la clase trabajadora.

1014 Acción estratégica y/o instrumental, en este texto se utilizan como sinónimos. Esta forma de acción, aquí, debe entenderse como una actitud individual, ahora denominada actitud individual estratégica, dirigida sólo a unos determinados fines individuales, donde el otro se convierte en un simple medio.
} 
comunicativo, autoriza la acción instrumental. A partir de ahí, existiendo la posibilidad de la subordinación de la voluntad de los demás, el agente subordinante puede retirar la plusvalía, derivada del trabajo alienado. Los límites para esta acción deben ser estrictos, permitiendo sólo que el mínimo de "agentes subordinantes" retiren la plusvalía de este agente subordinado.

Cuando el Estado autoriza, por parte del poder constituyente originario, el uso del otro como medio, autorización fruto del proceso comunicativo, con el fin de interpretar este uso similar del medio, se debe utilizar la acción comunicativa, fruto del discurso fundamentado en que el otro deja de ser sólo un medio y comienza a ser un agente activo en la aplicación de la norma. A fin de aplicar la norma creada por el proceso comunicativo, que permite la acción estratégica, el método de interpretación y de aplicación de esta norma debe tener como base la acción comunicativa, regla de formación de la voluntad de la mayoría que, en el caso, no permite que se someta a un trabajador a la doble alienación.

Sobre tema, Janriê Rodrigues Reck apunta que el derecho, como ordenamiento, tiene su formación a partir de la acción comunicativa, acción que usa la comunicación para la comprensión sobre sí, sobre el mundo como hechos y cosas, sobre qué hacer. Este mismo derecho, ya que hace uso de la acción comunicativa, abre ciertos espacios a la acción estratégica. Sin embargo, todo el modelo de relaciones está pautado por la acción comunicativa, porque también la acción estratégica se sirve de la acción comunicativa. Se debe, por tanto, tener como guía, al analizar la estructura del derecho, la acción comunicativa y no la estratégica. ${ }^{1015}$

Continúa afirmando que mediante la acción comunicativa se configura el ordenamiento, creando una expectativa. Deben probar no sólo con relación al otro

\footnotetext{
${ }^{1015}$ RODRIGUES RECK, Janrie, "Perspectiva pragmático-sistêmica da liberdade de cátedra: direito social ou individual?", no prelo.
} 
sus argumentos, sino con respecto a toda la sociedad ${ }^{1016}$. De ahí que surge el derecho. De ahí que surge la autorización para la acción estratégica. De ahí, finalmente, surge el deber de analizar las posibilidades de la acción estratégica mediante la acción comunicativa.

Cabe destacar que el encabezamiento del citado artículo $7^{\circ}$ de la CFB también genera esta limitación ya que permite la acción estratégica y la alienación del ser humano así como la mejoría de la condición social de los trabajadores.

No podía ser de otra manera. Tomemos el ejemplo, de casos de fideicomiso. Si hubiera la legislación que limita el fideicomiso, ¿qué ocurriría con el comercio y con los consumidores? ¿Cómo se deberían interpretar estas normas? Las empresas deben actuar en los estrictos límites de la norma establecida, bajo pena de infracción de esta ley, así como deben actuar en los estrictos límites del derecho vigente en cuanto a la subcontratación.

Lo que se debe tener en cuenta -y no sólo por el establecido por Thomas Frank-, es que la tercerización, además de valorar las acciones, aumenta el beneficio. El trabajador, además que su condición sindical empeore, estará sufriendo una "doble alienación"1017, utilizado doblemente como medio, generando aún más riqueza para los que se benefician de su trabajo. Marx ya decía que la disminución de los salarios es uno de los principales medios de aumento del beneficio ${ }^{1018}$, de dónde se puede concluir que la tercerización también lo es.

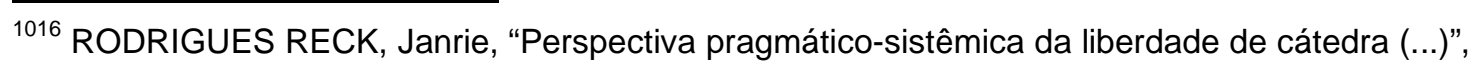
cit.

7 Alienación es la pérdida, por parte del trabajador del producto de su trabajo, a partir de la división del trabajo, que proviene de la superación del feudalismo por el capitalismo, que comienza a tener vida propia, separada de quien lo produjo y de las técnicas de producción. A través de la alienación el trabajador se convierte en un engranaje, un número dentro del sistema capitalista. La doble alienación no es más es que la potenciación de la alienación capitalista. Hay pérdida del bien o servicio producido doblemente, cuando presta servicios para el prestador, que vende este bien o servicio al tomador.

1018 "Pero, por otra parte, este mismo desarrollo capitalista realiza otra transformación en la naturaleza del Estado. El Estado actual es, sobre todo, una organización de la clase capitalista dominante. Si él se impone a sí mismo, en el interés del desarrollo social, es únicamente porque y solamente en la medida en que estos intereses y el desarrollo social coinciden, de una manera
} 
Incluso siendo fruto de un supuesto proceso comunicativo, las normas de protección al trabajo siguen la senda del interés del capital ${ }^{1019}$, que utiliza, en el espacio de la norma, el ser humano como medio, teniendo como límites la propia razón comunicativa gestora del proceso, sin permitir la doble alienación o la contratación mediante la intermediación de terceros, norma ésta que va más allá del proceso legítimo de legislación establecida.

Donde no hay democracia, fruto del proceso comunicativo, no hay derecho. Fuera de la acción comunicativa, se encuentra la dictadura, que es el noderecho. ${ }^{1020}$

Sólo la actuación orientada a la comprensión justifica los patrones mínimos de convivencia pacífica dentro de los límites del Estado. Sin embargo, el Estado limita al ser en el mundo. Estas limitaciones están o al menos se deben hacer presentes a todos, sin excepción. Si a unos se les da el derecho de subordinar, a los subordinados se les da el derecho de ser mínimamente subordinados, observando los exactos límites de la norma que, en el caso de Brasil, no prevé la subcontratación y tampoco la interpretación, todo eso hará posible la diferenciación entre la actividad-medio y la actividad-fin.

Lo cierto es que la norma legal, fruto del proceso democrático, y que aborda la cuestión laboral, no es más que algo que mantiene el orden establecido. Nunca dejará de ser capitalista un país que tiene una legislación laboral protectora, ya que esta legislación acaba por reformar el capitalismo en lugar de superarlo. Por

general, con los intereses de la clase dominante. La legislación obrera, por ejemplo, se hace tanto en interés de la clase capitalista, como de la sociedad en general. Pero esta armonía no dura sino hasta un cierto punto del desarrollo capitalista". (LUXEMBURGO, Rosa, Reforma ou revolução?, São Paulo; Editora Expressão Popular, 4a edição, 2005, p. 45/51).

1019 Rosa Luxemburgo añade a este respecto, que "al mismo tiempo la propiedad privada se convierte cada vez más en una forma de explotación capitalista abierta del trabajo ajeno, y el control del Estado se impregna cada vez más de los intereses exclusivos de la clase dominante" (LUXEMBURGO, Rosa, Reforma ou revolução?, cit., p. 57).

${ }^{1020}$ HABERMAS, Jürgen, Direito e democracia: entre facticidade e validade, Rio de Janeiro, Editora Tempo Brasileiro, volumes I e II, 2003. 
ello, la forma de interpretación debe ser restrictiva, o en los términos exactos permitidos por el propio orden jurídico para la acción estratégica, teniendo aún como base así la razón comunicativa.

Surge, también, el deber de interpretar la norma teniendo como base la razón comunicativa $^{1021}$. Si el capitalismo legisla en su propio beneficio pero, aún así, estas normas son fruto del proceso democrático, por tanto presumiblemente comunicativo, la aplicación de las mismas se fundamentan también en la razón comunicativa de la que parten, autorizando, por tanto, sólo una interpretación restrictiva y en beneficio de quien es utilizado como medio, en el caso concreto, el trabajador subordinado.

La finalidad del artículo 7º̣, I, de la Constitución brasileña de 1988 puede que sea la de garantizar la lógica capitalista. Con todo, si lo consideramos fruto del proceso comunicativo en su aplicación al caso concreto, que el espacio para la relación de empleo sea restringido, se acaba vinculando el trabajador directamente a quien explote su plusvalía o le cosifica. La doble alienación o cosificación sólo lo hace aún más medio que lo que es, alejándose de la Carta Magna de 1988. Ello nos lleva a concluir que la "súmula" 331 del Tribunal Superior del Trabajo puede considerarse como "norma" inconstitucional, así como las demás que prevén la subcontratación.

Para K. Marx, en el momento en el que se pasa a la realidad capitalista el trabajador pierde el contacto con los bienes y los medios de producción ${ }^{1022}$. Pierde

\footnotetext{
1021 Rosa Luxemburgo, cuando se ocupa de la reforma y/o de la revolución, hace referencia a aquellos que defienden las reformas legales y/o legislativas: "(...) partiendo de las concepciones políticas del revisionismo, la conclusión es la misma a la que se llegó partiendo de sus teorías económicas, es decir, que en el fondo, no tienden a la realización del orden socialista, sino únicamente a la reforma del orden capitalista, no a la supresión del asalariado, sino a la disminución de la explotación, en resumidas cuentas a la supresión de los abusos del capitalismo y no del propio capitalismo". (LUXEMBURGO, Rosa, Reforma ou revolução?, cit., p. 97).

1022 "Uno de los supuestos del trabajo asalariado y una de las condiciones históricas del capital es el trabajo libre y el libre intercambio de trabajo por dinero, con el objetivo de reproducir el dinero y valorarlo; del trabajo que es consumido por el dinero - no como valor de uso para el que disfruta, sino como valor de uso para el dinero. Otro supuesto es la separación del trabajo libre de las condiciones objetivas de su realización - de los medios y del material del trabajo. Esto significa,
} 
el contacto en primer lugar con la tierra, comenzando a ser la mano de obra utilizada en la industria o incluso en el campo. Lo que el trabajador mantiene, por el modo de producción capitalista, es sólo su trabajo, vendiendo su energía al tomador del trabajo que la vende a terceros, en forma de mercancía, por un precio más alto de lo que está pagando.

Todo esto está intermediado por el dinero que, en el modo de producción capitalista, se convierte en el núcleo de la propiedad ${ }^{1023}$ y la principal mercancía, puesto que intermedia el cambio de mercancía, generando no sólo el valor de uso (pre-capitalista) sino también el valor de cambio. En este proceso el trabajador es un medio, con el fin de que el dinero se convierta en un fin en sí mismo, para enriquecer a las clases más ricas y detentadores de este mismo capital.

Dentro de esta lógica, un poco amaestrada por los denominados derechos humanos por el Estado Democrático de Derecho, se generó el artículo 7º, I, de la Constitución brasileña de 1988. Así mismo, se presume que el proceso de formación de este Estado brasileño y que dio origen a esta disposición legal, fue fruto de la acción comunicativa. No podemos olvidar tampoco el modo de producción y los espacios dados por el proceso comunicativo a la acción estratégica.

Reforzando lo anteriormente expuesto, Marx afirma que en la sociedad burguesa "el trabajador existe sólo subjetivamente, sin objeto; sin embargo, a lo que se 'enfrenta' se ha convertido, ahora, en una 'verdadera entidad común' que él

principalmente, que el trabajador debe ser separado de la tierra como su laboratorio natural significa la disolución tanto de la pequeña propiedad libre como de la propiedad comunal de la tierra asentada sobre la comuna oriental". (MARX, Karl, Formações econômicas pré-capitalistas, Tradução João Maia, São Paulo, Editora Paz e Terra, 2006, p. 65).

1023 "La propiedad, por lo tanto, significa que pertenece a una tribu (sociedad) (por tener su existencia subjetiva/objetiva dentro de ella) y, a través de la relación de esta comunidad con la tierra, con su cuerpo inorgánico, es la relación del individuo con la tierra, con la condición externa primaria de producción - porque la tierra es, al mismo tiempo, la materia prima, el instrumento de trabajo y fruto - como las precondiciones correspondientes a su individualidad, como su modo de existencia". "Reduzimos esta propriedade ao relacionamento com as condições de produção". MARX, Karl, Formações econômicas pré-capitalistas, cit., p. 86. 
trata de devorar y por la cual es devorado"1024. Es decir, él sólo es un instrumento, un medio para el autor alemán, esto bajo la lógica capitalista.

Marx afirma que "para el capital el trabajador no constituye una condición de producción, sino sólo el trabajo lo es. Si éste puede ser ejecutado por la maquinaria o, incluso, por el agua o por el aire, tanto mejor. $Y$ el capital se apropia no del trabajador sino de su trabajo - y no directamente, sino a través de cambio". ${ }^{1025}$ En este pasaje de Marx está el núcleo que acabamos de exponer. El trabajador es sólo un instrumento dentro del engranaje capitalista. Instrumento porque de él se obtiene el trabajo, que es lo que importa. Cuestiones de dignidad, existencia, aunque importen a la persona, son despreciadas por el capitalismo. Sin embargo, en una sociedad que se define democrática, cuyo proceso de formación de las leyes se presume comunicativo y que respeta los derechos humanos, una sociedad centrada en un Estado Democrático de Derecho, el espacio para uno de sus miembros o incluso una clase o categoría de los mismos ser utilizado como un medio, debe derivar del proceso comunicativo de formación de la norma.

El espacio para la acción estratégica debe estar autorizado por la norma legal e, incluso ahí, debe tener como modelo las acciones de coordinación y comunicación, que requieren la mínima reducción del ser humano a una cosa. Es por esta razón, por supuesto, que una vez autorizada la relación de empleo, tal como establece Marx, se debe utilizar en los estrictos límites de la norma, con alienación simple y sin ampliación de efectos, con el fin de que se preserve la lógica de comunicación inserta dentro del proceso constitucional de formación de las leyes.

El proceso que permite utilizar al trabajador como un medio, sin mayores límites no conduce a la emancipación, uno de los principales objetivos del Estado Democrático de Derecho. Ni siquiera conduce a la información, y menos aún a una

\footnotetext{
${ }^{1024}$ MARX, Karl, Formações econômicas pré-capitalistas, cit., p. 91.

1025 MARX, Karl, Formações econômicas pré-capitalistas, cit., p. 93.
} 
etapa posterior como sería la de hacer al ser humano ciudadano y agente de transformación de la realidad personal y social. Tomada literalmente la interpretación del artículo $7^{\circ}$, I, de la Constitución brasileña de 1988, de que basta el reconocimiento de vínculo de empleo por parte del prestador que cumple con el requisito constitucional, estaría autorizando, por ejemplo, la pena de muerte, ya que los que creen en el alma, saben que ella jamás muere ni puede ser suprimida por los seres humanos.

Marx subraya el papel del dinero en el proceso de cosificación del trabajador. ${ }^{1026}$ Es entonces cuando el trabajador se convierte en una pieza. Y así sigue siendo hoy en día, incluso en un estado democrático de Derecho. Por eso las normas deben tener en cuenta eso. El ser humano como ser en el mundo para la felicidad, la independencia y la emancipación, fruto de sus acciones y de la reducción mínima a la condición de cosa.

Marx también apunta que la separación del trabajador de los bienes y los medios de producción estimula la transformación del dinero en capital y aumenta así el valor de cambio. ${ }^{1027}$ El trabajador, por lo tanto, se separa de los medios de producción, lo que genera el capital y el proletariado. La transformación del dinero en capital, apunta Marx, implica este proceso histórico que separó al trabajador de los medios de producción o de las condiciones objetivas de trabajo, volviéndose,

\footnotetext{
1026 "El dinero, en sí, aunque participe en el proceso histórico, lo hace sólo, en la medida en que es, él mismo, un agente extremadamente poderoso de disolución que interviene en el mismo y, por tanto, contribuye a la creación de trabajadores libres, despojados, sin objetivos; pero seguramente, no porque genere para ellos las condiciones objetivas de su existencia sino más bien para acelerar su separación de las mismas, es decir, apresurar su pérdida de la propiedad". (MARX, Karl, Formações econômicas pré-capitalistas, cit., p. 103).

${ }^{1027}$ MARX, Karl, Formações econômicas pré-capitalistas, cit., p. 105. En este sentido añade Marx que "otras circunstancias ayudaron la disolución de las antiguas relaciones de producción, acelerando la separación del trabajador o del no trabajador capaz de trabajar, de las condiciones objetivas de su reproducción y, así, estimularon la transformación del dinero en capital. Tales fueron, por ejemplo, los factores que incrementaron, en el siglo XVI, la masa de mercancía en circulación, la masa circulante de dinero, creando nuevas necesidades y, en consecuencia, aumentando el valor de cambio de los productivos locales, elevando los precios, etc. nada podrá, por tanto, ser más estúpido que concebir la formación original del capital como si significara la acumulación y creación de las condiciones objetivas de la producción - alimentos, materias primas, instrumentos - que se ofrecieron, entonces, a los trabajadores alejadas de las mismas. Lo que sucedió, en realidad, fue que la riqueza monetaria ayudó, en parte, a privar de estas condiciones la fuerza de trabajo de los individuos capaces de trabajar".
} 
así, en contra del propio trabajador. Hay que tener en cuenta, advierte el filósofo, que el capital destruye el trabajo artesanal ${ }^{1028}$, tanto que, en Francia, en 1791, se creó la Ley Lee Chapelier, que prohibía la asociación de los trabajadores y las huelgas, que no fue revocada hasta $1870^{1029}$.

Volviendo a la cuestión de la interpretación de las disposiciones constitucionales brasileñas, especialmente el inciso I, del artículo $7^{\circ}$, de la CFB, debe entenderse que, fruto de un proceso presumiblemente comunicativo, esta norma legal deja espacio a la acción estratégica. Sin embargo, la manera de leer este espacio requiere un razonamiento que se podría llamar comunicativo, vinculado a la génesis de la norma, donde el otro sólo puede ser utilizado como un medio dentro de los límites estrictos del derecho, considerando, con respecto a la cuestión del trabajo, la alienación de forma directa o "simple", sin intermediación de mano de obra.

Dentro de este critério, es posible dar un carácter de emancipación a la norma legal o, por lo menos, dar menos exclusión social a la emancipación. Pero para ello es necesaria la buena reflexión, además de las bases y los conceptos que hacen del ser humano un fin en sí mismo. Además, es lo que establece la Constitución brasileña de 1988 cuando, en su artículo 1ํ, III, adopta como reglaprincipio la dignidad de la persona humana, núcleo constitucional que, al lado del trabajo y de la educación, acaban por permitir el desarrollado, la comprensión y felicidad. ${ }^{1030}$

\footnotetext{
${ }^{1028}$ MARX, Karl, Formações econômicas pré-capitalistas, cit., p. 109.

$1029 \mathrm{http}: / /$ www.assistentesocial.com.br/agora3/coutinho.doc - acceso 02 de dezembro de 2009, às $18 \mathrm{~h} 17 \mathrm{~min}$.

${ }^{1030}$ En este sentido Habermas apunta que "pienso aquí en la experiencia de la fuerza emancipadora de la reflexión, que experimenta, en sí el sujeto en la medida en que ella misma convierte, a sí misma, en transparente en la historia de su génesis. La experiencia de la reflexión se articula, en términos de contenido, en el concepto de proceso formativo; metódicamente la misma conduce a un punto de vista a partir del cual la identidad de la razón con la voluntad resulta de forma espontánea". (HABERMAS, Jürgen, Conhecimento e interesse, Rio de Janeiro; Guanabara, 1987, p. 219).
} 
Si el núcleo es la emancipación del sujeto, hecha de forma procedimental y comunicativa, fruto de un proceso presumiblemente comunicativo, la norma legal debe tener presente estos critérios de inclusión del otro. Permitir sólo que repita una lógica donde el trabajador es sólo un medio y una pieza (característica capitalista), acaba por no generar la emancipación y la independencia, objetivo mayor del ser humano en el mundo y que puede llevarlo, de una forma más facil, a la felicidad. ${ }^{1031}$

Si el interés implica necesidad, la necesidad a la que alude Haberlas se refiere a la de emancipación y de vida buena y feliz. Esta relación de vida buena y feliz debe ser utilizada dentro de estándares de lectura de la Constitución.

Y todo eso se volvió contra el dogmatismo. La reflexión es la percepción sensible y de emancipación, comprensión imperativa y liberación de la dependencia de los dogmas en una misma experiencia. El dogmatismo, que disuelve la razón en términos prácticos e incluso analíticos, no es más que una falsa conciencia. Es el error, es la experiencia aprisionada. Solamente el Yo, en el cual la intuición intelectual se considera como sujeto, que se afirma por sí mismo, adquiere la autonomía. El dogmático, al contrario, no encontrando la necesaria fuerza que lo pueda llevar a la reflexión, vive como un sujeto dependiente y cosificado, llevando una existencia no-libre, no teniendo conciencia de la propia espontaneidad reflejada. "Lo que denominamos dogmatismo no es menos un defecto moral que una incapacidad teórica: es por eso que el idealista corre el riesgo de elevarse sobre el dogmático, burlándose de él en lugar de aclararlo". ${ }^{1032}$

Así, emancipar es ser en el mundo. Dejar de lado elementos dogmáticos llevan al ser humano a alejarse de la cosificación y encontrar el camino a la

\footnotetext{
${ }^{1031}$ Sin embargo, Habermas enseña que "el interés por excelencia es aquél del bienestar que combinamos con la idea de la existencia de un objeto o una acción. El interés tiene el objetivo de existir, he aquí que se expresa una relación del objeto que interesa nuestra capacidad de deseo. El interés implica una necesidad, o entonces el interés engendra una necesidad". (HABERMAS, Jürgen, Conhecimento e interesse, cit., p. 219/220).

${ }_{1032}$ HABERMAS, Jürgen, Conhecimento e interesse, cit., p. 228/229.
} 
emancipación. Para ello, además de la preparación, debe existir el conocimiento de las reglas del mundo y del ser humano en el mundo. Cómo se comportan, lo qué son las cosas, cómo son las cosas, conocer las cosas y saber qué hacer y qué se espera de ellas. Todo ello, dentro de los límites comunicativos de la comprensión racional donde prevalezca, después de la discusión, el mejor argumento, es el desafío. Llevar esta lógica al derecho como elemento central de la justicia y de la democracia, como quiere Habermas.

Como subraya Habermas, el interés debe estar ligado a las acciones que fijan las condiciones de todo el conocimiento ${ }^{1033}$, en función de los procesos de conocimiento. "Aclaramos la interdependencia entre el conocimiento y el interés al examinar aquella categoría de 'acciones' que coinciden con la 'actividad' de la reflexión, es decir: las acciones emancipatorias. Un acto de la reflexión que 'altera la vida' es un movimiento de emancipación", concluye.

Se trata de la auto-reflexión, en lo que se conoce como jurídico, que permitirá una interpretación de la Constitución (hermenéutica) que, además, consta ordinariamente en los libros de doctrina y en la jurisprudencia. Teniendo el Tribunal Superior del Trabajo la posibilidad, a través de sus ministros, de hacer una reflexión, teniendo en cuenta la vida, la alteración de la vida y la búsqueda de la emancipación, su forma de actuar también será emancipadora y actuará presidido por la acción comunicativa, incluso en el espacio de la acción

\footnotetext{
${ }^{1033}$ Volviendo a las acciones instrumental y comunicativa Habermas afirma que "Las condiciones de la actuación instrumental y de la actividad propia de la comunicación son, simultáneamente, las condiciones de la objetividad inherente a un conocimiento posible; fijan el sentido de la validez de proposiciones nomológicas o hermenéuticas. La inserción de procesos cognoscitivos en complejos vitales llama nuestra atención para la función de intereses capaces de orientar el conocimiento: un complejo vital es un conjunto de intereses. En el nivel, en el cual la vida social se reproduce, tal haz de intereses no puede ser definido independientemente de estas formas de acciones y de las categorías correspondientes del saber. El interés por el mantenimiento de la vida está, en el plano antropológico, comprometido con una vida organizada mediante la acción y el conocimiento. Los intereses que orientan el conocimiento están, por lo tanto, determinados por dos factores: por un lado, testifican que los procesos cognoscitivos tienen su origen en conjuntos vitales y en ellos ejercen su eficacia; pero, por otro lado, a través de estos intereses se expresa igualmente el hecho de que la forma de vida, reproducida socialmente no puede ser caracterizada adecuadamente sino por el vínculo específico entre conocimiento e interés". (HABERMAS, Jürgen, Conhecimento e interesse, cit., p. 232).
} 
estratégica. Esto hará al Tribunal y su jurisprudencia más real, más cerca de la colectividad y de la humanidad. Reflejará lo que realmente quiere y lo que es el derecho, la toma de conciencia constitucional.

Interpretar la Constitución teniendo en cuenta la razón comunicativa es el camino que conduce a la emancipación del sujeto y de la colectividad. Leer las disposiciones constitucionales teniendo como modelo la emancipación originada por la acción comunicativa, permite que se interprete el citado artículo $7^{\circ}$, I, entendiendo que no es posible la subcontratación.

Sobre la base de reglas económicas, en Brasil se parte del principio de qué se puede tercerizar. Esta práctica está internalizada, es decir, forma parte de la cultura jurídica nacional, asfixiada en una realidad constitucional distante y no compatible con la presente. Esta internalización no permite la discusión de los signos y valores reales. Se parte del principio, a través de un análisis pobre de la realidad del trabajador, de que es mejor tener un empleo, aun cuando el trabajador se reduce única y exclusivamente a la cosa, que no lo tener.

El hecho de que se acepte pasivamente la tercerización tiene en cuenta el hecho de que esta forma de contratación forma parte de la vida de las personas y de que ellas dependen de esto. Se está introyetando en la mente de los brasileños el discurso de que es mejor tener un empleo que no tener nada cuando, al contrario, al no ser un trabajo tercerizado, este trabajo va a ser ocupado por un trabajador contratado de forma directa, ya que es un trabajo permanente, de acuerdo con el artículo $3^{0}$ de la consolidación de las Leyes Laborales Consolidação das Leis do Trabalho-.

Esta forma de interpretar la norma habita en la mente de las personas, sobre todo en las que, técnicamente, deberían velar por el cumplimiento de la norma legal, como los jueces y quienes aplican la ley. Los motivos que justifican esta precarización derivan de lo económico, que comienza a dominar el mundo de la 
vida, creando una falsa verdad, tocando el verdadero mundo del ser, mundo de la vida, centrado en los derechos fundamentales y en la dignidad humana, permitiendo que se utilice al otro sólo como un medio, sin tener en cuenta los límites constitucionales que permiten la acción estratégica, ésta de forma restrictiva.

A través de símbolos lingüísticos, las comunicaciones se propagan de forma histórica. Habermas llama histórico este proceso, porque "la continuidad del origen sólo se preserva a través de la tradición, a través de una filología en grandes líneas que se realiza de una manera natural". La intersubjetividad de la comunicación en el lenguaje corriente se rompe y necesita ser reconquistada de nuevo, de forma intermitente. "Esta realización (Leistung) productiva de la comprensión hermenéutica, efectuada, implícita o explícitamente, está ahí motivada desde el principio por la tradición, que así va progresando". La tradición no se aprende a dominar, pero sí el lenguaje por el que se transmite. ${ }^{1034}$

La comunicación lingüística entre el presente y la tradición era el evento, el acontecer y que traza su camino alrededor de la comprensión. "La experiencia hermenéutica, como auténtica experiencia, necesita asumir todo lo que le está presente. Ella no tiene la libertad para previamente seleccionar y rechazar", no pudiendo, sin embargo, afirmar una libertad absoluta en "dejar las cosas como están". ${ }^{1035}$

De ahí se puede deducir la idea de que los límites constitucionales, de formación de una Constitución, derivado de la tradición o incluso de los debates comunicativos, deben servir como base para que el intérprete diga lo que es la Constitución. Estos eventos son la propia Constitución, de manera que quien interpreta y aplica la norma no se pueda separar.

\footnotetext{
${ }^{1034}$ La manera de ser de la tradición es el lenguaje, y el "escuchar, que lo comprende, incluye su verdad en un específico comportamiento en el mundo lingüístico, en la medida en que interpreta textos". (HABERMAS, Jürgen, Dialética e hermenêutica, tradução Álvaro Valls, Porto Alegre; L\&PM Editora, 1987, p. 19).

${ }^{1035}$ HABERMAS, Jürgen, Dialética e hermenêutica, cit., p. 19/20.
} 
Si una norma constitucional establece una determinada forma de actuar, bien sea instrumental o estratégica, esta actuación debe estar guiada por su tradición y por su historia, sin dejar de lado, por tanto, que quien lo crea, lo hace a través de un medio comunicativo, donde no hay espacio sólo para las acciones mediosfines. La forma de interpretar esta actuación instrumental/estratégica, por lo tanto, es mediante la acción comunicativa, que constituye su fuente de validez. De aquí se puede concluir que, una vez garantizado por la norma, sus efectos y aplicación en el mundo práctico deben limitarse a causar el menor daño posible a terceros y a la colectividad, excluyendo también la doble alienación cuando se contrate a los trabajadores.

El lenguaje es una especie de meta-institución de donde dependen todas las instituciones sociales, dado que la acción social sólo se constituye en la comunicación del lenguaje corriente. Sin embargo, esta meta-institución del lenguaje depende de los procesos sociales que no son absorbidos por los contextos normativos. ${ }^{1036}$

De ahí se demuestra la importancia del proceso de formación de la norma legal en la aplicación e interpretación de esta norma en el caso concreto. La tradición de la formación, la historia del proceso de formación de la regla o del principio acaban por formar parte de los mismos, de manera que el jurista no puede alejarse de ellos. Son importantes los eventos creadores de la norma. Como también lo son los que fundamentan y que sustentan el debate, así como el proceso de elaboración del Estado. No se puede tolerar un Estado Democrático de Derecho donde no se busque la emancipación del sujeto, la descentralización del ego y que no tenga como modelo los derechos fundamentales y la dignidad humana. $^{1037}$

\footnotetext{
${ }^{1036}$ HABERMAS, Jürgen, Dialética e hermenêutica, cit., p. 21.

1037 Una nueva Constitución tiene un poder revolucionario. Y así sucedió en 1988, en Brasil, cuando se salió de un modelo de Constitución dictatorial, la Constitución de Brasil de 1967 y Enmienda Constitucional número 1 de 1969 que, aunque tratasen de los derechos fundamentales,
} 
La transformación en el modo de producción termina por cambiar o reestructurar la imagen de la lingüística del mundo ${ }^{1038}$.

Por lo tanto, cuando se promulgó la Constitución brasileña de 1988, el 05 de octubre, entró también en vigor el citado artículo 7ํㅡ, I. En esta disposición hay referencia expresa a los derechos de los trabajadores, entre ellos la relación de empleo, obviamente, que tienen como base el carácter revolucionario de la norma, tomando en consideración no sólo las nuevas interpretaciones, sino también las antiguas que se rigen por esta norma. Hay que tener en cuenta lo que es un Estado Democrático de Derecho y lo que representa el concepto emancipatorio de sociedad, pautada por los derechos fundamentales y la dignidad humana.

No podemos olvidar que esta norma constitucional, resultado del proceso comunicativo, también está pautada para ser interpretada teniendo como telón de fondo este proceso comunicativo. Esto se produce aun cuando este proceso comunicativo autorice la acción instrumental/estratégica, que debe seguir una patrón de interpretación restrictiva, siguiendo la senda de los derechos fundamentales y la dignidad humana.

En relación a la también citada "súmula" 331 del Tribunal Superior del Trabajo, se puede afirmar que una falsa comunicación genera un sistema de malentendidos que ni siquiera es descubierto o percibido aparentemente como un

\footnotetext{
también consagraban, principalmente esta última, las normas de seguridad nacional, concretadas por el Acto Institucional número 5. El Acto Institucional número 5 o Al 5 se hizo famoso en el Brasil dictatorial por justificar las prisiones políticas. Basándose en el mismo, los militares, además de cerrar el Congreso Nacional, comenzaron a perseguir a los enemigos del régimen, es decir, a aquéllos que se oponían al gobierno de los uniformes. Fueron tiempos de sombra. Pocos intelectuales optaron por quedarse. Brasil, coloreado por el sol y por el carnaval, se puso gris...

1038 " (...... Una transformación de los modos de producción conlleva una reestructuración de la imagen lingüística del mundo. Eso puede ser estudiado, por ejemplo, en la ampliación del terreno profano en sociedades primitivas. No hay duda de que revoluciones en las condiciones de reproducción de la vida material son, a su vez, medidas lingüísticamente; pero una nuevo procedimiento no es puesto en marcha sólo por una nueva interpretación, y sí antiguos modelos de interpretación vienen a ser también 'de abajo hacia arriba', alcanzados por un nuevo procedimiento y revolución". (HABERMAS, Jürgen, Dialética e hermenêutica, cit., p. 22).
} 
falso consenso ${ }^{1039}$. De ahí se puede ver que los juegos del lenguaje y la actuación de los magistrados del Tribunal Superior del Trabajo, cuando elaboraron la "súmula", en realidad, tenían como modelo un derecho constitucional que ya no estaba en vigor. La "súmula", en su primera redacción, es de $1993^{1040}$, por tanto cinco años después de la promulgación de la Constitución brasileña de 1988.

En el caso de la redacción de la "súmula" 331 del TST, los conceptos constitucionales utilizados fueron los anteriores a la Constitución vigente pero que, debido a la falta de comunicación y estrecha relación con el nuevo modelo constitucional, acabaron por servir de base a toda la jurisprudencia brasileña en materia de subcontratación. El Tribunal Superior del Trabajo se desvinculó de la tradición y de la historia. Dejó de lado los debates legislativos de 1988 y se orientó por la jurisprudencia que ratifica o mantiene vigente la norma constitucional anterior.

Hay que tener en cuenta que la falsa comunicación puede ser resultado de una falsa racionalidad, donde las cosas parecen racionales fruto del proceso comunicativo pero no lo son. La comunicación, para no pecar por esta falsedad, debe estar exenta de violencia, sin que se pueda distorsionar. Una falsa apariencia de verdad es lo que surge con la lectura de la "súmula" 331 del Tribunal Superior del Trabajo. Ello obedece a que los magistrados del Tribunal, cuando formularon el enunciado jurisprudencial en cuestión, tenían como modelo una

\footnotetext{
${ }^{1039}$ HABERMAS, Jürgen, Dialética e hermenêutica, cit., p. 42.

1040 Redacción original (revisión de la 'Súmula' oㅜ 256) - Res. 23/1993, DJ 21, 28.12.1993 y 04.01.1994

№ 331 - I - La contratación de los trabajadores por empresa interpuesta es ilegal, formándose el vínculo directamente con el tomador de los servicios, salvo en el caso del trabajo temporal (Ley no 6.019, de 03.01.1974). II - La contratación irregular de trabajador, a través de una empresa interpuesta, no genera un vínculo de empleo con los órganos de la Administración Pública Directa, Indirecta o Fundacional (art. 37, II, de la Constitución de la República).

III - No forma un vínculo de empleo con el tomador la contratación de servicios de seguridad (Ley no 7.102, de 20.06.1983) y de mantenimiento y limpieza, así como la de los servicios especializados ligados a la actividad-medio del tomador, siempre que sea inexistente la personalidad y la subordinación directa. IV - El incumplimiento de las obligaciones laborales, por parte del empleador, implica la responsabilidad subsidiaria del tomador de los servicios, en cuanto a aquellas obligaciones, siempre que hayan participado en la relación procesal y consten también del título ejecutivo judicial.
} 
tradición superada por el proceso comunicativo de la Constitución brasileña de 1988. No estaban, por tanto, atados a la historia democrática brasileña, repitiendo una noción falsa de los hechos presentes, consecuencia de la falsa comunicación con los conceptos modernos de democracia y formación estatal.

Ello hace perpetuar los malentendidos, que los antiguos llamaban "ceguera", aun cuando aparentan un acuerdo fáctico y una relación directa entre la acción y el lenguaje. Eso distorsiona la comunicación y el lenguaje corriente ${ }^{1041}$, creando una especie de tangente. Se llega a un mundo irreal con apariencia de verdadero, mejor y feliz. De ahí la necesidad del análisis de los conceptos constitucionales: Estado Democrático de Derecho, derechos fundamentales y dignidad humana, todos ellos fruto del proceso comunicativo que dio origen a la Constitución. De ahí también la pertinencia, si está autorizado, por la norma constitucional, de la acción instrumental/estratégica, que hace posible otra lectura: el proceso comunicativo que legitima el Estado Democrático de Derecho, la supremacía de los derechos fundamentales y la dignidad humana, que desembocan, sin duda, en la emancipación del sujeto.

Por lo tanto, se puede decir que el consenso, fruto del proceso comunicativo, que crea la Constitución, también crea la posibilidad de la acción instrumental/estratégica. Esta última forma de acción, aunque autorizada, para ser permitida, depende de la acción que la fundamenta y que crea la Constitución, que es aquella fruto del proceso comunicativo, de la comprensión y de la intersubjetividad, donde el discurso racional impera y donde vence el mejor argumento. Para permitir la acción instrumental/estratégica, por supuesto, se escogen cuidadosamente sus hipótesis de incidencia. Cualquier ampliación de esta regla de excepción, si choca con la norma constitucional crea, dentro del derecho, una no norma o una imposibilidad de aplicación.

${ }^{1041}$ HABERMAS, Jürgen, Dialética e hermenêutica, cit., p. 63. 


\subsubsection{Hermenéutica, dialéctica e historia.}

Para aclarar aún más el sentido del texto, conviene recordar que la hermenéutica filosófica investiga la "competencia interactiva de los hablantes adultos desde el punto de vista de como un sujeto capaz de lenguaje y de acción puede comprender (sich verständlich macht), en un ambiente extraño, manifestaciones o expresiones incomprensibles". La hermenéutica se preocupa o se ocupa de la interpretación como una realización excepcional, y que se hace necesaria cuando relevantes sectores del mundo de la vida se vuelven problemáticos, cuando certezas culturalmente ensayadas "se rompen y los medios normales de la comprensión fallan". ${ }^{1042}$

Partiendo de esta lógica pretendemos defender la "inconstitucionalidad" que establece la "súmula" 331 del Tribunal Superior del Trabajo. Y para llegar a esta conclusión, es necesaria la ayuda de la hermenéutica filosófica, que tiene como objetivo reconstruir los caminos rotos en la comunicación en el tiempo de la acción del ser humano en favor de la comprensión libre de la violencia.

Una comunicación puede ser disturbada cuando algunas de sus condiciones lingüísticas, que apuntan a una comprensión directa entre al menos dos individuos de la interacción, no se cumplen. Por ejemplo, el caso de un texto transmitido por la tradición. "El intérprete parece inicialmente comprender las proposiciones del autor, pero seguidamente hace la experiencia inquietante de no comprender el texto tan bien como para poder eventualmente 'contestar' correctamente a las preguntas del autor". El intérprete recibe esto como un indicio de que erróneamente sitúa el texto "en 'otro' contexto y de que ha comenzado por otras cuestiones que no son las del propio autor". ${ }^{1043}$

\footnotetext{
${ }^{1042}$ HABERMAS, Jürgen, Dialética e hermenêutica, cit., p. 63.

1043 HABERMAS, Jürgen, Dialética e hermenêutica, cit., p. 87/88.
} 
Podemos decir que el intérprete, cuando se enfrentó con la Constitución brasileña de 1988, fruto de un proceso comunicativo y que le da validez, siguió interpretándola conforme lo hacía durante la vigencia de la Constitución anterior, no partiendo, por tanto, de las cuestiones planteadas por el nuevo orden, sino de otras, extrañas al ordenamiento jurídico vigente. El intérprete se aleja de los autores del nuevo orden constitucional. Se separa de su historia y considera irrelevantes los debates que han dado origen a la nueva Carta constitucional, sin tener en cuenta el hecho de que están vinculados, ahora, a un Estado Democrático de Derecho, a las normas de derechos fundamentales y al megaprincipio de la dignidad humana.

El intérprete sólo va a descubrir el sentido de un texto cuando descubra porqué el autor del texto lo creó, presentando determinadas afirmaciones como verdaderas, reconociendo determinados valores y normas como correctos y exteriorizando determinadas experiencias como sinceras. ${ }^{1044}$

De este contexto de elementos cognoscitivos, morales y expresivos del legado cultural del saber, el autor y sus contemporáneos realizan sus interpretaciones, pudiendo aclarar el sentido del texto. Por otro lado, el intérprete nacido años más tarde no puede identificar estos supuestos si no toma posición con respecto a las pretensiones de validez vinculadas al texto. ${ }^{1045}$ Esta vinculación histórica es la que permitirá una lectura constitucional dirigida a los derechos fundamentales y a la dignidad humana. De otro modo, se depreciará todo lo que fue pensado y hecho durante los debates en la Asamblea Nacional Constituyente.

"El intérprete, mientras no esté en condiciones de explicar las razones que el autor habría podido mencionar en las debidas circunstancias", no puede

\footnotetext{
1044 "El intérprete tiene que aclarar para sí el contexto que tiene que haber sido asumido por el autor y por el público contemporáneo como un saber común, para que por aquel entonces no necesitasen aparecer aquellas dificultades que hoy el texto nos presenta, y para que pudiesen aparecer entre los contemporáneos 'otras' dificultades, que para nosotros, inversamente, parecían triviales". (HABERMAS, Jürgen, Dialética e hermenêutica, cit., p. 89).

${ }^{1045}$ HABERMAS, Jürgen, Dialética e hermenêutica, ibidem.
} 
comprender el contenido y el significado de un texto ${ }^{1046}$. El intérprete tiene el deber de entender el texto que lo vincula a la tradición y a la historia. Si no presenció o se no se enteró de los debates en el momento en el que sucedieron, en materia constitucional, el propio intérprete debe buscar en la doctrina o incluso en las informaciones de la época, tradición, historia y cultura, para obtener sus conclusiones.

Para permitir la interpretación de la norma en cuanto a este texto, se necesitan ciertas actitudes. La primera de ellas es un debate racional, cuyo procedimiento acepte los argumentos, sin que haya ningún vicio o violencia, venciendo el mejor y más bien fundamentado. Lo que va a justificar la victoria de un argumento es la dialéctica, la contradicción venida de otros argumentos. Esta dialéctica legitimará el discurso. Esta actuación íntersubjetiva, por otro lado, acerca el ser humano a la verdad, a la corrección y a la sinceridad. Lo que es resultado de la acción comunicativa (por tanto racional) es verdadero, correcto y sincero. Estas bases fundamentan el orden constitucional establecido y es a partir de las mismas como se deben trazar los marcos y caminos de una interpretación de la Constitución.

La intersubjetividad procedimental, derivada de la acción comunicativa, hace de todos los miembros de la sociedad verdaderos agentes legisladores y transformadores. La emancipación, la descentralización del ego, que progresa hacia una intersubjetividad donde uno reconoce en el otro el propio yo, permite que se creen conceptos de conducta que podrán llevar a la emancipación del ser. Además de la hermenéutica filosófica, en la dialéctica es esencial la presentación de los verdaderos sentidos de los actos del habla y de la comunicación, especialmente en situaciones difíciles. Ambas legitimarán el procedimiento constitucional y traerán la respuesta correcta a las preguntas elaboradas por los juristas.

${ }^{1046}$ HABERMAS, Jürgen, Dialética e hermenêutica, cit., p. 89/90. 
Aunque no se describan explícitamente los procedimientos que se deben adoptar, identificándolos con una u otra corriente filosófico-doctrinal, la dialéctica y la hermenéutica constituyen las vías sobre las cuales gira el debate actual sobre "la cuestión del método como instrumento de producción de racionalidad, a través de la convergencia entre filosofía y ciencias humanas, se desarrolla en una esfera que trasciende la fragmentación de los procedimientos científicos en general". Es posible desarrollar una cuestión filosófica a través del análisis de las relaciones, de las diferencias y "del universo común del pensamiento crítico-dialéctico y de la hermenéutica filosófica". ${ }^{1047}$

Los dos métodos (dialéctico y hermenéutico) ${ }^{1048}$ se relacionan "a través de un contacto que no se constituye al modo de fundante y fundado. Básicamente los dos métodos se presentan, como ningún otro, con una pretensión de universalidad. Pretensión que puede ser entendida como el deseo de constituir el punto de partida y el eje fundamental de las posiciones filosóficas". Pueden ser considerados, simplemente, también, como método de trabajo, que afirma la superposición entre el método y la cosa, moldeándose a una cierta especie de discurso en el que la justificación de las proposiciones está hecha de manera circular. $^{1049}$

1047 STEIN, Ernildo, "Dialética e hermenêutica: uma controvérsia sobre método em filosofia". Em HABERMAS, Jürgen, Dialética e hermenêutica, tradução Alvaro Valls, Porto Alegre; L\&PM Editora, 1987 , p. 99.

1048 "(....)los dos métodos, el dialéctico y el hermenéutico, y las dos posiciones filosóficas que se manifiestan en él, encuentran su estatuto teórico en la referencia con esta polaridad de la reflexión. Pero esta polaridad no sólo hace compatibles el método crítico y el método hermenéutico. Ella ha instaurado, desde siempre, una proximidad entre ambos. De tal manera que uno no puede operar sin el otro. Por consiguiente, tanto en la filosofía crítica como en la filosofía hermenéutica, el ideal de la reflexión aparece como la búsqueda de la racionalidad. Sólo la reflexión crítica acentúa la diferencia, el contraste y la reflexión hermenéutica acentúa la identidad. El método crítico se presenta básicamente como un instrumento para detectar la ruptura del sentido, como el método hermenéutico busca en los muchos sentidos la unidad perdida. Esta estructura ambivalente de la razón humana como reflexión fundamenta, o al menos justifica, la pretensión de universalidad tanto de la crítica como de la hermenéutica". (STEIN, Ernildo, "Dialética e hermenêutica: uma controvérsia sobre método em filosofia", cit., p. 103/104).

1049 STEIN, Ernildo, "Dialética e hermenêutica: uma controvérsia sobre método em filosofia", cit., p. 107/108. En este sentido "el método dialéctico, como también el método hermenéutica, trabajan sobre un plan en el que hay propiamente sólo el hombre. Por supuesto, una tal reducción del espacio de la teoría trae consigo también nuevas posibilidades de una ampliación de la producción de racionalidad desde la integración y de la convergencia entre filosofía y ciencias humanas, convergencia que sustituye la seudo-racionalidad y transparencia de un tipo de discurso que parte 
No se puede defender que la dialéctica pueda ser comprendida sin el recurso a la hermenéutica. La dialéctica no será entendida en su profundidad sin los recursos hermenéuticos. Por lo tanto, para el proceso de liberación del hombre por el diálogo y de la interacción, es necesario recurrir a la hermenéutica y a la dialéctica. Cabe destacar que "sin la participación efectiva de todos en la elaboración de las instituciones, éstas siempre se convierten en estructuras de violencia y dominación". Si existe un ideal filosófico y que afirma estos análisis de la ideología, este ideal es descubrir, en la historia, "todos los rastros de violencia y de dominación que sofocan el diálogo e impiden la comunicación en la mayoría de los grupos humanos". ${ }^{1050}$

Y así, Stein sostiene que "considero la ideología como absolutamente necesaria como el medio de identificación de los grupos con un determinado sentido moral y político. A través de la ideología se realiza la adhesión a determinados comportamientos que empiezan a definir las funciones de grupos dentro del contexto social". Y a la autocrítica delega el papel de relativizar la adhesión a la ideología. Si esto no existe, la crítica y la relativización deben ser socializadas por los intelectuales y por la reflexión filosófica. Es la filosofía quien tendrá el papel de destruir las falsas identidades, y de "desmoralizar y despolitizar los comportamientos ideológicos, en la medida en que se crispan y dogmatizan".

de dos supuestos excluidos del campo hermenéutico y del campo dialéctico: el punto de partida del mundo natural o el punto de partida del mundo teológico". Es necesario que se perciba las consecuencias de este gesto filosófico. Recusa la totalidad de la tradición metafísica por un lado. Por otro, introduce una idea de totalidad que se hace en el propio proceso, operada dentro del trabajo teórico, que no se finaliza o completa. "Esta totalidad, como ella es siempre teóricopráctica, se repone en cada momento del esfuerzo teórico y permanece una especie de horizonte regulador en las cuestiones de la práctica. Ya no es una totalidad hipostasiada, ni tampoco una totalidad que sin duda resulta de determinaciones que van siendo progresivamente puestas hasta alcanzar la fase final". Es evidente que tanto la dialéctica como la hermenéutica no perciben el paradigma inaugurado por ellas, sino su modo de actuar como un método, lugar en el que se cruzan la filosofía y las ciencias humanas, dándoles una "autoridad epistémica capaz de dar cuenta de sus supuestos y producir niveles de racionalidad cuya legitimación se van reponiendo a través del proceso del trabajo teórico". (Ibidem, pp. 108-109).

1050 STEIN, Ernildo, História e ideologia, cit., p. 10/12. 
Stein añade que no quiere encubrir los peligros que la ideología representa dentro de los diversos grupos humanos, justificando la crítica a la ideología por parte de la Escuela de Frankfurt. ${ }^{1051}$

Por ello resulta tan necesario el recurso a la técnica de la hermenéutica y de la dialéctica. Si la ideología es necesaria para que se conozcan perfectamente los grupos presentes dentro del tejido social y la forma de actuación política y social de ellos, no menos importante es la crítica a la dialéctica, con el fin de superar los falsos conceptos e identidades, utilizando como método emancipatorio no sólo la hermenéutica sino ésta junto con la dialéctica. La autocrítica y el análisis de sí mismo y de la sociedad, a través de un proceso intersubjetivo donde el otro así como el Yo es un fin en sí mismo, conduce a la emancipación del sujeto y al desarrollo de conceptos correctos de convivencia sana, libre y feliz.

La interpretación del derecho y la discusión sobre la mejor respuesta al caso concreto, o incluso las discusiones de constitucionalidad o no de una norma jurídica, dependen de la actuación de los agentes emancipados y que se centren en una idea de acción comunicativa, dirigida, por tanto, a la comprensión, donde venza el consenso por el mejor argumento. Debe imperar la razón comunicativa incluso en situaciones en las que la propia norma, fruto del proceso comunicativo, autorice la acción instrumental/estratégica. Conociendo bien la cuestión ideológica de una sociedad se podrá, sin perder de vista la crítica a la ideología, encaminarse hacia a esta emancipación del sujeto y, por consiguiente, de la sociedad y de las decisiones judiciales.

Sólo cuando el hombre se inclina sobre su trabajo, su economía, su técnica, sobre su sociedad, su estado, su derecho, su costumbre, su educación, su

\footnotetext{
${ }^{1051}$ Es que ella (la crítica) trata de vigilar "todo el comportamiento ideológico y desenmascarar sus distorsiones, sobretodo, en tres áreas fundamentales de la actividad humana: en el trabajo, en el lenguaje y en el poder. Es ahí donde se procesan los mayores conflictos ideológicos generando racionalizaciones y defensa de intereses. La crítica ideológica trata de salvar en estas áreas de la praxis humana el verdadero nivel de comunicación capaz de deshacer las falsas identidades". (STEIN, Ernildo, História e ideologia, cit., p. 13/14).
} 
lenguaje, sus mitos, artes, religión, ciencia, filosofía, etc., se le podrá entender a través de su obra ${ }^{1052}$. Las ciencias humanas que exploran los reinos del hombre están distribuidas principalmente en tres facultades: teología, derecho y filosofía. Es en estas facultades donde se estudia absolutamente todo lo que afirma, entretiene y conduce al hombre en su historia concreta. Es en ellas donde se procesa la autocomprensión del hombre a través de su obra. Y es en estas áreas donde se lleva a cabo la interpretación concreta del ser humano y de la vida humana en el mundo. Son las áreas de la hermenéutica y que podrá haber diferentes formas conforme al campo al que se aplica, pero que trae como interacción profunda y que fomenta la comprensión del hombre. De ahí que sea la hermenéutica el método de comprensión del fenómeno ser humano y su obra. ${ }^{1053}$

Así, la era de la hermenéutica, de la interpretación, de la comprensión que se hace presente hoy en día desencadena los aspectos de la condición humana tomando un nuevo relieve. El hombre comienza a verse en el mundo de otra forma. Empieza a tener una visión diferente de su lugar en el mundo. Él ya no parte de un a priori para saber la verdad de su naturaleza y de su destino. Desde varios puntos dentro de la historia y de la cultura intenta llegar a la verdad. El hombre comienza a rechazar las soluciones definitivas y las afirmaciones intemporales y los absolutos abstractos. La hermenéutica acaba por alimentar las muchas caras de la misma verdad y desarrolla el análisis de la multiplicidad de

\footnotetext{
1052 Se objetiva en la historia concreta. "En la proporción en la que él se encamina hacia su comprensión, a través del método que alcanza su obra, el hombre abandona como valor único la abstracción y la ciencia natural y se aproxima a sí mismo por el método hermenéutico-ergológico, propio de las ciencias humanas, también llamadas ciencias de la cultura, de la historia, del espíritu". Este método, de hecho, según Stein, significa que las ciencias humanas no se entienden como construcciones teóricas. Es la mediación que trata de interpretar el trabajo del espíritu. Sorpresas, giros e incluso las irregularidades no nos permiten una sistematización rígida, lo que hace que la constitución de las ciencias del espíritu se procese aún actualmente. Tal vez un día se llegue a construir una ciencia universal comparativa del hombre y de la cultura, estableciendo en ella las diversas bifurcaciones históricas y que tendrían como primer grupo la historia, la filología, la literatura, etc. Como segundo grupo, el conjunto de las ciencias que tienen por objeto establecer los principios como la teoría comparada del lenguaje, la teoría comparada del derecho y etc., y que descubren un universo común de categorías y conceptos. Un tercer grupo tendría las disciplinas filosóficas, que estudiarían los campos específicos de la ciencia del espíritu como la filosofía de la religión, la filosofía del derecho, la filosofía de la historia, la filosofía de la cultura y etc. (STEIN, Ernildo, História e ideologia, cit., p. 19).

${ }^{1053}$ STEIN, Ernildo, História e ideologia, cit., p. 18.
} 
estas caras. El hermeneuta no absolutiza los puntos de vista, sino que prueba la verdad en situaciones concretas, buscando la universalidad inherente a su interpretación. ${ }^{1054}$

La hermenéutica va a sostener la tensión de la historia, porque el hombre es esencialmente histórico. La temporalidad radical del ser humano es la historicidad. Esta historicidad brota del pasado, del presente y del futuro, las tres dimensiones del tiempo. El tiempo de la historicidad surge del futuro. Porque el hombre es un ser para la muerte que regresa al pasado y se ocupa del presente. Ante la total imposibilidad de cualquier posibilidad, la muerte, el hombre recoge en el pasado las posibilidades de su poder-ser, tratando de concretarlas en el presente. Este espacio de tiempo es su historicidad y tiene una linealidad aparente, "pero que en sí misma está compuesta de movimientos totales en que el todo de la existencia es asumido como futuro, pasado y presente". ${ }^{1055}$

Es el propio pasado que juzgamos lo que da su color al juicio del hombre en cada momento. El hombre está envuelto en las cargas de la tradición cuando interpreta la tradición, de manera que la historia como pasado pesa sobre este mismo hombre, incluso cuando considera que haya actuado de forma libre. Es la propia tradición quien lo afirma. Solamente cuando el hombre tiene la plena conciencia de la acción de la historia sobre sí mismo es cuando puede conocer su situación en la historia. De ahí se puede decir que la conciencia que el ser humano tiene en cada momento es el resultado de la acción de la historia. ${ }^{1056}$

La conciencia que se tiene en cada momento es el resultado de la acción de la historia. Se puede, por otro lado, hablar de una conciencia de la acción de la historia. Esta conciencia es determinada por la acción de la historia y puede

\footnotetext{
${ }^{1054}$ STEIN, Ernildo, História e ideologia, cit., p. 21/23.

1055 "La muerte como límite, como última posibilidad, hace que el hombre explore su poder-ser y trate de realizar las posibilidades que le son dadas en el espacio de tiempo de su historia. El regreso al pasado no es más que la búsqueda de las posibilidades que me fueron dadas con mi hecho de ser, con mi nacimiento". (STEIN, Ernildo, História e ideologia, cit., p. 28).

${ }^{1056}$ STEIN, Ernildo, História e ideologia, ibidem.
} 
asumir, lúcidamente esta acción mientras determina al ser humano o lo limita. Y la finitud de esta comprensión resulta de la inmersión del ser humano en el movimiento de la historia, de la imposibilidad de una distancia que lo retire de la historia sobre la cual él piensa y medita. ${ }^{1057}$

La hermenéutica, como una ventana abierta a la historia del hombre, aproxima el hombre a la verdad. Es aquella verdad vinculada a la tradición y a la historia del hombre la que se hace evidente desde un análisis hermenéutico. Vinculado a su historia el hombre hace el presente, siempre teniendo como objetivo el futuro.

De ahí que cuando afirmamos la posibilidad de la tercerización, en realidad, se cierra esta ventana en la historia del hombre y se deja la hermenéutica de lado, para vincularla a las falsas verdades que se escapan de la verdad histórica del ser humano. Si el proceso comunicativo de formación de la Constitución, y que evidentemente es fruto de la historia de la sociedad presente, decidió atribuir como derecho de los trabajadores la relación de empleo, es evidente que, con el fin de reservar la tradición histórica (vínculo de empleo) y de proyectar el futuro (sociedad libre, justa y solidaria ${ }^{1058}$ ), no se puede aceptar la doble alienación, no se puede tolerar una doble explotación de la plusvalía sobre un trabajador.

Este elemento permite defender, con razón, la inconstitucionalidad de la contratación por intermediación de la mano de obra, teniendo como base la Constitución brasileña de 1988, artículo 7ํㅡ, I, sin dejar de lado el aspecto filosófico/histórico. Si las "súmulas", en el caso concreto la "súmula" 331 del TST, aseguran el conocimiento y alejan los juristas del proceso histórico, es la lectura histórica de la Constitución que permitirá las decisiones judiciales más vinculadas

\footnotetext{
1057 "La ingenuidad ante la historia, como acontecer concreto, desaparece en la medida en que asumimos lúcidamente la acción de la historia, como un elemento decisivo que nos limita y nos obliga a asumir nuestra finitud frente a la comprensión de la historia". (STEIN, Ernildo, História e ideologia, cit., p., 30).

${ }^{1058}$ Art. $3^{\circ}$ Constituyen objetivos fundamentales de la República Federal de Brasil: I - construir una sociedad libre, justa y solidaria; (...).
} 
al objetivo del ser humano en el mundo que es la felicidad, el amor y el placer de estar vivo.

Es esta unión entre la dialéctica y la hermenéutica la que va a permitir que, a través del lenguaje y lejos de esta dominación, se llegue a un consenso sobre lo que se puede o debe hacer. Si la sociedad comienza por la Constitución, fruto del proceso comunicativo, los lazos del lenguaje que derivan de la Carta Magna deben ser interpretados con el fin de conocer cuál es la voluntad del legislador, sin dejar de lado todos los argumentos, tanto los utilizados en la elaboración de la norma constitucional, como aquellos posteriores a la misma que tienen como objetivo la interpretación de la propia norma.

A partir de ahí, el agente operador del derecho va a decir lo que es el derecho y cuál el alcance de una determinada disposición, teniendo siempre como modelo la acción comunicativa de la génesis del proceso constitucional así como la aplicación de la eventual acción instrumental autorizada por el proceso democrático constitucional.

Por tanto, la acción del intérprete debe tener como base la acción comunicativa, incluso en situaciones en las que está autorizada la acción instrumental/estratégica. El núcleo de la Constitución se centra en la acción racional y para la comprensión, donde debe vencer el mejor argumento. Por esta razón, una vez autorizada la acción estratégica (relación de empleo) la misma debe ser limitada a los parámetros mínimos de simple alienación, sin que consagre la doble cosificación del hombre por el hombre. Si el sistema constitucional permite que uno utilice a otros como un medio, que lo haga de forma que minimice el riesgo de convertirse en una cosa, es decir, la alienación simple y el vínculo de empleo directo.

Por último, para Habermas, la acción comunicativa es la interacción simbólicamente mediada, orientándose según las normas de vigencia obligatorias 
y que definen las expectativas recíprocas de comportamiento y que deben ser entendidas y conocidas por al menos dos sujetos. Las acciones, por tanto, tienen en cuenta las expectativas de comportamiento sancionadas y recíprocas. ${ }^{1059}$

Por tanto, a partir de estas expectativas, que derivan de la acción comunicativa, se pueden autorizar las acciones destinadas a fines, estratégicos/instrumentales, aunque no pueden perder de vista la base que las autoriza, es decir, la interacción intersubjetiva originada en el discurso racional.

\subsubsection{La relación de empleo como concepto constitucional.}

Ferdinand Lassalle se pregunta si alguien puede plantar un manzano y colocar en su tronco un papel con el escrito "esto es una higuera". ¿Bastará este papel para transformarlo en una higuera? La respuesta es evidente. Para el autor, este folio de papel no transforma el manzano en una higuera. Aun cuando vecinos, amigos o parientes, por cuestión de solidaridad, comiencen a llamar al manzano higuera, sus frutos serán manzanas y no higos. En el mundo real, siempre será un manzano. ${ }^{1060}$

Esta es la razón por la cual, cuando la Constitución brasileña de 1988 establece que son derechos de los trabajadores la relación de empleo, adoptando este concepto de la legislación ordinaria, en el caso del artículo tercero de la Consolidación de las Leyes del Trabajo ${ }^{1061}$ que define al empleado, no se puede, sin legitimidad democrática, cambiar el concepto. No puede una "Súmula" o incluso una ley ordinaria, cambiar la definición de empleado, puesto que ésta altera la definición de relación de empleo.

${ }^{1059}$ HABERMAS, Jürgen, Técnica e ciência como ideologia, Lisboa; Edições 70, 2009, p. 59/60.

1060 LASSALLE, Ferdinand, Que é uma constituição?, São Paulo; Edições e publicações Brasil, 1933 , p. 33.

1061 Art. $3^{\circ}$ - se considera empleado a toda persona física que preste servicios de cualquier eventual naturaleza al empleador, bajo la dependencia de éste y mediante salario. 
En la el artículo $7^{\circ}$, encabezamiento de la Constitución, se consagra el no retroceso social, por lo que habría que redefinir lo que es empleado y lo que es relación de empleo. Aun cuando el Tribunal Superior del Trabajo etiquete la relación de empleo diciendo que es lo que no es, sus frutos no son lo que el tribunal piensa que son, aunque, fácticamente, haya convencido a muchos juristas.

La función de este apartado, por tanto, es llamar la atención sobre esta realidad. No se puede cambiar, aunque sea indirectamente, un concepto constitucional a través de la interpretación de los tribunales. Éstos no tienen legitimidad para hacerlo. Quien muda la Constitución es el pueblo, es éste el guardián oficial de la soberanía y es quien puede decir lo que es una relación de empleo y lo que es, en Brasil, un empleado.

Hay que reconocer que, en Brasil, existe una especie de tradición sobre esta línea de actuación. El legislador y los tribunales, transversalmente, también "revocan" la Constitución.

El caso clásico, dentro del derecho del trabajo, es el del sistema de compensación de jornadas denominado "banco de horas". Las horas extraordinarias, prestadas hasta un año, pueden ser compensadas, sin la necesidad del pago del adicional legal o normativo, dentro del mismo año. Esta modificación legislativa surgió con la ley 9.601/98 y, posteriormente, por medios de “medidas provisórias' del jefe del poder ejecutivo, de acuerdo con el artículo 62 de la CF/88 ${ }^{1062}$, para reformular el artículo 59, párrafo segundo, de la CLT. ${ }^{1063}$

\footnotetext{
${ }^{1062}$ Art. 62. En caso de relevancia y urgencia, el Presidente de la República podrá adoptar medidas provisionales, con fuerza de ley, y las someterá de inmediato al Congreso Nacional.

${ }_{1063}$ Art. 59 - La duración normal del trabajo podrá aumentarse en horas extras a un máximo de 2 (dos), mediante acuerdo escrito entre el empleador y el empleado, o mediante el contrato colectivo de trabajo. [...].§ 2o Podrá ser dispensado el añadido de salario si, mediante acuerdo o convención colectiva de trabajo, el exceso de horas en un día se ve compensado por la correspondiente disminución en otro día, de manera que no exceda, en el período máximo de un año, la suma de las jornadas semanales de trabajo previstas, ni supere el límite máximo de diez horas diarias.
} 
Esta norma legal del articulo 59, parrafo $2^{\circ}$, de la CLT, preveía, cuando de la promulgación de la Constitución brasileña, el 05 de octubre de 1988, la posibilidad de compensación de las horas extras prestadas sólo en los límites de una semana, es decir, en la misma semana, suprimiendo el trabajo en uno de los días. Se creó la clásica jornada de ocho horas y cuarenta ocho minutos con la supresión de la jornada de trabajo de los sábados.

Cuando la Constitución de 1988, en su artículo 7º XIII $^{1064}$, autoriza la adopción del régimen de compensación, lo hace sobre la base de que estaba vigente cuando se promulgó, es decir, la antigua redacción del artículo 59, párrafo segundo, de la CLT, validando y poniendo en la Constitución un concepto existente de derecho común. La modificación de este concepto, en realidad, es la modificación de la norma constitucional, lo que sólo está permitido por el poder constituyente originario (que es el caso) o derivado.

Lo mismo sucede, a nivel de Tribunal Superior del Trabajo, en cuanto a la adopción de la "súmula" 331. Este añadido de jurisprudencia repite la lógica a la que anteriormente hemos aludido en lo que se refiere al sistema de "banco de horas". La "Súmula" cambia el concepto de empleado, absorbido por la Constitución cuando habla de relación de empleo. Cuando la "Súmula" establece una división de actividad-fin y actividad-medio, sin autorización legislativa/constitucional, de forma inversa, revoca la norma de protección al trabajo que considera empleado, sujeto de la relación de empleo, quien preste trabajo no eventual, de forma permanente a terceros y mediante salario. ${ }^{1065}$

\footnotetext{
${ }^{1064}$ Art. $7^{\circ}$ Son derechos de los trabajadores urbanos y rurales, además de otros destinados a la mejoría de su condición social: [...]; XIII - duración del trabajo normal no superior a ocho horas diarias y cuarenta cuatro semanales, facultada la compensación de horas y la reducción de la jornada, mediante acuerdo o convención colectiva de trabajo.

1065 Según la nota anterior, no hay, dentro del concepto de empleado, ninguna referencia a la actividad-medio y a la actividad-fin, sino al trabajo prestado de forma permanente, no temporal. $\mathrm{Si}$ el orden del empleador viene de la producción, de la previsibilidad en la prestación del contrato, trabajo éste por cuenta ajena, ¿cómo puede una "súmula" del tribunal superior, que ni siquiera es una ley ordinaria, alterar un concepto legal, aún más cuando este concepto se refleja de forma directa en la Constitución?
} 
No se puede olvidar que, en Brasil, la interpretación de las leyes laborales tiene lastro constitucional, articulo $7^{\circ}$, encabezamiento, de la Constitución. Las alteraciones y/o interpretaciones menos favorables, pueden, como hace la "Súmula" 331 del TST, perjudicar el trabajador, lo que las hace insconstirucionales.

Es interesante decir que la mutación constitcional ${ }^{1066}$ debe ser aceptada. Pero solamente cuando tenga por norte la mejora de la condición soial de los trabajadores. No se permite el regreso social en temas de derecho del trabajo, aún más cuando hay una alteración, por decisiones de Tribunales, de conceptos constitucionales que la Constitución corrió de la ley ordinaria.

No se puede excluir a dichos trabajadores vinculados a la actividad-medio el derecho a una relación de empleo con quien se apropia de su trabajo. Además, esta es una forma de flexibilización de los derechos sociales, prohibida, conforme a lo dispuesto expresamente en la Constitución, interpretacion flexibilizadora que no tiene ningún sentido y no sigue la lógica jurídica brasileña, articulo 7, encabezamiento, de la Constitución. Es lo mismo que flexibilizarse el derecho a la vida, o el derecho a la propiedad, o la salud, a la libre expresión del pensamiento o de cátedra. Quién sabe si se deja de defender la libertad de prensa, o de reunión. Las formas indirectas de flexibilización de los derechos sociales de los trabajadores se deben evitar porque si no se lo hace, uno puede defender la revocación de aquellos derechos antes citados. $Y$ es competencia del poder judicial, además de otros, garantizar la buena aplicación e interpretación de las normas relativas a los derechos fundamentales. ${ }^{1067}$

\footnotetext{
1066 "Se considera como transación constitucional o mutación constitucional la revisión informal del compromiso político formalmente plasmado em la constitución sin alteración del texto constitucional". GOMES CANOTILLO, JJ, Direito Constitucional e Teoria da Constituição, Coimbra; Almedina. $7^{\text {a }}$. Ed., 2003, p. 1228.

${ }_{1067}$ En este mismo sentido, vid. ERMIDA URIARTE, Oscar, A flexibilização da greve. Tradução Edilson Alkimin, São Paulo; LTr, 2000, p. 14. El autor afirma que "Éste no es el momento de entrar en detalles sobre las diferencias entre la desregulación y la flexibilización; entre la desregulación y la flexibilización impuesta y negociada colectivamente; sobre los límites que la irrenunciabilidad de los derechos fundamentales imponen a la flexibilización (¿cómo podría flexibilizarse, por ejemplo,
} 


\subsubsection{Las leyes civiles y comerciales y el articulo 455 de la Consolidación de las Leyes del Trabajo.}

No se puede dejar de hacer un analisis sobre el derecho civil y el derecho comercial. Ello porque eso es necesario si uno mira los argumentos lanzados en este estudio. El derecho civil y el derecho comercial, por el concepto de propriedad privada, libertad contratual y libre-iniciativa, o mismo libertad de empresa, articulo 38 de la Constitución Española, permiten cualquier forma de contratación no prohibida por la Ley.

És por eso que los contratos civiles y comerciales deben adaptarse a lo que presenta la Constitución y la legislación laboral.

Pero antes de seguir es necesario decir lo que se entiende por empresa. Empresa es la forma de "ejercitar las libertades económicas de producción e intermediación de bienes y servicios para el mercado; esto es el sistema de organización del ejercicio profesional de la actividad económica en el mercado". Sobre el aspecto juridico la empresa es una pieza esencial del sistema económico de mercado en régimen de libertad de competencia, sujeta al principio de la eficiencia económica, sin dejar de echar una mirada en la participación social y en los límites constitucionales. ${ }^{1068}$

Si las leyes civiles y comerciales autorizan la contratación de empresas de construcción y subcontratación de empresas de construcción, contratas y subcontratas, lo hacen mirando no solamente los preceptos y normas civiles y comerciales, los derechos laborales, legales y constitucionales, porque los contratos y arreglos comerciales y civiles seran ejecutados por trabajadores. La

el derecho a la vida, a la salud, a la libre expresión del pensamiento (...) o a la justa remuneración, a la limitación de la jornada, al descanso?).

1068 MONTERO PEREZ, José Luis, "Nuevas formas de organización de la empresa, entre centralización y descentralización (y II). Teoría jurídica y modelos de regulación de la empresa". Relaciones laborales. Revista crítica de teoría y practica, 7/2011, p. 27/28. 
legislación, en este caso, debe ser conectada como un todo, y no de forma cortada. El ordenamiento jurídico es lógico y debe cerrarse en si mismo. La critica, aqui, es aplicable al concepto de tercerización e, igualmente, de descentralización productiva.

Ello es lo que si puede llamar de interpretación sistemática. El sentido del ordenamiento está en el sistema y en la interpretación que uno hace de él, como un todo. Cada norma tiene un propósito y no puede ser echada. ${ }^{1069}$

Y es por ello que la Consolidación de las Leyes del Trabajo brasileña autoriza, en su articulo $455^{1070}$, la subcontratación, en la forma de contratas y subcontratas. Pero, si la ley lo hace, estas formas de contratación deben tener en cuenta los límites de la ley laboral, y no solamente lo que preceptúan las leyes civiles y comerciales. Estos contratos deben llevar en cuenta lo que dice la ley laboral. Son limitados por la ley laboral.

De ahi se puede concluir que la Consolidación de las Leyes del Trabajo de Brasil, cuando autoriza la contratación por contratas y subcontratas, subcontratación de mano-de-obra para la realización de obras, lo hace para los casos de servicios especializados y para la mejora de la condición social de los trabajadores, conforme articulo $7^{\circ}$, encabezamiento, de la Constitución brasileña de 1988 y consonante los articulos 9e e 468, encabezamiento, de la CLT ${ }^{1071}$. Ello porque la forma de ejecución del trabajo, por los princípios y reglas constitucional

\footnotetext{
1069 FREITAS, Juarez, "L'intèrprete et le devoir de concrétiser les objectifs fondamentaux de la constitution". Em Direitos Fundamentais e Justiça, ano 2, n. 5, out/dez. 2008, HS Editora, p. $139 / 140$

1070 Art. 455 - En los contratos de subcontrata, respondera el subcontratista por las obligaciones de los contratos de trabajo que formar, cabendo a los empleados el derecho de reclamación contra el contratista principal en el caso de no pago de aquellas obligaciones por parte del primero.

${ }_{1071}$ Art. 90 - Seran nulos de pleno derecho los actos praticados con el proposito de desvirtuar, impedir o fraudar la aplicacion de los preceptos habidos em esta Consolidación.

Art. 468 - En los contratos individuales de trabajo solamente es posible la alteración de las condiciones por mútuo consenso y sin que resulten, directa o indirectamente, perjuicios al empleado, sob pena de nulidad de la clausula que viole esta garantia.
} 
y legal brasileñas, deben ser observadas por los arreglos civiles y comerciales, debiendo ser aplicadas en benefício del trabajador.

Como regla, por lo tanto, para los casos de contratación para la realización de obra, se puede subcontratar, más llevandose por cuenta la condición más benefíca al trabajador, como dicho arriba. Es por ello que no se podria, en Brasil, tercerizar (contrato de prestación de servicios solamente, concepto de tercerización propuesto en este estudio). Es que la norma legal no preve esta forma de contratación (tercerización) y exige, en los casos de subcontratación de obra, por una interpretación sistematica, la observancia de las normas laborales y interpretaciones más benefícias al trabajador, ello por el encabezamiento del artculo 7 de Constitución de 1988, que exige la mejoría de la condición social de los trabajadores.

De otro lado, uno debe saber que la ley dice más de lo que esta en su texto. Un texto dice mucho más do que pretende y menos de lo que se piensa. ${ }^{1072}$

Lo que se retira de lo que esta planteado arriba es que la norma del articulo 455 de la CLT no necesita decir que está prohibida la subcontratación o la tercerización de servicios. De este articulo uno puede deducir eso, porque las normas laborales (principios y reglas) son de protección, con previsión de nulidad cuando no se observan sus parámetros, articulo 9ํ de la CLT.

Y, de otro lado, la libertad de empresa, por ejemplo, que esta, por ejemplo, dentro de la Constitución española, no seria una libertad amplia. No se puede hablar de libertad sin igualdad. La igualdad, en el caso de la empresa, es equivalente al princípio de la maxima proximidad. O sea, si el empresario puede administrar su empresa y sus empleados, debe él, por los límites de la

1072 DUARTE, Francisco Carlos, SEVERO ROCHA, Leonel e URQUHART CADEMARTORI, Luiz Henrique, "A constitucionalização do tempo", en Direitos Fundamentais \& Justiça. Revista do Programa de Pós-Graduação Mestrado e Doutorado em Direito da PUCRS, Porto Alegre; HS Editora, Ano 4, número 12, julho/setembro de 2010, p. 143. 
Constitución, observar los objetivos de la intervención publica y participacion social, articulos 128.2 y 129.2 de la Constitución Española, lo que determina una mayor proximidad igualitária entre los agentes dentro de la empresa. ${ }^{1073}$ Ello permite, por una lectura de toda la Constitución, limitar la libertad de empresa, y adaptar las normas de derecho civil y comercial a los preceptos de justicia social y igualdad, sin grand precarización del trabajador.

Es interesante decir, para complementar y reforzar la interpretación que esta arriba que la riqueza de España, por el articulo 128.1 de la CE, está subordinada al interés general, lo que hace con que el Estado puede modular y ordenar la riqueza, como exige el interés de todos, dentro de las restriciones que implican a los derechos fundamentales. ${ }^{1074}$

Volviendo al caso brasileño, la non-eventualidad del articulo $3^{\circ}$, encabezamiento, de la CLT, nada más es do que la consagración del principio da previsbilidad de conduta y continuidad de la prestación del trabajo. Si es posible la intermediación de mano-de-obra solamente cuando existe autorización legal, artículos 9, 455 y 468 de la CLT, las demás actividades ejecutadas de forma permanente seran consideradas como de empleo, creando vinculo jurídico laboral entre el obreo y la empresa contratante.

No hay, por lo tanto, contradición entre lo que se defiende en esta tese y las normas civiles y comerciales. Estas ultimas deben adaptarse a las normas de derecho laboral (princípios y reglas), hasta porque la forma de interpretación del derecho del trabajo, en Brasil, esta en el articulo 7, encabezamiento, de la CF/88, debiendo buscar la mejoría de la condición social de los trabajadores.

\footnotetext{
1073 Sobre ello, ver también, DÍAZ DE LA ROSA, Angelica, "Reflexiones a proposito del articulo 129.2 de la Constitución española", En Anuario de la Facultad de Derecho de la Universidad de La Coruña (AFDUDC), 14, 2010, pp. 311-324.

1074 PAZ ARES, Cándido y AGILA-REAL, Jesus A., "Ensayo sobre la libertad de empresa", en http://portal.uam.es/portal/page/portal/UAM ORGANIZATIVO/Departamentos/AreasDerecho/AreaD erechoMercantil//nvestigaci\%F3n/Trabajos\%20y\%20WP/Trabajos\%20y\%20Working\%20Papers/CP A\%20y\%20JAAR\%20-\%20libertad.pdf - acceso el 27 de octobre de 2012, a las 22h01min.
} 
Es por eso que es posible la tercerización solamente en los casos en que el trabajador ejecute servicios especializados y en mejores condiciones que los empleados de la empresa tomadora del trabajo, como ocurre, normalmente, en los casos de los empleados informaticos, quedando combatida la subcontratación en los casos en que no hay mejoria de la condición social de los trabajadores, lo que lleva a un retraso social no solamente salarial, mas tambien sindical.

\subsubsection{Trabajo subordinado como tiempo de vida.}

Basta un simple análisis de la filosofía de Hannah Arendt para constatar lo que es la reproducción de la vida humana. Para ella, esta reproducción se presenta en tres formas: labor, trabajo y acción. La labor es la actividad vinculada al metabolismo del ser humano; el trabajo concierne a la reproducción material de la vida humana; y la acción, considerada la actividad humana por excelencia, se destina a la producción del bios politikos. ${ }^{1075}$

Se explica con más claridad la acción: es la única actividad que se ejerce directamente entre los hombres, sin la mediación de cosas o materia, y que corresponde a la condición humana de pluralidad. Todos los aspectos de la condición humana tienen relación con la política, pero esta pluralidad es esencialmente la condición no sólo sine qua non, sino la conditio per quam de la vida política. $^{1076}$

Continúa Hannah Arendt argumentando que para los griegos de la Antigüedad Clásica la acción es prerrogativa sólo de los hombres, excluyendo a los animales y los dioses. Mediante la palabra que los griegos se insertaban en el mundo del ser humano, significando, esta inserción, un segundo nacimiento de su individualidad. Con la palabra nacía la importancia del "nosotros", de la acción conjunta, de donde nace el poder, entendido como el recurso generado por la

\footnotetext{
1075 ARENDT, Hannah, A Condição Humana, Rio de Janeiro; Forense Universitária, 1981, p. 15/30.

1076 ARENDT, Hannah, A Condição Humana, cit., p. 15.
} 
competencia de los miembros de una comunidad de que estén de acuerdo con un curso de acción. La libertad, para los griegos, no es la libertad moderna y privada de la no interferencia, sino la pública participación democrática. ${ }^{1077}$

Las acciones para la comprensión, relacionadas con la vida política de la persona humana y la libertad democrática deben ser el objetivo de quien viva en sociedad. Las acciones relacionadas con la comprensión, partiendo de un discurso fundamentado y coherente, por tanto racional, hacen que se llegue a un denominador común de comprensión democrática, clasificado por Habermas como la acción comunicativa. ${ }^{1078}$

Para el filósofo alemán, es también necesario para la comprensión, que los más diversos canales de comunicación estén a disposición de todas las personas para que se llegue a la comprensión. No habrá comprensión si no hay discusión racional (racionalidad ${ }^{1079}$ ) y crítica, donde no hay aclaración y emancipación, con competencia de reflexión para la comprensión. ${ }^{1080}$

Cuando se habla de aclaración y emancipación, en realidad se quiere dar una nueva cara a la Teoría Crítica, cara traída por la lógica del discurso, es decir, de que un consenso sólo estará racionalmente motivado o será un consenso fundado en el caso de que se deba exclusivamente a la fuerza del mejor argumento, y no

1077 STEILTJES, Cláudio, Jürgen Habermas. A desconstrução de uma teoria, São Paulo; Germinal, 2001 , p. $16 / 7$.

${ }^{1078}$ Ésta acción comunicativa es, para Habermas, la acción orientada al entendimiento, donde al menos dos sujetos actúan de forma coordenada o incluso superan esta coordinación, por el dialogo, reconociendo, un frente al otro, las pretensiones de validez de este discurso, alejándose del cálculo centrado en sí, para compartir los planes de acción del otro. (En HABERMAS, Jürgen. Teoria de La Acción Comunicativa. V. I, Racionalidade de la Acción y racionalización Social, Madrid; Taurus, 1987).

1079 Para Habermas, la racionalidad no es "una facultad abstracta, inherente al individuo aislado, sino un procedimiento argumentativo por el cual dos o más sujetos se ponen de acuerdo sobre cuestiones relacionadas con la verdad, la justicia y la autenticidad. Tanto en el diálogo cotidiano como en el discurso, todas las verdades anteriormente consideradas válidas e inquebrantables pueden ser cuestionadas; todas las normas y valores vigentes tienen que ser justificados; todas las relaciones sociales son consideradas resultado de una negociación en la cual se busca el consenso y se respeta la reciprocidad, fundados en el mejor argumento". (FREITAG, Bárbara, $A$ Teoria Crítica Ontem e Hoje, São Paulo; Brasiliense, 1988. p. 59-60).

1080 STEILTJES, Cláudio, Jürgen Habermas, cit., p. 67. 
de las coacciones externas ejercidas sobre el discurso o de las coacciones inherentes a la estructura del propio discurso. ${ }^{1081}$

El ser humano, sí en sí mismo, hace la historia y hace de la historia su historia y viceversa. Cada momento de vida hace historia y existe como ser completo, como algo central y final. De esta historia es de donde surge su inmortalidad. Este tiempo de vida entre los otros hombres hace nacer su historia.

$Y$ eso no se diferencia en el momento en el que trabaja. En que lo hace de forma subordinada o no. Todo es tiempo de vida. Ocio, placer, encuentros, desencuentros, cenas, cines, investigación y trabajo. Es por ello que para continuar su historia el hombre debe vivir. Para ser inmortal debe vivir, escribiendo su historia. De ahí surge el importante papel del trabajo. Escribiendo su historia el hombre escribe también la historia de su modo de vida y de su modo de producción.

Este tiempo de vida debe ser entendido como algo único, como un fin, limitado al contrato social y, en el presente caso, como Estado Democrático de Derecho. Y si en esta forma del Estado se limita la acción de los hombres, se restringe la explotación del tiempo de vida de los otros hombres a una simple explotación de la plusvalía. No deben crearse "normas" o "súmulas" mediante interpretaciones que pierdan contacto con la historia del hombre, con el hecho de que sea el hombre un ser mortalmente eterno. Que la vida se reproduzca en cada tiempo de vida de cada hombre de forma plena, limitada a la forma del Estado y a la convivencia escogida por la mayoría en un determinado momento y en una determinada región.

Cuando el hombre deja de hacer las cosas y las mezcla con sus necesidades acaba por crear el artificio ser humano. De ahí deriva el valor de uso de las cosas y lo que las hace durables. ${ }^{1082}$

${ }^{1081}$ STEILTJES, Cláudio, Jürgen Habermas, cit., loc. cit. 
La realización del trabajo por el homo faber es lo que se conoce como cosificación. Creando el artificio humano, acaba por destruir la naturaleza. Deja de trabajar como su siervo, como lo hacía como animal laborans, para ser su señor. ${ }^{1083}$

El problema radica en el hecho de que cuando el hombre trabaja para producir valor, como señor de la naturaleza, haciéndolo también con máquinas, acaba dejando de armonizar los movimientos de su cuerpo con los movimientos laborales para condicionar sus movimientos a los de las máquinas, teniendo, así, una acción mecánica sobre las cosas, sustituyendo el movimiento y el ritmo de su cuerpo. ${ }^{1084}$

Conviene destacar, en este apartado, la referencia al tiempo. El tiempo, para el ser humano, es algo caro. Como tiene la conciencia de la finitud, sabe que su tiempo de vida en la tierra, en cada momento, pasa y es menor. Quien escribe este texto, y quien lo lee, letra por letra, disminuye su tiempo de permanencia aquí, puesto que no se puede controlar o dominar el tiempo. ${ }^{1085}$

Pero este tiempo de vida, conciencia de la finitud, también hace de la vivencia en la tierra algo mágico, fantástico. El hombre debe aprovechar el tiempo, aprovechar el día. Aprovechar bien su permanencia. Debe hacerlo, sin embargo, no sólo para sí mismo sino también para las generaciones posteriores, esbozando pequeños trazos con el fin de justificar su pasaje y el tiempo invertido en la tierra, a fin de continuar su existencia y la existencia de los demás.

$Y$ eso interfiere en sus decisiones. Inserto el ser humano en un contexto económico y social capitalista, éste ser, incluso consciente de su finitud, tendrá

\footnotetext{
1082 ARENDT, Hannah, La condición humana, cit., p. 165.

${ }^{1083}$ ARENDT, Hannah, La condición humana, cit., p. 167/168.

1084 ARENDT, Hannah, La condición humana, cit., p. 172/173.

${ }^{1085}$ Ver imagen en el centro de la Basílica de San Pedro en Roma, donde hay un reloj de arena en las manos de un esqueleto humano.
} 
que dedicar al menos un treinta por ciento de su tiempo, por regla general, trabajando de forma subordinada. ${ }^{1086}$

Valdete Souto Severo añade que el tiempo de trabajo está vinculado al poder directivo del patrón, de modo que el tiempo de vida, durante la ejecución del contrato, también lo es. Por eso es indispensable ver el derecho del trabajo como fruto de una historia del tiempo de trabajo ${ }^{1087}$, historia ésta que vincula toda la estructura laboral y de donde se pueden extraer los elementos para una lectura social y humana de los conceptos pertinentes al derecho del trabajo, especialmente aquellos estructurales como la duración del trabajo, el vinculo de empleo, la higiene y la seguridad en el trabajo y las cuestiones sindicales, siempre teniendo al ser humano como elemento central de este juego.

Conviene señalar que el ritmo del tiempo de vida del trabajador en el mundo se ha convertido en el ritmo de funcionamiento de la máquina. Si el pastel se quemó, es porque no se ha horneado al ritmo de la máquina. El trabajador sabe actuar sólo conforme al ritmo de la máquina. Eso convierte al trabajo, que antes era un elemento sólo de existencia humana, en algo que va más allá de lo existencial, es decir en una pieza de producción económica y acumulación de riqueza para terceros.

La cuestión del tiempo del trabajo es tiempo de vida a disposición del tomador de los servicios. El trabajador debe dejar de lado el placer y el ocio ${ }^{1088}$ para subordinarse a la voluntad de terceros. Subordinar la voluntad, el tiempo de vida, serlo en el mundo es dejar de actuar para sí mismo para actuar para el otro. Los bienes e intereses económicos de los otros toman el lugar de los placeres,

1086 SOUTO SEVERO, Valdete, Crise de paradigma no direito do trabalho moderno: a jornada, Porto Alegre; Sérgio Antônio Fabris Editor, 2009, p. 68.

${ }_{1087}$ SOUTO SEVERO, Valdete, Crise de paradigma no direito do trabalho moderno: a jornada, cit., p. 69.

${ }_{1088}$ Constitución brasileña de 1988 (...). Art. 6o Son derechos sociales la educación, la salud, la alimentación, el trabajo, la vivienda, el ocio, la seguridad, la prevención social, la protección de la maternidad y de la infancia, la asistencia a las personas sin hogar, en la forma de esta Constitución. 
deseos y ocios del hombre trabajador. Por esta razón, el trabajo, como elemento de existencia humana, hoy existencia humana subordinada, núcleo del modo de producción capitalista, precisa de una lectura que no se limite solamente al ámbito económico, una lectura centrada en el aspecto social y de vida en grupo, donde el propio ser humano trabajador es el centro, no pudiendo ser usado sólo como medio.

Actualmente, incluso en los momentos de placer y de ocio, el hombre está condicionado al proceso productivo dado por la actual organización de la forma de trabajo, conservando la misma conciencia que tiene dentro de la fábrica. Esta lógica es una estrategia para mantener la represión de los comportamientos espontáneos que podrían perjudicar o abrir una brecha en la lógica de la producción. Estos son, sin embargo, momentos tristes. ${ }^{1089}$ Momentos en los que el ser humano deja de ser humano para ser humano subordinado para otros. Ser para la producción y para el consumo. Ocio y placer dejan de ser ocio y placer para ser de una forma estratégica de ocio productivo, centrado en los límites y términos de la producción manufacturera.

Se llega así a una subjetividad, denominada por Guattari "subjetividad capitalística", de naturaleza industrial, "maquínica", esencialmente fabricada, modelada, recibida y consumida. ${ }^{1090}$

Progresivamente, los propios trabajadores "adquieren más o menos pasivamente los modelos sociales dominantes, las actitudes y los valores de la

\footnotetext{
1089 BOLZAN DE MORAIS, José Luiz, A subjetividade do tempo. Uma perspectiva transdisciplinar do direito e da democracia, Porto Alegre; Editora Livraria do Advogado e Santa Cruz do Sul; Edunisc, 1998, p. 50/53.

${ }^{1090}$ Es la producción de la subjetividad, "de toda una estructura social industrial que está ligada a 'una inmensa máquina productiva de una subjetividad industrializada y nivelada en escala mundial que se ha convertido como algo básico en la formación de la fuerza colectiva de trabajo y de la fuerza de control social colectivo"'. (BOLZAN DE MORAIS, José Luiz, A subjetividade do tempo (...), cit., p. 66).
} 
burguesía (...)", al actuar como piezas programadas de su propia dominación y deshumanización. ${ }^{1091}$

La reproducción del modo de vida y deseos de la burguesía se extiende a la clase trabajadora, reforzando, por sí misma, su alienación y deshumanización. Cada día de trabajo, cada tiempo de vida destinado a la producción el propio trabajador se cosifica a sí mismo aún más.

Ahí es donde él (el trabajador) se transforma en cosa. El tiempo de vida dedicado al trabajo se convierte en el tiempo de la máquina, del patrón, del precio, del valor de cambio y del beneficio. Se desnuda al trabajador que es para ser un medio, también un artificio para la creación de los artificios humanos, sustituyendo un tiempo de vida suyo, una historia suya por la "vida e historia" de aquellos que producen o de aquél que le paga para producir.

En esta lógica las normas deben ser pensadas e interpretadas. Deben ser puestas en práctica sin que el intérprete o incluso el ejecutor o el legislador se desnude de estos conceptos. Por lo tanto, el tiempo de vida del trabajador, medio por excelencia, será sólo usado de esta forma en los estrictos límites de la norma, en el caso brasileño en el inciso I, del artículo $7^{\circ}$, de la CFB.

Subrayamos que la democracia, como concepto de vida del ser humano, necesita establecer lazos y vínculos fuertes con la vida humana. Es un estado de compromiso de todos que participan en el proceso democrático. Ninguno de los miembros puede o debe estar sometido a cualquier situación de violencia institucionalizada. ${ }^{1092}$

La democracia real, por tanto, es un proceso continuado de cambios e implica la caída del modelo de trabajador y ciudadano autómata que la sociedad

\footnotetext{
1091 BOLZAN DE MORAIS, José Luiz, A subjetividade do tempo (...), cit., p. 69.

1092 BOLZAN DE MORAIS, José Luiz, A subjetividade do tempo (...), cit., p. 106.
} 
industrial intenta proyectar para el hombre moderno y plasmar en el hombre moderno. Abriendo el camino para el libre ejercicio de la inteligencia humana se podrán inventar medios inteligentes de producción. ${ }^{1093} 1094$

El compromiso debe ser con la vida, un tiempo de Eros, apartado de la racionalidad tecnocrática que decide entre lo que es bueno y lo que no es bueno. La democracia requiere el "desmantelamiento de las estructuras de 'representación alingüísticas' donde el ideal de abolición de la justificabilidad de las normas de control social sería el ápice para el dominio de una estructura tecnoburocrática". Democracia implica la posibilidad de lo incompleto, de lo contradictorio, del desorden ordenado, de la fluidez, ajenas a los patrones impuestos por el capitalismo presente, aceptando la naturaleza humana como es y como se presenta, sin imposiciones de cuño técnico y científico dirigidos a la producción de bienes. ${ }^{1095}$

Habermas llama la atención sobre el hecho de que el capitalismo tardío está determinado por una política de compensación que asegura la lealtad de las masas dependientes del trabajo, evitando el conflicto (política que evita el conflicto), regulando el capital en términos privados. Este capitalismo, regulado por el estado, genera esta pacificación de las masas frente a las amenazas generadas por el propio sistema con la enorme desigualdad social y de clases. ${ }^{1096}$

La primera fuerza productiva, dominada por la técnica, procedente de los avances técnico-científicos, se ha convertido en el fundamento de la legitimidad. Esta nueva forma ha perdido el contacto con la vieja forma de ideología. Esta nueva ideología, tecnocrática, separa los criterios de justificación de la

\footnotetext{
${ }^{1093}$ BOLZAN DE MORAIS, José Luiz, A subjetividade do tempo (...), cit., p. 106/107.

${ }^{1094}$ Ver también MARCUSE, Herbert, El hombre unidimensional, Barcelona; Ariel, 2008.

1095 BOLZAN DE MORAIS, José Luiz, A subjetividade do tempo (...), cit., p. 107/108.

${ }^{1096}$ HABERMAS, Jürgen, Técnica e ciência como ideologia, cit., p. 76.
} 
organización de convivencia, de las regulaciones normativas de interacción en general, los despolitizados y los vinculados a un sistema dirigido a fines. ${ }^{1097}$

Esta forma de interés se extiende tanto al mantenimiento de una intersubjetividad de la comprensión como al establecimiento de una comunicación libre de dominación. La conciencia tecnocrática hace desaparecer el interés práctico por detrás del interés de ampliación del poder de disposición técnica. ${ }^{1098}$

La técnica, por tanto, también se apropia, en la ejecución del trabajo, del tiempo de vida del trabajador, haciendo que esta vida, es decir, este tiempo de vida, se vuelva en contra del mismo. El trabajador, condenado por la técnica dirigida sólo a fines instrumentales, somete su propio "yo" a algo que lo transforma en una pieza dentro del engranaje del capital, encaminado a la dominación y despolitización pacificadoras.

De ahí se desprende el concepto de tiempo de vida. Lo que es y a que está sujeto el trabajador cuando trabaja de forma subordinada. Además de vincular sus anhelos, placeres y deseos a terceros, repite la lógica, a través de su propia conciencia, que lo esclaviza, y lo aleja, aún más, del propio "yo". El intérprete,

1097 "En la conciencia tecnocrática, no se refleja la anulación de una relación de conexión ética, sino la represión de la 'eticidad' como categoría de las relaciones vitales en general. La conciencia positiva común pone fuera de acción el sistema de referencia de interacción mediante el lenguaje ordinario, en el cual la dominación y la ideología surgen bajo condiciones de una comunicación distorsionada y en la cual también pueden ser penetrados por la reflexión. La despolitización de las masas de la población, que es legitimada por la conciencia tecnocrática, es al mismo tiempo una autoproyección de los hombres en categorías, tanto de la acción instrumental como del comportamiento adaptativo: los modelos cosificados de las ciencias transmigran hacia un mundo social cultural de la vida y logran allí un poder objetivo sobre la autocomprensión. El núcleo ideológico de esta conciencia es la 'eliminación de la diferencia entre la praxis y la técnica' - un reflejo, pero no el concepto de la nueva constelación que se establece entre el marco institucional desprovisto de poder y los sistemas autonomizados de la acción racional dirigida a fines". (HABERMAS, Jürgen, Técnica e ciência como ideologia, cit., p. 81/82).

1098 La nueva ideología viola un interés que es inherente "a una de las dos condiciones fundamentales de la ciencia cultural: al lenguaje o, más precisamente, a la forma de socialización e individualización determinada por la comunicación mediante el lenguaje común”.

"La reflexión que la nueva ideología desafía debe, pues, remontar tras un interés de clases históricamente determinado y traer a la luz el complejo de intereses que como tal caracteriza una especie, que a sí misma se constituye". (HABERMAS, Jürgen, Técnica e ciência como ideologia, cit., p. 82). 
principalmente el directamente ligado al derecho del trabajo, debe tener esto en cuenta. Cada situación refleja toda esta lógica. Las normas de derecho también.

\subsection{Tercerización y vinculación del trabajador al bien o al servicio que produce}

La tercerización, implica que el trabajador presta servicios a quien no es su "patrón", sino a un tercero, conocido como tomador de los servicios. El dueño del bien producido no es quien lo contracta o quien paga sus salarios, sino quien detiene el producto producido o el servicio creado/prestado.

Por ello, antes de analizar la cuestión de la inconstitucionalidad de la tercerización en general -y de la "súmula" 331 del Tribunal Superior del Trabajo en particular-, son necesarias algunas consideraciones, siempre teniendo como modelo la lógica capitalista, el hecho de que quien emplea no es dueño del bien o del servicio producido y la doble alienación (por el tomador y por el prestador).

\subsubsection{Porque quien produce no es dueño - cuestión de la apropiación de la plusvalía}

La principal característica de la tercerización, desde la perspectiva del trabajador, es desvincularlo del bien que produce. No es que el trabajo subordinado "directo" no lo haga, como ya hemos visto al tratar el fetiche de la mercancía. A diferencia de lo que sucede en esta última situación, hay un "doble fetiche de la mercancía", porque el trabajador, además de producir bienes o servicios a favor de terceros, acaba por desconectarse aún más del bien que ha creado o del servicio prestado, bien o servicio estos que se destinan a otra empresa que no es la real empleadora, al no ser ya este bien o servicio el que podrá garantizar la contraprestación por el trabajo realizado. 
Es decir, el producto elaborado o el servicio prestado por el trabajador dejan de pertenecer a su patrón y pasan a formar parte del patrimonio del tomador de los servicios. No es este bien, producto o cosa, como sucede en la contratación "directa", lo que garantizará, en teoría, el pago del trabajador, sino los frutos de la venta de este bien, producto o cosa, que le da menos seguridad de ganar.

El bien producido, es lo que asegura el cumplimiento del trabajo prestado. Si lo que es producido no pertenece al patrón del trabajador, su garantía de pago por los servicios prestados disminuye de forma significativa, aumentando todavía más al trabajador los riesgos de la producción, lo que está prohibido, en el caso brasileño, según el artículo $2^{\circ}$ de la $\operatorname{CLT}^{1099}$.

La tercerización, como se ha señalado, no sólo afecta a las disposiciones del artículo $3^{\circ}$ de la $\mathrm{CLT}^{1100}$, norma ésta que no la autoriza, en razón del concepto de subordinación, sino también a lo establecido en el artículo $2^{\circ}$ de la CLT, cuando se ocupa de los riesgos de la actividad y los dirige al empleador. En efecto, quien terceriza infringe dos reglas legales del derecho, aumentando sólo el producto del trabajo como beneficio, reduciendo en parte los costes de producción y revalorizando las acciones de los que tomen este servicio.

Quien acaba por hacerse cargo de todo el riesgo es quien presta el trabajo. El empleado, parte más débil de la relación y quien efectivamente producen el bien o el servicio, del quien depende el modo de producción capitalista, en el caso del trabajo tercerizado, acaba por sentir todo el peso de la riqueza generada en provecho de terceros. Él la crea, genera y la transfiere, de forma barata, a la empresa prestadora de servicios y a la empresa tomadora. Entrega parte de su ser, de su esencia fruto del trabajo prestado, a un coste bajo a quien no corre ningún riesgo y a quien, sin mayores garantías, transfiere este bien a terceros.

\footnotetext{
1099 Art. $2^{\circ}$ - se considera empleador a la empresa, individual o colectiva, que, asumiendo los riesgos de la actividad económica, admite, asalaria y dirige la prestación de servicios).

1100 Art. $3^{0}$ - se considera empleado a toda persona física que presta servicios de cualquier naturaleza al empleador, bajo la dependencia de este y mediante salario.
} 
Por esta razón, combinando el concepto de subordinación que la vincula no sólo al trabajo prestado de forma directa, bajo órdenes, pero dentro de la estructura de la empresa y bajo la condición de previsibilidad, junto con el hecho de que el producto del trabajo se desvincula de forma "doble" de quien efectivamente lo produce, la tercerización no sería posible en el ordenamiento brasileño.

A esto hay que sumar que la subordinación es una consecuencia de la relación de empleo. En el caso del empleo hay, necesariamente, una relación de poder de donde deriva la subordinación jurídica. Y esta relación de poder aparece de forma aún más evidente en los casos de tercerización, donde la acción del trabajador está vinculada no sólo a lo que quiere su "empleador directo", sino también a su "tomador". 1101

Ockert Dupper, apunta que la tercerización es una forma de flexibilización. Considera que hay discriminación entre los trabajadores tercerizados y la empresa tomadora. En el mundo real, la relación de empleo se produce entre el empleado y la empresa tomadora. La subcontratación ya no es que una ficción jurídica donde hay interpuesta persona entre el tomador del trabajo y el prestador del trabajo. ${ }^{1102}$

\footnotetext{
1101 Para Godinho Delgado, "la 'fórmula de la tercerización laboral' permite la desconexión entre la relación socioeconómica de la real prestación laboral y el vínculo laboral del trabajador que sería correspondiente con el propio tomador de sus servicios". Entre el trabajador y el tomador de sus servicios se inserta una tercera persona, intermediaria, denominada prestadora de los servicios y que comienza a responder por el vínculo con el trabajador. Hay, por tanto, una separación artificial entre el trabajador y el tomador de los servicios, puesto que quien comienza a detentar el vínculo de empleo es el prestador de los servicios. (GODINHO DELGADO, Maurício, Capitalismo, trabalho e emprego (...), cit., p. 43/4). Sin embargo, la "tercerización laboral (ahora examinada) concierne al mencionando proceso de disociación del vínculo socioeconómico de prestación laboral en detrimento del respectivo vínculo jurídico-laboral, el que se une con la empresa llamada prestadora de servicios. Por la tercerización laboral, el efectivo tomador de los servicios deja de ser, a través de la astuta fórmula jurídico-administrativa, el real empleador del trabajador".

1102 DUPPER, Ockert, Palestra no Seminário internacional de direito do trabalho no mundo contemporâneo, organizado por la 'Escola Judicial do TRT da Quarta Região', Porto Alegre, RS, el 29 de octubre de 2010.
} 
Nos adherimos a la tesis de Reginaldo Melhado, según la cual, el empleado, a diferencia de lo que defiende Palma Ramalho ${ }^{1103}$, no tiene la opción de sujetarse o no a la relación de empleo. Esta opción es una fantasía. ${ }^{1104}$

El empleado se vincula al contrato de trabajo por necesidad, con el fin de negociar la única cosa que posee para poder subsistir, que es su fuerza de trabajo, fuerza de trabajo ésta que produce mercancía, la única cosa que va efectivamente a garantizar el pago del salario es el producto de este trabajo alienado.

Cuando se separa al empleado del producto que ha producido, en que se subcontrata la prestación de trabajo, aquél que produjo un determinado bien no tiene acceso al bien, puesto que este mismo bien "pertenece" a alguien que no es su empleador (a quien ni siquiera puede dirigirse durante la ejecución del contrato o en eventual caso de impago, puesto que no es el empleador formal, conforme al inciso III, de la "súmula" 331, del Tribunal Superior del Trabajo ${ }^{1105}$ ). Esta lógica acaba por aumentar la alienación del trabajador y tiene como consecuencia que el empleado tenga menos certeza en cuanto a su pago. Esta teoría, por tanto, aleja cualquier posibilidad de subcontratación o tercerización.

Conviene subrayar que el trabajo subordinado, en las palabras de Melhado, no es un elemento esencial para caracterizar la relación de trabajo. Es más que eso. Es consecuencia de esta relación de sujeción, donde el agente de poder,

\footnotetext{
$\overline{1103}$ MELHADO, Reginaldo, Poder e sujeição (...), cit., p. 96.

1104 Efectivamente la opción es una fantasía ya que el capitalismo se basa en el poder. La precariedad del empleo, de hecho, es un medio de coacción utilizado por los empleadores sobre los trabajadores. Hay necesidad de subsistir. La oferta de trabajo es inferior a la demanda. Por lo tanto, forma parte del chantaje del empleador, con el fin de reducir el precio de compra del trabajo y por el hecho de poder, en cualquier momento, rescindir el pacto. Esto también permite que el empleado se someta de forma más suave a las reglas del tomador del trabajo, ya que, de lo contrario, podría quedarse sin trabajo, perdiendo la posibilidad de vender lo único que tiene para ganarse la vida: su fuerza de trabajo. (Vid., MELHADO, Reginaldo, Poder e sujeição (...), cit., p. 128/9).

1105 III - No forma vínculo de empleo con el tomador la contratación de servicios de seguridad (Ley no 7.102, de 20.06.1983) y de mantenimiento y limpieza, así como la de los servicios especializados relacionados con la actividad-medio del tomador, siempre no exista la personalidad y la subordinación directa.
} 
empleador, actúa de forma que pueda dirigir a plazos el trabajo. Hay una relación de compra y venta. Es decir, sin embargo, no elimina los conceptos mencionados anteriormente sobre lo que es la subordinación., sino que los refuerzan. Vincula a aquél de quien se toma la plusvalía al bien que produjo o al dueño del bien, ya que esto garantiza, en teoría, mayores posibilidad del debido cumplimento por parte del trabajo prestado.

No se puede, por tanto, tolerar que el trabajo sea utilizado sólo como un medio. El trabajo subordinado es la regla, el elemento central, la espina dorsal del modo de producción capitalista. Así, el producto creado por el trabajador es lo que garantizará el pago por el trabajo prestado, la retribución pecuniaria, la contraprestación del empleador en el contrato de compraventa.

Este análisis aleja la posibilidad de subcontratación y tercerización. Como hemos mencionado anteriormente, el trabajo posee un valor social. Quien va a pagar por el trabajo prestado es quien se beneficia por el producto creado por el trabajo prestado. Es este producto, la mercancía, convertible en dinero, la que garantiza el cumplimento de las obligaciones por parte del empleador.

Por eso, quien presta trabajo por cuenta ajena lo hará necesariamente de forma subordinada, vinculándose a quien sea el dueño del producto creado. El dueño de este producto, capitalista, para crear este mismo producto, cuenta con el trabajador, depende de él, creando expectativa en cuanto al trabajo que debe prestar, con el fin de alcanzar su objeto social. Este producto es lo que garantizará la retribución por el trabajo prestado, de manera que el empleador será aquél a quien pertenece el producto una vez hecho.

Esta teoría se aplica también a los servicios. De la misma forma con respecto al producto creado, los servicios que deben prestarse, aquéllos entregados al público también son productos, entregados al consumidor final o al intermediario. 
Es acreedor el trabajador de los salarios, debiendo pagarlos quien se beneficia de este producto.

Por todo ello sostenemos que no es posible la tercerización en el ordenamiento jurídico brasileño ${ }^{1106}$. Además, no es el elemento central de reducción de los costes de producción. Lo que proporciona la tercerizacion, verdaderamente, es el aumento de los beneficios en el mercado financiero. ${ }^{1107}$

\subsubsection{La alienación y los efectos de la "doble" alienación en la perspectiva constitucional - Los límites a la alienación}

El trabajador presta servicio a su empleador de forma alienada. Esta es una de las características del trabajo en el modo de producción capitalista. Seguidamente abordaremos esta cuestión, haciendo alusión a la subordinación y al tiempo del trabajo. Quien mejor trató esta cuestión y quien mejor situó al trabajador dentro del modo de producción capitalista fue Marx, en sus Manuscritos Económicos y Filosóficos, que utilizaremos como referencia.

Aunque Marx afirma que la alienación económica es la alienación de la vída real, en oposición a la alienación religiosa que tiene lugar en la conciencia, y que la superación de la alienación económica trae la superación de todas las formas de alienación ${ }^{1108}$, no defendemos en esta investigación la superación de ninguna

\footnotetext{
${ }^{1106}$ Aunque no sea posible tercerizar en Brasil, el caso español es diferente. En la Constitución española no hay una norma similar a la del artículo $7^{\circ}$, I, de la Constitución brasileña de 1988, pero a partir del principio de la libertad de empresa, el empresario podrá hacer lo que no está establecido en la ley. Además, como se indica en el artículo 42 del Estatuto de los trabajadores la tercerización es posible, al no haber, en los tribunales españoles ninguna sentencia que acoja el sentido de inconstitucionalidad.

${ }_{1107}$ FRANK, Thomas, Deus no céu e o mercado na terra, cit., p. 443, nota 13, donde consta "Allan Sloan 'The Hit Men', Newsweek, 26 de fevereiro de 1996, p. 44. James J. Cramer, "Let Them Eat Stock", The New Republic, 29 de abril de 1996, pp. 24-25. Otro punto interesante: "Cremer describió la valorización de los precios de acciones como 'riqueza que ellos [los trabajadores] crearon' simplemente siendo despedidos".

1108 RANCIÉRE, Jaques, "El concepto de crítica y la crítica de la economía política de los $<$ Manuscrits de 1844> al <Capital> ". Lire le capital, luis Althusser, París; PUF, 2ª edición, 2008, p. 90. "En el 3ํㅡㄹ Manuscrits (p. 88), Marx declara que la alienación económica es la alienación de la vida real (por oposición a la alienación religiosa que se basa sólo en la 'consciencia'). Por
} 
de las formas de alienación sino el efecto y las consecuencias de la misma en la relación de empleo y en la vida del trabajador.

La alienación en el trabajo ya no es fruto de la evolución del feudalismo hacia el capitalismo donde el trabajador, por la división del trabajo, ha comenzado a disponer cada vez menos del producto de su trabajo, perdiendo también el contacto con la técnica de elaboración. El trabajador empieza a ser el mero engranaje en el sistema, donde el capitalista, detentadoras de los bienes y medios de producción, a cambio del salario, lo aliena apropiándose de la diferencia entre el valor utilizado para la fabricación del producto y su valor de cambio en el mercado.

El trabajador empezó a formar parte, como una pieza, del mercado. Tanto es así que, en los albores del capitalismo, y eso se repite hasta hoy, al no tener el prestador del trabajo las condiciones para ejecutar su trabajo, es sustituido por otro al igual que se cambia una pieza en una grande máquina de tejer. ${ }^{1109}$

El valor pagado al trabajador sirve sólo para que se reproduzca como pieza de producción. Como medio de ganancia por parte de su patrón capitalista. El salario pagado equivale al mínimo necesario para que viva y continúe pudiendo ser utilizado como mano de obra, sin tener en cuenta la cuestión de la dignidad del trabajador o incluso su existencia y felicidad. ${ }^{1110}$

consiguiente, la supresión de la alienación económica arrastra la supresión de todas las demás alienaciones".

1109 "El valor de la competencia para trabajar durante una unidad de tiempo de trabajo es el de la masa de medios de vida necesarios para que consumiéndolos el trabajador posea de nuevo competencia para trabajar que vender a la unidad de tiempo de trabajo siguiente: por debajo de unos mínimos la fuerza de trabajo no podría reproducirse y cesaría la producción". (CAPELLA, Juan-Ramón, Los ciudadanos siervos, Madrid; Trotta, 1993, p. 86).

${ }_{1110}$ Raymond Aron afirma, en un análisis de la obra de Marx, que el trabajador es víctima del sistema capitalista. del producto de su trabajo, el trabajador recibe la menor parte, lo suficiente para ser un obrero y nunca hombre. (ARON, Raymond, O marxismo de Marx; tradução Jorge Bastos, São Paulo; Arx, 2003, p. 569). 
Para Capella, el concepto de plusvalía y la explotación capitalista pueden ser percibidos fácilmente en términos de teoría del valor-trabajo. Habrá plusvalía cuando los trabajadores venden su capacidad de trabajar durante un cierto período de tiempo a cambio de dinero que les permita comprar el equivalente, en horas de trabajo, a menos de lo que se produjo. "La plusvalía así entendida es la forma que adquiere el sobretrabajo en la sociedad capitalista". ${ }^{1111}$

Marx decía que el trabajador, en la sociedad capitalista, era explotado tal como lo había sido en la esclavitud y en la sociedad feudal. Para él, la explotación capitalista sobre el trabajo es oculta, enmascarada. Con la teoría de la plusvalía desenmascara esta situación. ${ }^{1112}$

Para desenmascarar esta situación Marx tomó prestada la teoría laboral defendida por Ricardo y, en mayor o menor grado por otros economistas clásicos como Adam Smith y Stuart Mill. Para esta doctrina, el valor de la mercancía depende del total de trabajo necesario para producirlas. Marx también distinguió entre los bienes en general y las mercancías. La producción de mercancía es típica de la sociedad capitalista. Un bien se convierte en mercancía cuando es producido no para el consumo directo sino para el intercambio. Quien crea un determinado bien para sí mismo no da un valor de intercambio sino sólo un valor de uso. No crea mercancía. Para producir mercancía se debe producir un valor de uso no sólo para sí mismo sino también para los otros, es decir un valor de uso social. Las cosas producidas y que tienen utilidad para otras personas sólo pueden ser intercambiadas, según Marx, por tener algo en común, es decir, por ser producto del trabajo. ${ }^{1113}$ Todo esto se mide por el tiempo de trabajo necesario para producir una determinada cosa o mercancía. $Y$ se utiliza como tiempo del

\footnotetext{
1111 CAPELLA, Juan-Ramón, Los ciudadanos siervos, cit., p. 87.

1112 HUBERMAN, Leo, História da riqueza do homem, cit., p. 214.

1113 HUBERMAN, Leo, História da riqueza do homem, cit., p. 215.
} 
trabajo necesario para fijar el valor de cambio de la mercancía la media del trabajo empleado. ${ }^{1114}$

Para Marx, el trabajador es tanto más pobre cuanta mayor riqueza produce, cuanto más aumenta su producción en poder y extensión. El trabajador se convierte en una mercancía tanto más barata, cuanto mayor es el número de bienes que produce. ${ }^{1115}$

Por el valor que recibe de su patrón tendrá que, en un círculo vicioso, trabajar mucho más para adquirir aquello que él mismo produjo, convirtiéndose cada vez más en un esclavo del sistema capitalista. Es interesante que el trabajador produzca no sólo el producto, sino su salario, dejando parte de la plusvalía al tomador del trabajo. ${ }^{1116}$

La alienación no se produce sólo en el resultado del trabajo, sino también en el proceso de producción, en el seno de la propia actividad productiva. Recuerda

1114 HUBERMAN, Leo, História da riqueza do homem, cit., p. 215/219. "Cuando el trabajador se alquila, vende su fuerza de trabajo no sólo por el tiempo que lleva para producir el valor de sus salarios, sino también por la extensión de todo un día de trabajo. Si el día de trabajo es de 10 horas, y el tiempo necesario para producir el valor de su salario es igual a 6 horas, entonces sobran 4 horas durante las cuales el obrero no está trabajando para sí mismo, sino para su patrón. A las 6 horas Marx las llama el tiempo de trabajo necesario, y a las 4 horas, tiempo de trabajo excedente. Del valor del producto total de 10 horas de trabajo, seis décimos corresponden al salario, cuatro décimos son iguales a la plusvalía, que se queda en poder del patrón y constituye su ganancia".

1115 "Con la 'valorización' del mundo de las cosas, aumenta en proporción directa la 'desvalorización' del mundo de los hombres. El trabajo no produce sólo mercancía; se produce también a sí mismo y al trabajador como una 'mercancía', y precisamente en la misma proporción con que se producen los bienes". Tal hecho implica sólo que lo que se produce por el trabajo (objeto), se opone al trabajador como ser extraño como un poder independiente del productor. "El producto del trabajo es el trabajo que se fijó en un objeto, que se transformó en cosa física, es la objetivación del trabajo. La realización del trabajo constituye simultáneamente su objetivación. Cuanto más bienes el trabajador produce tanto menos él puede poseer y más se somete al yugo del capital".

Continúa Marx argumentando que "la realización del trabajo aparece en la esfera de la economía política como la desrealización del trabajador, la objetivación como la 'pérdida y servidumbre del objeto', la apropiación como la 'alienación'". (MARX, Karl, Manuscritos Econômicos-filosóficos, São Paulo; Martin Claret, Coleção Obra Prima de Cada Autor, Textos Integrais, 2001, p. 111).

${ }^{1116}$ Para Marx, "La 'alienación' del trabajador en su producto, significa no sólo que el trabajo se transforma en objeto y que asume una existencia 'exterior', sino que existe independientemente, 'fuera de él' y es a él extraño, convirtiéndose en un poder autónomo en oposición a él; que la vida que dio al objeto se convierte en una fuerza hostil y antagónica". (MARX, Kart, Manuscritos Econômicos-filosóficos, cit., p. 112). 
Marx que el trabajador no podría estar alienado en una relación con el producto de su producción y no estar en el tiempo del acto de producción del mismo producto. $^{1117}$

En el modo de producción capitalista el trabajo es exterior al trabajador, no pertenece a su característica. En el trabajo, el trabajador no se afirma sino que se niega a sí mismo, acumulando infelicidad y no desarrolla libremente sus energías físicas y mentales, agotándose y arruinado su espíritu. Por esta razón, el trabajador sólo se siente libre fuera del trabajo, fuera de la línea de producción capitalista. El trabajo alienado es un trabajo sacrificado no placentero, de martirio. ${ }^{1118}$

De ahí la idea de que tercerizar potencia esta alienación. La tercerización trae la "doble" alienación, en beneficio de lo económico, hiriendo a los principios básicos de la dignidad y reducción de la desigualdad social. Si la alienación "simple" ya permite la desigualdad, la "doble" lo hace aún más.

Según Marx, el trabajo aliena la naturaleza del hombre. ${ }^{1119}$ Es este trabajo el que, en el sistema capitalista, permite que el trabajador se mantenga y viva, aunque se haya producido la muerte de su (trabajador) alma.

El trabajador tiene la mala suerte de ser un capital vivo y con necesidades que en cada momento de no trabajo pierde sus intereses $y$, por tanto, su existencia. ${ }^{1120}$

\footnotetext{
1117 El producto constituye sólo el resumen de la actividad, de la producción. En consecuencia de eso, si el producto del trabajo es la alienación, la producción en sí tiene que ser la alienación activa - la alienación de la actividad y la actividad, de la alienación. En la alienación del objeto del trabajo, se condensa sólo la alienación en la propia actividad del trabajo". (MARX, Kart, Manuscritos Econômicos-filosóficos, cit., p. 114).

${ }_{1118}^{118}$ MARX, Kart, Manuscritos Econômicos-filosóficos, cit., p. 114.

1119 "Aliena el hombre en sí mismo, su papel activo, su actividad fundamental, aliena del mismo modo el hombre con respecto a la especie; transforma la vida genérica en un medio de vida individual". (MARX, Karl, ibidem).

${ }_{1120}$ MARX, Kart, Manuscritos Econômicos-filosóficos, cit., p. 123/124. "'Como el capital, el valor del trabajador varia de acuerdo con la demanda y la oferta, y su existencia física, su vida, ha sido y es valorada como una oferta de mercancías, parecida a cualquier otra mercancía. El trabajador
} 
Cada vez que el trabajador presta su trabajo, por tanto, al empleador capitalista, lo hace de forma alienada. Esta alienación no implica sólo el aspecto del trabajo en sí y de los bienes que haya producido o el aspecto de la desconexión con el bien elaborado y las técnicas de elaboración de este bien, sino también la parte existencial. El trabajo, en las comunidades primitivas, no era alienado. Había trabajo para suplir necesidades inmediatas y demandas. Las personas trabajaban para justificar su existencia, repitiendo lo que hacían sus antepasados y dominaban ${ }^{1121}$, en su mayoría, las técnicas de producción de forma global.

En el sistema de producción capitalista esto ya no existe. El trabajador aliena su trabajo, el producto de su trabajo, su existencia, su vida a su empleador. Aliena también su conciencia, puesto que repite esta lógica dócilmente y sin pensar. El dinero fruto de la alienación de esta misma existencia no se revierte más que a quien detenga el capital. El capital se convierte en el centro de la sociedad, el elemento principal en detrimento de la vida humana, de la condición humana.

El trabajador es sólo un número en el sistema, una mercancía ${ }^{1122}$. El valor de la mercancía es equivalente al tiempo del trabajo socialmente necesario para

produce el capital, el capital produce al trabajador. Además, él se produce a sí mismo, y el hombre, como trabajador, como mercancía, constituye el objeto de todo el proceso. (...) Con respecto al capital - por acontecimiento necesario o voluntario - deja de existir para el trabajador, éste también deja de existir para sí mismo, no tiene trabajo, ni tampoco salario, y exclusivamente existe como trabajador y no como hombre, por lo que se puede dejar sucumbir al hambre, a enterrarse a sí mismo, etc. El trabajador solo existe como un trabajador desde el momento en que existe como capital para sí mismo, y solo existe como capital cuando hay un capital para él. La existencia del capital es su existencia, su vida, ya que éste, independientemente de él, determina el contenido de su vida".

${ }_{1121}$ MARCUSE, Herbert, Cultura e sociedade, volume II, Rio de Janeiro; Paz e Terra, 1998, p. 7/50. 1122 "La economía política analiza el trabajo abstractamente como una cosa. El trabajo es una mercancía: si el precio es elevado, la demanda es alta, si el precio es bajo, la oferta es grande, como acontece con otras mercancías. El precio del trabajo debe disminuir; es en parte la competencia entre el capitalista y el trabajador, en parte la competencia entre los propios trabajadores lo que provoca esta bajada. 'La población trabajadora, que vende su trabajo ¿queda necesariamente reducida a la menor parte del producto? ... ¿Será la teoría del trabajo como mercancía diferente de una teoría disfrazada de servidumbre?' '¿Por qué considera el trabajo sólo como un valor de cambio?' (...) El trabajador, con relación al patrón, no se encuentra en modo alguno en la situación de vendedor libre... el capitalista es siempre libre para emplear el trabajo y el 
producirla. La fuerza de trabajo, sin embargo, es una mercancía con una peculiaridad única, cuyo uso consiste en la creación de valor y de plusvalía ${ }^{1123}$.

Pero ¿qué es la mercancía? Marx adopta la teoría del valor desarrollada por los clásicos por la cual el valor de una mercancía es determinado por el tiempo del trabajo socialmente necesario para su producción, pero lo hace integrándola en un contexto diferente, donde la dialéctica hegeliana, despunta el encabezamiento, debe conducir a la trama de las teorías. Desde esta perspectiva, la mercancía es vista como una contradicción que, al mismo tiempo es un objeto útil, teniendo, por tanto, un valor de uso, y como un objeto útil para otros lo que le garantiza también un valor de cambio. ${ }^{1124}$

El dinero se convierte en una mercancía que ocupa una posición muy especial dentro del sistema de cambio: todas las mercancía se refieren al mismo para encontrar la expresión de su valor. Lo que el trabajador produce es una utilidad, un valor de uso, no produce para sí, sino para otro, que deberá poseer otra utilidad con la cual cambiará el resultado del trabajo. En el mercado se encuentra una mercancía muy especial, la fuerza de trabajo que, como valor de cambio, tiene su valor determinado por el tiempo socialmente necesario para su producción, pero como valor de uso sólo puede ejercer concretamente, como agricultor, artesano y así sucesivamente. El producto, sin embargo, cae en las manos de aquellos que compraron el trabajo. El que compró el trabajo, y después vende el producto, por un lado, recibe el valor que invirtió y por otro, una plusvalía, un excedente que proviene del resultado del trabajo. De ahí la definición del capital como propiedad que garantiza al capitalista explotar el trabajo ajeno. Como

obrero se ve obligado a venderlo. (...) El trabajo es vida, y si la vida no es todos los días permutada por alimento, sufre daños y muere rápidamente. Para que la vida del hombre sea una mercancía, debe entonces admitirse la esclavitud. Por esa razón, si el trabajo es una mercancía, surge como mercancía de la más miserable especie". (MARX, Karl, Manuscritos Econômicos-filosóficos, cit., p. 77/8).

${ }^{1123}$ GORENDER, Jacob, "Introdução”. En Para a crítica da economia política; salário, preço e lucro; o rendimento e suas fontes: a economia vulgar. Karl Marx. Tradução de Edgard Malagodi, São Paulo; Abril Cultural, 1982, p. XIX.

${ }^{1124}$ GORENDER, Jacob, "Introdução", cit., p. XIX. 
este capital crece en sí mismo, asume un carácter de expoliación. El sistema capitalista se orienta a la explotación de la plusvalía. ${ }^{1125}$

Marx hace especial hincapié en el fetichismo de la mercancía. Este fetichismo representa una visión concretada del concepto de alienación: una vez en el mercado, la mercancía tiene vida propia, independiente de su creador. El destino del creador dependerá de lo que va a producirse con la mercancía, que asume una facción de fetiche, con poderes misteriosos, porque puede traer la felicidad si se vende con un beneficio, como puede fallar y arruinar al productor. ${ }^{1126}$

Lenin muestra que el surgimiento del capital implica condiciones históricas previas, la acumulación de una suma de dinero en manos privadas, en una etapa relativamente elevada de la producción mercantil; y la existencia de obreros "libres" bajo los siguientes puntos de vista: a) libres de cualquier coacción y restricción en cuanto a la venta de su fuerza de trabajo; b) libres porque eran despojados de las tierras y sin ningún medio de producción en general. Son obreros que sólo pueden vender su mano de obra. ${ }^{1127}$

El problema está también en la forma en cómo este mismo capitalismo se reproduce. Las propias personas, especialmente los trabajadores, son sus propios verdugos. Se fiscalizan a sí mismos, a través de una ética de trabajo sin ningún

\footnotetext{
${ }^{1125}$ Marx, con respecto al ciudadano, sostiene que la "emancipación política, es la reducción del hombre, por un lado, a miembro de la sociedad civil, individuo 'independiente y egoísta' y, por otro, 'ciudadano', la persona moral". Solamente será plena capacidad humana para él cuando el hombre real e individual tenga en sí, el ciudadano abstracto "cuando el hombre individual, en su vida empírica, en el trabajo y en las relaciones individuales, se convierte en un ser genérico; y cuando tenga reconocido y organizado sus propias fuerzas (fuerces propres) como fuerzas sociales de manera que nunca más pueda separarse de sí su fuerza social como fuerza política". (GIANNOTTI, José Arthur, "Introdução". Em Marx, São Paulo; Nova Cultural, 2006, p.15/16).

${ }_{1126}$ GORENDER, Jacob, "Introdução", cit., p. XXI.

Lenin recuerda que "(...)habiendo comprado la fuerza de trabajo, el poseedor de la moneda tiene el derecho de consumirla, es decir de obligarla a trabajar todo el día, digamos doce horas. Sin embargo, en seis horas (tiempo de trabajo 'necesario'), el obrero crea un producto que cubre los gastos de su sustento, y, durante las seis otras horas (tiempo de trabajo 'suplementario') crea un producto 'suplementario', no-retribuido por el capitalista, que es la plusvalía". (LÊNIN, "Karl Marx". En: As três fontes e as três partes constitutivas do marxismo, São Paulo; Global Editora, $6^{\mathrm{a}}$ ed.; 1988, p. 31).
}

${ }^{1127}$ LÊNIN, Karl Marx, cit., p. 32. 
conciencia emancipadora. La sociedad moldea su vida considerando en primer lugar el trabajo, la mayoría de las veces asalariado, pero siempre alienado. Fiscalizando su propia prestación de servicio, en una actitud contraria a la propia existencia humana, el sufrimiento se multiplica y las condiciones de ser efectivamente ser humano se deshacen, en provecho de una lógica perversa que mantiene sólo los medios de subsistencia.

Sin embargo, el modo de producción existente es el capitalista. La comprobación de eso es simple: basta la lectura, sin compromiso, del artículo 1ํㅡ, IV, segunda parte ${ }^{1128}$ y del inciso XXII del artículo 5a ambos de la CF/88 ${ }^{1129}$, que garantiza en el país la libre-iniciativa y la propiedad privada. En el caso de España, basta la lectura del artículo 38 de la Constitución ${ }^{1130}$, entre otros.

Como el trabajador, cuando presta servicios a su empleador, lo hace de forma alienada, separándose del producto de su trabajo, de las técnicas de elaboración de este producto y, principalmente, de su existencia, comenzando a ser visto como una mera pieza dentro del sistema productivo ${ }^{1131}$, además de ser ampliamente protegido por el sistema vigente, al final es él quien garantiza, con su trabajo, la estructura capitalista, la acumulación de capital, sólo puede someterse al poder del empleador en los estrictos límites previstos en la norma jurídica.

Forma parte del contrato de trabajo, en sí mismo, la sujeción del trabajador al poder de su tomador de trabajo ${ }^{1132}$, lo que remite a una interpretación y aplicación

\footnotetext{
1128 Art. 1. La República Federal de Brasil, formada por la unión indisoluble de los Estados y Municipios y el Distrito Federal, se constituye en Estado Democrático de Derecho y tiene como fundamentos: (...); IV - el valor social del trabajo y la libre iniciativa.

${ }^{1129}$ Art. $5^{\circ}$ Todos son iguales ante la ley, sin ninguna distinción, garantizando a los brasileños y a los extranjeros residentes en el País el derecho inviolable a la vida, a la libertad, a la igualdad, a la seguridad y a la propiedad, en los términos siguientes: (...) XXII - es garantizado el derecho de propiedad.

${ }^{1130}$ Artículo 38. Se reconoce la libertad de empresa en el marco de la economía de mercado. Los poderes públicos garantizan y protegen su ejercício y la defensa de la productividad, de acuerdo con las exigencias de la economia general y, en su caso, de la planificación.

1131 MARX, Karl, Manuscritos Econômicos-filosóficos, cit., p. 78.

1132 BARBOSA GARCIA, Gustavo Garcia, Direito do trabalho, Rio de Janeiro; Método, 2010, p. $164 / 170$.
} 
de la norma jurídica con el fin de eliminar cualquier sometimiento a los poderes superiores del empleador sobre el empleado. El primero queda preso en los límites de la norma legal, si no se tolera, por la interpretación jurisprudencial, ninguna ampliación de los conceptos de alienación, sujeción o incluso de relación de trabajo a causa de terceros, a través de un intermediario de mano de obra.

Como apunta Bray, es el trabajo lo que le da valor. Cada hombre tiene un derecho indiscutible a todo lo que, si se trabaja honestamente, se produce. Eso da lugar a que este mismo hombre se aproxime de los frutos de su trabajo, sin cometer ninguna injusticia con otros hombres, puesto que no limita el acceso de otros hombres. Todas las ideas de superioridad y de inferioridad, de maestro y de obrero, derivan de haber descuidado los primeros principios, habiéndose introducido, en consecuencia, la desigualdad. Mientras se mantenga esta desigualdad, será imposible arrancar la desigualdad fundada en estas ideas. El gobierno no es una causa, sino un efecto, no crea la desigualdad sino que es creado por ella, siendo, por tanto, resultado de esta desigualdad. ${ }^{1133}$

El trabajo asalariado, capitalista, además de alienar al trabajador, acumula beneficio sobre beneficio en manos de los que explotan el trabajo. El gobierno no crea esta situación. Es la situación (explotación del trabajo por parte del capitalista y la necesidad de preservar el beneficio y la propiedad) la que crea el gobierno con el fin de limitar, por el concepto de libertad y de propiedad, el acceso por parte del trabajador al fruto de su trabajo. Por este motivo, cada vez que el obrero trabaja, y lo hace de forma alienada, alejándose de los bienes que produce, estas horas de trabajo deben ser consideradas como excepción, sin ningún margen más allá de lo que establece la norma legal, límite éste que el propio Estado, creado por la propiedad, establece para la expoliación del obrero.

\footnotetext{
1133 "El beneficio del empresario siempre será una pérdida para el obrero, hasta cuando el intercambio entre las partes sea iguales y el intercambio no puede ser igual mientras la sociedad esté dividida entre capitalistas y productores, mientras los últimos vivan de su trabajo y los primeros engordan los beneficios de este trabajo". (MARX, Karl, A miséria da filosofia. Tradução José Carlos Orsi Morel, São Paulo; Ícone Editora, 2004, p. 65/68).
} 
La subcontratación o tercerización, incluso la lícita, no es más que la posibilidad de que no sólo una, sino dos personas exploten la actividad de un tercero (obrero), acumulando capital fruto de este trabajo. Sin embargo, si la alienación por el trabajo ya es (al menos debería ser) un elemento de excepción, qué podría decirse existiendo tercerización donde el agente alienante es más que una persona. La expoliación llega a niveles extremos donde dos estructuras jurídicas privadas se benefician y lucran del trabajo humano. La degradación es tan grande que llega a los márgenes de la miseria total, hiriendo uno de los pilares del propio sistema de producción capitalista que es el de que el salario debe proporcionar condiciones para que el obrero pueda, al menos de forma mínima, alimentarse y vestirse, con el fin de que pueda permanecer dentro del engranaje capitalista (pieza) generando lucro. ${ }^{1134}$

Al modo de producción del capital no le interesa que el trabajador llegue a la miseria total, ya que si así fuera, la mano de obra se extinguiría y, por consiguiente, se extinguiría el modo de producción. Por esta razón, una vez situados en la lógica capitalista, las normas que permiten la utilización del hombre como medio deben interpretarse de forma que privilegien al hombre y no a la máquina o al capital. Si no hay una norma que prevea la posibilidad de la subcontratación o tercerización, no se debe tolerarla.

De la alienación, por tanto, fruto del contrato de trabajo, deriva la subordinación. Dentro de esta estructura se mantiene el empleado. Independientemente del número de empleos, el trabajador estará subordinado a la estructura, puesto que su trabajo es permanente y de lo cual depende el tomador de los servicios, aun cuando sea "tercero". Es, por tanto, el trabajo de forma

\footnotetext{
1134 La media salarial em Brasil es de $\mathrm{R} \$ 1.800,00$ al mês. http://portal.mte.gov.br/data/files/8A7C812D2E7318C8012FE039D8AA15D9/resultado 2010.pdf acesso 19 de março de 2012 às $21 \mathrm{~h} 17 \mathrm{~min}$.

$\mathrm{La}$ media salarial de los "tercerizados" es de $\mathrm{R} \$ 1.000,00$ al mes. http://www1.folha.uol.com.br/mercado/991990-salario-de-terceirizado-e-54-do-contratado-formalem-sp.shtml - acesso 19 de março de 2012, às 21h23min.
} 
alienada para otro, de dónde este "otro" obtiene la plusvalía que conlleva la subordinación. No hay trabajo alienado que no sea subordinado.

Lo que debe quedar claro es que el derecho brasileño no prohíbe la tercerización de forma expresa. La interpretación de los preceptos jurídicos ya expuestos, tomando principalmente como referencia la filosofía especialmente marxista, que se fundamenta en la cuestión de la subordinación, permite concluir que no es posible la tercerización en Brasil. Sin embargo, el Tribunal Superior del Trabajo, en la ya tantas veces citada Súmula 331, permite que se contrate el trabajo a través de terceros ya que no se trata de actividad-fin del tomador, manteniendo la personalidad y la subordinación con relación al prestador de los servicios. Nuestra investigación tiene, como uno de sus objetivos, una crítica a esta "súmula" y a las diversas decisiones existentes sobre el tema. ${ }^{1135}$

Se hace referencia, por último, a la "doble alienación", no autorizada, como ya se ha mencionado, por el sistema, y al fetiche de la mercancía, que existe en doble dosis en los casos de tercerización, "doble" desprendimiento del bien producido de aquél que lo produce, alejando aún más este último del bien producido por él, sin ningún tipo de respaldo normativo.

\subsection{La ley brasileña de tercerización y la cuestión constitucional.}

Se tramita en el Senado Federal brasileño el proyecto de ley 4.302/98 que modifica las disposiciones de la ley 6.019/74 y que dispone sobre el trabajo temporal e incluye, en ésta, las normas que regulan la tercerización.

El artículo 4-A de la ley 6.019/74, según el proyecto, define quien es la empresa prestadora que deberá suministrar servicios determinados y

1135 'Súmula' no 11 - RESPONSABILIDAD SUBSIDIARIA DE LA ADMINISTRACIÓN PÚBLICA DIRECTA E INDIRECTA. CONTRATOS DE PRESTACIÓN DE SERVICIOS. LEY 8.666/93. La norma del art. 71 , § 10, de la Ley no $8.666 / 93$ no aleja la responsabilidad subsidiaria de las entidades de la administración pública, directa e indirecta, tomadoras de los servicios. Resolución Administrativa no 07/1999, Pub. DOE-RS días 10, 11 y 12 de mayo de 1999. 
especializados a una tercera empresa, clasificada como tomadora. Es la prestadora quien contrata, dirige, paga y fiscaliza la prestación de trabajo, pudiendo subcontratar, párrafo primero del mismo artículo.

El párrafo segundo del artículo 4-A de la ley aleja la relación de empleo de la empresa tomadora. Esta es la empresa persona física o jurídica, que contrata unos servicios determinados y específicos, no pudiendo servirse de la mano de obra salvo en los estrictos límites del contrato existente entre las empresas.

La empresa contratante será solidariamente responsable de los débitos laborales y de la seguridad social no pagados por la prestadora, conforme al párrafo quinto, del artículo 4-B de la norma.

Lo que llama la atención es que el proyecto de ley permite la tercerización en actividad-fin de la empresa. Ya no existe la limitación presente en la "súmula" 331, III, del TST ${ }^{1136}$, que "autoriza" la subcontratación sólo en las actividades-medio. Hay una evidente retroactividad. Si la jurisprudencia del Tribunal Superior del Trabajo tiene un efecto retroactivo, al autorizar la tercerización fuera de lo que la ley autoriza, la ampliación legislativa también para las actividades-fin acaba por consagrar la retroactividad en materia laboral, en flagrante contradicción con lo que consta del artículo $7^{\circ}$, encabezamiento, de la CF/88 ${ }^{1137}$.

No cabe sostener la posibilidad de "cambiar" la responsabilización subsidiaria de la "súmula" 331 con la posibilidad de tercerización en actividad-fin. La utilización de recientes decisiones del Tribunal Superior del Trabajo que autorizan la tercerización en los casos de las empresas de telecomunicaciones tampoco

\footnotetext{
${ }^{1136}$ III - No forma vínculo de empleo con el tomador la contratación de servicios de seguridad (Ley no 7.102, de 20.06.1983) y de mantenimiento y limpieza, así como la de los servicios especializados relacionados con la actividad-medio del tomador, siempre que sea inexistente la personalidad y la subordinación directa.

${ }_{1137}$ Artículo 7 Los derechos de los trabajadores urbanos y rurales, y otros destinados a mejorar sus condiciones sociales: (...).
} 
permite que se extienda esta modificación legislativa a los trabajadores en general.

Algunos defienden el proyecto, argumentando que una vez que se apruebe la ley, Brasil se insertará en el contexto internacional de la economía globalizada, dando el tratamiento debido a la tercerización. ${ }^{1138}$

Sin embargo, no participamos de esa opinión porque Brasil, desde hace años, ya forma parte de la economía globalizada por existir una contratación directa de trabajadores no se impedirá al país que siga la senda del mercado global internacional. Asimismo, hay que añadir que los deseos de la población, manifestados en la Constitución de 1988, son los de mayor dignidad, empleo digno y salario y todo eso no lo da la subcontratación.

La consagración de este proyecto permitirá que todas las empresas y las secciones industriales y de servicio sean administradas por empresas prestadoras en provecho de grandes conglomerados sin empleados. Estos conglomerados obtendrán sólo el beneficio, con poquísimo coste de producción y ninguna responsabilidad social. Habrá empresas especializadas en tercerizar cualquier cosa, dado que todo es especializado en una sociedad industrial consagrada por la división del trabajo.

Por último, Novais, cuando se le preguntó sobre la ley de tercerización contestó que lo necesario es una "primerización" y no una tercerización, dada la precarización que, en su opinión, conlleva la tercerización. ${ }^{1139}$

\footnotetext{
${ }^{1138}$ FERRAZ ANDRADE, Tatiana Guimarães, Tercerización: debate inherente a los períodos de expansión económica y de crisis - Comentarios al proyecto de ley 1.621/2007. En Revista Eletrônica do Tribunal Regional do Trabalho da Quarta Região, año VI, número 107, segunda quincena de octubre de 2010, www.trt4.jus.br.

${ }_{1139}$ http://www.adital.com.br/site/noticia.asp?lang=PT\&cod=40636. Acceso el 30 de noviembre de 2010, a las 19h01min. "Lo ideal sería que la tercerización de lugar a la 'primerización' y acabara, como sucedió recientemente en Ecuador. En mi opinión, entre los textos que pretenden regular la tercerización, se puede citar el Proyecto de Ley $n^{\circ} 1621 / 07$, del diputado Vicentinho (PT-SP), cuya propuesta prohíbe la tercerización de la actividad-fin, estableciendo que las empresas deben
} 
El problema son los límites. Si existe la posibilidad de tercerizar todas las actividades de una determinada empresa, ¿para qué contratar de forma directa? Tanto los despidos como la subcontratación sobrevaloran las acciones en el mercado financiero, aumentando aún más la desigualdad social y la concentración de la renta.

\subsubsection{Objetivos de la ley}

Los objetivos de la ley son la regulación de la tercerización existente en Brasil en situaciones puntuales y "regulada", en general, sólo por la "súmula" del Tribunal Superior del Trabajo.

Sin embargo, hay otro objetivo. La reducción de los costes de producción sería el primero. Este fundamento, sin embargo, cede espacio al mercado. El coste del trabajo no es tan grande, para las grandes empresas hasta el punto de que la mismas corran el riesgo de tercerizar y ser responsables solidarias. Por eso, además de tratar de reducir en parte los costes de producción, están destinadas a valorar las acciones en el mercado financiero. Cuanto menor sea el número de empleados contratados de forma directa, mayor será la posibilidad de la valorización accionarial.

También está la cuestión sindical. El sindicato es el lugar donde la colectividad de trabajadores se reúne. Es allí, en teoría, donde deben estructurar su pensamiento de clase y sus estrategias e ideas frente al capital. Sin embargo, una vez descentralizada la organización de los trabajadores, donde en una gran empresa habría empleados de tres, cuatro o hasta cinco sindicatos diferentes, de guardias de seguridad, conserjes, del personal de limpieza, programadores, y artífices por ejemplo, la realidad material tendría mucho menos posibilidad de 
volverse a favor de estos mismos trabajadores, ofreciéndose, sin mayores problemas, para el control por parte de las elites dominantes y del sistema de administración de las empresas.

Además de regular lo que ya forma parte de la realidad, los objetivos de la tercerización son la mayor posibilidad de valorización de las acciones de las grandes empresas en el mercado financiero y el distanciamiento del trabajador del sindicato, lugar este destinado a la emancipación y a la formación de la conciencia de clase.

\subsubsection{Beneficiados con la "legalización” de la tercerización.}

Como ya hemos mencionado, los que realmente se beneficiarán con la legislación sobre la tercerización son las grandes empresas y los conglomerados que explotan las actividades en el mercado financiero de la bolsa y que mantiene a sus propios empleados apartados del movimiento sindical, repitiendo, de manera suave, la "conciencia" de clase de estas mismas elites dominantes.

Si los costes de producción, única y exclusivamente, justificaran la tercerización, la misma no estaría en el centro del proyecto de ley, sino en la reducción del número de empleados, de miembros de la Comisión Interna de Prevención de Accidentes, y mayor automación, mediante Enmienda constitucional (modificación del artículo 7ํㅜ XXVII, de la Constitución brasileña de $1988^{1140}$ ), junto con proyectos reales para reducir los costes sociales sobre la nómina y la producción, para que se tasara más la especulación y las transacciones financieras.

\footnotetext{
${ }^{1140}$ Artículo 7 Los derechos de los trabajadores urbanos y rurales, y otros destinados a mejorar sus condiciones sociales: (...); XXVII - protección con respecto a la automatización, de acuerdo con la ley (...).
} 
Ello obedece a que el coste del trabajo no es el principal objetivo del proyecto, sino la reducción de la conciencia de clase, la mayor alienación y la mayor posibilidad de valorización de las acciones en el mercado financiero.

Siguiendo a Bauman, cabe observar que la tarea del cambio en el trabajo se vio más afectada por el proceso de desregulamentación y privatización. Esta tarea está escapacndo de las manos del poder público, mediante la "tercerización", completa o parcial, para mantener como obejto de cambio la mano de obra. La prefencia por empleados fluctuantes, "flex", sin compromiso, desechables, en lugar de especializados, transferindo al mercado la tarea de los cambios en el mundo del trabajo. ${ }^{1141}$

Este último parrafo muestra, como lo hacen los demás, que el mercado, sob el control de las empresas transnacionales, controlan el mundo del trabajo, y hacen del trabajo algo que les puede solamente traer beneficios. La ley de la tercerización, como parte del todo, añade, aún más, la posibilidad del acumulamiento de renta en las manos de las grandes empresas y corporaciones, sin un beneficio gerenal a la sociedad.

\subsubsection{La cuestión sindical y la tercerización.}

Como crítica al proyecto de ley, hay que decir que la cuestión sindical no está bien resuelta. La cuestión sindical es crucial para los trabajadores. Una norma que prevea la tercerización debe tener en cuenta, necesariamente, este hecho.

Se trataría de igualar, en materia sindical, a los empleados de la prestadora con los de la tomadora, modificando el artículo 570, encabezamiento, de la $\mathrm{CLT}^{1142}$, con el fin de que los empleados de la primera tengan los mismos

\footnotetext{
1141 BAUMAN, Zygmund, Vida para o consumo: a transformação das pessoas em mercadoria, tradução Carlos Alberto Medeiros, Rio de Janeiro; Zahar Editora, 2008, p. 16/18.

${ }_{1142}$ Art. 570. Los sindicatos se constituyen, normalmente, por categorías económicas o profesionales, y específicas, en conformidad con la discriminación del marco de las actividades y
} 
derechos y accesos sindicales que los de la segunda, con el fin de fortalecer la asociación dentro de la propia empresa, extendiendo esta realidad de cohesión sindical más allá de los muros de la tomadora.

Las ventajas para el tomador, en el caso de la tercerización, sería la posibilidad de sustitución inmediata de un trabajador incumplidor sin los costes de la rescisión contractual, además de la mayor valorización accionarial para las grandes corporaciones que, al final, son las que más tercerizan.

Josiane Fachini Falvo, subraya que la acción sindical ejerce una protección limitada frente al trabajador tercerizado, eso porque la mayoría de los sindicatos de América Latina no tienen representación jurídica sobre los trabajadores "externos", como establece la legislación nacional. Hay una pulverización del movimiento sindical, con una interrupción de la representación sindical y una dificultad para aunar las demandas. Lo que se debe hacer es vincular a los trabajadores tercerizados al sindicato de la empresa tomadora, aun cuando la actividad sea temporal ${ }^{1143}$, lo que ocurre, en parte en Francia.

La realidad sindical, en cuanto a la tercerización, por tanto, debe cambiar. La norma legal tiene ante sí una excelente ocasión de aportar estos cambios. No hay un interés político o económico. Las grandes empresas, que financian las campañas políticas presionan. Las federaciones de empresarios también. En medio a todo esto queda el trabajador tercerizado, que recibe poco más de trecientos euros al mes, contando con la buena-voluntad del tomador de servicios de pagarlo en caso de incumplimiento o de querer, después de unos seis años, contratarlo como su empleado.

profesiones al que se refiere el art. 577 o según las subdivisiones que, bajo propuesta de la Comisión de la Afiliación Sindical, que establece el art. 576, son creados por el ministro del Trabajo, Industria y Comercio.

${ }^{1143}$ FACHINI FALVO, Josiane, Balanço da regulamentação da terceirização (...), cit., p. 05/06. 
Robert Brenner, apunta que la introducción de la "producción ajustada", al estilo japonés, funciona para el aumento de la producción y del beneficio, lo que conduce a una intensificación del trabajo obrero, como sucedió con la reorganización de la cadena productiva a través de la tercerización, implicando una reasignación de la mano de obra para el sector no-sindical, donde los trabajadores no tenían ni siquiera la menor protección. ${ }^{1144}$

Aún, Jounin añade que el movimiento sindical, en los casos de tercerización, es más limitado. Ls empresas que tercerizan, las empresas de trabajo temporal, normalmente pequeñas, no tienen sindicatos. Los sindicatos de los trabajadores de empresas de trabajo temporal están más preocupados con los trabajadores administrativos y permenentes, lo que hace con que los derechos de los empleados tercerizados queden muy lejos de la protección sindical. ${ }^{1145}$

El autor añada que "en l'absense de délégués représentant l'ensemble du chantier, il n'y a guère de représentation que du collectif, très minoritaire, des ouvriés embauchés de l'entreprise générale. Non seulement de tels représentants ne sont pas vus par les sous-traitants et/ou intérimaires comme des alliés, des défenseurs potentiels, mais ils peuvent être vus comme des enemies"1146 lo que confirma el perjuício en nivel sindical a los trabajadores.

Compete no sólo al legislador sino también al intérprete repensar la cuestión de la tercerización, permitiendo la interpretación más beneficiosa para los trabajadores, que garantice, empíricamente, la incorporación sindical real y fuerte, con la posibilidad real de negociación ante los tomadores de trabajo, lo que acaba por equilibrar la relación capital/trabajo.

\footnotetext{
1144 BRENNER, Robert, O "boom" e a bolha: os Estados Unidos na economia mundial, Rio de Janeiro; Editora Record, 2003, p. 126.

1145 JOUNIN, Nicolas, "L'illegalité sous-traitée? Les conséquences du reours à des employeurs intermédiaires dans ke secteur du bâtiment". En Revue Droit Social, numero 1, janvier 2007, p. 43.

1146 JOUNIN, Nicolas, "L'illegalité sous-traitée? (...), cit., p. 43
} 
Para otros autores como Ferraz Andrade, la ley no podría impedir que el sindicado, por acuerdo colectivo, estuviera en contra de la tercerización ${ }^{1147}$, fundamento éste que sigue la línea de lo establecido en el artículo $7^{\circ}, \mathrm{XXVI}$, de la Constitución brasileña de $1988^{1148}$, que garantiza a los trabajadores el reconocimiento de las normas colectivas como derecho fundamental, teniendo como modelo interpretativo el encabezamiento del artículo $7^{\circ}$, que permite sólo la mejoría de la condición social de los trabajadores.

\subsubsection{Huelga y tercerización.}

La subcontratación debilita el movimiento sindical. Retira una parte importante de trabajadores del centro de las empresas y les envía a la periferia. La capacidad de reivindicación de estos trabajadores es prácticamente nula, junto con los bajos salarios pagados y la constante amenaza de desempleo, por tratarse de mano de obra no cualificada.

La tercerización, fruto del proceso toyotista de administración empresarial, supone para los trabajadores la difícil capacidad reivindicativa, la reducción de los salarios de los empleados subcontratados, que requieren menos empleados debido al actual proceso de automatización, reduciendo el número de trabajadores contratados con un vínculo de empleo directo. ${ }^{1149}$ De ahí que la cuestión de la huelga se vea afectada.

Si el trabajador contratado de forma directa trabaja todos los días, trabajando durante el día para comer por la noche, ¿qué se podría decir del subcontratado? Cuando, a través de una reivindicación justa, éste intente hacer huelga, ¿de qué

\footnotetext{
1147 FERRAZ ANDRADE, Tatiana Guimarães, "Terceirização (...)", cit., p.

${ }^{1148}$ Artículo 7 Los derechos de los trabajadores urbanos y rurales, y otros destinados a mejorar sus condiciones sociales: (...); XXVII - reconocimiento de los convenios y acuerdos de negociación colectiva; (...).

1149 PEREIRA MARCELINO, Paula Regina, Terceirização do trabalho no Brasil e na França, cit., p. 05.
} 
vivirá si su salario ya está reducido? Y ¿cuáles serán las condiciones de movilización? Prácticamente cero, dada la constante amenaza del desempleo.

La subcontratación, que destruye el movimiento sindical y las condiciones de salario y trabajo de los obreros, también hace que el derecho de huelga, en el mundo real, sea sólo una ilusión. Y eso, en el caso brasileño, acaba por afectar lo que establece el artículo $9^{\circ}$ de la Constitución federal que garantiza a todos los trabajadores el derecho a la huelga como una norma de derecho fundamental.

Así, una vez que se entienda como constitucional la subcontratación, superadas todas las condiciones ya descritas en esta investigación, aún así, habrá que constatar si, empíricamente, el tercerizado tiene derecho a la huelga. Si podrá organizarse. Si su sindicato, organizado, es lo suficientemente fuerte como hacer valer este derecho fundamental. De lo contrario, no se puede, en una determinada empresa, subcontratar a trabajadores.

\subsubsection{Alternativas de tutela en caso de tercerización.}

Una vez aprobado el proyecto de ley que regula la tercerización, será demasiado difícil sostener, ante la Suprema Corte brasileña, su inconstitucionalidad, como de hecho así ha sucedido con relación a una "súmula", que teóricamente "debe valer menos que la ley".

De ahí que una de las alternativas sea la lucha por los salarios y por la afiliación sindical de los empleados de la empresa tomadora, además de una fiscalización rígida por parte de la autoridad competente, con multas pesadas y caras, y hasta con la posibilidad de crimen en el caso de fraude, como ocurre en Francia, articulos 8234-1 e 8243-1 de Código del Trabajo francés, con la posibilidad de prision por hasta diez años y multa de treinta mil euros. 
También se deben crear obstáculos a la subcontratación, especialmente en el ámbito de las políticas fiscal y presupuestaria, con el fin de no hacer esta opción atractiva para el tomador de los servicios. Se pueden adoptar pequeñas prácticas como, por ejemplo, las citadas en el párrafo anterior. La mayor, sin embargo, proviene de la propia ley: considerar al tomador un responsable solidario. El crédito no pagado por el prestador, hace del tomador un responsable sin beneficio de orden, incluso en los casos de "cuarterización".

Lo cierto es que poco se podrá hacer una vez aprobada esta ley. La inconstitucionalidad, basada en el citado artículo $7^{\circ}$, encabezamiento, de la CFB, difícilmente sería aceptada por los juristas no sólo de la Suprema Corte, sino de los tribunales inferiores y juzgados de primer grado.

El sentido común teórico de los juristas ${ }^{1150}$, fundamentado en el extremo positivismo, apego a la ley y a la idea de la legislación soberana, sin tomar en consideración la dignidad humana, el valor social del trabajo y los derechos fundamentales, acabaría con cualquier intento de garantizar la contratación directa.

La tutela, por lo tanto, deberá venir del propio poder legislativo y de la fuerza de los sindicatos e instituciones verdaderamente preocupadas por los derechos de los trabajadores. Se podría pensar en diversas formas de controlar y limitar la acción nefasta de la subcontratación de los trabajadores, tales como el aumento de la incidencia tributaria en el caso de la tercerización y la rígida fiscalización con posibilidades reales de auditoria. Además, el pago del mismo salario y la afiliación sindical de los empleados de la tomadora serían otras posibilidades.

${ }^{1150}$ Sobre este tema específico ver WARAT, Luis Alberto, O direito e sua linguagem, passim. 


\subsection{Pleno empleo y tercerización.}

Uno de los fundamentos de la tercerización es que constituiría una mejor oportunidad de generar empleo. Que la tercerización podría resolver en parte uno de los mayores problemas modernos como es la falta de trabajo. Pero ¿será esta la solución? Con el fin de generar empleos de mala calidad ¿se puede tercerizar, con el fin de poder aumentar el número de empleados? ¿No se puede contratar de forma directa, con los mismos puestos de trabajo, sin que suponga una precarización del trabajador?

Hay que tener en cuenta, en primer lugar, que no se puede justificar la tercerización con el fin de cumplir el principio del pleno empleo conforme al inciso VIII del artículo 170 de la CF/88. El trabajo con pésimas condiciones laborales, sin efectivo compromiso real con los sindicatos, y que tengan bajos salarios no es un empleo sino un subempleo. Cuando la norma constitucional establece el pleno empleo, se refiere a un trabajo de calidad, conforme a las normas del artículo 7ํㅡ, I, primera parte e inciso XXVI, entre otros, porque autoriza expresamente la explotación de la plusvalía, sin que esto implique, sin embargo, que se acojan normas que fragmenten los derechos que excluyen al trabajador de su compromiso sindical y que reducen salarios.

Por esta razón es necesario estudiar, en el tema de la tercerización, el pleno empleo. Y ello porque se podría justificar, de forma retórica, que la tercerización genera millones de empleos, cumpliendo de forma razonable el principio que se está debatiendo.

\subsubsection{Principio del pleno empleo.}

La consecución del pleno empleo ${ }^{1151}$ es también el principio del orden económico y está ligado directamente a la reducción de las desigualdades

${ }^{1151}$ Art. 170. [...], VIII - búsqueda del pleno empleo. 
sociales y regionales -artículo $3^{30}$, III, de la CF/88-. ${ }^{1152}$ Es el principio impositivo, debiendo el poder público buscar su aplicación mediante políticas públicas. Es, también, una garantía para el trabajador, ligado a la dignidad del trabajador por la valorización del trabajo humano y a la protección contra la automación, artículo 7ํㅜㅇ $X X V I^{1153}$, de la CFB, con el fin de que la robotización y la tecnología no hagan que se extingan los puestos de trabajo y los trabajadores acaben en la miseria con la consecuente pérdida de dignidad.

El pleno empleo es un principio rector de la economía que se opone a las políticas recesivas. Se trata de propiciar trabajo a todos los ciudadanos que están en condiciones de ejercer una actividad remunerada productiva, armonizando con las reglas del orden económico, que se fundamenta, ante todo, en la valorización del trabajo humano. ${ }^{1154}$

Recuerda Bocorny que el trabajo tiene una doble finalidad: desde el punto de vista económico, la producción de riqueza; y también es un elemento de inclusión social. De ahí el porqué la búsqueda del pleno empleo no tenga solamente un carácter humanístico ${ }^{1155}$, sino, como ya hemos mencionado, de inclusión social.

No se puede justificar la búsqueda del pleno empleo, por ser el trabajo también un elemento de existencia humana, a través de la precarización de los derechos y de la transformación del trabajador en sólo una pieza dentro del orden productivo. El pleno empleo es distinto del subempleo. El empleo con dignidad, salarios justos, buena conciencia y afiliación sindical es lo mínimo que se puede exigir. Como sabemos hay una lista generosa de derechos sociales de los

\footnotetext{
1152 Art. $3^{\circ}$ Constituyen objetivos fundamentales de la República Federal de Brasil: (...); III erradicar la pobreza y la marginación y reducir las desigualdades sociales y regionales; (...). ${ }_{1153}^{1154}$ Art. $7^{\circ}$ [...], XXVII - protección con respecto a la automatización, de acuerdo con la ley (...).

1154 "Se quiere que el trabajo sea la base del sistema económico, reciba el tratamiento de principal factor de producción y participe del producto de la riqueza y de la renta en proporción de su posición en el orden económico". (DA SILVA, José Afonso, Curso de Direito Constitucional Positivo, São Paulo; Editora Malheiros, 17ª Ed., 2000, p. 771).

${ }_{1155}$ RAUPP BOCORNY, Leonardo, $A$ valorização do trabalho humano no Estado Democrático de Direito, Porto Alegre; Sérgio Antônio Fabris Editor, 2003, p. 69.
} 
trabajadores, tales como el derecho del trabajo y los derechos fundamentales sociales, según el artículo 6º de la Constitución brasileña de 1988.

Por lo tanto, con el fin de cumplir adecuadamente lo que establecen los capítulos del orden económico y del orden social, artículos 170 y $193^{1156}$ de la CFB, respectivamente, es necesaria la consecución del pleno empleo, mediante empleos de calidad, sin precarización extrema. Esto implica, dada la doble explotación de la plusvalía, la compatibilidad de la tercerización con esta forma de orden económico y social propuesto por la Carta Magna de 1988.

\subsubsection{El trabajo como elemento de existencia humana digna.}

Se ha discutido mucho acerca del surgimiento de los derechos de los trabajadores. Durante años, gran parte de la doctrina sostuvo que ellos surgieron para dar mayor confort y dignidad a los trabajadores, ya cansados de la forma en que el modo de producción capitalista les trataba. Esta concepción actualmente no se sostiene. En efecto, los derechos laborales surgieron para frenar movimientos sociales que se dirigían a la extinción de la propiedad privada de los bienes y de los medios de producción, además de controlar y dar alguna satisfacción a las masas, de manera que estos mismos trabajadores continuaran trabajando para los patrones, permitiendo que los últimos acumulasen, de forma tranquila, segura y sin percances, el beneficio fruto del trabajo. ${ }^{1157}$

El trabajo, en el modo de producción capitalista, se convierte en el elemento central. Mediante el trabajo de terceros, el capitalista se apropia de la energía del trabajador y de parte del producto de esta energía, plusvalía, y acaba generando el beneficio, que lo conduce a la acumulación de capital.

\footnotetext{
1156 Artículo 193. El orden social tiene como base el primado del trabajo, y como objetivo el bienestar y la justicia social.

${ }^{1157}$ MARTINEZ, Luciano, Curso de direito do trabalho, São Paulo; Saraiva, $3^{\text {a }}$ Ed., 2012, p. 754.
} 
Por ello, la Constitución brasileña de 1988 elevó el trabajo humano a la condición de fundamento de la República -artículo 1ํㅡ. IV- y fundamento del orden económico -artículo 170, encabezamiento- y también lo clasificó como un derecho social, fundamental por naturaleza, artículo 6ํㅜㅇ, protegido, incluso, contra enmiendas a la Constitución -artículo 60, párrafo cuarto, IV- protegiéndolo del modo capitalista, precisamente para mantener el orden como se presenta. ${ }^{158}$

Esto, sin embargo, no hace que el trabajo sea un elemento únicamente económico. Hay, evidentemente, un concepto económico de trabajo, como también hay un concepto económico del consumidor, por ejemplo, aunque éste no sea un elemento tan sólo económico.

Es el trabajo, ante todo, un elemento de existencia humana ${ }^{1159}$, del ser humano, o más bien, de que el ente ser humano pueda realizarse como persona, pueda dar énfasis a su dignidad ${ }^{1160}$, no sólo para satisfacer sus necesidades, sino también sus demandas. Siendo el elemento de existencia humana y habiendo una apropiación del capitalista como parte del fruto del trabajo, el trabajador no aliena sólo el producto del trabajo, sino también una parte considerable de su existencia.

Recuerda Jean Paul Sartre que las dos categorías de la existencia son el ser "en sí" y el ser "para sí". En el primer caso, corresponde al mundo de las cosas materiales tales como las piedras, las plantas y otros. El segundo es el "mundo de

1158 En este sentido se manifiesta Gomes Canotilho, para quien “(...) la Constitución erigió el 'trabajo', el 'empleo', los 'derechos de los trabajadores' y la 'intervención democrática de los trabajadores' en elemento constitutivo del propio orden constitucional global y en instrumento privilegiado de realización del principio de democracia económica y social (cfr. Art. 20)". (GOMES CANOTILHO, J. J., Direito Constitucional e Teoria da Constituição, cit., p. 347).

1159 MARCUSE, Herbert, Cultura e sociedade, cit., p. 7/50. Ver, también, sobre el tema la película canadiense "La gran seducción" de Jean-François Pouliot, donde los residentes de un pequeño pueblo hacen de todo para que un médico se establezca en el lugar, para que, con ello, se instale una fábrica de embalajes, porque ya no pueden soportar el vacío y la vergüenza de vivir sin trabajo y pagar sus cuentas sólo con el desempleo.

1160 "El trabajo es, conforme a la experiencia, un valor moral aceptado por las sociedades contemporáneas y posee en sí una doble función: en primer lugar, es una de las formas de descubrir y alcanzar el ideal de la dignidad humana, además de promover la inserción social; y en segundo lugar, es el elemento económico indispensable, directa o indirectamente, para que haya crecimiento". (RAUPP BOCORNY, Leonardo, A valorização do trabalho humano no Estado Democrático de Direito, cit., p. 71). 
la conciencia, de aquello que tiene existencia por sí mismo, de la realidad humana" ${ }^{1161}$. No se refiere el filósofo francés al trabajo, pero se cree que el texto antes citado puede aplicarse a la cuestión en objeto, ya que "ser para sí"” sería nada más que la relación del ser consigo mismo incluso, con sus elementos de existencia y supervivencia, realización, placer y felicidad. El trabajador, por tanto, trabajando de forma subordinada, no hace más que alienar ${ }^{162}$ parte de esta existencia - producto del trabajo - a tercero, el capitalista.

Al analizar el concepto de trabajo o incluso interpretar las normas de protección del trabajo debe, quien así lo hace, atenerse al elemento existencial del trabajo y no al meramente económico, relacionado sólo con los costes de producción, dejando al trabajador a merced del aspecto económico, por tanto, sujeto a la tendencia flexibilizadora y no protectora del mercado.

De este modo, no sólo el intérprete, sino también la sociedad contribuirá a la reducción de las desigualdades sociales y regionales y a la erradicación de la pobreza y de la miseria, objetivos fundamentales de la República, -artículo 3는, de la CF/88- promoviendo el bien de todos, -artículo 3ํㅡ, II, de la CF/88- y acercando al máximo, de la igualdad material, la forma racional de aplicación de la Constitución.

\footnotetext{
1161 DA PENHA, João, O que é existencialismo, São Paulo; Brasiliense, 2004, p. 54/5.

1162 CODO, Wanderley, O que é alienação, São Paulo; Brasiliense, 2004, p. 93/4, para quien "En la fase actual del capitalismo, el trabajo ya se encuentra colectivizado pero la posesión de los medios de producción se encuentra individualizada, es decir: el trabajo social es expropiado por el dueño solitario de los medios de trabajo. La forma en cómo se produce eso es la forma-mercancía, el valor de uso se subvierte en valor de cambio. La transformación del producto en mercancía que genera el logro (la plusvalía) demanda la transformación del propio trabajo en mercancía, vendida y apropiada como cualquier otra. He aquí el reinado de la alienación: el producto se separa del productor, 'se enfrenta a él como un ser extraño', mi trabajo, mi modo de ser en el mundo no me pertenece. De esta manera yo me separo de mí mismo, del otro, de la historia. Dondequiera que el capital imponga relaciones entre las mercancías, la alienación se manifiesta; es la relación social generada por el capital, su forma de ser humano".
} 


\subsection{Hipótesis de constitucionalidad de la tercerización - Posibilidad de que sea más beneficiosa para el trabajador.}

El tema de la tercerización como fenómeno moderno no se puede ignorar. Estamos haciendo un análisis constitucional de la subcontratación de los trabajadores, principalmente en Brasil, pero sin perder de vista cómo se regula en otros países y en la Unión Europea.

Esta forma de contratación, por tanto, conforme a lo que venimos exponiendo en este texto, es perfectamente posible en los casos en que existen derechos y condiciones laborales del trabajador, en que ejerza un trabajo especializado, recibiendo, además del salario, la integración sindical y profesional superior a los empleados de la tomadora.

De esto, además, trata la Consolidación de las Leyes del Trabajo brasileña cuando permite la contratación y la subcontratación en los casos de obra, -artículo $455^{1163}$ del texto antes mencionado-, norma ésta que debe interpretarse en conjunto con las demás presentes en la CLT y la Constitución, interpretación sistemática de la norma jurídica, lo que permite concluir que es lícita la tercerización sólo cuando se destina a la mejoría de la condición social de los trabajadores, -artículo $7^{\circ}$, encabezamiento, de la CF/88- ${ }^{1164}$.

Así, en los casos de contratos de obra, donde el contratante contrata la ejecución de una determinada obra, los empleados de la contratada serán registrados y pagados por la misma, y quedarán subordinados a ella. Del mismo modo, en los casos de subcontratación o subcontrata, los empleados de la

\footnotetext{
${ }^{1163}$ Art. 455 - En los contratos de subcontrata responderá el subcontratista por las obligaciones derivadas del contrato de trabajo estipulado, cabiendo, sin embargo, a los empleados, el derecho de reclamación contra el contratista principal por el incumplimiento de aquellas obligaciones por parte del primero. Párrafo único - Al contratista principal se le dispensa, en los términos de la ley civil, de la acción regresiva contra el subcontratista y la retención del valor a éste debido, como garantía de las obligaciones previstas en este artículo.

${ }_{1164}$ Artículo 7 Los derechos de los trabajadores urbanos y rurales, y otros destinados a mejorar sus condiciones sociales: (...).
} 
subcontrata, ejecutando un trabajo más especializado que el de la empresa contratista, tendrán mejores condiciones económícas, sociales y sindicales que los empleados de esta última.

Ésta es la forma posible de conciliar la libertad de empresa y la legislación civil y mercantil con la laboral. De lo contrario, al no haber una simple intermediación de mano de obra, subordinación o ejecución de trabajo permanente para el contratante o para el contratista, sin mejora significativa en términos salariales, sindicales o sociales, serán éstas y no el subcontratista, el empleador del trabajador, por fraude en la contratación, siendo esta última, en virtud del artículo 942 del Código Civil brasileño ${ }^{1165}$, de aplicación subsidiaria a la legislación laboral, responsable solidaria -artículo 8º, párrafo único, de la CLT-. ${ }^{1166}$

Sino, se produciría una doble alienación y expropiación de la plusvalía, utilizando al trabajador únicamente como una pieza de producción, al no poder permitir la subcontratación. Por esta razón, las normas que autorizan la subcontratación en Brasil son inconstitucionales. Son también los términos de la "súmula" 331 del Tribunal Superior del Trabajo que autoriza la subcontratación en una actividad-medio, como por ejemplo de aseo y limpieza. En estos casos, más allá de la doble explotación de la plusvalía la cuestión social, salarial y sindical se ve perjudicada, separando al trabajador del bien que produce a cambio de un sueldo inferior y peores condiciones que las del trabajador de la empresa tomadora.

\footnotetext{
1165 Art. 942. Los bienes del responsable por la ofensa o violación de los derechos de otros están sujetos a la reparación del daño causado; $y$, si la ofensa tiene más de un autor, todos responderán solidariamente de la reparación. Párrafo único. Son solidariamente responsables con los autores los coautores y las personas designadas en el art. 932.

1166 Art. $8^{\circ}$ - Las autoridades administrativas y la Justicia del Trabajo, a falta de disposiciones legales o contractuales, decidirán, conforme al caso, por la jurisprudencia, por analogía, por equidad y otros principios y normas generales de derecho, principalmente del derecho del trabajo, y, también, de acuerdo con los usos y costumbres, el derecho comparado, pero siempre de manera que ningún interés de clase o particular prevalezca sobre el interés público. Párrafo único - El derecho común será una fuente subsidiaria del derecho del trabajo, en aquello en que no sea incompatible con los principios fundamentales de éste.
} 
Por último, conviene dejar constancia de que la Consolidación de las Leyes del Trabajo, articulo 3ํㅜ, de donde la Constitución brasileña de 1988 extrae el concepto de empleado y también los límites para la subcontratación (articulo 455) solamente para los llamados contratos de obra, contrata y subcontrata, no autoriza la Itercerización (llamada "subcontratacón de servicios"). No hay previsión legal para este tipo de actividad, de donde podemos concluir que la compatibilidad entre las dos normas sólo permite, como un añadido para el trabajador en los casos de trabajo en servicios especializados de obra (por autorización legal pero que no son tercerización), quedando las demás posibilidades (tercerizaciones), tales como la seguridad, la limpieza, la consiergería, la actividad-medio, así como la tecnología de la información ${ }^{1167}$ por ejemplo, fuera del amparo legal y constitucional.

1167 Esta discutible porque puede ser mucho más benefica la tercerización que la contratación directa. 


\section{CONCLUSIONES}

Una tesis jurídica no se concluye. Cada estudiante de doctorado que tiene por objetivo investigar y presentar algo nuevo, una vez que participa en la investigación y en la búsqueda del conocimiento más que acabar la Tesis, la abandona. Es un momento de dolor y emoción. Podría haberlo hecho mejor. Podría haber investigado más. He tenido que dejar fuera varios pasajes excelentes de la doctrina y de la jurisprudencia.

Como eternos insatisfechos, los humanos que tienen por objetivo la ciencia y la investigación se sienten un poco más vacíos cuando depositan su Tesis. Cuando se les pone a prueba y no por la posibilidad de que se planteen críticas y errores por parte del Tribunal, ni tampoco por el hecho de presentarse casi desnudado ante terceros, mostrando todo su esfuerzo y esencia.

Quien termina una tesis se siente más vacío porque deja parte de sí. Porque termina un ciclo. Porque abandona algo que formó parte de la vida y que le hizo madurar y, quién sabe, si le ha ayudado a ser mejor.

Con la Tesis se va una parte de doctorando. Al mismo tiempo, queda otra parte expuesta al mundo académico, vinculado al conocimiento y a la emancipación del ser.

La razón exige que se investigue para presentar una contribución al mundo de la investigación y del conocimiento. La emoción no quiere separarse del texto, de los libros, de los artículos, de los resúmenes, reseñas y jurisprudencia. El tema escogido es de la vida del doctorando. Forma parte de su "ser" y es libre, vivo, con el fin de seguir su rumbo. Es casi un fetiche y da miedo.

Concluir una Tesis Doctoral significa dar un paso más allá de sí mismo. Pero también significa formar parte de una elite intelectual que, de una u otra manera, 
tiene como objetivo construir un mundo mejor. Cuando el investigador tiene conciencia de este fetiche, y sigue con la intención de concluir su Tesis, tal vez está pensando en contribuir al avance de la ciencia, sintiéndose también más feliz. Y la felicidad, así como el lenguaje, es la morada del ser. Es un fin. Es lo que nos permite ser verdaderamente humanos.

Seguidamente presentamos las conclusiones de nuestra Tesis Doctoral.

Los derechos que han surgido, fruto del principio de igualdad, derechos denominados de segunda dimensión, han acabado por fortalecer la formación del Estado de Derecho con el fin de que se evolucionara a un Estado Democrático de Derecho $^{1168}$. La superación del Estado de Bienestar Social, de estabilización capitalista, se hizo necesaria para superar la idea de un Estado meramente prestacional. No se conceden más derechos de forma paternalista y con el objetivo de preservar la lógica capitalista. De hecho, el objetivo del derecho vigente es la emancipación social, intelectual, económica y humana del ser. Es la dignidad humana.

Es una realidad cercana a los derechos de los trabajadores. Estos derechos, fundamentales por naturaleza, clasificados dentro del título II de la Constitución brasileña como "derechos y garantías fundamentales", forman parte, como los de primera dimensión, del núcleo de derechos humanos y fundamentales y se relacionan con la dignidad humana, valores sociales del trabajo y de la libreiniciativa y limitación del poder del capital y de la propiedad privada dentro del orden económico.

En España, el sistema constitucional de garantía de los derechos fundamentales privilegia aquéllos ligados a las libertades en detrimento de

\footnotetext{
1168 Art. 1 La República Federativa de Brasil, formada por la unión indisoluble de los Estados y Municipios y de Distrito Federal, se constituye en Estado Democrático de Derecho y tiene como fundamentos: (...).
} 
aquéllos que tienen relación directa con la igualdad, realidad ésta que no se corresponde con el modelo constitucional brasileño.

Defendemos que los derechos humanos y fundamentales deben incorporarse a unos valores dentro de la lógica legal y, porqué no, capitalista, de forma que el Estado debe intervenir en el orden económico. Cuando la Constitución brasileña establece que la propiedad privada deberá tener una función social, artículo 5, XXIII, y que la economía deberá pautarse por el orden (orden económico ${ }^{1169}$ ), el capitalismo brasileño deja de ser un capitalismo exclusivamente de mercado para adquirir un tinte humanista, impregnado de los valores sociales del trabajo y de la libre-iniciativa, derechos humanos y fundamentales.

No se defiende la extinción de la propiedad privada y de los bienes y medios de producción, sino que se intenta racionalizar y humanizar la explotación del hombre por el hombre, teniendo como parámetro de interpretación jurídica de la Constitución, los derechos humanos y fundamentales.

Hemos llamado la atención sobre la colonización del mundo de la vida que, por el poder administrativo y del dinero y la transformación del humano trabajador en pieza, eliminó del trabajador el movimiento sindical, la conciencia de clase y su perspectiva de emancipación social. Debilitó a la clase trabajadora hasta el punto de permitir que mediante acuerdos y convenios colectivos se redujeran los derechos de estos trabajadores significando un flagrante retroceso social, y al margen de lo que establecen los artículos $7^{\circ}$, encabezamiento ${ }^{1170}$, y 114, párrafo segundo ${ }^{1171}$, de la CF/88 .

\footnotetext{
${ }_{1169}$ Art. 170. El orden económico, fundado en la valoración del trabajo humano y en la libre iniciativa, tiene como fin el de asegurar a todos una existencia digna, conforme a los dictámenes de la justicia social, observando los siguientes principios: [...].

${ }_{1170}$ Art. $7^{\circ}$ Son derechos de los trabajadores urbanos y rurales, además de otros destinados a la mejora de su condición social: (...).

${ }_{1171}$ Art. 114. Es competencia de la Justicia del Trabajo procesar y juzgar: (...).§ $2^{\circ}$ Recusándose cualquiera de las partes a la negociación colectiva o al arbitraje, es facultado a las mismas, de común acuerdo, enjuiciar un desacuerdo colectivo de naturaleza económica, pudiendo la Justicia del Trabajo decidir el conflicto, respetando las disposiciones mínimas legales de protección al trabajo, así como las convenidas anteriormente.
} 
Sin la capacidad de reivindicación y sin contacto directo con su papel en la historia y su función dentro del modo de producción capitalista, la consecuencia fue la mayor debilitación de la cuestión de clase y la toma de "conciencia" de la lógica capitalista como patrimonio del propio proletariado. El trabajador comenzó a repetir, por sí mismo, la lógica capitalista, como si fuese él mismo el principal agente que recoge los frutos del sistema económico vigente.

Ayudados por los aparatos ideológicos y represivos del Estado, las elites dominantes, entendidas como las grandes empresas transnacionales y sus respectivos ejecutivos y economistas, comenzaron a tener un total control sobre el movimiento e incluso sobre los deseos de la clase trabajadora. Se ha llegado hasta tal punto que actualmente el trabajador agradece a su patrón por tener un empleo.

Nos hemos lamentado de esta lógica perversa, influida directamente por los medios de comunicación y por los aparatos ideológicos de Estado, hizo del trabajador subordinado, en muchos casos, un "tercero" no vinculado directamente a quien sea su real empleador (tercerización). Hizo de él alguien conforme con la situación social y económica en la que vive, sin tener en cuenta, realmente, lo que implica no sólo de contratación subordinada sino también de la subcontratación subordinada (tercerización).

Para solucionar este problema proponemos un sistema educativo de emancipación, más allá del capital. No se puede aceptar, racionalmente, que los aparatos ideológicos de Estado, al servicio de las elites dominantes, se mantengan como los que educan la sociedad, al trabajador, a los hijos del trabajador. Como únicos exclusivos medios de acceso a la información, porque venden una falsa idea de conocimiento, educación y límites de emancipación del ser. 
Para que esta educación más allá del capital sea viable defendemos el desarrollo de un concepto de democracia distributiva, con el mayor número de ventajas para todos, rechazando la idea utilitarista de maximización del placer y minimización del dolor, con el fin de que, a través de un discurso fundamentado y comunicativo, fundamentado en la idea del Estado Democrático de Derecho que tenga por principios los derechos humanos y fundamentales, los valores internos de la sociedad y la dignidad humana, el otro sea visto como un fin en sí mismo, prevaleciendo el mejor y más bien fundamentado discurso que lleve a la verdad y a la emancipación del trabajador como ser de derechos y deberes ante sí y sus similares.

Esta norma de democracia, denominada democracia distributivacomunicativa-educativa termina por complementarse por la cuestión cultural.

En aras de esta consecución propugnamos el acceso a la cultura que sólo es posible con una educación más allá del capital. Se debe superar la cuestión de la pérdida de la conciencia de clase.

En esta Tesis Doctoral no hemos pretendido sostener la superación del modo de producción capitalista. En el ámbito del derecho del trabajo y de los derechos sociales, lo que presentamos es una alternativa. Una vez plenamente consciente de su papel dentro del modo de producción capitalista, es más fácil para el trabajador negociar de forma abierta, justa y coherente con el tomador del trabajo, con el fin de que se avance en el campo económico y social. El acceso a la verdad y la emancipación permiten, por ejemplo, una mayor presión sobre el poder legislativo con el fin de impedir un retroceso en materia laboral.

No basta, sin embargo, actuar de forma distributiva-comunicativa-educativacultural. Para que se llegue a este nivel de entendimiento y de emancipación, es necesario que se dé mayor visibilidad y sostenibilidad a la dignidad humana. 
El trabajador que presta servicios a su empleador, aliena su existencia a quien le toma los servicios. Y eso sucede porque cuando trabaja, el prestador de trabajo lo hace no sólo en razón del sostén, sino por una cuestión de dignidad y para suplir sus demandas de ser en el mundo. El hombre siempre trabajó.

La diferencia es que hoy el trabajo se presta de forma alienada, donde aquél que presta el trabajo no tiene contacto con el bien que produce. Este bien, una vez producido, adquiere vida propia, porque las técnicas de elaboración de este mismo bien no se hacen presentes o no están accesibles al trabajador.

Si el prestador de trabajo aliena su existencia al tomador de servicios ${ }^{1172}$, prestando trabajo por cuenta ajena y de forma alienada, esta alienación, autorizada por el proceso democrático, debe ser de interpretación restrictiva. $Y$ eso se justifica por una cuestión de dignidad humana. Subrayamos que el principio de la dignidad humana es un mega principio que abarca todas las relaciones humanas, no siendo el ambiente de trabajo una excepción.

Por esta razón sostenemos que no hay que separar al prestador de trabajo del tomador del trabajo, de aquél que recoge los frutos de este trabajo. Si el trabajo es permanente, si el tomador depende de aquel servicio, es porque de él se obtiene "plusvalía", debiendo hacerse cargo de esta elección de emplear a tercero, vinculándose a él de forma directa.

De ahí parte el concepto de subordinación. Lo que defendemos, a diferencia de la doctrina brasileña, es que el trabajo prestado de forma permanente genera un vínculo de empleo, independientemente de si este trabajo está relacionado con la actividad-fin o no de la empresa. Si existe prestación de servicios de forma permanente, habrá, necesariamente, subordinación, consecuencia de esta forma de prestación de servicios por cuenta ajena.

\footnotetext{
1172 SILVA MARQUES, Rafael da, "Trabalho - um elemento mais do que econômico". En Jornal O Sul, Porto Alegre, Caderno Colunistas, 23 de julio de 2006, pág. 2.
} 
Dependencia, de hecho, no es más que sujeción a las órdenes, además de ser también un trabajo permanente y previsible. Es decir, una vez que al empleador se le encomiende una determinada tarea.

En el contexto de la subordinación nos hemos ocupado también de la doble dependencia. No sólo del empleado, en sus divisiones de dependencia técnica, económica y jurídica, sino también del tomador del trabajo que cuenta con aquel servicio que se debe prestar para alcanzar su objeto social.

Defendemos, así, un concepto diferente de subordinación, que permitirá avanzar hacia el reconocimiento de la relación de empleo de forma directa, en la intermediación de mano de obra.

Por otra parte, en razón del fetiche de la mercancía, quien preste trabajo subordinado se separa, en razón de la alienación, del bien que produce. Este bien comienza a formar parte del patrimonio de un tercero que lo vende o lo negocia con el fin de obtener un beneficio.

Lo que va a garantizar el pago de quien preste servicios es el bien que haya producido o el servicio que haya prestado directamente. La vinculación directa del trabajador a todo aquello que él produce es una forma de preservarse aquél que tiene contra sí la apropiación de la "plusvalía" y la alienación.

Defendemos que no se debe excluir al trabajador de la vida social. No se le debe quitar el derecho de saber quién sea y cuál es su importancia dentro del modo de producción capitalista. Hay que darle lo que es suyo, sin falsos discursos sobre las necesidades económicas para justificar la tercerización.

En esta investigación hemos concluido que la legislación brasileña no autoriza la tercerización. Como dice el Ministro Aires Brito del Supremo Tribunal 
Federal brasileño, no hay, en la Constitución, autorización para la subcontratación de trabajadores.

Conforme al artículo 7ํㅡ, I, de la CF/88, es derecho de los trabajadores la relación de empleo, de donde se presume la relación de empleo directa, ya que la Constitución, parte del concepto de empleado, empleador y relación de empleo de la ley laboral, que no incorpora, salvo la subcontrata del artículo 455 de la CLT, la tercerización en el trabajo.

Si la norma constitucional permite la relación de empleo es porque autoriza la explotación de la "plusvalía". Ya lo hace cuando, en su artículo 1ํ, IV, consagra de la libre-iniciativa como fundamento de la República y en el artículo 5ํ․ XXII, cuando se ocupa del derecho a la propiedad privada.

Si se garantiza la propiedad privada y la posibilidad de explotación de la "plusvalía", donde un hombre puede mantener a otro hombre como subordinado y extraer del mismo parte de su existencia, fruto del trabajo alienado, hay que revisarlo. La interpretación, por la propia regla del encabezamiento del artículo $7^{0}$ de la CF/88, debe ser la que tenga por objeto la mejora de su condición social. Y mejor condición social es mejor agrupación sindical, salarios y convenios colectivos, que, como cabe ver la introducción del capítulo II, no se produce en los casos de tercerización, cuando los salarios son pagados en valores equivalentes a un 60 por ciento aquéllos que alcanzan a los empleados "directos".

Por otra parte, según el artículo 7º, encabezamiento, de la CF/88, no es posible, en Brasil, la tercerización después la promulgación de la carta Constitucional. El concepto de empleado previsto en el artículo $3^{\circ}$ de la CLT no autoriza el trabajo por intermediación de mano de obra, siendo inconstitucional cualquier modificación legislativa que no mejore la condición social de los trabajadores. La tercerización, como podemos constatar en especial por lo dicho en el párrafo anterior, no mejora la condición social de los trabajadores. Reduce la 
ganancia, la protección sindical y el acceso directo al bien que produce que es, al final, quien garantiza el pago de sus créditos.

Por otra parte, la Constitución no tiene una regla de excepción con respecto a la relación de empleo. No autoriza el trabajo por cuenta "doblemente ajena". No permite "alienación de la alienación". La regla del 5 de octubre de 1988, era la contratación directa, porque tenía prestado el concepto de empleado y empleador de la Consolidación de las Leyes del Trabajo, que no prevé la subcontratación, salvo en el caso de la subcontrata, artículo 455 de este mismo texto.

Cualquier modificación posterior en la forma de contratación acaba por ser inconstitucional, ya que se estará cambiando, sin legitimación democrática, un concepto constitucional, concepto éste de empleado y empleador, prestado por la Carta de la Consolidación de las Leyes del Trabajo brasileña.

La norma del artículo 7ํㅡ, I, de la Constitución brasileña de 1988 es un imperativo categórico, en oposición al imperativo hipotético. El trabajador, por este artículo de la Constitución, tiene derecho a la relación de empleo.

Sostenemos que no tiene derecho a la relación de empleo tercerizada porque viola lo que establece el encabezamiento del artículo $7^{\circ}$ de la Constitución, que establece como derechos de los trabajadores los que tienen por objeto la mejora de su condición social.

Por otra parte, la norma del artículo 7ํㅡ, I., de la CF/88 se apropia del concepto de relación de empleo de la Consolidación de las Leyes del Trabajo (CLT), donde, salvo excepción, no se prevé a la subcontratación. Esta forma de contratación no está autorizada en la Constitución brasileña. Por ello concluimos que el trabajador tiene derecho a la contratación directa. 
Si el proceso comunicativo ha decidido fijar como derecho de los trabajadores la relación de empleo, esta relación de empleo debe ser interpretada conforme a los parámetros de este proceso democrático. No cabe servirse del otro, sin que haya actuación de ninguna de las partes de forma instrumental, salvo, como ya hemos dicho, en los estrictos límites de la norma constitucional vigente.

Defendemos que mediante el proceso comunicativo, fruto de la elección democrática, se autoriza la relación de empleo, la posibilidad de utilización del hombre como medio, pero esta utilización del otro como medio debe tener como objetivo el propio proceso que la instituye, comunicativo, donde el otro, de ninguna forma, podrá ser el medio.

Así, los límites son la relación de empleo directa, sin ninguna posibilidad de subcontratación, salvo la excepción, fundamentada ésta de forma indirecta en la Constitución, mediante la recepción del artículo 455 de la CLT, para los casos de subcontrata.

Adoptar como parámetro interpretativo el artículo 7º, encabezamiento e inciso I, primera parte, de la Constitución brasileña de 1988 y como matrices teóricas la teoría marxista de la alienación y habermasiana de la acción comunicativa, nos permite concluir que no es posible la doble alienación, dada la regla de acción comunicativa por parte de la colectividad, en el caso del empleador, incluso en los casos en los que la norma constitucional permita la acción instrumental/estratégica.

La doble alienación no forma parte de la autorización constitucional para la utilización del otro como medio. Lo que la norma constitucional permite es la alienación "simple". Pautado por la acción comunicativa, incluso en el espacio para la acción estratégica, no se puede admitir la subcontratación de trabajadores en Brasil. 
Hemos partido, en nuestra investigación, de las teorías que tienen como origen el proceso comunicativo de formación de la norma constitucional. Por ello, en Brasil, sostenemos la inconstitucionalidad de la subcontratación.

Cada vez que el trabajador trabaja de forma subordinada deja a la disposición del tomador de servicios parte de su tiempo de ser "en el mundo". Deja con el empleador parte de su existencia y, en razón de eso, la norma que prevé esta posibilidad debe tener una interpretación restrictiva que tenga en cuenta el interés del trabajador.

Para la erradicación de la tercerización defendemos que es necesario:

1. una educación más allá del capital, que devuelva al trabajador la conciencia de clase y su papel en la historia, lo que fortalecería el movimiento sindical y de reivindicación con el fin de superar las situaciones de extrema explotación del hombre por el hombre;

2. modificar en parte el concepto de subordinación, relacionándolo no sólo con el hecho de que el empleador de las órdenes o de que el prestador de trabajo preste servicios vinculados a la actividad-fin del tomador, sino utilizando el criterio de la permanencia y de la doble dependencia, del empleado y del empleador;

3. un análisis serio de la cuestión de la tercerización en Brasil, con datos referentes a la situación económica y humana del trabajador tercerizado, así como de su realidad sindical;

4. una dogmática constitucional de emancipación por parte de los agentes administrativos y judiciales, con el fin de que comiencen a interpretar la Constitución de forma que concreten el principio de la dignidad humana y el valor social del trabajo, teniendo en cuenta lo que efectivamente establece el artículo 7, encabezamiento I, de la Carta; 
5. superar el sentido común teórico de los juristas y enfrentar los errores de la doctrina y de la jurisprudencia de forma seria y fundamentada, a través del discurso que permite reconsiderar el derecho como ciencia;

6. tener por objetivo, en el marco del Estado Democrático de Derecho la Constitución brasileña de 1988, así como la interpretación de la legislación y la laboralista, considerando que el origen de la Constitución es el proceso comunicativo, utilizándolo, también, como regla de interpretación del derecho y como regla de procedimiento y de acción;

7. interpretar lo que establece el artículo $7^{\circ}$, I, de la Constitución brasileña de 1988 como un imperativo categórico, interpretado en consonancia con lo que consta en el encabezamiento de esta misma disposición, de donde se concluye que no se puede subcontratar, en Brasil, a los trabajadores;

8. una acción más activa de los juristas y académicos, con una lectura seria de la norma constitucional teniendo como parámetro los valores de la Carta de 1988, así como el hecho de que el Estado brasileño, de forma expresa, autoriza la intervención pública en la economía, con el fin de privilegiar al ser humano y no el mercado;

No consideramos constitucional la subcontratación de trabajadores. Alienación y proceso comunicativo como matrices teóricas y base para una interpretación constitucional sólo hacen posible, en los límites de la Constitución, la utilización del trabajador como medio por un tomador de servicio y no por más de uno. Esto impide la validación de cualquier norma u orientación de jurisprudencia que defienda la subcontratación de trabajadores, tal como sucede con la súmula 331 del Tribunal Superior del Trabajo reiteradamente argumentada en esta Tesis Doctoral. 
Finalmente, una vez aprobado por el Congreso Nacional brasileño el proyecto de ley que regula la subcontratación de trabajadores en un sentido amplio, esta nueva norma jurídica estará en flagrante contradicción con la Constitución federal de 1988, salvo si se trata de una situación más benéfica para el trabajador, conforme a la regla del artículo $7^{\circ}$, encabezamiento, de la CF/88.

Los patrones constitucionales no pueden modificarse. El derecho infraconstitucional debe adaptarse a la Constitución y al proceso constitucionalcomunicativo, para tener validez dentro del orden jurídico vigente.

Aceptar pasivamente la posibilidad de la subcontratación es rechazar el avance de la teoría constitucional y de los patrones comunicativos de entendimiento en el tiempo de la formación del Estado Democrático de Derecho brasileño. Es entender como posible, ya sea por legislación, ya sea por interpretación de los tribunales, que la regla de las acciones se establezca no por la voluntad soberana del pueblo, sino por lo que dicen los tribunales y el legislador ordinario sobre la norma jurídica.

Constatamos, por otro lado, que en el caso de España no se puede sostener la imposibilidad de la tercerización, porque está autorizada por el artículo 42 del Estatuto de los Trabajadores ${ }^{1173}$ y por el artículo 38 de la Constitución española ${ }^{1174}$ que consagra la libertad de empresa.

\footnotetext{
1173 Artículo 42. Subcontratación de obras y servicios. 1. Los empresarios que contraten o subcontraten con otros la realización de obras o servicios correspondientes a la propia actividad de aquéllos deberán comprobar que dichos contratistas estén al corriente en el pago de las cuotas de la Seguridad Social. Al efecto, recabarán por escrito, con identificación de la empresa afectada, certificación negativa por descubiertos en la Tesorería General de la Seguridad Social, que deberá librar inexcusablemente dicha certificación en el término de treinta días improrrogables y en los términos que reglamentariamente se establezcan. Transcurrido este plazo, quedará exonerado de responsabilidad el empresario solicitante. (...).

${ }^{1174}$ Artículo 38. Se reconoce la libertad de empresa en el marco de la economía de mercado. Los poderes públicos garantizan y protegen su ejercicio y la defensa de la productividad, de acuerdo con las exigencias de la economía general y, en su caso, de la planificación.
} 
Hay que tener presente que el texto constitucional español no tiene analogía con el artículo $7^{\circ}$, encabezamiento y I, de la Constitución brasileña de 1988, no pudiéndose sostener, en este país europeo, la inconstitucionalidad de la tercerización tal como se hace en el caso de Brasil.

Confiamos en haber podido aportar algo con esta Tesis Doctoral. No pretendemos imponer un entendimiento o rebelarnos contra la doctrina y la jurisprudencia. Quien cree en la democracia, cree en el discurso fundamentado, en la dialéctica y en la diferencia.

Democratizar es discutir. Democracia es conflicto de ideas. Democracia es oír y aceptar el mejor argumento racional y hacer de este la regla de las acciones entre las personas. Democracia es tener como rumbo interpretativo el origen del proceso democrático-comunicativo y los límites que este mismo proceso imponen con el fin de llegar a la emancipación.

Hemos pretendido demostrar que la norma constitucional no permite servirse del trabajador sólo como una pieza. Que él es el elemento central dentro de la lógica capitalista, no sirviendo de mero instrumento. Como pieza central es también un sujeto de derechos, y no se puede legitimar democráticamente una interpretación que considere la posibilidad de dos alienaciones dentro del mismo tiempo de trabajo, del mismo tiempo de vida, del mismo tiempo de vida en el mundo.

Esta investigación no está completa. Sirve como una especie de preliminar para otras teorías, otros debates y para que otros juristas discutan el tema y, si es posible, en el futuro, se legisle en favor del trabajo y contra la subcontratación. 


\section{FUENTES.}

\section{Libros y artículos.}

AAVV, Descentralización productiva y nuevas formas organizativas del trabajo, Zaragoza, 28 y 29 de mayo de 1999, Colección Informes Y Estudios; serie Relaciones Laborales, n. 28, Madrid, 2000;

AA.VV.: Descentralización productiva y protección del trabajo en contratas, Tirant lo Blanch, Valencia 2000;

ABRIL-MARTíN, Paula Arenas, Gramática de la lengua española, Madrid; Edmart Libros. Colección Manuales de la lengua española, 2006;

AGRA BELMONTE, Alexandre, "Aspectos jurídicos atuais da terceirização trabalhista". Em Revista do Tribunal Superior do Trabalho, Porto Alegre; Magister Editora, ano 74, no. 4, outubro a dezembro de 2008;

AGUIAR DIAS, José, Da responsabilidade civil, Rio de Janeiro; Forense, $6^{\mathrm{a}}$ ed., vol. 1, 1979;

AIRES BRITO, Carlos, Teoria da constituição, Rio de Janeiro; Editora Forense, 2006;

ALBIOL MONTESINOS, Ignacio, ALFONSO MELLADO, Carlos, BLASCO PELLICER, Ángel y GOERLICH PESET, José Maria, Estatuto de los trabajadores: concordando con la jurisprudencia de los Tribunales Constitucional y Supremo, Valencia; Tirant lo Blanch, $2^{a}$ ed., 2001; 
ALBUQUERQUE MOURÃO, Fernando Augusto, COSTA PORTO, Walter e MANTOVANINI, Thelmer Mário, As constituições dos países de língua portuguesa comentadas, Brasília; Senado Federal, Conselho Editorial, 2007;

ALEXY, Robert. Teoría de los derechos fundamentales. Traducción de Ernesto Garzón Valdés, Madrid; Centro de Estudios Constitucionales, 2002;

ALEXY, Robert, Teoria dos direitos fundamentais. Tradução Virgílio Afonso da Silva, São Paulo; Malheiros, 2008;

ALFLEN, Kelly, Susane, "Os valores como fundamento da Constituição e a justiça constitucional material”. Em Revista Bonijuris, Ano XXII, número 558, maio/10, Curitiba; Instituto de Pesquisas Bonijuris, 2010;

ALLAIN, L.-M., Le travail ouvrier, Paris; Presses Universitaires de France, 1949;

ALLEVA, Piergiovanni, "O rubicão do trabalho subordinado". Em Revista LTr, legislação do trabalho, São Paulo; LTr, ano 73, fevereiro de 2009;

ALONSO OLEA, Manuel e CASAS BAAMONDE, Maria Emilia, Derecho del trabajo, Navarra; Thompson Civitas, 24를 Ed., 2006;

ALONSO OLEA, Manuel y CASAS BAAMONDE, Maria Emilia, Derecho del trabajo, Madrid; Thompson Civitas, 26루 ed., 2009;

ALTEF BARROS, Veronica, "Trabalho autônomo economicamente dependente". Em Revista justiça do trabalho, Porto Alegre; HS Editora, no. 305, 2009; 
ALVARES DA SILVA, Antônio, "Responsabilidade da administração pública nas terceirizações". Em Revista LTr, legislação do trabalho, São Paulo; LTr, ano 75, março de 2011;

ALVAREZ RODRIGUES, José Luiz, El trabajador economicamente dependiente,

En http://www.madrid.ccoo.es/comunes/recursos/14/doc34441 EL TRABAJADOR E CONOMICAMENTE DEPENDIENTE.pdf;

ALVES, Giovanni, Toyotismo e mundialização do capital, http://globalization.sites.uol.com.br/toyotism.htm;

ALVES, Amauri Cesar, Novo contrato de emprego: parassubordinação trabalhista, São Paulo; LTr, 2004;

Amoroso, G, DI CERBo, V e MARESCA, A., Dirito del lavoro. La Costituzione, II Códice civile e Le leggi speciali, Milano, Giuffrè Editore, volume I, terza edizione, 2009;

AMARANTE MERÇON, Paulo Gustavo de, "Além dos portões da fábrica O direito do trabalho em reconstrução". Em Revista do Tribunal Regional do Trabalho da $3^{a}$ Região, Belo Horizonte, MG; no. 74, 2006;

ANTUNES, Ricardo, "A nova morfologia do trabalho e do desenho multifacetado das ações coletivas”. Em Além da fábrica: trabalhadores, sindicatos e a nova questão social, São Paulo; Boitempo Editorial, 2003;

ANTUNES, Ricardo, "Anotações sobre o capitalismo recente e a reestruturação produtiva no Brasil”. Em Autores vários, O avesso do trabalho, São Paulo; Expressão Popular, 2004; 
ARENDT, Hannah, A Condição Humana, Rio de Janeiro; Editora Forense Universitária, 1981;

ARENDT, Hannah, La condición humana, Barcelona; Paidós, 2005;

ARESE, Cesar, "Intermediación de mano-de-obra y responsabilidad solidaria". Em Revista do Tribunal Regional do Trabalho da 15ª Região, Campinas, SP; Editora da Escola Judicial da Magistratura, numero 32, jan./jun. 2008;

ARON, Raymond, O marxismo de Marx; tradução Jorge Bastos, São Paulo; Arx, 2003;

AUDARD, Catherine, "O princípio de legitimidade democrática e o debate Rawls-Habermas". Em Em Habermas: o uso público da razão. Rainer Rochlitz (coord.), Rio de Janeiro; Tempo Brasileiro, 2005;

AVILA FIGUEIREDO, Renata, Sociedade $X$ mercado. Uma proposta para desarmar os mercados e desenvolver o poder para a sociedade. In www.integracao.fgvsp.br/11/noticias.htm;

BARATA SILVA, Carlos Alberto, Compêndio de direito do trabalho: parte geral e contrato individual de trabalho, São Paulo; LTr, 1976;

BARBOSA GARCIA, Gustavo Filipe, "Responsabilidade da administração pública na relação de trabalho triangular". Em Revista Justiça do Trabalho, número 291, Porto Alegre; HS Editora, março de 2008;

BARBOSA GARCIA, Gustavo Filipe, "Equiparação salarial na terceirização de serviços". Em Revista Justiça do Trabalho, número 296, Porto Alegre; HS Editora, agosto de 2008; 
BARBOSA GARCIA, Gustavo Garcia, Direito do trabalho, Rio de Janeiro; Método, 2010;

BAUMAN, Zygmund, Vida para o consumo: a transformação das pessoas em mercadoria, tradução Carlos Alberto Medeiros, Rio de Janeiro; Zahar Editora, 2008;

BAYLOS, Antonio, "Crisis y Derecho del trabajo o el Derecho del trabajo en crisis. Sobre la reforma laboral española de 2012". En Derecho laboral. Revista de doctrina, jurisprudencia e informaciones soiales, Montevideo, Uruguay, tomo LV, n. 245, enero-marzo 2012, Fundación de Cultura Universitaria;

BELLOSO MARTÍN, Nuria, "El principio de dignidad de la persona humana en la teoría kantiana: algunas contradicciones". Em Direitos Fundamentais \& Justiça. Revista do Programa de Pós-Graduação Mestrado e Doutorado em Direito da PUCRS, Porto Alegre; HS Editora, Ano 2, número 04, julho/setembro de 2008;

BELLOSO MARTÍN, Nuria, "Algunos dilemas sobre la jurisdicción constitucional". Em Revista do Direito no. 33, Programa de pós-graduação em direito - PPGD, Santa Cruz do Sul, Edunisc, junho/dezembro de 2010 (no prelo);

BLACKBURN, Robin, A construção do escravismo no novo mundo. Do barroco ao moderno - 1492-1800. Tradução Maria Beatriz de Medina, Rio de Janeiro; Record, 2003;

BLAT GIMENO, Francisco, "El marco socioeconómico de la descentralización productiva - Estudios en recuerdo de Francisco Blat Gimeno". En Descentralización productiva y protección del trabajo en contratas. Autores varios, Valencia; Tirant lo Blanch, 2000; 
BOBBIO, Norberto, Teoria geral da política. A filosofia política e as lições dos clássicos, Rio de Janeiro; Editora Campus, 2000;

BOLZAN DE MORAIS, José Luiz, A idéia do direito social: O Pluralismo Jurídico de Georges Gurvitch, Porto Alegre; Livraria do Advogado Editora, 1997;

BOLZAN DE MORAIS, José Luiz, A subjetividade do tempo. Uma perspectiva transdisciplinar do direito e da democracia, Porto Alegre; Editora Livraria do Advogado e Santa Cruz do Sul; Edunisc, 1998;

BOLZAN, José, Habermas: razão e racionalização, ljuí; editora UNIJUI, 2005;

BOMFIM CASSAR, Vólia, Direito do trabalho, Niterói; Impetus, 4ª Edição, 2010;

BONAVIDES, Paulo, Curso de Direito Constitucional, São Paulo; Malheiros, 2004;

BOULMIER, Daniel, "Salarié mis à disposition:élegibilité aus élections de la délégation du personel”, En Droit social n. 3, mars 2013, Dalloz, 2013;

BRENNER, Robert, O "boom" e a bolha: os Estados Unidos na economia mundial, Rio de Janeiro; Editora Record, 2003;

CAMERLYNCK, G. H., Traité de droit du travail. Contrat de travail, Paris: Librairie Dalloz, 1968;

CAMINO, Carmen, Direito individual do trabalho, Porto Alegre; Síntese Editora, 1999; 
CAMINO, Carmen, Direito individual do trabalho, Porto Alegre; Síntese Editora, 4a ed; 2004;

CAPELLA, Juan-Ramón, Los ciudadanos siervos, Madrid; Trotta, 1993;

CARVALHO FILHO, José Santos, Manual de direito administrativo, Rio de Janeiro, Lumen Juris, $17^{\mathrm{a}}$ edición, 2007;

CASTILHO, Ricardo, Justiça social e distributiva. Desafios para concretizar direitos sociais, São Paulo; Editora Saraiva, 2009;

CHACARTEGUI JÁVEGA, Consuelo, "La actuación de las empresas de trabajo temporal como agencias de colocación. La crisis como pretexto en el avance de la iniciaitiva privada". En Revista de derecho social, n. 57, 2012;

CHEVALLIER, Jean-Jaques, As grandes obras políticas de Maquiavel a nossos dias. Tradução Lydia Cristina, Rio de Janeiro; Agir, $8^{a}$ ed; 2002;

CODO, Wanderley, O que é alienação, São Paulo; Brasiliense, 2004;

COIMBRA SANTOS, Rodrigo, "Repensando a responsabilidade subsidiária do tomador de serviços terceirizados nas atividades lícitas". Em Revista justiça do trabalho, Porto Alegre; HS Editora, no. 288, dezembro de 2007;

COIMBRA SANTOS, Rodrigo, Relações terceirizadas de trabalho, Curitiba, Juruá, 2008;

CONFALONIERI, Juan Angel, la organizacion de la empresa en la actualidad. su incidencia en el concepto de empleador. Documentacion Laboral 2011; 
CORREIA DE ARAÚJO, Eneida Melo, As relações de trabalho. Uma perspectiva democrática, São Paulo; LTr, 2003;

COUTO MACIEL, José Alberto, "Terceirização na atividade-fim. Empresas de telecomunicações e outras concessionárias do serviço público. Novos projetos de lei e inovações de liminar concedida no STF". Em Revista do Tribunal Superior do Trabalho, Porto Alegre; Magister Editora, ano 74, no. 4, outubro a dezembro de 2008;

CRISTÓBAL RONCERO, Rosario, "Subcontratación de obras y servicios". En Autores Vários. Contratación temporal, empresas de trabajo temporal y subcontratación en la negociación colectiva. Comisión Consultiva Nacional de Convenios Colectivos. Colección Informes y Estudios: relaciones laborales no. 94, Ministério de Trabajo e Inmigración, 2010;

CRISTÓBAL RONCERO, Rosario, "Real Decreto-Ley 3/2012, de 10 de febrero, de medidas urgentes para la reforma del mercado laboral". En Revista española de dercho del trabajo, n. 154, Civitas, Thompson Reuters, abril-junio 2012;

DA PENHA, João, O que é existencialismo, São Paulo; Brasiliense, 2004;

DA SILVA, José Afonso, Curso de Direito Constitucional Positivo, São Paulo; Editora Malheiros, 17ª Ed., 2000;

DE ESTEBAN, Jorge y GONZÁLEZ-TREVIJANO, Pedro José, Curso de derecho constitucional español III, Madrid; Universidad Complutense de Madrid, 1994; 
DE FERRARI, Francisco, Lecciones de derecho del trabajo, Montevideo; Facultad de Derecho y Ciencias Sociales de la Universidad de la Republica, Tomo I, 1961;

DE FERRARI, Francisco, Lecciones de derecho del trabajo, Montevideo; Facultad de Derecho y Ciencias Sociales de la Universidad de la Republica, Tomo II, 1962;

DEL PUNTA, Riccardo, Diritto del lavoro, Milano, Giuffrè Editore, Terza edizione, 2010;

DEL REY GUANTER, Salvador, "A proposito de los requisitos des articulo 42.1 TRET, y en especial sobre la 'propia actividad': notas la luz de la STS 24 de noviembre de 1998", En AAVV, Descentralización productiva y nuevas formas organizativas del trabajo,Zaragoza, 28 y 29 de mayo de 1999, Colección Informes Y Estudios; serie Relaciones Laborales, n. 28, Madrid, 2000;

DE TONI, Mírian, "Fim do trabalho versus centralidade do trabalho". Em Dicionário de trabalho e tecnologia, Organizadores Antonio David Cattani e Lorena Holzmann, Porto Alegre; Editora da UFRGS, 2006;

DE VAL ARNAL, Jesús, "Subcontratación internacional: libertad de comercio y derecho del trabajo. Límites postulados por la Organización Internacional del Trabajo y la Unión Europea", En Descentralización productiva y nuevas formas organizativas del trabajo : $X$ Congreso Nacional de Derecho del Trabajo y de la Seguridad Social, Zaragoza, 28 y 29 de mayo de 1999, Zaragoza, Minist'rio del Trabajo y Asuntos Sociales, Subdireción General de Publicaciones, 2000; 
DÍAZ DE LA ROSA, Angelica, "Reflexiones a proposito del articulo 129.2 de la Constitución española", En Anuario de la Facultad de Derecho de la Universidad de La Coruña (AFDUDC), 14, 2010;

DINIZ DE MAORAES, José, Terceirização e contrato de prestação de serviços: separando 0 joio do trigo. Em http://www.trt21.jus.br/ej/revista/2008/paginas/doutrina/tercerizacao.html;

DUARTE, Francisco Carlos, SEVERO ROCHA, Leonel e URQUHART CADEMARTORI, Luiz Henrique, A constitucionalização do tempo. Em Em Direitos Fundamentais \& Justiça. Revista do Programa de Pós-Graduação Mestrado e Doutorado em Direito da PUCRS, Porto Alegre; HS Editora, Ano 4, número 12, julho/setembro de 2010;

DUARTE SAAD, José Eduardo, "Terceirização de serviços e a nacessidade de uma norma legal”. Em Revista LTr, legislação do trabalho, São Paulo; LTr, ano 73, janeiro de 2009;

DUGUIT, Leon, Le droit social, le droit individuel et la transformation de I’Etat, Paris; Librairie Félix Alcan, 1922;

DUPPER, Ockert, Palestra no Seminário internacional de direito do trabalho no mundo contemporâneo, organizado pela Escola Judicial do TRT da Quarta Região, Porto Alegre, RS, em 29 de outubro de 2010;

DWORKIN, Ronald, "A democracia e os direitos do homem". Em Democracia. Organizadores Robert Darnton y Olivier Duhamel. Tradução Clóvis Marques, Rio de Janeiro; Editora Record, 2001; 
EHLERS DE MOURA, José Fernando, "Condições da democracia". Em Cadernos da AMATRA IV. $5^{\circ}$ Caderno de estudos sobre processo e direito do trabalho, Porto Alegre; HS Editora, 2007;

ENGISCH, Karl, Introdução ao pensamento jurídico. Tradução J. Baptista Machado, Lisboa; Editora Fundação Caloustre Gulbenkian, 9ª Edição, 2004;

ERMIDA URIARTE, Oscar, A flexibilização da greve. Tradução Edilson Alkimin, São Paulo; LTr, 2000;

ERMIDA URIARTE, Oscar, A Flexibilidade, São Paulo; LTr, 2002;

FACHINI FALVO, Josiane, Balanço da regulamentação da terceirização do $\begin{array}{llll}\text { trabalho na América } & \text { Latina. }\end{array}$ http://www.iela.ufsc.br/uploads/docs/134 texto3.josiane.pdf;

FAVENNEC-HÉRY, Françoise et VERKINDT, Pierre-Yves, Droit du travail, Paris; Lextenso Éditions, 2011;

FEINMANN, José Pablo, A sombra de Heidegger. Tradução Márcio Vilela, São Paulo; Planeta do Brasil, 2006;

FERNANDEZ LOPEZ, Maria Fernanda, "Descentralización productiva, contratas y despido por causa organizada", en Autores varios, Descentralización productiva y protección del trabajo en contratas, Valencia; Tirant lo Blanch, 2000;

FERNANDEZ ORRICO, Fco. Javier, "La contradictória figura del trabajdor economicamente dependiente", En Revista de la Facultad de Ciencias Juridicas y Sociales de Elche, Volumen I, numero 3, enero de 2008; 
FERRAZ ANDRADE, Tatiana Guimarães, "Terceirização: debate inerente aos períodos de expansão econômica e de crise - Comentários ao projeto de lei 1.621/2007. Em Revista Eletrônica do Tribunal Regional do Trabalho da Quarta Região, ano VI, número 107, segunda quinzena de outubro de 2010, en www.trt4.jus.br;

FERREIRA DE CASTRO, Rubens, A terceirização no Brasil, São Paulo; Editora Malheiros, 2000;

FERREIRA JORGE NETO, Francisco e QUADROS PESSOA CAVALCANTI, Jouberto de, "A terceirização na administração pública e constitucionalidade do art. 71, lei n. 8.666/93, declarada pelo STF (novembro de 2010). Em Revista LTr, legislação do trabalho, São Paulo; LTr, ano 75, março de 2011;

FERREIRA PRUNES, José Luiz, Trabalho terceirizado e composição industrial, Curitiba; Juruá, $2^{a}$ ed., 2009;

FIGUEIRAS DE GOIS, Luiz Marcelo, "A súmula 331 do TST à luz da certidão negativa de débitos trabailhas". En Revista Justiça do Trabalho n. 331, Porto Alegre; HS Editora, julho de 2011;

FRANK, Thomas, Deus no céu e o mercado na terra. Tradução de Maria Luiza X. de A. Borges, Rio de Janeiro; Record, 2004;

FREIRE DE ALBUQUERQUE, Bruna Maria Jacques, Subcontratación y precarización del trabajo. Un estudio comparativo de la norma laboral brasileña y española, Tese doctoral, Universidad de Salamanca, 2011, no publicado;

FREITAG, Bárbara, A teoria crítica ontem e hoje, São Paulo; Brasiliense, 1988; 
FREITAS, Juarez, "L'intèrprete et le devoir de concrétiser les objectifs fondamentaux de la constitution". En Direitos Fundamentais e Justiça, ano 2, n. 5, out/dez. 2008, HS Editora;

GALLEGO-DÍAZ, Soledad, "Marbury contra Madison". Em El País, Columna, Opinión, domingo, 04 de julio de 2010;

GAMBINO, Silvio, "La jurisdición constitucional de las leyes. La experiencia italiana desde da optica comparada". En Autores Vários, La aplicación jurisdicional de la constitución, Geraldo Ruiz-Rico Ruiz (dir.). Valencia; Tirant to Blanch Alternativa, 1997;

GANDRA DA SILVA MARTINS FILHO, Ives, "O fenômeno da terceirização e suas implicações jurídicas". En Revista LTr, legislação do trabalho, São Paulo; LTr, ano 75, novembro de 2011;

GARCIA-PERROTE ESCARTIN, Ignácio y GOÑI SEIN, José Luis, "Contratación administrativa y aplicación de las normas laborales sobre contratas". En Descentralización productiva y protección del trabajo en contratas. Autores varios, Valencia; Tirant lo Blanch, 2000;

GARCIA SCHWARZ, Rodrigo, Direito do trabalho, Rio de Janeiro; Elsevier, $2^{\text {a }}$ ed; 2009;

GARMENDIA ARIGÓN, Mario, Ordem pública e direito do trabalho, São Paulo; LTr, 2004;

GAUTHIER, Gustavo, "Amplificación de la responsabilidad del empresario que utiliza subcontratistas, intermediarios o suministradores de mando de obra: el caso uruguayo a partir de la sanción de la ley n. 18.099". Em Revista do Tribunal 


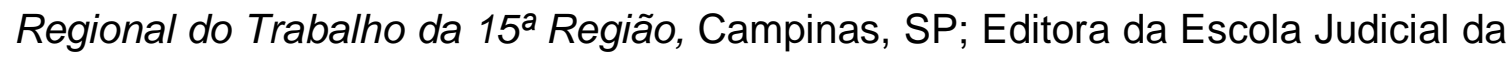
Magistratura, numero 31, jul./dez. 2007;

GENRO, Tarso Fernando, Direito individual do trabalho. Uma abordagem crítica, São Paulo; LTr, 2ª ed; 1994;

GESTA LEAL, Rogério, "Habermas, Jürgen”. Em Dicionário de Filosofia do Direito. Vicente de Paulo Barreto (org.), Rio de Janeiro; Unisinos e Renovar, 2006;

GIANNOTTI, José Arthur, "Introdução". Em Marx, São Paulo; Nova Cultural, 2006;

GIDDENS, Anthony, Mundo em descontrole. O que a globalização está fazendo de nós. Tradução Maria Luiza X. de A. Borges, Rio de Janeiro; Record, 4⿳亠丷厂 ed; 2000;

GIL Y GIL, José Luis, "Espagne”, Dans Revue de droit comparé du travail et de la sécurité sociale, 2012/1, Bordeaux, Université Montesquieu, 2012;

GIMÉNEZ AMAYA, J.M., y SÁNCHEZ-MIGALLÓN, S., Diagnóstico de la Universidad en Alasdair Maclntyre. Génesis y desarrollo de un proyecto antropológico. Pamplona, Eunsa, 2011;

GODINHO DELGADO, Mauricio, Direitos fundamentais na relação de trabalho. Em LTr. Legislação do Trabalho, São Paulo, LTr, Ano 70, junho/2006;

GODINHO DELGADO, Maurício. "Os direitos fundamentais nas relações de trabalho". Em O MPT como promotor dos direitos fundamentais, Juliana Vignoli Cordeiro e Sebastião Cordeiro Caixeta (coord.), São Paulo; LTr, 2006; 
GODINHO DELGADO, Maurício, Curso de Direito do Trabalho, São Paulo; LTr, $6^{\circ}$ ed; 2007;

GODINHO DELGADO, Maurício, Capitalismo, trabalho e emprego: entre o paradigma da destruição e os caminhos da reconstrução, São Paulo; LTr, 2006;

GOERLICH PESET, José María, "Determinación del supuesto: la noción de contrata y subcontrata de obras y servicios". En AA.VV.: Descentralización productiva y protección del trabajo en contratas, Tirant lo Blanch, Valencia 2000;

GOERLICH PESET, José María, "Actividades laborales externalizables: régimen jurídico". En Autores Vários, La externalización de actividades laborales (outsourcing): uma visión interdisciplinar, Abdón Pedrajas Moreno (dir.). Valladolid; Lex Nova, 2002;

GOMES CANOTILHO, J. J., Direito Constitucional e Teoria da Constituição, Lisboa, Almedina, 7ª ed; 2003;

GOMES, Orlando, GOTTSCHALK, Elson, Curso de direito do trabalho, Rio de Janeiro, Forense, $13^{\mathrm{a}}$ Ed., 1994;

GONZÁLEZ ALTABLE, Maria Pilar, John Rawls. Una concepción política y liberal de la justicia, Barcelos Portugal; Biblioteca Universitaria, 1993;

GONZÁLEZ GONZÁLES, Antonio, "La descentralización productiva. Algunos comentarios desde la perspectiva sindical”, En Autores varios. Descentralización productiva, Madrid; Consejo General del Poder Judicial, 2000;

GONZÁLEZ-TREVIJANO SÁNCHEZ, Pedro José, El tribunal constitucional, Navarra; Editorial Aranzadi, 2000; 
GORCZEVKI, CLÓVIS e SIMÕES PIRES, Francisco Luiz da Rocha, "Direitos fundamentais, educação e cidadania: tríade inseparável". Em Direito constitucional: constitucionalismo contemporâneo, Renato dos Reis, Jorge e Gorczevski, Clóvis (org.), Porto Alegre, Norton Editor, 2005;

GORCZEVKI, Clóvis, Direitos humanos, educação e cidadania: conhecer, educar, praticar, Santa Cruz do Sul; Eitora da Unisc, 2009;

GORELLI HERNÁNDEZ, Juan, La tutela de los trabajadores ante la descentralización productiva, Madrid; Grupo Difusión, 2007;

GORENDER, Jacob, "Introdução". Em Para a crítica da economia política; salário, preço e lucro; o rendimento e suas fontes: a economia vulgar. Karl Marx. Tradução de Edgard Malagodi, São Paulo; Abril Cultural, 1982;

GRAMSCI, Antonio. Americanismo e fordismo. Tradução Gabriel Bogossian, São Paulo; Hedra, 2008;

GRAU, Eros Roberto. A Ordem Econômica na Constituição de 1988, São Paulo; Editora Malheiros, $8^{\mathrm{a}}$ ed., 2003;

GRISOLIA, Julio A. y AHUAD, Ernesto J., Ley de contrato de trabajo comentada, Buenos Aires; Editorial Estudio, 2ª edición, 2009;

GRISOLIA, Julio Armando, Manual de derecho laboral, Buenos Aires; Abeledo Perrot, $6^{\text {a }}$ edición, 2010;

GUERRERO, Diego, Un resumen completo del Capital de Marx, Madrid; Maia Ediciones, 2008; 
GUIMARÃES FELICIANO, Guilherme, "Direito, Marx, Althusser, Neoliberalismo - Direito e Economia: Marx, Althusser e os Desafios da Sociedade Capitalista na Era Pós-industrial". Em Revista Síntese Trabalhista, Porto Alegre; Síntese Editora, número 180, junho/2004;

GUIMARÃES FELICIANO, Guilherme, "Terceirização e contratos de fornecimento industrial: notas sobre a responsabilidade jurídica de clientes e fornecedores". En Revista Magister de directo trabalhista e previdenciário, Porto Alegre, Magister, n. 24 maio/junho de 2008;

HÄBERLE, Peter, Teoría de la Constitución como ciencia de la cultura, Madrid; Ed. Tecnos 2000;

HABERMAS, Jürgen, Teoría de La Acción Comunicativa. V. I, Racionalidad de la Acción y racionalización Social, Madrid. Taurus, 1987;

HABERMAS, Jürgen, Dialética e hermenêutica, tradução Alvaro Valls, Porto Alegre; L\&PM Editora, 1987;

HABERMAS, Jürgen, Conhecimento e interesse, Rio de Janeiro; Guanabara, 1987;

HABERMAS, Jürgen Agir Comunicativo e Razão Destranscendentalizada, São Paulo; Tempo Brasileiro, 2002;

HABERMAS, Jürgen, Direito e democracia: entre facticidade e validade, Rio de Janeiro, Editora Tempo Brasileiro, volume I, 2003;

HABERMAS, Jurgen, "Sobre o significado do socialismo hoje. Revolução recuperadora e necessidade de revisão da esquerda". Em Diagnóstico do tempo: seis ensaios, Rio de Janeiro; Editora Tempo Brasileiro, 2005; 
HABERMAS, Jürgen, Técnica e ciência como ideologia, Lisboa; Edições 70, 2009;

HEIDEGGER, Martin, Cartas sobre el humanismo. Traducción de Helena Córtes y Arturo Leyte, Madrid; Alianza Editorial, 2006;

HEINEN, Lenir, “Terceirização, um passo a diante...”. En www.trt4.jus.br;

HOBSBAWN, Eric, Ecos da marselhesa. Dois séculos revêem a revolução francesa. Tradução Maria Célia Paoli, São Paulo; Editora Companhia das Letras, 1996;

HOBSBAWN, Eric, "Introdução: a invenção das tradições". Em $A$ invenção das tradições, Eric Hobsbawn e Terence Ranger (Org), tradução Celina Cardin Cavalcante, São Paulo; Editora Paz e Terra, $5^{\text {a }}$ edição, 2008;

HÖFFE, Otfried, Justiça política: fundamentos de uma filosofia crítica do direito e do Estado. Tradução Ernildo Stein, São Paulo; Martins Fontes, 2001;

HOLZMANN, Lorena e PICCININI, Valmiria, "Flexibilização". Em Dicionário de trabalho e tecnologia, Organizadores Antonio David Cattani e Lorena Holzmann, Porto Alegre; Editora da UFRGS, 2006;

HUBERMAN, Leo, História da riqueza do homem. Tradução Waltensir Dutra, Rio de Janeiro, LTC Editora, $21^{\text {a }}$ ed., 1986;

HUNT, E. K. SHERMAN, Howard J., História do pensamento econômico. Trad. Jaime Larry Banchimol, Petrópiolis; Editora Vozes, $13^{a}$ ed., 1995; 
IGLESIAS CABERO, Manuel, "La descentralización productiva y el derecho colectivo del trabajo. Incidencias y efectos en la relación con las representaciones unitaria y sindical de los trabajadores, con las elecciones sindicales y con los convenios colectivos", En Autores Varios, Descentralización productiva, Madrid; Consejo General del Poder Judicial, 2000;

JAVILLIER, Jean-Claude, Manual de direito do trabalho, São Paulo; LTr, 1988;

JAVILLIER, Jean Claude, Manuel droit du travail, Paris; Librairie Générale de Droit et de Jurisprudence, 1996;

JOUNIN, Nicolas, "L'illegalité sous-traitée? Les conséquences du reours à des employeurs intermédiaires dans le secteur du bâtiment”. En Revue Droit Social, numero 1, janvier 2007;

LOS COBOS ORIHUEL, Fancisco Pérez, "El concepto de 'propia actividad' empresarial". En Descentralización productiva y protección del trabajo en contratas. Autores varios, Valencia; Tirant lo Blanch, 2000;

LOKIEC, PASCAL, Droit du travail, Tomo I, Paris; PUF, 2011;

LUDOVICI, Alessandro, II lavoro interinale, il contratto di fornitura di prestazioni di lavoro temporaneo, il contratto per prestazioni di lavoro temporaneo, l'impresa fornitrice, la retribuzione, proroga del contratto per prestazioni di lavoro temporaneo. Sistema sanzionatorio. Em http://www.diritto.it/materiali/lavoro/ludovici3.html;

KANT, Imanuel, Fundamentação da metafísica dos costumes, São Paulo, SP. Editora Martin Claret, Coleção Obra Prima de Cada Autor - Textos Integrais, 2005; 
KROST, Oscar, "Interditos proibitórios e greve: por uma tutela da posse compatível com o exercício do direito de paralisação do trabalho". Em Cadernos da AMATRA IV. $11^{\circ}$ Caderno de estudos sobre processo e direito do trabalho, Porto Alegre; HS Editora, 2009;

LACAN, Jaques, Televisão. Versão brasileira, Antonio Quinet, Rio de Janeiro; Jorge Zahar Editor, 1993;

LACRUZ BARDEJO, José Luis, SANCHO REBULLIDA, Francisco de Asís, LUNA SERRANO, Agustín, DELGADO ECHEVERRÍA, Jesus, RIVERO HERNÁNDEZ, Francisco y RAMS ALBESA, Joaquín, Elementos de derecho civil I. Parte general, Madrid; Dykinson, 2002;

LAMMÊGO BULOS, Uadi, Constituição Federal anotada, São Paulo; Editora Saraiva, 2005;

LAPLANE, Mariano, "Inovações e dinâmica capitalista". Em Autores vários, Os clássicos da economia, Ricardo Carneiro (org.), v. 2, item "Adam Smith", São Paulo; Editora Ática, 2003;

LASSALLE, Ferdinand, Que é uma constituição?, São Paulo; Edições e publicações Brasil, 1933;

LAULOM, Sylvaine, "La directive 2008/104: avancées et limites de la protection des travailleurs intérimaires". Revue de Droit du Travail, n. 5, Dalloz, mai, 2012;

LEAL AMADO, João, Tratamento mais favorável e art. $4^{\circ}, n$. 1, do Código do Trabalho português: o fim de um princípio? In www.anamatra.org.br seção "artigos"; 
LÊNIN, "Karl Marx". Em As três fontes e as três partes constitutivas do marxismo, São Paulo; Global Editora, 6ª ed.; 1988;

LLANO SÁNCHEZ, Mónica. Responsabilidad empresarial en las contratas y subcontratas, Madrid; La Ley, 1999;

LOCKE, John, Segundo tratado sobre o governo. Tradução Alex Marins, São Paulo; Martin Claret, Coleção Obra Prima de Cada Autor, Textos Integrais, 2006;

LÓPEZ GANDÍA, Juan y TATAY PCHADES, Carmen, "Contratas y subcontratas y responsabilidades de seguridad social”. En Descentralización productiva y protección del trabajo en contratas. Autores varios, Valencia; Tirant lo Blanch, 2000;

LOZANO MIRALLES, Jorge e SACCOMANNO, Albino, El tribunal constitucional. Composición y princípios jurídico-organizativos (el aspecto funcional), Valencia; Tirant lo Blanch, 2000;

LUXEMBURGO, Rosa, Reforma ou revolução?, São Paulo; Editora Expressão Popular, $4^{a}$ edição, 2005;

LYON-CAEN, Gérard, PÉLISSIER, Jean et SUPIOT, Alain, Droit du travail, Paris, Dalloz, 1994, 17a Edição;

MACHADO MARCA, Maurício, "A aplicação do princípio da igualdade às relações de trabalho como limitador a autonomia privada á luz da jurisprudência do Tribunal Superior do Trabalho". En Revista LTr, legislação do trabalho, São Paulo; LTr, ano 72, julho de 2008; 
MACHEREY, Pierre, "A propos du processus d'exposition du "Capital" (le travail des concepts)", Diverses Auteurs Lire le capital, Louis Althusser, Étienne Balibar, Roger Establet, Pierre Macherey et Jacques Rancière, Paris; Quadrige/Puf, 2e. ed, 2008;

MAGALHÃES ARRUDA, Kátia, "Las transformaciones del mundo del trabajo y sus repercusiones em el Brasil actual". En Revista General de Derecho del Trabajo y de Seguridad Social 24, 2011;

MARCUSE, Herbert, Cultura e sociedade, volume II, Rio de Janeiro; Paz e Terra, 1998;

MARCUSE, Herbert, El hombre unidimensional, Barcelona; Ariel, 2008;

MARINHO FALCÃO, Ismael, $A$ terceirização no direito do trabalho, Bauru, São Paulo, Edipro, 1996;

MARTELLONI, Federico, "Brève histoire italienne d'um droit du travail 'em mode mineur'”. Em Revue de Droit du Travail, mensuel 4, Dalloz, avril 2013;

MARTÍN ARRIBAS, Juan Jose, "Aproximación general a la figura del outsourcing en su vertiente internacional". En Autores Varios. La externalización de actividades laborales (outsourcing): una visión interdisciplinar. Abdón Pedrajas Moreno (org.). Valladolid; Lex Nova, 2002;

MARTÍN PUEBLA, Eduardo, "La reforme 2012 du marché du travail en Espagne: la flexibilité jusqu'au bout”, dans Revue de Droit du Travail numero 7/8, juillet/août 2012, Dalloz;

MARTíN VALVERDE, Antonio, "Responsabilidad empresarial en caso de subcontrata de obras y servicios". En Autores Varios, Comentarios a las leyes 
laborales. El Estatuto de los Trabajadores, Tomo VIII, artículos 39 a 44, Madrid; Editorial Revista de Derecho Privado, 2ª ed., 1998;

MARTÍN VALVERDE, António, "Descentralización productiva y protección del trabajo en contratas: a proposito de la tesis doctoral de Francisco Blat Gimeno". En Descentralización productiva y protección del trabajo en contratas. Autores varios, Valencia; Tirant lo Blanch, 2000;

MARTÍN VALVERDE, Antonio, RODRÍGUEZ-SAÑUDO GUTIÉRREZ, Fermín y CARCÍA MURCIA, Joaquin, Derecho del Trabajo, Madrid; Tecnos, 18 Ed., 2009;

MARTINEZ, Luciano, Curso de direito do trabalho, São Paulo; Saraiva, $3^{\mathrm{a}}$ Ed., 2012;

MARTINS CATHARINO, José, Compêndio de direito do trabalho, São Paulo; Saraiva, 2aㅡㄹ ${ }^{\text {Ed } 1981 ;}$

MARTINS CATHARINO, José, Neoliberalismo e seqüela: privatização, desregulamentação, flexibilização, terceirização, São Paulo; LTr, 1997;

MARX, Karl, Trabalho Assalariado e Capital, São Paulo; Global Editora, $2^{a}$ ed.; 1983;

MARX, Karl e FRIEDRICH, Engels, Manifesto Comunista. Comentado por Chico Alencar, Rio de Janeiro; Garamond, 1998;

MARX, Karl, Manuscritos Econômicos-filosóficos, São Paulo; Martin Claret, Coleção Obra Prima de Cada Autor, Textos Integrais, 2001; 
MARX, Karl, A miséria da filosofia. Tradução José Carlos Orsi Morel, São Paulo; Ícone Editora, 2004;

MARX, Karl, A ideologia alemã. Tradução Frank Muller, São Paulo; Martin Claret, Coleção Obra Prima de Cada Autor, Textos Integrais, 2006;

MARX, Karl, Formações econômicas pré-capitalistas, Tradução João Maia, São Paulo, Editora Paz e Terra, $7^{\mathrm{a}}$ edição, 2006;

MAZEAUD, Antonie, Droit du travail, Paris; Montchrestien, 6ª Ed; 2008;

MEDAUAR, Odete, Direito administrativo moderno, São Paulo; Editora Revista dos Tribunais, $11^{\mathrm{a}}$ Ed., 2007;

MELHADO, Reginaldo, Poder e sujeição: os fundamentos da relação de poder entre capital e trabalho e o conceito de subordinação, São Paulo; LTr, 2003;

MELHADO, Reginaldo, Metamorfoses do capital e do trabalho: relações de poder, reforma do judiciário e competência da justiça laboral, São Paulo, LTr, 2006;

MENENDEZ CALVO, Remédios, Negociación colectiva y descentralización productiva, Madrid, Consejo Económico y Social España, 2009.

MENEZES LEITÃO, Luís Manoel Teles de, Direito do trabalho, Coimbra; Almedina, 2008;

MERCADER UGUINA, J. y DE LA PUEBLA PINILLA, A., «Comentario a la Ley 20/2007, de 11 de julio, del Estatuto del Trabajo Autónomo». Relaciones Laborales, vol. II, 2007; 
MERLIN CLÈVE, Clémerson, "A eficácia dos direitos fundamentais sociais". Em Revista de Direito Constitucional e Internacional. Cadernos de direito constitucional e ciência política. Ano 14, número 54, São Paulo; Editora Revista dos Tribunais, janeiro a março de 2006;

MÉSZÁROS, István, A educação para além do capital. Tradução de Isa Tavares, São Paulo; Boitempo, 2005;

MIRANDA, Jorge, Escritos vários sobre direitos fundamentais, São João do Estoril, Princípia Editora, 2006;

MONTEIRO FERNANDES, António de Lemos, Direito do trabalho, Coimbra; Almedina, 13를 ed; 2006;

MONTERO PEREZ, José Luis, "Nuevas formas de organización de la empresa, entre centralización y descentralización (y II). Teoría jurídica y modelos de regulación de la empresa". Relaciones laborales. Revista crítica de teoría y practica, 7/2011;

MONTOYA MELGAR, Alfredo, "Sobre el trabajo dependiente como categoria delimitadora del derecho del trabajo". En AA.VV. , Trabajo subordinado y trabajo autónomo en la delimitación de las fronteras del Derecho del Trabajo. Estudios en homenaje al prof. José Cabrera Bazán, Madrid; Tecnos, 1999;

MONTOYA MELGAR, Alfredo, Derecho del Trabajo, Madrid; Tecnos, 2009;

MORATO GARCIA, Rosa María, "El reconocimiento legal de la figura del trabajador autónomo económicamente dependiente en España”. En Revista Complejus, vol. 1, numero 1., jan/jun. 2010; 
MOREIRA, Luiz, Fundamentação do direito em Habermas, Belo Horizonte; Mandamentos Editora, $3^{\mathrm{a}}$ ed., 2004;

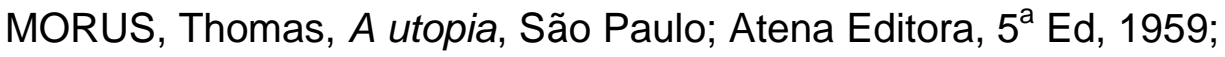

MOTTECY OLIVEIRA, Carmela, "O elemento subordinação na distinção entre "contratas" e cessão ilegal de mão-de-obra no direito espanhol". Em Revista Justiça do Trabalho, número 285, Porto Alegre; HS Editora, setembro de 2007;

MUNGARAY LAGARDA, Alejandro, RAMIREZ ANGULO, Natanael, "Subcontratación en microempresas y pequeña empresas de baja California". Em Revista Frontera Norte, Tijuana, Mexico, año/vol. 16, Julio/diciembre 2004;

OLIVEIRA, Francisco Antônio, Comentários às súmulas do TST, São Paulo; Eitora Revista dos Tribunais, $6^{\circ}$ ed., 2005;

OLIVEIRA, Nythamar, Rawls, Rio de Janeiro; Jorge Zahar Editor, 2003;

OTHON SIDOU, J. M., Dicionário Jurídico: Academia Brasileira de Letras Jurídicas, Rio de Janeiro; Forense Universitária, 9ae ed; 2004;

PACHECO ZERGA, Luz, La dignidad humana en el derecho del trabajo, Navarra; Thompson Civitas, 2007;

PALMEIRA SOBRINHO, Zéu, Terceirização e restauração produtiva, São Paulo, LTr, 2008;

PAPADIMITRIOU, Costas, "Grèce", Dans Revue de droit comparé du travail et de la sécurité sociale, 2012/1, Bordeaux, Université Montesquieu, 2012; 
PASCAL, Georges, Compreender Kant. Tradução Raimundo Vier, Petrópolis, RJ; Editora Vozes, 2005;

PASTORE, José, "Terceirização: uma realidade desamparada pela lei”. Em Revista do Tribunal Superior do Trabalho, Porto Alegre; Magister Editora, ano 74, no. 4, outubro a dezembro de 2008;

PAZ ARES, Cándido y AGILA-REAL, Jesus A., "Ensayo sobre la libertad de empresa",

en

http://portal.uam.es/portal/page/portal/UAM ORGANIZATIVO/Departamentos/Area sDerecho/AreaDerechoMercantil/Investigaci\%F3n/Trabajos\%20y\%20WP/Trabajos \%20y\%20Working\%20Papers/CPA\%20y\%20JAAR\%20-\%20libertad.pdf;

PEDRAJAS MORENO, Abdón, "La cesión ilegal de trabajadores". En Autores Varios. La externalización de actividades laborales (outsourcing): una visión interdisciplinar. Abdón Pedrajas Moreno (dir.). Valladolid; Lex Nova, 2002;

PEDRAJAS MORENO, Abdón y SALA FRANCO, Tomás, Contratas y empresas de trabajo temporal; responsabilidades, Valencia, Tirant lo Blanch, 2006;

PEDRAZZOLI, Marcelo, "Trabajo subordinado y nuevas formas de empleo en Italia (1)". En Relaciones Laborales, Seccíon doctrina, Editorial La Ley, Tomo I, 1989;

PEIXOTO GIORDANI, Francisco Alberto Motta, "Intermediação de mão-deobra - uma leitura que leva à responsabilidade solidária entre as empresas prestadora e tomadora de serviços". Em Revista LTr, legislação do trabalho, São Paulo; LTr, ano 72, julho de 2008; 
PEREIRA MARCELINO, Paula Regina, Terceirização do trabalho no Brasil

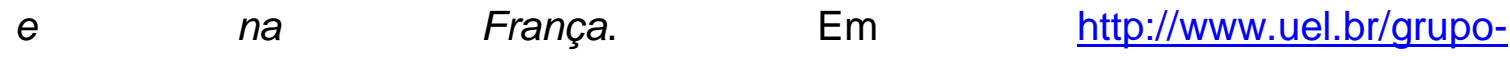
pesquisa/gepal/segundosimposio/paulareginapereiramarcelino.pdf;

PÉREZ BERMEJO, Juan Manuel, Contrato social y obediencia al derecho en el pensamiento de John Rawls, Granada; Editorial Colmares, 1997;

PÉREZ GUERRERO, Maria Luisa y RODRIGUES-PIÑERO ROYO, Miguel, "El articulo 43 del Estatuto de los Trabajadores: empresas de trabajo temporal y cesión de trabajadores", En Revista del Ministerio de Trabajo y Asuntos Sociales, n. 58,2005 ;

PEREZ LUÑO, Antonio E, Los derechos fundamentales, Temas clave de la Constitución española, Madrid; Ed Tecnos, 9ª ed., 2007;

PÉREZ LUÑO, Antonio .E., "El trabajo como problema filosófico: un libro del Profesor Luigi Bagolini", en La Filosofía del derecho en perspectiva histórica. Estudios conmemorativos del 65 aniversario del autor. Homenaje de la Facultad de Derecho y del Departamento de Filosofía del Derecho de la Universidad de Sevilla. Coordinador: R. González-Tablas Sastre. Universidad de Sevilla, Secretaria de Publicaciones, 2009;

PESKINE, Elsa, Reseaux d'entreprise et droit du travail. Thèse Doctoral, Université Paris X, Nanterre, 2004;

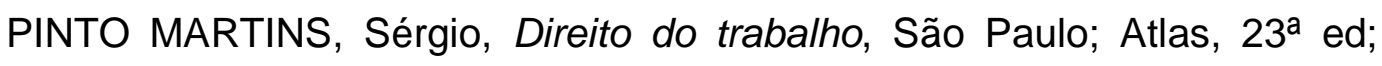
2007;

PINTO MARTINS, Sérgio, A terceirização e o direito do trabalho, São Paulo; Atlas, $9^{\text {a }}$ Ed., 2009; 
PERULLI, Adalberto, Levori atipici e parasubordinazione tra diritto europeo e situazione italiana. En Rivista Giuridica del Lavoro e della Previdenza Sociale. Roma, Ediesse, anni LVII, n. 4.;

PIOVESAN, Flávia, "Direitos humanos e o princípio da dignidade humana". Em Dos princípios constitucionais. Considerações em torno das normas principiológicas da Constituição. George Salomão Leite (org.)., São Paulo; Editora Malheiros, 2003;

POSSAS, Silvia, "Valor, capital e riqueza nos primórdios da Economia política”, Em Autores vários, Os clássicos da economia, Ricardo Carneiro (org.), v. 1, item “Adam Smith”, São Paulo; Editora Ática, 2004;

PRIETO SANCHIS, Luis, Justicia constitucional y derechos fundamentales, Madrid; Trotta, 2003;

QUADROS DE MAGALHAES, José Luiz, O controle de constitucionalidade e a reforma do poder judiciário: a necessidade de um novo supremo tribunal federal.

http://www.uj.com.br/publicacoes/doutrinas/default.asp?action=doutrina\&coddou=3 $\underline{565}$.

QUEIJA ALVAR, Maria Vitória, Os direitos fundamentais dos trabalhadores e o princípio do não-retrocesso social no Brasil, http://www.ambitojuridico.com.br/site/?n link=revista artigos leitura\&artigo id=9212\&revista cadern $\underline{0=25}$;

RAMALHO RABENHORST, Eduardo, "Teoria da justiça”. Em Dicionário de Filosofia do Direito. Vicente de Paulo Barreto (org.), Rio de Janeiro; Unisinos e Renovar, 2006; 
RAMIREZ MARTÍNEZ, Juan M. Y SALA FRANCO, Tomás, "Contratas y subcontratas de obras y servicios y cesión ilegal de trabajadores". En Descentralización productiva y protección del trabajo en contratas. Autores varios, Valencia; Tirant lo Blanch, 2000;

RAMÍREZ MARTÍNEZ, Juan M., "Las responsabilidades del empresario principal en las contratas y subcontratas". En La externalización de actividades laborales (outsourcing): uma visión interdisciplinar, Autores Vários. Abdón Pedrajas Moreno (org.). Valladolid; Lex Nova, 2002;

RAMOS FILHO, Wilson, "Bem-estar das empresas e mal-estar laboral: o assédio moral empresarial como modo de gestão de recurso humanos". Em Cadernos da AMATRA IV. $11^{\circ}$ Caderno de estudos sobre processo e direito do trabalho, Porto Alegre; HS Editira, 2009;

RANCIÈRE, Jaques, "Le concept de critique et la critique de l'econimie politique des <Manuscrits de 1844> au <Capital>". Lire le capital, Louis Althusser, Paris; PUF, 2eme édition, 2008;

RAUPP BOCORNY, Leonardo, A valorização do trabalho humano no Estado Democrático de Direito, Porto Alegre; Sérgio Antônio Fabris Editor, 2003;

RAWLS, John."A teoria da justiça como equidade: uma teoria política, e não metafísica". Em Justiça e democracia. Tradução Irene A. Paternot; seleção, apresentação e glossário Catharine Audart, São Paulo; Martins Fontes, 2000;

RAWLS, John. Uma teoria da justiça. Tradução Almiro Pisetta Lenita Maria Rímoli Esteves, São Paulo; Marins Fontes, $2^{a}$ ed., 2002;

RIBEIRO DE CAMPOS, José, A terceirização e a responsabilidade da empresa tomadora de serviços, São Paulo; IOB-TOMPSON, 2006; 
RIBEIRO DE VILHENA, Paulo Emílio, Relação de emprego: estrutura legal e supostos, São Paulo; Saraiva, 1975;

RICARDO, David, "Princípios de economia política e tributação". Em Autores vários, Os clássicos da economia, Ricardo Carneiro (org.), v. 1, item "Adam Smith”, São Paulo; Editora Ática, 2004;

ROCHLITZ, Rainer, "Razão e racionalidade em Habermas". Em Habermas: o uso público da razão. Rainer Rochlitz (coord.), Rio de Janeiro; Tempo Brasileiro, 2005;

ROCHLITZ, Rainer, "Filosofia política e sociologia em Habermas". Em Habermas: o uso público da razão. Rainer Rochlitz (coord.), Rio de Janeiro; Tempo Brasileiro, 2005;

RODILLA, Miguel Angel, Leyendo a Rawls, Salamanca; Ediciones Universidad de Salamanca, 2006;

RODRIGUES GOMES, Fábio, $O$ direito fundamental ao trabalho. Perspectivas histórica, filosófica e dogmático-analítica, Rio de Janeiro; Editora Lumen Juris, 2008;

RODRIGUES PINTO, José Augusto, "Por que ter medo da tercerização brasileira". En Revista LTr, legislação do trabalho, São Paulo; LTr, ano 75, novembro de 2011;

RODRIGUES RECK, Janriê, A construção da gestão compartida: o uso da proposição habermasiana da ação comunicativa na definição e execução compartilhada do interesse público, Dissertação de mestrado, UNISC, 2006; 
RODRIGUES RECK, Janrie, "Perspectiva pragmático-sistêmica da liberdade de cátedra: direito social ou individual?", no prelo;

RODRÍGUEZ ESCANCIANO, Susana, "La coordinación empresarial como estrategia de descentralización productiva: carencias normativas”. En Revista de derecho social, Alicante, Ediciones Bomarzo, 2001;

RODRIGUEZ-PIÑERO, Miguel, "La dependencia y la extension del ambito del derecho del trabajo", Revista de Política Social, 1966, ํo 71;

RODRIGUEZ-PIÑERO, Miguel, "Contrato de trabajo y autonomia del trabajador". En AA.VV., Trabajo subordinado y trabajo autónomo en la delimitación de las fronteras del Derecho del Trabajo. Estudios en homenaje al prof. José Cabrera Bazán, Madrid; Tecnos, 1999;

RODRIGUEZ-PIÑERO, Miguel, "La réforme espagnole de la negociation collective de 2011/2012". Dans Revue de droit comparé du travail et de la sécurité sociale, 2012/1, Bordeaux, Université Montesquieu, 2012;

ROPPO, Enzo, O contrato. Tradução de Ana Coimbra e M. Januário C. Gomes, Coimbra; Almedina, 1988;

ROSENBAUM, Jorge y CASTELLO, Alejandro, Régimen jurídico de La subcontratación e intermediación laboral, Montevideo; Fundación de Cultura Universitaria; 2007;

ROSENFIELD, Cinara L., ALVES, Daniela A. de, "Teletrabalho". Em Dicionário de trabalho e tecnologia, Organizadores Antonio David Cattani e Lorena Holzmann, Porto Alegre; Editora da UFRGS, 2006; 
ROSSAL DE ARAÚJO, Francisco, A boa-fé no contrato de emprego, São Paulo, LTr, 1996;

ROSSAL DE ARAÚJO, Francisco, "O direito do trabalho e o ser humano". Em Continuando a História. Direito do Trabalho no limiar do novo milênio, São Paulo; LTr, 1999;

ROUSSEAU, Dominique, Droit du contentieux constituitionnel, Paris; Editions Montchrestein, 4ª Ed., 1995;

RUIZ DE AZÚA, Javier Bengoa, De Heidegger a Habermas: hermenéutica y fundamentación última en a filosofía contemporánea, Barcelona; Editorial Herder, 1992;

RUIZ MIGUEL, Alfonso, "Concepciones de la igualdad y justicia distributiva”. Em Autores Vários, Estado, justicia, derechos. Elías Díaz e José Luis Colomer (coords.), Madrid, Alianza Editorial, 2002;

SAAD, Eduardo Gabriel, DUARTE SAAD, José Eduardo e CASTELLO BRANCO, Ana Maria Saad, CLT comentada, São Paulo; LTr, 41 a ed, 2008;

SALGADO, Joaquim Carlos, $A$ idéia da justiça em Kant: seu fundamento na liberdade e na igualdade, belo Horizonte: Editora UFMG, $2^{a}$ edição, 1995;

SAMPAIO OLIVEIRA, Murilo Carvalho, Direito do trabalho e tecnologia: o teletrabalho e a parassubordinação,

p. 13. http://www.facs.br/revistajuridica/edicao julho2007/convidados/con1.doc;

SÁNCHEZ ÁLVAREZ, Manuel María, "Nuevas formas de organización empresarial. Deslocalización, descentralización y externalización. Empresa principal, contratas y subcontratas". En Siniestralidad laboral y derecho penal, 
Madrid; Consejo General del Poder Judicial. Centro de Documentación General. Cuadernos de Derecho Judicial, XV - 2005, 2006;

SÁNCHEZ BRAVO, Alvaro, A nova sociedade tecnológica: da inclusão ao controle social. A Europ@é exemplo?, Santa Cruz do Sul; Edunisc, 2010;

SÁNCHEZ, Mayela, Outsourcing, en auge $y$ sin control. Em http://ungenio.blogspot.com/2010/08/las-subcontratadoras-en-mexico.html;

SARATT, Newton, DUTRA DA SILVEIRA, Adriano, DAIBERT, Arlindo e PIRES MORAES, Rogério, Quarteirização, Porto Alegre; Badejo Editora, 2000;

SCHUMPETER, Joseph Alois, "A instabilidade do capitalismo". Em Autores vários, Os clássicos da economia, Ricardo Carneiro (org.), v. 2, item "Adam Smith", São Paulo; Editora Ática, 2003;

SEABRA DA CRUZ JÚNIOR, Ademar, Justiça como equidade: liberais, comunitaristas e a autocrítica de Rawls, Rio de Janeiro; Editora Lumen Juris, 2004;

SEN, Amartya, L’idée de justice. Paul Chemla et Éloi Laurent, Paris; Flammarion, 2010;

SERNA BERMUDEZ, Pedro, "La dignidad de la persona como principio del Derecho público", Derechos y libertades 4, Madrid, Dykinson, 1995;

SERNA BERMUDEZ, Pedro, "La interpretación constitucional del principio de dignidad de la persona en el derecho alemán”, En Interpretación constitucional, director E. Ferrer-Mac Gregor, Mexico, Porrúa-UNAN, 2005; 
SERNA BERMUDEZ, Pedro, "Politica posmoderna y crisis de la razón jurídica", En Anuario de la Facultad de Derecho de la Universidad de a Coruña, 13, 2009;

SICILIANO AIETA, Vânia, "Democracia". Em Dicionário de Filosofia do Direito. Vicente de Paulo Barreto (org.), Rio de Janeiro; Unisinos e Renovar, 2006;

SIERRA BENÍTEZ, Esperanza Macarena, "Comentario de las novedades del Real Decreto Ley 3/2010, de 10 de febrero, de medidas urgentes para la reforma del mercado laboral español", en Revista Justiça do Trabalho, Porto Alegre; HS Editora, no. 344, agosto de 2012;

SILVA FILHO, José Carlos Moreira da, "Locke, John”. Em Dicionário de Filosofia do Direito. Vicente de Paulo Barreto (org.), Rio de Janeiro; Unisinos e Renovar, 2006;

SILVA MARQUES, Rafael da, "Trabalho para além do meramente econômico". Em Revista do Tribunal Regional do Trabalho da Quarta Região, Porto Alegre, HS Editora, número 34, 2006;

SILVA PEREIRA, Caio Mário da, Instituições de direito civil, Rio de Janeiro; Forense, vol. III, 1995;

SITTON, John, Habermas y la sociedad contemporánea. Traducción de Juan Carlos Rodríguez Aguilar. Ciudad del Mexico; FCE, 2006;

SMITH, Adam, "A riqueza das nações”, Em Autores vários, Os clássicos da economia, Ricardo Carneiro (org.), v. 1, item “Adam Smith”, São Paulo; Editora Ática, 2004; 
SPURK, Jan, "A noção de trabalho em Karl Marx". Em O trabalho na história do pensamento ocidental, Daniel Mercure, Jan Spurk (Orgs.). Tradução Patrícia Chittoni Ramos Reulliard, Sônia Guimarães Taborda, Petrópolis; Vozes, 2005;

SOTELO VALECIA, ADRIÁN, "La precarización del trabaljo. ¿Premisa de la Globalización?" Em Papeles de población, Toluca México; Universidad Autónoma del Estado de Mexico, numero 018, octubre a diciembre, 1998;

SOUZA SANTOS, Boaventura de, Pela mão de alice: o social e o político na pós-modernidade, São Paulo; Cortez, $9^{\mathrm{a}}$ ed., 2003;

SOUTO MAIOR, Jorge Luiz, "Terceirização na administração pública: uma prática inconstitucional”, en Revista Justiça do Trabalho, Porto Alegre; HS Editora, no. 273 , setembro de 2009 ;

SOUTO MAIOR, Jorge Luiz, Curso de direito do trabalho: a relação de emprego, Volume II, São Paulo, LTr, 2008;

SOUTO SEVERO, Valdete, Crise de paradigma no Direito do Trabalho moderno: a jornada, Porto Alegre; Sérgio Antônio Fabris Ed., 2009;

SOUTO SEVERO, valdete, "O direito do trabalho ferido de morte pelo STF!". Em Jornal Estado de Direito", Porto Alegre, Ano V, número 28, 2010;

STEILTJES, Cláudio, Jürgen Habermas. A desconstrução de uma teoria, São Paulo; Germinal, 2001;

STEIN, Ernildo, "Dialética e hermenêutica: uma controvérsia sobre método em filosofia". Em HABERMAS, Jürgen, Dialética e hermenêutica, tradução Alvaro Valls, Porto Alegre; L\&PM Editora, 1987; 
STEIN, Ernildo, História e ideologia, Porto Alegre; Movimento, 3ae ed; 1999;

STOLZE GAGLIANO, Pablo, PAMPLONA FILHO, Rodolfo, Novo curso de direito civil. Responsabilidade civil, São Paulo; Editora Saraiva, Vol. III, $7^{\text {a }}$ ed., 2009;

STRECK, Lênio Luiz e BOLZAN DE MORAIS, José Luis, Ciência política e teoria geral do estado, 2004, Porto Alegre; Livraria do Advogado Editora, 2004;

SUPIOT, Alain, Il futuro del lavoro. Traduzione Lorenzo Giasanti, Giovanna Fullin, Laura Centemeri e Andréa Allamprese, Roma; Carocci Editore, 2003;

SUPIOT, Alain, Critique du droit du travail, Paris; Quadrige Puf, 2e. ed, 2007;

SÜSSEKIND, Arnaldo, Curso de direito do trabalho, Rio de Janeiro; Renovar, 2002;

TEIXEIRA DOS ANJOS, Alberico, "Höffe, Otfried". Em Dicionário de Filosofia do Direito. Vicente de Paulo Barreto (org.), Rio de Janeiro; Unisinos e Renovar, 2006;

THIBAULT ARANDA, Javier, "Sobre la utilización de las empresas de trabajo temporal y las 'empresas de multiservicios'”. Autores Vários. Contratación temporal, empresas de trabajo temporal y subcontratación en la negociación colectiva. Comisión Consultiva Nacional de Convenios Colectivos. Colección Informes y Estudios: relaciones laborales no. 94, Ministério de Trabajo e Inmigración, 2010; 
TOLOMEI TEIXEIRA, Marcelo, "Os efeitos do contrato de trabalho nulo". Em Revista jurídica da Amatra $17^{a}$ Região, Vitória, ES; Ano 5, no. 09, volume V, 2008;

TOURAINE, Alain, Após a crise, Petrópolis, RJ; Editora Vozes, 2011;

TRINDADE DE SOUZA, Rodrigo, Função social do contrato de emprego, São Paulo; LTr, 2008;

UGARTE, José, Luis, "Relaciones laborales triangulares: la sucontratación y el suministro de trabajadores en la nueva ley chilena". Em Revista do Tribunal Regional do Trabalho da 15ª Região, Campinas, SP; Editora da Escola Judicial da Magistratura, numero 30, jan./jun. 2007;

VALDEZ DAL-RÉ, Fernando, "Descentralización productiva y desorganización del Derecho del Trabajo", En Revista Universitaria de Ciencias del Trabajo y Protección Social en Europa, Valladolid, 2002, Secretariado de Publicaciones e Intercambio Editorial de la Universidad de Valladolid, 2002;

VALDÉS DAL-RÉ, Fernando, Homenage al profesor Fernando Valdés DalRé a través de sus prólogos. 25 años de catedrático de derecho del trabaljo (19772002), Valladolid; Editoral Lex Nova, 2002;

VALDÉS DAL-RÉ, Fernando, "La externalización de actividades laborales: um fenómeno complexo". En Autores Varios. La externalización de actividades laborales (outsourcing): una visión interdisciplinar. Abdón Pedrajas Moreno (org.). Valladolid; Lex Nova, 2002;

\section{VALDÉS DAL-RÉ, Fernendo y LAHERA FORTEZA, "La flexiseguridad laboral en España”. En Documento de trabajo 157/2010,}


http://www.falternativas.org/laboratorio/documentos/documentos-de-trabajo/laflexiseguridad-laboral-en-espana;

VASCONCELOS PORTO, Lorena, "A relação de emprego e a subordinação - a matriz clássica e as tendências expansionistas". Em Revista LTr. Legislação do trabalho. São Paulo, LTr, Ano 72, no. 7, julho de 2008;

VASCONCELOS PORTO, Lorena, Parassubordinação: aparência $x$ essência, p. 02. http://www.ambito-juridico.com.br/pdfsGerados/artigos/5767.pdf;

VIANA, Márcio Túlio, NEVES DELGADO, Gabriela e SANTOS AMORIN, Helder, "Terceirização - aspectos gerais - a última decisão do STF e a súmula n. 331 do TST - novos enfoques". Em Revista LTr, legislação do trabalho, São Paulo; LTr, ano 75, março de 2011;

VICENTE GIMÉNEZ, Teresa. "La exigibilidade de los derechos sociales", Valencia; Publicaciones Universidad de Valencia, 2006;

VICECONTE, Massimo, "Il lavoro interinale: la casistica nella legge e nella contrattazione colletiva". Em Lavoro e previdenza oggi, 3, 1999;

WALKER ERRÁZURIZ, Francisco, Derecho de las relaciones laborales. Un derecho vivo, Santiago; Editorial Universitária, 2003;

WARAT, Luis Alberto, Introdução geral ao direito II. Epistemologia jurídica da modernidade, Porto Alegre; Sérgio Antônio Fabris Editor, 1995;

WARAT, Luis Alberto, O direito e sua linguagem, Porto Alegre; Sérgio Antônio Fabris Editor, $2^{\text {a }}$ ed., 1995; 
WARD, Allen, "Prologo". Em KENNEDY, Michael N., El desarrollo de productos en Toyota, Barcelona; Deusto, 2007;

WEISSHEIMER, Marco Aurélio, As escolas itinerantes do MST, En http://rsurgente.opsblog.org/2011/05/06/as-escolas-itinerantes-do-mst/;

WOLFGANG SARLET, Ingo, Dignidade da pessoa humana e direitos fundamentais na Constituição Federal de 1988, Porto Alegre; Livraria do Advogado Editora, $3^{\mathrm{a}}$ ed., 2004;

WOLFGANG SARLET, Ingo, "As dimensões da dignidade da pessoa humana: construindo uma compreensão jurídico-constitucional necessária e possível". Em Dimensões da Dignidade: ensaios de Filosofia do Direito e Direito Constitucional. Ingo Wolfgang Sarlet (org.), Porto Alegre; Livraria do Advogado Editora, 2005;

WOLFGANG SARLET, Ingo, "Dignidade da pessoa humana, parte II". Em Dicionário de Filosofia do Direito. Vicente de Paulo Barreto, Rio de Janeiro; Editora Unisinos e Renovar, 2006;

WOLFGANG SARLET, Ingo, "Entrevista ao Jornal da Associação dos

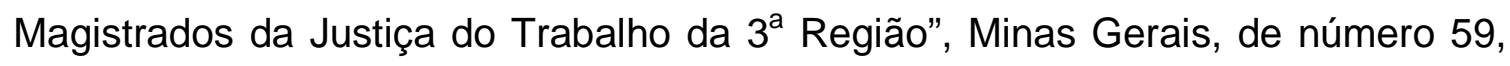
julho, agosto e setembro de 2008;

ZACHERT, Ulrich, Lecciones de derecho del trabajo alemán. Traducción del italiano por Fernando Martínez Rodriguez y Natividad Mendoza Navas, Madrid; Ministerio del Trabajo y Asuntos Sociales de España, 1998;

ZIMMER JÚNIOR, Aloísio, Curso de direito administrativo, Porto Alegre; Editora Verbo Jurídico, 2007. 


\section{Diccionários.}

"Dicionário de Filosofia do Direito". Vicente de Paulo Barreto (org.), Rio de Janeiro; Unisinos e Renovar, 2006;

"Diccionario de la Lengua Española de la Real Academia Española". Tomo II, Madrid; Editorial Espasa Calpe, 22aㅡ ed; 2001;

"Dicionário Jurídico: Academia Brasileira de Letras Jurídicas", Rio de Janeiro; Forense Universitária, 9a ed; 2004;

"Dicionário de trabalho e tecnologia". Organizadores Antonio David Cattani e Lorena Holzmann, Porto Alegre; Editora da UFRGS, 2006;

\section{Revistas y periódicos.}

Guide per esami e pubblici concorsi. Elelemti di diritto del lavoror e legislacione sociale, Napoli; Edizioni Giurdiche Simone, 1998;

Pesquisa Setorial 2009/2010 do Sindicato das Empresas de Prestação de Serviços a Terceiros, Colocação e Administração de mão-de-obra e de Trabalho Temporário no Estado de São Paulo (SINDEPRESTEM), São Paulo, SP, $2009 / 2010$

Revista da Associação Nacional dos Magistrados da Justiça do Trabalho, ano XIX, número 56, janeiro de 2009; 


\section{Sítios de internet.}

www.elpais.com;

www.trt4.jus.br;

www.tst.jus.br;

www.trt3.jus.br;

www.facs.br;

www.ambito-juridico.com.br;

www.planalto.gov.br;

www.anamatra.org.br;

http://www.assistentesocial.com.br/agora3/coutinho.doc;

http://www.Ifg.com.br/artigos/Blog/Abstrativizacao do Controle Concreto d e Constitucionalidade.pdf;

http://www.mds.gov.br/bolsafamilia;

http://infoleg.mecon.gov.ar/basehome/codigos.htm;

http://infoleg.mecon.gov.ar/infoleglnternet/anexos/25000-

29999/25552/texact.htm;

http://dre.pt/pdf1sdip/2007/05/09800/33873397.pdf; 
http://www.mtss.gov.pt/docs/Cod Trabalho.pdf;

http://www.legifrance.gouv.fr/affichCode.do?cidTexte=LEGITEXT000006072 $\underline{050 \& \text { dateTexte }=20101201}$;

http://www.studiocataldi.it/argomenti.asp?opt=dettaglio\&codice=9;

http://www.appuntigiurisprudenza.it/appunti-di-diritto-dellavoro/parasubordinazione-e-lavoro-a-progetto.html;

http://eurlex.europa.eu/LexUriServ/LexUriServ.do?uri=CELEX:31991L0383:PT:HTML;

http://eurlex.europa.eu/LexUriServ/LexUriServ.do?uri=OJ:C:2010:117E:0176:0180:ES:PDF;

http://www.camera.it/parlam/leggi/97196l.htm;

www.lemonde.fr;

www.elmundo.es;

www.empleo publico.net;

www.wikipedios.com;

http://iris.nyit.edu/ shartman/mba0101/trust.htm;

http://www.sistema9041.com.ar/Legislacion/Laboral/Contrato de Trabajo/Co ntrato de Trabajo 01.asp\#axzz1xVr4zY00; 
http://www.seg-social.es/Internet 1/Normativa/095093

http://www.contrattoprogetto.info/il-lavoro-parasubordinato;

http://portaljuridico.lexnova.es/jurisprudencia/JURIDICO/138920/sentencia-tssala-4-de-12-de-junio-de-2012-trabajador-autonomo-economicamentedependiente-cont;

http://recull.creinsa.com/archivo/245 TSupremo1007.pdf; 